LIBRARY

UNIVERSITY OF CALIFORNA

DAVIS 






\section{JOHN H. B. LATROBE}

\section{AND HIS TIMES}

1803-1891 
A LIMITED EDITION ONLY HAS BEEN PRINTED AND THE TYPE DISTRIBUTED 



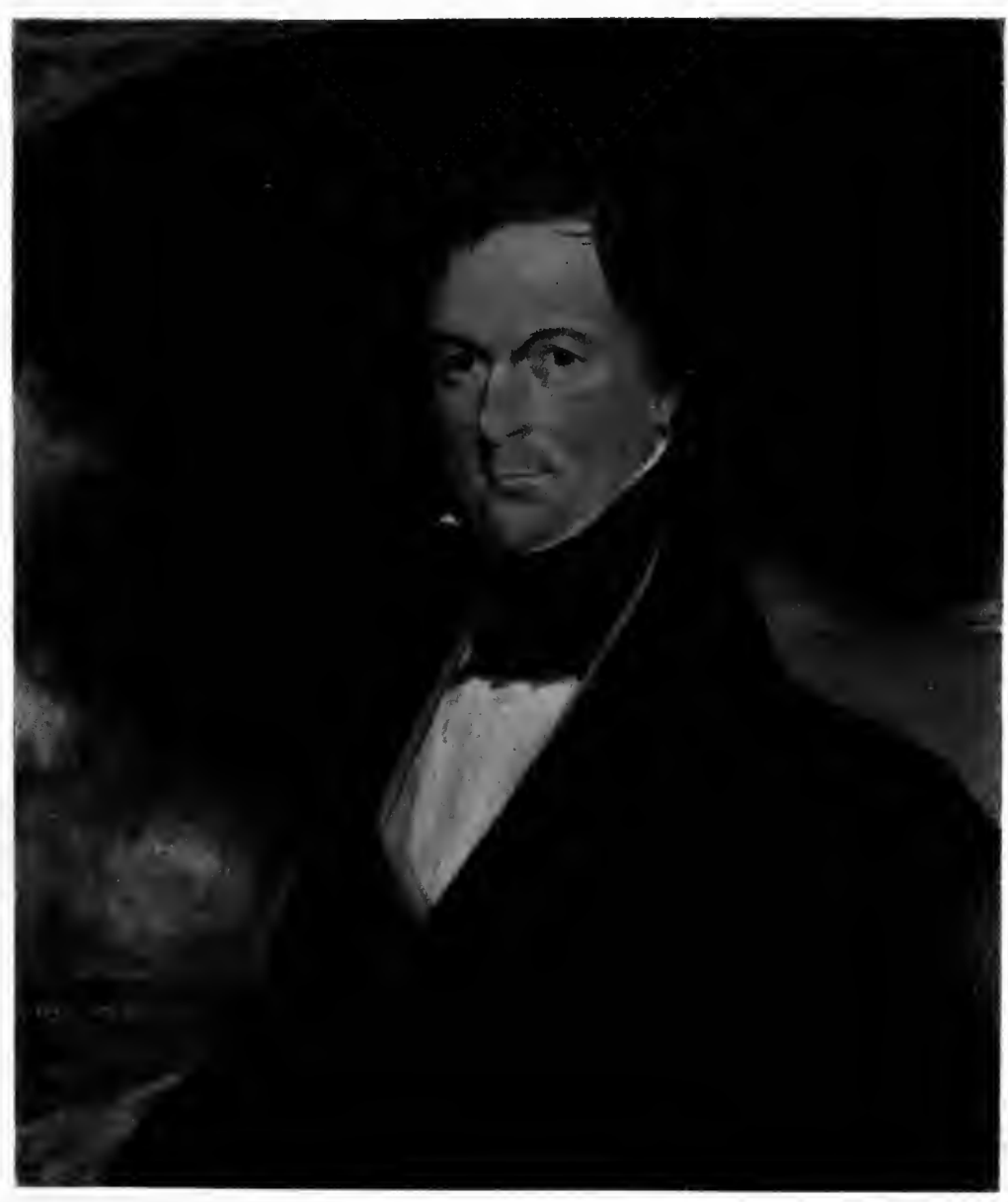




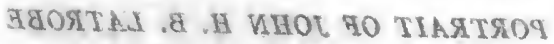

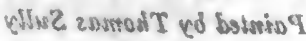


PORTRAIT OF JOHN H. B. LATROBE

Painted by Thomas Sully 


\title{
JOHN H. B. LATROBE AND HIS TIMES 1803-1891
}

\author{
BY \\ JOHN E. SEMMES
}

WITH THIRTY-EIGHT ILLUSTRATIONS

IN COLOR, AND BLACK AND WHITE

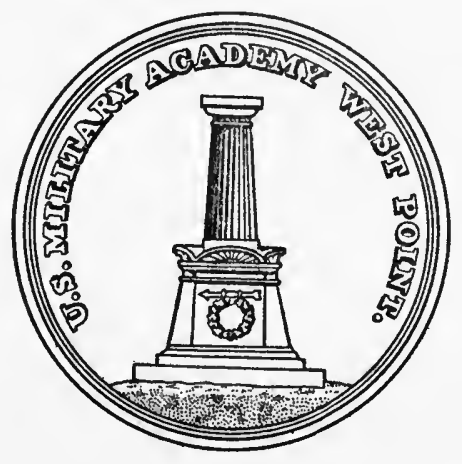

THE NORMAN, REMINGTON GO. BALTIMORE, MD. 
COPYRIGHT, 1917, BY THE NORMAN, REMINGTON CO.

PUBLISHED OCTOBER, 1917

PRINTED BY

THE WAVERLY PRESS

BALTIMORE, U. S. A. 


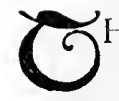

HE DESIGN ON THE COVER is a graphic representation of the life of John H. B. Latrobe.

The axes on either side are the fasces of the law which constituted the chief activity of his career. The medallion in the lower centre recalls his West Point service and the architectural honor which came to him when his design was selected for the monument to the Polish patriot, Kosciuszko, which was erected at the Military Academy. His architectural ability is further emphasized by the reproduction in the upper centre of his design for the buildings at White Sulphur Springs, known as the Baltimore Cottages. The book in the small circle at the Ieft testifies to his literary proclivities; while the circle at the right bears evidence to his prominence in Masonry as the Grand Master of the State of Maryland.

The circle on the lower left is a reminder of his unique services to the Baltimore and Ohio Railroad which he served faithfully and unselfishly from its organization until his death in 1891 . The circle at the right recalls the early days of the steamboat, when as a boy he frequented his father's works in Pittsburgh and watched the building of those boats which were the pioneers of steam power on the western waters.

Finally, the Indian peace pipes bear eloquent testimony to the vital assistance which he rendered to the Indian nations of Choctaws and Chickasaws in their long and hard fight after the Civil War to preserve their lands and moneys from the threatened confrscation of the United States government. 



\section{CONTENTS}

Chapter I. Benjamin H. Latrobe, Father of John H. B. Latrobe arrives in this country, 1796-Difference in Transportation and Communication, due to Steam and Electricity-The Civilization of the Nineteenth Century owes its great Advancement to this-The Elder Latrobe Architect of Capitol-Social Life in Washington-First Trip by Steamboat down the Mississippi in 1812, Made by Nicholas J. Roosevelt and Lydia Latrobe, His Wife, the Sister of John H. B. Latrobe-Fulton's Claim as Inventor of

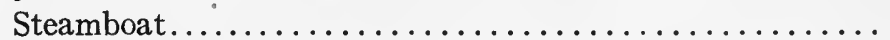

Chapter II. From 1803 to 1818-Date of Mr. Latrobe's Entering West Point-Life in Washington-First Theatrical Experience-Early Associates-Madame Bonaparte-Naval Ball-Family Left Washington 1812-Trip to Wheeling by Carriage-Life in Pittsburgh Building SteamboatsReturn to Washington 1815-Georgetown College-Left Washington for Baltimore 1817-Death of Benjamin $\mathrm{H}$.

Latrobe in New Orleans $1820 \ldots \ldots \ldots \ldots \ldots \ldots \ldots \ldots$

Chapter III. Life at West Point 1818-1821............ 67

Chapter IV. Return to Baltimore, 1821-Study of Law in the Office of General Harper...................

Chapter V. Mr. Latrobe's Connection with Things Military, After Leaving West Point in 1821-His Association of Six Years with Militia-Reception of Lafayette in Baltimore 1824-Trip to Philadelphia in Command of Light Infantry Company-Monument to Kosciuszko at West PointPresident, Board of Visitors, West Point in 1849-His Annual Visit to West Point-His Relations with General Thayer-The Three Battles-Friendship with General Gibbon.................................. 116

Chapter VI. American Colonization.................. 139

Chapter VII. Mr. Latrobe as a Lawyer-Friends and Acquaintances-Baltimore in $1824 \ldots \ldots \ldots \ldots \ldots \ldots \ldots . \ldots 172$

Chapter VIII. Courtship and Marriage of Mr. Latrobe and

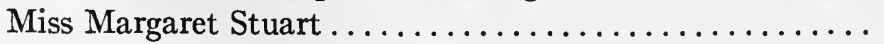


Chapter IX. Description of Montpelier-University of Virginia-Monticello and the White Sulphur Springs, as Mr. Latrobe saw them in $1832 \ldots \ldots \ldots \ldots \ldots \ldots \ldots \ldots .238$

Chapter X. Mr. Latrobe's Marriage to Miss ClaiborneShort Account of her Family-The "Claiborne Rebellion." 260

Chapter XI. Life after Second Marriage-Acquaintances and Clients-Friendship with Charles Harper and his Estrangement due to His Marriage-The Settlement of the Controversy over the Will and Codicil of Charles Carroll of Carrollton.

Chapter XII. Trip to New Orleans by Sea and Return by Land, 1834-Raiders and Natchez Trip-New Orleans and the Quadroon Ball-Trip in 1835 to New Orleans and Return with Wife to White Sulphur Springs......... 302

Chapter XIII. History of Mr. Latrobe's great Client, The Baltimore \& Ohio Railroad, and its Conflict with the Chesapeake \& Ohio Canal Company for the Valley of the Potomac............................... 320

Chapter XIV. Acquaintances formed by Mr. Latrobe after 1830 and Students who Studied in His Office-Directors of the Union Bank and Counsel-Bank Riots, 1835..... 364

Chapter XV. The Maryland Institute-The Maryland Historical Society-Latrobe Justice's Practice-Masonry-

J. P. Kennedy-Painter-Greenmount-Mr. Latrobe's Poetic Talent.............................

Chapter XVI. The Fireplace Heater-Experiences in PoliticsArchitectural Efforts-"Fairy Knowe"-Rev. Peter Latrobe-Cost of Living in 1830-Narrow Escape from Ruin by Robbery-State of Maryland Debt-Trip to Europe, 1847.

Chapter XVII. Trip to Europe in 1857-Counsel for the Winans Railroad Interests in Russia................ 469

Chapter XVIII. First Meeting with Indians, 1832-Contract with Choctaws and Chickasaws, $1868 \ldots \ldots \ldots \ldots . \ldots 29$

Chapter XIX. Mr. Latrobe's Connection with the first Telegraph Company-Druid Hill Park-Edgar Allan PoeLast Case in the Court of Appeals of Maryland-Last

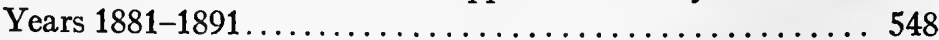

Latrobe Genealogy............................. 575

Index............................... 581

Topical Index. . . . . . . . . . . . . . . . . . . . . . . . . . . . 597 


\section{ILLUSTRATIONS}

Color Plates are indicated by an asterisk

*Portrait of John H. B. Latrobe. Painted by Thomas Sully.

Capital of Corinthian Column. Showing Ears of Corn,

Frontispiece

Designed by B. H. Latrobe for the Capitol in Washington 10

Capital of Corinthian Column. Showing Native Tobacco

Plant Leaves, designed by B. H. Latrobe for the Capitol 12

Thomas Jefrerson. Drawn by B. H. Latrobe........... 14

*Monticello. Painted by John H. B. Latrobe............ 48

A Silhouette of John H. B. Latrobe and Pencil Sketch

of John H. B. Latrobe. By himself............ 96

*The Tombigbee River. Painted by John H. B. Latrobe... 108

Monument to Kosciuszko. At the Military Academy, West

Point, designed by John H. B. Latrobe............. 124

Gold Medal Won by John H. B. Latrobe. In Competition

for best Désign of a Monument to Kosciuszko......... 126

${ }^{*}$ Canal Around the Falls of the Ohio. Painted by John

H. B. Latrobe............................ 164

Mrs. Waring as Margaret. In "A New Way to Pay Old

Debts." Drawn by John H. B. Latrobe............ 186

The Elder Booth as Sir Giles Overreach. Drawn by

John H. B. Latrobe...................... 188

*Louisville (Upper Landing), 1832. Painted by John H. B.

Latrobe............................... 204

*Landing at Three Rivers, 1830. Painted by John H. B.

Latrobe................................ 236

*White Sulphur Springs, 1832. Painted by John H. B.

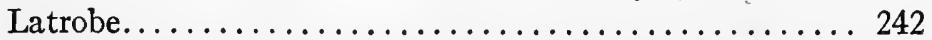

*Lawn of the White Sulphur, White Sulphur Springs, 1832.

Painted by John H. B. Latrobe.................... 248 
*Baltimore Cottages, White Sulphur Springs. Painted by John H. B. Latrobe........................ 254

*Dining Room, Stage Office, etc., at the White Sulphur, 1832. Painted by John H. B. Latrobe............ 258

*John H. B. Latrobe with the Claiborne Family at Botetourt Springs, Virginia. By himself........... 262

Western Block House, Fort Armstrong on the Missis-

SIPpi River. Drawn by John H. B. Latrobe.......... 270

Fort Snelling, St. Peter's, on the Mississippi. Drawn by

John H. B. Latrobe....................... 274

* Portrait of Mrs. John H. B. Latrobe. Painted by Thomas

Sully............................... 280

${ }^{*}$ Cincinnati (Looking up the Ohio), 1832. Painted by John

H. B. Latrobe......................... 302

*Near the White Sulphur Springs. Painted by John $\mathrm{H}$.

B. Latrobe............................ 308

*Falls of the Kenawha. Painted by John H. B.Latrobe.... 318

John H. B. Latrobe at the Age of $76 \ldots \ldots \ldots \ldots \ldots \ldots 340$

LAdY's HAND AND ARM. Drawn by John H. B. Latrobe in

his 15 th year.......................... 426

*Illustration for the Novel "Horse Shoe Robinson," By

John P. Kennedy. Painted by John H. B. Latrobe..... 436

Heater Invented By John H. B. Latrobe. Known as the

Latrobe Stove.............................. 442

Coat of Arms of the Latrobes.................. 448

The Walhalla on the Danube. Drawn by John H. B.

Latrobe.......................... 458

Outline of the Horizon at Rome. Drawn by John H. B.

Latrobe................................ 468

*Pass of James River, 2 Miles below Balcony Falis.

Painted by John H. B. Latrobe................. 482

John H. B. Latrobe. At the Age of $54 \ldots \ldots \ldots \ldots \ldots \ldots . \ldots 90$

Prince Gortschakofr. . . . . . . . . . . . . . . . . . . . . . 498

*Falls of the Ohio. Painted by John H. B. Latrobe....... 514

Wassily and Piotter. Servants of John H. B. Latrobe... 526

Receipt Given to John H. B. Latrobe. As one of the Sub-

scribers to the first Telegraph Company ever Organized. . 548

*Memphis, Mississippi, 1832. Painted by John H. B. Latrobe. 560 


\section{JOHN H. B. LATROBE AND HIS TIMES 1803-1891}

\section{CHAPTER I}

Benjamin H. Latrobe, Father of John H. B. Latrobe ARRIVES IN THIS COUNTRY, 1796-DIFFERENCE IN TRANSportation AND Communication, due to Steam aNd Electricity-The Civilization of the Nineteenth Century owes its Great Advancement to this-The Elder Latrobe Architect of Capitol-Social Life IN Washington-First Trip by Steamboat down the Mississippi IN 1812, MADE By Nicholas J. Roosevelt and Lydia Latrobe, his Wife, the Sister of John H. B. Latrobe-Fulton's Claim as Inventor of Steamboat

John H. B. Latrobe was the eldest son of his father's second marriage. He was born in Philadelphia on the 4th of May 1803, and died on the 11th of September 1891, at the age of eighty-eight. His father, Benjamin H. Latrobe, was born in England in 1764. His first wife was Lydia Sellen, whom he married in 1790. She died in 1793, leaving two children, Henry S. and Lydia; and two years later Mr. Latrobe sailed for America, embarking on Christmas Day, 1795. He reached Norfolk on the 17th of March 1796, almost four months from the date of his leaving England.

In those days the world moved slowly. No change had been made in methods of transportation and communication prior to the beginning of the nineteenth century. It took as long to travel from Paris to London in 1810, as it did in the time of Julius Caesar. The nineteenth century 
was destined to be the period of the world's greatest progress; which was embraced in the life of the subject of this memoir, 1803 to 1891, and was due to the development of rapid transportation, accomplished by steam, and rapid communication by electricity. In both of these John $\mathrm{H}$. B. Latrobe took an active part.

In Mr. Latrobe's "West Point Reminiscences" we find the following:

"In December 1817, when I was fourteen years old, I was appointed a cadet and directed to report myself at West Point for examination in September of the following year. On my last visit to West Point, in 1886, I left Baltimore in a luxurious railroad car, between 8 and 9 o'clock a.m. and dined the same day at the West Point Hotel, at 5 p.m. In 1818 I left Baltimore between 8 and 9 o'clock a.m. in one of the earlier steamboats and reached Frenchtown towards evening, when I was carried by stage across the Peninsula to New castle, where I slept; and on the following morning reached Philadelphia by a Delaware River steamboat, about noon. The next day a steamboat took me to Trenton, and by stage again I got to New Brunswick where I slept; and the day after by another steamboat I was landed in New York.

"At this time, there were but four steamboats on the Hudson. - . . I was told at the hotel where I dined that if I took an Albany sloop, numbers of which were at the wharves close by, I would reach West Point in season for breakfast the following day. . . . . I thus began what might have been called the seventh instalment-by steam, stage and sail-of a journey which had grown to be as important in my eyes as though I had been Hendrick Hudson himself, seeking by this route a highway to Cathay." 
In order to give an account of Mr. Latrobe's early life and associations, it is necessary to consider the character and life of the elder Latrobe, at least from the time of his landing in this country at Norfolk in 1796 to his death in New Orleans in 1820. He had passed three years at the University of Leipsic, one of the leading Universities of Europe. He subsequently studied architecture and civil engineering and was appointed Surveyor of public buildings in London. He was offered the office of Surveyor to the Crown, with a salary of $£$ r,oo० per annum; but the death of his wife and his desire to cast his lot in a new country led him to decline this offer, and, as above related, we find him in Norfolk, Va. He left Norfolk and went to Richmond, in order to investigate the James River navigation. During his stay in Virginia he made several surveys for the Dismal Swamp Company. He visited President Washington at Mount Vernon. Like his son, John H. B. Latrobe, he was a great admirer of beauty, and his tribute to Miss Custis shows his high appreciation of that lady's good looks. He writes as follows:

"Miss Eleanor Custis, the only one of four sisters who is unmarried, has more perfection of form, of expression, of color, of softness, and of firmness of mind than I have ever seen before, or conceived consistent with mortality."

While in Virginia, he designed the penitentiary, reported upon the Appomattox and James Rivers and designed a number of houses in Richmond. He left Virginia in $\mathrm{r}_{798}$ to live in Philadelphia. There he was employed to build the Bank of Philadelphia; and he also superintended the introduction of the water supply into the city. The Bank of Philadelphia is the work most strongly relied upon to establish Mr. Latrobe's reputation as an architect of high merit. The compliment which he treasured most and which 
he has taken pains to record is a criticism which he overheard in a conversation between two French officers who were looking at the building. One exclaimed: "C'est beau, et si simple."

It was in Philadelphia that he met the lady he made his second wife, Mary Elizabeth Hazlehurst, daughter of Isaac Hazlehurst who was the partner in business of Robert Morris, the great financier of the American Revolution. He made his residence in Philadelphia until the year 1807 . He was engaged in 1803 in making a survey and route of a canal to connect the Chesapeake and Delaware Bays. He had reported it as feasible in 1799. He was then called to Washington by President Jefferson and employed to complete the Capitol, commenced under the administration of General Washington. Mr. Latrobe moved among the best people of the day. He was a highly educated man; had command of several languages; was a naturalist of considerable reputation, and, like his son, was a man of many accomplishments.

In the "Journal of Latrobe," published by D. Appleton \& Company in 1905, Mr. Benjamin H. Latrobe gives an interesting account of the habits of the mud-daubers, a species of wasps.

"As a boy I was fond of collecting spiders, and in an old, abandoned stone house, minus the window frames, I found the mud-daubers had constructed their nests, generally consisting of three cylinders of mud. An egg was laid in each outside cylinder, and the center cylinder was filled with the most beautiful spiders. These seemed to be stupefied-not dead. Here they awaited their fate. The egg hatches into a grub or worm-the grub eats through the division wall, and consumes the spiders.

"There is much discussion as to whether insects and 
animals act from reason or from instinct. The results are the same.

"There are two other instances which have come under my observation where insects show great intelligence or great instinct. One is the case of the ant eater ( $I$ do not know its proper name). A small insect of very slow locomotive power, about one-half the size of the thumb nail, with strong mandibles or jaws, incapable of securing his food except by strategy. It is very difficult to detect the insect in the dust. Its color (brown) gives it the same complexion as the dirt it lives in. Under the eaves of the houses in the country where the ground is protected from the rain, it digs a pit-a funnel shaped affair. At the bottom, or what would be the apex of a cone, it takes up its position. Woe to the ant that attempts to pass along the sloping sides of the inverted cone. Immediately a cloud of dust appears-the ant eater fillips up with its legs and feet small particles of sand, which striking the ant, he is carried down and disappears. Like the hunter who met the bear, there are no remains.

"The other case is that of the caddis-fly. In its pupa state, it is a water insect, built somewhat like a wasp. The head and body from which the legs emanate are hard and horny. The tail of the portion of the body which contains the abdomen, connected by a slender wasplike waist to the rest of its anatomy, is soft and mushy. Almost any attack would result fatally. This insect makes a most beautiful cylinder of mosaic work, cemented together-open at one end, and closed at the other. It backs its vulnerable body into this, and with a coat of mail is ready for the battle of life, and its enemies are unable to destroy it."

A description of the elder Latrobe is contained in a letter written by his son John H. B. Latrobe to his cousin, John Frederick Bateman. 
"8 June, 1870.

"My dear Cousin

"I have forwarded to your London address a copy which I made of Reinhart Peale's very poor portrait of my father, the only merit of my work being that it is pretty nearly a facsimile.

"My father was 6 feet 2 inches, of erect and military carriage. In repose his face was almost dull. In conversation it was all animated, and his listeners thought him handsome. His hair was very dark, with a slight wavy curl. He spoke most living languages-German, French, Spanish, Portuguese and Italian with fluency, and understood most dead ones, Greek and Latin thoroughly, and knew a good deal of Hebrew; was a clever poet and an accomplished musician."

Benjamin H. Latrobe writes in Virginia, May 31, 1796.

"I have had considerable pleasure since my arrival here in attending the different courts of justice held in the Capital."

He then discourses upon the absence of wigs in America, and says that in England 'about a century ago a full bottom wig was as necessary to a beau as at present a tight pair of pantaloons are to a Virginian.' He then ridicules the wigs. The ladies of those days, not to be bested in the adornment of their heads, built up magnificent structures, works of art, which could not be done away with, but remained so built for some time; with dire results in some cases, for in Coke of Holkham we find in Vol. 1, Folio 232: 'Did you hear that my cousin Mrs. Coke was brought to bed of a dead son, occasioned by fright. A mouse got into her night cap and demolished the heir of Holkham.' The head dress having once been built, remained so, and by reason of the poma- 
tum used in its structure was attractive to mice, as well as men.

Quoting from the elder Latrobe's diary we have an interesting description of the three leading lawyers of VirginiaJames Innes, John Marshall, afterward chief Justice, and Edmund Randolph.

"Mr. James Innes, Attorney General of the State (also a Colonel), ranks, I think, first in genius, in force of thought, in power of expression and in effect of voice and manner. He is at the same time a man of the most amiable and benevolent disposition, open, generous and unreserved; more I think of the character of Charles Fox, than any other man I ever knew. His only fault is indolence. He has been known to return a fee of ten guineas, because he had neglected, from mere indolence, to give a short opinion and cared not to leave his bed, in which he was reading, to consider the case. Speaking of his first-rate abilities to Jack Stewart, he gave this opinion upon them, which I believe to be founded on truth. 'Sir,' said he, 'you admire Innes with good reason, for you have heard him only speak on the right side. Your opinion would change were you to hear him defend a bad cause. You would find him so embarrassed and embroiled with the honesty of his own heart, as to make no hand at all at it.' A gentleman, who was present, repeated to me the following close of a speech upon liberty of conscience made some years ago in the Virginia Assembly. 'May she' said he, 'lift her head to the footstool of the Almighty, may the whole earth be covered by her mantle, and may she embrace all human nature in her arms.' Has Demosthenes anything more sublime? The public opionin gives then next rank as an orator to Edmund Randolph, ci-devant Secretary of State. He speaks slowly, smilingly, in a musical voice with selected phraseology, a polished gentle manner, and with a plentiful 
flow of words. But his slowness gives his hearer time to anticipate, and renders him impatient for the end of his period. His smiles seem only to swim on the surface of his utterances. The sweetness of his tones does not reconcile one to a corrected turn of language and a selection of words apparently laborious. His manners seem to have been polished in the school of dissimulation, and the storehouse of his words seems to be his head, not his heart. At the instant he labors to persuade the jury he seems to be unconvinced himself, and to be ignorant that ars est celare artem. The coarse praise bestowed by a countryman upon James Innes will never be earned by the quondam secretary- 'He has his belly full of words and they come pouring along like a great fresh.' Perhaps he would have said 'Randolph has his head full of words, and there seems to be no end of them.' Considering all the circumstances of the political history of Edmund Randolph, I cannot help thinking the political allusions in his speeches upon all sorts of law cases are ill-judged. In the case of Tayloe, in which a suit was commenced to divide equally among his sisters, upon the principle of a late law, the property bequeathed by his father many years ago (1772), he said, pleading for the equal division, that 'his cause was the cause of the God of nature against the Demon of Aristocracy.'

"John Marshall (a general of militia) is inferior to Edmund Randolph in voice and manner, but for talent he substitutes genius, and instead of talking about his subject, he talks upon it. He possesses neither the energy of expression nor the sublimity of imagination of Innes, but he is superior to every other orator at the bar of Virginia in closeness of argument, in his most surprising talent of placing his case in that point of view best suited to the purpose he aims at, throwing a blaze of light upon it and of keeping the atten- 
tion of his hearers fixed upon the object to which he originally directed it. He speaks like a man of plain common sense, while he delights and informs the most acute. In a less captivating line of oratory than that which signalizes Innes, he is equally great and equally successful. The jury obey Innes from inclination, Marshall from duty.

"Mr. Bushrod Washington is my friend. Could I think impartially of him, I might place my judgment upon paper as of value. The public voice places him in the triumvirate of eminence with Innes and Marshall.

"N. B. This opinion (as regards Mr. Randolph) was written before I had any personal acquaintance with Mr. Randolph, while I was prejudiced against him. It is correct as to the effect of his speaking. But notwithstanding the partial view of his character, which at the time I wrote was unavoidable and is here exhibited, I freely acknowledge that my subsequent intercourse with him placed him in a light infinitely amiable. To respect, nay, to love Mr. Randolph, it is only necessary to see him at his fireside-the father, the husband and the friend." $*$

Mr. Latrobe frequently visited Washington. It was in 1798 that he first met Dr. Wm. Thornton, who was then one of the commissioners of Washington City. Dr. Thornton was an Englishman born in the West Indies. He invented

*Edmund Randolph was Secretary of State under Washington, when the Jay treaty between the United States and England was pending. The French party headed by Jefferson was outspoken in their opposition to any treaty being made with England. M. Fauchet, the French minister, wrote a number of letters in which he referred to statements made to him by Edmund Randolph, which, if true, were, to say the least, very indiscreet. These letters being brought to Washington's attention, he sent for the Secretary of State and asked for an explanation of Mr. Randolph's connection with the matter. The latter thereupon sent in his resignation the same day, August $19, \mathrm{r} 795$. He made a statement intended as a 'vindication', but it failed of its purpose; and his public career came to an abrupt termination. Moncure D. Conway defends Edmund Randolph in a work entitled 'Papers of Edmund Randolph, \&c.' 
a flutter wheel steamboat, and accused Fulton of having wrongfully deprived him of it. He was the first Superintendent of the Patent Office, and a man of genius and social accomplishments. His wife was a Miss Bordeaux, who had come to America from France. (Folio 1-S. H. Smith.) His plan of design of the Capitol was selected by President Washington. Dr. Thornton was a man of talent, but he was not an architect; in fact, he admits that his knowledge of architecture was most limited. Mr. Latrobe took charge of the building of the Capitol in 1803. He was furnished with a copy of the plan, which was perfectly useless. There were no details whatever, and in the Superintendent's office no drawings existed. In the United States at this time the functions of an architect were little understood; very little attention was given to the construction or designs of buildings. Mr. Latrobe found himself much harassed by adverse criticism made by persons absolutely ignorant of the duties of his position. In the debates in Congress he was designated as a contractor. He says in one of his letters that he wished that he had been a contractor, then he could have put money in his pocket; for the result of the performance of his duties for the magnificent sum of $\$ 1,700.00$ per annum had left him poorer than when he undertook the work. This compensation was subsequently increased to $\$ 3500.00$ per annum. Mr. Latrobe, while engaged in this work, invented what has been termed a new order of architecture, namely, designs applied to the capital of a column, representing corn in one instance and the tobacco plant in the other, which evoked much favorable comment. Mr. Latrobe, in his correspondence with Mr. Jefferson, describes these columns. As an appreciation of their beauty, Mr. Jefferson had several small columns of similar design placed in the portico at Monticello. The capital representing corn was introduced 


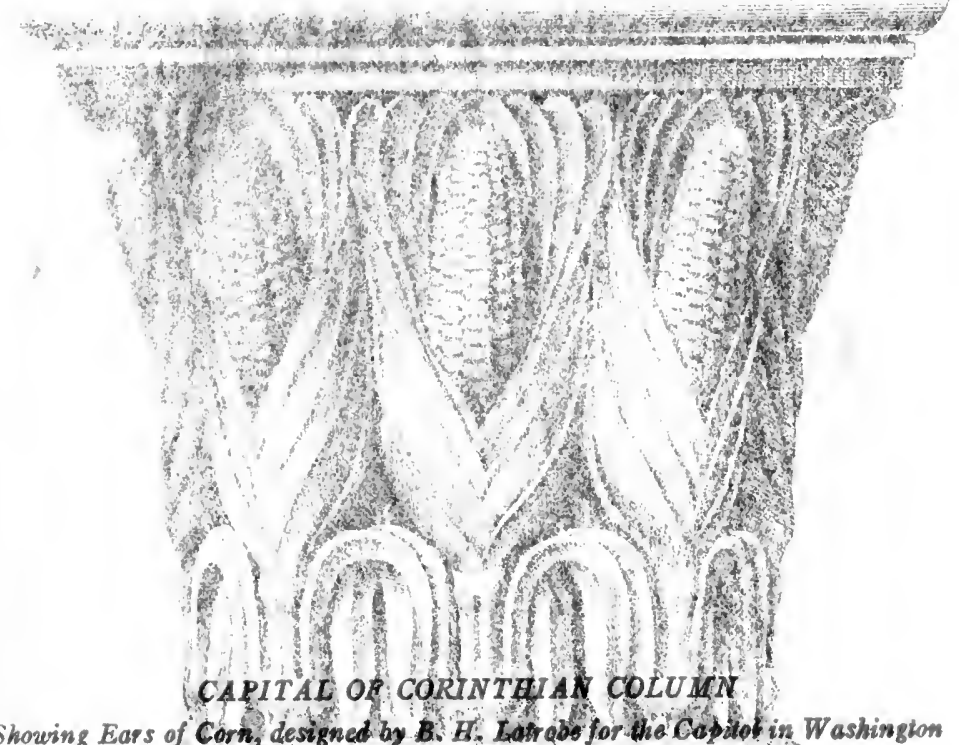
Showing Ears of Corn, designed by B. H. Lat abs for the Captet in Washinghon

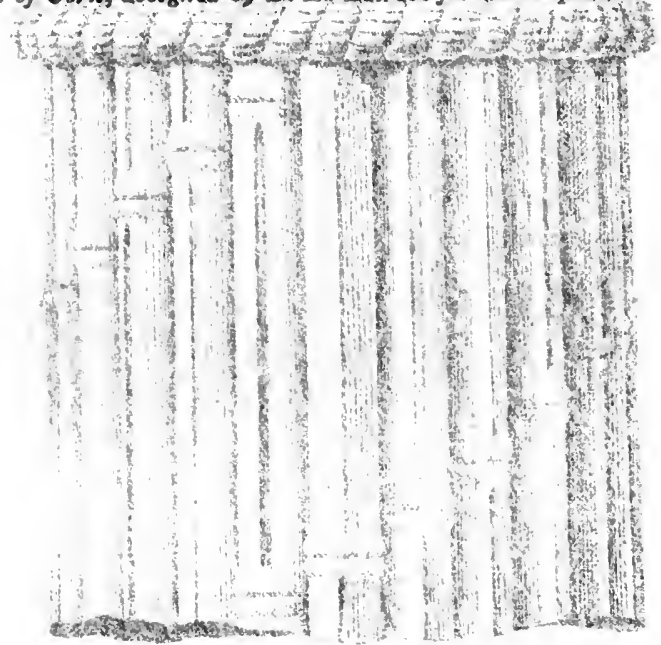




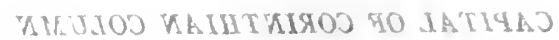

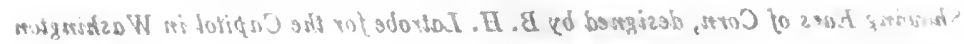




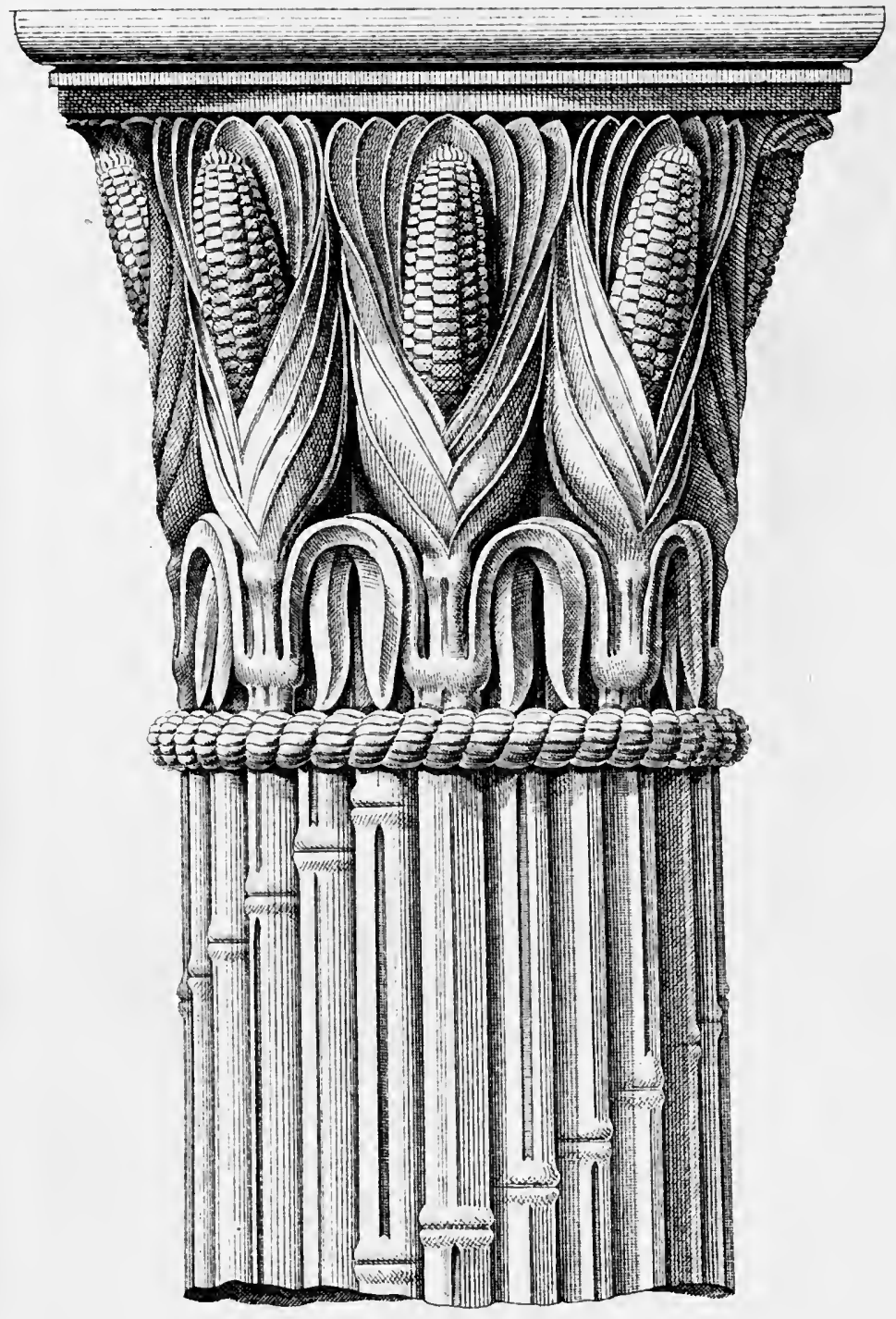



in the reconstruction of the Capitol after the fire in the North Wing. This reconstruction was superintended by Mr. Latrobe in 1815 to 1817 . The tobacco columns are found in the corridor arcade, North Wing.

Mr. Latrobe, in a letter to Mr. Jefferson in 1809, refers to the capitals representing "Indian Corn", saying that the Congressmen spoke of them as "corn-cob capitals." Mr. Robert Dale Owens wrote to Mr. J. H. B. Latrobe on May 27,1848 , in reference to these capitals, asking for the original drawing, which was sent him. He stated in this letter that he was preparing a small volume on "Public Architecture" for the Smithsonian Institution.

The writer of these memoirs was employed by Mr. John H. B. Latrobe to make a copy of the correspondence between Mr. Jefferson and Mr. B. H. Latrobe and others engaged in the construction of the Capitol. Constant complaints were answered by Mr. Latrobe in a courteous way. Some criticism was made about the strength of an arch, Mr. Latrobe asserting it was not strong enough to stand the weight which would be imposed upon it, while the other party to the controversy claimed that it was. Among the correspondence is a letter written by Mr. Latrobe, in which he states that a few days before the arch had fallen and crushed its advocate; so this controversy was ended.

The novelist, Charles Dickens, on his first visit to America, made great fun of our architectural efforts. Mr. Henry Van Dyke, speaking of American architecture, as exemplified by the bumptious looking and much bedecked cottages one sees asserting themselves in all their hideous ugliness, says that the English may have the "Wren" architecture, but we have the "English Sparrow" architecture. One never sees one of these absurd and aggressive looking buildings without thinking how highly appropriate was this description. 
Mr. Latrobe continued to work at the Capitol until 1811, when the funds were exhausted.

He was thrown with the leaders of society. I have before me a letter to his wife dated November 30,1802 , when he dined with the President, who repeated a rather risqué story, and another letter of March 18, 1807, in which he describes a dinner at the President's and the company he met there. These letters are both inserted as matters of interest.

Addressed to Mrs. Latrobe, Arch Street, Philadelphia:

"Washington, November 24, 1802.

"Having employed my morning in my business I went to dine with the President. His two daughters, Mr. and Mrs. Madison, Mr. Lincoln (Attorney General), Dr. Thornton, a Mrs. Carter from Virginia, and Captain Lewis (the President's Secretary) were the party. The dinner was excellent, cooked rather in the French style (larded venison), the dessert was profuse and extremely elegant, and the knicknacs, after withdrawing the cloths, profuse and numberless. Wine in great variety, from sherry to champagne, and a few decanters of rare Spanish wine, presents from Chevalier D'Yrujo. The conversation, of which Mr. Madison was the principal leader, was incomparably pleasant, and though Mr. Jefferson said little at dinner besides attending to the filling of plates, which he did with great ease and grace for a philosopher, he became very talkative as soon as the cloth was removed. The ladies stayed till five, and half an hour afterwards the gentlemen followed them to the tea table, where a most agreeable and spirited conversation was kept until seven, when everybody withdrew. It is a long time since I have been present at so elegant a mental treat. Literature, wit, and a little business, with a great deal of miscellaneous remarks on agriculture and building, filled every 
CAPITAL OF CORINTHIAN COLUMN

Showing native tobacco plant leaves designed by $B$. $H$. Latrobe for the Capitol in $W$ ashingtors 


\section{\%UUJOJ VAIHTWYROO 70 JATTMAJ}

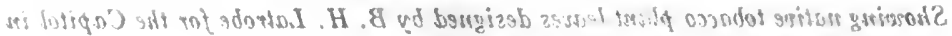
notgrisatzo $\mathrm{H}$ 


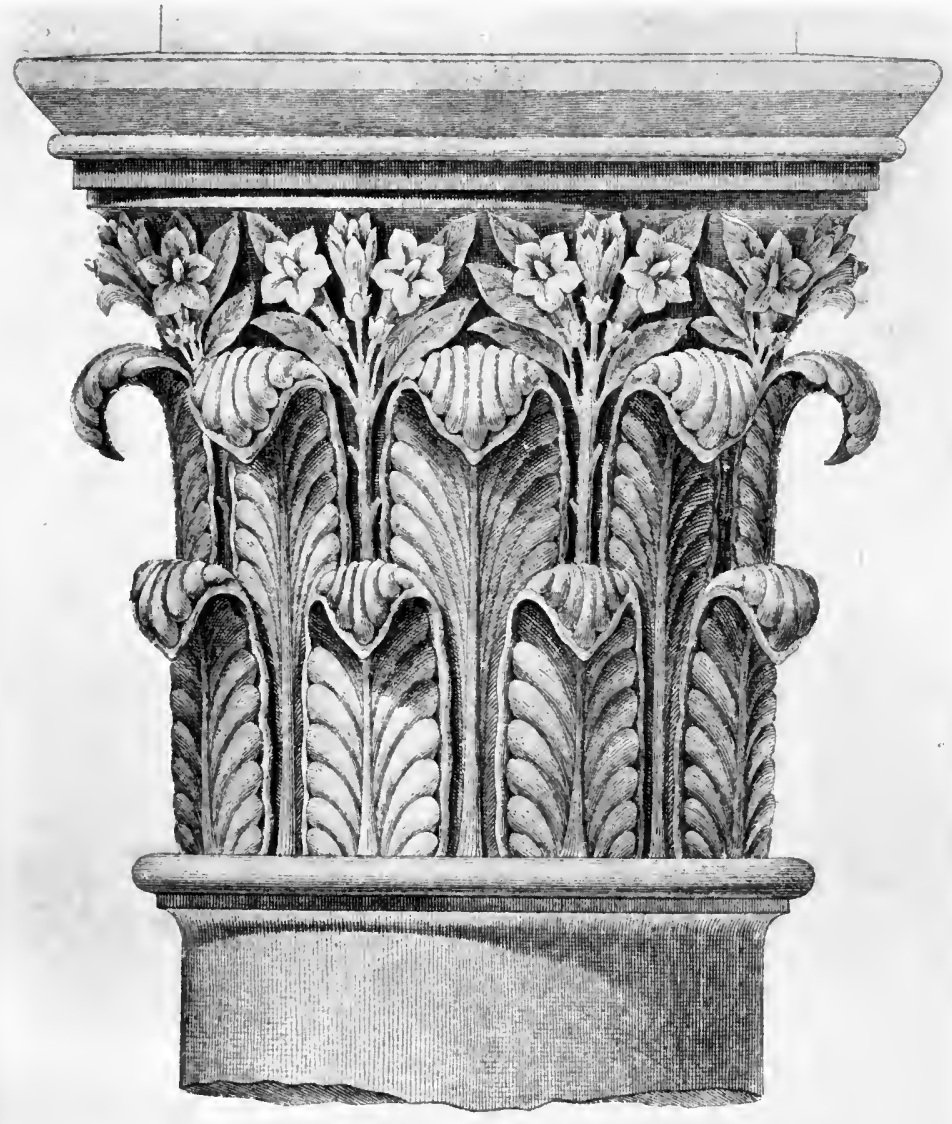



minute. There is a degree of ease in Mr. Jefferson's company that every one seems to feel and to enjoy. At dinner Mrs. Randolph was asked by Mr. Carter to drink a glass of wine with him, and did so. Mr. Jefferson told her she was acting against the health law. She said she was not acquainted with it, that it must have passed during her absence. He replied that three laws governed his table-no healths, no politics, no restraint. I enjoyed the benefit of the law, and drank for the first time at such a party only one glass of wine, and, though I sat by the President, he did not invite me to drink another."

"Washington, November 30, 1802.

"My dearest Mary:

"I had dined with the President, his invitation was to meet a small party of friends; accordingly I found only three besides myself. . . They were all men of science. . . The conversation turned on the best construction of architecture. The difference between the French and English habits of living as far as they affect the arrangement of their houses. . . On several new experiments on the property of light; on Dr. Priestly; on the subject of emigration; on the culture of the vine; on the dishonesty of Peter Legox and his impudence; on the domestic manners of Paris, and the orthography of the English and French languages. By this time the President became very entertaining, and told the following story:

"A number of Englishmen and some French ladies with their husbands were assembled at Dr. Franklin's, who spoke wretched French. Dorcas, whose proficiency was not much greater, undertook on several points to set him to rights, and had become very ridiculous by some of her corrections. At that moment, Temple Franklin* entered and, in one of

* Temple Franklin was the son of Wm. Franklin, the illegitimate son of Benjamin Franklin. He died in Paris in 1828. 
his freaks of assurance, kissed the lady who stood nearest to the door, and then went round the room saluting each of them, and last of all he kissed Mrs. Jay. Mrs. Jay, not used to such gallantry, blushed so deeply that Dr. Franklin, observing it, asked why she blushed. Mrs. M. immediately answered:- 'Parcqu'il'a lui baisé le derrière instead of la dernière.' Poor Dorcas might as well have used the broad English phrase of Moll Turner.

"The races have brought hundreds to the City, and among the rest Judge and Mrs. Washington, who called upon me for ten minutes and appeared, and I am sure were, so unfeignedly glad to see me, that I have not felt so much pleasure since I left home. You are absolutely bespoke for Mt. Vernon, and no denial is to be taken."

Another letter by Mr. Latrobe to his wife:-

"My dearest Love:

"Washington, March 18, 1807.

" . . Last night I sat up after dining at the President's till twelve, studying the plan for laying out the ground around the President's house.

"Yesterday, as I said, I dined with the President. The party consisted of the Secretaries of State, War, Treasury and Navy; the Attorney General, Rodney; the Vice-President (Clinton); Senator Gillman, (Count Camomile), General Mason, Mr. Law, Mr. Purviance (the bearer of the treaty) and myself. . . On Saturday I am to dine with Mr. Erskine. To Mr. Gallatin's, Smith's, Madison's I have general invitations, none of which $I$ have been able to accept.

"Mr. Erskine called on me today, and had a long chat about the treaty. He said that there was no objection, excepting the article about our seamen, to prevent its ratification, 
THOMAS JEFFERSON

Drawn by B. H. Latrobe 


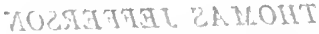

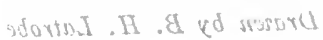



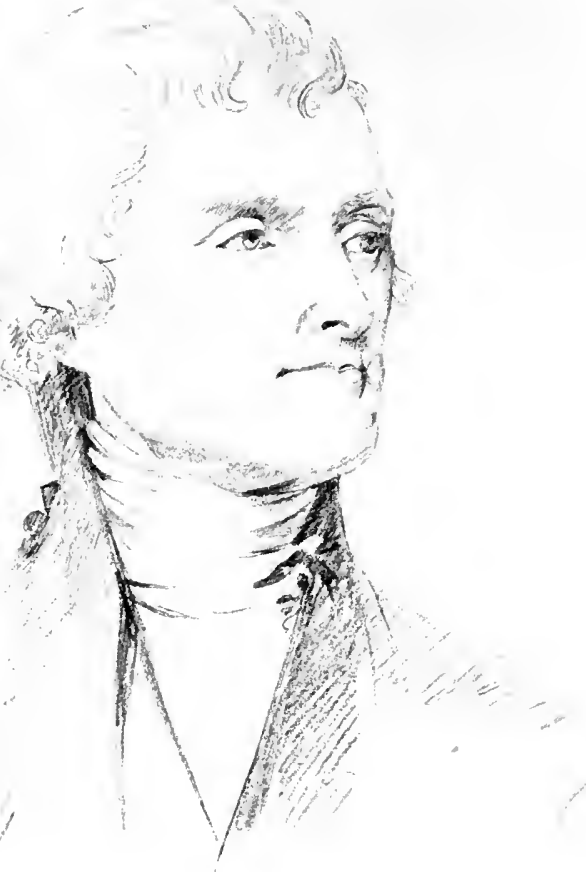

and that the President and Secretary of State have treated him as politely as could be expected. It will not be sent back."

This treaty was sent back, however, and the controversy ended in the war of 1812 between the United States and Great Britain for free trade and sailors' rights. The Mr. Erskine referred to was the British Minister.

The following letters, written by Mrs. Latrobe to Juliana Miller of Philadelphia, are here inserted, the object being to show the atmosphere and character of the home of Mr. John H. B. Latrobe.

"Washington, February 17, 1812.

"You will be surprised, my dearest Juliana, at so early a reply to your letter. It is not ten minutes since $I$ received it, but it is a gloomy day and I am alone, except our children, and my husband is away on business. I was not surprised at M- $\mathrm{n}$ 's death, having heard from my brother of his illness. Mrs. M- $\mathrm{n}$ has surely a clear conscience; having fulfilled her duty to two most detestable husbands, she has the more merit.

"As to the gaiety of Washington, you are quite misinformed. The City was never so dull as this winter. The Drawing Room was the only place of gay resort, except the two Balls given by the French and English Ambassadors. They have each given two to which we have been invited; and went over to Serrurier's; and this night week over to Foster's, where we saw a number of our Philadelphia friends and many from New York. We spent a charming rational evening for those who did not dance. There was a room provided with all the new publications and new prints; and at one time there were as many as twenty persons engaged in reading. There were six or seven rooms opened for the evening, 
all filled; some of the company were dancing, others reading, conversing, etc. In short, the novelty of the entertainment made it charming and far superior to the French Minister's ball. Foster having resided here formerly as Secretary of Legation to Mr. Merry, can accommodate himself to our manners."

(Perhaps Mr. Foster viewed our manners as Oscar Wilde did when he made one of his characters, an American, say, "We have no ruins, no curiosities in America." "No ruins, no curiosities!" answered his host. "You have your Navy and your manners.")

"I have just parted with a very pleasant girl who has been staying ten days with me-Sophia May, sister to our friend the Doctor. We have given three evening parties within the last six weeks. One was of forty strangers and natives; and on Saturday evening we had a most agreeable musical party of about twenty-five. Young Dallas and R. Bache were among them, and Derby who sings so delightfully. Mrs. Otis from Boston, who has two daughters who sing and play to admiration. The Hanson family also very much excel in their performance. Madame Bonaparte and Miss Spear and young Garaman, Secretary to the French Minister, who plays with wonderful execution. The Hamilton family were all here and a number of beaux. Count Gilman (my old slave); a number of officers, etc. In short, I do not know when I have passed so rational and delightful an evening; every one was gay and pleased. Harper is here at present; he dines with us on Sunday always, and also Fulton, who has been here for three months past; he took Sophia home in his carriage last evening. On Thursday there is a grand ball at the Marine Barracks given by the officers; we are invited. We were last week at a dance given by the officers of the Enterprize in the great sail loft of the Navy Yard; 
the insufferable smell of tar gave me a headache, or I should have spent a pleasant evening.

"We are about to remove from our present habitation to a larger house on Pennsylvania Avenue. We shall be very near the Hamiltons and not far from the President's; and, what is equally agreeable, we shall be very near the market and can offer you, my dear Juliana, a much better accommodation than when you were last here, as I count upon seeing you before a great while. Mrs. Rush is to live in Georgetown. I know nothing of them, as the distance is great; but I rather think she has not arrived, as I saw him alone at the Drawing Room.

"We have had several smart shocks of an earthquake, which to me are awfully alarming. I felt two. We (Latrobe and myself) were awoke at the same moment with the rattling of our chamber door at four in the morning. They have providentially done no damage. I have no idea of the noise proceeding from an earthquake, but thought it proceeded from the moving about in the next house, as I knew our neighbor, Mrs. Ben Sprigg, lay dead at the time, and thought the sitters-up were walking. I was extremely shocked the next day to learn the cause, having all my life been inexpressibly afraid of an earthquake. Mrs. Crawford is well I believe; I saw Tom at Mr. Foster's ball. She spent a week in the City some time ago, and I have not since seen her. I think Claiborne's marriage will be a shock to Mrs. W-_ f, for it is a fact that two months ago she informed me she expected him, and should then make her mind up whether or not to receive him as her future husband. Henry took with him the two monuments for his former wives."

Notes by John H. B. Latrobe.

"Went over to." A phrase justified by the distances then to be travelled in Washington. 
"Sophia May." This lady was the grand-aunt of Colonel Charles May of Mexican fame. The family is now Baltimorean. Doctor Frederick May attended my mother when my brother Ben was born.

"Young Dallas." A son of Alexander J. Dallas, Secretary of the Treasury.

"R. Bache." Known to my recollection as "Dick Bache," a nephew of Dr. Franklin, and celebrated as a wit.

"The Hamiltons." A well known and distinguished family in social life, from Philadelphia.

"Harper." Robert Goodloe Harper, then in the Senate from Maryland, with whom I studied law ten years later.

"The Enterprize." Subsequently celebrated for her engagement with and capture of the "Boxer" in 1813.

"Claiborne." William C. Claiborne, afterwards Governor of Louisiana. The designs for the monuments were made by my father, and the "Henry" mentioned was my half brother by my father's first marriage in England.

It was probably at the theatre where took place the fight mentioned in one of these letters, that Mr. John H. B. Latrobe received his first impression of a theatrical performance, described in one of his addresses hereinafter referred to.

Addressed to Juliana Miller, 185 Walnut Street, Philadelphia:

\section{"My dear Juliana:}

"Washington, February 10th.

"When you see Mr. Ewing tell him we are more than ever pleased with Irving; we find him a charming acquaintance. - . . On Thursday we had quite a collection of men of talent to dine with us-Bayard, Gardinier, Harper, Morier, Politica, Irving, Warden and Caldwell (our neighbor). . . You know Bayard is very eloquent and Harper first-rate. You would be charmed with Morier, he drives an elegant 
equipage and is an unaffected, amiable man, and is thought extremely handsome; visits us frequently. . . On Wednesday they all appeared at the Drawing room, we also went there. I made a dash in a new white satin, the piece you purchased for me in Philadelphia, and made up in my usual way, with a long train; on my head I wore the new lace handkerchief you sent, thrown carelessly over a white lilac that was put on the left side of my head; white shoes, and I certainly was no despicable figure as Dubster would say . . . Macon has moved that Latrobe, as surveyor of public buildings, be called upon by the President to give an estimate of what it would cost to complete the whole Capitol, centre and all. I did not forget your message to Mrs. Madison."

Another letter to the same party:

"Washington, June 27th.

"Dear good little Mrs. Breck was here, and my great friend, Mrs. Custis, . . says Mrs. Lloyd is getting well. It was my intention to have called upon her this morning, but our coachman (David) was not very well, and I did not like to take him into the hot sun.

"My husband and myself are quite dull at the departure of Minister Foster. This inevitable war has indeed produced a great change. The French Ambassador is the only person who seems in good spirits, and he was here a few evenings ago in high glee.

"Foster passed our house yesterday on his way to New York, in his chariot and four. His Secretary, Mr. Baker, remains here a month longer. . . We were at a party at Walter Jones', the District Attorney's, a few nights ago. . . We dined at the President's on Tuesday, with a company of thirty. . . Charles Goldsborough and his two daughters were there. They are charming girls. We drank tea with 
Mrs. Eustis last evening. . . I have just received a long epistle from her friend De Calve, who is Ambassador to Stockholm. Mrs. Madison has a profusion of elegant things. Among these affairs a cambric dress at $\$ 130$, only a wrapper. We are near neighbors to Secretary Hamilton. They ask after you always and are most kind and good people. We are frequently together."

(This was Paul Hamilton, Secretary of the Navy during Madison's first adminstration.)

"The theatre is nearly opposite to our present residence. They have full houses. Many of the members of Congress, never (I suppose) having seen a play, avail themselves of it. There was a terrible riot last evening, owing to the musicians refusing to play "Hail Columbia." One of them called out "Play Foster's March," upon which Sam Ringgold threw a bisket at him, and another gentleman, Mr. Howell of the Senate, caught him by the collar and dragged him over the railing. A terrible battle ensued which ended in an apology from Warner and an order to start up "Hail Columbia," which was played so long a time that most probably none of the audience will ever wish to hear it again."

Extract of a letter from Mrs. Latrobe to Mrs. Juliana Miller, dated December 14, 1812:

"The dullness of the City has, however, been revived, in some degree, by a splendid entertainment on board the frigate Constellation. We were invited to be there at eleven to pass the day. The vessel lay about half a mile from the shore, and two very elegant barges of twelve oars conveyed the company. This was the only unpleasant part of the amusement; for the day proved extremely cold and a high wind was blowing. However, we all arrived safe about twelve; and the deck was closed in with flags, awnings, etc., 
and two stoves so effectually heated it as to make the temperature delightful. The dancing soon commenced and continued till three, when the boatswain's whistle called us to a magnificent dinner below. The President and Mrs. Madison were seated at the end of a very long table; but I cannot tell you all the company and can only say that the number was said to be 500. After dinner the dancing commenced again and continued till about six in the evening, when the company broke up. On Tuesday a very splendid ball was given to the Navy Officers-Hull, Morris, Stewart, etc. My husband could not be absent as he holds an office in the Navy Department, and I was not sorry we went, as it is not likely that I shall ever witness such another scene. At about five in the evening my husband came home and informed me that we must immediately illuminate our house, as the account of a victory gained by Commodore Decatur had just arrived. My house in ten minutes was prepared for lighting up, and we prepared for the ball. The avenue was very brilliant on our way to the Capitol Hill, and the company assembling, the crowd was immense. Mrs. Madison was there, but not the President. The evening went on with crowded dancing and treading as usual upon the toes and trains of those that did not dance; when about ten o'clock a loud huzza announced the arrival of young Archibald Hamilton, who had that moment appeared with the colors of the Macedonian. He was borne into the room by many officers. Good little Mrs. Hamilton, his mother, stood by me, and was so much agitated at the sight of her son that she must have fallen, had I not stepped forward and offered her my arm. The young man sprang into her arms; his sisters threw their arms around him, and the scene was quite affecting. The colors were then held up by several gentlemen over the heads of Hull, Morris and Stewart, and 'Hail Columbia' played and there were huzzas until my head swayed. 
"The aforesaid colors were then laid at the feet of Mrs. Madison. Oh tempora! Oh mores! This was rather overdoing the affair. I forgot to say that the flag of the "Guerrière" was festooned on one side of the room, and of some other vessel. Now, between ourselves, I think it wrong to exult so outrageously over our enemies. We may have reason to laugh on the other side of our mouths some of these days; and, as the English are so much stronger than we are with their Navy, there are ten chances to one that we are beaten. Therefore it is best to act moderately when we take a vessel; and I could not look at those colors with pleasure, the taking of which had made so many widows and orphans. In the fullness of my feelings, I exclaimed to a gentleman who stood near me, 'Good heavens, I would not touch that color for a thousand dollars', and he walked quickly away, I hearing the gentleman say, however, 'Is it possible, Mrs. Latrobe?' I looked around, and it was a good staunch Federalist from Rhode Island, Mr. Hunter, so that I shall escape hanging after so treasonable a speech. I came home with a raging headache at twelve, and went the next evening to the Drawing Room by way of curing it. I must not fail to leave room to announce the marriage of Commodore Tingey, who was united to Miss Dulany, on Wednesday evening, after they had been engaged three weeks. She is twenty-eight and he 61. He gives a ball tomorrow evening. We are invited, but are engaged at Madame Bonaparte's and on Thursday at the French Minister's. Madame Dashkoff is here, but does not entertain; she is a charming woman. My time is fully accupied, not a moment of the day is spent in idleness. I have undertaken the education of my children; the schools here are miserable. You remember John; he used to go to school in the neighborhood to an Irishman, where he learned the brogue so completely that it has taken 
me six months to cure him of it. Julia is so amiable, and is of so fine a capacity that she is easily taught; Ben is a little refractory."

From John H. B. Latrobe's notes we have:

"My earliest recollection of my father and mother dates from the Navy Yard House. The occasion was their appearance when dressed for a 'Drawing Room' to which they were going at the President's. I remember well a tall striking looking person, six feet two inches high in fact, in black, wearing knee breeches and silk stockings with silver buckles in his shoes, erect as a soldier, and, without being handsome in the face, of distinguished carriage. My mother was as distinguished in her appearance as my father was in his. She was a very tall woman, five feet eight inches, and had always been celebrated for the beauty of her figure. Her face was in no ways remarkable. She had been a leading belle in Philadelphia, and had the air of a woman of fashion of that day. On this occasion, she was dressed in white satin with a long train, and wore a turban of spangled muslin with a gold crescent, fastening a heron's upright plume. After an interval of more than seventy odd years, I can still, in my mind's eye, see my father and mother in their full dress on this particular occasion. They must have been regarded as a very noble looking pair; and so they were, as I have always understood.

"My grandfather was the partner in business of Robert Morris, the great financier of the American Revolution. The firm had bought the 'Alliance' frigate from the United States at the close of the war, and sent her to India, the first vessel that made the voyage from this country to that. The India goods in the drawing room are accounted for by my grandfather's mercantile pursuits.

"In the Navy Yard House was gathered all that was 
agreeable and intellectual in Washington life in those days. Mr. Madison was a frequent visitor, Chief Justice Marshall, Mr. Foster, the British Minister, who was a connection of my father by marriage, Mr. Serrurier, the French Minister, Madame Dashkoff, the wife of the Russian Minister, Robert Fulton, Dr. Mitchell, Gilbert Stuart, the painter, and many others whose names I have forgotten. My half-sister, afterwards Mrs. N. J. Roosevelt, a lively, bright girl just coming into society, added to the social attractions of the Navy Yard House. There was a very entertaining Russian, named Svenin, that I remember, mainly because he drew and showed me pictures. As a precocious boy, I was in and out of the parlor at all times. Mr. Fulton I recall as a spare man with a head of dark shock hair and large eyes, who often had me on his knees. Mr. Madison I think I remember at this early day; but I saw him so frequently afterwards, that I may confound one date with another. He was small and spare, and wore his hair in powder. All his published likenesses are excellent. "In addition to my father's other accomplishments he was an excellent musician, and my mother was celebrated for her voice, cultivated, when she was a girl, under the instruction of the best masters in Philadelphia of that day. It is not saying a great deal to say that the Navy Yard House was an attractive one for the society of Washington in 1808, or thereabouts. My mother's friends, too, from Philadelphia paid her visits; and I remember well a Miss Mollie Hamilton, a leader in the fashionable world of that city, who with others came to the races and impressed herself on my mind mainly because she wore a jockey cap, with a silver effigy of a horse and rider at full speed in front the object of many a childish longing. Another visitor was the dearest little woman in the whole world, my moth- 
er's bosom friend, Mrs. Juliana Miller, one of the most diminutive of her sex, but one of the best and truest. No biography that I could write would be complete without the mention of her name, in terms of the most exalted praise.

"Both my father and mother were fond of society. My father was a man of great conversational powers and rare accomplishments. My mother was a brilliant talker and a wit. On one occasion, when standing with the French Secretary of Legation, M. de C_- behind a young lady whose very low dress displayed an uncommon amplitude of neck, the Secretary whispered that the number of moles that were visible formed quite a constellation. 'True' replied my mother, 'and it is the great Bare."

In considering Mr. Latrobe's life and times, we shall in some detail relate his connection with the Railroad and Telegraph Companies. The other branch of transportation-by steamboat-might be considered as a collateral relation of his, as Nicholas J. Roosevelt, who, in 1808, married Lydia, his elder sister, built the first steamer that navigated the Western waters, and with his wife made the first voyage by steamboat in those waters.

Mr. Latrobe wrote two pamphlets published by the Maryland Historical Society, one entitled "First Steamboat Voyage on the Western Waters," the second "A Lost Chapter in the History of the Steamboat." "The Lost Chapter" was first written, both, however, bearing date 1871. It is a record of his employment as a lawyer in 1828, to bring suit, on the Roosevelt patents, against infringements on the patent for the "vertical wheel" which was the first practical and successful method devised of applying steam to steamboat propulsion.

Mr. Latrobe describes his interview with John Devereux 
DeLacy, a genial Irishman, who brought out from his pocket the original patent to Nicholas J. Roosevelt "for a new and useful improvement in propelling boats by steam," dated December 1, 1814. It had at that date-1828-but a few months to run.

Roosevelt was a great-great-grand-uncle of former President Roosevelt. I have a letter dated December 14, 1915, from the latter, as follows:

"Dear Mr. Semmes:

I think that Nicholas Roosevelt was a brother of my great-great-grandfather, but it may have been one generation back.

I wish you all good fortune in what you are doing. Sincerely yours, TheOdore RoOSEvelt."

Mr. Latrobe consulted Mr. William Wirt, and Roger B. Taney. Both were of the opinion that the Roosevelt patent was good, but money was required. Mr. Latrobe says in his pamphlet:

"In a word, it was apparent that more means were needed than I, as a young lawyer just beginning in the world, could command. DeLacy had a one-quarter interest in the patent. DeLacy was a source of trouble. He had procured on credit from Patterson, the then fashionable tailor on South Street, a complete outfit, and not having the money to pay for it, Patterson, who was unwilling to wait until our success at law made my client's fortune, put him in jail, in spite of his sounding name and lofty bearing. I had to become security for him and ultimately to pay the debt. I tied up my papers and placed them in a pigeonhole, where, with a single exception, they have remained undisturbed for forty years." 
While not disposed to take away any credit Mr. Fulton may be entitled to, it would appear that Nicholas J. Roosevelt was, in fact, the inventor of a device which made the use of steamboats at that time practical.

Nicholas J. Roosevelt had built a steamboat in Pittsburg in 1811. Mr. Latrobe writes in 1871 his recollection of the trip of this boat, which was the first boat that appeared upon the Western waters. He says that his recollections are deepened by the fact that his father removed their family to Pittsburg in 1813 where he was superintending the building of the "Buffalo," the fourth of the steamboats launched at Pittsburg, and that his playmates were boys who had seen the "New Orleans" leave the town for the Mississippi, "New Orleans" being the name of the boat built by Nicholas J. Roosevelt two years before. Livingstone had supplied the capital, and Roosevelt had superintended the building of the boat.

Before this trip could be taken it was necessary to investigate the currents of the Mississippi River. In 1809 Roosevelt built a flat-boat at Pittsburg and floated from Pittsburg to New Orleans with his wife, whom he had recently married. In the latter part of September 1811 the "New Orleans" commenced her voyage, which changed the relations of the West. The speed was from eight to ten miles an hour and on the second day after leaving Pittsburg, the "New Orleans" rounded to opposite Cincinnati. The whole town turned out. The people said: "Your boat may go down the river, but as to its going up, the idea is absurd."

At Louisville Mr. Roosevelt invited a company to dinner upon the boat. During the dinner a perceptible motion was felt, and the company rushed upon deck, believing that the boat was adrift and would drift over the Falls of 
the Ohio. Imagine their surprise and delight, when they found that the boat was doing the impossible thing-going up stream. While waiting for the high water to pass over the Falls of the Ohio, the boat returned to Cincinnati, to the great astonishment of its citizens. When the depth of water passing over the Falls exceeded by five inches the draft of the "New Orleans," the boat navigated them in safety.

As the boat made its way down the river, Indians attempted to approach it, but fled in fear as it came nearer. They looked upon it as a monster which would injure them, and in this they were not far from the truth, as the development of the country meant their departure. A fire broke out on board and added to the excitement and dangers of the trip. A series of earthquakes visited that region. At some points the banks fell in and trees were engulfed: Some of the people were terror stricken and asked to be taken aboard, and others seemed to be as much afraid of the boat as of the earthquakes. There was no choice. It was impossible to take aboard the people who wished to escape from the dangers. Quakes continued; the crew was oppressed and awed. The journey was made in silence; the change in the banks caused by the earthquakes and disappearance of large trees confused the pilot, and he acknowledged that he was lost on the river, and could not tell where it was navigable. Once they stopped at the foot of an island, and during the night a continual scratching was heard and several hard blows were delivered against the side of the vessel, causing it to tremble. The cause was discovered in the morning; the island had disappeared. Mrs. Roosevelt described the voyage as one of "anxiety and terror." The romance and its terrors ended at Natchez. 
The "New Orleans" was 138 feet long, of about 400 tons, and cost forty thousand dollars. She continued in service until 1814, when she was wrecked at Baton Rouge. (Bishop, History of Manufactures, vol. 11, p. 173.)

It is an interesting fact that the term "Stateroom," now used to designate cabins or rooms on steamers, had its origin in the custom of naming the rooms or cabins of the Mississippi Steamboats after the different States in the Union. A survival of this custom still obtains in the West where a structure on the hurricane deck of a steamer containing officers' cabins, etc., is called Texas.

The material from which this pamphlet was obtained was an account written by Mrs. Roosevelt, who accompanied her husband. Mrs. Roosevelt was Lydia Latrobe, a half sister of John H. B. Latrobe. I write this because my attention has been called to a description of the voyage in the "Rambler," written by C. J. Latrobe and published in 1836. Mr. C. J. Latrobe was a cousin of Mr. John H. B. Latrobe. He made his first visit to the United States in 1835. While in Baltimore he stayed at Mr. John H. B. Latrobe's house and the latter introduced his cousin to Harper and Brothers, who published Mr. C. J. Latrobe's book. All the information he had of the first trip of the steamer on the Western waters of the country was obtained from Mr. J. H. B. Latrobe. In another portion of the work an account is given of a trip in 1832 from Natchez to Cincinnati, in a steamboat called the "Lady Franklin."

Among Mr. Latrobe's papers is the following letter on the subject of Nicholas Roosevelt's claim, and the claim of Robert Fulton to be the inventor of the steamboat:

"The extent of Fulton's claim to the invention of the steamboat as stated by himself.

"In a paper read by me before the Maryland Historical 
Society entitled 'A lost chapter in the history of the steamboat' I contended that to Nicholas J. Roosevelt was due the invention of the vertical wheels over the sides of the vessel adopted by Fulton, to which his success was owing.

"In the above paper I speak of Roosevelt having been associated with Fulton in the introduction of steamboats on the Western waters; in a letter from my father to $\mathrm{Mr}$. Fulton of February 9th, 1809, I find a reference to the proposed association, thus:

Mr. Roosevelt, however, expects aid from me as a common friend, and has transmitted to me the agreements formerly entered into between the Chancellor, Stevens, and himself and the correspondence which supports his contention, even to the proof that the Water Wheels System was proposed by him to the Chancellor and rejected, etc.

I wish to throw all this to one side, and try by a union of all these interests and abilities to produce a monopoly of the system, from which each shall derive advantages, undiminished by rivalry. Let us meet and converse.

"On the same day my father writes to Mr. Roosevelt:

"My dear friend

"Washington, February 9, 1809.

"The enclosed is a letter I wrote to Mr. Fulton, in order to open the negotiation respecting the steamboat. I had hardly closed it, before he, as if sent to me, walked into my office. I gave it to him, and the following is the substance of what passed after he read it: "I know nothing of Mr. Roosevelt's claim or Mr. Stevens' or the Chancellor's. I have indeed heard of an old agreement between them, but that can only bind the parties and not affect me. I HAVE No Pretensions to be the First Inventor of the Steam Boat. Hundreds have tried it and failed. Neither do I pretend to an exclusive right to navigate steamboats, except in New York. Perhaps that may be disputed, I am told; but I am not afraid of the event, and in the mean time I shall go on. Mr. Stevens may build a dozen boats if he pleases. Anybody else may do so; but I shall prevent their adopting my principles. That to which I claim an exclusive right 
is: The so proportioning the boat to the power of the engine and the velocity with which the wheels and the boat, or both move, with the maximum velocity attainable by the power, and the construction of the whole machine." He then explained his principles at large, which I need not repeat.

"In the paper above referred to I attempted to prove that it was to Roosevelt that Fulton was indebted for the element of the vertical wheels, that made the experiment, that had, from the showing of Golden, his biographer, been a failure in Paris, a success in America, owing to the information that the Chancellor gave him of [Roosevelt's rejected plan. I think that this may now be regarded as fully established. Not only does Fulton make no claim to the vertical wheels, but he puts his claim on a combination of proportions which, as we now understand the law, would not be patentable.

"And yet, notwithstanding, as I have already fully admitted, this does not detract from the merit that the world has awarded to Fulton of being the first who made the great idea a practical success; although few would now adopt such shapes as he matured in 1809.

"In the Capitol at Washington, there is a marble statue of Fulton, seated-in the dress of an artizan, in his shirt sleeves-pondering over a miniature of a boat that he holds in his left hand. The statute in Washington might have illustrated George Stephenson,-but it misrepresents Robert Fulton. Whatever may be its merit as a work of art, in one respect it does him injustice. He was not a mechanic, working in his shirt sleeves. He belonged in social life to the rank of what are called gentlemen. He was a skillful miniature painter, the associate in England of persons of rank, and his wife was the sister of Chancellor Livingston, our minister to France in 1797. I remember him, when I 
was a boy, as a visitor to my father's house in Washington, and I fix the date approximately by one of my father's letters, in which the fact is mentioned, incidentally, that the British fleet was then lying before Alexandria, a letter in which reference is made to Fulton's torpedoes, that he was trying to induce the Government to adopt, and a portion of whose appurtenances I most distinctly recollect seeing somewhere."

\section{JoHN H. B. LATrobe,} May 14, 1888.

Benjamin H. Latrobe had made a contract in 1811 with the city of New Orleans for a water supply. Under the terms of this contract he was to have the right to supply water for twenty years from May 1813, at which time it was presumed the work would be finished, but the war of 1812 interfered with and destroyed all chance of completing the work at that date. The machinery was built in Washington. It was loaded and shipped to New Orleans. The vessel on board of which it had been shipped was captured by the British, which resulted in a great loss to those engaged in the enterprise. It was about this time that the Capitol was partially burned by the British.

Mr. Latrobe removed to Pittsburg in 1812, for the purpose of constructing the machinery which was to be used in the New Orleans water works and which was to be shipped by water to that place. In Pittsburg Mr. Latrobe also constructed a steamer to be used upon the Mississippi River. It is interesting to note that the works, at which Mr. Latrobe built his machinery and his steamboat, are now occupied as the depot of the Pittsburg and Connellsville Railroad, a Railroad built under the supervision of his son Benjamin as Engineer. The steamboat built by Mr. Latrobe was the fourth one to be used on the waters of the 
Mississippi. Chancellor Livingston and Nicholas J. Roosevelt were interested in the navigation of the Mississippi.

The steamboat enterprise being unsuccessful, Mr. Latrobe was very much harassed financially and otherwise and, for the first time in his very active life, appears to have become keenly discouraged.

In 1815, however, he was reappointed the surveyor of Public Buildings of the United States. He returned to Washington to superintend the reconstruction or completion of the Capitol, and he lived in Washington until 1817. His eldest son, Henry, who was superintending the works at New Orleans, died in 1817 of yellow fever. Mr. Latrobe's interests required him to visit New Orleans from time to time. In 1817 or 1818 he moved to Baltimore with his family. He designed the "Exchange" and the "Cathedral," which latter was under roof in 1818. General Robert Goodloe Harper was a great friend of his, and during a part of this time he stayed with him at his house. His interests in New Orleans required him to move to New Orleans, so that in 1820 he took up his residence there with his family. The elder Latrobe died in September of yellow fever at New Orleans.

We take up now Mr. John H. B. Latrobe's life in the first period from his birth to December 1821, when he resigned from West Point to join his family in Baltimore.

He lived in Philadelphia from his birth to 1807; in Washington until 1813; in Pittsburgh until 1815; and again in Washington until 1817; in Baltimore until 1818; and in West Point from 1818 until 1821.

Sometime after this biography was begun, in an old trunk belonging to his son Osmun was found a manuscript written by Mr. Latrobe, giving to his children a history of his life. This is incomplete, but includes details which would otherwise have been unavailable. 


\section{CHAPTER II}

From 1803 to 1818 -Date of Mr. Latrobe's Entering West Point-Life in Washington-First Theatrical Experience-Early Associates-Madame Bonaparte -Naval Ball-Family Left Washington 1812-TrIP to Wheeling by Carriage-Life in Pittsburgh Building Steamboats-Return to Washington 1815Georgetown College-Left Washington for BaltiMORE 1817-Death of Benjamin H. Latrobe iN New ORLEANS 1820

The only record of this period consists of notes made by Mr. Latrobe late in life.

His father's occupation required him to move from place to place. He took up his abode in Washington in 1807, and the house which he first occupied was known as the "Navy House." It was not very far from the Navy Yard. Subsequently, in 1811, he moved to a house on the north side of Pennsylvania Avenue, about half way between the Capitol and the President's house and, according to a letter of Mrs. Latrobe's, nearly opposite the house occupied by Paul Hamilton, Secretary of the Navy.

The family, as shown by the letters of Mr. Latrobe, took an active part in society. Mr. Jefferson, the leading members of the Cabinet, and, later, Mr. Madison, were very intimate friends of theirs. They seem to have lived in some style, as they speak of their coach and coachman.

Mr. Latrobe writes, speaking of the Navy House:

"Here happened the first great event of my literary life, the reading of 'Robinson Crusoe.' 
"Among other visitors at the house, I recall, were Mr. and Mrs. Barlow.* On the eve of their departure they went with my father and mother to Bladensburg, then a favorite afternoon drive from the City, where there was a spa or mineral spring which was the attraction of the place. It bubbled from the eastern branch of the Potomac, a very small spring shaded by some fine old trees. It was here that I first heard the oft quoted lines, repeated by my mother apropos of the occasion:

By the side of a murmuring stream,

An elderly gentleman sat,

On the top of his head was his wig,

And on the top of his wig was his hat, etc.

"Along with these lines, I recall most distinctly the slender, gray haired, elderly gentleman and his wife, a soft spoken low voiced lady, remarkably thin almost to emaciation, of great refinement.

"I remember being with my father in Cooper's Book Store one day, when we met Francis, the actor, and, I think, the elder Jefferson; and my father mentioning a promise he had made to take me to the theatre, they suggested that we should go to see 'She Stoops to Conquer,' with the after-piece of the 'Forest of Bonday' or 'the Dog of Montargis.'

"These were my first theatrical experiences. I shall never forget the night of joy. Rachel has given me less pleasure than did Warren in the character of Old Hardcastle, Barrett as young Marlowe, and Jefferson as Tony

*Joel Barlow was prominent in the political world and was appointed Minister of the United States to France, 1811-12. Known also as one of the "Hartford wits," he was the author of "The Columbiad" and other books. Theodore Roosevelt says of the "Columbiad"-

"I have one of the copies of the original edition. I wouldn't have it out of my library for any consideration, unless I were required to read it." 
Lumpkin on the occasion. My father took us to the play once more that season, when Barrett played Bertram in 'The Castle of St. Aldobrand.' I recall nothing of the tragedy, but the dog of Montargis, who rang the bell as he sprang at the sausage on the bell rope, I never can forget.

"Two of my father's visitors at the Navy Yard House were the Colonel of the Marine Corps and Commodore Tingey, the Commandant of the Yard. Colonel Wharton was a grand looking man, tall, stately and dignified in the extreme. I see him now in a black frock coat, buttoned to the chin, which was held up by a stiff leather stock. He wore powder after a fashion that had not quite gone out of use. Commodore Tingey looked the reverse of Colonel Wharton. He was what, when I read Peregrine Pickle at a much later date, I supposed Commodore Trunnion must have been, a rotund man, with a quarterdeck roll in his walk, a round red face, and a speaking trumpet voice. His laughing good humor and gray eyes shine through a long vista of memory. A jolly sea dog, but a refined gentleman, Commodore Tingey."

In one of Mr. Latrobe's lectures, he speaks of the impression he received on seeing the performance of "Aladdin and His Lamp," and also refers to his admiration for the room of the House of Representatives. This building was under the charge of his father, and the probabilities are he visited the Capitol from time to time.

He gives rather a graphic account of "Mammy Kitty," who was his nurse:

"Mammy Kitty, my nurse, was a most remarkable woman, a small, red-haired, freckled face, pale eyed and very romantic person of Scotch descent, with wonderful memory for old Scotch ballads. Better educated than most women 
who took service in those days and from respectable connections, and of the most fierce and ungovernable temper. Her temper was only equalled by the most devoted affection to my family. She would not be turned away. Through good times and bad times she clung to our fortunes, and died a terrible death in our house, long years after.

My character even at this day has marked impressions upon it by Mammy Kitty. She knew Chevy Chase by heart and a ballad about a lover who hid himself upon the bank of a narrow stream to escape from foes who leaped their horses from bank to bank over his hiding place. She would go singing about the house scraps of songs relating to Scotland. 'Roy's Wife of Aldevellock,' I can repeat in part even now, as I learned it from Kitty. I have a notion that there was chronic disposition to fall in love that accompanied her romantic turn. . . . . It is proper to say that absolute fidelity never had such an illustration as her life afforded; the nearest parallel that I can recall is that of Caleb Baldwin in the 'Bride of Lammermoor.' And there were times in the history of the family, while Mammy Kitty lived, when stringent circumstances made her services next to indispensable.

"The envy of the 'Academy' in those days was a boy who left us to enter the Navy as a midshipman, and whose ship, the 'John Adams,' the whole school got leave to 'go out' to see as she left the Navy Yard, under topsails and jib. Trifles impress themselves on the memory; and at this day I can recall the set of the jib. Charley Macaulay we called the lad, who afterwards became distinguished as Commodore Macaulay.

"Adjoining the Navy Yard House was the house occupied by the Rev. Dr. Hunter, a Presbyterian clergyman, who was, if I remember aright, chaplain to the Marine 
Corps. The two families were intimate, and my playmates and schoolfellows were Moses and David Hunter. Moses was a much bigger boy than I was, and one day when passing by some brick ponds on our way home from school, he put on my shoulders lumps of soft clay, saying that he made a general of me. His brother, David, was afterwards my class-mate at West Point, on his way to become the well-known General of the Union Army in the late war, (he commanded the main column of McDowell's army in the Manassas campaign and participated in the Battle of Bull Run), while I, notwithstanding my clay epaulets, never got higher than a Cadet.

"I remember Commodore David Porter, the father of the present* (1887) Admiral, before he became celebrated in the War of 1812, by reason of his fight with two English vessels. He was a spare built man and used to pet me. He was an admirer of my eldest sister before she became Mrs. Roosevelt. Then there was Lieutenant Brooks, afterwards killed in the battle on Lake Erie, one of the handsomest men in the Navy. The sash worn by him when he died on the deck of the 'Lawrence' was shown to me by his father, Governor Brooks of Massachusetts, when, with other cadets, I dined at his house at Medford on the march of the cadets to Boston in 1821.

"But to return to my autobiography. Among my playmates, while we lived on the Avenue, I remember the children of Albert Gallatin, the Secretary of the Treasury, 18011813, and an intimate friend of our family. He had the reputation of being one of the greatest financiers of the age. He lived not far from the Capitol, in an odd-looking house with an immense garret in which the Gallatin boys and my-

*His ship, the Essex, was captured. His report on this event was "We have been unfortunate, but not disgraced." 
self were wont to harness chairs as horses and drive four in hand, without fear of the fate of Phaeton. I think that I can recall the appearance of Mr. Gallatin at this time, but it is very possible that, having seen him afterwards when I was in active life, I may confound the dates. His daughter, Mrs. Stevens, was the first sweetheart of the eight or ten year old charioteer of the garret. My acquaintance with her brothers* was renewed when we became men.

"Going to dancing school is sometimes an epoch in a boy's life. In mine this epoch is only remarkable in connection with my first teacher, one of whose scholars, at an earlier date, had been no less a person than Marie Antoinette. His name was Duport. I can recall his bald head, the ring of gray hair around the back of his head from ear to ear, his portly body, and well shaped limbs indued in small clothes, and his air in handling his 'kit' or little violin. I do not think that I could have made much progress with Duport, for I was soon sent to a Mr. Generes where I probably did no better, and I only mention his name because I was reminded of my dancing school days by seeing it on the door of a merchant's counting house in New Orleans, when I was once engaged in the trial of a cause in that city. The merchant, I was told, if I recollect rightly, was of the family of my old instructor.

"Duport kept a perfumer's shop in Georgetown, and on one occasion my mother went there to obtain a particular pomatum — say 'pomade de la rose.' Opening one pot Duport smelled it, when, pronouncing it to be 'pomade de la reine,' he opened a number of pots in succession with the same result. $\mathrm{He}$ then turned to my mother, saying 'Ah! Madame, que je suis au désespoir, je n'ai que la pomade de la reine dans la boutique.' My mother laughed, and told him that it was

*James Gallatin whose diary was published by Scribner, 1916, was one of them. 
no wonder that he thought so, for he had carried from the first pot a lump of its contents on his nose when he had opened the others. Poor Duport! although he did not teach me the 'minuet de la cour,' it was something even to have seen the dancing master of Marie Antoinette.

"Paul Hamilton, Secretary of the Navy, 1809-13, was one of my father's friends, that I often saw at the Avenue house. I remember him most distinctly - a tall, straight, well-made man, who wore powder, and dressed in a blue coat and metal buttons. His daughter Susan was a friend of my sister Julia and was my second sweetheart, and 'reigned supreme until, when eleven years old, I fell desperately in love with Ann Van Ness, the daughter of a leading man in Washington, a friend of my father, our near neighbor at the Avenue house. She afterwards married Arthur Middleton, I believe.".

John Peter Van Ness of Kinderhook, New York, was a member of Congress in 1801. He lost his seat in 1803, by accepting the post of a major of the militia of the District of Columbia. He married Miss Marcia Burns in 1812, and from her acquired a fortune. Benjamin $H$. Latrobe built him a splendid house, and he and his beautiful wife entertained in Washington lavishly for many years.

Writing of their life on Pennsylvania Avenue, the notes continue:

"It must have been sometime in 1811 that we moved from the Navy Yard House to a large three-story house on the north side of Pennsylvania Avenue, about half way between the Capitol and the President's house. There was the same collection of pleasant people around my father and mother at the Avenue house that I have spoken of, and in addition was Madame Bonaparte, the beautiful wife of Jerome Bonaparte, whose name, in connection with the imperial family, is historical. 
"I remember her well-she had, almost to her death, the wit and vivacity of her early days. Intimate in my father's family, she was unquestionably one of the most attractive of my mother's visitors. Ten or twelve years afterwards, and when I was a member of the bar, I met her in society in Baltimore, still beautiful and attractive, and still later by some twenty years or more, an old acquaintance was revived, when all that remained of her beauty was the sparkle of her dark eyes, when no one could have recognized in the clumsy old woman, in a well-worn bonnet and faded cloak, the beautiful and attractive ornament of society in the days of Mrs. Madison. But Madame Bonaparte, as she liked to be called, was still as bright and clever as ever.

"She had been much in Europe in the intervals, and was full of anecdotes of the distinguished persons whom she had met when abroad, and, being one of the best raconteurs I ever listened to, was always glad to have an audience listen to her. She boarded not far from our house on St. Paul Street, and my wife often invited her to meet strangers who passed an evening with us. And so, with long intervals, my acquaintance with Madame Bonaparte continued, I may say, from my infancy to old age, and closed only when I, as one of her pall-bearers, followed her to her grave."

Madame Bonaparte, whose name, Mr. Latrobe writes, is historical, is one of the important personages of his times.

A short sketch of her must form a part of the history of this period.

She was the daughter of William Patterson, a prominent and wealthy merchant of Baltimore. Mr. Latrobe speaks of him as one of the leading spirits who were interested in promoting the building of the Baltimore \& Ohio Railroad. He was a member of the Board of Directors at the time of his death in 1835. Mr. Latrobe drew up the resolution of 
the Board, passed in commemoration of him. His will, recorded in Baltimore, is a remarkable document. He recognized, as all of us do, that papers and records kept by private institutions, disappear in a few years, and he adopted a novel way of perpetuating the history of his family, through the medium of his will. He starts out with the declaration that it would be interesting to his family to have a record.

He then gives this record (about fourteen thousand words). It is the only family record which is placed in a position to be cared for by the public, and the probabilities are that it will last as long as the City of Baltimore exists.

Mr. Patterson was born in Ireland. His parents were Scotch-English descent.

When Jerome Bonaparte visited Baltimore with the French fleet, Elizabeth Patterson was eighteen years of age, and a beautiful girl. The glamor of his position and the glitter of rank blinded her, and she accepted his attention. Her father was not carried away by it. $\mathrm{He}$ refused his consent, and did everything he could to prevent the match. The daughter insisted, and she was married to Jerome Bonaparte in December 1803 by Bishop John Carroll, a cousin of Charles Carroll of Carrollton.

Their wedded life was a short one. After a bridal trip they sailed for Europe. Napoleon Bonaparte refused to permit her. to land in France, so they went to Portugal. Napoleon endeavored to have the Pope issue a bull annulling the marriage.* Upon the Pope's refusal to do so, $\mathrm{Na}$ -

*James Gallatin refers to this in his diary. He says:

"In order to compel him to accede to his wishes, Napoleon made the Pope a prisoner."

Gallatin says that he visited Fontainebleau:

"I was shown an apartment that Napoleon gave to the Pope when he made him a prisoner. The Pope would not allow a divorce between King Jerome and his wife, and that was one of the reasons he brought him to Fontainebleau, as he himself wished to divorce Josephine." 
poleon had a decree passed by the French Senate, more subservient than the Pope, declaring the marriage void. Jerome protested weakly, then yielded, abandoned his wife, married the Princess of Würtemberg, and was made King of Westphalia.

Madame Bonaparte landed at Lisbon; but subsequently she went to England, where her son Jerome was born in 1805. She made several efforts to obtain recognition from Napoleon Bonaparte, without success. The conduct of her husband naturally aroused her contempt. She always admired Napoleon, however, and worshipped at the shrine of royalty. She passed her time between the United States and Europe. She was at Geneva with her son attending to his education; and came back to the United States when he went to Harvard. She negotiated from time to time for his marriage to a Princess of the house of Bonaparte, and saved up money for the purpose of securing a foreign match for him. Position, rank and money were her gods.*

She wrote caustic sentences, and of her sister-in-law, Mrs.

*Extracts from the diary of James Gallatin, published by Scribner's, 1915. He writes of Madame Bonaparte, who visits his father's house in Paris, February 18, 1815, and quotes her as saying:

"Had I but waited, with my beauty and wit I could have married an English Duke, instead of which I married a Corsican blackguard."

Gallatin writes that there was quite a scandal about the Duke of Wellington and the sister-in-law of Madame Bonaparte, Mrs. Robert Patterson. On page 165 he says:

"There is a great scandal about her and the Duke of Wellington. He follows her everywhere. In fact, 'tis an open secret that she is his mistress."

At this date-1820-Mrs. Patterson was a widow.

Again he writes, January 18, 1822:

"Mrs. Robert Patterson dined with us on Thursday (yesterday). She is really beautiful, and has a wonderful charm of manner. Her one topic of conversation is the Duke of Wellington. They say he allows her one hundred thousand francs a year-at least, so says Madame Bonaparte. Her jewels are very fine. Madame Bonaparte says they are mostly imitation, but I think it is a case of 'sour grapes.' " 
Robert Patterson, who was then a widow, she says, writing from Europe:

"Mrs. Robert Patterson is coming out; she will be the best sailor in the world. Her sisters are not yet married, which, considering their persevering endeavors and invincible courage, rather surprises me."

Mrs. Robert Patterson was Mary Caton, who subsequently married the Marquis of Wellesley, Lord Lieutenant of Ireland. Of this marriage in 1825, the Madame writes:

"He is sixty-five. He married an Italian singer, by whom he had a family of children. She is dead. He has no fortune. $\mathrm{He}$ is over head and ears in debt. He is the brother of the Duke of Wellington."

Her adoration of rank is so great, however, that, after this summing up, she says:

"She (referring to Mrs. Patterson) has made the grandest match that any woman has ever made."

She adds:

"If Jerome were a girl and had made such a match, I am convinced that I would have died with joy."

There was a great disappointment in store for her, for in 1829 Jerome Bonaparte, her son, married a Baltimore girl, a Miss Williams. She never entirely recovered from this marriage. Added to this she received another blow by the terms of her father's will, which was recorded in 1835. By this will he left his daughter less than he did other members of his family. He thus explains why he did this:

"The conduct of my daughter 'Betsy' has through life been so disobedient, that in no instance has she ever considered my opinion or feelings. Indeed, she has caused me more anxiety and trouble than all of my other children put together."

It is apparent that Elizabeth Patterson was a woman de- 
termined to have her own way, and willing to take the consequences. But her plans were doomed to disappointment.

Her son died in 1870.

She passed the last eighteen years of her life in Baltimore at a boarding-house. She was eighteen years older than Mr. Latrobe, and died in 1879. She had saved and accumulated money, and disposed, by her will, of about $\$ 1,500,000$.

Her protrait by Gilbert Stuart, unfinished, as many of Stuart's portraits are, was obtained by Robert Gilmor from Stuart and hung in the Gallery of the Maryland Historical Society.

Continuing Mr. Latrobe's narrative:

"It was at the Avenue House that I first saw Francis S. Key (author of the 'Star-Spangled Banner') and Henry Clay. Mr. and Mrs. Clay were frequent visitors, and here I had the honor of having my ears soundly boxed by Mrs. Madison. I had been on some outdoor errand, and was loitering along with my hat down over my ears on the gravel path, which was between the poplars which separated the carriage drive from the brick pavement in front of the house, when I suddenly found an immense gray horse on either side of me. Escaping under the belly of the horse on my right, I ran as hard as I could home, and hid myself. At that time the President drove four grays, and I had been caught between the leaders. Being sent for into the parlor, I found Mrs. Madison and my mother, and the former, who was standing up at the time, seized and shook me, saying as she boxed my ears, 'You young villain, you scared me out of my senses.' My mother shook me into the bargain, to make me stop crying, and I was dismissed in disgrace.

"It was in the Avenue house that I had my first lessons in drawing from an Italian sculptor named Andrei . . . The leaves at the base of the Breccia columns of the old House 
of Representatives are in part his work. My father had sent to Italy for sculptors for the work required to be done on the Capitol, and there are now before me, in my mind's eye, three, Franzonis Gairdello, Cousice and Capellano, as though I had parted from them yesterday only. . . It was among them that I picked up much that has been useful to me through life.

"The war of 1812 had begun. A ball was given to celebrate a naval victory. Mrs. Madison was among the guests, and the officers who had been charged with carrying the flags of the captured ship to Washington, brought them to the ball room and, after a proper address, unrolled them upon the floor, whereupon Mrs. Madison requested that they might be taken up, saying: "The ensigns of a brave enemy are worthy of too much honor to be trodden under foot." "

The war of 1812 shut off all funds which might be used for building the Capitol, and Mr. Benjamin H. Latrobe left Washington in 1813, with his family, for Pittsburgh. A description of the journey is given by John H. B. Latrobe thus:

"All things being at last ready, the journey began in our own carriage drawn by Peacock and Turkey, two stout bay horses that had been for some years in service. And this carriage deserves description. It had been built after a design of my father and its color was a dark olive green. It had the usual seats for four persons vis-à-vis, and the driver's seat was under the same roof. But instead of giving him the entire width of the seat a semi-circular space in the centre was surrounded with a back, elbow high, on either side of which were nooks that we children called 'nests' and which we occupied with our backs to the horses and our feet over the front seat. This gave us a capital chance to talk with David, the coachman, a jet black little fellow who drove for my father as long as the latter had horses to drive. To 
obviate the possibility of one of us children falling out of the usual side door, while leaning against it to look out, my father put the door behind, making it necessary to scramble over the hind seat to get into the carriage. The curtains were of leather, and were so contrived that by an ingenious arrangement of pulleys, they could be drawn into the roof instead of being fastened at the edges in the usual way. In the bottom of the vehicle was a well, a good sized box that could be lifted out, its cover forming a part of the floor. It was waterproof, as it needed to be when the carriage was crossing fordable streams. I am particular in this description because of the impression left on my memory of its remarkable contrivances. In those days our journeys from Washington to Philadelphia to see my grandfather were made in it.

"My impression is that the first stage of our journey was Montgomery Court-house, from which we dragged through the long and wearying distance to Pittsburgh. After passing through Boonsboro on the National road we had nothing better than the common country roads to travel on, and how we pulled through them with the same pair of horses is to this day to me a wonder. It rained nearly every day. Sometimes we would lay by to rest the horses, sometimes have to pass into the fields to avoid the mud holes of the road. I fell sick of fever and ague and shook and burned alternately for days. I remember stopping at a log house of some size in a clearing, which was the residence of General Arthur St. Clair, who had been beaten by the Indians in a battleknown in those days as 'St. Clair's defeat.* I remember, too, passing over the battle-ground of Braddock, that is to say, I heard it so spoken of, and have a recollection

* This battle was fought in November 1791 near Cincinnati. A force of 3000 troops, ill-equipped and undisciplined, was defeated and many of them killed. 
of fording a creek called Turtle Creek near the spot. I remember, too, that a number of gentlemen came out from Pittsburgh to meet my father. They were on horseback and rode alongside the carriage. Other things I remember also of this miserable journey, not worth recording.

"Our house in Pittsburgh was a handsome new threestory brick house, in which much of the furniture that had preceded us was already stored or placed in order by the exertions of Kitty who had gone before in the stage, and where we were very comfortable. My father addressed himself at once to his business, and it was not long before a social circle gathered about our fireside. I was put to school in Cherry Alley to the Rev. Mr. Stockton, and began Latin and grew weary over 'penna' and 'stella' and had the usual routine of schoolboy life. The 'works', as they were called and where my father's business lay and where the steamboat 'Buffalo' was built, were not far from our dwelling, and these 'works' were my playground. They were not far from the site on which Roosevelt had built the 'New Orleans'. My father's shipbuilder was a little man named Hurley, and the head carpenter was a Mr. Holdship. These are the only names that I can recall, but I was hand and glove with all the mechanics about the place, having had a weakness in that direction that has continued all my life.

"I am afraid that I was not as attentive to my lessons at Mr. Stockton's as I might have been. I was an inveterate reader, but Ross's Latin Grammar was not a favorite work. I remember my playfellows much better than I do my course of studies. All of them are dead now, I believe, except Ross Wilkins, who is, or was lately, a judge of a United States Court in Michigan.* He was a hand-

\footnotetext{
* The above was written many years ago.
} 


\section{MONTICELLO}

Painted by John H. B. Latrobe 


\section{U.Justrnou}

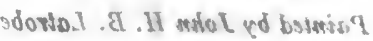




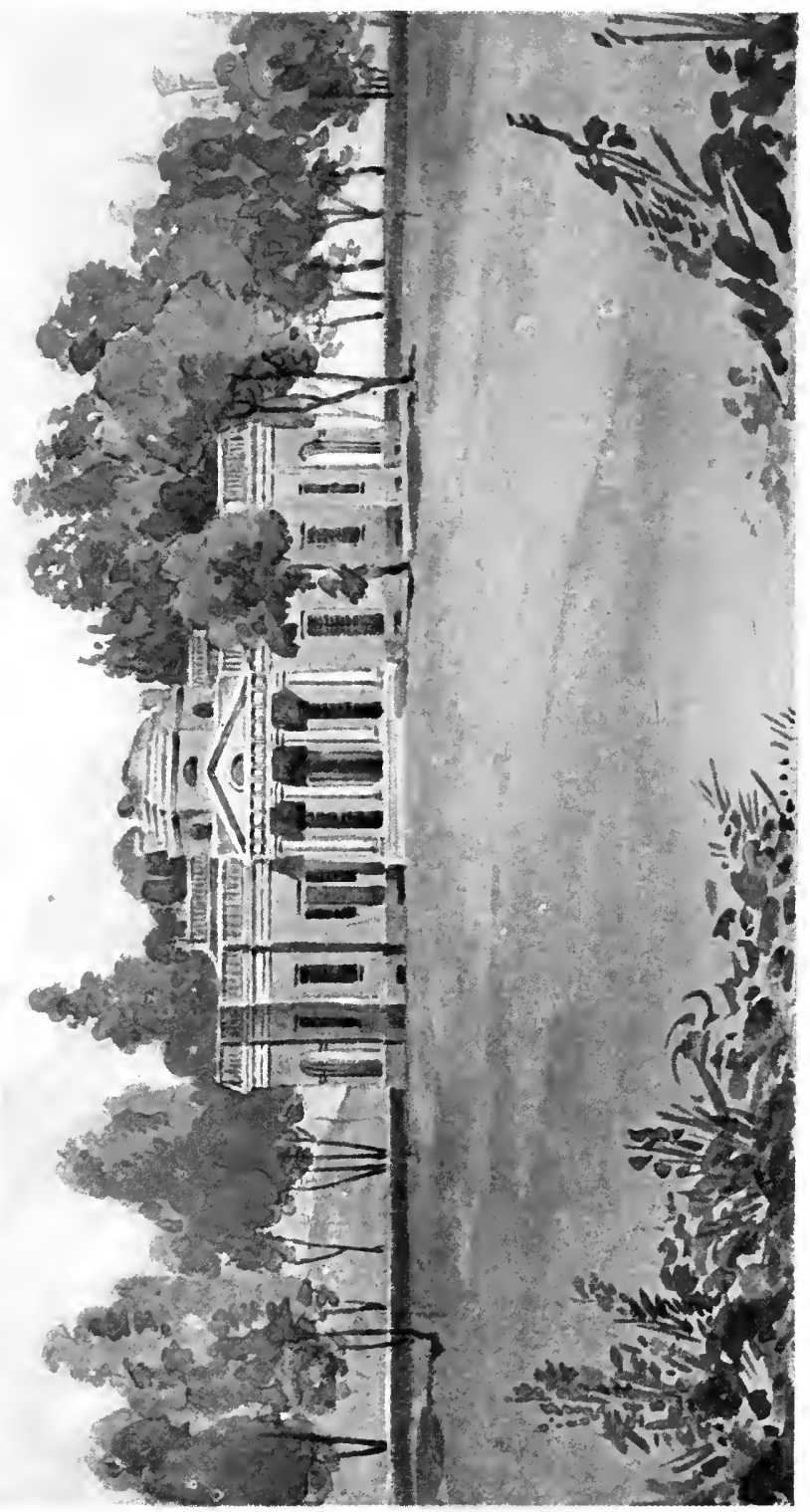



some, well-built lad, and the envy of the school when he mounted the rostrum formed by removing the master's chair and recited 'My name is Norval' or 'Gods, can a Roman Senate long debate?,' etc., on Saturdays. He was one of the big boys, and much my senior.

"It was in Pittsburg that my first circus experience was had. Pepin and Brechard came there with a troupe that performed in a temporary edifice that my father in the exercise of the humblest function of an architect designed and had erected. 'Peacock' and 'Turkey,' the carriage horses, and a saddle horse yclept 'Codger', which had been added to the stables of the family by this time, were borrowed by the circus people, and did their duty in the 'Grand Entree.' Since then I have seen a great many such exhibitions both in Europe and America. I recollect none of them now in their details, but I can recall every incident of my first experience in this line, and see Pepin, a heavy built man, throwing up knives and apples alternately as he rode around the ring, and exciting the boisterous applause of the audience as he caught an apple on the knife behind his back. The world was filled with simple folk in those days, who were amused by small matters.

"While in Pittsburgh the battle of Lake Champlain took place, and among other agreeable visitors to my father's house were two English officers, whose names have passed from me, who had been taken prisoner and were on parole. There was a sergeant of marines, too, who was in the engagement and became a prisoner, whom my father employed in some capacity about the works. This man found me a much apter scholar than did Mr. Stockton, and I learned the manual of the musket from him with an eagerness that was wanting in Cherry Alley. At this day I recall his looks. He was the beau ideal of manly beauty, some 
forty years old, about six feet in height, and as gentle as a woman in his way. I was a great pet with him, and when later I went to West Point, I had to unlearn the manual that he had taught me.

"It may amuse you to know what was in 1814-5 the fitting up of a well arranged workshop, that you may compare it with the appliances of the present day. My father's great fault was that he always wanted to do things of importance in the very best way, and he sometimes in consequence incurred the charge of extravagance; nor did he deviate, on this occasion, from his usual course, in the building he erected for the steamboat company. It was in the shape of a 'T.' Imagine four square apartments, three forming the top, and the other the stem of the letter. In the central apartment on the top was a great horizontal wooden wheel, sustained near the ceiling upon a centre shaft or axis, whose pivot of support was near the floor. This wheel was cogged, and the cogs meshed or worked into cogs on horizontal shafts extending into the apartment on the west, in which were the lathes of the establishment. From the great wheel there depended four yokes for the horses that supplied the motive power. The apartment to the east was the boiler shop and foundry, and the stem of the ' $\mathrm{T}$ ' was the blacksmith's shop. Whenever more motive power was wanted, a shaft was connected with the great $\operatorname{cog}$ wheel to supply it. And yet in such a shop, and there were none better in Pittsburgh in those days, admirable work was done, slowly done, but well done.

"I find myself tempted to linger over the reminiscences of those days and enumerate my schoolboy friendships, my fallings out, my makings up with those long dead, for I have survived the most of them all (1888). I think but very few of them now live. My intimates were the chil- 
dren of my schoolmaster, Mr. Stockton, and the son of Mr. Bakewell, the proprietor of certain glass works that had then achieved reputation. There was a George Bollman, and a Sinclair Denny who was afterwards my comrade at West Point. Poor George was run over by a cart and died in consequence.

"There was an incident at this time that $I$ have never forgotten. The steamboat 'Buffalo,' built under my father's direction, was launched not far from the 'works.' A shelf had been cut into the bank of a creek that flowed at the foot of Boyd's hill on the side of Pittsburgh as then built up, and at the river end of this shelf was a crib wharf that had been filled up with the earth from the excavation. Over this wharf the vessel had to be launched stern foremost. The pitch that had been given to it and the angle of the ways whose furthest end rested upon the upper log of the wharf had been calculated with reference to high water in the Monongahela, when it was expected that the steamer would be ready for the river. Now it so happened that when this time arrived, although there had been a rise, it did not by several feet come up to what had been anticipated. Hour after hour the gradual rise of the stream was watched, until it was apparent that the greatest rise probably for several months had been reached, and to all appearances the launch had become impracticable. Delay was ruinous. The risk to the vessel was very great if a launch were attempted at that stage of the river. My father was in great trouble. There was no time even for deliberation. The next half hour might witness a fall in the Monongahela. Hurley, the shipbuilder, hesitated, but he would not say 'No' and my father took the responsibility. The upper $\log$ of the wharf was cut away the width of the vessel. I see the place now in my mind's eye, and at the hour ap- 
pointed, when it had been believed that the continued rise of the water would make the launch a safe one, the signal was given. The shores were removed, the wedges were driven, and the 'Buffalo' commenced its slow descent. This was quickened somewhat as the vessel neared the wharf, then became slower-and then slower, until one half of the steamboat overhung the edge. At this moment, the thousand spectators expected to see the 'Buffalo' break asunder, but the downward movement continued, became rapid as the vessel tilted, more rapid still, as with a mighty rush the stern struck the turbid tide and was buried beneath it, until with a great concussion the bow dropped into the river.' As may well be supposed, my father drew a long breath when he saw by the water line that there was no 'hogging' and all was safe.

"The 'Buffalo' had been built upon estimates based upon prices that had ruled when Roosevelt had built the 'New Orleans.' They were all too low. Everything had advanced from fifty to one hundred per cent in the interval. This occasioned dissatisfaction. Money from the east was not forthcoming to make up the difference, and my father was in the greatest trouble. Fulton died too, and the confusion that existed prior to his death increased tenfold. These were days of bitter sorrow. My father, a highly sensitive and nervous man, was overcome, and for a season fairly broken down. The works, from which man after man had been dismissed, were closed, and the 'Buffalo' lay unfinished in the stream. I have vague recollections of the distress of my mother, and know that it was a season of actual distress in more ways than one.

"By this time there was peace between the United States and Great Britain. After the war with England, and in the midst of our family troubles, my mother received 
a letter from Mrs. Madison informing her that my father had been or would be reappointed to his old office as architect of the Capitol. Our return to Washington followed not long after, travelling in the same carriage that brought us to Pittsburg, with a pair of new horses, 'Peacock' and 'Turkey' having found another master in the season of distress. 'Codger' had been retained, and my mother rode him the whole distance almost from Pittsburg to Washington.

"It seems to me worth mentioning that, while at Pittsburg, I saw the launching of the 'Vesuvius' and 'Etna,' the second and third steamboats that ever floated upon the Western waters. They were launched sideways from a yard near the junction of the Monongahela and Allegany Rivers and, when they dropped from the end of the ways, rolled gunwales under in the water.

"It was in the spring of 1815 that my father returned to Washington. His residence in Pittsburg had been an unfortunate one in every way, and he was a poor man when he resumed his office as architect of the public buildings. Poor in having nothing ahead, and living upon his salary and earnings outside his office as an architect, with enough to maintain his position in society, but in a quieter way than before the war."

After the return to Washington, John H. B. Latrobe and his brother Ben were placed at Georgetown College-on June 26, 1815. They were entered as boarders and the entrancebook says: "To pay agreeable to the prospectus for all things except clothes, $\$ 150$. each per annum. They each brought their own bed and bedding." There is no record of their studies while in Georgetown College. The records of 1817 have the following entry. "In 1817 their father went home to Baltimore and took his two sons with him." 
Turning again to Mr. Latrobe's notes, he says:

"Our new house was on the range of hills to the north that overlook the City, and our nearest neighbor was Mrs. Joel Barlow, with whose fences at 'Kalorama' our fences joined. My mother was thus alongside of an old and valued friend. 'Speak's House,' for so was our new residence called, was a double house with a pleasant garden in front and a farm and fields in the rear; and, although not on the highway of the avenue, was still near enough to the city to be frequented by the old circle of friends.

"I was, at once, sent to Georgetown College as a boarder and resumed the detested 'hic, hac, hoc' and corresponding studies. I think I was among the good boys here, so far as not having had to stand in a corner by the clock near President Grassi's door more than once, or writing verbs more than three or four times. We had a poetical usher, named Kelly, who set me to turning passages of Ossian into rhyme, and who was pleased with something that I wrote about 'Torneo's hoary brow,' and made much of me. I remember on one occasion, when 'a retreat' was in progress, and we were confined for hours in the study room, with the lower half of inside shutters closed, so as to shut out the outside world, I amused myself by attempting to copy a full length picture of the Holy Virgin on a page of my copybook. For this, if I recollect aright, Jim Patton gave me an apple from his desk 'on the sly,' and the traffic being discovered and being deemed contraband, I was made to kneel in the middle of the refectory during the next dinner time, with a bit of bread and a tin cup of water for my meal. Perhaps I have not properly connected the offense and the punishment here. But I committed the offense and I received a punishment such as I have decribed for some offense or other. I had altogether a pretty good time at George- 
town College, and recall a thousand pleasant incidents of my schoolboy life there. I was great on whittling and made a set of wooden chessmen that were in use in the family long afterwards. I was strong on tops and clever at marbles. I belonged to a debating society too, and once let a bigger boy, T. D., write my argument on a question about Commerce, which I read and found, when he replied to it, that he had made me talk nonsense that he might prove me to be a fool. My revenge, not intended to be so at the time, was to burst into tears and tell the whole story, to the discomfiture of the said T. D.

"I do not know how it was, but I was the only Protestant boy in the College who stuck to his faith; not that I knew much about the matter, but I was obstinate by nature and impracticable. T. D. was as good a Protestant as I was, but he had no scruple at serving at Mass. I used to hear heretics harshly spoken of, and felt at times uncomfortable enough. Nor was I treated unkindly on account of my creed. On the contrary, I was petted rather than otherwise. Still, I was mulish enough, I dare say. I remember that on one occasion I saw good Mr. Henry, a lay brother, preparing the wafers to be consecrated for use in the Communion. They were made in a sort of waffle iron, the proper devices being engraved on the inner faces of the implement. The wafers fell out after the baking, leaving the intervening scraps of thin bread. These the boys, who were permitted to see the operation, ate eagerly as Henry gave them to his visitors, and I was offered my share of them, but was afraid to taste them, though sorely tempted, for fear that they might make me a Catholic. Little did I know about religion in my twelfth year.

"How well I remember our afternoons at the College, when at five o'clock precisely Father MacElroy appeared 
at the door of the Seminary Building, as it was called, with a mighty basket well filled with great chunks of bread, one for each of the boys, who would gather in expectation, and then rush for their rations, as I have seen the pigeons in the great square of Saint Mark at Venice. What appetites we had in those days!

"I think it was while I was at Georgetown College that an event occurred that affected my health seriously at the time, and made an impression that I must carry with me to my grave. It was during the Christmas holidays. My brother Ben and myself were home for the usual vacation, and on Christmas day were left at home with Mammy Kitty. My father and mother had gone to church in the carriage-the present St. John's Church-and the cook and chambermaid had leave of absence, Kitty undertaking the duties of the former in her absence for the occasion. My sister was with my father and mother, and Ben and I were playing chess in my mother's room upstairs. Some impulse which, without being at all superstitious, I have often fancied was inspired, prompted me to interrupt the game, and go down into the dining room which was on the opposite side of the house. Here I saw blackened rags on the floor, and fancied a strong and peculiar odor. Crossing the dining room to a door leading to a narrow passage on one side of which was a pantry leading to the kitchen, I saw poor Kitty, naked, at a big table with a roller in her hands, as though she would prepare a mass of dough before her. Her clothes had caught fire and every stitch of them had burnt off. She has evidently got as far as the dining room in search of help, had fallen probably, had lost her senses, and, in the madness of her agony, had returned to the kitchen and resumed there the last labor she had been engaged in. I remember running to her, and clasping my arms around her as she was falling 
and bearing her through the passage, through the dining room, the poor woman clutching the door knobs as she passed. How I got her upstairs, I now cannot tell. I never could tell. But I succeeded, and placed her in my sister's bed, which was in the back room adjoining my mother's and covered her up and tucked her in, supporting the edge of the bed by tilting the backs of chairs under it. Here I left my brother, then nine years old, in charge, and ran across the field that separated our place from 'Kalorama', and told Mrs. Barlow what had happened. Her sister, Mrs. Kennedy I think the name was, returned with me, with cotton and oil, and as we reached the house the carriage with my father and mother drove to the door. I have no distinct recollection of what followed, beyond finding myself in the dining room and feeling very sick.

"It was many weeks before I was able to resume my ordinary course of life. My nervous system, they said, had received a shock; and I have at times the nervousness, that I acknowledge now, as a characteristic due to my early experience as here detailed. For a long time afterwards it was only necessary to point a finger at me persistently to bring tears into my eyes. When I was well enough, I returned to College. From Georgetown College, where I was a boarder, I was entered as a day scholar at Mr. Carnahan's school in Georgetown. This must have been in the following spring.

"At Mr. Carnahan's I made good progress with my books and my health improved with my long walks to and from school. I remember that I was remarkable for the facility with which I read Latin hexameters. When Mr. Carnahan became, long years afterwards, President of Princeton College, he used to speak of me as one who was distinguished in this respect, when he was inquiring about his old scholars in view of knowing what they were about in the world. I 
think that I was a better boy after the death of Kitty who died, I ought to have said, the night of the accident that I mentioned before. By being better, I mean less inclined to be mischievous and very decidedly graver.

"In all these days, even from my being able to walk, I had a turn for drawing, and there is now somewhere in the family a note in my mother's handwriting, describing my first attempt at art-a soldier with his gun and bayonet. The merit of the production may be estimated by the legs, which were like two L's attached to a big $O$. But I did better than this in time; and at Georgetown College one Victor Dugour, a fellow student, gave me help in the way of drawing trees. In 'Speaks' House' I was quite clever at copying, and was equal to making copies of architectural drawings very cleverly. My father, who was an accomplished draughtsman and water color painter, helped me, but not much. He helped me with my Latin and French much more. Still, I was drawing whenever I could. And this was strange too, for I had no genius this way. I had a fancy only, great perseverance in what I fancied and untiring assiduity in laboring at it. I have little faith in genius, so called, but abiding faith in toil. I draw well now, I believe, and paint better than many of those who make their living by it. But all that I do or ever have done has been by good hard work in following out my fancies. My father designed St. John's Church, Washington, which was really a beautiful little thing in its day, before some dull fellow made a. Roman Cross out of a Greek one, and stuck on a stupid nondescript portico and an abominable pretext for a tower. During one of my father's absences for a few days from home, I made a copy of his drawings of the plan, elevation and section of the building, and when he came home surprised him with the exhibition of my work. 
"I rather think that this feat must have been at the beginning of the long summer holidays; for my father took me at once to the Capitol and set me to work there, nothing loath, in the office, copying drawings of various parts of the building. Since then I have been again and again in the Capitol, and never pass through certain parts of it without their recalling my labor in the office making copies of drawings of certain parts of it, now found there.

"When my holidays were over I had done so much that I was honestly entitled to a clerk's wages, and Colonel Lane, the Superintendent of the Public Buildings, a one armed man who had charge of the disbursements, paid me for my services $\$ 89$. This was my first earnings, and I spent it all. Melvin, the tailor, made me a suit of clothes for part, and what remained I invested in a tool box. This was in my twelfth year, perhaps my thirteenth-probably the latter. Among the clerks in the office was a M. Poussin, a Frenchman, a descendant of the great painter of that name. $\mathrm{He}$ was a man of decided talent, and, when I met him later in life, he often talked of my labors at the Capitol.

"My father gave me about this time my first lesson in geography in an original way. I stretched a large sheet of old drawing paper on a board, and on the edges my father marked the degrees of latitude and longitude. I was then made to find the latitude and longitude of a place in the Gazetteer, to use a $\mathrm{T}$ square to draw lines from the corresponding degrees on the edges of the paper where the intersection of the two lines would be the place required, where I printed as best I could the name of the place. In this way, a map would grow as far as the Gazetteer furnished materials. But my great delight was to copy pictures of soldiers. Horses came next in my esteem; and Horace Vernet's lithographs of these subjects were my great delight. Sometimes my 
father helped me, but not often. Somehow or other, however, I learned to draw just as any one can who has a will and a desire to succeed.

"As mentioned already, my father had a contract for supplying the City of New Orleans with water, and had sent my half brother, Henry, there to look after the work. While we lived in Speaks' house, news came to my father of his death. It was a heavy blow to him. Henry was a brave, gallant fellow who had distinguished himself at the battle of New Orleans on the 23rd of December, was accomplished for his years, had become an able architect, and was universally esteemed. My father felt his loss, not only in the death of a son, but in the confusion caused by it in connection with the contract. I remember the death and the gloom and the mourning. But I had rarely seen my brother, and to me the loss was a slight affliction. Children get over such things easily.

"Mr. Monroe was inaugurated about this time, if I recollect rightly (1817-1825), and I was permitted to take 'Codger,' and I actually rode in the procession from the 'Seven Buildings' where Mr. Madison and Mr. Monroe, his successor, then resided-for the President's house was still a ruin after its burning by the British in 1814-to the Capitol, or rather, a platform in front of the building built in a hurry after a design of my father's, on which the ceremony took place. This building afterwards acquired celebrity in the War of the Rebellion' as 'the old Capitol prison.' Mr. Madison was a small spare man and wore powder. I see him now in my mind's eye, as he advanced with Mr. Monroe to the front of the platform, and then retired, when Mr. Monroe, after taking the oath, delivered his address. I am not sure, on reflection, that Mr. Monroe was not residing at O'Neill's and not at the 'Seven Buildings' until the 
'White House' was repaired. At any rate I have a recollection of going with the crowd that followed the President after the inauguration into a large room at O'Neill's and seeing a lady at the upper end of it, who I thought was very handsome with a high color, and who somebody said was Mrs. Monroe. Writing in this desultory way the exact accuracy of my recollection is not very material, however.

"While we lived in 'Speaks' House,' I first saw our good friend Robert General Goodloe Harper, who came with his son Charles, the fidus Achates of my later life. Richard Derby, too, I remember well. I see him now as he sat one summer evening on the front door steps, and, bathed in moonlight, sang to my mother's guitar 'of a' the airs the winds can blow.' Few men in social life had a wider reputation, in those days, than Mr.Derby of Boston-Dick Derby, as he was commonly called. But our distance from 'the avenue,' as Pennsylvania Avenue was called, narrowed our number of visitors while we lived in 'Speaks' House.'

"My acquaintance with African Colonization began here. I often rode 'Codger' into Georgetown on errands for the family, and on one occasion, as I was returning, I was attracted by the lights in a church, not far, if I recollect, from the higher of the two bridges over Rock Creek. Curiosity led me to dismount, hitch 'Codger' and look into the church. A public meeting was being held there, and Mr. Francis Scott Key was the speaker. All I could gather was that he spoke about Africa; in what connection, however, I could not tell. I remained but a short time and then went home. I have in my own mind, when I have stated this fact, as I have often done, both in public and in private, fixed this church near the high bridge as the locality, but in this I may have been mistaken. The material fact, however, is independent of the locality. 
"Mr. Key was a friend of my father, and his counsel too. I remember him well. In after life, as a man grown, I saw him often when we were both actively engaged in Colonization. He was of the middle size, was very spare with a slight stoop. His features were aquiline, his eyes deep set, and his face thin and seamed. He spoke quickly and with energy, and no one ever conversed with him without recognizing his ability. He was a gentleman every inch of him, in the best sense of the term. It was long after my first acquaintance with Mr. Key, when I was but a boy, that I connected Colonization and himself with the meeting that I have described in Georgetown.

"Two friends of my father's must not be omitted from these reminiscences-General Swift of the Engineers and Colonel Bomford of the Ordnances. The latter was devoted to his gun, and I used to be his companion in his shooting excursions into 'the slashes,' a tract of low and marshy ground lying at the foot of the range of hills on which 'Speaks' House' stood. General Swift was a very handsome man with a finely developed head, and refined bearing. Colonel Bomford was a small man of very soldierly carriage. I was a favorite with both these gentlemen. If I remember rightly it was my faculty of drawing that attracted General Swift, and my good fellowship in our shooting tramps that influenced the Colonel. At any rate, they both suggested to my father that I should be sent to West Point, which was then beginning to improve under the reviving influences of Major Thayer, who had succeeded Swift in the Superintendency.* My father wanted me to follow him in his own career of engineer and architect, and consented in view of the fact

* A statute has now been erected at West Point in his honor, having an inscription in which he is called the "Father of the United States Military Academy." Mr. Latrobe gives in detail his own efforts to obtain a tardy recognition of Thayer's work during his life. 
that the education I should receive would be germane to both these callings. So one day there came a letter from the War Office to the care of my father, addressed to Cadet John H. B. Latrobe, signed by William Graham, acting Secretary of War, directing me to proceed to West Point in September 1818, there to be examined. I may mention here that my warrant, subsequently received, was signed by John C. Calhoun, Secretary of War. But my letter of appointment looked long ahead.

"There is little of interest to be recorded of my life while we remained at 'Speaks' House.' The most intimate friend of my mother was our neighbor, Mrs. Joel Barlow, the grounds of whose residence 'Kalorama' were the resort and playground of my brother, sister and myself for many a summer day.

"I remember it was at 'Speaks' House' that I began to pick up French in a way worth noting.

"While at Georgetown College I had committed to memory a page or two of 'Du Fieff's Dialogues' and had belonged to a French Signum, an association among the boys who agreed to speak nothing but French to each other, under the penalty of having a piece of tin called 'la signe' put upon the lad who replied to a question in English. This he kept until he could pass it to another of the club speaking English, when he thrust the tin on him saying 'prenez la signe'; and the unhappy lad who had the tin at sundown was mulcted some small sum, to be paid out of his pocket money, and at the end of the month the amount thus collected was sent into Georgetown and laid out in confectionery, when the members of the club had a 'feast' in the Seminary - the college for the priests.

"Some few words I no doubt picked up, but falling in with an amusing French story-book at 'Speaks' House' I deter- 
mined to read it, with the aid of a dictionary. My father would not assist me, although he spoke French as he did English, but let me worry on. I learned more this way than I ever afterwards did in the regular way. I recall now the pith of one of the stories, which told of a man who ridiculed the gift of a crutch that had been made by the will of a dying peasant, until one day when, using the crutch to beat a donkey, it broke in two and gold coins fell from the hollow sticks. My dogged perseverance helped me in learning French, as it has on other occasions stood me in good stead.

"It occurs to me, 'apropos of 'Speaks' House,' to describe a matter that $I$ do not remember to have seen mentioned in any publication-a mode adopted by my father in taking down the entablature, after the burning of the Capitol by the British had left it supported on the splintered and tottering wrecks of the friable sandstone columns that had supported it. He had the cord-wood, afterwards used in heating the Capitol, piled carefully between the columns up to the entablature, whose weight being thus sustained, the danger threatened by it was obviated.

"A memorable incident in this part of my life was a journey on horseback that I made, mounted on 'Codger,' with my father to Loudoun County, Virginia, where we were the guests of Mr. Samuel Clapham. The object of the visit was to examine a marble reported to exist in the neighborhood in the Blue Ridge. While at Mr. Clapham's, my father first saw, or rather saw for the first time, the Breccia from which the columns of the House of Representatives, then being rebuilt, were afterwards obtained. I remember his breaking off a piece from a protruding rock in one of Mr. Clapham's fields and holding it to a grindstone turned by a negro boy until a flat surface was obtained, which, wetted, showed what the appearance would be when polished. This was so satis- 
factory that an examination for quantity was made, which resulted in finding on the banks of the Potomac a place where quarries were opened and from which the great columns, some of them monoliths, were procured. I think that I paid a visit to the quarries at a later date, when Mr. Hartnet, the quarrier, was in full blast with his work."

In 1826 Madam Anne Royall, speaking of Mr. Latrobe, says, "This young man, it is well known, is the son of the great Latrobe who discovered the native marble on the Potomac, and showed the citizens how to use it-a source of wealth to the country. Look to the columns of the Capitol, and blush, ye sons of Maryland, that ye patronize such men as W. and W., and let the son of the great Latrobe perish." Black Book, Vol. 1, f. 104.

"I think I was much given to falling in love in these days, and the object of my adoration when we lived in 'Speaks' House' was a young lady very much older than myself who resided in the neighborhood, to whom my attachment exhibited itself in the very innocent way of reading aloud to her 'The Hungarian Brothers,' 'Thaddeus of Warsaw,' and I am not quite sure that I did not get as far as 'The Children of the Abbey.' I mention this incident of my boyhood to add that nothing in my opinion refines the nature of boys more than the influence upon them of refined women older than themselves.

"My father's relations with the authorities in connection with the public buildings in Washington were not agreealie. He was proud, high spirited and a sensitive man, and it was still the day when an architect was regarded as somewhat of a boss carpenter, on a larger scale. Under Mr. Madison's administration, the architect had absolute control. The expenditure of money appropriated by Congress for the building was under his charge; and it used to be my 
father's boast that of the enormous sums he had disbursed every cent had been accounted for. On his return from Pittsburgh he found the system changed. There was a commissioner who had charge and had certain authority, and somehow or other misunderstandings arose that culminated in my father's sending his resignation to Mr. Monroe. Of course there are two sides to this as to every other story, and I do not venture to tell my father's here, because it might affect parties now alive. Suffice it to say that my father ceased to be architect of the Capitol in the early part of 1817 .

"Of course, on his resignation his salary ceased and a great gap was made in his means. Washington did not then afford. employment to an architect independent of Government. My father had always lived up to his income, and when this was so much impaired as it was now, there was more or less pecuniary trouble." 


\section{CHAPTER III \\ Life at West Point \\ 1818-1821}

In December 1817, when he was fourteen years old, Mr. Latrobe was appointed a cadet and directed to report at West Point for examination in September of the following year.

A letter from Mr. Latrobe, Sr., to his father-in-law, $\mathrm{Mr}$. Isaac Hazlehurst, gives his reasons for sending his son to West Point. The letter is as follows:-

"Isaac Hazlehurst, Esq.

"Washington, March 9, 1817.

Philadelphia.

My dear Father:-

"As you have so lately seen our son John, and have had an opportunity of knowing what sort of a boy he is, both as to disposition, interests and growth, I need not describe him. $\mathrm{He}$ is in most respects everything a parent could wish, and his faults are partly those of his age; partly those of his extreme forwardness in bodily growth and mental development. He is, in fact, conscious of great superiority over all his companions of the same age, and he governs their bodies and minds rather despotically. I am not without apprehension that with such a constitution and strength, and with such a fearless mind, the faults which now appear most reprehensible in him will be much augmented as he grows up; although his goodness of heart may somewhat repair the injurious effects. Independent of the haughty manner which he, 
even in our family, does not always lay aside, we have no serious fault to find with him. We must now consider what part he is to act in the world. The reputation of the family on both sides forbids our looking to any profession but that of a gentleman for him. If he is to be a lawyer or a physician, he must receive a college education of three years at least. If a merchant, his time in any respectable counting-house will be extremely expensive to us. But as I am retrieving my affairs very rapidly, I am not in any doubt as to my being able to defray the expenses of his education, and I confess even now I could not have a more useful assistant in my office. But he ought to go from home, and that soon, and if it were otherwise desirable, I would much prefer to bring him up to any other profession. One of our most intimate friends here is Colonel Bomford of the Ordnance. $\mathrm{He}$ is a man of considerable professional merit, as well as private worth, and he and John have formed a very close acquaintanceship. Very unequal, but otherwise very intimate. Colonel Bomford has filled his heart with the advantages of an education at West Point, and whatever else he may submit to be done with him, nothing will so well satisfy him as to go to West Point. The advantages which this career afford are:-

"First: His education will cost us nothing, and it will be of the very best kind. He will learn to speak French fluently, and become an excellent mathematician, draftsman and chemist.

"Second: His pay- $\$ 19.00$ a month-will clothe him, and in fact $\$ 100.00$ per annum will be ample additional allowance for other expenses. He can spend two months annually at home.

"Third: The severe military discipline he must undergo, the early hours and exercise among the mountains, appear 
necessary to his indolence and the development of his constitution.

"Fourth: As a preparatory education for civil department of his preference, he cannot possibly have a better.

"Fifth: In three years he is entitled to a Second Lieutenancy, and may then stay at West Point or be employed at some fortification which may then be in the course of construction. He may then at twenty-one or twenty-two, if I live so long, take my place and continue as an architect or civil engineer.

"The objection seems to me to be comprised in one, namely, a determined taste acquired at West Point for military life, yielding in our country neither profit nor honor. We are now anxiously debating on the point, believing that in May or June we will be able to place him in a military school with advantage, but to your wishes we are determined to submit.

$$
\text { (Signed) "B. H. Latrobe." }
$$

As already stated by his son, the elder Latrobe moved to Baltimore, and was engaged in the duties of his profession. Among other buildings he erected were the Exchange and the Cathedral. The Cathedral, as shown by his letters, was under roof in 1818.

Mr. Latrobe thus describes the change:-

"The end was another change of residence, and my father moved to Baltimore and rented a house on the south side of Lexington Street, near Liberty, and opened his office as an architect. The selection of Baltimore as a place of residence was due to his having two important works there then in progress-the Roman Catholic Cathedral and the Baltimore Exchange; nor was the fact that his close and excellent friend, General Robert Goodloe Harper, resided there, without its influence. 
"As soon as the family was settled in Baltimore, I joined them, having been sent, while the moving was going on, to pay a visit to my grandfather Hazlehurst, whose country residence at 'Clover Hill' near Mount Holly, N. J., had been for many years a place of reunion. It was on this occasion that my uncle lent me his horse 'Sportsman.' I had driven across New Jersey, by way of Freehold, to pay a visit to my sister, Mrs. Roosevelt, matters that I mention only to show that at fourteen I was regarded as more worthy of confidence than boys of that age usually are.

"How well I remember the stage journey from Philadelphia, the wretched roads, the ferriage across the Susquehannah, the unbridged creeks that intersected the road, the 'stalling of the vehicle in the mud,' my ride on a leader of the team, with the driver on the other, to procure assistance, in a snowstorm, from a house a mile or two ahead, our arrival at Elkton, where a ball was in progress at the Tavern and where the fiddles and the dancing and the lights and the music formed such a contrast to the darkness and misery from which the bedraggled passengers had been finally rescued! I think it was late on the following day that the stage reached Baltimore.

"It has been its connection with this journey that has recalled the first time that I ever saw Charles Carroll of 'Homewood,' the son of Charles Carroll of Carrollton, unquestionably one of the most elegant and distinguished looking men that in a large intercourse with the world I have ever met. Of a noble presence and a most gracious manner, of an urbanity that marked his intercourse with everyone that approached him, that was remarkable in his treatment of even the domestics that waited on him, with the most scholarly acquirements, ready in conversation, full of anecdote and ready at repartee-it was 
impossible to be in his presence without admiring him. His likeness to the best portraits of George IV was singular; and persons who had seen the two reported that the manner of Mr. Carroll was that of the Prince Regent. Later in life I saw much of Mr. Carroll, and perhaps it was his invariable kindness that attached me to him, and colors my description after so long an interval.

"In Baltimore I was sent as a day scholar to Saint Mary's College. I believe that I was fairly proficient in Latin as far as Virgil and Horace, and could scramble through a part of a chapter in Leusden's Greek Testament, though I am not quite sure about the latter. I know that I could scan Latin poetry decently, for I used to be called upon out of order to show off. The ring of the hexameters was a delight to me. These were pleasant days, and it still stirs my heart to recall them. One of my most intimate friends in my Saint Mary's days was Sam Eccleston, older than I was and one or two classes ahead of me, a fine gallant boy, full of talent and gifted with great eloquence even as a boy. He afterwards entered the ministry of the Roman Catholic Church and died Archbishop of Baltimore. Many was the good time we had together in our schoolboy days.

"My career at Saint Mary's closed with my performing Pharaoh in Hannah More's drama of Joseph and His Brethren. My father wrote the epilogue that I delivered, and having divested myself of my Turkish costume, ignorant of the Egyptian dress, our dramatis personae followed the fashion of Constantinople. I recited a piece called the Battle of New Orleans, written by Mr. Sinnott, our English teacher, of which I recall but one line,

And fell a victim to a rifle ball.

"I remember that my recitation was followed byEccleston giving the audience, collected at the annual exhibition, 
'The Combat' from the Lady of the Lake, and being applauded ten times more than I was.

"My father, mother, brother and sister went to Clover Hill on a visit to my grandfather in New Jersey, leaving me to follow when I got through with theatricals at St. Mary's.

"I had all this time my warrant as a cadet and looked forward to going to West Point in September 1818, then but a few months off. Cockades were then much affected by military men, and I spent a portion of my pocket money in getting one made. I put this on my hat and was very much mortified when a pipe-clayed soldier from the fort; with his hair powdered with flour, refused to recognize the badge as entitling me to pass through the square in front of Colonel Armistead's dwelling on the occasion of his funeral. This was in April 1818. Colonel Armistead was brevetted Lieutenant-Colonel for his gallant defense of Fort McHenry in 1814.*

"As soon as the exhibition at St. Mary's was over, I joined my mother, brother and sister at Clover Hill, my grandfather's residence near Mount Holly, New Jersey, that I have already mentioned, where I passed a happy summer, until the latter part of September, when I set out

* From the American-Monday, April 17, 1818. A hero fallen.

It is with feelings of the deepest sorrow and regret that we perform the painful duty of announcing to the public the death of

COL. GEORGE ARMISTEAD,

The gallant defender of Fort McHenry.

On this melancholy occasion, the recollection of the ever memorable 14th September naturally occurs to our mind, when the Star Spangled Banner waved in proud defiance of a formidable foe, and after a furious bombardment of twenty-three hours continued to float triumphant on the ramparts. Then it was that Baltimore was saved, and a wreath of never-fading laurel encircled the departed hero's brow. 
for West Point. I remember the stage coach ride across Jersey, and my putting up in New York at a tavern looking on the North River, not very far from the Battery. I think I only took one meal there, having arrived in the City in the morning and having found a sloop at a wharf hard by that was going up the Hudson in the afternoon. I remained in New York, however, long enough to purchase a mahogany flute and a flaming bright green watch chain, or ribbon, which I at once attached to my dear mother's double cased watch, her parting gift. It must have been in the afternoon that the sloop set sail, for before sunset we were in the Tappan Sea, and came near being upset in a heavy squall. It was a terribly hot day, I recollect, for I see, even now, the liquid into which the butter was turned on the tea table.

"Along with my flute I had bought a music book with some preliminary instructions as to what holes were to be covered to produce the notes called for by the signs employed. I have no ear for music, cannot to this day turn a tune, and have again and again been laughed at in the family in my attempts to do so. But I had resolved to learn to play the flute and, during my voyage up the Hudson, was occupied unceasingly in attempting to master the 'March' in Blue Beard. And I succeeded, too, after a fashion; and, in later days, had quite a repertoire of tunes that I played sufficiently well to accompany my brother, who had a fine voice.

"It was about the middle of the afternoon that the sloop approached West Point. I was put into a small boat and landed, while the vessel was still under way, at Gee's Point, as it was then called, by being pitched ashore, and my trunk pitched after me. I got a boy, who was on the wharf, to take my trunk, and made my way up the road under the 
walls of Fort Clinton, and was directed by some one to 'Grid's', a tavern on the other side of the plain, where the hills came down to the river bank almost, leaving a narrow road across which was a gate, which it often afterwards became my duty to guard as a sentinel with a musket on my shoulder. At Grid's there were some ten or a dozen boys awaiting their examination. This I underwent the next morning, wrote a sentence from dictation, read it aloud, did a sum in the rule of three, another in decimals, and was then declared worthy of being admitted to the Academy. This was on the 28th September 1818, when I was duly recorded as being fifteen years and five months by the Post Adjutant. I was a lath of a chap, for I was as tall as I am now, or nearly so, and 'called off' 17 th or 18th from the right of the first company, consisting of the tallest boys in the Academy. I remember the Adjutant looked at me with surprise when I told him my age and said something about my looking young when I was old, for I certainly looked old when I was young.

"And now commenced the West Point period of my life, successful in spite of all the drawbacks of my schoolboy experiences. I presented myself, report it is called, the day after my arrival to the Superintendent, with a letter from my father, and another, I believe, to the Professor of Mathematics, and was most kindly received by both, for my father's sake. Major Sylvanus Thayer, who, as I write, is alive and in his 88th year, was a soldierly looking man, six feet high, straight as an arrow. He was one of the most dignified persons I have ever met, without the smallest pomposity of manner, yet impressing you with the conviction that he was the last person in the world to take a liberty with. His manner was of the old school, his language carefully accurate, and his enunciation precise without being formal. 
Take him all in all, he was, as far as externals went, every inch a gentleman, and a kinder hearted man never breathed. He was eminently qualified for his place. He dragged up the drowned Academy from a slough and placed it in the position in which I found it; and year after year, during his superintendency, the work of improvement went on, until the institution became in his hands, and in the hands of those who followed him in office, the pride of the country that it now is.

"The Professor of Mathematics, Mr. Andrew Ellicott (his father and uncles founded the town of Ellicott Mills, Howard County, Md.), had been engaged in many important surveys in Government employment, and carried out the plans outlined by Major L'Enfant for laying out the City of Washington, and had a deserved reputation as one of the best mathematicians of the day. He was, in 1818, quite an old man, who took a great deal of snuff, and was not, I think, as active in his habits or as clear in his eyesight as he had been. He was very regular in his visits to the recitation rooms that were presided over by his assistants, and, when he came to ours, always inquired of me when I had heard from my father, questioned me as to my progress, and had me marked 'plus three.' I am quite willing to admit that it was the liking he had to the father, rather than any proficiency of the son, that caused the highest marks for the day to be given to the latter. We used to call him 'Old Infinite Series,' and yet when he died and was buried with military honors, and I was one of the escort that fired over his grave, I felt that a good and true man had passed away, and that I had lost a warm and kind hearted friend.

"In these days, there were two barracks, the North and South. I was quartered with two brothers, Campbell and 
Alfred Graham, in the latter. When our cots were in place, there was scarce room enough for our table, with its three chairs, in the pigeon hole that was assigned to us. The room opened upon a big gallery in the third story of the building facing the South. Subsequently I lived in the North Barracks, the rooms in which are much larger and opened upon a hall running through the centre of the building. The two barracks have long been pulled down. When I was finally appointed assistant teacher of drawing, they gave me more comfortable quarters and ten dollars a month extra.

"I do not remember upon what principle our class of one hundred and seventeen members was divided into four sections. I recollect, however, that I was put into the first section, of which General Trimble and myself are now the only survivors. Our recitation room was next the guard room, on the first floor of the North Barracks. Here on a rostrum between the two windows sat Assistant Professor S. Stanhope Smith, and here, with the first volume of Hutton's Mathematics in hand, I began my West Point education. I may as well say that the first sifting, in June 1819 , of my one hundred and seventeen comrades of the year before, reduced the number to fifty-nine, the next sifting to forty-eight, and that the number that got through the meshes of the sieve was but forty. Of the others some resigned, some were 'turned back' to go over the year's course a second time, and some were found to be deficient altogether. These last were called, in the parlance of the cadets, 'Uncle Sam's bad bargains.' ",

Speaking of his position in his class, he says:

"As for myself, I got only as high as eighteenth in the fourth class; and when I complained to the Superintendent that my French was not credited to me, which would have 
made me sixteenth, I was told, in the Superintendent's courteous way, that, after all, two did not make so great a difference in so large a class; that if I had been one of the first five, for example, it would have been another thing. The next year, when I was, in fact, one of the five, I had the same cause of complaint, and I have sometimes thought that the Superintendent's remark may have had a good effect; for, certainly in my third year, I had no cause for complaint.

"The head of the class, the third year, was an object that more than one of us was striving for, and when, after supper, as we stood in rank, the Adjutant came with his papers to read the merits to us, there was more than one anxious heart as he cried out 'Those whose names are called, will step six paces to the front and close to the right,' and when my name was called, I felt just able to obey the command and no more. Some days after I was crossing the plain and was stopped by Major Thaesses, on duty, who said the Superintendent wanted to see me. He was walking to and fro, in front of his quarters, in his usual blue frock coat and white pantaloons, when I approached him. 'So, Cadet Latrobe,' he said with a pleasant smile, 'you have not been to make your usual complaint to me this year.'

"I did not go into camp this year. As an opulent teacher I was exempted, and occupied quarters in the South Barracks. I soon tired of my dignified idleness, and was oftener in among the tents than in my room. Major Worth, Commandant of Cadets, was then getting ready for the march to Boston, and offered me, if I would waive my privileges as teacher of drawing, to give me a place on his staff as Topographical Engineer No. 2. I was only too glad to accept his offer, and accordingly accompanied the Bat- 
talion, going to Albany in a steamboat, and then marching to Boston, Providence, New London, where we took steamer again to New York, and so back to the Point.

"The march to Boston was a gala time. I was appointed historiographer by the Commandant, and elected by my companions chairman of the committee that was to represent them on public occasions, when it became necessary to reply to invitations and the like. The first class having left, I, as the head of the second, was No. 1 in the institution, and had my full share of attention on the expedition. Topographical Engineer No. 1, Jonathan Prescott, was rarely in camp, so that I had a handsome marquee to myself. Ah! these were happy days, happy, happy days.

"I have no purpose to recall the events of the march. Some years ago my old friend, Alfred Mordecai, gave me a copy of my journal of the march-you will find it among my books. I look on its pages for living names. Not a half dozen of that merry crowd of youthful soldiers now remain on earth. Everywhere the greatest attention was paid to us. Boston was hospitality itself. We dined in Fanueil Hall, when as the head of the classes, I sat on the left hand of the Major. We dined at Cambridge, where I sat by the side of President Kirkland. Society took many of us into its gatherings. My mother had given me letters of introduction to Harrison Gray Otis, United States Senator, Richard Duly, Jonathan Mason, and one or two persons of consideration, and I was made much of by them all. But, we were all made much of.

"An incident of the march to Boston deserves notice here. I have told it again and again, and you are all familiar with it. The Corps had reached Springfield. The weather was intensely hot, and Major Worth, determin- 
ing to make a night march, sent for me about eight o'clock in the evening, and directed me to proceed at once and make arrangements some thirteen or fifteen miles ahead for breakfast the next morning, saying that he would commence his march at ten o'clock. I was to lose no time and to go alone. When I had followed the orderly to the Major's tent, I was in extreme dishabille, and was sent back with a sharp reprimand and ordered to appear in full dress to receive the commands of the Commandant. So when I set out on my march I was in the uniform I would have worn at dress parade.

"The night was close, muggy is the word, and not a breath of air was stirring. There were no clouds and the stars shone overhead; but they wanted their usual radiance as it seemed to me. There was no turnpike, and the Boston road was sandy and at times sank between banks that long travel and the rains had gradually ruined on either side. In a little while, the mosquitoes began to worry me, and I took the long black plume I wore out of its socket, turned the lozenge shaped trap plate in front of my cylindrical leather cap, and used it as a flapper. I then ungirt my sword and hung it around my neck by the belt; undid my heavy silk sash, and, making a long loop, wore it across my shoulders, unbuttoning my coat, the collar of which was strangling me, and loosening the heavy stock that formed a part of a soldier's uniform in those days. I was much more comfortable and trudged steadily along, wishing all the time that I had company, and feeling in my very marrow the intense silence of the hour, unbroken even by the fall of my foot upon the sandy road.

"I do not know how far I had traveled, when I saw a light in the window of a small house on the left of the road, and perhaps a hundred yards from it. Crossing the stile 
and following a path that led to the door, I inquired my way and the distance from Springfield, and being directed to keep always to the left hand road, I returned to the stile and pursued my journey. I had not gone far when I was joined by a man who came from a cross road, as it seemed, and of whose approach I was not aware until he spoke to me. That I was startled, I freely admit. He recognized me as one of the 'boys from West Point,' and as he walked along he entered into conversation with me, telling me, among other things, of a fearful murder that had been committed, but a short time before, at a spot on the banks of the Chicopee that we were approaching. $\mathrm{He}$ might have chosen a more agreeable subject, I thought, and with no expectation of trouble, yet with an uncomfortable feeling, I rearranged my dress, and clasped the hilt of my sword around my waist, and replaced my plume behind the lozenge shaped plate of my cap. By this time we had reached the bank of the Chicopee, lined with trees, between whose branches I could see the water with the stars reflected there but a few feet below the level of the road; while, on the opposite side, a densely wooded hill arose suddenly, whose trees, closing with those on the edge over the road, made it as dark as a tunnel almost. My companion then went on to tell me that the murderer had lain in wait for his victim where an operiing in the foliage on the hill side enabled him to see himapproach slowly along the road, on horseback. When he had a clear view; the assassin fired and the other man fell at once. Whereupon the former, taking him by the shoulders, dragged him into the wood alongside the river, and there 'smashed' his head with a heavy stone, using as an executioner's block a broad flag, which my informant pointed out to me and on which he assured me I could still see the blood, if 
I looked close enough. Some unaccountable impulse induced me to bend to look at the stone between the trees, when a dark object fell upon it and I started back, not knowing but that my head was to be smashed also. I charged some such purpose on my companion, who had sense enough to remark that my plume it was that had fallen on the stone. In attempting to replace it, I had missed the socket, and left it between the trap plate and the cap, where it had fallen when I stooped over the stone. The fact is I was just about as nervous on this particular night as I ever was for so long a time in my life, and was rejoiced when, emerging from the tunnel-like roadway, I found the early dawn at hand in the pale gray of the eastern horizon. In telling this story since $I$ have no doubt somewhat dramatized it, but the essential features of it were as here set down, and as late as 1869 , when traveling in the cars from Springfield to New York or Boston, I forget which, I recognized the road when it descended to the Chicopee, the scene of my adventure in 1821, nearly half a century before; there were two gentlemen, of my own age apparently, in the car, with whom I had been conversing, and the locality suggesting my old experience, I related it. They both recollected the murder, and gave me all the particulars, verifying my account in the main. They named all the parties, and said that two men were engaged in the deed, one of whom, I think they said, had been caught, tried and hung.

"I had a narrow escape from death or mutilation while at West Point. The battery of four old iron six pounders was manned to fire a salute on the occasion, I think, of General Brown visiting the Academy. I was No. 1, who sponged and loaded at Number One of the battery. The Captain of the gun was Andrew Jackson Donaldson, after- 
wards a prominent public man, and one of the handsomest of the Cadets. No. 2, whose duty it was to put the cartridge into the piece after it had been sponged, was John C. Holland, another handsome fellow, from South Carolina. A reckless dare devil, named Eager Craig, tended vent, or held his thumb on the 'touch hole,' while the gun was being sponged and loaded. One or two rounds had been fired, when Holland, as I stepped up to sponge, thrust the cartridge into the muzzle. Of course, I shouted to him to take it out until I had sponged, but he heeded not. I yelled at the top of my voice, but he took no notice. Number 2 had fired, Number 3 had fired, in a second Number 4 would fire, and Number 1 was not loaded. Donaldson shouted to make haste, and Craig, who understood the difficulty, shouted too; so I just rammed the cartridge in with the wet sponge and stepped back behind the wheel. I had not reached my place there, when the gun went off. To this day I have always said and believed that the cartridge was fired not by the tube and port fire used in these times, but by the fire remaining in the chamber. It was the first and last time I ever rammed a cartridge in with a sponge, and I advise no one to make the attempt. In my life I have had more escapes from peril than onenone narrower than this.

"Looking back at my West Point career, I am afraid I cannot say that I was a saint there. I was fond of fun, and took my share of the risks of being found out. Luckily for me, perhaps, there were then no demerit marks. Punishment consisted in extra hours of guard duty, or in having to go upon the police squad and sweep the barrack yards on Saturday afternoon. The account was settled in this way on the spot, instead of a balance being allowed to accumulate to tell at the end of the four years, in regulating one's standing for the army. 
"An event of my West Point life was a visit which my father paid me, bringing with him my brother Ben. They remained a day or two, during which my father, with his wonderful conversational powers, popularized himself with the Professors and those of my friends who were introduced to him.

"It was in the fall of 1820 that my father died. After the death of my eldest brother there had been no one to take his place, and being detained no longer by his employment at Washington, while I was at West Point, had gone to New Orleans to attend to his interest there. He had survived a yellow fever season, during which he had had the disease, and, fancying himself fever proof, had taken my mother, brother and sister there, intending to remain until the water works were completed. The year 1820 was a year of great fatality, and among other and numerous victims was my father, who was carried off in the month of September of that year. As soon as possible my mother, with Ben and Julia, returned to Baltimore and took a house in Lexington Street, on the South side, not far from Pine. With my father died, however, forever all prospects of realizing a dollar from the New Orleans contract, and the family was once more reduced to very narrow straits indeed. Some small sum that had been realized in New Orleans, my father's library, and some woodland that my mother had in New Jersey, were all she had to live upon.

"This created a change in my future. A good deal of correspondence took place, and ultimately it was determined, on the advice of my father's dear friend, General Harper, that it would be better for me to resign, enter his office as a student of law, and look forward to taking charge of the family and attempting its support by the time the means 
of my mother were exhausted. As soon as this was determined on, it was carried into effect. I resigned my cadetship, and came to Baltimore in the middle of my last year, in December or January 1821-22. I have often thought since that this was a mistake, that I should have remained until the end of my term, for my failure to do so has ever since imposed on me the necessity of a long explanation, when asked when I graduated. While I remained at the Academy in my fourth year, I fully maintained my position at the head of the class, and there is no doubt that I would have maintained it to the end. But then again, once actually in the army, with my strong predilections for the calling, it is not impossible I might have continued there, when it was clearly my duty to take my father's place and be at the head of the household. So, with regrets, of course, but willingly at the same time, I sent in my resignation, bade my dear old comrades 'Good-bye,' and, falling out of the ranks of the military, fell in among the civilians. I believe that my resignation was regretted by my dear old master, Major Thayer, who, belonging to the engineer corps, had a notion that I was fitted for that division of the army. Another friend of mine was Colonel Mansfield, Professor of Natural Philosophy. It was he who suggested and wrote the certificate that you have, and which has stood me in good stead more than once since, in place of a certificate of graduation.

"And so the curtain falls upon the happiest portion of my life perhaps-at all events the portion least charged with cares. It is now more than half a century that I ceased to be a cadet, that I doffed forever the gray coat and its bullet buttons; and yet my memories of my West Point days and of my comrades there are all of them as distinct as the events of yesterday, and fondly cherished by a heart 
as warm as that which beat in any bosom, when, after the announcement of my standing at the head of the class already referred to, I ran and walked and jumped and hollered in my excitement, as I went to my supper at the Miss Thompsons, prouder and happier than any monarch upon earth. In my old desk at Fairy Knowe are the mementoes of sacred things in my life, and more than one of them have a West Point history.

"I went to West Point when I was fifteen years and five months; I left it when I was eighteen and eight months.

"My father had always been a favorite in society. As stated more than once already, he had great conversational powers, was a capital story teller, and had a genial manner that was peculiarly his own. Of my mother's accomplishments I have already spoken, but my mother was a widow now, living on scanty means, and in a very modest way. True, the furniture had been brought back from New Orleans, and that which had been left in storage in Baltimore enabled her to give to our house in Lexington Street, above Pine, a more presentable appearance. But things were not as they used to be. Economy was the order of the day, and happily my mother had a prudence and a judgment that made money go a great way, while there was no appearance of niggardliness. Still my father's death changed many of the habits of the family. I shall not dwell on this point again."

During his stay at West Point he would visit, at different times, his grandfather, Isaac Hazlehurst, at his home near Philadelphia. He visited also his father in Baltimore in 1819.

The family, however, moved from Baltimore to New Orleans; starting in the early part of 1820 , they traveled 
by wagon to Wheeling, where they took a boat to New Orleans, arriving there six weeks after leaving Wheeling. His sister, Julia, writes giving an account of this trip down the Mississippi. Most of her letters have been lost, but I have in my possession one letter written from St. Francesville, La., 150 miles above New Orleans, April 1, 1820. Speaking of the boat she says:

"We had gone over the Falls immediately, and were lying at Shippenfort, two miles below Louisville. I believe I gave you some account of the latter place in a letter from there. I was less pleased with it than any town we had been at. We were entertained very handsomely by those to whom we brought letters. . . . After going on at the rate of 250 miles in twenty-four hours, we got to Shawnee, the first place of importance, on Sunday at four o'clock. There we went ashore out of curiosity. The town was very flat; and is entirely of log and wood. Only one brick house in the place, which is the Bank of Illinois, one of the best banks in the United States. Being Sunday the natives bore down upon us, and soon each one had a sight of the boat. We got off about seven o'clock and passed two of the most singular sights on the Ohio, the 'Battery Rock,' which is a high bluff with a bare perpendicular front of solid rock a quarter of a mile in length, and the 'Cave in the Rock,' but though the moon was bright, it did not shine so as to allow us to see either of these places to advantage. On Tuesday night at 11 o'clock we entered the Mississippi, 'the Father of Waters.' The moon was as bright almost as day, and showed us the great river to the utmost advantage. How often have I wished for you, my dearest brother, in this journey, which, were it not for $\mathrm{Pa}$ 's business being so pressing . . . . for we have plenty of time allowed to look about. We have 
the most sneaking, pitiable, smooth-tongued, softly moneymaking, scrapping, illiterate fellow for a captain that you can imagine, who almost starves us. For the last week we have had nothing for dinner but salt beef and pork and grey beans, with the addition of two stinking turkeys weighing about thirty pounds. Every day as we proceeded the woods became greener and more beautiful, and the shore is very uniform and flat, yet the grouping is always varied and makes it more interesting than I supposed.

"We had to stop and wood almost every day. This is a great thing for the country people, for, as they clear away the land for their fields, they cut the wood and pile it along the banks, where it is in constant demand for the steamboats.

"Where we stopped, we went into some of the houses of the settlers. At one place where the people had been only a year, they had a bedstead, table and chairs made without a single nail. Stools with a back put to them. Every year they do better. We went to one place which had been settled nine years. Every place was as clean as a pin. The house was $\log$ and the bare joists showed. The room was hung after the manner of the olden time, but not with tapestry, but with shirts, socks, etc., all made by the mistress of the house. There are no towns of importance after you pass New Madrid on the Mississippi, until you reach Natchez. We were five days and a half from Shippenfort to Natchez, 700 miles, going all the time, but we had to stop twice to make wedges, having lost ours. This delayed us a day altogether. On Friday at noon we reached Natchez, which is built upon a very high bluff. You do not see the City from the River, as it is built upon the top of the hill and at the foot of the hill are a good many grog shops and billiard houses, and this place really seems the 
sink of iniquity. . . . . We have seen sixteen steamboats going up and down since we left Wheeling. Imagine the business of this part of the world."

I insert here a letter from B. H. Latrobe to his son.

"My dear Son:

"May 4th, 1819, New Orleans.

"At the table at which I am sitting to write to you, and to congratulate myself on occasion of his birthday that I have such a son as you, I presume that my head is at least four feet below the present level of the water in the Mississippi, while yours is raised two or three hundred feet above the tide. You will please to observe that I am congratulating myself in the first instance, but $I$ also most sincerely congratulate you that you are now sixteen and have hitherto given nothing but pleasure and satisfaction to your parents, and can, I truly believe, look into your own heart without remorse, or even regret, for any serious fault. May God preserve you, my dear boy, what you now are, an honest, upright and generous being, conscious of the errors of his own heart and head, and indulgent to those of his fellow beings, never looking for his own gratifications in the injury done to others, but always making self subordinate to humanity, to friendship and to justice. I was going to say, remember that you are now, or soon will be, the head of a family of a name which has not hither been disgraced by any individual belonging to it; but it is unnecessary. The son of such a mother, and the brother of Henry Latrobe, requires no lecture, especially not on his birthday.

"Your mother and sister keepyouno doubt au fait of all my proceedings. I have perfectly succeeded as far as the speculation of my very good friend Grafaber would let me, that 
is, to one-fourth of the whole project. The water will flow in the streets this year yet, and next winter I must persuade your mother to accompany me hither with Julia. This is a strange country. The inhabitants live along a narrow strip of land in front of which is the Mississippi, behind marsh, swamp and lake, so that the only possible ride or walk is along the river bank. But the air is soft and mild and I believe as wholesome as any other air of a hot climate. I never was better in my life than since I have been here. Now, as you are an incipient philosopher, I wish you, with the aid of your brother mousquetaires, to attack this problem.

"The Susquehannah and the river Allegheny rise nearly at the same height in the Allegheny mountains. The Allegheny is about the same length from the source to Pittsburgh that the Susquehannah has to Columbia. Columbia is one hundred and twenty-eight feet above the tide. The two rivers have the same rapidity so far. I think the Allegheny the more rapid. You have seen it at Pittsburgh.

"Now from Columbia to the tide the Susquehannah has 128 feet fall in 41 miles. From Pittsburgh the Ohio runs 2500 miles to New Orleans, below which place the Mississippi falls into the Gulf of Mexico. We will suppose the Gulf of Mexico level, but as soon as you get into the straits of Florida, the Gulf stream runs to the northeast at the rate of from two to five miles in an hour. Opposite to the Capes of Virginia the two streams meet-that is the Susquehannah (for the Chesapeake is the Susquehannah) and the stream composed of the Ohio, the Mississippi, and the Gulf stream. In the first case you have a rapid falling from Columbia 128 feet to the tide (which we may suppose on a level with the water of the Capes) in 41 miles, that is about three feet in a mile; in the other you have a continued current of 5,000 miles, and a very rapid one. If this latter 
one falls only one inch in a mile it would fall 416 feet, and be, of course, at their meeting 288 feet below the tide of the Susquehannah. As you have no theological dogmas (the disgrace and the misfortune of Mankind) to discuss at West Point, here is a subject for you, in which my old friend Mr. Ellicott may be puzzled, if anything can puzzle him.

"Your mother was so good as to send me by the . . . all of your letters which gave me great pleasure and . . . but nothing more so than to find that the time has arrived in which your pride in your sister Julia would rival your affection for her. I also received letters from her and from Ben. Ben is a clever little fellow. To my astonishment he informed me that he had been under the necessity of giving a good thrashing to a certain telltale, Harris.

"I am glad that you have seriously taken to the study of history. Gibbon's work will explain my motives for detesting dogmatic theology. But all history is a thing of misrepresentations or absolute falsehood, excepting in respect to great leading facts and events. Nothing however, is so necessary to be known by a gentleman. Otherwise, a man may be apt to act one of the characters of your sporting clerk on the stage of real life.

"God help you, my dear son. Go on as you have done hitherto, stick to the truth as you have done, at all hazards. 'Vitam impendere vero' be your motto, and you will seldom go wrong, and always do unto others as you would they should do unto you. You see how old Daddies will preach. Your truly affectionate father and friend, (signed) B. Henry Latrobe.

It is of this letter that Chief Justice E. D. White of the Supreme Court writes. "It was very kind of you to think 
of me and send me the interesting letter of Mr. Latrobe. I could not help thinking how demonstrative it was of the high character of men of that day."

Further references to West Point life appear in Mr. Latrobe's journals at various times. Regarding the trip from West Point to Boston and his election as historian he says:

"In this way I became the historian of the march to Boston, as it is printed. In the Proceedings of the Alumni of 1885 will be found a letter to my family giving an account of the march of the corps up the Hudson in 1819."

Of Worth he says:

"It is to Worth, in great measure, that the cadets of today are indebted for their soldierly characteristics, and yet Worth was not a West Point man, but he was instinctively a soldier. He served with distinction in the Seminole and Mexican wars. Died 1849."

When Mr. Latrobe handed in his resignation from West Point in December 1821 he was the only member of his family capable of working for a living. His brother Benjamin was too young; and he himself, as he says, was only eighteen years and eight months. It was always a matter of deep regret to him that he had not stayed at West Point until the end of the term, when he would have graduated. At the time he did not appreciate the fact that his resignation might be attributed not to its true cause, but to his inability to graduate. It did not occur to him that he would be considered one of Uncle Sam's "bad bargains," as he terms them, and, in order to remove any such impression, he had printed what he called his "West Point Memoranda," dated July 16, 1874.

"It is now more than half a century, since, in December 1821, I resigned my cadetship at West Point. I was then 
at the head of the first class, in the middle of my last year's course; and there was no reason to believe that I would not retain my position until I graduated in the following June. But my father had died in New Orleans in September 1820, and my mother had returned to Baltimore in circumstances that seemed to make it my duty to attempt, at least, to do something more for the support of the family than I could reasonably expect to accomplish by remaining in the army. Hence my resignation, and my entrance, as a student of law, into the office of my father's friend the late General Robert Goodloe Harper. This was in January, 1822.

"So far as regarded the time of resigning, I here made a mistake, which has been an occasional mortification to me through life. Had I remained at West Point only five months longer, I would have graduated with my class; and afterwards, could still have left the army and pursued my professional career."

While it is true that Mr. Latrobe did not graduate, he received what is equivalent to it, a certificate signed by the Academic Staff of the Military Academy at West Point, November 21, 1821, which certificate says, among other things, that at the first examination he obtained the first honors and the first standing in a very numerous class of his fellow-students.

The following letter from General S. Thayer, who was the Superintendent of the Academy at the time Mr. Latrobe was a student in 1821, was written January 23, 1864:

"Forty-two years have not effaced from my memory the regret and disappointment I felt when, near the close of 1821, your resignation was handed to me, for I had counted on you as a future officer of Engineers. You were then at the head of your class and without a rival." 
That he was not a brave soldier at this time is admitted by a story told by him in which he says:

"One Saturday afternoon Sam Hobert and I had got to the summit of Crows' Nest almost, when I saw on a broad flat rock on which I was about to step, a handsome brown stick, which I at once determined to substitute for the rough affair that had helped me up the mountains, when, horror of horrors, the stick moved and the nicely tapered end that $I$ had intended for the ferrule began to rattle in a way that I can still fancy that I hear. It was a rattlesnake, lying lazily at full length in the October sun, that I was about to take hold of. Of course, we should have quickly walked out of the snake's way, or have taken a stone and killed it, but boys of fifteen do not think of everything, and on the occasion Hobert and I only thought of getting back as fast as we could to where we came from; and, in a panic that almost passes belief, we made a 'beeline' for the flag staff on the plain. I still remember our frantic race. I remember dashing past the ruins of the huts of the German soldiers of the revolution, flying over the flats, and not stopping until we reached the public road. Remembering this, I could perfectly understand the flight, in a panic, from Bull Run in 1861."

"On another occasion, in referring to a very severe storm, he says:

"Perhaps my memory of this particular storm is quickened by the well remembered fact that I thought, in no impeachment of my valor, to reverse my musket and, sticking the bayonet in the ground, keep at a respectful distance. This was but for a moment, however, for, looking toward the guard tent, I saw my class mate Silas B. Fillebrown, two inches taller than myself, walking there with his musket at a 'support,' when for very shame I resumed my own." 
Among other books belonging to Mr. Latrobe is a "Commonplace Book," endorsed "Manuscript, John H. B. Latrobe, Cadet, United States Military Academy. January 19, 1819." On the fly leaf is the following:

"In the course of a man's life we can often trace his character in the productions of his pen at the different periods in which they were written. At some future day to be able to see how my own character was formed, induces me to commence this book."

The first article in the book, dated January 19, 1819, is a composition in which he says, speaking of the decline of manhood:

"Let us consult the page of history and it will inform us that it was owing to the introduction of luxury, whose baneful influence enervated the minds of their inhabitants."

To luxury he attributes all decay in manhood and character.

This is probably the first production of his pen and he takes Goldsmith as his text:

Ill fares the land to hastening ills a prey,

Where wealth accumulates and men decay.

Among other articles he has the "Robber's Castle," translated from the German.

A great deal of the book is taken up with verses, some of which are composed by himself and some by his father. Some are copied from other authors.

There is a poem to Miss O'Connor by himself, written October 21, 1821. This seems to have been written to a young lady whom he met at Boston, for in the correspondence between himself and Wm. Otis, |whom he met in Boston, it would appear that he had made quite a sensation among the belles of Boston, and Otis speaks of the different poems which he had written to the different girls. 
To M - - - O.

Ne'er tell me the diamond allures by its splendor,

Though set in tiaras of gold,

It wants all that's soft, all that's lovely and tender,

It dazzles, but still it is cold.

Of the brilliants which wealth may have purchased a queen,

None shine with such glory upon her

As the rosebud which blooms 'mid its foliage of green,

And is wreathed o'er the brow of $\mathrm{O}$ 'Connor.

Tho' turned in rich circles o'er ebony hair,

The pearl lends its aid to adorn,

Tho' the gems of the coronet blaze on the fair,

Eclipsing the brightness of morn,

The diamond and pearl are unheeded, unseen,

We mind not the pageants of honor,

When compared with the rose 'mid its foliage of green,

Which is wreathed o'er the brow of O'Connor.

Lines written on leaving West Point forever.

December I82I.

Farewell, the friends I leave behind, The good, the generous and the kind,

Farewell, I fear forever.

Affection's bond, tho', still endures, My heart, while beating, still is yours, And $\mathrm{Oh}$ ! forget me never.

In sorrow's hour, mid beauty's wiles,

To merit still your care, your smiles,

Shall be my first endeavor.

Then think of him who, far away,

Has known and loved yet many a day,

And $\mathrm{Oh}$ ! forget him never.

J. Latrobe. 
RETURN to BALtimore, 1821-STUdy OF LAW IN THE Office of General Harper

There can be no doubt that in the resignation of $\mathrm{Mr}$. Latrobe, the Government lost a most efficient and capable officer; but the Government's gain would have been unquestionably a loss to the country, and especially to his native city Baltimore, where, as is shown in his subsequent career, he took an active part in every matter which could lead to its improvement and progress.

We have considered Mr. Latrobe's life up to the period of his leaving West Point and entering Mr. Robert Goodloe Harper's office December 20, 1821. Mr. Latrobe was eighteen years and six months old, when he entered the arena to attain success in the profession which he had chosen for his life work. It was customary in the old days of chivalry, upon a knight entering the lists, for a herald to give some account of him, so that the champion who was about to break a lance might be known. In these days, when photography is used to such an extent that children are represented almost from the day they were born and during the different periods of life until the end, there is no difficulty in getting a picture of the subject; but at the period of which I speak-1821 - there was nothing of this kind, and I am not in possession of any picture or description of Mr. Latrobe which would enable me to give an idea of the man, except from a very meagre account of himself.

He has already stated that when he went to West Point in 
A SILHOUETTE OF JOHN H.B. LATROBE

By himself, with the note "John H. B. L. before he went to West Point"

PENCIL SKETCH OF JOHN H. B. LATROBE

$B y$ himself, with the note "Altempt at myself when a Cadet, by myself" 


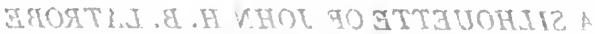

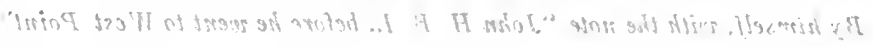

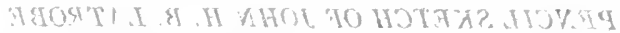

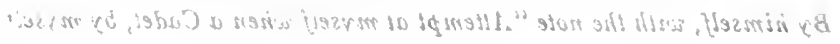



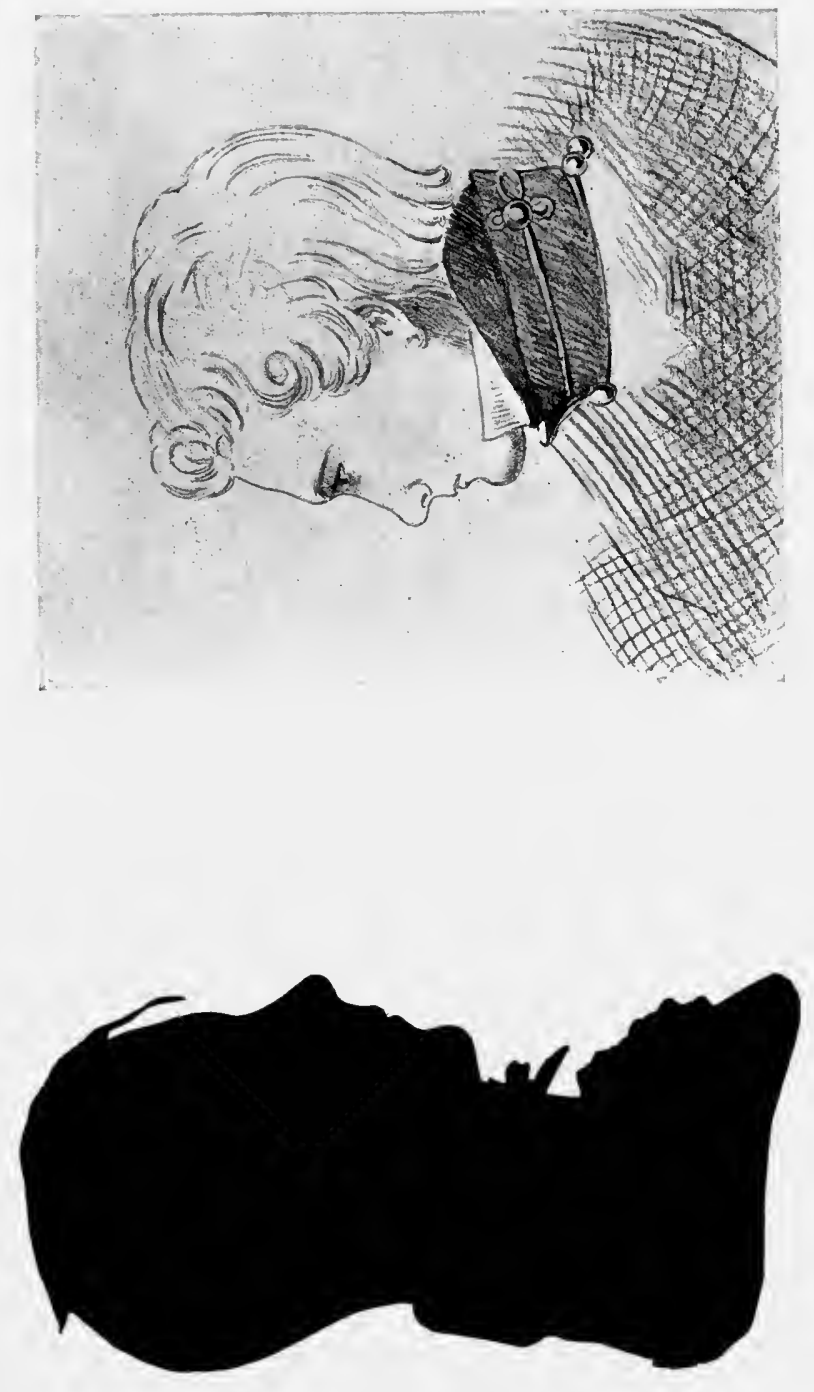

1818 he was an overgrown boy, six feet tall and awkward; but he says that this awkwardness was of value to him, in that, as one of the tallest men in the corps of cadets, he occupied the front rank. We can assume therefore that Mr. Latrobe at eighteen was a man of something over six feet in height and of rather a commanding presence. Apparently he was strong physically, and from the certificate of the teachers he was mentally well equipped for the battle. From his ancestors he had the right to a strong physique. Going back we find that his grandfather, the Rev. Benjamin Henry Latrobe, married in 1753, Margaret Antes, who was the daughter of John Frederick Antes, thus mixing the English stock with the German, for Antes' grandfather was one of the settlers from Frankfort, in what is known as Germantown, Pennsylvania. John Frederick Antes was a man described as of large frame, and of considerable force and reputation. His grandfather, Baron Von Blume, born in 1620, entered a monastery and adopted for name the Greek translation of the word Anthos, a flower; but later he left the monastery and married his cousin the Baroness Von Blume, who was the Superior of a convent at Maintz. They changed their faith, becoming Protestants, and emigrated to America, where they assumed the name of Antes.

The union of his great grand-daughter with the Rev. Benjamin Henry Latrobe, who became a Bishop in the Moravian Church, was blessed with five children who reached maturity-Christian Ignatius, the eldest son, who succeeded his father as Bishop of the Moravian Church in London; Benjamin Henry, the second son, who was the father of John H. B. Latrobe; John Frederick, the third, who married the Baroness Stackelberg and lived at Dorpat, in Livonia, Russia (Mr. Latrobe speaks of meeting the son, Edward de Latrobe, in St. Petersburg, 1857); a daughter, Mary 
Agnes, who married a Mr. Bateman, whose son was the distinguished English hydraulic engineer, John Frederick Latrobe Bateman, of London; and another daughter, Anna Eleanora, who married a Mr. Foster, prominent as a lawyer. One of the Foster family was the English Minister in the United States at the breaking out of the war of 1812.

I have, among the correspondence of Mr. Latrobe, a number of letters from his uncle, Bishop Christian Ignatius Latrobe, and also letters from the wife of his uncle John Frederick in Russia. Christian Ignatius was born in 1758 and died in 1836. He had six children, Peter, the eldest, Charles Joseph, Charlotte, Agnes, Frederick and John.

John was a curate of St. Peter's, Hereford, and was quite an authority on church music. The father was also noted for his knowledge of music.

Charles Joseph was an author. He wrote the "Alpine Stock," "Sketches of Swiss Scenery and Manners," "The Pedestrian or Rambler in Italy," "The Rambler in North America," which was written from travels taken by him in company with Washington Irving, and "The Rambler in Mexico." He died Governor of Australia in 1875. He was born in 1801 .

This short record is given to show the high degree of intelligence and ability displayed by the various members of the family from which John $\mathrm{H}$. B. Latrobe was descended.

In one of the letters written by Christian Ignatius to Julia Latrobe, the sister of Mr. John H. B. Latrobe, he gives a description of his family and says that he understands that she is like the rest of the Latrobes - of large stature; that he himself was frequently mistaken for his brother Benjamin Henry Latrobe, after the latter came to this country; and that when his family walked through the streets of London they drew attention, from the fact that 
he himself was six feet two inches, Peter six feet one inch, Charles Joseph six feet one inch, Frederick six feet two inches, and John six feet one inch. Their magnificent appearance always created a sensation when they were together, and it appears as if, in fact, they belonged to the Patagonian breed.

This characteristic of size seems to have been a heritage of the Latrobes in this country. Mr. Ferdinand C. Latrobe, the eldest son of John H. B. Latrobe, was over six feet tall, Osmun Latrobe, the second son, was over six feet tall, Stuart Latrobe was a man of six feet, and the only one who was undersized was John H. B. Latrobe, Jr. Benjamin Latrobe, Jr., the brother of John H. B. Latrobe, was over six feet tall, and his son Charles Latrobe was a man of six feet, and his son in turn, Gamble Latrobe, is about the same height.

It was necessary that Mr. Latrobe should have strong physique and good health. He had to meet a condition which required strength of mind and body. He was the head of a family consisting of his brother Benjamin, four years younger than himself, Julia, his sister, two years younger, his mother and himself. They had little or no means. Isaac Hazlehurst, his maternal grandfather, was not in a position to lend any financial aid. Mr. Benjamin Latrobe's enterprises in the South were not successful.

From 1822 to December 1832, the date of Mr. Latrobe's second marriage, was the period of bitterest struggle.

Human life at times has been compared to a river. Rising in the mountains the stream rushes over obstacles, fretting, foaming, falling with occasional quiet stretches. It passes through turmoil and strife, and at last reaches the valley through which it flows in comparative tranquillity, until the spirit, like little Paul Dombey's, reaches the sea of eternity. 
The years between twenty and thirty are formative, and afford an index to the character. Dr. Samuel Johnson says: "He whoever hopes to thrive must begin by thirty-five."

The promise given of fulfillment by Mr. Latrobe's career at West Point was ratified by the substance of his achievement during these ten years. Through the whole web of his life, however, is found the woof or thread of his military experience at West Point. One can see that he took pride in his record there, and he harks back to his first love frequently.

Mr. Latrobe writes:

"The day after I reached Baltimore I reported myself with military punctuality at General Harper's office in Gay Street and had a volume of Blackstone put in my hand and a seat given me in the same room with the General, he occupying a place rather on one side of the centre of the space immediately opposite the fire, and I an arm chair with a writing desk arm close to the mantle piece on the side next the windows.

"The house was immediately opposite the 'Exchange' and had been one of the handsomest dwellings of its day, thirty feet front and three stories high. On the right hand of the wide hall of entrance was the office fronting the street; the dining room was back. The drawing room was the large front room in the second story. But the office was a dark, dingy apartment. Some shelves on either side of the door from the hall contained a few old time law books - Coke on Littleton in folio, Bacon's Abridgment, Ferne on Contingent Remainders, Cruise's Digest, Coke's Reports, the Acts of Assembly of Maryland, and the Maryland Reports. There was an India folding screen behind General Harper's seat, and there was a large table 
between the windows with bundles of papers on it. It was not the fashion in those days to carpet lawyers' offices, and the General's office was no exception in this respect. There was no current practice to bring a succession of clients into the room. The General's practice was confined to the Supreme Court, the Court of Appeals, and, occasionally, to the trial of cases in the United States and State Courts in Baltimore. The General was a silent man too; so that the transition from my West Point life to the daily and most oppressive existence in the quarters I have described was very marked and uncomfortable, to say the very least. It was a long walk from Lexington near Pine to Gay Street, and if the fresh air and the active life of the streets exhilarated me on my way to the office, I was dull enough by the time I closed my book for the day. Still there were times when the General would talk, and would take an interest in my studies.

"At the end of a conversation that had a purpose of finding out something about the pupil in his office, the General asked me whether I rhymed at all, and when I confessed to efforts in that way, he advised me to write a poem. He said I wanted facility of expression. That my English education had been neglected at college for Latin or Greek, and at West Point for mathematics; and that if I took to rhyming I would be obliged to hunt up words to find synonyms and learn to round periods. He advised me also to translate Latin poetry and prose with the same view as well as to keep up my knowledge of the language. $\mathrm{He}$ further suggested that I should read Spenser's Fairy Queen, but to do all this at odd times, when I was tired of reading; and I did it all, and read law into the bargain faithfully. I was in the mire, I fancied, and law was to get me out of it, and law I tried to be faithful to, and think I succeeded. At any rate $I$ have been as successful as the average. 
"This advice was not given all at one time, but it dropped from the General in the course of my first year. In my old desk you will find some of my poetic exercises, and see that I preferred Catullus to the duller pages of Cicero ad familiares. There was a society at this time called the Philokrisean, composed of students of law. This I joined, and to help my oratorical studies I frequented ward meetings and portrayed the virtues and the claims of Jacob Small for the office of the Mayor, though this must have been in the latter portion of my student life. I collect together in this place all that I now recall that affected in any way my professional education. I worked hard, very hard, during the entire term of my probationary period, at the law and at the other things as well.

"One of the first things to be thought of was how best to eke out the very scanty means at my dear mother's command, and I tried very hard at literature in a small way. I had made the acquaintance of Fielding Lucas and William Gwynn, the former the leading bookseller in Baltimore and the latter a lawyer of great experience and the editor of the Federal Gazette. Of all the friends of my life none were truer than these. Mr. Gwynn saw that I was working hard to become a lawyer and suggested that I should begin to write a book on the duties of a Justice of the Peace and Constable, by way of learning something of these subjects myself. Hard by General Harper's office was an old gentleman named Griffith-Thomas Griffith - a magistrate. He was my first acquaintance on Gay Street and I used to drop in at his office on my way home in the evening and talk with him on every subject under the sun. He was an old bachelor, straight and spare, with his Roman visage sustained by a high white cravat, and his hair done up in a queue. He had known better days, had lived some time 
in France, was an antiquarian born, and was engaged in gathering the materials which afterwards appeared in print under the title of the Annals of Baltimore. Mr. Gwynn's suggestions, his most useful aid, and Griffith's practical information, were the helps I had to produce Latrobe's Justice Practice, which was first published after I was admitted to the bar, but which was begun while I was yet a student. Mr. Lucas wanted to help me and I wrote a good deal for him that was paid for in law books which otherwise I would have had great difficulty in procuring. For Mr. Lucas I both wrote and drew. I revised Jack the Giant Killer, wrote in rhyme and illustrated the Juvenile National Calendar. Invented Tray's Travels and showed the good dog upon them. Put Hogarth's two apprentices into verses and portrayed them both. Cinderella did not escape me in those days, and the boys and girls of Baltimore, now elderly people, may some of them, perhaps, remember the small octavo, sixteen paged books, on each page of which was a gaudily colored print, explained by eight lines of doggerel below it.

"But I aimed higher than this department of literature. An old friend of my father's, Mr. Matthew Carey, of Philadelphia, knew how hard I was put to it to scratch along and employed me to write - after the manner of the "Selectae e profarus' of my schoolboy studies-a volume in which moral axioms and rules were illustrated by anecdotes, and sent me a great collection of books in French, Spanish and English, from which I was to select my materials. This was a heavy but useful labor that I performed at night at home, and this book made its appearance under the name of 'Practical Reading Lessons on the Duties that Man Owes to his God, to his Fellow Beings and to Humanity.' Mr. Carey paid me two hundred dollars for it, a small fortune in those days. 
"The publishers of Sanderson's Biography of the Signers of the Declaration of Independence having applied to General Harper to write the life of Charles Carroll of Carrollton, the General handed the task over to me, and I wrote the life accordingly from the notes furnished to me by Mr. Carroll from the newspapers of the Revolutionary days, and from what I could pick up from the family. This I was paid for at so much a page. When I had completed it, I read the biography to Mr. Carroll, who listened to it with great gravity and, when I ceased reading it, said with much naïveté, 'Why, Mr. Latrobe, you have made me a much greater man than I ever fancied myself to be, and yet, really, you have said nothing that is not very true!'

"Mr. Lucas was publishing, while I was yet a student, 'McKenny's Tour to the Lakes,' and I drew illustrations that the books contained and obtained a further credit on my law book account. At a later date I condensed for Mr. Lucas 'Scott's Infantry Tactics,' and followed it by the 'Rifle Tactics' of the same author, and I wrote 'Lucas' Progressive Drawing Books' and drew all that it contains. This was a very expensive book selling for $\$ 12.00$ and was gotten up at great expense. For a long time it was in general use.

"The Atlantic Souvenirs were at this time being published by the Messrs. Carey, of Philadelphia, and I became a contributor of prose and rhyme under the nom de plume of Godfrey Wallace. The three tales or novelettes of the 'Esmeralda,' the 'Mortgage' and 'Giles Heatherby,' and in rhyme 'The Bower of Paplius' and one or two other jingles were from my pen. These paid very fairly. My friend, Henry D. Gilpin, afterwards Solicitor of the Treasury and then Attorney General, was the editor. Had I liet him know who Godfrey Wallace was, as he afterwards 
told me, he would have helped me in my efforts to obtain literary work, but I had a morbid feeling in these days, and I kept these matters to myself. 'The Heroine of Suli' was one of my stories.*

"Nor must I forget the 'Rainbow,' an ephemeral periodical that reached four numbers and then died out, and which had been gotten up by my fellow students, David Stewart and Robert Purviance, and myself, and published by Edward L. Coale, a leading bookseller, and one of the kindest, warmest hearted and useful of my friends. It was an imitation, Congo intervallo, of Salmagundi. I was the principal contributor, and in my care it breathed its last; the pleasure of seeing oneself in print while a student of law was all the compensation this little affair afforded.

"Mr. Lucas got up a 'Picture of Baltimore' while I was still working with my pen to eke out my professional earnings, and I wrote the letter press and drew the pictures. It sold well and was regarded as clever enough. I saw a copy of it the other day, and only wonder that Lucas had the courage to publish what now strikes me as below criticism even.

"The above is not intended to give the order of my heterogeneous productions. They extended over many years. I put them all together as falling within the time when I worked for money or for a literary cause, outside of my calling of a lawyer.

"To get through with the narrative of these my rough days, it is perhaps as well to say now as at any other time, that one of my objects was to maintain, as well as I could,

* Mr. Edward Stabler, Jr., writes an article entitled "Godfrey Wallace," giving an account of an interview he had with Mr. Latrobe on the subject of his contributions to the "Souvenir." It is published in Maryland Historical Magazine, Vol. v, No. 4. 
the social position of my father. I do not pretend that 1 was influenced by only my own romantic ideas upon this subject, but my education before I went to West Point, my associations coupled with my rank there, made other society and habits of life than those I had been accustomed to distasteful, and when in Baltimore on my return from the Military Academy I availed of the occasions that presented themselves of keeping up the intimacy I desired in quarters which my father and mother would have approved. I am not sure that this is worth mentioning, or that it will do me any credit with my children, who might prefer the record of one who, utterly indifferent to social surroundings, depended upon others finding out his merits to give him his proper place. The fact is, however, as I stated; but the difficulty was, on my extremely narrow means, to manage to do this. Ah! those were days when a good coat lasted a long time, and when clothes were worn threadbare. Fortunately, my brother Ben and myself were about the same height, and many a time had that been found a convenience, when one of us wanted to avail of the better supplied wardrobe of the other. Why! when, I had been admitted to practice and had become engaged to be married, I borrowed Ben's best coat to wear to New York on a visit to my intended there. Still, I managed to get along, and was as prominent at balls and parties as most of the young men of my age about town.

"My own merits had little to do with this most probably. My good friend, General Harper, was a son-in-law of Charles Carroll of Carrollton, and brother-in-law of Mr. Richard Caton, and with the Carroll and Caton families my father and mother had been very intimate in the lifetime of the former. Mr. Caton's house, where Mr. Carroll passed his winters, was the resort of the best society in Baltimore, 
and the house that all distinguished foreigners sought when they visited the City. I was received there as though I belonged to the family. Mr. Robert Gilmor and Mr. Robert Oliver had been friends of my father, and did not forget his son when my mother came back to Baltimore. These were wondrous helps to me,- - to mention none otherin the social world. And, then, I had the prestige of position at West Point when I left it, and I could write verses and draw tolerably, and had odds and ends of knowledge, picked up, rather than learned, that helped me socially. Professionally my fine acquaintances did precious little for me.

"In those days I was inordinately fond of the theatre, but had no money to spend there, and actually used to avoid the theatre-bills on the walls on the streets. I never saw Charles Mathews, Senior, but once, and that was owing to the liberality of an old school friend, Morton, who insisted on treating me, and we went into the gallery to see 'Goldfinch.' Morton and I had been cronies at West Point. I do believe I was, in many things, good perforce, and look back now, without regret, to my impecuniosity in those days.

"I rather think I was regarded as clever by my fellow students in the beginning of my novitiate, for I was appointed to deliver the annual address before the Philokrisean Society, a copy of which can be found in the old desk. The performance was a jejune one, and we had a supper after it, which was so jolly an affair that the memory of it still remains.

"I was admitted to the bar May 8, 1824, without an examination. I had just completed my 21st year when I made application. A committee was appointed to inquire into my qualifications. Colonel U. S. Heath was one 
of the committee. It had so happened that my good old friend, Mr. William Gwynn, had stated a case to me some days before and asked me to look into the authorities and give him an opinion in writing. This I did, and when he heard that Colonel Heath was to examine me, he handed him what I had written, whereupon the Colonel said that an examination was unnecessary and signed my certificate.

"Adjoining General Harper's home was a small twostory building, the back room of which the General gave me as an office. It was a very gloomy room, looking out upon General Harper's stable yard. I am not sure that I did not complete my legal studies here. I rather think I did, because I was joined in it by other students that the General took, after my first year in his own office. My companions were Charles Carroll, the grandson already mentioned, Charles Harper, the General's son, William George Read, of South Carolina, and Richard Bennett Mitchell and James D. Mitchell, young men from the Eastern Shore. It was here that T. Yates Walsh, afterwards a prominent member of the bar, came into the General's office. On the death of General Harper and the dispersal of the students, I retained the office for a short time as my law office. Charles Harper occupied the rooms above.

"Charles Harper I described as one of the Aides at the reception of Lafayette (Chapter V). Charles Carroll was only nominally a student. He was rarely in the office, and when there did not devote himself to his law books. Both Harper and himself were graduates of Harvard and were alike popular with the rest of us. Read was a man of distinguished ability and a high-toned gentleman, too elevated perhaps, if that could be-a person to whom the term chivalrous was eminently applicable. He wrote admirably, was a poet-perhaps I should rather say, was of 
THE TOMBIGBEE RIVER Painted by John H. B. Latrobe 
XIVIA AXIRHOT AHT gCownd . A . H wol nd batrios 


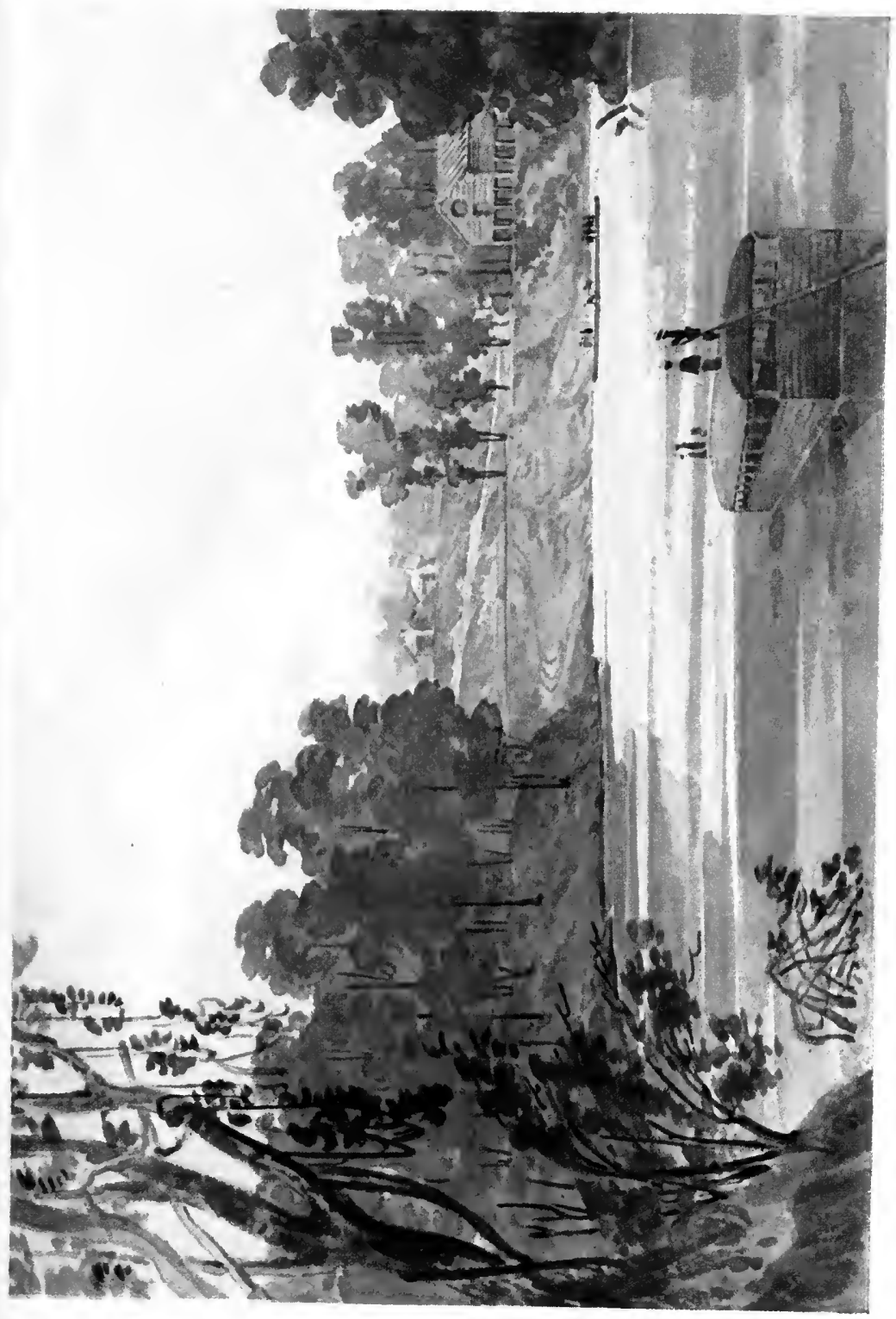



a poetic temperament-and one more sensitive on points of personal honor I never knew. We had become quite intimate, and I had given him an account of my West Point career. Someone told him I had been dismissed from the Academy. He at once asked me if it was so, and it was then I found the value of my certificate from the professors, for the idea that I had not made a clean breast to him seemed to give him actual bodily pain. While he lived, he was one of my warmest, firmest friends. He became a Roman Catholic while in the office, and many were the discussions we had upon the subject. He went to his first Communion, and I became confirmed by Bishop Kemp of the Protestant Episcopal Church. He never succeeded at the Bar. He was too sensitive for the rough and tumble of the profession, and, besides, a very happy marriage with a very lovely woman made him ultimately independent of its labors. The two Mitchells were young men of means, but kind and genial companions.

"After the first month or two I ceased to be afraid in the presence of the grave, dignified, refined and punctilious gentleman of the old school, in whose office I had my chair. Of the middle height, straight as an arrow, strongly rather than delicately built, square shouldered, of a florid complexion and very bald, with regular features, an aquiline nose, clear gray eyes, and compressed lips, of formal carriage and precise speech, my dear old master at the end of half a century stands now before my mental vision as if $I$ had parted from him within the hour. I see him in his blue coat and buff waistcoat, his tight pantaloons, and highly polished and carefully fitting boots, with his feet turned out in soldierly fashion, laying down the law to me in the office as to the jury in the Court room with a clearness and accuracy of expression such as few men possessed. Always 
cool, never excited, speaking always in the same agreeable voice, he was a model of a forensic orator. More of a politician, in the highest sense of statesmanship, than a lawyer of forms and precedents. There were men in the profession, who at times got the better of General Harper in matters of details. But when in a great cause great principles were to be discussed, developed and illustrated, he had not one superior at the Bar of Maryland. Taken all in all, Mr. Pinkney was a greater lawyer than General Harper. But with this exception he had no superior. He was without the arrogance of Mr. Pinkney, and while the latter was to be dreaded as a crushing opponent, General Harper was to be esteemed and beloved as a true man, and a powerful and generous advocate. His characteristic was clearness. He had no imagination. If he was eloquent, as he often was, it was the eloquence of simplicity. As a writer of pure English, he had no superior in the profession.

"So much for the lawyer. As a man, General Harper was the kindest and tenderest of husbands, the most affectionate of parents, and the truest and most devoted of friends. Generous to a fault, and in the social circles at the head of his own table with no superiors. No one ever felt inclined to slap General Harper on the shoulder, or take a personal liberty-he was one of the class of men with whom such things are simply impossible. When I say that I ceased to be afraid of General Harper, I mean that I found I could speak to him without embarrassment, when encouraged by the interest that he seemed to take in me. He had two great hobbies-internal improvement and African colonization. The part I have taken in these matter from my student hours to the present time is due to the impressions derived from General Harper in an intercourse 
which, making allowance for difference in age and standing, became gradually intimate. I am very sure that I gave my first vote to General Jackson because of the convictions derived from my intercourse with General Harper.

"I think the ice between General Harper and myself was first broken on the occasion of a ball given by public subscription in the Holliday Street Theatre in favor of the Greeks who were then struggling for their freedom. The General wanted a transparency painted, representing Marco Bozzaris storming the Turkish Camp, and I undertook the work and, with the aid of Cornelius Debeets, a very clever artist in oil, whose specialty, by the way, was flowers, and in an old building that used to stand behind the City Springs, managed the job. The figure was a capital one, for it was a careful enlargement of one of Flaxman's illustrations of the Iliad or Odyssey. As to the coloring I cannot say much. I remember the face looked terribly red, and the shadows of the nose were snuffy in the extreme. I painted the face, and Debeets did the rest. When that colossal figure was finished, the General wanted some descriptive lines, and I furnished the article.

"I was quite elated with the admiration bestowed on my performances, which occupied one end of the old assembly rooms at the Northwest corner of Holliday and Fayette Streets, until I heard George Howard, afterwards Governor of Maryland, read the verses aloud to a group of ladies, and when he came to the concluding lines,

Then to his tattered flag still closer clung And died with Greece and Freedom on bis tongue.

exclaiming, 'Well, if his tongue was well greased, it's no wonder it went with Freedom.' The roar of laughter that 
ensued spoiled much of my sport for that evening, and reduced my vanity to zero."

A copy of the verses as preserved by Mr. Latrobe's sister here follows:-

Thus marched Bozzaris on his bold career,

Hope nerved his arm and vengeance steeled his spear;

High in the air he waved his banner proud,

The Hero's glory, soon the Hero's shroud.

Like rocket hurrying through the gloom of night

To burst in splendor at its farthest flight,

So flew Bozzaris to o'er the 'rocky steep

And gained the Turk reposed in careless sleep.

Raised the loud war-cry, charged the startled foe

And, victory gained, received the fatal blow.

Then to his tattered flag still closer clung

And died with Greece and Freedom on his tongue.

"Writing these reminiscences, without searching for memoranda to fix dates, I may be mistaken in regard to the time of the Greek Ball.

"A memory of the house in Lexington Street beyond Pine flashes on me as I write. Among others of my mother's visitors was a Mrs. B-y C-e, a woman not far short of five feet ten inches in height, and large in proportion. She was a great bore to all her acquaintances. She timed her calls at tea, and not all her bright remarks, bitter and sarcastic generally, her varied information and knowledge of the world, prevented her room from being more desirable than her company. She was my 'bête noire.' I detested her, nor was my dislike lessened by the fact that I was obliged to see her safe at home after every visit. She fully appreciated my feelings, and late one night on our way down Lexington Street she stopped suddenly at the parapet of the culvert over Chatsworth Run, just under a lamp 
that shed its light full on her face. 'Young man,' she said, looking down into the Run some feet below where we stood, 'if you had your way, you would get rid of my company by pitching me into that muddy water. Now be honest, wouldn't you?' 'Upon my honor, Madame,' I answered, 'that is unquestionably what I'd do, without the smallest compunction.' Whereupon she laughed heartily, said she liked me for my frankness, and won my regard by never permitting me to go home with her again. Among my contemporaries the initials I have used would be all sufficient to identify a very remarkable person, of historic name in Maryland. (Chase)

"Another reminiscence I record for the sake of your Uncle Ben. We had, spending the winter with us, a cousin who attended the medical lectures and who was an expert pugilist, remarkably long in the arms and one of those teasing fellows who have the faculty of provocation in a most eminent degree. He was your Uncle's senior by several years, and took a special delight in tormenting that sensitive manboy rather, for he was but some sixteen or seventeen years old at the time. Ben remonstrated, so did I, so did my mother, but to no effect. A. took his cousin to be wanting in pluck, and at last mere teasing became bullying. The way we settled such things at West Point was to fight them out, and I told my brother that he would have to settle this in the same way. All the advantages of age, strength and skill were on A.'s side, and I regarded the contest, if one took place, as desperately against his victim. It so happened that there was a lull in the annoyances, and I had forgotten the matter until I was reminded of it one day on returning to my office by finding my mother with a soup plate of vinegar and half a quire of brown paper, plastering the battered visages of the two cousins. It seems that $\mathrm{A}$. 
had met Ben on his return from St. Mary's College, where he was a day scholar, and, as he passed him, baa'd like a sheep, or did something equally provoking; whereupon Ben went in and, pluck making up for adroitness, the two battered each other until my mother, rushing into the yard, separated the combatants and distributed between them the remedy for bruises in the year of 1826 . The cousins became excellent friends afterwards, agreeing that the honors of the fight were about equally divided. They had fought till both had to be put to bed.

"One recollection suggests another. I have mentioned that on my way to West Point I had purchased a flute, and on this, both at the Point and afterwards, I had hammered away until with good notions of time, but without notions of harmony, I had qualified myself to accompany my brother, who was blessed with an excellent voice and was a natural musician in the number of simple airs, such as 'Robin Adair, of a' the airs the winds can blow,' and such like. Both of us being at a sentimental age, we determined to serenade our idols for the time being, and on one occasion, while in the midst of a touching melody, were approached by a watchman and told to 'quiet that $\mathrm{d}-\mathrm{d}$ noise and go home.' He was, of course, a fellow of no taste, who preferred his 'ten o'clock and a cloudy night' to vocal music with a flute accompaniment.

"While in the Lexington Street house last mentioned, I worked hard to improve myself in English, for West Point was no place to learn it, and I read Spenser's Fairy Queen and translated Carmen, after Carmen of Catullus, together with letter after letter of Cicero ad familiares. I also learned to read Spanish. French I was already proficient in. I puzzled away, too, at Locke on the 'Human Understanding' and Say on 'Political Economy' and I read diligently and 
laboriously in the law. I am not sure that any of you have yet made up your minds as to what real hard work is. I was doing outside things, besides, that paid. In fact, I never had an idle hour, no, not an idle minute. The scraps of time before breakfast, waiting for my dinner, etc., were a find to me, that I invested in many ways, and in some form or other no knowledge I ever acquired has failed to be useful." 


\section{CHAPTER V}

Mr. Latrobe's Connection with Things Military, after Leaving West Point in 1821-His AssociaTION FOR SIX YEARS WITH MILITIA-RECEPTION OF Lafayette in Baltimore, 1824-Trip to PhiladelPHIA IN CoMmand of Light INfantry CoMpanyMonument to Kosciuszko at West Point-President, BOARD OF Visitors, West PoINT IN 1849-His ANNUAL Visit to West Point-His Relations with General Thayer-The Three Battles-Friendship with General Gibbon

Before taking up the relation of Mr. Latrobe's life as a lawyer, I shall complete the account of his military career begun at West Point in 1818.

Robert Goodloe Harper, whose office Mr. Latrobe entered after leaving West Point in December 1821, was the General of the Third Division of the Maryland Militia. Mr. Latrobe entered into and became a part of this Militia.

As Captain of the "Chasseurs of Lafayette," and as First Aide to General Harper, he participated in the reception given to Lafayette in Baltimore, in 1824.

In speaking of his position as Captain of the "Chasseurs of Lafayette," he says, in reference to his first speech which he made in the prosecution of McCullough for passing counterfeit money:

"The speech, which I made in court in the case of McCullough, procured .me more notice than I would have expected and was the cause of my being appointed the Captain of a Company of riflemen composed altogether of mechanics, who adopted the name of the 'Chasseurs of Lafayette.'" 
In what Mr. Latrobe calls "The Memoranda of My Life," he says:

"After I had been in General Harper's office for a year, I suppose, it was determined by the Military of the City to receive Governor Stevens with public honors, and to have a review of the citizen soldiery at Whetstone Point, then a barren tract of land without an improvement on it. General Harper, being the Major General of the 3rd Military Division of the State, was the officer in command, and at once appointed me his Aide, presented me with a uniform complete, and gave me the Damascus bladed sword that is still in my possession. It had been presented to the General by the Duke of Wellington, and the story connected with it was that it had been taken from the body of a French officer at the Battle of Waterloo. It was certainly a magnificent weapon of true Damascus steel.

"The orders of the Review and the general management fell upon me, to whom a West Point education made such things familiar.

"The review went off very well, and my prominence at it led to my being offered the command of a military company that was being raised in Baltimore, the members being the 'b-hoys' of the New Market Fire Company, a rough, kindhearted set of scamps, quite notorious in the City. I got it into shape, and paraded with it in a uniform that was supremely ridiculous, but which was to the taste of the material of the command. Plaid pants, plaid tunics, and a cap covered with plaid, the body of the cap being an old bell crowned hat, with the brim razied, and, to crown all, a black feather. It was with some difficulty I was persuaded to dress myself in this paraphernalia; but I did, and my 'Butterflies,' as they were 
nicknamed, soon became a well-drilled body of men. It was while I was Captain of the 'Butterflies' in 1824 that Lafayette came to Baltimore, and great was the military display on the occasion. I preferred, of course, acting as Aide to the Major-General rather than figuring at the head of my New Marketters; but I designed a flag for them, called them the 'Chasseurs of Lafayette,' and got the General to present it. The painting of the flag was far better than common. On one side of the flag were the date and name, and on the other side a hand grasping at a star with the motto 'Forward.' I rather think my men understood the idea of the painting no better than they did the pronunciation of the Company's name, which in their mouths became 'Chassers,' and even 'Chasers.' I forget what became of the 'Chassers.' I resigned after the Lafayette visit, and I think my jolly dogs got some new fancy into their heads, and let the company run down. The only man belonging to it that I now see sometimes is the runner of the Eutaw Savings Bank, a good, religious, elderly man, named Snyder, who still calls me 'Captain.'

"It may not be uninteresting to say a word or two here about the Lafayette visit. General Harper appointed three additional Aides on the occasion. One was his son, Charles Carroll Harper, my intimate, most intimate friend, a man of brilliant talents, charming manners, refined and generous, a man whose superior in all these qualities I have yet to meet. A graduate of Harvard, a powerful and elegant writer, and, in every respect, an accomplished gentleman. $\mathrm{He}$ is still the exemplar of all that is worthy and noble. I loved him very dearly. But this is a digression. The third Aide-de-Camp was Charles Carroll, the grandson of Charles Carroll of Carrollton, and the fourth was S. Owings Hoffman, an excellent gentleman and the friend of the other Aides. 
"Here, as in the case of Governor Stevens' reception, I had virtually command, and, when everything was arranged, the General and his staff went on board the 'Constitution' Steamboat, which was to proceed to Frenchtown, there to receive Lafayette on his way from Washington. He had been delayed on the route, and some hours elapsed, after the steamboat reached the wharf, before he made his appearance. General Harper and his Aides were seated in the dimly lighted cabin. The General was talking politics, and, as a staunch Federalist, was commenting on the conduct of Mr. John Quincy Adams in no measured terms, as one who had left the Federal party, when who should descend the cabin stairs but $\mathrm{Mr}$. Adams himself, who had come across the peninsula on the regular stage line on his way to Baltimore. General Harper was still speaking as Mr. Adams approached, ignorant, of course, of his vicinity, when turning around, he saw him within a few paces. Rising, with his peculiar and dignified manner, he advanced and held out his hand, which the other took. That Mr. Adams had not heard a portion of General Harper's remarks was not to be believed; but the two veteran politicians were not to be startled out of their proprieties, and they greeted each other with seeming cordiality.

"It is not my purpose to dwell on the details of Lafayette's visit. After the review he presented the flag to my company, and after the dinner he was put into one of Stockton and Stokes' four horse stages, and, with General Harper's Aides on each side of the vehicle, set out on the road to Washington. We were met at the Prince George's County line by the Cavalry of that County, who were to escort him to the line of the District of Columbia. Without the smallest consideration for the fact that I had been 
in the saddle all the morning and was withal not accustomed to lengthy equitation, the coachman undertook to show off the merits of his team, by keeping them up to their most rapid trot between Baltimore and Waterloo, a well remembered distance of twelve miles. Unluckily my steed, a handsome black, chose to keep step with the wheels of the coach and, being a rough trotter, put me to torture after the first five miles, which was not relieved by the banging against my legs of the honored sabre from another Waterloo. Still pride feels no pain, and after the arrival of the cortège at Waterloo and the vanishing of the stage, General and all in the dust kicked up by the Prince George's Cavalry, I accepted an invitation from Colonel Ridgeley, in command of the cavalry that had escorted the General from Baltimore, to go with him to his place, "Oaklands," some miles to the North. By the time we reached there I was helped off my horse and hobbled into the house, with about as little enthusiasm remaining as may be imagined. It was still early, however. I was of an age when such damages are soon repaired and the small hours came before Colonel Ridgely allowed the Staff of the General to stop drinking toasts in honor of Lafayette and go to bed.

"I have, of course, read of Murat and seen pictures of 'le Beau Sabreur,' and have no doubt he was the ideal he is described to be. But Colonel Ridgeley was his equal. Nature intended this Maryland gentleman for a cavalry officer. About the middle size, perhaps, without a spare pound of flesh, all sinew and with a corresponding activity, quick and imperious of speech and as a gentleman could be, with eyes that gleamed when he became excited, and withal a splendid horseman, who entered into all the feeling of his temporary vocation, Colonel Ridgeley was, by nature, 
intended for a soldier, and a good one was spoiled by his becoming a country gentleman and a member of the Volunteers of Anne Arundel County.

"I saw a good deal of General Lafayette during his short visit to Baltimore. As General Harper's senior Aide, I was necessarily near him at the dinners, at the review, when I arranged with him about the presentation of the flag, and I rode on the side of the coach that he occupied on the ever remembered drive to Waterloo. Of course, I looked at him well. He was tall and heavily built, walked with a cane, and limped somewhat. He was without the energy of manner I would have expected from a Frenchman. His countenance was dull rather than intelligent, and when he spoke, it was slowly and with little facial expression. His manner was kind and gentlemanly, and what he said seemed to be with deliberation. General Harper had a good deal to say to him at the dinner, and I was close to them, standing behind the chair of Lafayette with the other Aides. George Washington Lafayette, his son, on the contrary, was more like a Frenchman in his manner, and was ready and apt in conversation. But he was by no means a distinguished looking man. There is an admirable likeness of Lafayette in the Capitol at Washington, or rather there was such a likeness there some years since. It hung on the old wall of the House of Representatives. The impression made upon me by Lafayette at the time was that a good deal of the attention paid to him was submitted to rather than enjoyed.

"We are excited now-a-days by the coming of distinguished persons; but there has never, since Lafayette's visit, been an occasion in which as much honest enthusiasm has been displayed, as was then exhibited."

It was during this trip that Congress made Lafayette a present of $\$ 200,000$. 
General Harper died in January 1825. Mr. Latrobe, as First Aide, turned over the papers in his possession to General McDonald, and he writes to General McDonald: "The appointment I had the honor to hold on the staff of the late Major-General Harper expired at his death. . . . The delay arose from a wish to make the return complete by inserting the strength and arms of the regiments of the 14th Brigade, and for the Brigade of artillery, for which no return has been made up to the 27th of December. Charges have been preferred against Brigadier Generals Smith and McLaughlin."

He continues his recollections thus:

"Although I had ceased to take an active part in military matters, after General Lafayette's advent, yet when 'The First Baltimore Light Infantry' determined to pay a visit to Philadelphia, the first visit of the sort that had yet taken place, I was asked to drill them. And this I did nightly during an entire winter. They were sturdy, wellbuilt mechanics, and took great pride in being taught, and they were taught, and well taught too, and when the spring came, they were no disgrace to Baltimore, to say the least of it. I had them in perfect order, and they were as well set up as old soldiers. It was a labor of love for me to teach, and with them to be taught. I remember wishing that I had an opportunity of drilling them against my old company at the Point. It had not been my design to command them on the march, but to let that be done by their Captain, John Spear Nicholas, a member of the Bar, and in every way competent. But they insisted I should go, and thinking, very justly too, that I might be reluctant to incur the expense of uniform and outfit, they prepared the whole for me without my knowledge, and the manner in which it was presented left me no alternative but to take 
command. We had a glorious time, though I had to suppress two mutinies. The men wanted to remain a day longer in Philadelphia and sent word to me that if I wanted to go home I might go alone. I said 'Very well, then we'll have a march around the City, ' which we had, and it ended on the upper deck of the steamer, where I kept them going through the manual for the edification of the crowd on the wharf, until the lines were cast off and the vessel was under way. In the ranks I was their master; out of the ranks they took their own ways. They were angry to a man, the privates, when they saw Philadelphia fading in the distance, and swore they would stay at New Castle that night. 'Very well,' said I, when this was told me, 'we must at any rate march into the town, it will never do to enter it like a mob.' There was a good deal of grumbling and some suspicion, but at last all fell into line, and we marched with drums beating to the Court House and then to the outskirts, when I wheeled the whole into line. Then wheeling the first platoon to the right, the Captain kept it moving ahead, I continuing to drill the remaining platoons at the facings and the manual till the first was one hundred yards off, when I ordered the second platoon to march in the same way. I brought the last myself. I certainly verified here the saying 'decide and govern.' In this way I got the whole command of upwards of one hundred and twenty men across the Peninsula as far as the Halfway House, on the road to French Town that night. The next day's march was an easy one, and making French Town in time, we returned good friends, all of us, to our home. With this campaign I ended my military life. I have often thought that I ought to have been a soldier. How I should have stood the test of warfare I cannot say, but all of my instincts were in this direction; even now I feel excited by a drum, 
and a trumpet or a bugle sets my blood to run in faster currents."

An account of this trip appears in the Philadelphia Palladium:

"The First Baltimore Light Infantry Company, Captain Latrobe, about ninety strong, landed from the steamboat at Chestnut street wharf, on the morning of Tuesday, the first day of May. They were royally entertained; reviewed by General Cadwallader, and were banqueted in high style. The standard of the Light Infantry was presented to them by Col. John Eager Howard. . . . . Thus has terminated the visit of the Baltimore Light Infantry, a visit that has done much to beget a noble and kind feeling and bring nearer together the citizens of Baltimore and Philadelphia."

On May 10, 1827, Mr. Latrobe wrote a letter to Lieut. Thomas Barrett, "Baltimore Light Infantry," the National Guards, thanking them for the resolutions sent to him and accepting the honorary membership conferred. He resigned from this organization in 1827. He says that for six years he had been actively engaged as a member of the Militia, but that he finds that he will not be able to continue to take interest in military matters, and will not again join a Company, unless there is war, or danger of war. This resolution was not kept, for on October 12, 1835, we find the command of a regiment of volunteer infantry offered to him in Baltimore; the committee tendering him the command was composed of James M. Anderson, James E. Stewart and A. W. Thompson. This he declined, but he must have subsequently accepted a position, because on October 7, 1840, we find the following:- 
MONUMENT TO KOSCIUSZKO

At the Military Academy, West Point, designed by John H. B. Latrobe 


\section{OASZUIDZOA OT THAMUVOM}

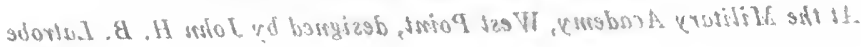




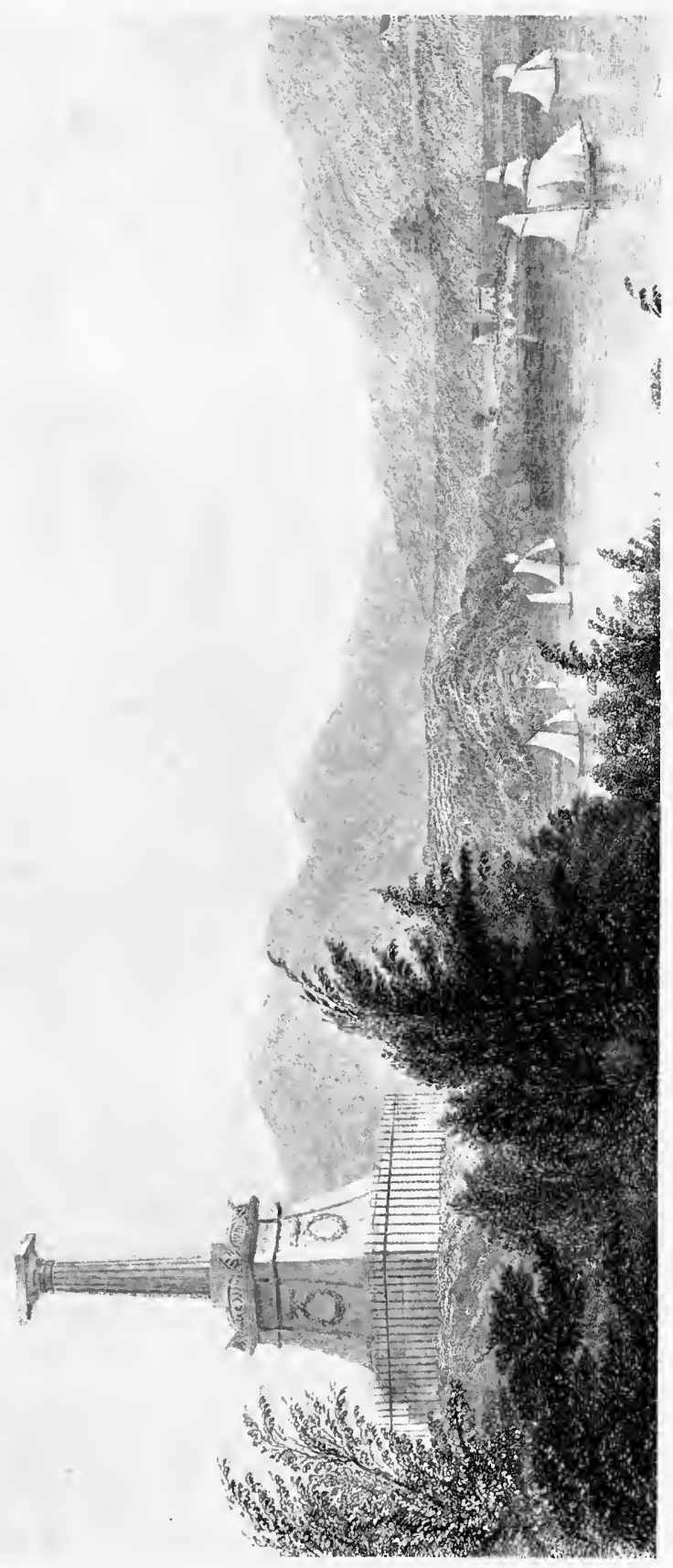



"Captain Latrobe, 10th Ward, City Guard.

"In obedience to orders from General O'Donnel, you are directed to hold your company in readiness to act at short notice, should occasion require it.

(signed) Wm. Pinkney, Col. 2 Reg. G."

There is an order from the Adjutant-General's office, Annapolis, April 8, 1840, signed by Thos. N. Watkins, Adjutant-General, to Captain Latrobe, directing that one hundred rifles should be delivered to him. The following letter is among his papers:-

$$
\begin{aligned}
& \text { "Headquarters, Army of Occupation, } \\
& \text { Matamore, June 29, } 1846 .
\end{aligned}
$$

"Your views and appreciation of the movements of the army under my command are as soldierlike and accurate as if you had been a participant, and I gratefully acknowledge to you the expression of your views. I am, with much respect,

\section{Your Obedient Servant, \\ Z. Taylor, B. G. \\ United States Army." \\ (President 1849-50)}

Mr. Latrobe wrote a description of three great battles, the Battle of Buena Vista, February 22nd and 23rd, 1846 (it was this article to which General Taylor refers); Seven Days Battle, June 26th to July 2nd, 1862; Battle of Gettysburg, July 3, 1863.

It would appear from this that, as already stated, Mr. Latrobe kept up his interest in military matters. $\mathrm{He}$ designed Kosciuszko's Monument, which is erected at West Point. An engraving of it appears in American Scenery, Vol. 1, Folio 30, West Point, by N. P. Willis, illustrated 
by Wm. B. Bartlett, and is here reproduced. A letter from Adjutant's office, U. S. Military Academy, September 1, 1863, written to Brig. General John Gibbon, says:

"I am directed by the Superintendent to acknowledge, through you, the receipt of a certificate of the Academic Board, relative to the high position in his class and at the Academy of Cadet John H. B. Latrobe of Maryland, and also a copy in silver of a medal furnished by the Corps of Cadets to Cadet Latrobe in recognition of his services in designing Kosciuszko's Monument. The Superintendent has directed both to be placed in the Museum of the Academy. I am, General,

\section{Very respectfully, \\ Your Obedient Servant, Ed. C. Boynton."}

"I cannot now fix the date, but it must have been in 1824 or 1825, that I saw an advertisement in a New York paper, offering a prize of $\$ 50.00$, or a gold medal of that value, for the best design of a monument to the memory of Kosciuszko, to be erected at West Point. The name of the Polish hero had been suggested by the legend that a ledge of rocks, to which the cadets often resorted, overlooking the North River on the eastern side of the Plateau had been a favorite spot of his, and that he had been almost hit by a cannon ball, whose dent in the granite was still shown to strangers." (After the battle of Saratoga, Colonel Kosciuszko was placed in charge of the fortifications at West Point.) "As I had not given up my pencil, I became a competitor, and had the good fortune to succeed. The Kosciuszko monument on the capital of the North Eastern bastion of Fort Clinton is of my design. But a grave question arose when I was informed of my success-should I 
GOLD MEDAL WON BY JOHN H. B. LATROBE

In Competition for best Design of a Monument to Kosciuszko, erected at West Point At the time he was only 21 or 22 years of age

(The design is reproducad on the medal) 


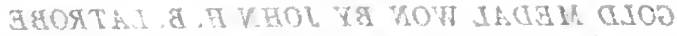

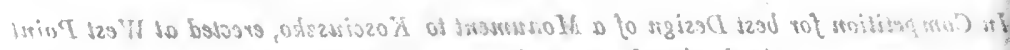

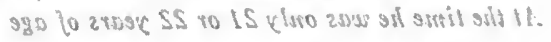

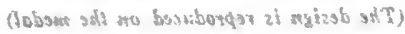




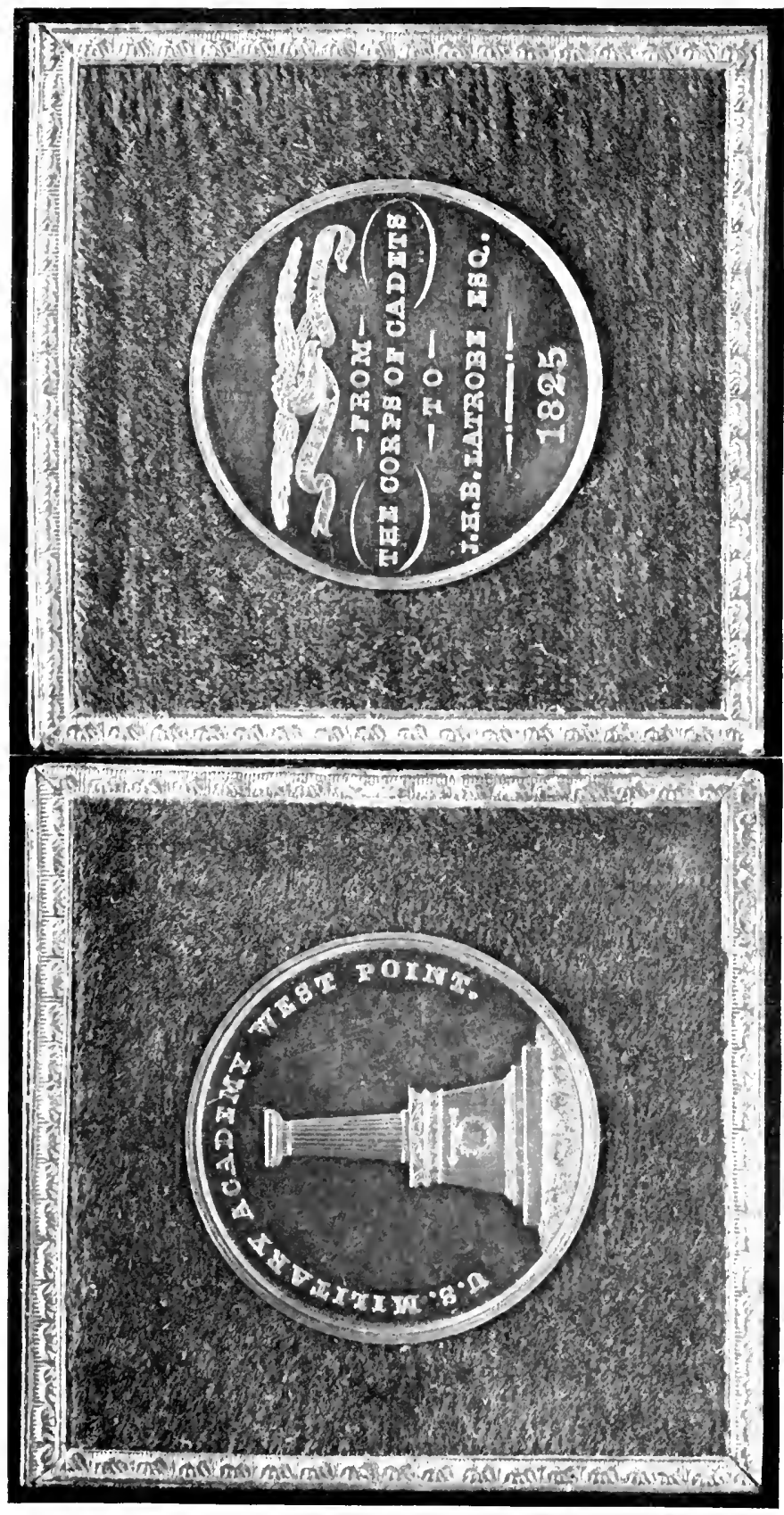



take the medal or the money? The latter was greatly needed, for my dear mother had her own troubles in making headway against narrow means. There was considerable consultation, and we both, my mother and myself, looked wistfully at the money. But my mother settled the matter, saying, 'We would have gotten along if you had failed, we could get along still, the money would soon disappear; the medal will be an inheritance for your children.' So the medal came. When I was able to do so, I got silver duplicates of it struck at the United States Mint, and now each of you owe your copy to your grandmother's counsel and self-denial. On one side is the monument, on the other the words 'The Corps of Cadets, to John H. B. Latrobe. Detur Digniori, (Let it be given to the worthiest), with the date 1825.' Where so much Latin was picked up among the Professors I never could guess. After the design was adopted, the original plan of placing the monument in the garden was abandoned, and the place was assigned to it which makes it the most conspicuous object seen in the approach to the Point in either direction.

\section{APPOINTED VISITOR TO WEST POINT.}

"Among the events of my life that I look back to with much pleasure was my appointment by General Taylor, when he was President, as one of the Board of Visitors to West Point." (Perhaps his descripton of the Battle of Buena Vista had something to do with his appointment.) "There were several old cadets on the Board, Tyler, Bennett King, Jefferson Davis and myself. Mr. Davis did not attend. Horace Mann was also a member, Mr. John L. Gow, of Pennsylvania, and others whose names I have forgotten. Very unexpectedly I was chosen President, and performed the duties of the office. General Scott 
visited the Point during the session of the Board. He was under a cloud at the time after his return from Mexico, and $I$ had great pleasure in getting the Board to call on him at Coggens, which some of the politicians among us were unwilling to do. Still I managed it. Quincy A. Gilmore was the head of the Institution at the examination-a place I had once occupied myself. Sheridan, now Lieut. General, was in one of the classes. So was Jerome Bonaparte, afterwards distinguished in the French service in the Crimean war. Things had greatly changed from what I had known them in 1818-22. The only persons still alive were the Misses Thompson, at whose mother's I had boarded some thirty years before. I have never been able to free myself from more or less sentiment, and all that was in me was aroused as I sat in my room at the hotel, looking up the Hudson, and going over all these thronging memories of the interval that had elapsed since I was a happy boy with a soldier's temperament and a soldier's life before me. One day Horace Mann proposed that we should test the ability of the cadets at English Composition, so the bugle was blown, 'Turn out the first class' was called, and the young men were marched to the drawing academy, and each, with pen and ink and a sheet of letter paper placed before him, was required to write, fold and address a letter to anyone they chose, upon any subject they chose, in twenty minutes. At the given time they commenced. At the expiration of fifteen minutes, they were informed that they had but five minutes left and the letters were then gathered and sent to the Board of Visitors. The result was better than was to have been expected, though but few came up to the mark. The best letter was written by the lowest in the class, who addressed it to the board, lamenting his deficiencies, and suggesting that he would 
make a good cavalry officer, and a cavalry officer he became, and a good one too. The Governor of Bermuda, I think it was, who was present one day while the examination was in progress and sat next to me, asked whether social position had anything to do in the selection of cadets. In reply I pointed to two young men who were then preparing their demonstrations on the black board, one of whom was the son of a sergeant and the other the grandnephew of Napoleon the 1st. I took my report to General Taylor and on that occasion made the acquaintance of the brave old man. I had reviewed personally the battle of Buena Vista, and he told me that he had believed the article to be written by an eye witness. My review will be found in a pamphlet published, called 'Three Great Battles.'

"One of the battles discussed in the pamphlet is the Battle of Gettysburg, which was written while General Gibbon, who was wounded there, was staying at 'Fairy Knowe.' I read the letters received by him from the officers under him, and had the advantage of his verbal description of the localities and the events up to the moment when he was wounded.

"With these materials, it is no wonder that I succeeded well enough to be complimented by General Mead and General Mercy of Massachusetts on the accuracy of my account, and when Rothermel painted his picture of the battle for the State of Pennsylvania, he adopted, as he wrote to me, my description or that part of it relating to the incident which I made prominent-when Mead came upon the ground by the stone fence, and was told by Hascall, Gibbon's Aide, that the Confederates were retreating. The descriptive legend which accompanied the picture, when it was exhibited, contained an extract from my 'Three Great Battles.' It reads: 
Mead stopped to speak to General Gibbon's Aide (Hascall), and said in his sharp way, "How is it going here?" or something that sounded like it. He was told that the attack was repulsed, when he repeated, "What! Is the assault entirely repulsed?" When the Aide again told him he thought it was, he said, "Thank God," and made a motion to wave his hat, but did not, but waved his right hand and hurrahed, while his son took off his hat and hurrahed like a good fellow.

"I do not know why I should not relate here a part I had in making my dear old master at West Point, General Thayer, a Brigadier-General. Why may not a mouse tell the story of the nibblings that freed the lion?

"This was during the late war. While the Generals on both sides had many of them been his pupils, and were winning laurels on the strength of the education that he had superintended, Colonel Thayer, on the retired list, was living at South Braintree in Massachusetts, a quiet, unknown life. Various attempts had been made to secure for him Brevet of a Brigadier, that he might at any rate have 'General Thayer' inscribed upon his tomb. Among his intimate friends was Mr. George Ticknor, of Boston, a friend of mine also, and when I happened to be in Boston on one occasion, we took the car and, going to South Braintree, found Colonel Thayer in wretched health, scarcely able to receive us, and living, as he said, upon the soft parts of half a dozen oysters a day. This was during the war. When we left him, Mr. Ticknor expressed his regret that among all of those who were constantly receiving laurels Colonel Thayer was not found, although Mahan (Professor) and other of his army friends had done their best to have the injustice remedied. I suggested to $\mathrm{Mr}$. Ticknor that perhaps something might be done by a memorial from Boston, and said that if he would get one up, and 
have it signed by leading men in Boston, headed by Chief Justice Bigelow, I would take it to Washington, and present it to the Secretary of War, Mr. Stanton, with whom I was acquainted. My companion liked the idea, and in due season sent me on the memorial, and I went with it to the war office. Mr. Stanton was at a cabinet meeting and could not be interviewed, so I went to General Halleck's office, he being the General in command. Here I met General Cullum, his Chief of Staff, who gave me no encouragement, telling me of the ineffectual efforts for the same purpose that had been already made. Nothing daunted, I persisted in seeing General Halleck, who came from an inner office and, without even asking me to sit down, heard what I had to say, and told me the thing was impossible - that there was a cartload of such applicationsthat this was another of McClellan's men, or to that effect, and that he could have nothing to do with the matter. Inasmuch as I was not in the army and had no fear of the General's power, I persisted, reminding Halleck of what the country owed Thayer, etc., but in vain. He was cold, brusque and unsympathetic, and turned off without ordinary courtesy. Cullum and I had to chew the cud of disappointment. However, I left my memorial, notwithstanding Halleck's indifference to it.

"Of course, I had to report progress, which I did in a letter to Mr. Ticknor, in which I gave the events of my visit in detail. Now it so happened that Mr. Ed. Everett was with Mr. Ticknor when the latter received it, and the two gentlemen read it together. Mr. Everett took the matter up warmly, said it was a shame that Colonel Thayer's services were not recognized, and at once interested Mr. Wilson, Chairman of the Military Committee in the Senate, in whom the cause, I found, had a most efficient friend, and 
Colonel Thayer was confirmed as a Brigadier-General by brevet the next day.

"I saw him the following summer, restored to health, and able to eat the green corn that he planted with his own hands the day I dined with him. So much for the mouse's doings.

"I have General Thayer's photograph in his 83rd year, given to me the year before his death in his 87 th year, I believe. In my West Point memoranda there is a copy of a letter he once wrote to me. The letter itself, as a catalogue of the cadets during the time I was at West Point, is an heirloom which I hope my children will preserve:

"South Braintree, near Boston, January 23,1864 .

Jno. H. B. Latrobe, Esq.,

Counsellor at Law.

My dear Sir:

Seldom, if ever, have I received a letter more gratifying than yours that has just come to hand. To be kindly remembered by those who were under my care at West Point is a blessing I prize above all others, and doubly gratifying is it to receive such a token of kind remembrance from one who left so honorable a record of himself at the Academy, and whose subsequent career has for many years been a subject of great pride to our Alma Mater. Fortytwo years have not effaced from my memory the regret and disappointment I felt when, near the close of I82I, your resignation was handed to me, for I counted on you as a future officer of Engineers. You were then the head of your class without a rival. Had you waited a few months before resigning you would have been the recipient of the highest honor and prize the Academy and the Government could bestow as the reward of distinguished scholarship and merit. No one can now doubt, however, that you made a wise choice of a profession-as a civilian you have rendered a greater amount of service to your country and mankind, and have caused higher distinction for yourself than you could have done in the military service. 
In rummaging among some books I have laid aside as of little or no value, I met with a small volume containing light catalogues of Cadets, commencing with the first published and including of course all those in which your name appears. Thinking it might be acceptable to you I send it herewith.

In reading over the list of your class mates they come up before me in their Cadet uniforms with as much distinctness seemingly as though I saw them but yesterday.

The history of the class is a remarkable one. It was the largest of any on admission, consisting of I30 members, but one of the smallest on graduation, having lost ninety of its members, including many of the most distinguished for talent. This was owing mainly to the peculiar condition of the Academy, it being then on its passage from chaos to order. Nevertheless after all its losses it was a most respectable class.

There are many subjects touching the Military Academy, the war and the state of the Country generally, subjects that occupy my mind almost exclusively, in relation to which I would wish to communicate with you, but am compelled to pass them by.

Should you ever have occasion to visit Boston, I beg you to afford me the pleasure of seeing you. My place is on the Old Colony and Fall River Railroad, less than a quarter of a mile from South Braintree depot. The distance from Boston is eleven miles and is passed over in thirty minutes. Twelve trains pass each way daily.

Most respectfully and affectionately your friend,

S. Thayer.

Connected with the above is the following letter from Professor Mahan.

"My dear Sir:-

"West Point, May 5, 1864.

"Every friend of Colonel Thayer owes you thanks for your exertions and their successful results for even the tardy justice done to his great services. The parable of the unjust steward seems to find its application to all times; pertinacious solicitation obtaining what a regard for justice should have prompted; and what would have been graceful 
if spontaneously yielded, by being unreasonably withheld robbed of its principal charm.

"I trust, but fear, that our old friend has yet in store to enjoy this late honor. I say I fear, from not having heard from him for some weeks, and his last letters, which bore the marks of great physical debility, having informed me that he had only then commenced to rally from indisposition during the winter which had reduced him to a mere shadow.

"With my best thanks for what you have done in this matter.

$$
\text { Very truly yours, }
$$

(signed) D. H. Mahan."

A letter from John Eager Howard from Tolucca, May 9, 1848, during the Mexican War, to Mr. Latrobe, kept by him, shows how his interest in military matters was always with him.

"Dear Sir:-

"The all absorbing subject here is the treaty which still drags its slow length along, and I must say I am decidedly opposed to it, for no other reason on account of the disbanding of the army that will take place. People at home have no idea what a sacrifice of life and how much time it takes to make a soldier. One of the men we have here now I think without exaggeration worth ten raised should the war breach out again, even supposing the cost no more than the one, and they would not cost much under fifteen times as much. There is a certain process of sickness, dying off, drilling and breaking in which every body of men has to go through before they learn how to take care of themselves and become able to stand campaigning, and to live on the soldier's rations. I have heard it said that a thousand volunteers have died on the Rio Grande for not knowing how to boil beans . . . " 
THE IDEA THAT AN ARMY CAN BE CREATED IN TWENTYFOUR HOURS IS SO ABSURD THAT IT SHOULD NOT BE NECESSARY TO REFUTE IT WITH THE EXPERIENCES OF THOSE WHO HAVE SERVED IN THE ARMY; AND YET WE HAVE MEN LIKE MR. BRYAN OPPOSING PREPAREDNESS, MAKING STATEMENTS THAT WE COULD ASSEMBLE AN ARMY OF A MILIION MEN BETWEEN SUN-UP AND SUN-DOWN.

Another letter shows how he kept in touch with his military friends:

"Headquarters, District of the Nohtoway, Petersburg, Va., September 7, 1865.

"My dear Mr. Latrobe:-

"I was very glad today to greet your handwriting from our 'Alma Mater.' 'I should have written to you before, but hearing you had left Baltimore did not know where to direct, and was only waiting to learn of your return home to resume our correspondence. I spent a very quiet time in the vicinity of Philadelphia with my wife and children, balanced between hope and fear in regard to the life of my poor little boy, who is now, I am happy to say, somewhat. improved, but very thin. I trust the cool weather (if you have it cool up there, for it is terribly hot here) will enable Mrs. Gibbon to leave there and get to Baltimore, where she will feel more at home and eventually join me here after the frost, if I stay here that long, which I have at present no reason to doubt. I remained with my wife and children to the last moment allowed by my leave, and did not remain in Baltimore long enough to run out and see Mrs. Latrobe, which I otherwise would gladly have done, so I hope you will make my apologies to her. Need I say. how happy I should have been to have met you at West Point and accompanied you to that dinner at Mr. Kemble's? 
I can fancy how you enjoyed it and also the explorations, old yet ever new, of West Point. Did you happen to meet there my old Chief of Staff, General Potter? He was there a short time ago staying with the Commandant, Colonel Black, and doing a little courting on his own account. You speak of meeting Schoolfield. I thought he had gone to Europe under orders. Did you hear anything about it? I am getting along very quietly and pleasantly here, trying to reconcile civil and military law in the same place-a very difficult matter, by the way, but I hope it will come out straight in the end. The two are, of course, incompatible, but, with modification and no disposition to be a despot, I hope to have no trouble. The temper of the people is much better than I expected to find and much better than in Richmond, which I suppose was to be expected. A number of gentlemen have called on me and cordially invited me to their houses. Such a thing is almost unknown in Richmond. Tell Mrs. Latrobe I think the ladies are the great obstacle, but I think if I were a young bachelor I could even bring some of these over to the right side. As it is, I do not feel at liberty to 'try my hand upon them.' The great question is 'the inevitable negro,' and I presume the winter will be the turning point in their existence. They are flocking into town in great numbers, and some steps will have to be taken to get rid of the surplus population before the cold weather comes on, and I shall probably send a number of them out to one of the old camps three or four miles from camp, where cabins and wood are plenty. They are lazy and disinclined to work, and the mischief of it is that the negro question is a delicate one to handle without burning one's fingers in these ticklish times of freedom and free suffrage. I think you might manage to come down, pay me a visit, and look over these celebrated 
lines with me now. I should like to have a long talk with you, and consult you on several legal questions which come up now and then, for I must plead guilty to being no lawyer, 'nothing but a soldier,' with his occupation gone. I wish I had something to fall back upon when they come to muster me out, for as far as going back to the command of a company-the thing is out of the question, so if you hear of an opening for a 'quiet, sober young man of tolerable character,' let me know. Remember me most kindly to Mrs. Latrobe and all your children at home, and those abroad when you write. What is the last news from my friend Johnnie?

Yours very truly, (signed) John GibBon."**

This short recital covers the actual participation in military affairs and matters connected therewith, but the studies pursued by Mr. Latrobe at West Point were of great use, especially in his profession and in that branch known as "patent law," where his facility with his pencil and the mechanical knowledge acquired gave him a great advantage. His eye was so trained as an engineer that with his habit of observation he was quick to observe defects of any kind. A most interesting example of this is furnished in the following letter:

$$
\text { "Philadelphia, 31st May, } 1848 .
$$

"Ibaum forte via sacra." I met you, my worthy neighbor and friend, some five weeks since, and we strolled over Market Street Bridge, dawdling and twaddling along, entirely merged in the usual talk of such a stroll; when, passing by the Old Town Corner, I believe it is Pitt but will be Fayette Street (continued), we halted and took a passing squint at the iron bridge, nearly finished.

\footnotetext{
*Gen. John Gibbon.
} 
"You may not, but I do, and very distinctly too, remember your saying to me, with emphasis, 'That bridge will and must fall, it is against every principle of construction and down it must tumble,' and on we sauntered. Now I have seen that 'Jones' Falls' has received another fall in its bosom, and I was immediately reminded of our conversation, and said to myself, 'I must write to my neighbor and remind him of our walk and talk and of his prediction. So do I now do.

\section{Christopher Hughes."}

(Christopher Hughes represented the United States longer than any other American at the several European Courts in successive diplomatic intercourse.)

In a letter from Washington Irving we find him referring to Mr. Latrobe as a soldier.

Mr. Latrobe, writing in 1882, says:

"For many years I have been an annual visitor at West Point Hotel, and have, during the several weeks of my stay here, attended morning and evening parade and guard mounting as regularly as when discipline compelled me, and now, in the ebbing tide of life more than ordinarily prolonged, look forward to the time of my annual pilgrimage with a feeling that has not weakened by the lapse of years."

These lines aptly describe Mr. Latrobe's feelings:

My heart is in the hills, the shades Of night are on my brow;

Ye pleasant haunts, ye quiet glades,

My heart is with you now. 


\section{CHAPTER VI}

\section{African Colonization}

Mr. Latrobe left very copious notes on the subject of African Colonization. It was a work in which he took a deep interest, as can be seen from the following extracts:

"When I lost my feeling of-I scarcely know what to call it, it was not timidity, it was not especially reverencewell, without seeking for a word, when I got to be on easy terms with General Harper, he talked freely with me on all topics that interested him; and the two leading topics of his life were Internal Improvement and African Colonization. General Bernard's report had not yet demonstrated the impracticability of a canal by the Potomac route, between the waters of the East and West; and Canals, stimulated by what Pennsylvania was doing, were a subject of exceeding interest to the people of Baltimore. There were river routes, the Potomac and the Susquehanna; and General Harper advocated the former and George Winchester, Esquire, the latter, at a great meeting held in the Rotunda of the Exchange. Of course, I took sides with the General, and the interest was planted in me then, which endures to this day in all matters of internal improvement. I am President of the American Colonization Society now, as a consequence of my having sat at the feet of the great authority in Maryland in this connection.

"General Harper made it a point to introduce me to all his friends, and in that way I became acquainted, sooner than I otherwise might have done, with leading men in Baltimore. Some of them I now see before me. 
"It was while I was reading in the same room with General Harper that there entered one day a tall, gaunt, square shouldered, spare, light mulatto, who announced himself as Abel Hurd. He was a Bostonian by birth, and a seaman by profession. In a voyage to the East his vessel had been captured by the Malays, and he alone, if I recollect rightly, escaped death, owing to his complexion. He had a varied fortune; had at one time been in CochinChina, again in Tibet, and, after passing some twenty years in the East, had returned to America, and was looking out for employment. Some one had heard how deeply interested General Harper was in Africa and African Colonization, and had sent Hurd to him. About this time there was a great doubt as to the mouth of the Niger; whether it was to be found at the bottom of the Bight of Benin, and whether it was not identical with the Congo, or Zaire, south of the line. This was a question in which General Harper was interested, and he determined to fit out Hurd and send him northward from Liberia until he struck the river, which he was then to follow to its mouth, and I was deputed to superintend the outfit.

"Hurd's idea was to take as little baggage with him as possible, and to rely upon the resources of his wit and ingenuity in making his way among the interior tribes. $\mathrm{He}$ had had a vast experience, and he directed his own equipment. I do not recollect all that he was furnished with, but I recollect having devised a hollow cane, in the top of which was a compass and the tube of which contained papers and pencils. These were to be resorted to when the compass and materials openly were lost. I think I wrote, at General Harper's dictation, a letter of instructions. Had Hurd lived and succeeded, he would have anticipated the Landers, Richard and John, who explored the Niger in 1832-34. 
$\mathrm{He}$ arrived safely in Liberia, and made several short excursions into the interior, but he had a theory that it was necessary to train himself for the great journey. Abstinence was a part of his training. It was a mistake. He took the acclimating fever, and, although he recovered from the first attack, he had a relapse brought on by some imprudence and died.

"It was about this time that I became acquainted with Dr. Eli Ayres. He had accompanied Captain Stockton when the latter made the purchase of Liberia from the natives, and, returning to Baltimore, came to see General Harper as the center of Colonization in Maryland. The Doctor was a man below the common size, with prominent features, a keen black eye, and a complexion proper to a fever and ague patient, without intervals of health. But he was every inch a man, and was deeply imbued with the Colonization scheme. He talked by the hour to General Harper in a high, cracked voice and nasal tone, and with a quaintness and originality of expression that was most amusing. An able physician, he was at the same time a kind, warm hearted man. One day after he had described the localities around Cape Mesurado, General Harper, who saw that I had been an attentive listener, asked me if I could turn my West Point knowledge to account and make a map of the country from what the doctor might tell me. So the doctor and I went to work, and we got up a map, the doctor constantly disfiguring my paper with broad and deep indentations that he would make with a long thumb nail. When the drawing was completed it was put into the hands of B. T. Welch, the engraver, who soon after sent General Harper a proof, on which the lettering was to be indicated.

"The General had the baptism of a new country thus 
given to him; but as I had made the map, he said it was but fair that I should have a hand as one of the sponsors; and it was understood that we should stand as such alternately. There was some difficulty in selecting the name of the Territory. Several names were suggested-among others Fredericks-when the General said, "The name of a free man in Latin is 'Liber,' cannot something be made out of that?" And after a while, and weighing numerous names from this root, Liberia was adopted and written down accordingly. My turn came next, when I proposed Monroe, the name of the then President, which in like manner was softened into Monrovia; and so we went on until the baptism was completed. The engraving of the names then followed, and you will find in the old desk at 'Fairy Knowle' a proof after lettering of the first map of Liberia ever made. At the next meeting of the American Colonization Society the nomenclature was formally adopted.

"General Harper's death inflicted an irreparable loss on Colonization. Dr. Ayres and myself felt that its right arm was severed from its body in Maryland. But we did not give it up. There were other warm friends who were willing to help it forward. I cannot now recall in order all that I did for it. It was the one thing then, and has ever been the one thing outside of my lawyer's calling, to which I have devoted myself. I do not remember when it was that I first became acquainted with the authorities at Washington. I think it was when Charles Harper and I attended an annual meeting as representatives from Baltimore, and when I made a speech, Mr. Clay in the chair, advocating a settlement at Cape Palmas. I had picked up from Ayres and from parties in Baltimore, especially one Captain Cooke, who had been a traveler, perhaps, more than a trader, upon the west coast, a great many facts, which gave me the notion 
that Cape Palmas was a proper place for a colony. I had heard, too, a good deal about the Island of Bulama; and I had a theory about settling Northern negroes at Bulama, those from the Middle States at Mesurado, and those from the South at Cape Palmas.

"My speech on this subject is in one of the early volumes of the African Repository.

"I was made a Mason in 1825, or thereabouts, and conceived the idea of getting the Masons to help, and a good many subscriptions of $\$ 10$ each were obtained in consequence. I wrote a tale, too, in the Masonic connection, which is to be found also in the Repository.

"I suggested the appointment of a committee in Baltimore to take charge of the interests of the society there, and my colleagues were Charles Harper, John I. Lloyd, Charles Howard, and, I think, Judge Brice. I did the work, however, and there was no expedition that left Baltimore in those days that I did not superintend. Someone always has to do the work in all bodies of men and I was willing and did it here.

"I remember our committee had a meeting of the colored people to consider the subject. It was held in the Sharp Street African Church. Harper wrote the address, and I spoke, and was answered by an intelligent whitewasher, as black as the ace of spades, who took the opposite side. He was answered by Fitzhugh Ravenswood, a Virginia gentleman of gallant bearing, handsome person and great eloquence. The meeting passed the resolutions appended to the address, and there was a sensation at the time. But such sensations soon die out, and so did this.

"About 1831 the Colonization feeling in Baltimore had become very dull and people were disposed to give up the scheme as a bad job, when there came to Baltimore Robert 
S. Finley, the son of the Finley of New Jersey, to whom the American Colonization Society owed its origin. Along with him was Mr. Elliott Cresson of Philadelphia, an ardent supporter of the cause. They called on me as one who was known to be a Colonizationist, to see what could be done in the State. Although I discouraged them they persisted, and at last I agreed to call on the Rev. Dr. Nevins and ask the use of the First Presbyterian Church. This was given and a meeting was held. I introduced Finley, he carried the audience away, all present became Colonizationists, and an adjourned meeting was held in St. Paul's Church. A State Colonization Society was formed at once, and, in place of filling the Board with clergymen, the directors chosen were business men of intelligence and character-a good business arrangement, but one that prejudiced the Society then and ever afterwards with the clergy. An agent was appointed, and one hundred and fifty emigrants were sent to Liberia in the ship 'Lafayette.' And as many more could have been obtained. The emigrants were not treated as they should have been on their arrival in the colony. The reports were unfavorable, and the Society determined to send no more, and the cause, as above stated, went to sleep in Baltimore. Afterwards, however, a schooner, the 'Orion,' was dispatched with a few colonists and some supplies, carrying out with it Dr. James Hall, who on his arrival in Africa entered the service of the American Colonization Society as a physician.

"The expedition of the 'Orion' led to important results. Dr. Hall was sent down the coast in a schooner belonging to the colony to buy rice, and was becalmed off Cape Palmas. It so happened that there was on board a copy of the African Repository for 1828 that contained my speech at the annual meeting of the American Colonization Society urging the 
purchase of Cape Palmas. Dr. Hall had read it for want of something better on board, and, recollecting it when he found where he was, determined to go ashore and see what probability there was of such a settlement as I had proposed. He found things even better than I had imagined them to be, and when he got back to Monrovia, he wrote to Dr. Ayres, whom he had left as agent of the State Society, corroborating all my statements and urging that a colony should be founded at the place I had indicated. When the letter reached Baltimore Dr. Ayres was dead, and it was sent to the corresponding secretary-myself. I at once took the matter up, worried the members about it, until I got the nickname in the board of 'Cape Palmas,' and finally succeeded in persuading them to send out an expedition, purchase Cape Palmas from the natives, and found a colony there. When this was determined on, the managers of the State's appropriation agreed to supply the funds that were necessary. The brig 'Anne' was chartered. Mr. Solomon Etting, an old merchant, entered into the matter heartily, so did my friends, Charles Harper and Charles Howard, and Cape Palmas became a favorite. I mean the idea of the colony there.

"I have a regular diary beginning on the 9th of October 1832, which I kept up rather punctually for some years, and looking over it today I find references to transactions that seem to suggest the busy life of a professional man. Colonization figures somewhat largely. The Southhampton Massacre had created a great excitement, and the negro question had been increasing in importance. Maryland had made an appropriation of $\$ 200,000$ to be expended at the rate of $\$ 10,000$ per annum for Colonization purposes under the supervision of three commissioners, Moses Sheppard, Charles Howard and Nathaniel Williams, all members 
of the Maryland State Colonization Society, of which I was then the corresponding secretary and, in fact, the factotum. The management of the American Colonization Society at Washington had not been satisfactory to the friends of Colonization in Maryland. Money had been raised in Baltimore to a large amount in the incipiency of the Society, as well as afterwards, and as was natural the disposition of it was a matter of interest to the contributors.

"In the meanwhile a good deal had to be done. The Colony, to be independent of the American Colonization Society and to be the creation of the State Society, had to be called 'Maryland in Liberia,' a suggestion of Robert S. Finley, who happened to come along while we were busy in making preparation for the voyage. It was necessary to provide a settlement with a government to give it laws. This I undertook to do. So I prepared a charter containing a Bill of Rights, to begin with. I studied the charters and constitutions of the different states of the United States and selected the best, or made one up from the best of them. I then took Nathan Danes' ordinance of 1787 for the government of the Northwest Territory and modified it until I fancied it would do for the Maryland colony. I introduced a clause into the Bill of Rights making it a penal offense to drink. In the ordinance I made real and personal property assets in the hands of the administrator without distinction, save that the personal property was to be resorted to in the first instance. And I would have done away with the trial by jury in civil cases, but was deterred by a decent respect for the opinions of mankind. I forget all the modifications I made in existing systems; but there were others than those here mentioned, which I have no means at hand to verify. It was a rare opportunity to a young lawyer to lay the foundations of what might grow to be a great 
nation, and I did the best I could. I had the constitution and the Bill of Rights written on a large sheet of parchment by the best penman in Baltimore, and the ordinance for the temporary government was copied from my rough MS. into a quarto blank book by a young man that I had shut up in my library at my dwelling, where he could work without interruption until it was finished; for there was not an hour to spare. The work was then submitted to the Board of Managers, who adopted it in gross, on their very complimentary faith in the author, and the seal of the society was attached to the parchment, the riband interlaced in the sheet and passing through the tin box containing the wax being a blue waist riband of Mrs. Latrobe. The President of the society then was Mr. George Hoffman, whose bold hand was not unlike that of John Hancock on the Declaration of Independence; and when all the directors had signed the instrument in its general appearance it was not unlike that celebrated document.

"I do not tell this story in vanity, but it is necessary to state the facts, and I have done so without exaggeration. In all societies someone must do the work. I was willing to do it here, and hence I suppose my prominence.

"But I run a little ahead of my story. After the expedition was determined on, the vessel chartered and emigrants engaged, we were without a leader that we were satisfied with. We had one if we could do no better, but he was not the right man and we all knew it. To have sent the expedition off with him would have been a pis aller. I was perhaps more uncomfortable than anyone else now, for I thought I knew what was wanted, and felt too that we had not what was required. At times I almost regretted having got the affair up.

"Now just at this time a most singular coincidence took 
place. I have often thought I should call it Providential, not accidental. In the midst of my anxiety about a leader, I received a message in my office from Dr. Smith, stating that a gentleman who was too ill to leave the house wanted to see me. On following the servant that brought the message to Dr. Smith, I found there a lame, sick man on a couch who introduced himself to me as Dr. James Hall, who had just returned from Liberia, and who wanted to see me about a claim against the American Colonization Society. Instead of giving him advice about his claim, I told him in a few words of the receipt of his letter already mentioned, its influence on our society, and the getting up of the expedition, together with our want of a leader, concluding my narration with the question, 'And now, Doctor, will you go back to Africa and be the founder of Maryland in Liberia?' Dr. Hall: 'I will.' Mr. Latrobe: 'When will you go?' Dr. Hall: 'At once. No, I must see my two children in Vermont; I can do that in a week, and then I am ready.' Mr. Latrobe: 'Set out to see them tomorrow; be absent one week, and get on board the "Ann" as soon as you return!' Dr. Hall: 'I will be on hand, be sure of it.' And so Dr. James Hall became the founder of Maryland in Liberia. He was as good as his word. He went on board, or was carried, a sick man, on board the day after his return, and sailed in the 'Ann' and founded the colony.

"For years afterwards I conducted the correspondence with regard to it, and took, indeed, the most active part in everything that related to it on this side of the Atlantic; writing the reports, visiting Annapolis every winter to hold the annual meeting of our society there, and preventing any interference with the colonization taxes. And this continued until 1853, or until I was chosen President of the American Colonization Society, when I resigned my 
connection with the State institution. It was not long after the Colony was founded, that Simleh Ballah, King Freemans Messen, came to Baltimore to obtain a code of laws for his people. We received him in state, heard his story, and Mr. Hugh D. Evans and I prepared the simple code that was carried to Africa and adopted by King Freemans, the native sovereign, at Cape Palmas. The volumes of the reports of the Maryland State Colonization Society may be turned to for a number of facts in this connection, if you are anxious to know more about it. Sometimes I have thought when the history of Liberia shall be written, my name may appear more than once in it.

"It was while I was President of the State Society, that Governor Russwurm of the Maryland Colony came to Baltimore, when the Board of Directors gave a very handsome dinner and drank his health-beloved man as he was, this was a brave thing in those days. But in truth, African Colonization is a thread which is to be found woven throughout the web of my life. After Dr. Hall left the Government, we appointed Dr. Holmes as a temporary Governor, and gave the place permanently, after a brief discussion, to John B. Russwurm, the first colored Governor or agent of the cause of colonization on the coast. I had the intelligence to see that sooner or later white agencies must cease, and, as we had a proper man in Russwurm, proposed we should give him the appointment.

"One of the most important incidents of my term of office was the correspondence with the American Board of Foreign Missions whose missionaries at Cape Palmas claimed exemption from military service for such of our colonists as were employed by them. Dr. Anderson came to Baltimore to see me on the subject, contending that we were two benevolent societies, meeting in a savage country, 
the agents of neither of which could claim or exercise authority as regards the other, directly or indirectly. The ground I took was that the Maryland Society was, by purchase, the government de jure et de facto of the territory, and that the missionaries thereunder, while they were on our soil, were exempt from military duty by courtesy only. I was right in this, and it was so admitted, and Governor Russwurm was the man to maintain the doctrine in Africa that I insisted on in America.

"After the death of Mr. Clay, the office of President of the American Colonization Society became vacant, and I was chosen to succeed him; and thus became the fifth in line of succession, beginning with Bushrod Washington and continuing with James Madison, Charles Carroll of Carrollton and Henry Clay. As these had all been Honorables, the title of Honorable began to be lashed to my name. I owed my elevation to this position to my connection with colonization for Maryland for a number of years, and I have been elected and reëlected from 1853 to the present date-1879. My predecessors were distinguished men, whose names gave éclat to the society. I had nothing of the sort to justify my election, but a working President was wanted, and I have worked accordingly. I have written a good deal, and spoken more, and when I have passed away, my children may not be unwilling to recognize my labor in adding to the reputation of their father. Their sympathies have been in other directions, and none of the seven-six now-have ever felt an interest in the subject. I have always felt proud of the position.

\section{George Bancroft.}

"I623 H Street, Washington, D. C.

"My dear Contemporary.

April Ir, I880.

"I have read with delight your charming historical sketch of Liberia. You have stood forth always as the Champion and support 
of that Republic; your part in it is greater and more persistent than that of any man of my acquaintance; and now in your hale old age. you deserve the honors of your career.

Yours till death, George Bancroft."

"Washington, D. C., November 9, I88I.

"Hon. John H. B. Latrobe, "My dear Mr. Latrobe.

"Baltimore deserves to have had illustrious ancestors, she knows how to honor their memory so well; she will always abound in able citizens, for she proves herself determined to render just tribute to those who distinguish themselves most. For these reasons the memorial volume is most welcome; doubly welcome since it becomes a memorial of your own long friendship for

Your ever very faithful, George Bancroft."

"A very gratifying note from Judge Charles E. Phelps in regard to my paper on 'Maryland in Liberia,' read before the Maryland Historical Society, March 9, 1885.

"Hon. J. H. B. Latrobe.

$$
\begin{aligned}
& \text { "Superior Court of Baltimore City. } \\
& \text { Baltimore, March Io, 1885. }
\end{aligned}
$$

"My dear Sir:-

"I feel that I cannot remain content with the conventional vote of thanks of the Maryland Historical Society last night, which falls short of expressing what is due to you, not only for the interesting and important contribution to history - the history of human progress -which was its immediate occasion, but still more, and in an infinitely wider sense, for your lifelong efforts in the cause which your paper so ably commemorates.

The leading impression left upon my mind, as I mentioned to friends upon leaving the rooms last night, was one of surprise at the extraordinary combination of the sentimental with the practical, without which the enterprise could not have been projected in the first place, nor successfully prosecuted in the next. Not less remarkable, I thought, was the uncompromising tenacity of purpose-the 
vigorous and sustained will power-that carried the scheme over all obstacles to its aim.

Whatever may be the destiny in the future of "Maryland in Liberia," and whether or not the sanguine prediction ventured in my SesquiCentennial address is destined to become a reality, one thing is certain; and that is, the world will be the better for the effort and the example.

I received your favor of late date, and am very much obliged for the thoughtful suggestions contained.

\section{Very truly yours, (signed) Ch. E. Phelps.}

We have seen from the quotation of Mr. Latrobe's autobiography, that he first became interested in the question of colonization in 1822 .

Before proceeding with the story of his life, I think it right to give this subject, to which he devoted so much of his life, proper consideration.

Recognizing as he did, and as I do, that there are many who will consider his efforts Quixotic and of no effect, a careful examination of the question in some detail will help in ascertaining if it is, in fact, of no particular advantage that he had exerted so much effort and spent so much time for a barren result. Although it does not detract from a hero that he should perish without accomplishing his object, nevertheless in this era we are prone to judge by results.

Mr. Latrobe spent about one quarter of his working hours during ten years of his life in advocating Colonization. At a meeting held by the Maryland Historical Society in memory of Mr. Latrobe, a memorial was presented, and, among other addresses there was one made by Dr. Daniel C. Gilman, President of the Johns Hopkins University, in which he says, in reference to Mr. Latrobe:

"Probably his greatest distinction, outside of his professional life, was acquired in promoting the cause of African 
Colonization in ante-bellum days. Events have diverted the public attention from this chapter of American history, and from the efforts which were made by Mr. Latrobe and his fellow workers, under the leadership of Henry Clay, to establish well ordered colonies for the blacks on the Western Coast of Africa. It seems to me not impossible that, as the Dark Continent is opened to civilization, the germs of civil government that were planted in Liberia will produce a harvest. If that time does come, the work of Mr. Latrobe will be more fully appreciated."

In order to understand Mr. Latrobe's position in this matter and his views, it is necessary to take a bird's-eye view of slavery and African Colonization, especially as it affected the State of Maryland.

Slavery has existed from the earliest times. It was the result of war-the conquered became the slaves of the conqueror. As civilization progressed, this condition was somewhat mitigated. The capture of a people, for the sole purpose of using them as slaves, was confined to the negro race. The negroes are depicted in the Pyramids as the hod-carriers. Negroes were captured and sold in the fourteenth and fifteenth centuries in Spain as slaves.

The first cargo of negro slaves sold in this country was brought here by a Holland ship and sold in Virginia in the year 1619. Massachusetts led in establishing slavery by statute law in America.

Negroes, Indians and other classes of slaves existed in all the original States, until the Northern and Eastern states passed laws from time to time, prohibiting the institution. The importation of negroes was almost entirely a Northern industry.

In 1769 Virginia had attempted to protect herself against the further importation of negro slaves, but England over- 
ruled the enactments of Virginia, because the trade was of great advantage to England. It was proposed in the first draft of the Declaration of Independence by the Virginia statesmen, to embody a recital charging England with fostering the trade in negroes for its own interests, thus imposing slavery upon the States. The only reason that this recital was omitted was for fear that it would offend the Northern States, who had carried on the same trade for their profit. (See Ford's Edition of Jefferson's Works, Volume 4, pages 145-146.)

Indians and negroes were held as slaves and sold into slavery in the North. A child of nine years, the son of King Philip, was sold into slavery, notwithstanding the fact that he was the grandson of Massasoit, who had always befriended the whites. (Fiske's Beginnings of New England, folio 298.)

The chief slave market for negroes was Newport, Rhode Island-later called "RogueIsland, "due to persistent efforts to pay debts with depreciated paper money. The boats of New England were loaded with negroes and rum. Peter Fanueil dealt in these articles. His ledger is headed "Laus Deo," and the book is filled with items of slaves and rum. He gave to Boston Fanueil Hall, known as the "Cradle of Liberty." It was built out of the proceeds of slavery and, when destroyed by fire in 1761 , was rebuilt out of the proceeds of a lottery.

In 1787 Rhode Island prohibited slavery. In 1792 the Providence Society for Promoting the Abolition of Slavery was incorporated.

The slave trade did not cease, however, for many years after laws were passed prohibiting it in the Eastern States. Their ships continued to bring in cargoes designated as "slops," in fact, negroes. 
A respectable elder who sent ventures to the coast always returned thanks on Sunday, after hearing of the arrival of the vessel in Newport, "that it should have pleased the Almighty to bring to this land of freedom a cargo of benighted heathen to enjoy the blessings of a gospel dispensation." One may pardon the classification of the New Englander's conscience by H. C. Conwell who says: "When his conscience pricked him for holding slaves, he quickly unloaded them on a Virginia tobacco planter, and immediately organized an abolition society, expiating the sin of trafficking in slaves himself, by freeing the slaves of others."

In Maryland, we had four kinds of slaves: (1) Negroes; (2) Indentured (men and women, who, in order to pay for their transportation, were bound over for a term of years); (3) convicts (Maryland received more of this class than any other colony in America); some of these were political convicts; (4) Apprentices. (Johns Hopkins Studies: Social and Industrial History, 228. White Servitude in Maryland. 1634-1820. McComas.)

The United States prohibited the slave trade in 1807. It was not, however, broken up until many years afterwards.

In 1800 Maryland was the most northern of the slave States. Slavery did not meet with the approval of the best citizens of Maryland. Its blighting influence was recognized. If we look over the works of authors who traveled in the United States between the years 1820 and 1835, we find that most of these people, when they reached Maryland and found slavery, criticized the institution; but in almost every instance they say that the citizens recognized that it was wrong, but how to get rid of it was the question. It was easy enough for the Northern States, where the slaves were few, to pass laws to provide for their emancipa- 
tion within a certain time, and then let their citizens sell them to the South; but slaves in the Southern States were held in large numbers, and there was no longer any State upon which they could shove them off, as was done by the Northern and Eastern States, who held comparatively few.

It is unnecessary to quote all the different travelers who referred to this condition. Thomas Hamilton wrote in 1831 in "Men and Manners of America," page 113: "When Pennsylvania, for instance, abolished slavery, she passed an Act that after a certain number of years all the slaves within her territory should be manumitted, and what was the consequence? Why, the great body of slaves belonging to Pennsylvania planters were in the meantime sold and exported to other States."

Again he says: "It is only fair to state that during the whole course of my tour I never conversed with any American on the subject of slavery, without his at once admitting the magnitude of the evil."

Michael Chevelier wrote in 1834:

"In our days slavery is a scourge to all the countries in which it exists; of this the people of the United States, in the South as well as in the North, are convinced; but how to end it?" (Page 154.)

And so to the same purpose wrote some twenty or thirty people at this time upon the same subject.

The fact that the South was not responsible for the institution of slavery, and yet was in no condition to admit or consent to immediate abolition, was recognized by Abraham Lincoln, who expressed himself as follows in a speech delivered October 16, 1854, at Peoria:

"Before proceeding, let me say that I have no prejudice against the Southern people. They are just what we would be in their situation. If slavery did not now exist among 
them, they would not introduce it. If it did now exist among us we should not instantly give it up.

When Southern people tell us they are no more responsible for the origin of slavery than we are, I acknowledge the fact; and when it is said that the situation exists and it is very difficult to get rid of it in a very satisfactory way, I can understand and appreciate the same . . . . If all earthly power were given me, I should not know what to do as to the existing situation. My first impulse would be to free all the slaves and send them to Liberia, their own native land . . . . What next? Free them and make them completely and socially our equals? My own feelings will not admit of this, and if mine would, we well know that those of the great masses of people will not.

"Whether this feeling concurs with justice and sound judgment is not the sole question, for indeed a universal feeling, whether ill or well founded, cannot be safely disregarded. We cannot then make them equals."

There is, therefore, no doubt that the South recognized the fact that slavery was an institution which should not exist, and Mr. Latrobe was one of those who took an active interest in trying to solve this problem, as well as that of the final disposition of the black. For while it is true that the war-a great convulsion-has settled the question of slavery in the United States, it has not settled the negro question. This question is one which, according to the opinion of Jefferson, Bishop Turner and many others, who were best qualified to pass upon it, is bound to have one of two solutions. Either the negro race must be absorbed into the white, and the effect of this will be to make a negroid people: or else they will have to live elsewhere.

In considering the future of the negro, there can be no question that as we stand today the immediate loss of the 
entire negro population of the South would be a calamity. When in the future this country is thickly populated, when the negro asserts his rights to equality, social and political, when there is room for but one on the plank, the negro will go under, and colonization in Africa or some other country will be his salvation.

One of the best speeches ever made upon this subject was delivered by Grady of Georgia, now dead, at a meeting of the Bar Association in Boston, December 1889.

"My people, your brothers in the South, brothers in blood, in destiny, in all that is best in our past and future, are so beset with the problem that their very existence depends upon its right solution. Nor are they wholly to blame for its presence. Slave ships of the Republic sailed from your ports; the slaves were in our fields. You will not defend the traffic, nor I the institution, but I do here declare that in its wise and humane administration, in lifting the slave to heights of which he had not dreamed in his savage home, and giving him a happiness he has not yet found in freedom, our fathers left their sons a saving and excellent heritage. In the storm of war this institution was lost; I thank God, as heartily as you do, that human slavery has gone forever from American soil. But the free man remains, with him a problem without precedent or parallel. Note its appalling conditions. Two utterly dissimilar races on the same soil, with equal political and civil rights. Almost equal in number, but terribly unequal in intelligence and responsibility, and pledged against fusion. One for a century in servitude to the other, freed at last by a desolating war. The experiment sought by neither, but approached by both sides with doubt. These are the conditions . . . . Never, Sirs, has such a task been given to mortal stewardship 
The black man affecting but one section, is clothed with every privilege of government, and pinned to the soil, and my people are commanded to make good, at any hazard and any cost, his free and equal heirship of American privilege and prosperity. It matters not that every other race has been routed or excluded without rhyme or reason. It matters not that wherever the whites and blacks have touched in any area, or in any clime, there has been irreconcilable violence. It matters not that no two races, however similar, have lived anywhere at any time on the same soil, with equal rights, in peace . . . . Can we solve it? . . . . The God who gave it into our hands, He alone can know . . '. Whether the issue be lost or won, we shall feel your strong arms about us, and hear the beating of your approving hearts . . . .

"Whatever the future may hold for them-whether they plod along in servitude from which they have never been lifted since the Cyrenian was laid hold upon by the Roman soldiers and was made to bear the cross of the fainting Christ-whether they find homes again in Africa, and thus hasten the prophecy of the psalmist who said, 'and suddenly Ethiopia shall hold out her hands unto God'-whether forever dislocated and separated, they remain a weak people, beset by stronger, and exist, as the Turk, who lives in the jealousy rather than in the conscience of Europe-or whether, in this miraculous Republic, they break through the caste of twenty centuries and, belying universal history, reach the full stature of citizenship, and in peace maintain it-we shall give them uttermost justice and abiding friendship."

The experiment is still on trial. Can the whites and the blacks, in nearly equal numbers, live as one race, with equal rights, in peace? 
The Northern brother is better informed today than he was at the end of the war, when the Radicals, greater traitors than those who fought for secession, endeavored to treat the South as conquered territory and to force the negro into the position of governing his former master.

As I sat watching the "Birth of a Nation," when the conflict between the whites (Ku-Klux) and the negroes was portrayed an audience in Boston arose and applauded. What a change! But it demonstrated one thing - that the whites will never again fight against their brothers for the negro race. If, after a fair trial, the problem is lost, it will be a united white race against the negro.

We are constantly reminded of the difficulties which are brought about by contact of the blacks and whites, by reading news items of conflicts between negroes and whites; and of efforts on the part of cities like Baltimore to segregate the negro and to confine him in certain sections, for it has been found that he is a blight upon all sections where he settles, and destroys the value of property. Such a movement is now on foot in the District of Columbia. A case from Missouri (1916) has just been argued in the United States Supreme Court to test the constitutionality of such laws. No one who thinks at all can help seeing that the matter is far from finally settled. The proposition of removing or segregating the negro from the whites is considered by many people impossible, due to the fact that the negro race has been in this country for several hundred years, and that it is too firmly fixed in the soil to consider the possibility of extradition. But as this country becomes more thickly populated and the struggle for existence becomes more acute, there can be no question that one of these races will have to give way, for they cannot live as equals; in the meantime, as long as the negro does not assert his social rights there may be a truce. 
As the educated negro comes at last to realize the actual conditions under which he lives and which constitute an impassable barrier between the white race and himself, he must, and will, see that he can never become the white man's equal; and he will want to withdraw to some country where this distinction will not exist. And it is with this in view that the future of Liberia may become so important. It will be the place of refuge and equality, and one of the purposes for which Mr. Latrobe fought the fight of colonization will be achieved.

In Abraham Lincoln's Eulogy of Henry Clay, July 16, 1852, First Volume, Folio 167, of "Speeches, Letters and State Papers", compiled by Nicolay and Hay, he says:

"The American Colonization Society was organized in 1816. Mr. Clay, though not one of its projectors, was one of its earliest members, and he died its President, as he had been for many preceding years. Quoting the language of Clay:

'There is a moral fitness in the idea of returning to Africa her children whose ancestors have been torn from her by the ruthless hand of fraud and violence; transplanted in a foreign land they will carry back to their native soil the rich fruit of religious civilization, law and liberty. May it not be one of the great designs of the Ruler of the Universe whose ways are so often inscrutable for shortsighted mortals, thus to transfer an original crime into a signal blessing to that most unfortunate portion of the globe.' "This suggestion was made twenty-five years ago . : : may it indeed, be realized."

Mr. Lincoln's attitude towards the negro and Colonization was that slavery should be abolished gradually, and that the negro should be colonized. He considered the possibility of acquiring territory in South America for this 
purpose. The South American countries protested against this proposed action. In speaking of Liberia in a number of instances he showed his appreciation of this effort by his endorsement.

In a speech of Mr. Everett, delivered in 1853, he says, adopting the idea of Henry Clay:

"Africa will be civilized, and civilized by the descendants of those torn from the land."

If we examine the history of the past we see the truth of Mr. Grady's statement that never have two distinct races successfully lived side by side in equality. Starting with the Jews when they were driven from Egypt, we find that they have been moving on ever since. They were banished from England in 1290, and it was not until the middle of the seventeenth century that they were permitted to live there unmolested in England. They were driven from Spain in 1492. Until this year they were not entitled to citizenship in Russia, and many of them came to this country to reach what they call "The Promised Land." The Moors, in their great movement, swept over Spain in the eighth century. But they were driven out of Grenada, and their last city captured in the fifteenth century. They remained in Spain until the beginning of the seventeenth century, when they were driven out and deported as a peopleextradited from the country, in which they had lived for nine hundred years. They were not like the negro, an undesirable people of a low order. They were more refined, more intelligent and of a much higher order than the Spaniards who surrounded them. As we travel through Spain today, the beauty of their architecture is the subject of our admiration, and yet these people, representing the wealth and intelligence of their country, were picked up bodily and driven out of Spain. To be sure, this was done 
in the name of religion, under whose banner the greatest outrages ever perpetrated upon humanity have taken place. But still there has been no change in men's character, and when a contest arises between a stronger and a weaker race, the weaker will go down. Africa, as in the case of the Moor, will be the plare of refuge for the blacks.

Man's inhumanity to man is the same today as it was in the seventeenth century. In our own country, for example, the Indian has gradually been driven from place to place, and moved from one section of the country to another, as his existence has been found inconsistent with the progress of the white race.

Another illustration, on a much smaller scale, is the case of the Acadians who had settled in Nova Scotia. In 1755 they were forced aboard ships, and were scattered, to the number of six thousand, over the United States, as it was claimed that their existence as a people was opposed to the advance of the English in their civilization.

So, while it may shock one to consider the possibility of moving a people like the negro race out of the country, it is not an unheard-of thing; and in fact the records show in every instance where the conflict has come, that that people has been moved which belonged to the weaker race.

We have today reports of the Armenians, who possess perhaps the garden spot of the world. They and the Turks, two alien races, cannot live together, and in consequence the Armenians are being butchered and driven from their homes until they will cease to exist as a people.

The impossibility that there can ever be a condition under which the two races, the negro and the white, can live in equality, is realized by many of the negroes themselves. Dr. E. W. Blyden, a negro who was highly educated, in an article which appeared in the African Reposi- 
tory on "Latrobe's Maryland in Liberia," says of Mr. Latrobe that:

"He has always seen that emancipation would not solve the social or racial difficulty, and has continually preached and illustrated, in a thousand ways, the views of Thomas Jefferson on the subject. It is not to be expected that the present generation of colored Americans, or even white Americans, will grasp these ideas."

B. H. M. Turner of the African Methodist Episcopal Church says:

"There is no instance mentioned in history, where an enslaved people of an alien race rose to respectabliity upon the same territory of their enslavement, and in the presence of their enslavers, without losing their identity or individuality by amalgamation."

The views of Thomas Jefferson, to which Blyden refers, are expressed by him in the following language:

"Nothing is more clearly written in the Book of Destiny than the emancipation of the blacks; and it is equally certain that the two races will never live in a state of equal freedom under the same government, so insurmountable are the barriers which nature, habit and opinion have established between them."

The views of Abraham Lincoln endorse Jefferson's. Page 369, Volume 2, September 18, 1858, Debate at Charleston, Abraham Lincoln's opening speech:

"I will say then, that I am not, nor ever have been, in favor of bringing about in any way, a social and political equality of the White and Black races. . . . And I will say in addition to this, that there is a physical difference between the White and Black races which I believe will forever forbid the two races living together in terms of social and political equality." 
CANAL AROUND TAE RALLS OF THE OHIO Painted by Jokn $\boldsymbol{B}$. B. Latrobe 


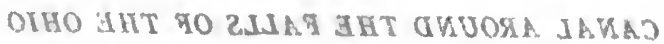

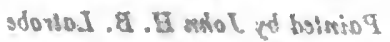




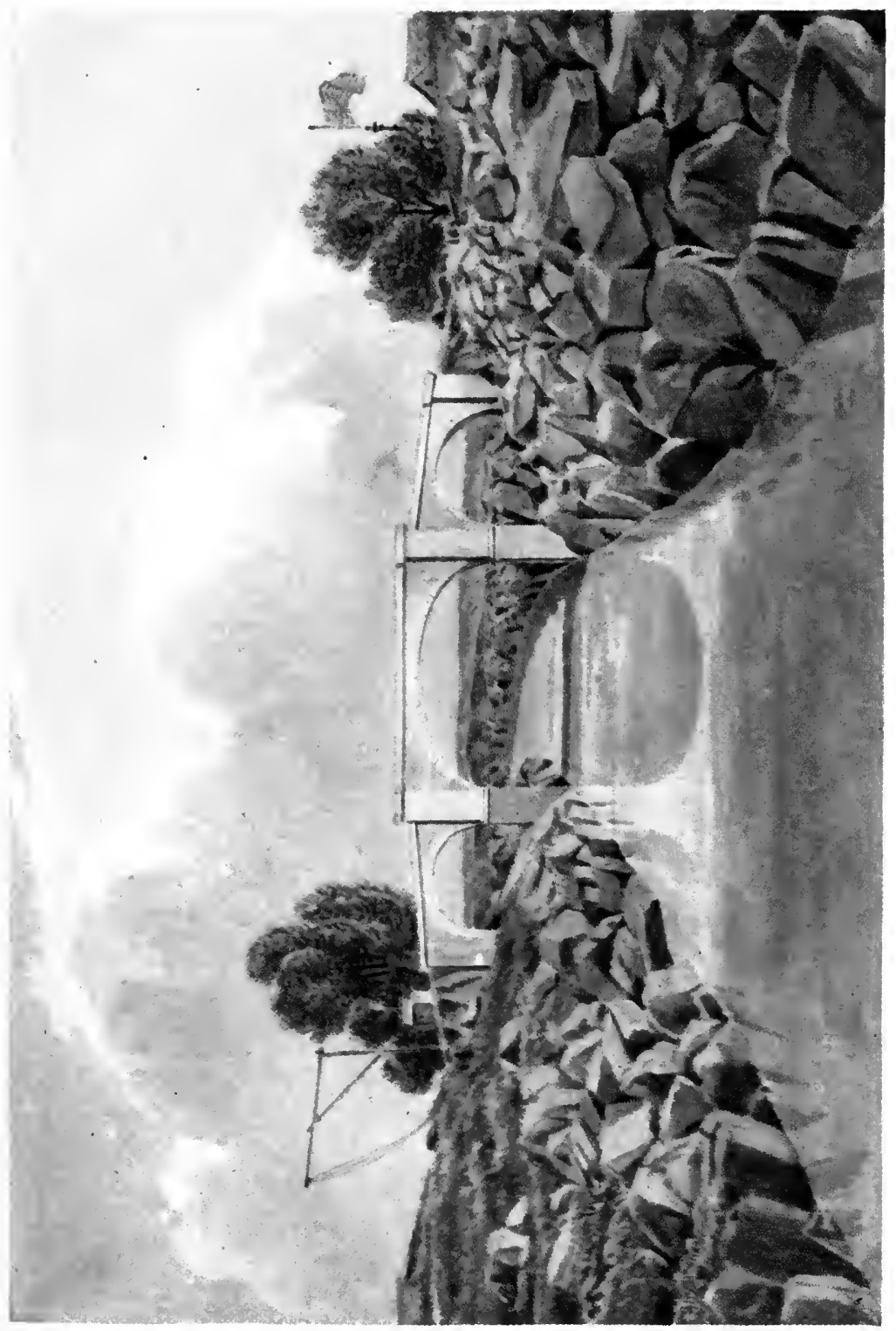



Speech delivered to colored men on Colonization, August 14, 1862, page 222, second volume:

"Why shall the people of your race be colonized? You and we are different races; we have between us a broader difference than exists between almost any other two races. . . . Your race suffers very greatly, many of them, by living among us, while ours suffers from your presence. . . . But even when you cease to be slaves, you are yet far removed from being placed on an equal with the Whites. You are deprived of many of the advantages which the other race enjoys. The aspiration of man is to enjoy equality with the best when free, but on this broad continent not a single man of your race is made the equal of a single man of ours."

And in the same speech a little later he said:

"The Colony of Liberia has been in existence a long time. In a certain sense it is a success."

There can be no doubt, therefore, that the views entertained by Mr. Latrobe, namely, that there must be ultimately a place of refuge for the negro, were entertained by the leading minds of the country, and, while this question may at present be sleeping, it still exists, and its solution will have to be found.

The result of the efforts of those, who like Mr. Latrobe believed in the establishment of colonies upon the coast of Africa, has resulted in the creation of a nation, and Liberia exists today, and has entered the family of nations as a Republic. As to its condition, we find a variety of expression of opinion.

Commodore Shufelt, who visited the coast in 1876, said in an address delivered in 1877 that it became his duty to revisit the coast of Africa, after an absence of twenty-five years . . . . "All this indicated life, business and commercial and agricultural prosperity." 
Mr. Stanley, the great African explorer, speaking of the young Republic in 1884, says:

"This State, which they might regard with honest pride (that is, the United States), . . . . It was an act (its establishment), well worthy of the Great Republic Of significant import, in view of its interests of the future weal of the seven million people of African descent within its borders."

In a recent publication of Frederick Starr, Chicago, 1913, he speaks, giving the history of Liberia, as follows:

"Africa has been portioned among the nations. The little Kingdom of Abyssinia on the north and the Republic of Liberia upon the West Coast are all of the continent that remains in the hands of Africans. Liberia alone is in the hands of the negroes . . . .

"A successful Liberia would be a star of hope to the Dark Continent. In Liberian success there lies African redemption; redemption not only in the religious sense, but redemption economic, social, governmental. If the black man can stand alone in Liberia he can stand alone elsewhere; if the negro is able to organize and maintain a government on the west coast, he can do the same on the east coast and in the southern part of Africa. Africa is restless under the white man.

"If Liberia prospers, it will stand as an example of what black men can do to all the other negro population of the continent. Its example would stimulate advance for all; the sight of enterprises originating with negroes and carried out by them would give heart and stimulus to negroes everywhere."

To quote Mr. Starr further:

"From this little State, the size of Belgium, whose population does not surpass, including the natives, a fifth part 
of the population of that country, will go forth, perhaps, some day the best imaginable missionaries, to extend over the Black Continent the benefit of civilization and to found the free United States of Africa, sufficiently powerful to defy the covetousness of white men, and to make justice reign as far as it can reign among men."

Whether it is, or is not a failure, is immaterial. Certainly there was a justification for the work, and the men who sacrificed their time are entitled to credit.

The idea of Colonization existed for many years. We find Brissot speaking of it in 1788, after Dr. Thornton had brought it to his attention. There was a movement on foot in the United States, as Jefferson shows when he says:

"In the disposition of these unfortunate people, the first rational object to be distinctly kept in view is the establishment of a colony on the coast of Africa which may introduce among the aborigines the arts of civilization and science."

An interesting page in the history of Maryland, showing its efforts in this respect, is set forth in the "Maryland in Liberia," already referred to, published by the Maryland Historical Society.

Mr. Latrobe became the President of the corporation in 1837 and continued as President until "Maryland in Liberia" became a part of Liberia as a County in 1853, at which time he was elected the President of the American Colonization Society, holding this position up to the time of his death in 1891.

Maryland took the lead and was the most liberal of all the states in this effort to solve the question. There were auxiliary societies in a number of the states, and, as Blyden says, the three names which will be honored in the annals of Maryland in Liberia are Latrobe, Hall and Russwurm. Russwurm was a negro and was at one time President of Maryland in Liberia. 
The creation of this colony was to solve the problem complicated with the question of slavery. It is not contended that all persons who were interested in this effort were actuated by love of the negro. Many were profoundly affected by the institution of slavery and the wrongs of the slave. Many realized the wrongs of the slaves; others believed that the condition of the free slaves created a population more dangerous than the slaves themselves, and that as a class such people, devoid of education, should be removed from the soil. No movement of this kind ever existed without motives of various kinds being involvedsome high, some low. Many States passed laws prohibiting the negro from remaining within their borders. The cry was like Sarah's of old:

"Wherefore, she said unto Abraham, cast out the bondswoman and her son, for the son of the bondswoman shall not be heir with my son."

Charles Carroll Harper, a young man of the same age as Mr. Latrobe, writes to him on January 3, 1826, from South Carolina:

"John, we must not die until we find some place of refuge for the blacks. A fearful conflict is in preparation for our posterity."

In speaking of Mr. Latrobe in this connection, a memoaial of the Maryland Historical Society says:

"But we had a true philanthropist and his sympathies were broader than the lines of City or State. He took a leading part in the organization of the Maryland Colonization Society, whose constitution declared that they looked forward to the extirpation of slavery in Maryland by proper and gradual efforts addressed to the understanding and experience of the people of the State, as the peculiar object of their labor. He framed the constitution of the Colony 
of Maryland in Liberia, inserting therein among other wise provisions a strict prohibition of the manufacture or sale of intoxicating liquors. His labors in the enterprise were so wise and efficient and important, so well adapted to throw a ray of light upon the Dark Continent, that he has not unjustly been styled 'The Creator of a State.' "

Bradley $\mathrm{T}$. Johnson, in a speech made at the same time, says:

'And he also prepared a code of laws for the people. His code and his constitution were ready. Mrs. Latrobe, then a young and charming woman, gave him a blue ribbon belt, and the constitution and code of Maryland in Liberia to this day have the Great Seal appended to Mrs. Latrobe's belt."

At the annual meeting of the American Colonization Society, held in Washington, D. C., January 19, 1892, the Rev. Thomas G. Addison presented and read a paper touching the death of President Latrobe, and it was adopted by a rising vote, as follows:

"The year 1891 will be memorable in the annals of the American Colonization Society because on the eleventh day of last September, John H. B. Latrobe departed this life. No words can express our sorrow as we gather today around the empty chair he filled for thirty-eight years as our President. We shall see him here no more, but he still lives and will live on when we are gone, in the wisdom, the ability and the generous enthusiam that are a part of the life of this society and are enshrined in its history. $\mathrm{He}$ felt that he occupied a great office in a great cause, and, though that cause was obscure and the world regarded it as quixotic, and scornful criticism depreciated and ridiculed it, he never lost his love for it or abated his efforts in its behalf. 
"There was indeed little in the present to animate him, but to his faith the future was bright with splendid visions of redeemed millions worshiping God in spirit and in faith and rejoicing in the rich civilization of Christendom.

"How large and grand he seems as we contemplate him amid all his manifold interests and employments, thinking, planning and laboring-not for himself but for others, not for a day but for the ages, not for a tribe but for a sentinent. His was no dreamy, romantic sentimentalism, spending tself in emotion and fine words. His enthusiasm for Africa meant self-denial. As far back as 1823 he laid aside his loved law books and made a map of Liberia. As the years passed his business as a lawyer increased, the cares of life crowded upon him; many loved pursuits solicited his attention. He was a painter, a poet, a litterateur, a musician, an inventor; his hours were precious to him; and yet the enthusiasm of his early manhood for the Liberian Republic never forsook him. It triumphed over the charms of the painter's brush and of the poet's ecstacy. Literary ambition, musical skill, inventive genius were often subordinated to the claims of colonization. It is perhaps difficult to realize today the amount of work involved in originating the Maryland State Colonization Society, in securing State aid to Liberian emigration, in influencing the Maryland Legislature in successive years to make the several appropriations of money aggregating the large sum of $\$ 250,000$. His sublime zeal was not confined to the people of his own State. It reached across the Atlantic. He was the originator of the Colony of Cape Palmas. He prepared its bill of rights and the constitution and ordinance for its temporary government. England's famed Wilberforce was not more earnest, energetic and persistent in his efforts for negro emancipation than was our Latrobe. Over 
this life we have so much admired a singular glory has been shed. A high Christian motive controlled him. The busy man of the world was conscious of the presence here of the invisible Kingdom of God, and of the blessings it offers to the barbarians of the Dark Continent. The source of his long service, the inspiration of his untiring heroic devotion, his own beautiful words, recently published, reveal to us:

Oh, were I left to choose the fame

That evermore might cling

Around the mention of my name,

Like ivy on a tower close clustering,

The Triumphs, trumpet told, of war,

The Senate's plaudits, and the crowd's hurrah,

Might all unnoticed ring.

Potosi's teeming mine, Golconda's sunny gem;

Aye, all the powers that boast the diadem,

I'd hold as worthless, spurn unsought,

If but a single voice

Of Gratitude, unbought,

From Africa should say

I'd made one heart rejoice,

Or in that heathen land had caused one soul to pray. 


\section{CHAPTER VII}

Mr. Latrobe as a Lawyer-Friends and AcquaintANCES. BALTIMORE IN 1824

The solid foundation of character on which Mr. Latrobe's whole life was built was as significant at the beginning of his career as later; and we find in his memories evidence of the confidence which he then inspired.

"I ought not, in this record of my life, to omit what should have been told in its place-the circumstances under which I commenced my professional life (pecuniarily). The day I was admitted to practice, we-my mother and Iwere many hundred dollars in debt. The sale of my father's library had long since been realized and there remained of availables of a tangible shape only my mother's interest in some New Jersey woodland and a claim, afterwards realized, of some few hundred dollars on the Chesapeake and Ohio Delaware Canal Company. One could live in a modest way and comfortably on some $\$ 1200$ a year, but it was necessary to have this sum. Without it the cost might as well have been $\$ 20,000$. We had it not. So I went to Philip Laurenson, the grocer, and to Philip Baltzell, the dry goods merchant, and to William Surly, the tailor, and asked them to trust me, stating that if I lived I would pay them-if I died they had little to expect. And they trusted me, and they were all paid in money. The debt of gratitude is still unpaid. They have long since passed away, and this record of their kindness is my only way to liquidate it." 
He relates a story showing the financial straits to which the Latrobe family were reduced. Benjamin Latrobe was at St. Mary's College, where he took high honors in 1824 in mathematics. While attending college he lived with his brother. He afterwards became chief engineer of the Baltimore and Ohio Railroad. Mr. Latrobe used to speak of their very meagre means of living. He told me that in those days the dress of a gentleman was short knee breeches and black silk stockings. Black silk stockings were very expensive, and he and Ben between them could only afford one pair, so that when one went to a party the other did not. The beauty of black silk stockings was their blackness; by reason of constant use they became thin, and would show white. Then they used to ink their legs in order to keep up a handsome appearance.

It was his custom to write verses which would be set to music by one of his friends. These would then be introduced at the different entertainments. Among other verses that he wrote was one, a part of which is probably a quotation from Byron and which had contained the line "My bark is upon the deep, love." When this was repeated, its usefulness was entirely destroyed by the French Consul who, when he heard it, said, "Qu'est-ce que c'est que ça-my bark, bow-wow, bow-wow?" This was fatal to the verse which never recovered. The first verse of a serenade in "Odds and Ends," written by Mr. Latrobe, has the following words. This, no doubt, is the song of the story:

My bark is upon the deep, love,

My comrades, impatient, call;

Awake, while the fairies sleep, love!

Awake then, more bright than all,

Awake-awake-awake, Elvira, love. 
He remained with General Harper until the latter's death in 1825 . He was admitted into the Baltimore County Court May 8, 1824; Court of Appeals of Maryland 1827; the United States District Court, September Term 1825; United States Circuit Court 1827; United States Supreme Court, 1830.

It seems almost incredible that one could accomplish so much, in such a variety of fields, as Mr. Latrobe did. The secret of his being able to do so lay in his theory of life, which he announced in an address delivered to the Law Department of the University of Georgetown in 1874 and which may be designated as the "utilization of scraps of time." He was never idle. As a soldier, lawyer, inventor, poet, painter, philanthropist and writer, he was a practical illustration of what could be accomplished by carrying out his own theory. How different from the method of living now in vogue among those who arrogate to themselves the position of the leaders of society, where, as Lowell has said, the "highest achievement of our present civilization is to waste time without lassitude."

Quoting from a letter which he wrote to his most intimate friend, Charles Carroll Harper, some years later, in which he states that he has started for a holiday of four weeks, he gives a list of his equipment, which would hardly be duplicated by a fashionable visitor of today. He says in this letter:

"There was a trynk of goodly dimensions, a carpet bag of glaring pattern, a surtout and an umbrella in its appropriate case. This in the ordinary course. Then there was a sketch book, with a new fangled contrivance of mine own to keep the pencils and brushes safe. Then a book on botany for beginners and a more scientific one for adepts. A magnifying glass, with three lenses, to ferret out the 
secrets of the class cryptogamia, a pocket thermometer to make myself wiser about the temperature of the countless springs I am to visit, a folding foot rule and an ample map of Virginia done up in a portable shape. 'Truly,' said I, as, in looking in all my pockets and finding what I sought, my pencil case, as usual, in the last receptacle examined, I tumbled out the most of the articles here enumerated, 'Truly, Denon was a fool to me, and as for Belzoni and the Landers, they are not to be named in the same breath with John H. B. Latrobe, a member of the Baltimore Bar, etc., equipped for a journey to the White Sulphur Springs.' "

I have always believed that no information was ever lost upon a lawyer. I recollect appearing in a case in which the other side endeavored to establish the mental capacity of a testatrix. One of the principal witnesses was a man who had lived in the same boarding house with the deceased and who on examination testified that he had based his judgment on the game of whist he had seen her play. Being a whist player myself, I was able, on cross-examination, to develope the fact that his knowledge of the game was such that, if judged by it, he would be a fit candidate for the insane asylum; and this utterly destroyed the value of his testimony.

Mr. Latrobe says in his address to the Law School:

"Clients do not seek you to discuss abstract principles, but to deal with facts growing out of their various occupations; and the wider your information in regard to these, the more highly appreciated will your advice be and the greater its usefulness. 'Your profession, dealing by turns with every branch of human knowledge, brings by turns every faculty, taste and accomplishment into play. Not that you can expect to be admirable Crichtons; or to have it said of you, as was said of a celebrated professor, substituting the word 'law' for 'science,' that 'science,' was his 
forte and omniscience his foible.' But if you cannot be adepts, you need not be ignoramuses. If you are not, like Mrs. Somerville, at home with the Differential Calculus, you may know enough to avoid confounding it with secretions requiring surgery to remove. If you are not a practical photographer, you may be familiar enough with optics and chemistry to understand how the sun is made to work its artistic wonders. If the ticking of the telegraph speaks to you in an unknown tongue, you may at least comprehend enough of electricity and mechanics and horology to understand how it is that clocks in Washington swing their pendulums isochronous with others in San Francisco. Nor is such knowledge ornamental merely - to be regarded as a gentlemanly accomplishment and nothing more. On the contrary, Woodward's solar camera was the subject, not long since, of a prolonged litigation in Maryland, in which the black-board was introduced into the Court Room, and the science of optics was made familiar to the Judge. The case of O'Reilly v. Morse, which brought all the learning of the electric telegraph and all other telegraphs before the Supreme Court, is now a leading authority in the profession. In Burr vs. Duryea, the illustration of the mechanical and philosophical principles involved was a working model, which actually felted a hat in the presence of the same august tribunal. To fix the meaning of the words' entertainment of the state,' in the Act of 10 , George IV, ch. 28, it became necessary to review the whole dramatic literature of the period, and the arguments regarding Lady Hewley's charity turned upon the nicest points of theological controversy and biblical criticism. There is not one of the many cases of collision in admiralty that does not absolutely demand, on the part of counsel, some knowledge of the principles of navigation and the peculiar characteris- 
tics of steamers and sailing vessels. Turn to the decisions of the Supreme Court, from those of Judge Story to the last exhaustive treatise of Judge Clifford, invoking principles of the mechanical arts and practical science, and you will find the amplest illustration of the value to a professional man of the knowledge that has enabled the Bar to make intelligible to the Bench the matters coming before it for judgment. You will find in these judgments, too, the most logical reasoning and the profoundest knowledge of the law. The stronghold of old times was not the less impregnable because the sternness of its aspect was softened by the ivy that clung to the buttresses that supported it. Neither is law, today, weakened in its power because those whose ministry upholds it unite the accomplishments of various knowledge with legal erudition. Great lawyers, it is true, have won their way to greatness, to whom such accomplishments were unknown; but no lawyer's greatness was ever lessened by their possession. Even of Lord Eldon it was said that, in his high office, "he suffered greatly from the want of liberal knowledge and a more cultivated taste.'

"Nor need the acquisition of such knowledge interfere with the diligence demanded by purely professional studies. 'Let a man do all he can,' says Hazlitt, 'in any one branch of study, he must exhaust himself and doze over it, or vary his pursuit, or else be idle. All our real labor lies in a nutshell. We have to climb a steep and narrow precipice; but, after that, the way is broad and easy, where we may drive several accomplishments abreast.' But to realize this, time must be economized, and method is essential. Scott, the most voluminous writer, perhaps, of the century, whose miscellaneous prose works deal with all manner of subjects, was always at leisure after midday. His secret was method, nothing else. The division of time that suited 
the great novelist may not suit you. You may have but scraps of time, saved here and there, to give to outside learnings. But have a method of using up the scraps. For every scrap of time have a scrap of useful knowledge to credit it with. Throw no scraps away."

In the same lecture he says, speaking of success:

"The humblest client or the most feeless case may afford or lead to it. The early days of their practice, with most young lawyers, may be called, emphatically, the days of small things; and with ample time upon their hands, these aspirants for fame should adopt and adhere persistently to a rule to study as carefully and to prosecute as thoroughly the smallest case, as though a fortune depended upon success."

This same advice was given to another law class by $\mathrm{Mr}$. Wise, who illustrated it by saying that the smallest case was like the smallest crab in a basketful. You picked him up and he had hold of the next one, and so by a proper attention to the smallest crab you had a whole basketful.

Again Mr. Latrobe speaks of courtesy and politeness. Courtesy is a quality susceptible of cultivation and within the reach of all; and courtesy should be a characteristic of our lives. Courtesy smooths many a rough place. Courtesy and politeness have been compared to an air cushion which, while it has nothing in it, softens the bumps wonderfully.

One of the judges of our court told me that Mr. Latrobe was noted for his politeness and suavity. Mr. James McClure, a lawyer, once said that he could not help feeling, while trying a case in which he was opposed to Mr. Latrobe, and getting the worst of it, that he was being licked all over, prior to being swallowed. 
Politeness and courtesy, however, sometimes lead people into error.

A friend of mine was trying a case in the Court of Appeals, and Judge Bartol, who was the Chief Judge at the time, was extremely polite and showed a great interest in the case. My friend, when he returned home and summed up the chances of success, as lawyers will, trying to count noses by recalling the aspect of the Judges, placed Chief Judge Bartol at the head of those whom he thought he had favorably impressed. The case was decided and Judge Bartol wrote the opinion, leaving not a shred of the cause which my friend represented. Sometime afterwards, he went down to try a case in the Court of Appeals, and Judge Bartol commenced to show a great interest. My friend, being somewhat of a wag, stopped him and said, "Your Honor, you disconcert me considerably by the interest which you apparently take in my case," and then he said: "the last time I was here you seemed to be on my side and you wrote the opinion against me. In fact, I remind myself of a man whose duty it was to place his head in the lion's mouth. While his head was in this position, feeling a slight pressure he turned to his assistant on the outside and said, 'Tom, is he wagging his tail? If he is, I'm a goner.' ",

At a meeting of the Historical Society held in commemoration of the Honorable John H. B. Latrobe on September 12 th and October 11 th, 1891, the report of the Committee composed of Henry Stockbridge, John B. Morris and Albert Ritchie, speaking of Mr. Latrobe as a lawyer, speaks thus eulogistically of him:

"His mechanical knowledge and ingenuity and his thorough mastery of the law applicable to inventions soon placed him among the foremost of the 'patent lawyers'of the country; and at the same time the same knowledge, coupled 
with his position as the legal counsel of one of the first railroads in the land, made him a pioneer in a branch of the law which then first came into existence, and has since become a branch second in importance to almost no other. . . Neither his labors in this special field nor the burden of an extensive general practice absorbed all his energies or blinded him to the interests or the needs of society or the world. He held the office of Justice of the Peace and gave to the world the book which has been for more than half a century the sole guide to the practice of the law within that jurisdiction in the State of Maryland, and the demand for which has required him to prepare edition after edition."

Before going into the details of Mr. Latrobe's life as a lawyer from the records left by him, a description of Baltimore in 1824 will not be out of place.

At that period Baltimore stood third in the list of cities of the United States, with a population of about seventy thousand. Next to New York and Philadelphia, it was then the most important city of the Union. New York has maintained its position as first; Philadelphia has dropped from second to third place, and Baltimore now stands seventh or eighth, with a population of about six hundred thousand. Second place is held by Chicago; and St. Louis, Boston, and Cleveland have all passed Baltimore in the race. It is but fair to say, however, that the records show that, for enterprise, Baltimore stood high in those days. The first passenger railroad was constructed by investments of its citizens; and they had the Baltimore "clippers," ships which were known all over the world.

The clipper ships for which Baltimore was noted are described on page 460 of the "History of Baltimore" edited by Clayton C. Hall. One of the special features was the 
amount of topsails which they carried, and they established a reputation for speed. The vessel of which Mr. Latrobe speaks, as having been built for Isaac McKim, was named "Anne McKim" after his wife.

The first telegraph line was built from Baltimore to Washington; and the first electric railroad in the United States was constructed in Baltimore. The first Gas Company in America was organized in Baltimore on June 17, 1816. The men interested were Rembrandt Peale, Robert C. Long, James Mosher, William Lurman and William Gwynn.

The aristocratic section in 1824-30 was at about the center of the city. In the suburbs there were a number of places which were given names as was the custom in England, and the owners were known after the name of the place, as was Charles Carroll of Carrollton.

The story that Charles Carroll who signed the Declaration of Independence added "of Carrollton," to assume the responsibliity for the action, which he might otherwise escape because of the large number of "Charles Carrolls" in existence, has often been repeated. We find it in the "Colonial Mansions of Maryland and Delaware," folio 120; and in a speech of Robert C. Winthrop, delivered July 4, 1876. We find it also in Appleton. On page 121 of the "Colonial Mansions of Maryland and Delaware," Mr. Latrobe is quoted:

"I have no recollection of having heard the reason, given in Appleton, for the attaching of the "of Carrollton" to the signature of Charles Carroll to the Declaration of Independence. No such reason was given me by $\mathrm{Mr}$. Carroll during my connection with him in the preparation of his biography."

But there can be no question that the "of Carrollton" was attached for the purpose of identification. 
The McHenry mansion was situated on Fremont Street, a property afterwards acquired by $\mathrm{Mr}$. Winans and now occupied by Thomas Winans' residence. Dr. Stuart, whose place on Maryland Square is so often mentioned by $\mathrm{Mr}$. Latrobe, was located in the now thickly built-up neighborhood around Franklin and Union Square, as was also John Donnell's residence, known as "Willow Brook," he being a near neighbor of Dr. Stuart.

Charles Carroll of Homewood was the son of Charles Carroll of Carrollton. The handsome colonial house on Charles Street, now the property of the Johns Hopkins University, was "Homewood." It was built by Mr. Charles Carroll of Carrollton in 1800, and given to his son as a wedding gift upon his marriage to Miss Chew.

Among other suburban, or at that time, country residences around Baltimore, whose names were attached to the names of the owners, were;

Barrister Carroll of "Mt. Clare" (now Carroll Park).

William Patterson of "Homestead."

Robert Oliver of "Harewood."

Dr. William Gibson of "Rose Hill."

George Grundy of "Bolton."

Colonel James H. McCullough (the site of whose home is now occupied by the Administration Building for the public schools, corner of Madison and Lafayette.)

Thomas Tennant, whose daughter married John P. Kennedy, had a country residence now occupied by the Ready School.

Louis Pascault lived on Saratoga Street between Green and Pine.

James Gallatin makes the following notes in his diary: "September 24, 1823. - I went this afternoon to M. Pascault's house. It is the oldest house in Baltimore. Most beautiful iron gates, that he had sent from France. 
"An air of refinement about the interior that I have never seen out of France.

"M. Pascault, who is the Marquis de Polion, is a gentleman of the old régime." Page 246.

"M. Pascault has another daughter married to a Mr. O'Donnell, the son of a rich Indian Nabob. She was married when she was fifteen, and had a child before she was sixteen."

The second daughter of Louis Pascault married James Gallatin. The Archbishop of Baltimore refused to perform the ceremony because Gallatin was a Protestant. They were married in the Protestant Church, and Archbishop Carroll excommunicated M. Pascault.

John Eager Howard lived at "Belvedere," the mansion being at the head of Calvert Street, north of Eager, destroyed when Calvert Street was cut through.

The aristocratic part, as I have already stated, was on Gay Street, south of Baltimore Street. Here lived Robert Oliver, R. L. Colt, his son-in-law, William Gilmor, Thomas Tennant, Judge Purviance and General Harper, and on Water Street Robert Gilmor, Jr., his residence filled with works of art, Mr. Dugan and Mr. Hollins, who lived opposite Mr. Gilmor. John Donald, Robert Gilmor, Sr., and William Patterson lived on South Street. On Gay Street, north of Baltimore, lived John Ridgely of Hampton. The two McKims, Isaac and William, lived on Baltimore Street, east of the bridge; Smith and Buchanan on the west side of Monument Square, Alexander Brown and Dr. Bartholomew lived on Fayette Street, now occupied by the Equitable Building, George Brown, the Wilsons and John McKim lived on Holliday Street.

The Didiers, Dishan and D'Orsey were names familiar but foreign. 'Von Kapf, Brune, Mayer and Hoffman were 
names prominent in those days-these names suggesting a German origin, as the Didiers and others suggested a French.

Mr. Latrobe writes:

"Shortly after my admission to the Bar in 1824 I became interested in an association which afterward assumed shape as the Maryland Institute. Those who were interested with me, like the ghostly procession in Macbeth, move before me: Fielding Lucas, one of the handsomest old men I ever saw, and my dear good friend, William Meeter, almost as large as Lucas, with his rounded shoulders and his clear brown eyes. Hezekiah Miles of the Register, a short stout built man, stooping as he walked, speaking in a high key, addicted to snuff, but with a keen gray eye, that lighted up a plain face with shrewd expression. Col. Wm. Stewart, with his square shoulders, light hair, kindly countenance, and Scottish cast of features. And so I might go through the list of my old associates, dead now, all dead, all dead. Plain men as regards the fashionable world, but the men on whom rested the prosperity of a city, as they pursued the calling that connected them with its varied industries. Of this body, I was the corresponding secretary, and the working man from the beginning until a conflagration destroyed our collection of material and our meeting place (The Athenaeum) in 1835. I was getting along in the profession, too, in these days, slowly, but always doing better the current year that $I$ had done the year before.

"It was about this time, I think, that I became a member of the Delphian Club, its youngest member, and the last that was installed with the ancient ceremony. The club was composed of literary men, who had a vein of humor in their composition. My good friend, Mr. Gwynn, fancied 
I was fit for membership, and I was elected, notwithstanding my age. We met once a week, and our Secretary was Dr. John Readel, whose inexhaustible fun kept every member aroused. Fun? No, indeed; wit and learning did it. His club name was Von Crambograph, and it was his privilege to record what he pleased as the doings of the meeting, putting what words he chose into the mouths of the members. The reading of the record was generally the choice morsel of the evening. General Winder, one of the leading members of the bar was an active member, called in the Club, Opechancanough Sulikonqui; Breckinridge, the author of "Modern Chivalry," was another. John Neal, still living, the only survivor besides myself; another was Solomon Allen, the Editor of the 'Chronicle'; another yclept Solomon Fitzquiz, of the direst humor, Dr. McCullough, the author of antiquarian researches, the only man in Baltimore that the Abbé Correa da Serra* asked for as worth knowing-I forget his Club name. Pierrepoint, the poet, was another. His name does not come to me either. Professor Ducatel, called Basaltes Craniosiorsus, William Gwynn, perpetual Flamen, entitled Odopœus Iliyosticus, and myself, who rejoiced in the name of Sir Joselyn Mittimus of Mittimus Hall. These made the nine. Then we had William West, Fielding Lucas, Francis Foster, the giant good fellow, who had taught me writing at St. Mary's, and perhaps more whose names I have forgotten. The records were the delight of Dr. Readel. They were kept in folio volumes, whose chirography was beautiful, and were filled with wit; the contributions of the members, if he deemed them worthy, being transcribed into

* Abbe Correa: Jose Correa da Serra, Minister from Portugal, the most famous wit and epigrammatist of his day. He it was who called Washington the "City of magnificent distances." 
it. After the club disbanded, Readel commenced an expurgated edition in quarto-for these were specimens of wit that were freer than he fancied they should be. I should be glad to see them once more. They are in existence somewhere. It was a rare companionship for a lad of two or three and twenty, but time, and circumstances made it expedient to extinguish the club, and a meeting was held of such members as could be gotten together at the rooms of the Flamen, and in succession, each member was regularly expelled, until none remained save the Flamen and the secretary. But the former had two votes, so he expelled the secretary, and then sent in his own resignation to Apollo. It was melancholy, and Von Crambograph's eyes filled with tears as he delivered his beloved records to the Flamen, whose voice was choked as he attempted to reply. If these were men playing child's play, it was a' pleasant play, and innocent recreation, and the Delphians, noted and renowned even at the time, are now but a shadow of a memory-and that fast fading into the invisible.

"I have mentioned the rooms of the Flamen-they were in a graceful little building, designed by Robert Carey Long, in the rear of the Gazette office, and called the Tusculum; and here, after the Delphian died, would collect many of the choice spirits of the day, our champagne paid for by assessments of fifty cents on each person present. Champagne, the best, then cost $\$ 1.50$ a bottle. At these meetings Mr. Gwynn presided, and we used to meet many a clever man, now long since dead. I recall particularly the late Judge Frick, * who was the life and soul of any circle that he joined, and who used to set to music the rhymes I wrote, to be published by John Cole, another humorist who visited at the Tusculum. Also Colonel Hamilton of

*William Frick, Judge of the Superior Court, died 1855. 
MRS. WARING AS MARGARET

In "A New Way to Pay Old Debls," drawn by John H. B. Latrobo 


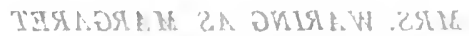

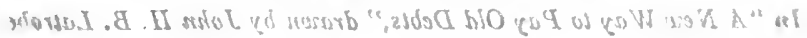




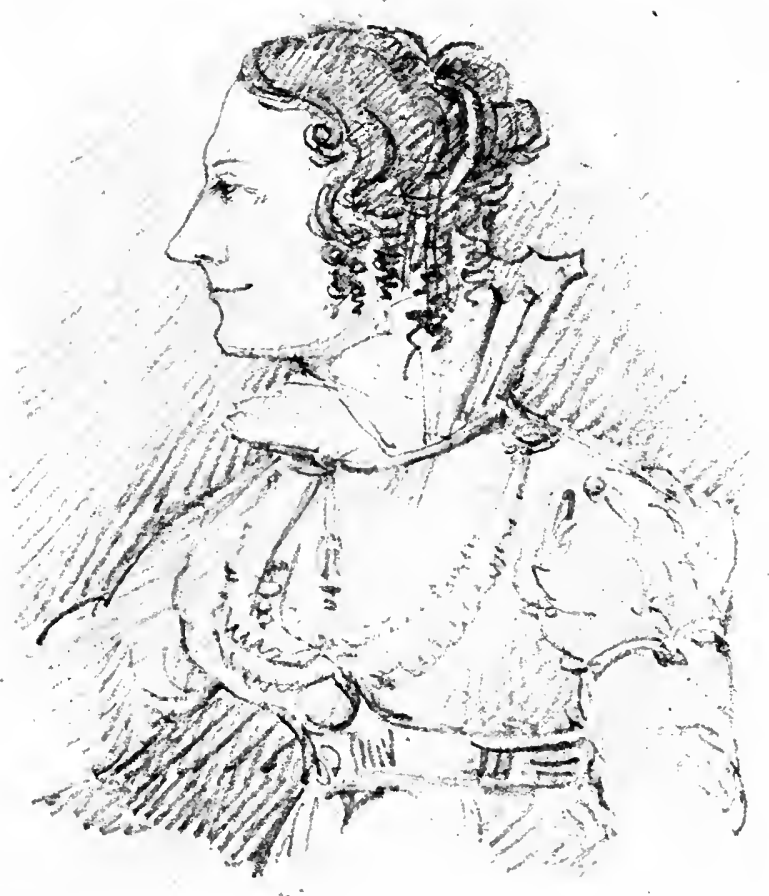



South American fame.* I met there Sheridan Knowles, actor and author, who left the stage to become a Baptist minister, and many, many others. Philip Lawrenson was a constant visitor; he was educated a priest at St. Omers, and was at this time the principal grocer in the City. A slight touch of Bohemianism about me is to be traced, I think, to the Tusculum.

"This same Bohemianism made me acquainted with artists, and, now and then, with an actor or actress. I knew Sully well-one of his best known paintings is 'Washington Crossing the Delaware'-and learned from him to paint in oil; Albright, a clever landscape painter, for whom I occasionally put in figures in foregrounds-certainly on two occasions; and Nagle whom I knew but slightly.

"I was always devoted to the theatre. Not far from the portion of Baltimore already described was Holliday Street Theatre. The attraction here was acting, not scenery nor the comfort experienced by the audience. The price for admission was one dollar for the boxes, seventy-five cents for what was then called the pit, and fifty cents for the gallery. The seats in the former were long, uncushioned benches, without backs, and the cry to 'sit closer' was common. As to the scenery, the less said about it the better, for it was execrably bad. But the acting compensated for all deficiencies. There was Warren whom I knew and saw often at Mr. Gwynn's. He was the best Falstaff and the best Sir Peter Teazle that ever trod any stage. There was Wood whose Joseph Surface, Marlowe, Captain Absolute, could not be excelled. Mrs. Waring was one of the best actresses of her day. I have now a fair profile likeness of her drawn

* Colonel J. P. Hamilton was the head of the Commission appointed by Great Britain to investigate the conditions of Colombia. He wrote a book entitled "Travels through the Interior Province of Colombia." 
from memory as 'Margaret' in 'The New Way to Pay Old Debts.' I knew Mrs. Duff the tragedienne, with Mr. Duff as a tragedian. The elder Booth described her as being the best actress in the world. There was Clara Fisher, afterwards Mrs. Meader, for whom I wrote the song 'All Hail to the Brave and Free,' which John Cole set to the French Air of 'Le Petit Tournebour,' and which was sung on the occasion of the Greek Benefit, and whistled by the negroes for some weeks in the streets of Baltimore. And Mrs. Francis Wallack at the head of what is known as genteel comedy; Jefferson, the grandfather of Rip Van Winkle; Wilkins, whose Tony Lumpkin was renowned; Thayer, one of the best light comedians of the day. These, with Mr and Mrs. Barnes and others, were the stock company which, oscillating between Philadelphia, Baltimore and Washington, attracted crowds to old Holliday before the stars of the theatrical heaven dimmed inferior luminaries. Mr. Cole got me to write for him, to a well-known French air, 'Our Way Across the Sea,' generally known as 'Home, Fare Thee Well,' which had a great run and is, sometimes, still in repute with young ladies. To please Colonel Hamilton I wrote, too, the lines beginning 'We have broken the fetters that have bound us' to the air of a grand old Spanish song. I wrote the verses and Judge Frick set them to music. Another short lived favorite Cole published, 'Oh, lady, if I were the Knight of Old.' Besides all this music I wrote year after year the addresses of the carriers of the Gazette, trying to make them better than common, but with all I worked at law and gradually got more and more to do.

"Literature in those days was represented by the Library which had its home next door to the theatre; and, to the credit of the City be it said, its admirable collection of books, 
THE ELDER BOOTH AS SIR GILES OVERREACH Drawn by John B. B. Latrobe 
พวน.

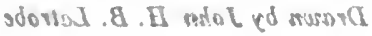




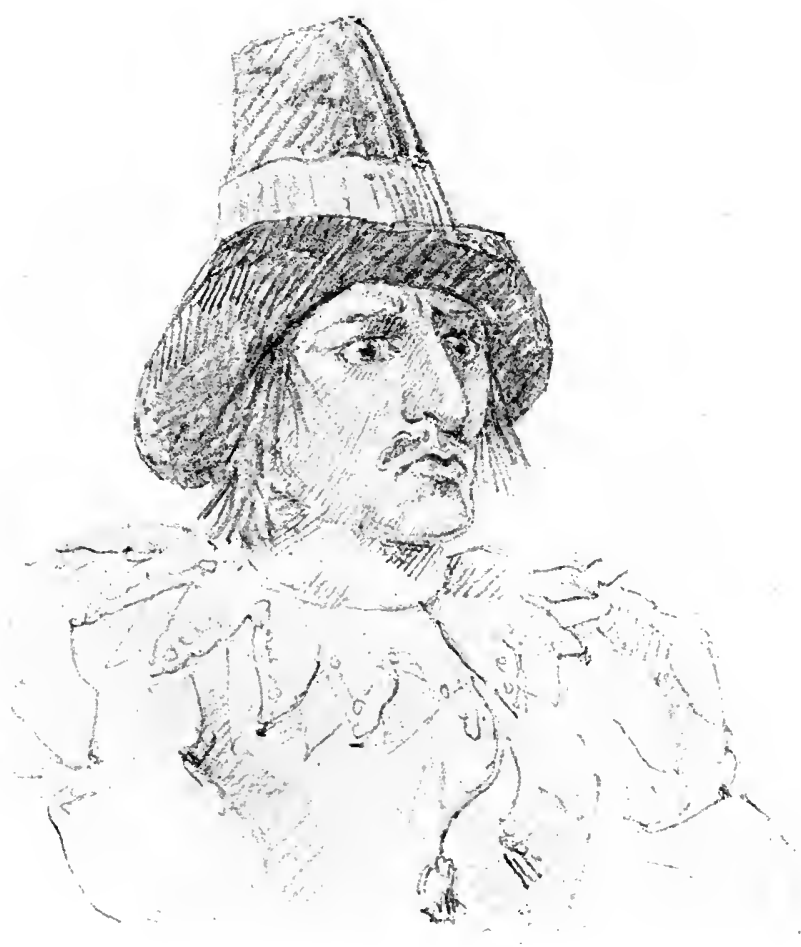



now belonging to the Historical Society, was thoroughly appreciated and in constant use."

The assembly room and library of which Mr. Latrobe speaks were erected in 1797, at the northeast corner of Fayette and Holliday Streets.

Rembrandt Peale (whose father, Charles Wilson Peale, was the greater artist) erected a building afterwards used as the City Hall on Holliday Street. When owned by Rembrandt Peale it was known as the Baltimore Museum. The museum was afterwards transferred to the corner of Baltimore and Calvert Streets, and purchased by P. T. Barnum in 1845; and here some of the leading actors and actresses of the day made their debut.

"Wealth had much less to do with social position then than it has now. In 1824 a salary of $\$ 3000$ per annum gave its possessor the reputation of being a rich man. The cashiers of great banks got no more. When Mr. Louis McLane was invited to take the presidency of the Baltimore and Ohio Railroad Co., he was offered $\$ 4000$, which was regarded as a very great salary, sufficiently large to tempt him to leave New York where he was president of the Morris Canal and a banking company. Few professional men made more. If people's means were moderate, their expenses were in proportion. A lady's silk dress could be obtained, trimmings and all, for twelve dollars. Eight yards of gros. de Naples were all that was required at one dollar a yard. If a merchant's wife, whose husband was in fair business, gave one hundred dollars for an India shawl, if it did not affect business it was a matter greatly talked about. There was a club composed of leading belles of the City, called the 'Cotton Cambric Society,' who rejoiced in not wearing silks at balls and parties, nor have I ever understood that they perilled the reputation of Baltimore for beauty on that account. 
"It was necessary to have the reputation for wealth in those days to justify keeping a carriage. Indeed, in 1824, I think there were not a dozen private carriages in Baltimore, not because of the excellency of the hacks, for they were worse than indifferent, but because the style of living was plainer, and that strife had not arisen in which victory constituted outdoing your neighbor in dress and equipage. In a word, society was on a simpler, easier and more natural footing than it afterwards became. Mothers and fathers still accompanied their children to balls and parties. Mature ladies still danced while daughters looked on. The cotillon ruled the day. An occasional whirl in what was called a 'Spanish Dance' was regarded as doubtful propriety, and when one couple more audacious than the rest went to the extreme of a regular waltz, mothers turned their backs in dismay, and melancholy were the predictions of the future."

Gallatin writes of New York, July 24, 1823:

"There are only about three private coaches in New York. No means of getting about. The streets are absolutely filthy . . . the horrible chewing of tobacco; the spitting-all too awful.

July 8th. We are in Baltimore, not quite so dirty as New York."

"At a dinner all the dishes were set on the table at the same time, and woe to the guest who had a popular dish before him. Courses were unheard of.

"Among my law labors was a case given to me by one of my fellow students in General Harper's office. It involved a good deal of delicate investigation and made a stir at the time. Mr. M. had married the daughter of his second wife by a former husband under circumstances that were not the most delicate, as it was reported; and her half brother, 
my fellow student, caused the husband to be prosecuted under an Act of Assembly of Maryland that imposed a penalty in such a case. My colleague was my after-lifelong friend, John P. Kennedy. We convicted $M$. and the result was a final separation. For this trial, which was had in Annapolis, I received one hundred dollars, and presented to my mother and sister silk dresses, and I record the fact that the dresses cost nine dollars each, being full patterns of gros de nap at one dollar per yard."

William Howard, who was one of the sons of John Eager Howard, was a client of Mr. Latrobe, and he has spoken of him elsewhere in his autobiography as being a man of genius. It is apparent that Mr. Latrobe did not by any means overestimate the value of his services, for I found among his papers the following addressed to him:-

" 1828

"Dear sir:-

"Enclosed is a check for one hundred dollars to you order. I am very sorry to differ with you in opinion at any time, but in the present case, from the trouble I have given you and am now giving you, I must take the liberty of saying that the fee you mention is by no means an adequate one.

Yours truly,

WiLLIAM Howard."

"There was Robert Oliver, the leading merchant of this City and a noble old gentleman, upwards of six feet in height, a powerfully built man, erect as an Indian, with handsome features, a florid complexion, and the very image of health and strength at three score and ten. His hair was white and thin, his grey eyes keen, and with a dash of merriment in them. Splendid horseman, and the leader 
always in the hunt. There was something in the tone of his voice that.inspired you with confidence in this giant of a man. He gave me my first lesson in the importance of punctuality at a dinner party, as he announced in his merry manner, when he chose to be merry-none more sothat I was ten minutes past the hour. At twenty, one submits to rebukes on such occasions, as well as deserves them. There is not one merchant $I$ have known since Mr. Oliver's day that had his presence, his port, and his power-no, not one."

Robert Oliver of Harewood, described by Mr. Latrobe, was deeply interested in agriculture, besides being one of the leading merchants of Baltimore. In a book published in 1908, "Coke of Norfolk," we have a record of his having visited at Holkham, the country seat of Thomas William Coke, first Earl of Leicester, at Holkham.

"Mr. Oliver," writes a common acquaintance, "often exclaims that his visit to you alone was worth the voyage across the Atlantic. Mr. Oliver has enlarged and improved his system of farming since his return, no doubt to imitate your great example, so that he is now considered the Coke of Maryland."

Coke was a strong friend of his trans-Atlantic cousins. In the House of Commons he was a friend of Fox, and his house was always opened to visitors from America. Among other names registered there we find Richard Caton, Robert Patterson, whose wife was Mary Caton, and many other Americans. In a public speech he stated that the hands of George III were red with the blood of English patriots of America. This speech deprived him of an earldom; for George IV said he would not give an earldom to a man who called his father a murderer. Coke did not come into the earldom until after the death of George IV. He had 
no son by his first wife, and the failure of male heirs would have caused the title to fall to his nephew who was a dissipated person. After he had been a widower for a number of years he became anxious that his nephew should marry in order to perpetuate the name and title in the family. He was then sixty-nine years of age, a master of the hounds, and a splendid figure of a man. He called on Lady Keppel, a young woman of twenty years, and urged her to marry his nephew. The old story of John Alden and Priscilla was re-enacted. When the girl stated that if he asked her in his own behalf she would marry him, he adopted the suggestion and married her. He had four boys. When the news of the last arrival was received at the House of Lords, of which he was a member (he was then seventyeight years of age), the House arose, as he walked across the floor, and applauded.

In the Creevy Papers, 1768-1838, Volume II, folio 332, Creevy writes of a hunt led by Coke at eighty-five, his chief competitor being his son of fifteen-a remarkable case of vigor and vitality. At a public dinner in 1820, Coke said: "Every night during the American war did I drink the health of George Washington as the greatest man on earth." We presume this toast was drunk not as an excuse to take a drink, but as an evidence of his sympathy and interest in the American cause.

"Then there was Robert Gilmor, a very different sort of man. A merchant, too, but with great wealth derived from his father, who was another of the merchant princes of the olden day. But Mr. Gilmor's tastes were not counting-room ones. He loved art and science. A man much below the common size, stooping, walking apparently with difficulty at times when affected with asthma, to which he was subject. He was a refined and elegant gentleman, of 
polite manner, and many accomplishments. His home, besides being a picture gallery, was the home of elegant hospitality, and by none could the honours of such an establishment have been done with more effect than by his beautiful wife and himself. While he lived he was my kind and constant friend. Our tastes for art in common drew us together, and I was a constant visitor at his house. His portrait by Sir Thomas Lawrence is the best of that great painter's work in America. I ought to say male portrait, for the portrait of Lady Wellesley by the same artist is fully equal in its way. These were days when gentlemen prided themselves on their wines; nor was Mr. Gilmor without a cellar that warranted even a weakness in this respect. There was one thing in this connection, however, that he was particular about; and it was at his table I first learned the phrase, "Fill what you please, but drink what you fill." Between Mr. Gilmor and myself there was a strong mutual regard, which led me to dedicate to him 'Lucas' Progressive Drawing Book,' which, however inferior it would now appear, was at the time of its publication a work of some consequence and value of its class. To Mr. Gilmor, as one of the trustees of the Washington Monument, fell the arrangement of the inscriptions, and the preparation of them was one of the things in which, in consultation with him, 'I bore a hand.' This monument, begun in 1815 , languished for the want of funds until 1829, when it was completed with State money and a lottery.

"I soon found out that fashionable balls and parties and invitations to luxurious tables were not likely to advance one in my profession by adding to my list of clients; and that I must begin with a very different class of persons, if I wished to succeed as a lawyer. My political efforts did me some services, perhaps. I do not know whether I did 
not derive some advantage from being a member of a beneficial society, whose Treasurer was a devout member of church, but whose necessities required him to use some considerable amount of our funds. I think my military offices of Captain of the Chasseurs and Sharpshooters and Aide to the Major-General were important in multiplying acquaintances in the class apt to employ young men.

"There was an apprentices' library in those days in a room over the old Watch House, in Belvedere Street, which owed its origin and maintenance to a worthy gentleman named Roberts, who earned his bread in some capacity that afforded him just enough of that indispensable article and none to spare. Somehow I became acquainted with Mr. Roberts and agreed to deliver to his boys in the Library Room lectures on history and geography during the long winter evenings. This I did most faithfully, reading up for each evening's work and speaking from notes. This was an excellent school for me, in more ways than one. Every now and then today some gray headed old fellow claims acquaintance as one of my hearers half a century ago." (The manuscripts of these lectures delivered in 1824 are among the papers of Mr. Latrobe.)

"The Philokrean Society was still alive, and its annual oratory had been delivered successively by Mr. Steele, Mr. Tevis, Mr. Richardson, and David Stewart, all afterwards prominent lawyers, when the choice fell on me and and I held forth in the court room of the U. S. Court in the old Masonic Hall to an audience of the fashionable world, for we were simple folk in those days, and small matters attracted us. I mention the incident because it would seem from my education that I had at that time won a standing that was at least respectable among the young lawyers and students of my day. 
"General Harper died in the winter following Lafayette's visit. I was confined at home by indisposition when I heard of it. The last time I saw him alive was when he called to see me as I lay in bed, bringing me his pocket full of oranges. I see him now as he stood at the foot of the bed and talked to me so kindly. I loved him very dearly and mourned him truly. I followed him to his grave at "Oaklands," his country seat. I designed his monument, which was executed in Italy and is now in Greenmount, having been removed from "Oaklands" when the place passed out of the family. After his death I removed my office from the back room in Gay Street to the old Athenæum, afterwards burned down and rebuilt as the present 'Law Building' (now the 'Plaza'). I was admitted to practice in May, 1824, and removed to the Athenæum the following winter or early spring.

"As soon as I was admitted to the bar I tried, of course, to work for success, but I had many things to discourage me. I had not one single friend to push me forward. I had no acquaintance with the world of merchants, and even now I wonder how I got along at all. In one of my note books there are some comments made at the time, in which I speak of "Hope without success becoming changed into melancholy indifference." I have already stated that I kept a record of every fee I ever received in my life, from the lowestwhen a man named Wynds, dying of consumption and just able to creep about, employed me to make his will and offered me three dollars which I indignantly refused as below the minimum of five dollars, but which he left in silver half dollars at the corner of my table, saying he intended to die owing no man, and which, notwithstanding my disclaimer, I pocketed when he went away-up to the $\$ 60,000$ fee for five months work in Russia, besides all the 
expenses of my journey and residence in St. Petersburg. And had I this record before me a thousand things would be recalled that might afford material for my reminiscences.

"I think perhaps I owed a shove ahead professionally to a queer case, which at a later date was recalled to me by Dickens' novel of 'A Tale of Two Cities.'

"Aspirants for the laurels of the bar in those days usually sought the smallest sprigs in the City Court, where the late Judges Brice, McMechen and Worthington presided over the criminal trials, and where I among others used to take my seat. On one occasion a prisoner was put into the box charged with robbing an old lady, who had some small matters in the Lexington Market, of a few dollars in silver change. Judge Brice, when the man said he had no counsel, asked me to serve as such, and I accordingly consulted forthwith the client thus thrown upon me. $\mathrm{He}$ had no other defense than his own persistent denial. The witness was the market woman who described the theft as having been committed in the dark of the evening, and identified the thief by a remarkable scar which traversed his face diagonally from one side of his temple to the opposite side of his chin, creasing his nose heavily en route. The man was a light mulatto, and the scar had healed of a bluish white. The identification was so positive and the proof was so strong that there was apparently no hope of my success, when the court took its usual recess of ten minutes. I left the court room and returning to the Hall saw to my surprise my client in freedom, talking very unconcernedly to another person. I asked him how he had escaped. He looked astonished and said he had never been in court. Yet, there was the man I was defending to all appearances. The same stature, the same complexion and the same remarkable scar. I persuaded him to return with 
me and placing him in the box alongside of the prisoner recalled the market woman and asked which of the men had robbed her. She looked at them in amazement, exclaiming-'Good Lord, was there ever the like.' As she could not say which of the two had taken her money, the identity was not found, and my client was acquitted, the Attorney General directing the jury to find their verdict of 'not guilty.'

"The oddity of the case attracted some little notice and the late Elias Glenn, who was then prosecuting for the State in the same court, asked me to join him in prosecuting a man named McCullough, for passing counterfeit money, both notes and silver. Mr. Compher had brought a wagon and team of six horses to Baltimore, where he had some horse trade with this man McCullough who kept a feed store in Franklin Street. McCullough was arrested for passing counterfeit money, which he swore he had received from the wagoner, against whom he procured a warrant and, following him a day or so afterwards, overtook him at Westminster, where his wagon was seized and counterfeit half dollars and notes of the same description that McCullough had received were found in the front portion. At McCullough's trial all this was sworn to and when the case was at an end for the day, which luckily was Saturday, McCullough's acquittal, which involved the conviction of Compher, seemed certain. But soon after the adjournment of the court I was told, or rather I learned in a very roundabout way and through a very odd channel, that a hackman named Fresh could give me important information if he would. Finding Fresh with some difficulty I learned that he had driven McCullough to Westminster on the night of the day on which he had been arrested on the charge of passing counterfeit money and released on bail. It was 
dark by the time I had closed my interview with the hackman whom I dispatched forthwith to Westminster, taking with him Compher's brother, a very intelligent person, with instructions to find out what he could; and if witnesses could be procured, to bring them back in Fresh's hack to Baltimore and to my office early on Monday morning. This visit was pregnant with results. It so happened that a butcher who lived hard by the wagon house, where the wagoner's brother had halted with his team on reaching the village, had been called out of his house at day break, and had seen a carriage coming from the direction of Baltimore, drive around the wagon, stopping in front of it long enough to permit a stout man in a plaid cloak to descend, mount the wagon pole, and bury his hand and arm in the fore part of the vehicle. The hack had then been driven to the cabin, where its single occupant got out and warmed himself, giving out that he had come from the west and was going to Baltimore. Another witness had noticed the tracks of the hack on a light snow that had fallen during the night. Now, the officers who had followed Compher's wagon on McCullough's information had found in the front of it a tin box containing counterfeit notes and half dollars, on the strength of which finding he had been arrested. It so happened that McCullough kept a feed store, had a plaid cloak, and dealt in such cut straw as the half dollars were packed in, and subscribed to the Federal Gazette, in which the bank notes were wrapped. The hackman had given me the information that led to all this, upon the express condition that he should not be summoned. But there was testimony enough without him.

"Mr. Glenn, who on Saturday had determined as prosecuting attorney to abandon the case, agreed to go on with it on Monday, and the day was occupied in the exami- 
nation of the witnesses. Our opponent was Mr. Thomas Jennings, the ablest criminal lawyer at the bar, and he did his best for McCullough, but the circumstantial evidence was overwhelming. He was convicted and sent to the penitentiary. The trial took place on a day in July, and I was to speak after the lights were lit in the court room. I was so interested, and it was so hot, that thoughtless of all etiquette I pulled off my coat, and put on a white linen roundabout. The associate Justices, Worthington and McMechen, were on the point of reproving me, when Judge Brice intervened in my behalf. 'Let him alone,' he said, 'He's brim full, and it may break him down now and forever, if we scold him.' This case made me many friends, and besides the $\$ 30$ that Compher paid me brought me some Criminal Court success.

"Things slip from my recollection while I am writing, or rather my mind skips them over, obliging me to go back to them when they afterwards occur to me. It is a lawyer's life that I am writing, and so my early practice claims a place upon my pages. When General Harper died he was engaged as counsel for Mr. Nicholas M. Bosley, a very wealthy merchant, one whose ships had been libelled for seaman's wages by a mate whose connections made the case one of feeling. As a compliment to General Harper's memory, Mr. Bosley, to whom I had as a student taken messages on law matters from the General, told me to consider myself in the place of my late master and as junior counsel to Mr. Taney, who had been employed to succeed him. Of course, I put "my best foot foremost," and read all that could be found on the subject and prepared a brief. Mr. Taney asked to see it, spoke kindly of it, and then saying that it was only fair I should see his, handed it to me. When I proposed to return it, 'Not at all,' he said, 'I place 
it at your disposal. If you can make use of it, I shall be all the better pleased; though do not let it interfere with your own line of argument.' When I said something about availing of his labors, he replied, 'Never mind that, I shall no doubt find something to say in reply to the other side, some pickings and stealings.' And this was Mr. Taney's way invariably. In numerous cases afterwards, he was the same liberal colleague, very different in this respect from Mr. Wirt, who kept his own counsel, and contributed little in consultation with his colleague. It was intensely hot weather when we tried the case of Smith v. Bosley in the District Court of the United States, and I was in a profuse perspiration while I spoke. When Mr. Wirt rose to reply, following Mr. Taney and myself, after some complimentary remarks he continued, 'And may it please your Honor, it only remains for me to say in this connection, that I sincerely hope that the pearly drops that have fallen from my young friend's brow may be regarded by his client as pearls of great price, and paid for accordingly.' Mr. Wirt was at this time in the full vigor of mind and body, a tall, portly, erect, and pale visaged man, with noble features and majestic carriage, the sweetness of whose voice was only equalled by the charm of his smile. Few persons that I have ever met with had this same presence, and in social life his manner was the perfection of refinement. At the bar I sometimes thought he was irritable; but this was an exception to his general manner, which was eminently courteous to his professional brethren. Mr. Wirt had a strong sense of the ludicrous, and was one of the best raconteurs I ever listened to.

"I was never satisfied that Mr. Wirt was a profound lawyer. But he was a most laborious one. The trouble he took in the preparation of his part of a case was wonder- 
ful. In the great case of the Canal and R. R. 4 Gill and J. 1, I was junior counsel with Mr. Taney and Reverdy Johnson, Mr. Wirt and Mr. Walter Jones on the other side. From the window of my room at Annapolis I could look into Mr. Wirt's room across the yard of the hotel, and at two o'clock in the morning I have seen him on a hot summer night, in his shirt sleeves, busily engaged in writing, where I had seen him at the same work since supper time. He had, when he spoke, not only written out his whole argument, but he had rewritten it, that he might improve and condense it. I know that this was so, for he showed me two manuscripts. I have no doubt that in a great cause Mr. Wirt's spoken argument would have been almost verbatim his written one. But it is an error to suppose, as I have heard it said, that he was not a fluent extemporaneous speaker. I have fancied that he was not sure of himself as a lawyer without preparation as I have described, and did not trust himself to wander from the manuscript, of which he had made sure beforehand.

"Between Mr. Taney and Mr. Wirt there was the greatest possible difference in manner and appearance. Portly and erect, with what must have been a handsome figure before he assumed Aldermanic proportions, Mr. Wirt, when he rose to address a jury, impressed them with the idea of perfect health, whose only drawback was suggested by the pallor of his skin. His opening sentences were always accompanied with a pleasant smile, and it was apparent that he desired to establish in the beginning personal relations with those to whom he was speaking. His voice I have already described. When Mr. Taney rose to speak, you saw a tall, square shouldered man, flat breasted in a degree to be remarked upon, with a stoop that made his snoulders even more prominent, a face without one good 
feature, a mouth unusually large, in which were discolored and irregular teeth, the gums of which were visible when he smiled, dressed always in black, his clothes sitting ill upon him, his hands spare with projecting veins - in a word, a gaunt, ungainly man. His voice, too, was hollow, as the voice of one who was consumptive. And yet, when he began to speak, you never thought of his personal appearance, so clear, so simple, so admirably arranged, were his low voiced words. He used no gestures. He used even emphasis but sparely. There was an air of so much sincerity in all he said that it was next to impossible to believe he could be wrong. Not a redundant syllable, not a phrase repeated, and, to repeat, so exquisitely simple. I remember once hearing him in a complicated case, and, when he sat down, fancying that I in my first year's practice could have done as well, so simple had become complications in his hands.

"In connection with Mr. Taney's style of address, a story current at the bar was that Mr. Pinkney had said when speaking of it, ' $I$ can answer his argument, I am not afraid of his logic, but that infernal apostolic manner of his there is no replying to." "

In after years Mr. Latrobe and Mr. Taney were next door neighbors. Mr. Latrobe owned and lived in the house on the N. E. corner of St. Paul and Lexington Street. Mr. Taney owned and lived in the house next door. In extending the back of his building, Mr. Taney claimed Mr. Latrobe had trespassed on his lot, and, notwithstanding his apostolic manner, wrote letters with little of the apostolic spirit in them. Reverdy Johnson was agreed upon as arbitrator and established the dividing line by a deed and opinion recorded in 1855 E. D. No. 94, folio 494, \&c., and there was peace between the houses of Latrobe and Taney. 
"Mr. Pinkney I never saw. He died the year I returned from West Point to Baltimore. Luther Martin I saw, but it was an affecting sight. He was in his dotage. He used to come into the Courts when they were in session, an aged man, decrepit in his movements, dressed in the style of the past generation, with knee breeches and buckles in his shoes, a long flapped white waistcoat, a blue coat and gilt buttons, with ruffles at his wrist and on the bosom of his shirt. On one occasion he came into the Circuit Court of the United States eating a star ginger bread as a child would do, and smiling with a vacant lack lustre eye as the members of the bar made way for him."

The most remarkable piece of illegal Legislation was enacted by the Maryland Legislature by which a tax of five dollars per annum was imposed on each lawyer in the State for the benefit of Luther Martin, demonstrative of the high opinion of his great gifts, destroyed by intemperance. Luther Martin was one of the most celebrated lawyers in Maryland. He was one of the delegates representing Maryland in the convention held in 1787 in Philadelphia, which framed the Federal Constitution. Martin took the position that the appointment of these delegates was to amend the Articles of Confederation, and not to form a nation. He voted "no" on all propositions which in his opinion destroyed or interfered with the right of the State. Upon returning to Maryland, Luther Martin said, "We had not been sent to form a Government over the inhabitants of America, considered as individuals. - The system of government we were intending to prepare was a Government of thirteen States." (Gay's Life of Madison, pages 92 and 93.)

After the Constitution was adopted, Martin defended it vigorously. He successfully defended Judge Chase of 
I.OUISVILLE (UPPER LANDING), 1832

Pained by John H. B. Latrobe 


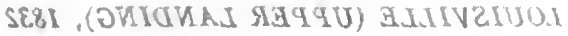

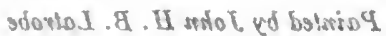




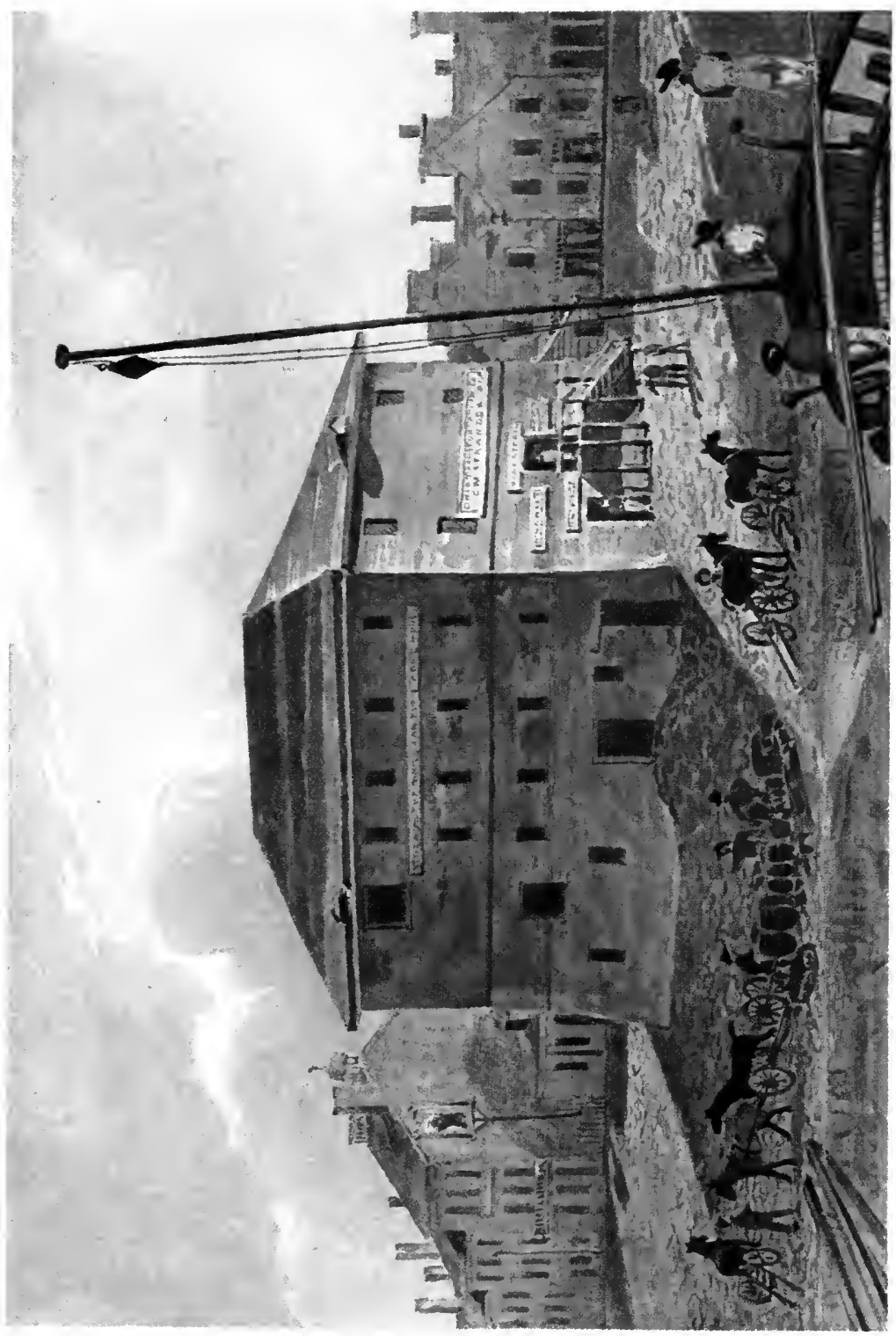



the Supreme Court when he was impeached. He was one of the counsel of Aaron Burr, and, after he had become an imbecile from drink, he passed his last years at Aaron Burr's house, dying at the age of eighty-two. (See a pamphlet of the Maryland Historical Society, called "Luther Martin, The Federal Bulldog.")

Perhaps the designation of the "Federal Bull Dog," applied to Luther Martin, was due somewhat to his fighting proclivities. In the case of Martin v. State, 1st, H. \& J. 420, there is the following statement:

"That the defendant Martin had been presented in Dorchester County Court in one hundred and one cases for assault and battery . . . . That the defendant appeared, confessed the charges, and was fined in each case."

In this case, Pinkney, representing the State, speaking of Martin says:

"He would not long trespass on the patience of the Court which had already been so severely taxed by the long argument of the Attorney General whose speech was distinguished for these two qualities, that of being remarkably redundant and remarkably deficient . . . He acquits the attorney-general of all criminal motives. No man is better acquainted with his generosity and utter negligence in pecuniary concerns."

Here the question was the collection of a fee as Attorney General by Martin, to which under the law he was not entitled.

"Then there was General Winder, a leader of the Bar of Baltimore, who, laying aside the toga for the sword, commanded the Americans at the Battle of Bladensburg.*

* The disaster is described in an article in the Maryland Historical Magazine, Vol. 1, Nos. 2 and 3. 
A quick, impulsive speaker, of soldierly abruptness, a well read lawyer, and a kind and genial gentleman. He was a member of the Delphian Club, and rejoiced, as I have already mentioned, in the cognomen of Opechancanough Sulikonqui.

"John Purviance was a prominent practitioner in those days, a learned man, a man of precedents, of untiring labor, with no pretensions as a speaker, but so honored for his honest truthfulness as to have collected around him as valuable a clientele as was possessed by any other one of the profession."

Jonathan Meredith, who showed his generosity to Mr. Latrobe as later stated, is thus described by him:

"Jonathan Meredith who to the manner of a man of the world joined the knowledge which placed him high in the ranks of his profession; remarkable for careful preparation and studied delivery, few men addressed the bench, who received more respectful attention. When he had completed the investigation of a case, it could fairly be assumed that nothing more was to be found in the books regarding it.

"Then, unlike all others, a man sui generis, was John Glenn, whose boundless energy and resistless will and untiring devotion to his clients' interests placed him from the beginning preeminently before the public, and whose practical ability secured for him what was probably the most profitable practice at the Bar in Baltimore. Too actively engaged in all branches of his profession to prepare his cases with the diligence that characterized others, he supplied the want of it with quickness that seemed like intuition. At the time I speak of, he was the readiest and, perhaps, the most available lawyer at the Bar. In every particular he was essentially a business man, and as such the public so appreciated him. 
"Associated with Mr. Glenn in many of his greatest cases was Charles Mitchell, than whom there was perhaps no better lawyer. But he was not true to himself, and while his abilities were universally acknowledged they never profited him as they should have done. Rarely endowed in many ways, of an excellent presence, and an emphatic and deliberate speaker, he made his mark whenever he addressed himself to the argument of a cause. Those who best appreciated him were his brethren of the Bar.

"There was George Richardson of a date following those just named; one of the closest reasoners in the profession. Intensely earnest and emphatic, McMahonwhose initials it is unnecessary to give, for there was but one McMahon-historian of Maryland and a profound and able lawyer, searching in investigation, who discussed no subject that he did not exhaust, lucid in argument, vehement and eloquent, there can be no question that as an orator he was primus inter pares among his brethren.

"William Schley, with the courtly manner of the old school of the profession, a thorough lawyer, ingenious and acute, was preeminent among the lawyers of the Bar.

"John Nelson, than whom the profession contained no abler lawyer, with the rarest faculty of condensation, saying everything in the best manner, and leaving nothing unsaid that was germane to his cause.

"Grafton Dulany, whose name cannot be omitted when enumerating the worthy, the able and the trusty.

"William Gwynn, editor, epigrammatist, and one of the most reliable of counsellors of his day, the contemporary of Pinkney, Taney, Wirt and Winder, surviving all of them, one of the kindest and most benevolent of men, loved by all who knew him, and fading from view as old age found him left behind in more active contests than those which 
he had been accustomed to. His portrait looks down from the walls of the Superior Court Room upon the scene in which he was at one time an honored actor.

"The last in this enumeration of those who figured in the Bar of Baltimore more than fifty years ago is one who, surviving his fellows, almost recently passed away-Reverdy Johnson, statesman, diplomatist and Jawyer. Few men have been more preeminently before the public in the Senate and at the Bar, and yet, with all his distinction, natural and unaffected as a child. Of all his contemporaries, not one is more affectionately remembered.

"Not long after my first marriage the Barnum and Gilmor divorce case created a great excitement in Baltimore, and I was engaged as junior counsel for the lady. In those days the legislature alone had the power to grant divorces, and the station in life of one of the parties in this instance and the wealth of both of them involved apparently the legislature itself in the excitement. For motives that I never could understand the gentleman applied for the divorce on the grounds of the adultery of his wife, and the application was resisted with all the vehemence proper to a conviction of the utter falsity of the charge. Mr. Taney and Mr. Jonathan Meredith were my seniors and the lady was our client. We were successful, and I was fortunate enough to satisfy my associates; and the divorce case gave me a further lift in the profession.

"In this case some of the aspirations which led me to embrace the profession of the law were realized to a greater degree than they have ever been since. The lady was handsome; she had suffered grievous wrong; more than one beautiful woman appeared as a witness and there was a 'concatenation' of circumstances that afforded a wide field for ingenious discussion on both sides. It was deemed 
proper by my colleagues that our client should tell her own story, and I was to obtain it from her lips and put it upon paper. I suppose I made the most of it, and when I read it to Mr. Taney and Mr. Meredith, while they expressed themselves satisfied with the way in which the facts were put together, Mr. Taney said, "Are you quite sure, Brother Latrobe, that the Committee on Divorces will not suspect your handiwork as they listen to the production? Suppose now that, without altering an idea or changing the position of a sentence, you try how simply you can tell the story. The facts, you know, are all we want, and these in the fewest words." Whereupon I went over my manuscript, and merely by leaving out superfluous words put it into a shape that passed muster with my colleagues without further change. But I had a wonderful number of words to give the go-by to. My Falstaff shrivelled into the dimensions of Prince Hal. I mention this now that you may benefit by the rule $I$ then adopted in every paper of importance afterwards prepared. I wrote it with the rapidity that the thought of the moment called for. I then struck out every word that could be dispensed with. I do not know how it is with others; but with me, when I plan my phrase as my pen presses the paper, thoughts in nine cases out of ten run ahead of me and escape, or if caught and dragged back are in my experience awkwardly or clumsily expressed.

The divorce case gave me the largest fee I had yet received. I had a retainer of $\$ 100$, and was to have had $\$ 1000$ when all was over. I only received $\$ 900$, however, the retainer being deducted, but $\$ 900$ was a young fortune in those days, and I was too well pleased to get it, to dispute the propriety of the subtraction.

The following is a copy of the letter enclosing the fee referred to. 
Dear Sir:

"At the request of my niece Mrs. Sarah Gilmor and the directions of her trustees (Mrs. Wm. Gilmor and Mr. B. C. Howard), I send you enclosed a check for 800 D. designed to compensate you in some degree for professional services on the late occasion at Annapolis.

"But there still remains a debt due from her and all the members of our family for the friendly interest you took in her case, and the zeal and exertion used to vindicate her fair fame, and release her from the unhappy thraldom in which she was bound, which we can never sufficiently repay, but which we must gratefully acknowledge, and no one more so than,

\section{My dear Sir,}

Yours very truly,

ROBERT GILMOR."*

Among the cases of domestic infelicity, I think the following, perhaps, is the most acute that ever came to my knowledge. As the case passed from Mr. Latrobe's to my office, I here insert it.

As a young lawyer, anxious for business, I sat at my office desk. A woman of a not very attractive countenance entered my door, and announced the object of her visit, stating that she had called upon Mr. Latrobe and had been referred to me.

She lived on Davis Street, a short street parallel with Calvert Street, entering Lexington Street, nearly opposite the Post Office. The legend is that this part of Baltimore was in olden times called "The Meadows," and a Mrs.

* In Maryland the right to grant divorces was exclusively with General Assembly until 1841 when the Equity Courts had concurrent jurisdiction. The constitution of 1851 divested the Legislature of the power to grant divorces. 
Davis, a woman of questionable repute, had an establishment, corresponding with her character, in this locality. In honor of her Davis Street received its name and, as far as I could ascertain, her reputation.

At least, Mrs. Davis (for so I shall name her) was a very worthy resident of such a locality. She told me that her husband had brought a suit against her for divorce; that she would be glad to be shut of him, but that she had a daughter, and she understood that if she made no defense the daughter might be taken from her.

I told her that this was possible. She then said she wished to have the suit resisted. I asked her whether she was guilty of the offenses charged. She said she was, but that her husband was equally bad. I then asked her where her husband was living, and she said with her at the Davis Street house, where they had a saloon. I then explained that her husband continuing to live with her condoned or forgave the offense, and that I would file affidavits, and have the case dismissed. This I did, and the Court directed the husband to pay me a fee of $\$ 75.00$ which he did not, and I had naught for my work and pigeon-holed the case among the cases where the compensation was nil.

Some months afterwards Mrs. Davis reappeared in my office and explained the purport of her visit to be that she wished advice. During her absence her husband would take her clothes out of the bureau or wardrobe and tear them into shreds, and pile them in that condition in the centre of the floor. She would be washing her face, and he would seize the basin, and in other ways make himself "pleasant." She was physically his superior, and goaded to desperation would attack him. The result would be that she would be arrested and locked up for assault.

I told her that there was nothing to do but to treat him 
in the same way, until he would resist it and strike her, and then to issue a warrant and have him arrested, and to take advantage of his absence to leave the place, taking her daughter and belongings with her.

I heard nothing of her for six months, when she again visited me. She said she had done what I told her, but had not left the place when he was locked up, and that he had behaved so much better for sometime, that she thought it would be alright; but that he was now resuming his old practices, and she wanted to know what she could do.

Then I told her I thought of issuing a writ to seize her husband's property in the saloon to pay my fee of $\$ 75$ which he had been directed to pay by the Court, but had not paid, and I would write her a letter to that effect, and perhaps if he knew of it, he might leave. I wrote her a letter, and a few days afterwards she came in delighted. She explained that she received the letter and put it in the bosom of her dress, taking care to have a portion of the letter exposed. Her husband, when she was behind the bar, asked what that was, and demanded that she give it up. She declined, and there was a struggle; but he got the letter. He then ordered two furniture wagons, took most of the furniture and departed. I congratulated her upon the success of our efforts, and considered the case finally closed.

Not so; for about three or four weeks afterwards Mrs. Davis called, and wanted to know if in the event of her husband's death she would be entitled to his body. I told her that the question of property in a dead human body had been one of much discussion. I recollected reading in one of Lever's novels that the coffin containing the body of a supposed debtor was seized and found to be loaded with stones; but I confessed to her that I was not prepared to answer this question. I said, however, "I cannot under- 
stand why you should be concerned about your husband's body. You had a good deal of trouble in getting rid of him when he was alive. Why should you want him after he is dead?"

She then explained that he was living with his sister, and supposed to be dying; that he had been living with one lung for many years, and was extremely thin; that she was informed that the doctors placed a particular value upon the cadaver of an emaciated person, and that she understood she could probably sell the body for $\$ 100$.

It is unnecessary to say that I took no further interest in this case.

To continue Mr. Latrobe's diary:

"I have spoken of my first jury case. My first case before the Court of Appeals I shall never forget. Mr. Charles F. Mayer gave me the opportunity. Mr. Meredith opened the argument for the appellant and like a goose I attempted to follow in his track. I had not spoken half an hour before I began to wish myself back in Baltimore. Big drops rolled down my forehead (it was July.2, 1827). The five judges of the Court of Appeals became fifteen, and I was on the point of taking my seat in utter confusion, when that most estimable gentleman and able lawyer, Chief Justice John Buchanan, took pity on me, and interrupting some incoherent nonsense, said the Court would take its usual recess, after which they would be happy to hear the remainder of my argument. Mr. Meredith came up to me at once, and gave me good counsel. 'Speak from your brief, man, never mind me; you will hit me as you go along, and do not make a ninny of yourself by attempting to track me step by step.' I followed the advice and got through without disgracing myself. I do not know that I am dis- 
posed to be much of a laudator temporis acti, but when I look back to the Court of Appeals of the day I refer to, it seems to me that we have not improved by the changes which made the people the electors of the judges.

"I have a record of all my fees. 'Richard Caton, a deed, $\$ 5.00$,' is at the head of the list. The deed was for Charles Carroll of Carrollton. It was drawn and paid for while I was yet a student. And this reminds me of all I owe to the Carroll family; and no memoranda of my life would be complete that omitted a mention of them.

"The family consisted in 1832 of the following:

Charles Carroll of Carrollton, born in 1737 at Annapolis, son of Charles Carroll who was a son of David Carroll of King's County, Ireland, educated by the Jesuits at St. Omer, sent to Rheims then to Bruges to study law, and in 1757 took apartments in the Temple to complete his study of law. In 1764 he returned to Annapolis, and married Miss May Darnell in 1768. In December 1776 he was elected to the Senate of Maryland; in 1788 to Senate of United States. In 1807 he retired from politics.

"Mr. and Mrs. Richard Caton, the latter being Mr. Carroll's eldest daughter, and Mr. and Mrs. MacTavish, Mrs. MacTavish being Mrs. Caton's youngest daughter, lived in Second Street "just beyond the bridge," as the phrase ran.

"Mrs General Harper, Mr. Carroll's second daughter, lived in Gay Street, as already said, opposite the Exchange. Mr. Charles Carroll of "Homewood," heretofore described, resided with his sister, Mrs. Harper, during the winter.

"The intimacy of my father and mother in years past with the Carroll family, and my almost domestication in General Harper's family, placed me on the footing of a relative, rather than a stranger in both families. 
"When I first saw Mr. Carroll, he was in his eighty-sixth year. He lived ten years longer. Below the middle size, weak and emaciated, his voice thin and feeble, writing with a trembling hand, but always signing his name "Charles Carroll of Carrollton," you saw in him, as he approached to greet you, a very feeble and aged man. His hair was scant and white and silky, and his eyes especially were suggestive of great age. His complexion, however, was healthy, and tremulous as were his movements, theywere quick. His hearing was but little affected by his years and he listened with apparent eagerness to all that was said in his presence. His dress was the knee breeches of the old school, when I first recollect him, his waistcoat as long as we see in oldtime pictures, and I never saw him except in a loose roquelaure, something between a dressing gown and a frock coat. His manners were charming, his countenance pleasant and sprightly, and as one looked at $\mathrm{Mr}$. Carroll, one saw a shadow from past days, when manner was cultivated as essential to a gentleman.

"Without being close in his dealings-indeed, he was otherwise-Mr. Carroll was painfully accurate. On one occasion, when he settled some costs with me, he sent out of the house for change rather than overpay the bill by a few cents. He paid me my first $\$ 20$ fee in a check, which forty years afterwards was given to me by a gentleman who. had obtained it, somehow or other, with the Bank's can-cellation, and who thought I might wish to preserve it as. an autograph. This is especially what I desired, but, unfortunately, my pocket was picked while I was registering my name at Willard's, and the autograph went with the cash.

"Mr. Richard Caton was a tall, and when young, must have been an extremely handsome man, of graceful and 
refined manner and good conversational powers.* His wife, when I first knew her, was extremely plain, both in person and face, but of all the women I have ever met, she was the most charming. Her enunciation, her manners, her extraordinary tact, made you forget altogether that she was not as handsome as her daughter, Mrs. Patterson. She became blind many years before her death; but, to the very last, retained her wondrous charm of manner. Mrs. Royal thus describes Mrs. Caton:

Blackbook published in 1828, Madam Ann Royall.

Mrs. — , daughter of the venerable Carroll of Carrollton, is one of the most accomplished persons, perhaps, in the world. I do not say this because she patronized me, as it has been meanly remarked very often, for she did not, but this does not prevent me from paying her those encomiums she so richly deserves. She is well known to have a daughter as accomplished as herself, married to one of the first noblemen in England, the Marquis of Wellesley, but Mrs. ——, though a lady of very young appearance, is one of the old school. Baltimore will never produce such another female, though I suspect it has not the honor of her birth. She appears to be about sixty-five years of age; rather lusty, taller than the ordinary height, round face and very handsomely featured, but her manners were the most fascinating of any person I had ever known. Sweetness and grace mark her every word and gesture.

"But the queenliest woman of her day was Mrs. Robert Patterson, afterwards Marchioness of Wellesley. Tall, lithe and extremely graceful, her figure was perfect and her face one of the handsomest I have ever seen, even after

\footnotetext{
* Richard Caton, a young Englishman, came to Baltimore in 1785. He married Mary Carroll in 1786.
} 
she had passed her first youth. A dark brunette, with large and wondrous eyes of deep hazel, with hair that corresponded, every feature regular, and a mouth, the sweetness of whose expression was unequalled, with teeth faultless in form and color, and, with her head set on her sloping shoulders, as head was never set before, Mrs. Robert Patterson's beauty was a thing not to be forgotten. I owe her much, for it pleased her to advise me in regard to many things not learned at West Point connected with the ways of the world and the fashions of social life. She was a devout Catholic, too, and I sometimes thought that when she dilated on the characteristics and value of her church, I was in far greater danger of being converted by the privilege of listening to her than by the matter to which I listened. I was a boy of nineteen and Mrs. Patterson a woman of forty. I remember being seated alongside of Charles Harper at a dinner given to Sir Charles Bagot, the British Minister, at Mr. Caton's, and we both agreed that Mrs. Patterson, blazing with diamonds in all the magnificence of full dress, was the impersonation of all earthly beauty. After the death of Mr. Patterson, she went to England on a visit to her sister, Lady Harvey, afterwards Duchess of Leeds, and became the Marchioness of Wellesley, and for a season presided over the Vice-Regal Court in Dublin. It was to her that an English Bishop alluded when he toasted: 'Charles Carroll of Carrollton. In the land from which his father's father fled in fear, his daughter's daughter now reigns as queen.'

"Grace and elegance of manner distinguished all Mr. Carroll's children and grandchildren.

"I have lived to know five generations of this family: Charles Carroll of Carrollton, Charles Carroll of Homewood, Charles Carroll of the Manor, my fellow student in 
General Harper's office, John Carroll of the Manor, his son, who married Miss Phelps, and their children.

"I dwell upon my acquaintance with this very queenly lady, for it had a refining influence upon a young life, whose antecedents had wanted (for three or four years of the most impressible period of existence) just such an influence as was then exercised upon me. My father was a man whose deference to women was a part of his nature; so that some of my feeling for the sex came by inheritance. I had been fascinated, as a lad, by Maturins' Lady Montriver, in 'The Wild Irish Boy,' and by Miss Edgeworth's Lady Delacour. Mrs. Patterson, the Marchioness of Wellesley, illustrated the best qualities of them both, and I hold her memory in reverence at the end of half a century."

We find in the Creevy papers the following in reference to the visit of Miss Caton to her sister in England. In speaking of a party given by the Duke of Wellington, he says:

"Our conversation was interrupted by Mrs. Harvey and Miss Caton coming up to the Duke, with a Yankee General on their hands (a relative of theirs). He had married one of Charles Carroll of Carrollton's daughters; just arrived from America, General Goodloe Harper, whom they presented to the Duke. It is not amiss to say these sisters, Mrs. Harvey and Miss Caton, were not content with passing themselves off as tip top Yankees, but played much greater people than Lady C. Greville and Lady F. Cole to me who remember their grandfather, old Caton, a Captain of an Indiaman in Liverpool, their father an adventurer to America, and know their two aunts, one in Woodville, and another in Liverpool, who moved in about the third rate society at that time."

Later, when one of these ladies had become Lady Welles- 
ley (in the second volume, page 590), he speaks of her being introduced to King William. Someone asked, "Lady Wellesley, do you come from that part of America, where they 'guess' and where they 'calculate'?" King William answered, "Lady Wellesley comes from where they 'fascinate."

Creevy was a good deal of a gossip, and it is well to know how his views changed, after one of the Misses Caton became Lady Wellesley.

The following is from the Baltimore Sun, November 26, 1905:

"Mary Caton, the eldest daughter of Richard and Mary (Carroll) Caton, married, first, Robert Patterson, brother of Mme. Jerome Bonaparte, and second, the Marquis of Wellesley, Governor-General of India and Lord-Lieutenant of Ireland. Mary Caton, Marchioness of Wellesley, thus held many years ago the honors as first lady of India. She was also appointed first lady-in-waiting to Queen Adelaide, who with William IV ascended the British Throne in 1830. The kindly grandfather, Charles Carroll, sent his beautiful granddaughter a gift of $\$ 10,000$ when she assumed these court honors, and the bejeweled robe and gold crown worn by her as Lady-Lieutenant of Ireland were bequeathed to her sister, Emily Caton Mactavish, of Baltimore, and the crown is said to have been committed to the keeping of one of the Jesuit churches of Maryland. The Marchioness of Wellesley died at Hampton Court, near Richmond, on the Thames, in 1853."

Elizabeth Caton, second daughter of Richard and Mary (Carroll) Caton, married in 1836 Baron Stafford, of Costessy Hall, near Norwich, and became Lady Stafford.

Louisa Catherine Caton, third daughter of Richard and Mary (Carroll) Caton, married Colonel Sir Bathurst 
Harvey, Aide de camp to his Royal Highness the Prince Regent. The wedding was solemnized at the home of the Duke and Duchess of Wellington, and that illustrious soldier gave the bride in marriage. After the death of her first husband Louisa Catherine Caton married the Marquis of Carmarthen, later Duke of Leeds.

Emily Caton, fourth and youngest daughter of Richard and Mary (Carroll) Caton, remained with her grandfather, Charles Carroll of Carrollton, whose favorite granddaughter she was. She married John Lovet MacTavish, of Scotland. Charles Carroll of Carrollton gave his granddaughter part of Doughoregan Manor as a wedding present, which was afterwards called "Folly Hall," from an estate owned by the MacTavish family in Scotland. She was the only one of Richard Caton's daughters who had children. Her son, Charles Carroll MacTavish married Marcella Scott, daughter of General Winfield Scott, and their living children are: Maris Mayo MacTavish, who is a nun in Belgium; Emily MacTavish, who is also a nun in the Convent of Mount de Sales, near Catonsville; Charles Carroll MacTavish, who lives abroad; and Miss Virginia MacTavish, who also resides abroad. The Catonsville estate was divided in 1857 among the Marchioness of Wellesley, Lady Stafford's estate, the Duchess of Leeds and Emily Caton MacTavish.

Before closing this chapter, I shall add a description of a Fancy Ball in Baltimore in 1829 at which Mr. Latrobe figured as Don Quixote.

\section{A FANCY BALL IN BALTIMORE 1829}

An extract from a letter written by Julia Latrobe to her brother Benjamin dated February 27, 1829:-

"Last night was the eventful night of the Fancy Ball, and as I have nothing better to amuse you with, I will 
e'en relate some of the features of this important affair. John wrote to you that he was going as Don Quixote, and never since the days of Cervantes did a better representative of the knight of the Rueful Countenance appear. His armor was perfect in all its parts, and looked like polished silver, and he made himself the express image of the man in the tin clothes. A copper basin of pasteboard covered his head. He wore a long nose, moustachioes and beard (pulled from the buffalo hide Frisbie had slept on); and a shield and spear completed the costume. He had his wedding pants altered tight to his shape and wore them under his armor.

"But Sancho-I despair of conveying an idea of his excellence, he looked the character so well. He wore pink stockinettes to about half way up his legs, when he had short velvet breeches slashed with pink, an olive doublet, slashed sleeves, pointed collar and cuffs, basket hilted sword, flat velvet cap, and a wallet. In this style, he was only a little squat fellow. He came here before the Ball and rehearsed. I said 'What have you in your wallet?' 'A slice of cheese, an onion, and a bottle of Fiery Brass,' he replied, producing a phial from which he occasionally dabbed his beard to make it stick. Had you seen the pair you would have almost expired with laughter. And then, to see John go up stairs-it would have made a tiger titter. It was decided that his was the best costume in the room. He supported it admirably and never smiled. Sancho assisted him, and said 'your worship, \&c. \&c.,' and repeated proverbs by the dozen. About twelve o'clock John changed his dress to that of Quentin Durward, leaving the armor on the arms and legs, and putting on a blue frock trimmed with silver fringe, a white satin cross on the breast and silver cord and tassels, \&c., from his uniform; a Scotch cap with two white 
plumes of mine, a brilliant ornament and a lace ruff, made, altogether, a brilliant dress. Barney (Sancho) changed also to the most inimitable Chippewa you ever saw. Now for Margaret. She was dressed as a Peruvian Princess, and looked splendid. She wore over satin a gold lama dress, embroidered to the knees and then striped up with bands of gold to the waist. These bands at the knees were finished by scarlet roses of gauze. A scarlet satin bodice, richly spangled gauze sleeves and bracelets of coral and gold alternately to the elbow, and a profusion of coral chains hanging from the throat to the waist. A coronet of gold with fifteen scarlet and white feathers and a gauze veil richly spangled and trimmed with gold fringe fell from the back of the head. Sandals, laced with scarlet ribbons, spangled. (Here there is a marginal sketch.) This will give you some idea of it. This dress was thought very elegant and was really very rich; and the best of it was that she had almost all the materials, and borrowed from her sisters the rest and wore my coral. M. chaperoned Alison who looked very lovely as a Scotch girl. Charles Harper went as Selim in a Turkish dress; his wife as a Polish lady. Tom Oliver was a Janizary, his wife Margaret of Navarre. R. B. Magruder as Prior Aymer, Cruse and Kennedy as palmers from the Holy Land-admirable, it is said. Gibbes as a courtier at the last Coronation-magnificent. Frick, (who with John were the two best) as a Dutch Burgomaster. Olivia Donaldson as Rosina. Madame Vallenilla as a Turkish lady; Mrs. Skinner, ditto. Skinner, a Spanish nobleman. Lawyer Finley and Tom Meredith as Kentucky hunters-horrid, \&c. \&c. \&c. At 10 o'clock a rattle was sprung and George Howard came in as a watchman. Tom Adair and young Etting as ballad singers scraping an old fiddle and singing,-very funny; and one man as the Amer- 
ican flag; no one yet knows who he was. Of course there was a good deal of fun from people choosing unsuitable characters; and there were some droll mistakes, \&c., \&c. John had to keep poking up his nose, to keep it on, and, under pretence of taking some balsam, apply the gum to his moustache. Charles Harper came up to Margaret with his moustachio on his cheek, having waltzed it nearly off; for waltzing is all the go now. Do you remember Salmagundi's account of the waltz? But, indeed, my dear Ben, people are growing more and more used to all sorts of things, and all sorts of sights. The Vestris is here with her husband and Mademoiselle Rosalie, and John and M. went to see them at the theatre. Imagine it, they had nothing but flesh colored inexpressibles, and a gauze petticoat reaching to the knee with nothing under it; and as they spun around on one leg, in this way (a marginal sketch), what became of the petticoat? I am so glad that I did not go, I could spin around on one leg for very joy."

\section{"Baltimore, February 27th, 1886.}

"Of all this merry company, Madame Vallenilla Alison (now Mrs. S. Lawrence) and myself are, today, the only ones alive, I believe. The writer of the letter, my very dear sister, as bright as ever, but on earth there is not now our dear brother Ben.

\section{NOTES}

"My armor was made of pasteboard by myself after drawings; was covered with tinfoil, and was rather clever, and, in those days of comparative simplicity, was wonderfully admired.

"Sancho was Lieutenant Joshua Barney, my schoolfellow at West Point; a man of talent and humor, with a 
strong perception of the ludicrous. I was his counsel before a court-martial at Fort McHenry growing out of a difficulty with Colonel Belton in which, if I remember, he was successful. He afterwards left the army and became a civil engineer.

"'Alison' was Miss Alison Turnbull, now Mrs. Samuel Lawrence of Massachusetts, then one of the very handsomest women I ever knew.

"Charles Harper, the son of General R. G. Harper, with whom I studied law, my most intimate friend, a noble, chivalrous, talented and refined gentleman, who was a member of the Legislature, and, later, Secretary of Legation under Mr. Rives, the American Minister to France. The mention of his name revives recollections that would fill a volume. He died long since at Paris.

"Tom Oliver, a schoolfellow at St. Mary's College, in after life a client. He was the son of Robert Oliver, a merchant prince of Baltimore. He married the daughter of Hall Harrison. She was the sister of W. G. Harrison, one of the most estimable of my old friends, respected and beloved by all who knew him. He was, at one time, president of the Baltimore \& Ohio Road.

"R. B. Magruder, a prominent lawyer, afterwards one of the judges of the old County Court, a kindly hearted gentleman, of a very full face, 'making up' admirably as Prior Aymer."'

"Cruse and Kennedy, lawyers both, addicted to literature rather than to law. While Cruse had talent as a writer, as witness his contributions to the Baltimore American, of which he was the editor, Kennedy had genius, as witness "Swallow Barn," "Rob of the Bowl," and his other imaginative works. Cruse began and ended with Literature. Kennedy made himself prominent in the political world, was a member of the Legislature, was sent to Congress from 
Baltimore, and became Secretary of the Navy, illustrating his ability in every position; and his "Annals of Quodlibet" was one of the best political productions of the day. But he was not as sturdy and finished a writer as Cruse. They were the Damon and Pythias of society in Baltimore. Cruse died of the cholera in 1832. Kennedy died only a few years since. Both had humor; but while Cruse was full of it, Kennedy was overflowing. I knew both well, and while they lived, they were my associates and friends.

"Gibbes, R. M., was one of the handsomest, most refined and elegant gentlemen that we had in Baltimore; $\dot{a}$ South Carolinian, with all the manners of the old school. He married the daughter of Robert Oliver. He was another of my friends.

"Frick, William, was one of the brightest and most humorous men at the Bar, who, without being a very learned lawyer, made, long after the Fancy Ball, an excellent Judge. Few men were ever more popular, and as a brilliant conversationalist he was unequalled. Among other accomplishments, the Judge was an admirable musician, not only instrumentally, but as a composer; and more than once he set to music verses that I had written or which I wrote for the occasion. One of these, I remember, was "My barque is upon the deep, love," and another " $\mathrm{O}$, lady, if I were the knight of old." Our offices adjoined, and we saw a great deal of each other while he lived. Some of his humorous anecdotes are traditional. Everybody liked Judge Frick.

"Olivia Donaldson was one of the handsomest women in a City where beauty is not rare. She married Grafton Dulany, an able and very distinguished member of our Bar, as handsome almost as a man as his wife was as a woman, and their children still perpetuate the beauty of their parents. Madame Vallenilla is Mrs. Dulany's sister. 
"Mr. and Mrs. Skinner. Mr. John S. Skinner was the postmaster, a person of wide and general information and a prominent politician in his day; a clever writer, the editor of the American Farmer, and at home in all agricultural matters. His paper gave him a wide influence in Maryland. His wife was an amiable and hospitable lady.

"Lawyer Finley and Tom Meredith were two members of the Baltimore Bar.

"George Howard was a son of Col. John Eager Howard of revolutionary fame. Howard was, at a later day, Governor of Maryland. He was one of six brothers, John, George, Ben, James, William and Charles, all of whom I knew, and with three of whom, Ben, Charles and William, I was intimate. I was William's groomsman, and Charles was a very dear friend. Colonel Howard's only daughter, Sophia, married my fellow-student in General Harper's law office, William George Read, and both husband and wife were my very dear friends. All are now dead. The widows of Ben, William and Charles are still living. William's widow is now Mrs. Rebecca Tyson. I was groomsman at her first marriage. The widow of Charles is the daughter of Francis S. Key, of Star Spangled Banner renown.

"Tom Adair and young Etting are the last persons named in my sister's letter. Adair was a young merchant, the brother of William R. Adair, a very excellent gentleman. The brothers were intimates in the family into which $I$ married (my first wife). I cannot recall Etting. The American flag remains an incognito to this day.

"Tom Levering, still active at eighty-two, meets me sometimes, and always reminds me of my Don Quixote, which he saw at the Fancy Ball. I am inclined to think that he is the only person now living, except those above mentioned, who was present at the Ball.

"Sic Transit Gloria Mundi et Ballorum" 


\section{CHAPTER VIII}

COURTSHIP AND MARRIAGe OF Mr. LATrobe AND MisS MARgaret StUART.

A man's affections and his acts in his domestic life form a part, perhaps the most human part, of his character; without a consideration of this phase of life it would be impossible fully to appreciate the character of the subject of any biographical sketch.

Margaret Stuart was the motive of Mr. Latrobe's life from 1824 until her death in 1831, after they had been married for only two years.

His diary was begun on September 1, 1824. In the preface he says: "The last six months have flown while building airy castles upon it." M. S. is a memento of this. In Mr. Latrobe's diary of this period these letters appear frequently, forming, like a dollar mark, the initials of Margaret Stuart.

There are very few men who ever realize the grand passion. Most men get in love, few fall. In the first instance a man realizes that it is a proper status to be married - to be the father of children and the head of a family. In this condition of mind he finds himself interested, and he encourages this interest and declares himself in love. The other condition is an accident, like falling down stairs, without rhyme or reason. "There crosses his life's path a maiden, but little different from other daughters of men; the blood rushes to his heart and all his senses are bewitched. Thereafter, until the madness ends, his life 
belongs wholly to the new found being of whom he knows nothing, except that the sunlight seems more beautiful when it touches her; he finds himself swept away by an absorbing passion. He pictures the object with all the perfections a human being can possess. It matters not whether that object has them; the picture is made in his own heart, and she is perfect. His very solicitude and anxiety interfere with his making a good impression or appearing to advantage, and the lover in such case is but a poor advocate for his own cause. He has placed a human object on a pedestal. He feels his inferiority and worships her at a distance. Where, perhaps, a more aggressive lover, who treats the object as a mere woman, would be successful, he fails. The creation of the ideal may be a fabric of the imagination. If he fails to obtain the object of his hope, the image he has created remains in his heart. If he succeeds, and the reality measures up to the ideal, it is a perfect union. Perhaps the veil drops away, and he is among those who "in courtship dream, and in wedlock wake,"-and he realizes that it is a delusion."

Mr. Latrobe's journal shows that he conceived the grand passion for Margaret Stuart, as he writes, Tuesday, September 14, 1824: "I walked out to Maryland Square to see Miss Stuart."

"October 8, 1824. Saw M. S. at the ball. Told B. G. of my . . . . $t$ to M. S." These initials B. G. stand for Miss Gill who was a sister of George M. Gill, a great friend of Mr. Latrobe. It is evident that his love affair was not running smoothly when on November 16, 1824 he wrote the following:

"Whoever laughs and jeers at feeling, whoever cries up the callosity of the human mind, whoever insists that it be made perfectly callous, is a fool, or at least knows not the 
depth of man's spiritual sensations. Feeling is the heart itself; destroy feeling, and you destroy the heart; life perishes. Can you steal the color from the lily? Can you manufacture a pigment from the rose leaf? If you can, you may extract feeling from the heart. Like the rainbow it is never seen in the cloudless sky of pleasure. Clouds, sorrow must be present, or it comes not. The winds that bring the storm are not more numerous than the points from which feeling, deep, gnawing, restless, indomitable feèling, may agitate, corrode and destroy the heart. But I am silly; I forget that I write only my own ideas; that other hands are firm, while mine tremble; that other heads are tranquil, while mine throbs to bursting. This cannot last forever; it must change for the better or worse. Change it must, and I should pray that the change may free me. It will all soon be decided; there need be no note of explanation. I never can forget the occasion of this day's misery; after all, a quick violent temper is much to be preferred, at least as an alternative, to one that is slow to rouse into action. The sorrows of the first, although frequent and, at the moment, violent, are soon forgotten; they are characters of chalk written on the wall, effaced as soon as formed. The sorrows of the latter, equally violent when roused, are enduring; they are like a record written deep, very deep into the marble. The loves of two such tempers are very different. The first is continued ebullition, always perceptible, always carrying with it the consciousness of loving. It may be lasting, but it is not so necessarily. The affection of the latter only becomes apparent by the intervention of an agent-most frequently sudden disappointment. We may at sea sail unconsciously with wonderful rapidity, but it is only when we strike against an obstacle that we become immediately aware of it. Experience is a dear teacher. 
I am now anxious only to profit by what the events of the last hours have taught me of M. S."

"December 2, 1824. Called to see Miss Gill in the evening, a fine woman, few like her in Baltimore, except M. S."

After this there appears to have elapsed quite an interval of time as the result of this apparent quarrel. There is no further entry in which M. S. is found until January 31, 1827 , when he says, writing of other matters connected with his profession:

"I have passed this time in hard legal professional labor," etc., and then:

"The cause of rhapsody in diary of 16 November 1824, connected with the 8th of October and 2nd December, was not cured but continued. How I shall ever recollect, although I may or may not write it. It may or may not terminate as I wish, but, at all events, my diary shall continue until it does and M. S. is changed."

"May 9, 1827. Saw M. S. at 5 P.M. in company until sundown. Hours like this with M. S. are worth years of common life.

"May 17, 1827. The feeling which after years of nourishment is finally engrafted in the human breast and called affection, is a blessing or a curse as it is gratified or disappointed. Up to the present day I have toiled diligently forward toward professional success, and have tried to devote all the powers of my mind and the resources of my energies to the accomplishment of this object. But ambition and necessity have not been the only feelings which have interested me and occupied me-another, that first mentioned, found an abiding place in me for two years and a half, and has been my governing principle, fed at times by hopes, discouraged at others by doubt. I have gone on with alternate zest and disinclination in my course of life, until I have reached that height at which I am con- 
fident that disappointment, final disappointment would leave me a half broken-hearted being without ambition, without energy, without one active principle within him to urge him from the dull listlessness of despair. Once I undertook to conquer these feelings, and for months removed myself from and avoided the presence of the object. Accidentally we met, and I was convinced that my fate, my happiness, were set upon the cast of a die; and my determination to run this risk was the consequence of a necessity, which I have neither the wish nor the power to overcome. All this has been made apparent to me for the fiftieth time today."

Here we are, admitted to the inner chamber of his being and we see the strong feelings that are the motive power of his life

"What moods, what passions, what nights of despair and gathering storms of anger, what sudden cruelties and amazing tendernesses, are buried and hidden in every love story," as a modern writer says.

In Byron's dream the same condition is met when he describes the lover:

He had no breath, no being, but in her,
She was his voice,
He had ceased to live within himself,
She was his life,
The ocean to the river of his thoughts.

Mr. Latrobe experienced the miseries in this courtship, so well described in language applicable to another character of suit by Spenser.

Full little knowest thou, that hast not tried,

What Hell it is, in suing long to bide,

To lose good days, that might be better spent,

To waste long nights in pensive discontent,

To speed today, to be put back tomorrow,

To feed on hope, to pine with fear and sorrow. 
He writes in his diary nearly three years after making the first entry, when he had passed six months in building airy castles, of which Margaret Stuart was the cause.

"July 13, 1827. At Maryland Square all the evening. In the course of my long acquaintance with the family, I never had spent so pleasant an evéning as this. The only human being I ever was attached to was there, and hour on hour flew unnoted by, while enjoying her society. To her I look for happiness as great as mortals deserve, for success, for encouragement, for improvement of head and heart; and a life devoted to her will be but a poor return.

"August 26. Sunday. Reading 'Life of Napoleon' by Scott. I am now four and twenty, and what have I done? At six and twenty, Napoleon was the conqueror of Italy. Have I done as much in my humble sphere, and with my limited means as much in proportion? No.

"September 10. Saw M. S. at 10 o'clock. Had a long and most delightful walk with her. The gratification derived from her presence surpasses all other enjoyment, and with a community and sympathy of feeling which never existed with another human being we go on in one delightful course of enjoyment."

On September 19th he is miserable.

On September 21st, M. S. made delightful amends for all the mistakes of Wednesday.

So far as the girl was concerned, this was the end of all his uncertainty; after three years and a half of courtship she finally decided in his favor.

"October 1,1827, Monday. Had a long talk with M. S. who leaves tomorrow with her sister for New York. We had previously agreed upon the separation as enabling me to ask her father's consent that she should be mine forever. The obtaining of this request was somewhat doubt- 
ful, and we agreed that even if it was refused it should make no alteration in our sentiments towards each other, but that faithfully we would still continue, until circumstances altered in our favor; until her father, finding us unchanged, ceased to oppose our wishes, or until some lucky accident or other would enable us to be united. We spoke of the matter as one which was to end but with our lives; and certain of my faith, and no more doubting her than I doubt my existence, I repose with confidence upon the delightful certainty of calling her, sooner or later, by the most endearing of names. I left her at 2 o'clock, and met her again at 3-accidentally. In the hope of meeting her, I had purchased a gold and many silver thimbles to replace one which she had lost. She refused the gold, but selected one of the silver, and gave it to me to have the initials of her name placed upon it. We had before exchanged eye glasses, and we now agreed that so long as we kept them, though silent and absent, so long should we be for each other.

"She wished to know the result of the election, when all the wards but the 12th were heard from. I mounted my horse, rode to the 12 th, reached it just as the counting was finished, obtained the aggregate, and galloped to her home in the country. It was half past nine when I reached the place. I rode up the hill on the right of the road, concealed my horse behind some trees, and stole to the front door. The house was silent, and fastening the sheet of paper to the handle of the lock, I rang the bell violently and ran off to my horse. Three springs nearly brought me to the gate and by 10 o'clock I was in bed.

"October 2, 1827. At 4 o'clock I started for the steamer to see M. S. off. Bought the 'Epicurean' to amuse her on the journey. Saw her, talked to her, and parted. She 
told me that she got the thimble, which I had left at the summer house on my nocturnal scamper. I stood on the wharf until the steamboat was out of sight, and returned home melancholy enough. George Gill played chess with me.

"October 4, 1827. It had been agreed upon between M. S. and myself that I should write to her, asking her permission to speak to her father on the subject of my attachment. This letter I wrote today, and sent off. What trouble did it not give me? A letter such as my feelings would have dictated could have been easily composed, but the business letter which I had now to write was intolerably different. Rode with Kennedy in the afternoon, and in the morning went to 'Clifton' with Mr. and Mrs. Charles Harper to see Henry Thompson and his wife.

"October 7th. How dull and uninteresting without M. S.

"October 9th. Received letter from M. S. informing me that she had enclosed mine to her father, referring me to him. Immediately wrote to him a frank and candid letter, and sent it to him at 3.30 .

"October 11th. On horseback at 10 o'clock and rode to Maryland Square to see Dr. Stuart on the subject of my letter to him of Tuesday. Found that he had left town for the farm on Sparrows Point, fifteen miles off. Turned my horse's head and rode after him. It was the loveliest day of our lovely autumn, when nature dresses herself in her many colored robes and, like a merry harlequin, disposes the whole heart to mirth and pleasure. There was not one cloud, and the partridge whistled and the lark sang its sweet notes in accordance with the scene. I verily believe I was the only melancholy thing within a mile of me as I moved, and I was sad only because the happiness of my future was depending upon the result of my visit to 
the Point. At last I reached the farm and saw its owner, and in five minutes was the happiest of men. He behaved like a prince as he is, heart and feeling. No human being could have acted more nobly or honorably - and his daughter is mine-and life is smiling before me. I remained only 20 minutes and returned to Baltimore a different being from what I was when I left it. Reached town at half past four, just in time to write a few lines informing her of my success, and calling her my own.

"Tuesday, October 18th. Reached New York ten o'clock sent a note to M. S. informing her of my arrival, and that I would be with her at twelve o'clock. Twelve o'clock I went to Mrs. Delpratt's and saw M. S. This day I became engaged to be married to Miss Margaret Stuart, whose initials have so often occurred in the record of the last three years. The doubt which had hitherto clouded my hopes was now entirely dispersed; Dr. Stuart has given me his consent, and, fondly and devotedly attached to her, I have this day plighted my faith and received hers-the greatest earthly gift-in return. The future may see these pages when I have passed away, and should Heaven grant me life and make me the head of a family, there may be those who would rejoice to read the description of her whom I have so long and truly loved. I am a lover, it is true, but still as a lover I can speak without exaggeration. In person Margaret Stuart is of the middle size of woman. Her figure is the most perfect that I ever saw-remarkable for grace and ease, and so erect and dignified as to give the impression of being a much taller woman than she really is. Her face is most animated and expressive, her eyes are unequalled for fire and tenderness, her mouth conveys the idea of decision and judgment, her hair is very dark and of the finest texture and most glossy hue. In her air and 
carriage there is the highest tone of fashion, and appear where she would, Margaret Stuart would always occasion the question 'Who is she?'

"Her mental qualities are of the noblest order. Her conduct as a daughter is unrivalled. Her religious sentiments are pure and holy, not exhibiting themselves in her words, but giving serenity to the mind and equanimity to her feelings. Her character is remarkable for soundness of judgment and energy. Her accomplishments are many and, far from being cultivated for the purpose of display, appear to have been acquired for her own amusement and that of her intimate friends. You discover only by degrees that she is a first rate musician and possesses more varied information than most women have found time to acquire. Joined to all this she is the tenderest and kindest of human beings, and the arch humor of her playful smile, like the energy of the animated countenance, is bewitching and enchanting. She has always lived the child of fashion, but has taken nothing from her parents but the elegance of her manners.

The mind can make

Substance and people planets of its own

With beings brighter than have been, and give

A breath to form which can outlive all flesh.

"Monday, October 22nd. Margaret procured a thimble from me as a keepsake, and gave me one more precious in return. I sat with her until half past eleven, when I started for the steamboat. At 12 I left New York, travelled with the Boatswain of the ship in which Lord Byron was in the Mediterranean and who swam with him from Sestos to Abydos. He gave me many amusing anecdotes.

"October 25th. Wrote to Margaret Stuart. Saw Bessy 
LANDING AT THREE RIVERS, 1830

Painted by John H. B. Latrobe 


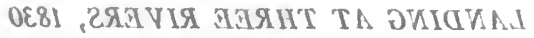
sdortal : C .H mol vis bolvinet 


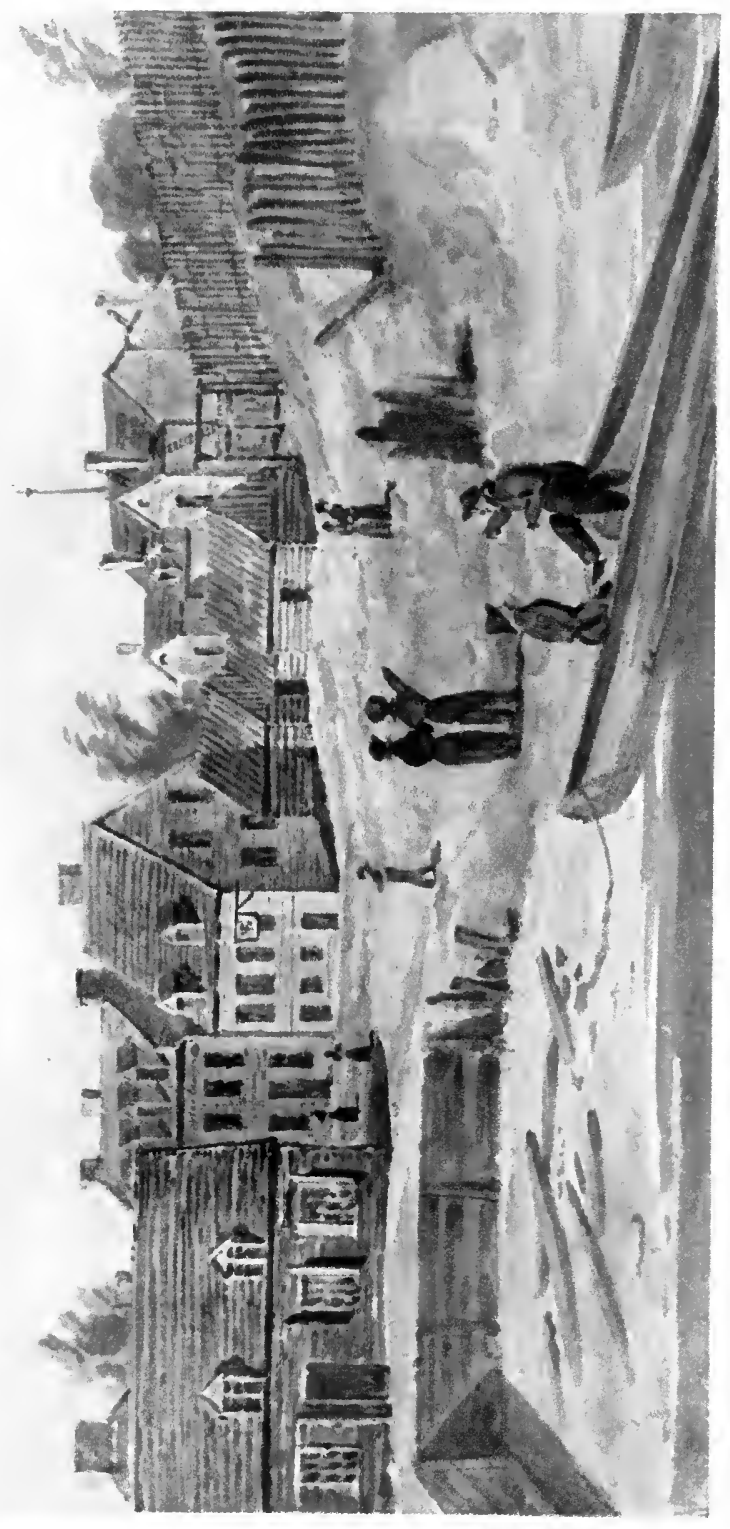



Stuart and spoke to her on the subject of our engagement, and with her all things are smooth."

In his autobiography we find the following:

"I had been for years attracted to the eldest daughter of Dr. James Stuart. She was one of the leaders of society in Baltimore. Distinguished in her carriage and noble in her heart and temper. Elegant in her figure, refined in manner, agreeable in conversation, and, without being handsome, with a countenance full of expression, and while attractive, remarkable for personal dignity. She was several years older than I was, and a woman of society. I was in earnest in the hope of winning her and persevered. At first she laughed at me, but in the end I succeeded. I have told the story of my courtship, I think, in one of the novelettes I wrote, perhaps 'The Mortgage,' perhaps 'Gates Heatherby.' My earnings of 1828 justified our marriage, which took place November 29, 1828, and I moved from Lexington Street above Pine to Lexington Street above Calvert, my office still remaining in the Athenæum Building."

Again quoting from his autobiography we find:

"On the 31st of January 1831 my dear first wife died. A truer, a nobler woman never lived. It is a long time to look back to the two years of my widower life, and I have but a very general recollection of the events that transpired during them."

His diary ended in 1830 . No other diary was commenced until 1832.

From a sketch book in my possession it would appear that shortly after the death of his first wife he traveled in Canada; he kept no record of his trip except his sketch book which contains pictures of the different places he visited. In the summer of 1832 he went to Virginia Springs, where he met Miss Claiborne, who became his second wife. 


\section{CHAPTER IX.}

DESCRIPTION OF MONTPELIER-UNIVERSITY OF VIRGINIA-

Monticello and the White Sulphur Springs,

as Mr. Latrobe Saw Them IN 1832.

On the 4th of August $1832 \mathrm{Mr}$. Latrobe left Baltimore to spend his summer holiday in Virginia. The route to the Springs was by stage, through Washington, and then by boat down the Potomac to a point where Potomac Creek enters the river. From this point he travelled by stage to Fredericksburg, through Orange Courthouse, Montpelier (Madison's mansion was about five miles from the Courthouse) and Charlottesville (University of Virginia and Monticello, Jefferson's home) to Staunton, and thence through the Warm Springs and Hot Springs to the White Sulphur Springs. Staunton is about 18 miles from the Alleghany Mountains, and the Springs are not far apart. It may be interesting to note Mr. Latrobe's description of the Captain of a river steamboat of that day. "The Captain has curly sandy hair and a long queue, wears a new beaver hat with an immense long nap, striped stockings, and buckles on his shoes, and being a good looking middle-aged man, is one of the happiest and best representatives of his kind that I have ever seen. He talks staidly too, is attentive to the ladies, and has a light quick, grey eye that speaks a whole volume of character for him. In a word, he is a man of mark."

In a letter to his friend, Charles Carroll Harper, he describes his visit to Montpelier, President Madison's home. 
"Charlottesville, Saturday Night, August 4, 1832.

"Dear Charles:

"Here I am continuing my helter skelter letter.

"Mr. Madison resides about five miles from the Court House, among the Southwest mountains, and upon the slope of one of them. You leave the Piedmont road about a mile from Montpelier and, turning to the left, pass through a dense forest for a considerable distance and until you descry at the end of a straight alley in the wood a high red gate, hung upon white posts. Entering this, you find yourself in a clearing, surrounded on all sides by the forest, and perhaps a quarter of a mile in diameter. Close against the opposite woods, you see the mansion of Mr. Madison, a double two story building of brick with low wings, and having a portico as high as the roof with four columns of the Roman, Doric or Tuscan order, and a pediment of about the same proportions as that of Nevin's Church. The whole design is in bad taste, yet sufficiently imposing. You now pass through a very large field, lying in fallow at this time, and showing here and there huge splotches of the dark red soil common to this whole region of country. Another red gate admits you into the plantation, which more immediately belongs to the establishment. Stopping at a small gate in a very handsome paling, you ascend the gravel walk and find yourself under the portico of Montpelier. To the right an avenue of trees is terminated by a temple of six Tuscan columns, and to the left, peeping through the foliage near the house, you catch a glimpse at some distance of the estate. Well now, I hope you see Montpelier in your mind's eye.

"I handed my letter from my mother to Mrs. Madison 
to the servant and was ushered into the drawing room. En attendant, let us look around it. Its walls are covered with paintings, save where two immense mirrors on the side at which you enter conceal large porticos. Here are Stuart's portraits of Mr. and Mrs. Madison, and one of his very best of Mr. Jefferson; also a copy by him of his original portrait of Washington; a very good head of the elder Adams by Trumbull; and numerous paintings, some quite large, procured by Paine Todd, when he was in Europe. Numerous small busts in terra cotta of distinguished men are upon the mantle piece and along the cornice of the principal door in the apartment; and under one of the looking glasses there is the finest statue in bronze of Napoleon at Elba, with the figure of Icarus upon the pedestal, that I have ever seen. Another statue of Napoleon, the same, but very small, is in a less distinguished situation. In the centre of the mantlepiece there is a bronze statue of Louis XVIII, the upper part of which comes off and discloses the small Napoleon I speak of-the whole is a capital caricature. The various books he presented to Mr. Madison, one containing a collection of American medals, lie about the drawing room. A piano is in one recess; an electrical machine occupies a corner; and sofas, chaises, lounges, a rich French carpet, and handsome chairs complete the furniture. To the right is a very broad passage with a waxed floor, wainscoted and hung with paintings of various merits and demerits. Another apartment, into which you get a glimpse from the drawing room, on the other side of the passage, contains a collection of casts, chiefly busts, many of which are very good-as Joel Barlow, Paul Jones, Clay, Mr. Madison himself, and John Quincy Adams. But Mrs Madison had made her appearance, and I must defer the gratification of my curiosity in the paintings and knick-knacks until another time. 
"My recollection of Mrs. Madison's appearance have always been very distinct; for she was considered like my mother some sixteen or twenty years ago, and when she entered the room it seemed to me as though I had parted with her only yesterday - so little had time been able to change her personal appearance- not a wrinkle, no alteration in her complexion, no difference in her walk. She had escaped unscathed as the spoiler passed; and Stuart's portrait, more than twenty years old, might still be judged without injustice to it, by comparison, with the original. A lady's age may not always be told, but Mrs. Madison was between sixty and seventy. I speak knowingly, for her son is my informant.

"Upon my enquiring after Mr. Madison's health, she told me that he had that day for the first time for twelve months ridden out, with especial benefit to him, and soon after she led the way to the room which he occupies on the eastern wing of the building. I remember Mr. Madison well, and recalled the image of a small, thin gentlemanly looking man in a full suit of black, with a head inclining to be bald, and hair neatly arranged and whitened by time, and the powder that he was accustomed to wear. But sixteen years had wrought here a change as if time, vexed at the little impression he could make upon the wife, had dealt towards the husband with a hand of no ordinary force and with double energy.

"Mr. Madison was lying upon a French bed, supported by pillows, a white cap drawn down to his eyebrows, and a white flannel dressing gown wrapt around his attenuated form. His face was extremely emaciated, and his eyes rested in their orbits with a quiet and almost dull inexpressiveness. Mrs. Madison mentioned my name, and, extending his hand to me, he gave warm and welcome greeting 
in a voice, whose clearness, strength and readiness astonished me, where I had expected from his general appearance but feeble and inarticulate tones. I seated myself on a chair at his bedside and the conversation was confined at first to ordinary topics on such occasions. One thing led to another, however, and dinner time arrived long before I expected it. Dinner was served in the room adjoining Mr. Madison's in very handsome style, Mrs. Madison, Paine Todd, her son, a niece of hers, Anne Paine, a child quite, and myself sitting down to it. Rarely have I drunk finer wine. After dinner Mr. Madison, who sees the table from where he lies, called me to him, and the conversation which dinner interrupted was resumed and continued until half past nine. I made several movements to leave his bedside, saying I feared that he fatigued himself, but he would not hear of it, replying that his lungs were the strongest part of him that was left; and I continued, therefore, with him until his usual hour of retiring for the night. I had proposed when I left the Court House to return there at night, but having been kindly pressed to remain until the next day, I dismissed my Jehu, and took up my quarters in an immense room fitted up with great taste and abounding in comforts. This morning I was up betimes, and, having commenced the day by getting a confounded hoist upon the waxed and dry rubbed floor, strolled about until breakfast time, after which Mr. Madison again called me to his bedside, and conversed until it was time for me to leave Montpelier to meet the stage that was to take me to Charlottesville. I was furnished with a horse, and Mr. Todd accompanied me to the Court House.

"This visit was worth all the fatigue of a much longer journey. Mr. Madison was excited by feeling that he was in better health than he had been for a long time, and spoke 
WHITE SULPHUR SPRINGS, 1832

Painted by John E. B. Latrobe 


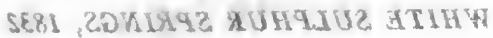
gNovad a , E whol wo bstwind 


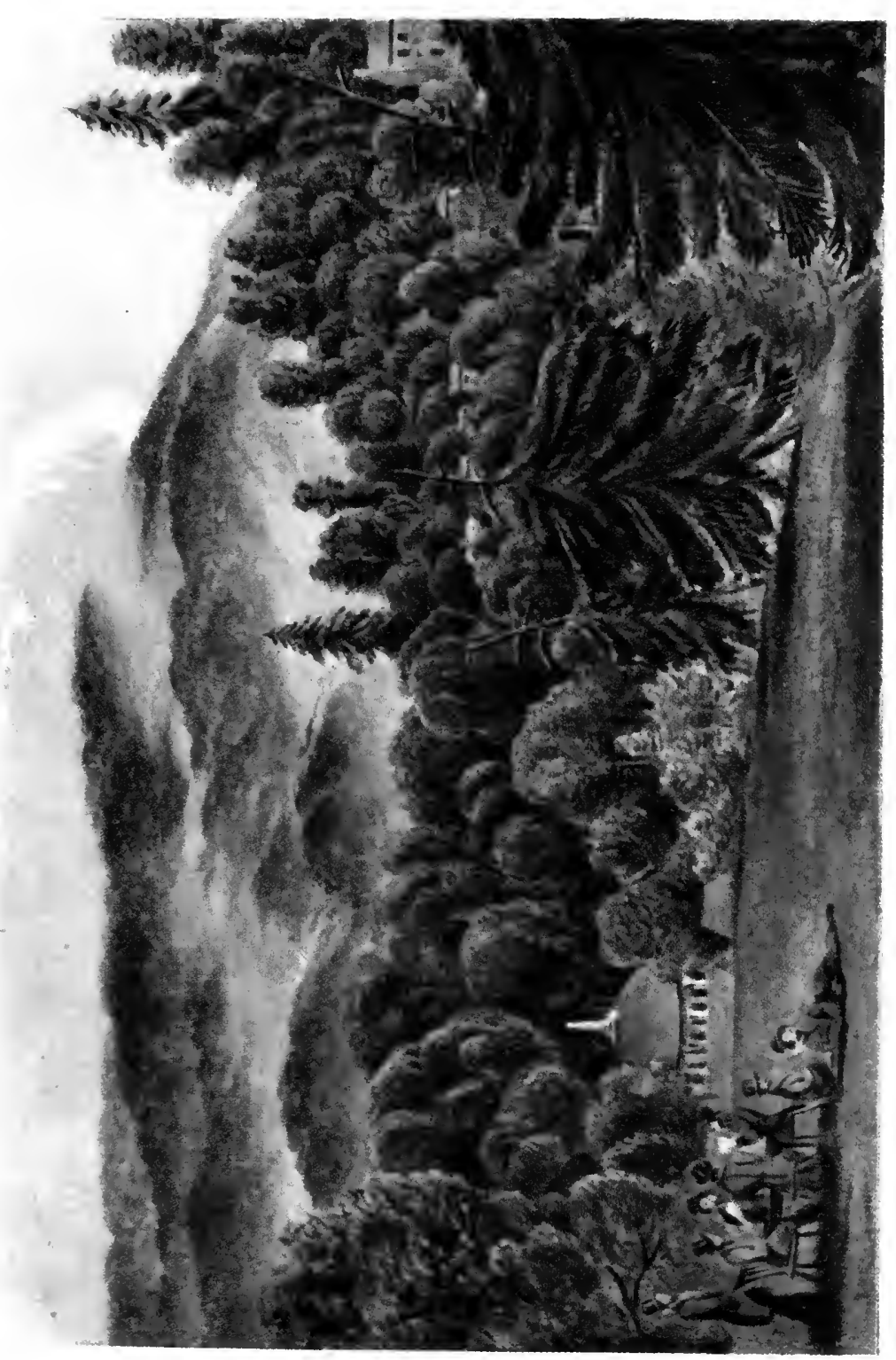



freely and fluently upon all the subjects of interest which now agitate the country. Once he laughingly suggested that nothing he said would get into the newspapers through me, as had been the case sometimes with his remarks to others who had visited him. He takes a deep interest in what is going on in the world, and is very fully posted as to facts. I could fill a quire with my recollections of what he said, but such is not my purpose. He spoke much of Colonization; took an interest in hearing what Maryland had done; regretted that the interest excited in the Virginia legislature at its last session seemed in a great degree to have died away, but considered that the scheme must and would go on. The journey of the Landers, Sparks, Denham and Clapperton were mentioned by him in a manner, too, which showed that he had reflected much upon the subject. Then came the present condition of Virginia; that led to the past, and reminiscenses of earlier times flowed fast from his lips. The Virginia Charter, as modified by the increase among and beyond the mountains, furnished interesting matter for remark; the late convention, details respecting it, that have not found their way to the public; his own motive for becoming a member of it, his relations during it with his constitutents, many of which were singular and deeply interesting; Governor Giles, John Randolph, Mr. Monroe, the Chief Justice, were all mentioned; also many names of less note, such as Brown, Johnson, McDowell, Watkins, etc. Then we got upon nullification; then the bank and the veto; the tariff; the Constitution and its construction; the most interesting part of the conversation by the way, was the causes of the depression in the South; the result of the threatened declaration of the Legislature of South Carolina, nullifying the revenue laws. Then Mr. Madison turned the conversation to internal improvement, and 
made many and minute inquiries about the railroad in Maryland, and went into an examination of the probable results of the systems of New York, Pennsylvania and Maryland upon each other, when completed. Literary subjects followed, and he spoke of Defoe's works, and asked many questions about Kennedy, author of 'Swallow Barn.' Occasionally during his conversation he would laugh heartily and throughout spoke with spirit and relish. Of course, I was but a listener, except when questioned, or when I wanted to give a particular direction to his remarks. His sketches of individuals were very happy. Pinkney he talked about much, Mr. Jay, Sam Chase, Daniel Dulany, Patrick Henry, your father, and others. He dwelt a good deal upon the events of the late war, and gave me a most interesting description of Paul Jones, and vindicated his memory from the common errors respecting his life and habits. He spoke, too, of the fine arts, though without pretense, chiefly confining himself to the statues and portraits of Washington. He asked me many questions about people now active in the world, whom I had seen; a great many about Taney, whom he got me to describe, and whose opinions he enquired much about. He asked me what General Harper's son was doing, whom you had married, whether you promised anything, what were your occupations, remarking that 'history, politics and political economy were apt studies to fit one for place and authority.' $\mathrm{He}$ then asked what your family consisted of, that is, whether you had brothers and sisters, and I beg you to tell Emily that I have had the honor of expressing my best, so far as I was competent to the task, in portraying her image to the mind's eye of my auditors. They both asked very kindly after your mother, as an old acquaintance. And thus, Charles, I whiled away my time at Montpelier, and 
could I always have such opportunity of playing listener, talker as I am, I would give up talking. I have passed, at all events, one agreeable and most instructive day on my journeying, and have got new material for thought, and I hope some valuable lessons for action from the lips of one who must soon pass away-one of the fathers of the land.

Note-By J. H. B. Latrobe years after:

"It was in the course of this conversation that Mr. Madison said the Constitution had two enemies-one that would stretch it to death, and one that would squeeze it to death." Leaving Orange, he reached Charlottesville, and visited the University of Virginia and Monticello.

A letter which I found in an old letter book of the elder Latrobe bears such a peculiar interest to John H. B. Latrobe's visit to and description of these historic places that I insert it and give some explanatory remarks concerning it at this point.

"Thomas Jefferson, Esq.,

"Washington, June 28, 1817.

Monticello.

"Dear Sir:

"I have so much pleasure in studying the plans of your College that the drawings have grown into a larger bulk than can be conveniently sent by mail. If you can point out to me any convenient mode of conveyance, within a few days, I shall gladly avail myself of it. I have put the whole upon a very large sheet which I am very unwilling to double, and to roll it on a stick would make it inconvenient for the mail boy.

"Respectfully,

B. H. Latrobe."

It has generally been accepted, I believe, that the design of the University of Virginia was the product of Mr. Jefferson's unaided genius. 
Mr. B. H. Latrobe was an architect engaged in building the Capitol during Mr. Jefferson's administration, and was subsequently engaged in the same work under Madison's administration in 1817 .

In Mr. Bernard Steiner's Report 1898-99 of United States Bureau of Education, Chapter XI, p. 577 is given a letter of Rev. Samuel Knox to Jefferson in 1798, setting forth his views of a University which are embodied in the University as built, modified somewhat.

As a student at the University thirty-six years after Mr. Latrobe's visit, I can vouch for the accuracy and truth of his criticism. There was about it an air of neglect and incompleteness, like a half finished building, abandoned for want of funds. I am happy to say that in late years the University of Virginia has had new life and vigor, and, under its present capable President, it is fast assuming a different appearance and position. Many valuable gifts and additions have been made. The original grand ideas are being carried out, and the University of Virginia is rapidly becoming one of the handsomest of our public institutions of learning.

LETTER OF JoHN H. B. LATrobe

DESCRIPTION OF UNIVERSITY OF VIRGINIA AND MONTICELLO

"August 1832,

Charlottesville.

"This morning I started with my letter to Dr. Dunlinson, a professor at the University. Found him at home, and, as he is a pleasant man, we soon became well acquainted. $\mathrm{He}$ is a professor from England selected by Mr. Jefferson for the University, and is highly esteemed. He was with Mr. Jefferson when he died. Mr. Dunlison took me over the 
building, and showed me the lines of the place. I will not attempt to describe the university, as I believe you have seen views of it. The recent large map of Virginia contains a very accurate one.

"There are four rows of buildings, composed of one. story colonnades, under which are the student's rooms; and at equal distances are the two inner rows and the professors' houses two stories in height, with porticos of various architecture. At the upper side of the lawn is the rotunda, containing the library, a beautiful room.

"The recitation and lecture room, and other philosophical chemical and mineralogical cabinets.

"See margin for general idea."

"Mr. Jefferson was certainly not a man of good taste, and this university, which was built under his direction, proves it. He has adopted the Roman order, the system of Palladio, the style of the age of Louis XIV, and has studiously kept out of view the very idea of Grecian proportion or form. His Doric is the worst Tuscan, his Ionic is from the worst models, his Corinthian is tolerable only, and the composite pillars of the library complete a mélange. which has nothing to recommend it but its general effect, which is striking and singular. The whole has a shabby genteel look, and is already showing marks left by time on its frail materials. The columns are of stucco, some of the capitals and bases of wood, others imported at immense expense from Italy to be joined to brick and plaster. The: mortar is peeling off in many places, showing the red bricks. underneath. The wood is yawning, with wide, long splits.

There is to be a marble pavement, which never will be. Here is a wooden terrace, which is fast taking rank among the 'has-beens.' Parts of the rotunda have not yet received their second coat of paint. The whole is, in fact, a half 
and half sort of an affair. The Legislature erected the building at great cost, and will let it tumble to pieces for the want of a small annual outlay. The endowment of $\$ 15,000$ is applied to the salaries of the Professors. Notwithstanding all this, no one can visit the University of Virginia without being struck, and though he may, like myself, indulge in minor criticism, he must award high honor to the State which erected this temple of learning, which after all may be fairly said to adorn this part of Virginia."

Mr. Latrobe then described his visit to Monticello.

"I got a horse on my return to the tavern, and started to Monticello, about two and a half miles off, on the summit of the mountain immediately above the Ravenna. It had rained heavily for the last hour. In the afternoon it cleared up cool and bright, then I entered the thick wood around the base of the mountain. A steep and rough road led me to the summit, and on the esplanade formed there, partly by nature and partly by art, was the mansion house and its offices, now the property of a Dr. Barclay. The first thing that strikes you is the utter ruin and desolation of everything. The house is of brick, in the same wretched style as the university, with a portico of four Doric columns on each front and an arcade of brick at the extremities of the wings. A dome surmounts the whole. Here again the general effect is good, notwithstanding the bad taste of the details. The owner was absent and I could not obtain admittance, but was shown through an open window the room in which Mr. Jefferson died. The internal arrangement, so far as I could judge of it by the peeps I made into peepable places, is whimsical and, according to present notions of country houses, uncomfortable, being cut up into small apartments. On this subject I really am not competent to speak. The roofs of the offices are on a line 
I.AWN OF THE WHITE SULPHUR, WHITE SULPHUR SPRINGS, 1832

Painted by John H. B. Latrobe 


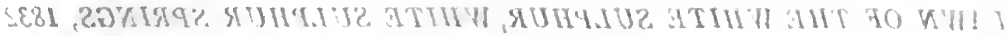

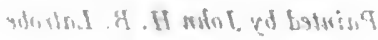




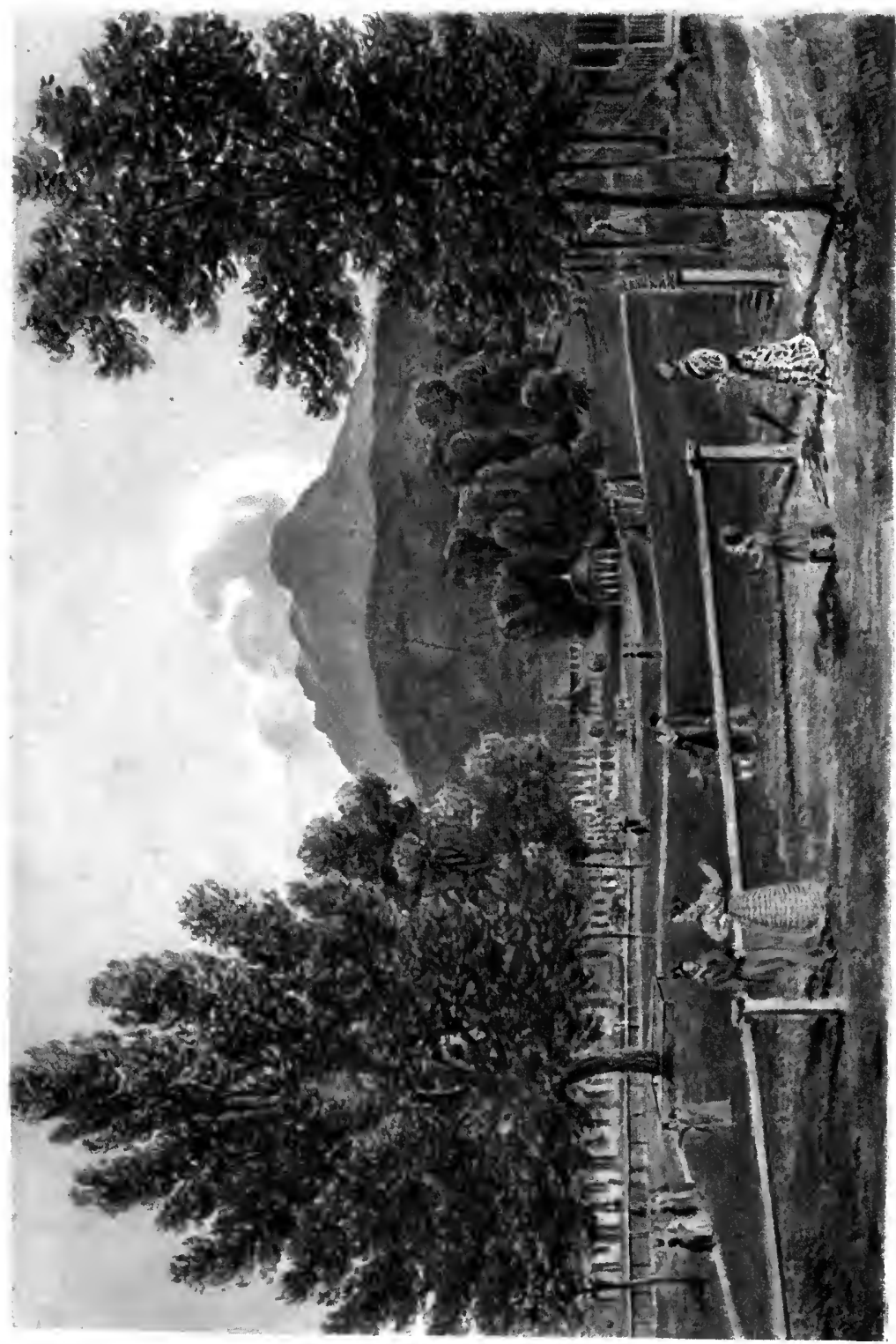


- 
with the floor of the main building, extend on either side of it, and are returned to the southwest, making the three sides of a parallelogram. They are flat and form a terraced walk. The northwest angle seems to have been a favorite spot of Mr. Jefferson. It is completely shaded by trees and garden chairs are permanently fixed there. The view from it is magnificent. You look across the valley between the southwest mountain and the Blue Ridge, until the high and rolling summits of the latter range from a bold horizon, extending from the south around into the north. Forests and cultivation are here mingled in goodly proportion. The University of Virginia has nestled upon the little eminence and embowering creeks, and nearer the Valley of Charlottesville, which is a pleasant resting place for the eye among the wide fields which surround it. Here and there the Ravenna glitters in the landscape, and the roar of the stream over the dam below rises up gently with a soothing influence. Vast masses of clouds, the remnants of the afternoon gust, are lying about the sun, and take those hues which pen cannot describe nor pencil imitate, and which few but us Americans have seen. Long shadows are stretching themselves further and further towards Monticello, until the disappearance of the sun behind the clouds throws one broad veil over the entire landscape, and the distant mountains take the hue of deeper purple. Then bursting forth again the sun, within a palm's width of the edge of that round, isolated hill, casts its level rays eastward, and the points of all the intermediate eminences glitter like diamonds with momentary lustre another moment, when the broad flood of mellow light westward along indicates that the sun has been there, and almost compensates by its beauty for the sun's departure. Would that you could see Monticello to advantage as I did, and watch the sun 
as it sets behind those glorious mountains. Northward and southward from the Esplanade, you see the mountains of this particular ridge, and eastward your eye roams over an unlimited and rolling forest, save where to the northeast a bit of cultivation appears along the base of the Southwest mountain. Take it all in all, Monticello is a spot on which one might well be contented to dwell in the silence and solitude of its lofty summit, above the contentions and meannesses and inconsistencies of his fellow men and gaze down upon this world which they inhabit, having his mind elevated by its glorious perfection to his Creator and Judge. The old philosopher who last inhabited it, despite his errors, and he had many both as a man and as a statesman, possessed too many of the attributes of real greatness, in his bold conceptions and firm, undeviating purposes, not to be worthy of this noble spot which he had selected and improved; and when his spirit took its flight from it, there remained a halo lingering around it, which has made it a monument to his memory. As such I visited it, and as such it will be visited until the history of America shall cease to exercise an influence upon the conduct of its people.

"I certainly did not expect to find at Monticello anything which would give rise to feeling, wholly personal to myself. Yet so it was. Singularly enough at the corner of the terrace before mentioned and overlooking Charlottesville, and in the centre of the square surrounded by the garden chairs, which I have already told you were fixed there, I saw a pedestal, deprived of that which the iron bolt projecting from its centre proved to have once belonged there. Not far off, however, I saw the capital of the column, somewhat mutilated, which had been thrown or fallen down from the pedestal, and recognized at first glance a capital of the order of architecture invented by my father during Mr. Jefferson's 
administration, in which the place usually occupied by Acanthus leaves of the Corinthian columns is filled by ears of corn, grouped together with due regard to beauty in their proportions. You see it in the vestibule of the North wing of the Capitol at Washington. You may not perfectly understand my feelings, and may smile at my mentioning such a trifle. But to think that this spot, visited by thousands in the life of Mr. Jefferson, contained something that recalled my parent's genius, caused a current of pleasant feeling to pass through my bosom, and with a sort of filial reverence I moved the stone from the wreck of the garden chair on which it had fallen and placed it upright. I know you are laughing at all this, but truly my poor father met in this world so little of that favor of reward or appreciation that much inferior qualities have won for other men, that I treasure up after his death anything that looks like a tribute to him, however trifling.

"Before I left Monticello I took a sketch of the building looking North, which I will show you upon my return."

TRIP TO THE VIRGINIA SPRINGS, WHITE SULPHUR

"August 1832.

"As we descended the mountain there were various indications of our approach to the center of attraction in this part of the Union. A gay barouche drawn by prancing, foaming horses, and filled with ladies, and followed by gentlemen on horses, dashed by us, and inquisitive glances were exchanged with the stage passengers, with parties looking for known faces. Then came a single cavalier, with the servant in livery, then a carriage and four, with curtains drawn, and a laughing party within. Then three or four sulkies and buggies, then the more staid sober hacks with people inside looking like invalids. And as the stage 
rolled nearer and nearer were groups of pedestrians, then the nurses and their children, and all this in the dense, thick forest. Presently a few open and well cultivated fields appeared, and then the scene widened a little and cultivation was extended. Columns of smoke were seen to rise over the crest of a small hill that the road crossed, and when the summit of this was reached, there was the spot. Cottages hidden in the dark green foliage, long rows of white homes of all descriptions scattered here and there, and as we came into the precincts, there on the right was the ascending lawn of the freshest verdure, surrounded with its picturesque cabins, with vehicles of all sorts under its trees. Gay groups laughing and enjoying the afternoon were assembled on the lawn. Here a gay party of equestrians careering on their return from their evening ride, here another prancing pell-mell, here were fencers, here a group starting greyhounds for a race, here a number of serious smokers on one side by themselves, here a whole bevy of children with their whoop and hallo. Servants were hurrying to and fro. The quoit was flying in the air, and the roll of the nine pin alley came upon the ear with the crash and clatter of the falling skittles. Over all the sun, now almost at rest for the day, shot his softest and mellowest beam. "'Is there room for a single gentleman?' I asked. 'Not today,' replied a plain, brown-faced man in brown clothes and looking all the time in a brown study. 'Are you Mr. Caldwell, Sir?' 'No, I represent him though.' 'Then you must go to Lewisburg.' 'But, my dear sir, that is out of the question. I came too far to be turned away.' 'Can't help it, there is no room, you had better keep on to Lewisburg.'

This he repeated several times, in response to my urgent entreaties that I be given some place in which to spend the night. In the most utter despair I was on the point of 
getting into the stage again to go to Lewisburg, nine miles away, when I saw the face of a servant I had known in Baltimore, and on inquiry found that he was waiter for Richard Gill, Eichelberger, Campbell and Spear Nicholas. I now ordered my baggage off to be put in their room, and coaxed the man in brown to let me take the risk of being accommodated by my friends. They were all out except Campbell who made me welcome and gave me a place to put a bed in, if I could get one. Reverdy Johnson and his wife were here. After resting and renewing my acquaintance with the Johnsons, I went in search of a bed, and, by dint of bribing the waiter and chambermaid, I got two benches and a miserable pallet, a pillow and a blanket. Sheets and a pillow case were out of the question. With these I was forced to be content for the first night, with the assurance that I was better off than many a single man had been for three weeks, first, because I had gotten in at all, next, because I had secured such admirable accomodations the first night, five hundred persons having been turned away recently after similar dialogues with the man in brown. After tea, in our cabin, we dressed for the Ball, and it was a pleasant and merry one.

"I found Miss Carlton, Miss Randolph, Miss Barbour, Mr. and Mrs. Livingston, Mr. and Mrs. Johnson, John Mercer and many others that I knew. There were Miss Anna May, a beautiful girl from Petersburg, and her sister, and Miss Maser from Richmond, Cora Livingston and Barton, Arthur Middleton with whiskers and mustache and check suit in a ball room, Mr. Carlton and Governor Barbour, Mr. and Mrs. Clay, and Mr. Standard of Richmond, and a dozen others, all good, clever and agreeable people to meet, so that I already had the promise of much enjoyment for some days. 
"The next morning when I got up, I realized the fact that I was nearly eaten alive by fleas; never was human flesh so scarified. They had, I believe, provided me with a horse blanket to sleep under. The day being the Sabbath, we had a sermon in the ball-room. In the evening Richard Gill and myself, together with a gay party of fifteen others, took a drive in Johnson's barouche. Monday morning Mr. and Mrs. Johnson, Messrs. Nicholas, Campbell, Eichelberger and Gill left for Salt Sulphur Springs, and I was moved to a cabin in Florida Row.

"I saw Mr. Clay a number of times, and had a long conversation with him on several subjects, unconnected with politics, of course. $\mathrm{He}$ is certainly the most pleasant man I ever was in company with, and I willingly confess myself indebted to him for much enjoyment.

"Mr. Standard of Richmond, a lawyer of great prominence is a person it has given me great pleasure to meet. Dr. Greenhow, the secretary of Mr. Livingston, is possessed of more varied information than any individual $\mathrm{I}$ ever met with.

\section{WHITE SULPHUR SPRINGS}

"Let us take a walk around the springs, commencing at our left-hand. The building that is within the enclosure is the gambler's dwelling, a comfortable cabin neatly fitted up, and the small framed house immediately behind it is the faro room. Those remarkably well dressed, genteel men lounging about the door are the priests of the temple of fortune. If you go tonight at any hour, you will find many, whom you would not suspect, among these votaries. The row of some ten or twelve cabins is called 'Fly Row,' and is the most ancient part of the establishment.

"Let us now cross the base of the steep grassy hill and 
BALTIMORE COTTAGES, WHITE SULPHUR SPRINGS Painted by John H. B. Latrobe 


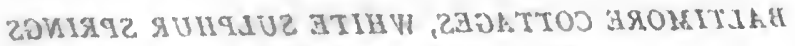

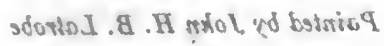




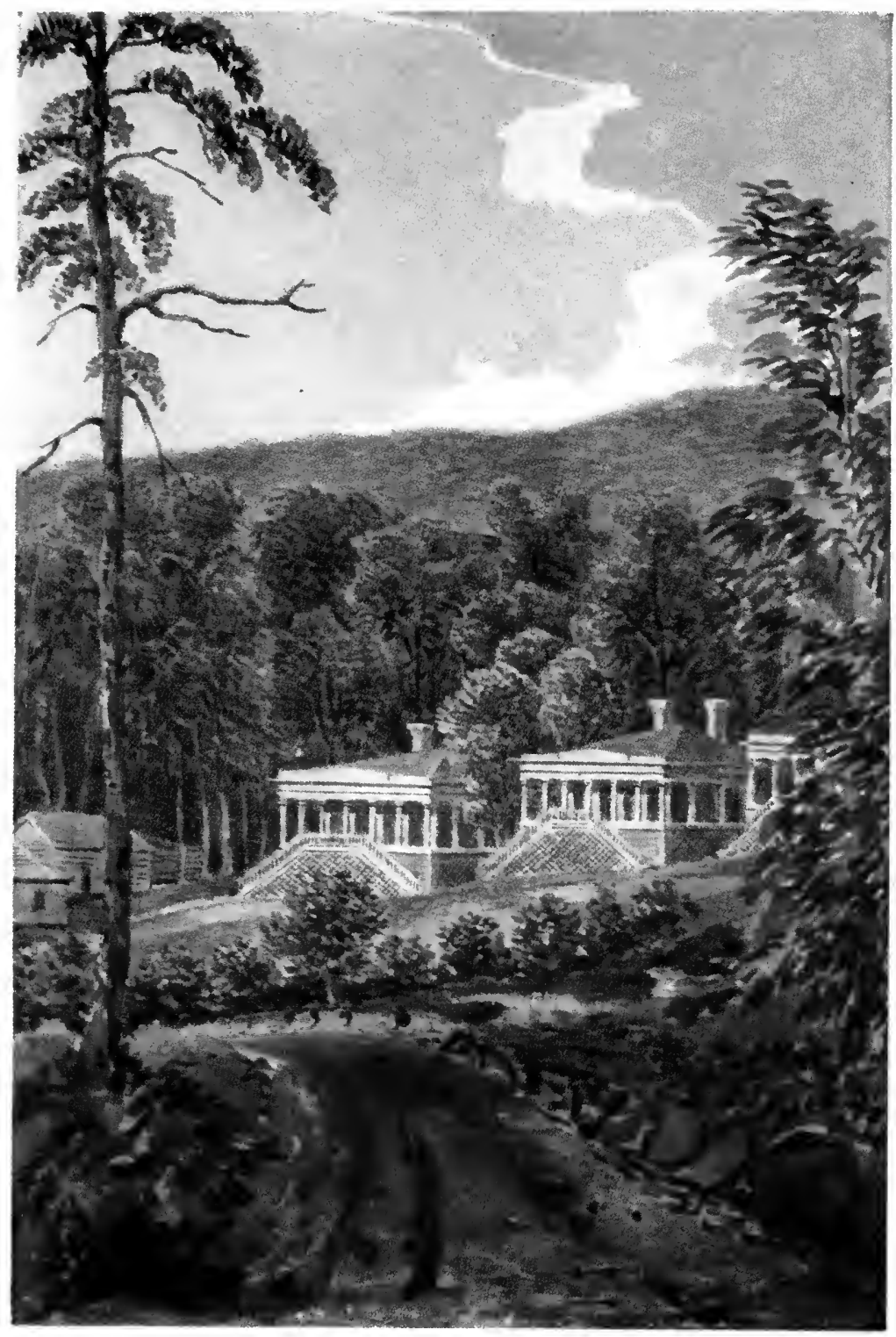



we arrive at a row of snug brick cabins, the best part of the Springs and the most aristocratic. The wide rail before them spoils the appearance of the place, but tends to keep off the carriages and horses. Arriving at the end of this row, we turned to the right and pass down a row of frame and $\log$ cabins, in one of which I slept on the first night of my arrival. Turning again to the right and walking towards the Springs, we passed under the shade of some noble trees, and in front of the prettiest cabin in the place was an improvised ball room, over which were sleeping apartments and a modest wing on each side of it. Thick shade trees surrounded it, and a merry crowd were enjoying the cool spot in the shade afforded by the trees. Truly, this is a lovely spot, in the heart of the mountains, but the owner is not as energetic as he might be, so the place is susceptible of tenfold improvement. In the hands of the Yankees it might and would become a veritable paradise. The same money that is being used now could be expended in furnishing accommodations for everyone who desired to stay here, and a little management would soon introduce order, where all is now confusion. Crowds collect around the dining room when the bell rings, and when they are opened there is a rush, like that at the booth at a contested election. Every man, woman and child rush to any seat which they may happen to find, and in a very short time the food upon the tables disappears consumed by the hungry mob. If you have a servant of your own, he must bribe the cook. If you have no servant, you must bribe one of those attached to the place, or you run the risk of getting nothing. Bribery furnishes you with the best of what is to be gotten in the place, and avoids the rushes at meal time. The day after I arrived, two waiters quarreled over an apple pie; one floored the other and neither got the pie, which 
was floored in the scuffle-and this scene took place while the guests were seated at the table. Bribe high and you live high; fail to bribe and you starve; look sharp and eat fast, you forget good manners. This is the motto of the dining-room of the White Sulphur. After the guests have dined, then come the working men and laborers on the place. After they have finished, then come the servants. Whatever a servant provides for his master belongs to him if his master does not eat it. This method quickens the activity and attention of the servants, but occasionally they battle amongst themselves. There is no pretense of providing lodging for your servants. They sleep where they can, for no rooms, beds or bed-clothing can be procured for them. The greater number of the cabins are comfortable enough, and many of them are private property. Single persons face the worst difficulty, unless they bring several horses and servants, whose pay is $\$ 4.00$ a week, and then they are given decent lodgings and meals, and all fare alike. I have seen a dozen servants slashing away at a saddle of mutton like so many hounds at a fox, just caught. There is no one to command and no one responsible. The man in brown attempts at times to set things to rights, and floors a few negroes, but there is no use in it, things go on as usual. I for my part bribe high and live well, but this is not economical. Yet, notwithstanding all this, the White Sulphur is a pleasant place to live. There is something eminently aristocratic about the place, and you feel that you are with your fellows here, more than at any other place of its kind in Virginia, quite as much so as at Saratoga or Ballston, and I hope, all things considering, to pay another visit one of these days.

"Visits are paid here with as much ceremony as in a city. If the cabin door is open the ladies are at home; if it is 
shut you must apply for admittance. As Mr. Carlton told me when he asked me to visit him, 'Our chambers, sir, are our parlors, and our beds are our sofas,' and so it is, and some very pleasant visits I have made.

"I have heard much of the butcher Charley, as he is called, and made his acquaintance today. I went down to a field beyond the creek and waited in the woods that lined its sides. It was near sun-down, and some sixty or seventy sheep and six or seven bullocks were in the field. After a short time Charlie made his appearance riding on a horse behind another man. He got down near the edge of the field, and I took occasion to get a good look at him. $\mathrm{He}$ was a black negro about forty-two years, of medium size, and with features most strongly marked. The expression of his face was that of a good humored tiger, fierce and savage, but with a look of sarcasm and wit. His eyes were blood-shot and his teeth irregular, and when he spoke, his huge lips brought every part of his face into action. His shirt was cut low in the neck and was extremely soiled and, where his sleeves were rolled up at the elbows, was red with blood. A black handkerchief was twisted around his neck. He wore pantaloons, which were greasy and stained with blood, and a pair of heavy shoes without strings; a surcingle of a horse served as a belt, in which was stuck a knife and from which hung, as a midshipman wears a dirk, a butcher's steel. On his head was an old leather cap, and he carried a rifle on his shoulder. This was Charley, the butcher of White Sulphur. While loading his rifle he entered into conversation with us, and exhibited a shrewdness which one would not have expected. There was much humor in his remarks, and he spoke with an air and tone, which showed that he considered himself superior to any human being. I wish I could recollect some of 
his slang, which was characteristic, wild and coarse as it was. He leaped over the fence, and, while he kept along the cover which it gave in case the bullocks became enraged, walked up on the open field and pointed to the spot in the forehead which he intended hitting. He got within sixty or seventy paces of the animals when he stopped, raised his rifle with perfect ease, steadied it for a moment and fired, and the beast dropped dead without a struggle. 'I told you so,' he said as he cut the throat, 'I'd have hit him in the center, but he turned his head a little, and I had to give it to him an inch to the right.' In less than half an hour the whole thing was done, and the meat skinned cleaned and cut up on its way to the shop. Charley picked out six sheep from the flock, shooting them all in the head, and hitting to a hair-breath the spot where he said he would. I have seen much good shooting in my time, but this fellow is the best shot I have ever seen. Were I a novelist, he would be invaluable to me. If you want delicacies, go to Charley and tell him so and bribe him; he will stalk into the kitchen among the waiters, and it is then that you see that you have applied to one all-powerful, for the things are heaped upon your plate. The pastry-cook, a sturdy little Englishman, is the only one who can hold him at defiance. If you are fond of studying human nature in queer shapes, look up Charley if you should visit the White Sulphur Springs.

"I saw here for the first time a hail storm so called, that is to say, a mint julep made with a hail storm around it. The drink is manufactured pretty much as usual and well filled with a quantity of ice chopped in small pieces, which is then put in shape of a fillet around the outside of the tumbler where it adheres like a ring of rock candy, and forms an external icy application to your lower lip as you 
DINING ROOM, STAGE OFFICE, ETC., AT THE WHITE SULPHUR, FROM THE NEW ORLEANS HOUSE, 1832

Painted by John H. B. Lasrobe 


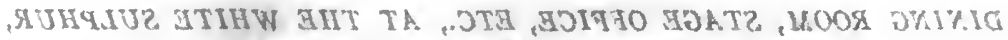
5E81, त2UOH ZVA. sdortas . \& . H mot yo botriva 


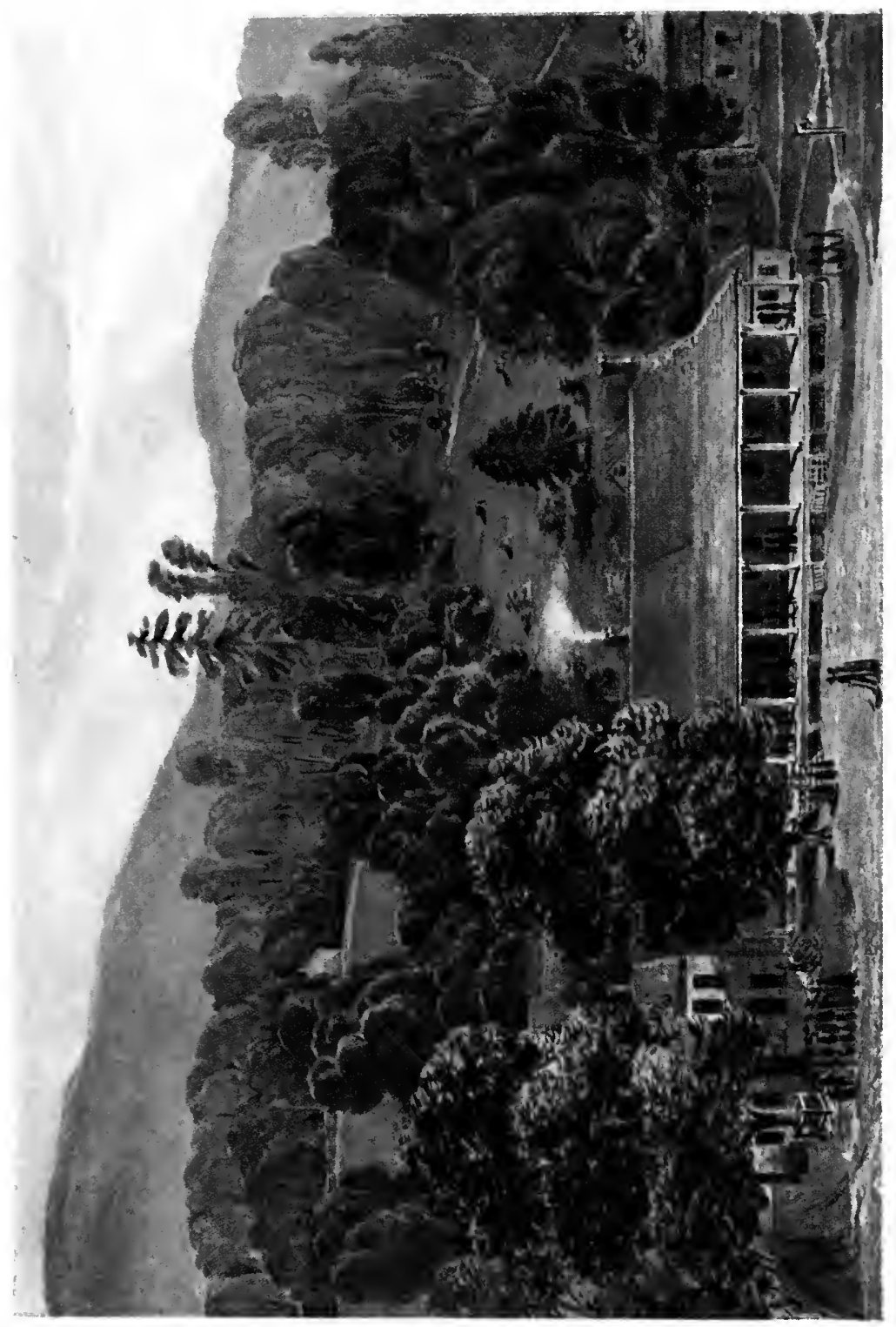



drink it, while the ice within the glass presses against your upper lip. It is nectar, they say, in this part of the country.

"And now, adieu to the White Sulphur, of which I have endeavored to draw a faithful portraiture. The purity of its atmosphere, the beauty of its location, and the charms of its society detained me, its guest, despite the annoyances I encountered and have attempted to describe." 


\section{CHAPTER $\mathrm{X}$}

Mr. Latrobe's Marriage to Miss Clatborne-Short ACCOUNT OF her FAMILY-The "ClatborNe REBELLION"

Miss Charlotte Virginia Claiborne, second wife of Mr. John H. B. Latrobe, was the daughter of General Ferdinand Leigh Claiborne. Her father died some years before Mr. Latrobe met her. She resided in a homestead known as "Soldier's Retreat," a few miles from Natchez, Miss. Mr. Latrobe met Miss Claiborne in Virginia in the year 1832, and became engaged to her after a short courtship.

Miss Claiborne having returned home to prepare for her wedding, Mr. Latrobe soon followed. Leaving Baltimore about the 1st of November, he arrived in Natchez on the 27th. The wedding took place on December 6, 1832. While the courtship was short-in fact Mr. Latrobe knew Miss Claiborne a littleless than six months before their marriagethere is every evidence that the union was a most happy one. Miss Claiborne was only seventeen when they were married, and Mr. Latrobe twenty-nine.

It was my custom to call daily at his office during the last years of his life, and one morning, when I called, I found him busily writing. He was then eighty-three. I asked him what he was writing, and he said he was writing some verses to his wife. It was her seventy-first birthday; and he had been in the habit of doing this for many years. I cannot find among his papers a copy of the verses that I saw that morning, but I was so struck with the character 
of a man who at the age of eighty-three continued to address verses to his wife of seventy-one, that I made a note of what he had written. I reproduce them here:

When seventeen summers only Thy youthful charms supplied,

I wooed and won thee, dearest, To be my beauteous bride. Reversing now the numbers, As stand they side by side, They tell of years departed, Of thee, my cherished bride.

And what though four and fifty Of these our love have tried, There has nought come to sever The bridegroom from the bride. But lingering, where fast ebbing Is life's receding tide, Still hand in hand together walk The bridegroom and the bride.

In this connection when he fears that the muse may not answer to his call he writes:

\section{To MY WIFE}

Dearest, if, when thy birthday came, My verses ceased to hail the hour, 'Twas not because my love was tame, Or thou hadst lost thy wonted power. But Time, although he leaves the heart Unscathed, amid his changing weathers, Through storm and sunshine, plays his part In clipping short the muse's feathers.

Then, dearest, if no flowing lines Greet now, as erst, thy natal day, Remember that Golconda's mines May hold the gem, yet hide the ray. 
So Love, though silent, may be deep

As ever woke the Poet's numbers; And vigil true, untired, may keep,

Although the muse beside it slumbers. 1860.

The only record that I can find of his second courtship is in several letters which he wrote to his intimate friend at that time, Charles Carroll Harper, from Botetourt Springs, Va. On August 25th he wrote:

"Moss and myself agreed to follow the Claibornes to this place, on our way to Natural Bridge, and here we are today. Miss Claiborne's pretty face and figure and pleasing manners, to say nothing of her cousin, Mrs. C., formerly a Miss Kershaw, of Carolina, may keep us some days out of our course. By the bye, I wish Miss Claiborne did not live in Mississippi; out of the way for a morning call."

Under date of August 27th we find:

"We have a party arranged tomorrow, if the weather is fair, to visit the summit of Tinker Mountain, when I hope to aid the footsteps of the fair Miss Claiborne, who is, as I have hinted before, very pretty, very sensible and very unsophisticated, and but for whom neither Moss nor I would have come so far South perhaps."

A later letter shows that he became engaged to Miss Claiborne on this memorable walk which occurred on the 28th of August, 1832. Their first meeting was on August 10 th.

In another letter written from Natural Bridge, Virginia, on August 30th, we read:

"My last letter was from Botetourt Springs, where I had gone upon a trip to see the country and some of the results of my visit to which I am now inclined to think I am in a fair way to remember very pleasantly during the 
JOHN H. B. LATROBE WITH THE CLAIBORNE FAMILY AT BOTETOURT SPRINGS, VIRGINIA

Painled by John H. B. Latrobe (1832) 


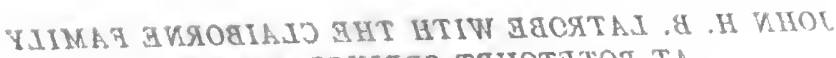

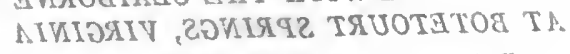

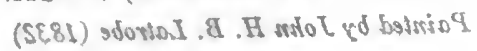




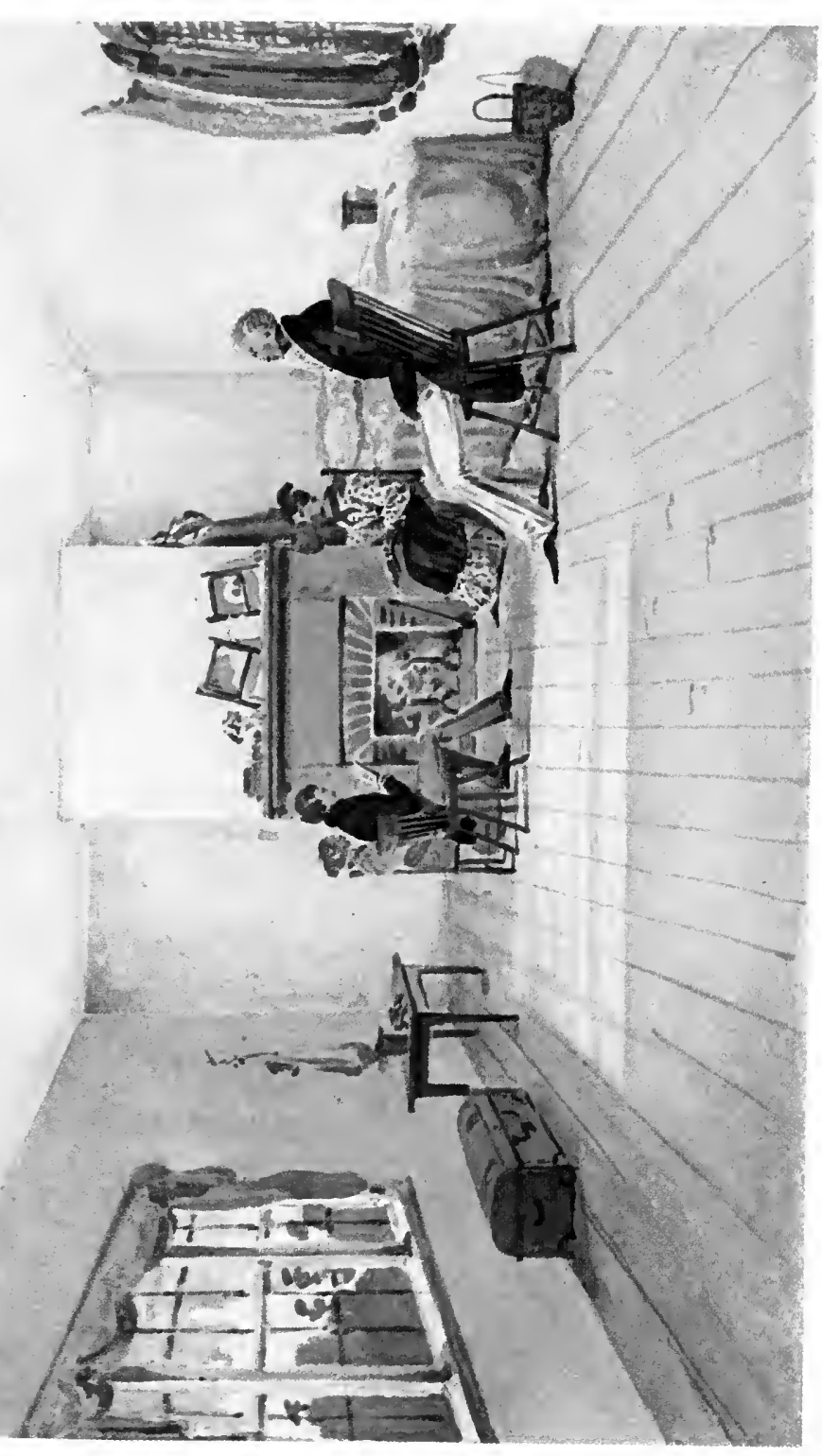



rest of my life. In truth, Charles, you will wonder and smile, too, at the narration of the last ten days, when I come to unfold to you that part of it (the only part I have withheld) which is not connected with the roads, the people and the natural features of the country. This Jetter will get to you in so short a time before I arrive myself, that any curiosity that I may excite will not be long before it is gratified."

Another extract:

"At Botetourt the Tinker Mountains terminate in front of the house. I have a sketch of the place to show you in my sketch book. A pleasant walk, which I shall long remember as connected strangely enough with my future destiny, was one to a graveyard, romantically situated on the wooded brow of the little knoll."

\section{BOTETOURT SPRINGS, 1832}

[From Mr. Latrobe's notebook.]

"They are in the great valley of Virginia. The quality of the water is the same as the White Sulphur water, although in a lesser degree. The arrangements of the establishments are on the same cabin system, and are made with much taste and judgment by the proprietor, Mr. Johnson, whose fortunes are reduced to his present occupation, without. his feeling or habits being altered with his circumstances. He still sits at the head of his long table, with an air, and. his daughter occupies the foot. The conduct of the guests. here is corresponding, and there is more general politeness here than is to be met with often at these Virginia watering places. Johnson was once made captive by the Indians, and you have doubtless seen or heard a narrative of his sufferings, which he published some years ago. The place is pretty. The country around is open, and the mountains. 
that rise in all directions do not press upon you so closely as other places I have visited in Virginia.

Again he writes from Franktown, September 1, 1832:

"Something which I have reserved for conversation will make you even more a hearer than you have been a reader of my concerns."

Mr. Latrobe, as I have already stated, started about November 1st for Natchez, intending to make Miss Claiborne his wife when he reached there. He had reason to object to the fact that she lived in Mississippi, and that it was an out of the way place for a morning call. In looking over the records of his trip there, we find that he reached Natchez on the 27th of November, which was about four weeks from the time he left Baltimore. There was a rest at Nashville of some three days, but during the rest of the time he was traveling night and day on the stage coach. AtNashville he happened to overtake the Claiborne party on their return home. He had with him his valet, James Wilson a colored man, who, when I went into Mr. Latrobe's office in 1876, was still with him, a venerable negro, with his wool as white as snow and with all the manners of a cultivated old fashioned gentleman. James lived for some years after, having been with Mr. Latrobe since 1824 .

It was no easy thing in those days to go and see your sweetheart, if you lived in Baltimore and she lived in Mississippi.

On his journey from Baltimore to Natchez, Mr. Latrobe writes from Charlottesville, Virginia, as follows:

"After reaching Charlottesville, I passed through the country which I had seen in mid-summer. It is now, in November, dressed in motley-yellow is the prevailing hue. Two weeks ago the forest was in its glory, but even now there are some strong and novel contrasts-the pine with 
its bright green, the dogwood with her flaming covering of scarlet, the hickory with its rich orange, and the maple the harlequin among trees. It is Indian summer. There are great multitudes of wild pigeons. Constant firing shows that the gunners are at work, and the vast pigeon pie at the Inn yielded up some of the results of the prowess.* On our trip we stopped at the little village of Lovingston. Here I visited the County Court House. The doors were wide open. The temple of Justice had little to boast of in architectural beauty. The Court Room was small. A rostrum elevated a few feet with a large arm chair on it and a bench on either side, was intended for the Judges, and upon the white wall over the Cathedra there was emblazoned the coat of arms of the United States. The eagle, which was, no doubt, copied from the impression upon a half dollar, had his neck forced out of all proportions, that there might be suspended from his beak a blue ribbon on which was written the.words 'fiat justicia.' Opposite the Judge's seat was a gallery, and in the front of it were painted the words 'Vertus-Keep God's Commandments-Veritas.' The jury rooms were little bits of apartments with seats, and no juryman, I swear, could ever remain in them for the comfort of the seat he enjoyed there. This is a pretty fair sample of a Virginia Court House.

"The selection of the Eagle as our National emblem is, considering his character, rather unfortunate. $\mathrm{He}$ is a notorious robber. Erasmus thus describes him: 'Of all the birds the eagle alone has seemed to wise men the type of Royalty, a bird neither musical nor beautiful nor good for food, but mischievious, greedy, hateful to all, the curse of all, and with its great powers of doing harm only sur-

*(So effective was the slaughter that at this date-1917 - not one wild pigeon is left of the vast flocks of those days.) 
passed by its desire to do it.' Yet this great Republic has selected this emblem of Royalty, with such a character to represent it.

"We stopped to dine at New Glasgow, a neat little village, pleasantly situated in a fine country, but exhibiting a full share of negro children and broken window panes. We reached Lynchburg. It is on the wane. The streets show spears of grass. The houses want paint; loungers are everywhere; there is a multiplication of dram shops, and a peculiar look about every man, woman and child you meet, indications of municipal decrepitude. Unfortunately Lynchburg is not the only place in Virginia where this is visible. Speaking of the valley of the Holstein River, the inhabitants of this section of the country are chiefly Germans or their descendants, and in consequence the agriculture of the country presents a very different appearance from that I have been accustomed to see. The travel was day and night through rain and snow. When Tennessee was reached, the post coaches were exchanged for Jersey wagons, but strung upon leather springs, a most uncomfortable vehicle, driving sometimes at break neck speed.

"Knoxville, the chief city of East Tennessee, is built upon a bluff. It has a striking and somewhat singular appearance. Cholera was the subject of conversation, as it swept across the land. The food as a general thing was wretched, well described as gastronomic incompatibilities. Nashville, too, is described as being extremely handsome, with very handsome private residences, and comparing well with any city in the Union."

The following is a description of one of the places at which the stage stopped:

"About three o'clock, after a very steep descent to a rapid and angry looking stream, and an equally steep and narrow 
and dangerous ascent on the other side, we reached the 'dinner house,' as it was called, and saw for the first time some specimen of the accommodations and fare that we were to expect as we advanced still further into the bowels of the land. Two log houses of perhaps sixteen feet square had been built about twelve feet apart, and the same roof covered both and also the space between them, which last was thus converted into a sort of porch to both houses. A door from each opened upon it, and there was also a door to each opening to the South. Windows there were none. To obtain light you were obliged necessarily to sit with the doors open. When the meal was prepared, the mistress of the house sat with her chair on the hearth and her back to the fire; and on a cold day, a day like that which met us at the house I am describing, the guests faced themselves as well as they could to obtain a glimpse of the blaze in the chimney. The floor was seamed with open cracks through which you saw the ground beneath, and between every log composing the walls you caught glimpses of daylight, notwithstanding the attempts that had been made to tighten them by nailing clapboards against them. Clapboards, it may be stated, are boards obtained by splitting, like rough staves, but wider. The chimney was of wood, the fire place being protected by coats of mud, which article was also supplied very freely up the flue. The doors deserved the name of gates, so open was their construction, and you stepped from them into a yard where pigs and cows were your immediate companions."

It might be noted here that the cost of the trip is shown by the fact that, when they were four or five days from the end of their journey, the party of seven, consisting of Mr. and Mrs. Claiborne, Miss Claiborne and maid, Mr. Latrobe, the cook, and a Major Dooley (Mr. Latrobe had sent his valet ahead), had spent $\$ 350.00-\$ 50$ apiece. 
Between Tuscumbia and Columbia, Miss., there was an accident to the carriage, which broke down.

"I, on the back seat, was undermost in the fall, and received the weight of Miss Claiborne and Mrs. Claiborne. Mr. Claiborne, on the middle seat, fell under cook and Aimey, the two servants, and the driver fell on Major Dooley, who sat on his left hand. Mr. Claiborne's shoulder was dislocated, but quickly reset by an active effort of his own. It was dreadfully bruised, however. Major Dooley's left arm and leg were seriously cut. Mrs. Claiborne had a severe cut on her forehead. Miss Claiborne's left hand was sprained and her side much hurt. Aimey was shaken and bruised, and I was pretty much in the same condition. The driver was but little injured, and cook escaped unhurt."

The custom of bleeding for nearly every ill, that was so prevalent in the early days, is well illustrated in the cure attempted for these injuries.

"Cook was at first too much astonished to know that he was unhurt, but as soon as that fact was ascertained, he was set to work to bleed Mr. Claiborne who, with his wife and cook, formed a group under one tree. Under another sat Miss Claiborne, quite bewildered, with her maid Aimey crying. Poor old Dooley was on a stump in great pain, and Steen, the driver, and myself were looking in consternation at the wreck of the stage.

"This was the place which our party now entered with gratitude and thanks that even such an asylum was at hand. As we got out of the wreck at the stable three or four white men, looking but one degree removed from barbarism, collected around us in silent curiosity and were joined by the Indians who came forth from the house at our approach, so that quite a procession was formed of which we were 
the principals. You must imagine, for I cannot describe, the looks of the ladies, as they cast their eyes around what we subsequently designated as the drawing room, and saw its utter destitution of every comfort. The weather was changing, too, at the time and very heavy clouds threatened to deluge us with rain in a short while.

"But there was no alternative; the baggage was brought up from the stables, and the first thing done was to bleed the maid Aimey, who was groaning with pain, and to attempt to bleed Miss Claiborne, who complained much of the injury that had been done to her side. This last we found impracticable with the skill of cook. While he was endeavoring to find the vein, I supported her, and ripped up the sleeves of her dress one after the other in hopes that the pulsation might be stronger in one arm than the other. Aimey was too sick to be useful; Mr. Claiborne was lying on one of the beds in great pain and his wife was attending to him. The Indian hostess was busy elsewhere, so that the negro servant and myself were doctor, surgeon, nurse and apothecary to Miss C. While her bare arm was exposed, the white men that I have mentioned came into the hut and stood with rude intensiveness, watching everything that was going forward. I could not stand this and ordered them peremptorily out; and they walked away, laughing at the whole of us. As to delicacy they knew not what it was. Finding it impossible to bleed Miss C., it occurred to me that fever might be prevented by medicine, so I got out my Seidlitz Powders, and under the appellation of 'Cooling Draughts' (she knew no better) administered two of them. Neither Mr. C. nor Aimey, who were bled, nor Charlotte who took the medicine, had fever, so I am satisfied with the equal efficacy of the two modes of depletion."

In Mr. Latrobe's journal we find the following in reference to his second marriage: 
"The year 1832 was the year of the Cholera, and when the August holidays came I hesitated in what direction to seek the summer vacation, which the work of the year made agreeable, if not essential. Accident settled the question, and I went to the White Sulphur Springs. At the Springs I met my present wife, the handsomest woman there and the most admired. I followed her to Botetourt Springs, and at the end of a courtship of less than a week was engaged to be married to her. This was in August. I ran a great risk, most people would say; so I did, but I drew a prize, for a better wife never man had. I could fill a sheet or two with honest heart-felt eulogy, but my children know their mother too well to need my praise to satisfy them with her worth. She went to Mississippi to her mother, and I returned to Baltimore to communicate the information to mine. And then to follow Miss Claiborne to her home, and marry her.

"On the first of November I set out on my long journey by stage coach from Baltimore to Natchez, passing through Washington, Lynchburg, Knoxville, Nashville, and the Indian Nation. At Nashville I overtook Miss Claiborne, who was traveling home inland, having been driven by the Cholera from the Ohio and Mississippi. She was under the care of Mr. and Mrs. Jas. H. Claiborne, and we made a party and completed the journey together. Had an upset and other adventures on the road, but got through safely. On the 6 th of December 1832 we were married at 'Soldier's Retreat,' my brother-in-law's plantation, and on the 13 th we set out for home, mine and now hers. On the 7 th of January 1833 we reached Baltimore and I returned to my office after an absence of two months and seven days.

"The Lady Franklin, a steamboat well spoken of, was recommended to me and I kept a good look out for her. 
WESTERN BLOCK HOUSE, FORT ARMSTRONG

On the Mississippi River, drawn by John H. B. Latrobe 


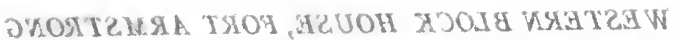

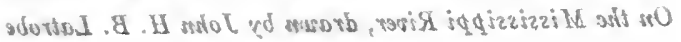




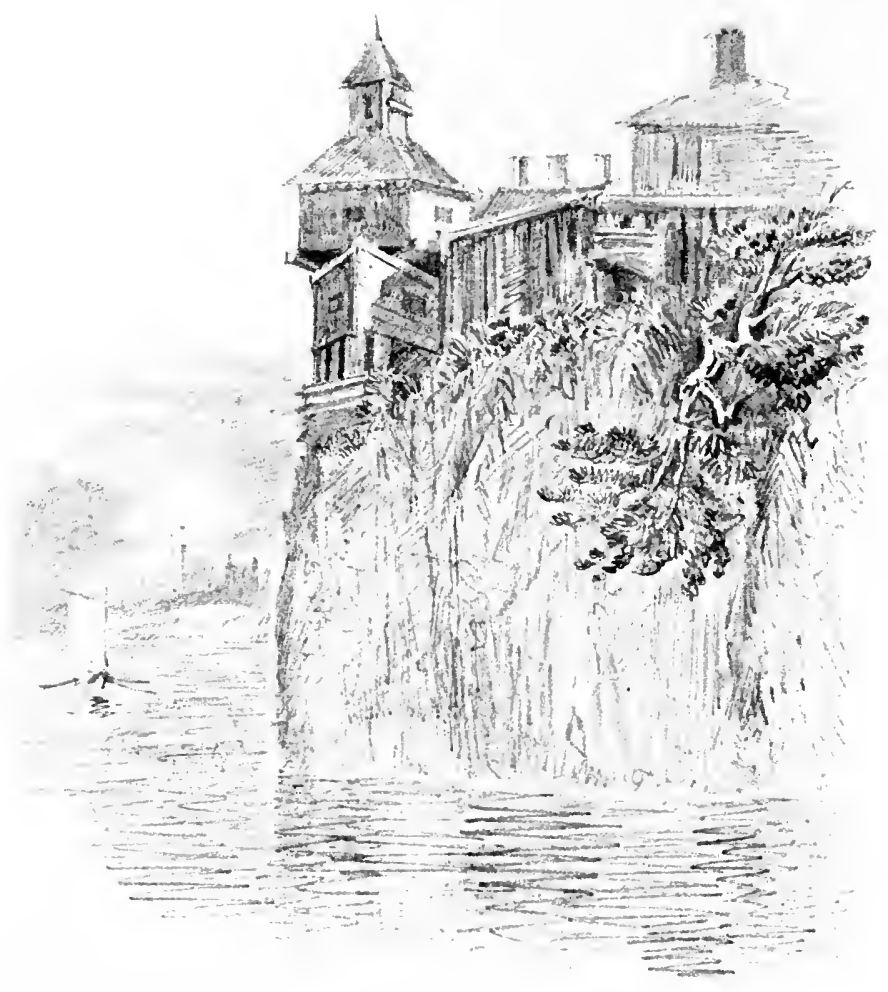



It arrived on the morning of the 10th, and I embarked with Charlotte and our two servants, Aimey and James. The steamboat stops to wood twice a day, in the morning and in the evening, and several times we wooded after dark. The scene then presented was singular and striking. The huge fire at the woodyard, built to guide the laborer, as well as to serve as a sign by night to passing boats; the steamboat with its many lamps and candles shining through the windows, and the blaze and heat from its open furnace; the deck passengers in their various colored costumes and the sailors hurrying to and fro on the plank from the boat to the shore and carrying their burdens of wood; and behind all on one side a dense, black forest, and on the other the wide and noble river reflecting every light as it whirls along.

"There are two descriptions of passengers on a boat on the Mississippi-deck passengers and cabin passengers. The former are generally flat-boatmen on their return home, and nothing more is provided for them on board than the conveyance and a shelter from the rain-sometimes the book-shelf hammock (hammocks suspended three deep, one over the other like hanging book shelves). They pay $\$ 7.00$ from New Orleans to Louisville, finding themselves in everything, $\$ 5.00$ if they assist in wooding the boat when it stops for that purpose. The transportation of them is clear profit.

"One of the handsomest men I ever saw in my life, the very perfection of manly beauty, was one of our passengers. He was a Kentuckian, of about twenty-nine or thirty years of age, who also 'belonged to the river' occasionally and was returning home from a trip with a kit to New Orleans. He was dressed in blue worsted homespun, with a black ribbon around his neck instead of a cravat, and wore a 
white hat the rim of which had been bent in every direction by the rain and its usage, and the front of which was turned up, which gave a bold expression to his good humored features.

"From one of the passengers from St. Louis, where he had resided while it was yet a French town, I heard a very amusing story. 'Did you ever hear of a King Ball?' he said to me one evening, as we sat before the cabin fire together. 'No,' I replied, 'What is it?' 'It is a thing that may cost a gentleman $\$ 400.00$. When I was at St. Louis, $\mathrm{J}-$ asked me if I would go with him to a King Ball at old S___'s, the Governor's interpreter for the Indians who were then in the neighborhood in great numbers. 'Yes,' I said, 'what's to pay?' 'Oh! nothing, it's a King Ball, costs nothing, so come along.' And down I went with him. The house was large and the rooms brilliantly lighted. The beauty and fashion of St. Louis were there, and in a little while I was perfectly at home and amused myself amazingly. In a pause in the dancing, a young girl, very beautiful and as graceful and dignified as you can imagine, came up to me and, with a bow, pinned a favor on my coat. I bowed and bowed without knowing what to say or do, when suddenly shouts of Vive le roi resounded in the room. Old S- was at my side. 'You are de King, Monsieur,' he said. 'Well, what then?' I answered. 'You must lead de queen to de trone, Monsieur.' 'Eh bien!' said I; and I led the lady to a small elevation at the upper end of the room. She stepped on it and remained standing. Again old $\mathrm{S}$ - whispered 'You must salute. Dat is, kiss de queen, Monsieur.' 'Eh bien!' said I, and I kissed the prettiest little pair of ready and ruby lips I ever touched, and in return my queen handed me a bow of ribbon. Old $\mathrm{S}-$ again prompted me. 'You must make de queen her favor, 
Monsieur.' 'Eh bien!' said I; and I pinned the favor on the dress of my pretty companion. She made me king, and the least I could do was to make her queen. And then the company shouted 'Vive la reine'; and again old Swhispered, 'Salute de queen, Monsieur;' and again I saluted her. The dance was then resumed, and we broke up a little while before dawn, after a merry night.

'The meaning of my coronation was now explained to me. Old S- informed me that, in the first place, I must provide for the next ball, which he would undertake to direct, but which I must pay for; and, in the second place, I must dress the queen for the occasion from top to toechemise, jupe, etc., were all to be paid for by me, and Mme. M. would attend to all that if I gave her the order to do the needful. So I gave the order and the ball was given, and in revenge I put the Kingship on the friend who got me into the scrape. The last act of the play was to pay $\$ 400.00$ for cakes, coffee, chemise, jupe, etc.; and this is a King's Ball, or was rather-for when the Yankees got among the French at St. Louis, they could not stand the cost and broke the pastime up all together.'

"You can see by referring to the map the States along which we went in the Lady Franklin. One morning we stopped at Arkansas, and, when we had finished wooding, the owner of the yard came aboard, saying that he had been robbed by two of his choppers the night before and that they had gone up the shore. He thought that they might hail the Franklin for a passage and he determined to go for a few hundred miles in the hope of catching them. Sure enough, the next morning the boat was hailed at daylight, and three men came off in the yawl which was sent for them. They were the thieves, and the first person they saw at the gangway was the man that they had robbed. 
The plunder was upon them, so that denial did not avail them, and, after exacting restitution, it was determined to set them ashore.

"There was a Kentuckian on board who was the personification of the character of a child of 'Old Kaintuck,' as we loved to call it, off-hand in his manner, thin in his person, a quick eye and aquiline nose, with long dark hair, tall but not ungainly, and every step indicating fearlessness and decision. He had attracted my notice from the first day I saw him. He played cards every night, and lost and won with as much nonchalance as that of a dandy lord, and in his red flannel shirt, home spun trousers, and broadbrimmed hat, sat alongside a well dressed man with the easiest self-composure at 'vingt et un.' This morning he offered to take charge of the thieves who were to land on the same spot with himself. 'I tell you what, you see. I am all sorts of a fellow, and could lick a dozen such critters as these in no time,' he said, as he proposed taking them to gaol anywhere. There was no gaol nearer than sixty miles, so he could not have been in earnest, but he persisted in seeing the vagabonds ashore, and the last we saw of him he was ordering them into a poor hut on the bank and following them in with his rifle on his shoulder and his powder horn and shot pouch at his side.

"We reached Point Chico, the county seat of Chico County in Arkansas, on the afternoon of the day when the above occurrence took place, and saw there the best looking building for many a long mile. It was the tavern and the Court House under the same roof. A tall building built of logs was the gaol, the cell being the second story of the edifice, reached by a ladder on the outside. A gentleman whom we took on board here and who had lived for many years at Little Rock, the seat of Government, gave me 
FORT SNELLING, ST. PETER'S, ON THE MISSISSIPPI Drawn by John B. B. Lalrobe 


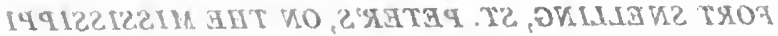

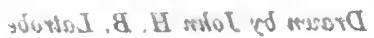




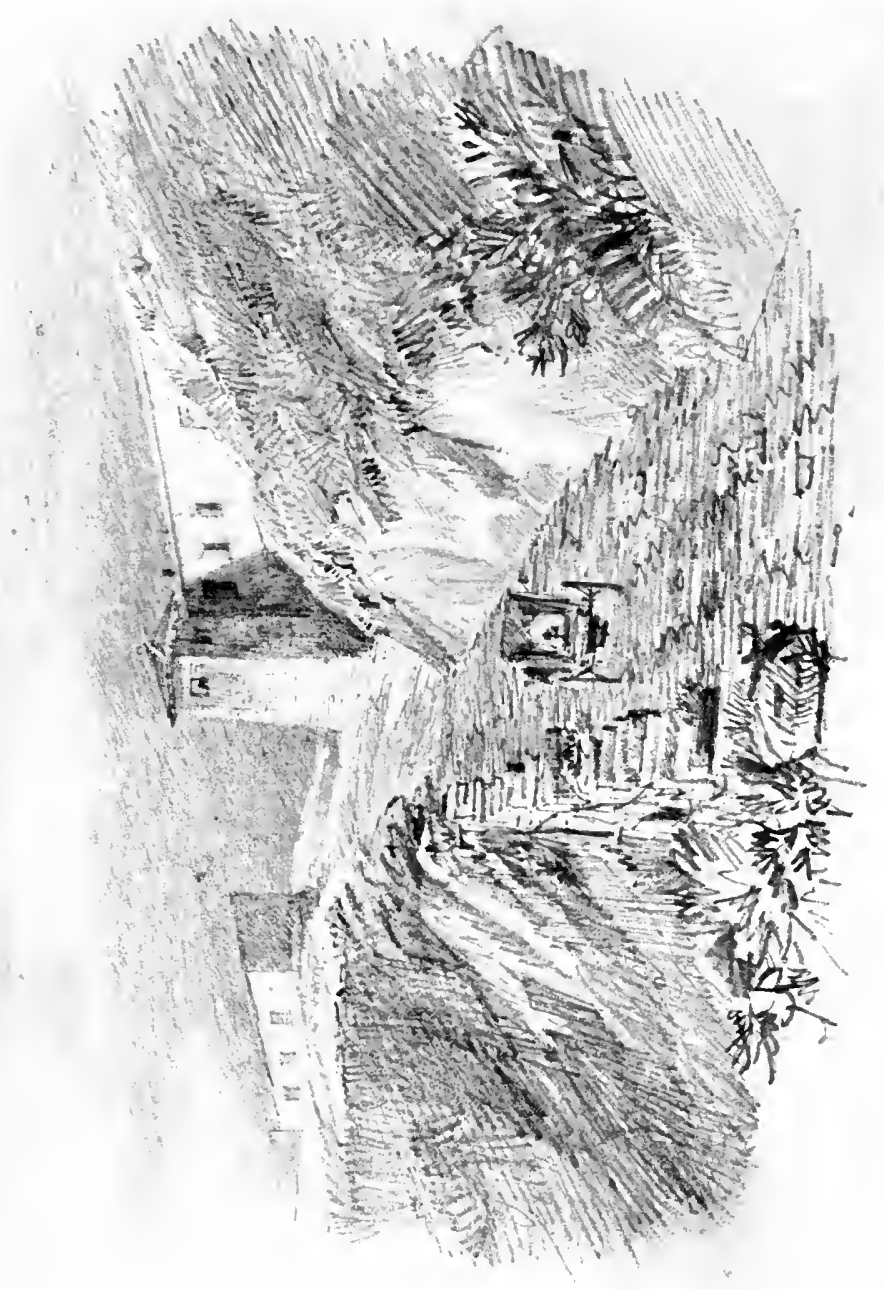



some curious sketches of the state of society in the Territory. All men go armed, and the rifle, the dirk, or the pistol make their mark on all persons who are aspirants for office, and who are not barely submissive to imposition. He showed me the knife he carried. It was called a Bouy (Bowie) knife, from its inventor. I had often seen them before. Bouy was once engaged in a personal rencontre, and, when in the grasp of his antagonist, drew out his Spanish knife and could not open it, as he had only one hand at liberty. $\mathrm{He}$ was worsted, and the Bouy knife was the consequence of his defeat. It is a knife that can be opened with one hand by pressing a spring on the side with the fingers as you clench the handle. The blade is like the blade of a Spanish knife, about six inches long, pointed and remaining open, until closed by raising a catch on the back of the handle, and yet what is all this against our country?* These people of whom I speak are all our pioneers. They have fought with the wilderness and overcome it, and if they have lost the polish of society (if they ever possessed it) or acquired the manners of isolated people who eat with their arms in hands, yet they have added a portion, and a goodly portion, to the great country which is the pride and the hope of the free spirits of the world. I am writing at this moment in Cincinnati. I am in the midst of a population of thirty thousand people. I have every evidence of the highest civilization, the greatest luxury and the most advancing improvement around me; and yet a gentleman, with whom I have just been conversing, has described to me a state of things existing on this very spot within the last twenty years not better by any

*This description was written in 1832. Bowie lost his life at the Alamo 1836. The knife we know as the Bowie knife is shaped somewhat like a scimitar without the spring. 
means than now is to be found at Little Rock in the Territory of Arkansas.

"The approach to Cincinnati is much like the approach to Louisville for the similarity of the landing at both places. At Cincinnati, however, it is wider and, as it appears, better paved; but there is the same singular effect produced by the crowds of people and carriages moving over the sloping bank. Cincinnati and New Orleans are the two great cities west of the mountains, and it would take me a volume were $I$ to attempt an account of either of them. I remained four days in Cincinnati, and walked over it in every direction. It is more like an eastern city than any city I have visited west of the mountains.

"But one need not go into the interior to find rough and uncouth manners. The river bank furnishes enough. The distances of Courts of Justice, the thin population, the ignorance of the inhabitants, the thousand ways of escape from the consequences of a crime by forest, cane brake, or by water, offer so many inducements to violence and fraud of every description, that it would be strange if this part of the land were exempt from them. Counterfeiters and the passers and venders of counterfeit money abound, and $I$ was asked twice to give my opinion upon two one hundred dollar United States Bank notes that had most evidently been ten dollar bills altered. They had been received by a deck passenger for goods out of his first boat at a place near $\mathrm{M} \longrightarrow$ on the river. I found at one wood chopper's that the mulatto owner of the 'Yard' had a good looking white wife, and at another wood-yard an Indian had just killed his wife-a white woman also. No notice seems to be paid to these things here. Justice and punishment appear to be out of the question, and, when we told of the murder at the next wood-yard, the only reply was "serves her right for marrying an Indian." 
"At Memphis the Captain agreed to take in tow for St. Louis the "Enterprise" which had broken a wheel. It was in the night that this agreement was made, else it would have been opposed and prevented by the passengers as certain to make much delay, but in the morning when they discovered their consort it was too late to do anything but complain, and this was indulged in most freely. The passengers, however, were divided in their opinions. Some were for taking her on, and others wanted her to be left at the first village we came to. I was for leaving the boat, as we had every reason to fear that a day's delay might prevent our getting to Wheeling, on account of the ice. A constant war of words was kept up until we reached Madrid. The Captain, to whom we addressed a petition, brought the Captain of the Enterprise to our cabin, where he made us a speech; and when the question was taken, it was decided in his favor, and he gave the passengers a "Wine Treat" in consequence. It turned out, though, that we suffered a delay of twenty-five hours on account of our taking in tow the Enterprise."

Mr. Latrobe's first impression of Memphis is thus recorded:

"Towards sundown we came in sight of Memphis at the end of a long reach in the river. It is situated on a bluff of naked clay soil, marked here and there with iron and having a barren and unpromising appearance. The town occupies considerable space to the right and left.

"On the 21st day of December we passed New Madrid, which is celebrated on account of the earthquake of 1812, which laid the greater part of it in ruins. The earthquake and the first steamboat visited it at the same time, and the inhabitants, it is said, at first scarcely knew which to fear the most. 
"We arrived at Louisville soon after breakfast, and our boat stopped among a crowd of others at the public landingslope, paved from top of the bank to the edge of low water, across which drags, carts, wagons, horses, men, women and children were hurrying in every direction going to and from the various vessels arriving and departing. Without this pavement the approach to the river would be always difficult and often impracticable; as it is, the rise and fall of the water cause no inconvenience, the equal grade of the slope indicating at all times to the pilot the limit of prudent approach to the shore and affording to the various vehicles employed on the land the easiest access to the water's edge. But the effect, as you approach, is singular and picturesque. Louisville is so important a place that it would take more time to describe it than I can spare. The public buildings are not deficient in taste, and many of the private ones are in first-class order. Kentucky has every reason to be proud of this one of its cities. Steamboats are arriving and parting at all hours, and as you walk the streets their bills stare you in the face everywhere. 'The Homer for New Orleans,' 'The Hawk Eye for Cincinnati,' 'The Rambler for St. Louis,' etc. Taverns are numerous. Upon one of the latter I copied the following enumeration of its attractions. 'Hot stews, hot punch, pig's feet, toast and tea, egg-nog, fried tripe, ham and eggs, beef steak and coffee, buckwheat cakes and honey.' The Falls of the Ohio are here passed by canal-the Louisville and Portland. This is truly a magnificent work. The locks are of hewn sandstone of a very fine grain, and are four in number. The closeness of the masonry, its neatness, its perfection, cannot be surpassed. The canal extends two miles in length, and is crossed by one bridge, a costly one of stone of three arches, equalling in execution the locks below. 
"We left Louisville in the evening, the day having been occupied in discharging the freight which the Lady Franklin brought up from New Orleans. By day break we were at Madison, a pretty thriving town in Indiana, where we stopped for four hours. The cabin passengers determined to celebrate Christmas day, and some of them went into the town and purchased all the Chinese firecrackers it contained, and then young and old, like so many children, amused themselves in setting them off. Truly, we had all gotten tired of the steamboat and resorted to anything that offered variety. The evening before I had taught some of my fellow travelers to play old bachelor, and when I got up the next morning I found that seven of them had sat all night at it and had gone to bed pretty well corned, as they say here; for they had played for a "treat" round from the old Bachelor and, having played some twenty or thirty games or so, they had drunk as many times. I had taught them solitaire as we came up the Mississippi, and it was amusing to see half a dozen of them, some old Kentucky boatmen, trying to arrange the suits in their sequence hour after hour, not speaking a word, except to swear to themselves occasionally at their disappointment, or to chuckle in the same manner at their success. Cards were indeed the great standby on the journey. Brag and Vingt et un were the favorite games. Money was always played for, and there was a party of Brag players who played very deep and between whom large sums were alternately lost and won. One had little society if he looked for similarity of taste, jesting and pursuits, but it was the very company for one who was a stranger in the land to pick up knowledge, in which to note classes of character and to see the habits of a peculiar and new people. Sometimes old Fagan, who had been thirty years and upwards on the river, would 
begin to dilate with a singular grandiloquence upon the coming glories of the West, and interlaced his conversation with anecdotes of the "Massesseppa," as he could recollect it. Then there was another man who told me of his fights, who was upon the river when it ran towards its source during the earthquake of New Madrid, and whose flat boat had actually ascended for more than an hour retrograde waters and then rushed back upon them with horrible velocity as they returned to their usual direction."

\section{THE CLAIBORNE FAMILY.}

Miss Claiborne was a descendent of William Claiborne who in 1625 was appointed Secretary of State for the Colony of Virginia. On April 6,1642, the King appointed him Treasurer of Virginia, for life.

In 1631 Claiborne, who had a grant from Charles I, made a trading settlement on Kent Island in the Chesapeake. The proprietors of Maryland claimed that the Island was included in their grant. The date of the Calvert grant was after the date of Claiborne's. Out of this grew what is improperly known as 'The Claiborne Rebellion.'

A struggle ensued, and several of Claiborne's men were killed and captured. Two of his vessels were taken, and he was expelled from the Island in September 1651. He was appointed one of the Parliamentary Commissioners the next year, and expelled Lord Baltimore's Governor. In 1654 the Claiborne party defeated the Lord Baltimore party, led by Governor Stone, and remained in possession until 1658.

One of the most rapid criminal proceedings of which we have a record grew out of this conflict.

In the harbor of the great Wicomico, Waren (agent of Claiborne) met Captain Cornwalles, of St. Mary's, in the 


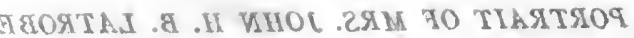

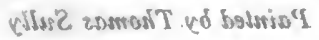




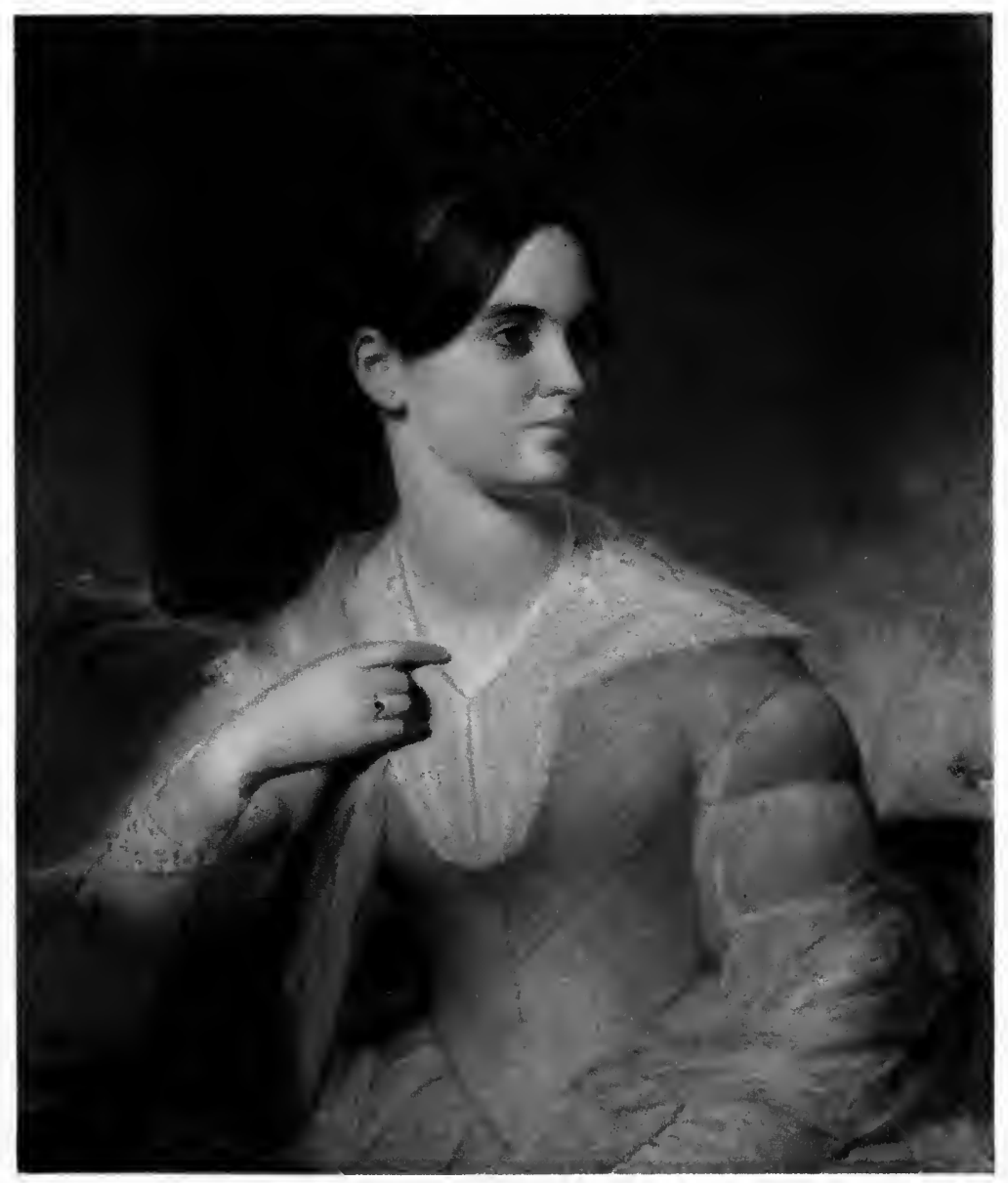



pinnace St. Margaret, and a fight ensued. Waren, John Belles and William Dorsey, of the Virginia party, were killed. Thomas Smith (Gent) was taken prisoner.

The fate of Smith is told in the Act of Assembly, 14th of March, 1637 (twenty-four freemen, names given):

"Then was Thomas Smith called to the barre, being indicted of pyracie, and the Secretary made himself attorney for the Lord proprietor and read his Lordship's warrant in that behalf. Then did the attorney put in an indictment and an arraynment, and demanded that the prisoner might be brought to trial upon his indictment, and the indictment being read, he pleaded "not guilty" . . . . Found guilty, except by one John Halfehide, who said "not guilty." Then sentence was pronounced in the name of all of the freemen, that Thomas Smith should be hanged by the neck until he be dead. Then did the prisoner demand his clergy, but it was answered by the President that clergy would not be allowed in this case, and, if it might, yet now it was demanded too late after judgment."

Here as will be seen, the Assembly acted as grand jury and petty jury. A unanimous verdict was not given. That any action of the prisoner should be too late, in such an expeditious trial, seems strange.

The benefit of clergy is sometimes confused with sanctuary.

A great iron knocker hangs on the outer door of Durham Cathedral. In olden days sanctuary was conferred on a man accused of crime who succeeded in reaching this knocker. There were many other places of sanctuary in England.

Benefit of clergy grew out of the great respect shown in olden times to those who could write, and the fact that it was chiefly the clergy who possessed the knowledge and ability.

The third Volume of Bacon's Works, 252, gives the origin of this practice: 
"This having their books is called their clergy, which in ancient times began thus. For the scarcity of clergy in the realm of England to be disposed in religious houses, or for priests and deacons, and clerks of parishes, there was prerogative allowed to the clergy, that if any man who could read as a clerk were to be condemned to death, the Bishop of the Diocese might, if he would, claim him as Clerk, and he was to see him tried in the face of the Court, whether he could read or not. The books were prepared, and brought by the Bishop, and the Judge was to turn to some place as he should think meet, and if the prisoner could read, then the Bishop was to have him delivered over unto him to dispose of in some place of the clergy, as he should think meet, but if either the Bishop would not demand him, or the prisoner could not read, then he was to be put to death."

MR. LATROBE IN RESFONSE TO A REQUEST TO DELIVER A LECTURE ON CLAIBORNE

"November 20, 1848.

"J. P. Kennedy, Esq.,

Chm, \&c. \&c.

My dear Kennedy:

I am far too much of a used-up man just now to adventure anything out of the beaten track of office duties; so that the Historical Society will have to find some other orator, and poor Claiborne's memory must bear a while longer all the obloquy which any effort of mine might relieve it from. In truth I am by no means certain that I could do his memory much service; although I have at times thought that sufficient allowance has not been made by history for the effect of circumstances on a strong-willed energetic man who, wiser than most of his contemporaries, was necessarily misunderstood and depreciated by them when they became 
his chroniclers. I must have a year or two's rest, however, before I can begin to look seriously into my memoranda on the subject.

Ever faithfully yours,

Jno. H. B. Latrobe."

We are now finding out that Claiborne's claim was probably better than that of the Calverts. In an address delivered by the late Bradley T. Johnson at Easton, July 26,1888 , he says in this connection:

"The actual foundation of the Eastern Shore was laid at Kent Island by Colonel William Claiborne, under the patronage of Sir William Alexander. William Claiborne was the first Eastern Shoreman, and no man has been so universally vituperated by Maryland and Virginia historians. Instead of being a rebel, or the "malignant Claiborne," as Mr. Bancroft calls him, or "the evil genius of Maryland," as Chief Justice Taney stigmatizes him, recent investigation has proved that he was a gentleman of ancient and honorable family, of high ambition, of great energy and untiring pertinacity, and that his life was one long struggle to protect his rights against the aggressions of the Calverts, to whom he was superior in both social and political influences."

An uncle of Miss Claiborne was Governor of Mississippi and also Governor of Louisiana, and a United States Senator. Her father, General Ferdinand Leigh Claiborne, was famous for his defeat of Waterford and the Creek Army. 


\section{CHAPTER XI}

Life after Second Marriage-ACquaintances AND Clients-Friendship With Charles Harper aNd His Estrangement Due to His Marriage-The SettleMENT OF THE CONTROversy OVER THE WILL AND CODICIL of Charles Carroll of Carrollton.

"With my marriage good fortune seemed to come. I moved from the house in Lexington Street west of Pine, where $\mathrm{I}$ found my mother on my return from West Point, to a house in the same street between Calvert and North Street, next door but one to what is now the Newton University, and to this I brought my wife.

"My brother had been sent to St. Mary's College on my mother's return from New Orleans, and graduated there in due time with much distinction. He then read law with Mr. Charles F. Mayer, and, as my business was not enough for two persons' support, went to New Jersey and opened an office in Salem County, at Alloways Town. This was a suggestion of my uncle, Mr. Samuel Hazlehurst who, with my mother, possessed some woodland hard by, of which my brother was the agent and which gave him something. But this business was uncertain. He left New Jersey where he was in some petty practice in Alloways Town, but where he was dying almost with fever and ague, and made his home with me. He was well read in the profession and, had he continued in it, would have made a mark; but he detested it. One day at dinner a friend and guest asked me, in my brother's presence, it I could help his brother to procure a situation in the engineer corps of the Baltimore \& Ohio R. R. Co. I promised to do my best. After dinner, when 
we were alone, Ben surprised me by asking for the influence in behalf of my own brother that I had promised to the brother of my friend. He had made up his mind, he said, and was only too glad to give Blackstone the go-by, and begin at the foot of the engineering ladder. And in a day or two he was measuring broken stones for ballasting on the track of the Railroad west of Ellicott's Mills at $\$ 1.00$ a day, as happy as a lord and as healthy as an Indian. When he retired very recently from active work in the profession, he was at the top of the ladder at whose foot he stood in 1829. And this is the way in which he changed professions.

"It was a swap between us. I had been educated as an engineer and became a lawyer, and he, educated as a lawyer, became an engineer. L'homme propose, et Dieu dispose.

"A friend of mine in those days, attracted by the part I took in Colonization, was Moses Sheppard, a Quaker, who was my friend through life, and he and I were delegates on one occasion to Washington at the annual meeting of the American Colonization Society. He was a man whose wisdom was sententious and profound. He spoke in epigrams. I think he loved me about as much as he loved anyone. Living in the narrowest way, his task was accumulation, and he left his money to found a lunatic asylum. He gave a little himself to Colonization, but he got others to give. He refrained from giving, not because he was mean, but because he had an object that could only be accomplished by accumulation. When he died all our mutual acquaintances wondered why I had no part assigned me in the execution of his plans. I wondered, too, and so much wonder was expressed that I was annoyed. It was only within the week in which I am now writing that I fell in causually with his nephew who knew all about it. I was to have been put in 
charge of his plans and his will was prepared accordingly. I had indeed drawn the technical part of it, names left blank, when, to use the words of my informant, "just at the moment shortly before his death when such a thing could be done, he was persuaded to put others in your place." What or who the malign influence was, was not told me, but I was glad to hear the explanation that Moses Sheppard died my friend. Well, he and I worked hard for Colonization anyhow in those days, and I have been a steady worker since."

The character here depicted-a man who, apparently mean, was really not so, having a worthy object that could only be accomplished by accumulation-has had many prototypes. Moses Sheppard's money is now used to support what is known as the Sheppard and Enoch Pratt Institute situated in Baltimore County, Maryland, near Towson. John $\mathrm{McD}$ onough, the founder of the McDonough Institute of Baltimore County has the following recital in his will: "They said of me 'He's rich, old and without wife or children; let us take from him what he has.' Infatuated men they knew not that this was to take from themselves; for I was laboring all my life not for myself but for them and their children." This is but a replica of the character of Godinot, whose reputation as a miser gave him the name of the "Griper." He had been impressed with the need of the poor and led a life of extreme frugality, that his savings might be laid out in building an aqueduct to furnish them with water.

As an indication of Mr. Sheppard's interest, the following letter, written just after Mr. Latrobe lost his first wife, is of interest:

"I enclose check for $\$ 50$. I do not give you this fee as a stimulant; as such it is not necessary. I do not give it 
in the belief that any apprehension exists that a due compensation would be withheld at the termination of the case. But as the painful occurrence to which you have lately been subjected must have detached your attention from pecuniary affairs, I give it now because I think it might be useful.

Jno. H. B. Latrobe.

Moses Sheppard.

12 January, 1831."

"But this is an episode. To get back to the bar and my married life. The first fancy ball ever given in Baltimore was one for which I manufactured out of pasteboard and tinfoil a complete suit of plate armour for 'Don Quixote,' whose character I assumed. It remained in the family stored away in a barrel, which long years afterwards was placed in the corner of the school-house at 'Fairy Knowe.' I had forgotten it, and was startled one day to find that a servant man, black as the ace of spades, had arrayed himself in it, and could not be extricated in time to escape detection when he heard approaching footsteps. It was predicted that this armour escapade of mine would do me a professional disservice, but I survived it; and it is referred to now as an indication of the mechanical turn that was afterwards so eminently useful to me as counsel in patent cases. I had shaped boats as all boys do, but my plate armour was an achievement.

"Turning not long since to the book in which are entered all the fees I ever received, I am reminded of more than one incident of my career, at this period of my life. Of John Bouis, the snuffy old tinman and lamp maker, for whom I drew my first specification for a patent; of Henderson and his biscuit machine, for whom I tried my first patent case; of old Richard Shipley, the builder, gaunt, quaint and square-shouldered, for whom I turned mechanical knowledge 
to account; of Mathew Smith, the Quaker client, who gave me my first trustee business, one of the kindest, truest and best of men, whose wife, surviving him many years and dying at a good old age, was a woman of remarkable intelligence, and fit mate for such a husband; of Barrett, the shipping master, who swore by me, because he found I knew the nomenclature of a ship from truck to keelson, and drew one to aid him in his explanation of a case of assault and battery he brought to me; of Charles Howard of S., the tobacconist, who from being my client became my student, and learned Latin well, while he rolled cigars with a grammar open before him-dead now, and the children even of many of them passed away.

"At one time during my student life and early practice, I had some temptation to turn my attention to literature as a profession. I had, as already said, written upon more than one subject, and found little difficulty in slinging words together. Among other things that came from my pen were three tales published in successive years in the Atlantic Souvenir - 'The Esmeralda,' founded upon the capture of the vessel of that name by Lord Cochrane, in the harbor of Callao; 'The Mortgage;' and 'Giles Hetherby,' the last two being purely imaginative. My nom de plume was 'Godfrey Wallace,' a signature that I adopted for some rhymes that the Atlantic Souvenir contained, the most pretentious of which had some little credit given to it and was called the "Bower of Paphos," being written to suit an engraving so named that was sent to inspire me. Had I been willing to work in the same way, I would have found, I think, a good deal of employment in penny-a-line literature. Luckily, however, I had other views and stuck closely to the law.

"On the same floor with Kennedy's office was the office 
of his fidus achates, Peter H. Cruse, a lawyer, too, more addicted to literature than to law, and who was at the time of his death editor of the 'Baltimore American.' We were excellent friends, and I saw a great deal of him, being a frequent visitor to his room. He was a very able writer and a man of great information, genial, too, when not out of sorts with the world which treated him below his merits, a polished gentleman of the highest sort of honor, and one of the most affable men in the society of Baltimore. One of those men who everyone thinks ought to make their mark, and yet don't make it. He died of the Cholera in 1832 .

"In the room of Mr. Cruse there was often a clever reunion of good fellows. Josiah Pennington, Kennedy's most intimate friend, Charles Blodgett, Charles Walsh, Alexander Turnbull-all names that I now recall. Pennington was a man of reading and given to the law, a hard and successful worker in the profession, who attended to his business thoroughly and profitably. Charles Blodgett was an odd, eccentric, learned man, of great wit and keen observation, another of the unmarking men. Charles Walsh was another lawyer also given to literature and a musician. He wore the fetters of the profession lightly, and made no mark. Alexander Turnbull was a merchant, and a very estimable gentleman, whose friendship for the society of literary men made him seek Cruse's room, which was perhaps a center of it in Baltimore.

"But while I consorted with these, all older than myself, I was oftener with William Gwynn than any other. The Federal Gazette office was my house of call when I had an idle hour. I was on terms of familiar intimacy with $\mathrm{Mr}$. Gwynn, and wrote for the paper, or rather he published what I wrote. I found the other day a number of articles in which I reviewed an exhibition of paintings at the Balti- 
more Museum. I wrote rhymes, too, and the carriers' addresses, I think I have already said, for many years. With no claims to poetical power, I think I did, at all events, better than my predecessor in the office I assumed.

"I forgot to say, when stating that I had become a member of the Philokresian Society, that I was elected in the third year of my membership to deliver the annual oration. The audience was a large one and very fashionable. I refer to this only because it introduced to me many friends that I found useful afterwards. My oration was jejune enough. I read it some years ago without discovering that I had been a Demosthenes then.

"I remember that on one occasion, when Mr. Gwynn was temporarily absent, he left the control of the editorial columns to me, and, as ill luck would have it, in my ignorance that John Randolph, of Roanoke, and himself were intimate personal friends, I wrote a few paragraphs headed "The last of the Powhatans" (Cooper's novel "The last of the Mohicans" was then very popular), in which I described Mr. Randolph, as I thought and still think, justly and not in the most flattering manner. On the return of $\mathrm{Mr}$. Gwynn, he was advised of what I had done by a reproachful letter from Mr. Randolph. As a matter of course an apology appeared in the columns of the Gazette and my editorship came to an untimely end.

"I think that I was employed in 1831 to dock the entail of Dougheragan Manor, "The Manor," so called parexcellence, of Charles Carroll. A deed of bargain and sale to his grandson, with a covenant to stand seized to the use of Mr. Carroll for life, did it. But the family was a divided one. A portion of it denied Mr. Carroll's competency to do any lawful act concerning his estate, and, as I knew how matters stood, it was my intent that the circumstances 
attending the execution of the deed should be such as should clear my reputation as a lawyer in the event of its ever being assailed. There never was perhaps a deed previous to the signing of which more pains were taken to satisfy bystanders of the capacity of the maker. The scene was an impressive one. There were many visitors at the Manor. The Judge who was to take the acknowledgments, the late T. B. Dorsey, was one of them. All gathered in the back parlor on the right of the hall at my request, and, seated in his easy chair in the center of the room, a man of ninetyfour, with a clear, though thin and passing voice, Mr. Carroll, without being aware of the object of the conversation, waited to speak of the motives that induced him to break an estate that had existed for generations, and of the scope and effect of the instrument he was about to sign. Subsequently, in the course of the litigation that followed Mr. Carroll's death and growing out of his will, the deed here referred to was spoken of, but its validity was never assailed, although portions of the will of prior date were regarded as the act of a man of an unsound mind.

"The litigation here mentioned had an effect upon my feelings and friendship, if not on my fortunes. I might pass over the matter as one which has lost its interest, but there are still alive those who may tell to their children a story that may be repeated to mine, and therefore I make my statement of my connection with the will of Charles Carroll of Carrollton.

"The will of Mr. Carroll was drawn by Mr. Taney, except the last codicil which I prepared. What the will contained I neither knew nor cared to know. Whether the Caton or the Harper branch of the family fared well under it never entered my mind, when Mr. Caton, saying he came on the part of Mr. Carroll, asked me to prepare a codicil 
which would forfeit the interest under it of any party that questioned the validity of the instrument. This I did and the codicil was executed. When Mr. Carroll died and the will was opened, it was seen that the Caton branch was benefited to the prejudice of the Harper branch and of Charles Carroll, the grandson of the testator. That I was innocent of any purpose to injure my most intimate friends, Charles Harper and his sister Emily or their mother to whose kindness I owed so much, was at once understood by all three. That I should have had any agency, however unconsciously, in doing what they conceived to be a disservice was a subject to me of great regret, and they were sure of it. But Mrs. Charles Harper took a different view, and, from this time out, she became my 'unfriend'-this is the gentlest word I can use. She made it her business to speak of me most unkindly or worse, and, I have every reason to believe, impressed her mother with the conviction that I had been guilty of some gross wrong to my best friend. Under such circumstances the intimacy that for years had been that of a brother with her husband could not continue. Also, although Mrs. Gen'l. Harper and her daughter, to this day, did me justice, Mrs. Chas. Harper died, I fear, without forgiving me for an act in which I was as guiltless of wrong as any act of now a long life time. That I had no interested motive antagonistic to that branch of the family that thus became separated from me needs no argument to prove. And when the litigation commenced, I returned the retaining fee that was sent me on the part of Mrs. McTavish who was the representative in the contest of the Caton branch. I do not know whether I suffered any actual injury in general reputation or primarily, on account of this lady's persistent unkindness, but, unquestionably, I suffered much in feeling, and even now cannot refer 
to this period of my life without sorrowful regret. Charles Harper was to me as a very dear brother, and the friendship that existed between us has never been entertained on my. part for another of my subsequent acquaintances, nor, so far as I can learn, was my place with him afterwards filled. There are women who desire that their husbands concentrate all their affections on themselves. I think Mrs. Charles Harper was such a woman."

This episode of his life made a lasting impression. The above is a recital of the break which occured in 1832. In his diary 19th February, 1834, he writes "A page in my life:"

"What I am about to record gives me pain; so much so that I have more than once hesitated to proceed with it. But I owe it to myself-to my children-to leave some record of circumstances which from others may receive a very different gloss from that which I will give to them.

"My bosom friend was Charles C. Harper. His father, General Robert G. Harper, was my father's friend and my friend. When I left West Point, where I was educated, I entered his office as a student at law. I was on terms of the most intimate footing in his family. I had a place always at his table. He gave me his countenance. $\mathrm{He}$ spoke kindly of me in the world. His confidence was mine. In truth I owed everything to him. He was my benefactor. I loved and venerated him, as though he had been my father. No father could have done more for me. History will pronounce his eulogy. He was one of the great men of America, and his friendship for me was the highest honor I ever enjoyed. I followed him to the grave. I designed his monument and I wrote his epitaph. Charles Harper, his son, was about my own age and became my bosom friend. His father's death made us more intimate 
than ever. When he married Miss Chiffelle of South Carolina, I tried to love her as I loved him. I had no other intimates, and there was nothing that I would not have done for Charles Harper and his wife. Upon commencing the practice of the law during General Harper's lifetime, I had obtained the business of Charles Carroll of Carrollton and his family, which I enjoyed until the death of $\mathrm{Mr}$. Carroll in 1832. Charles Harper, his wife, mother, sister and brother went to France, Charles as Secretary of Legation to Mr. Rives. While he was absent I frequently wrote to him and he replied regularly. Distance made no difference in our friendship. While he was in France, Mr. Carroll gave to his grand-daughter, Mrs. McTavish, the Folly Farm on Doughoragan Manor. The world talked much of this at the time and I wrote the gossip of the day to Charles, advising him to come home and attend to his own interests. During his absence Mr. Caton, Mr. Carroll's son-in-law, brought me one day a memorandum from which to prepare a codicil to make void the legacy of any one of the distributees who should dispute any of Mr. Carroll's previous acts. I advised against the preparation of such a codicil as likely to produce unpleasant feelings, and suggested the propriety of surrounding Mr. Carroll with witnesses who would testify to his competency hereafter. I was told this had been done-that Mr. Carroll wanted the codicil drawn, that Mr. Taney who had done such things heretofore was in Washington, and that, as his regular attorney, Mr. Carroll had fixed upon me to prepare the instrument. I did so, and in the codicil took especial care that it should have no prospective operation, that it should not protect itself even; so that while, if (as I believed he was) Mr. Carroll was competent to execute it, it would be binding upon his heirs and legatees, they would run no risk in disputing it 
on the ground of his incompetency. The fact of competency was one, to the investigation of which I was determined that the codicil should interpose no obstacle. In all this I was influenced by a wish to act fairly between all the parties. What dispositions had been previously made of his property by Mr. Carroll I knew not, nor could I anticipate any objections that the codicil might be subject to, unless those arising out of Mr. Carroll's mental capacity at the time. That he was imbecile was, I knew, asserted by some. I did not believe it, however. Still I would have preferred that the codicil should have been prepared by another than myself, and I drew it with reluctance, and under a sense of professional obligation. My refusing would have merely devolved the task on another, and one, too, perhaps, who, without my feeling of friendship to all concerned, would have made the instrument in all respects more exceptionable than it was. I therefore drew the last codicil of Mr. Carroll's will. Hinc illae lachrymae. I immediately wrote to Charles Harper what had been done by me, explaining to him all the circumstances. I told other gentlemen, the friends of Charles Carroll, Jr. of Homewood. I made no. secret of the codicil. All this trouble I took, anticipating future objections and desirous to let the true state of the case be understood. I disliked having to draw the instrument and did it only because I thought it my duty to prepare: it when requested. Never for a moment did I believe that I had violated one of the obligations of friendship in what I had done.

"On the return of Charles Harper from France, I told" him all about the codicil, nor did he say one word from which I could infer that he was displeased with me on account of it. On the contrary our friendship was, if anything, more intimate than ever during the year 1832. I designed the 
addition to his house at Oakland. I was constantly there, took my child there, and when I became engaged to be married to my present wife, Miss Claiborne, he was for a long time the only confidant that I had. With Charles Carroll, his cousin, I was on equally good terms, though he, too, knew I had prepared the codicil, because I told him so. In the fall of $1832 \mathrm{I}$ went to Natchez and got married. On my return I found Mr. Carroll dead. The town was full of the will and codicil and I found that persons had said that, considering my intimacy with the Harpers, I ought not to have drawn the last codicil. I saw Charles Harper, however, whose wife was in Charleston, and although he did think, as he now said, that I should not have drawn it, yet he explicitly declared that it made no change in his feelings. It is true I could not understand why he should now think otherwise than he had done when I just told him of the codicil-but so it was. We were now at Annapolis together, and as intimate as ever. We went up the Potomac together, slept in the same bed, and our friendship knew apparently no change. In the spring of 1833 Mrs. Charles Harper returned home from Charleston, and I called upon her. I told Harper I would take my wife to visit her. He said she owed the first visit to my wife and would pay it. She did not, and when I met Harper he apologized and made excuses for the delay. At last conversation led in the fall of 1833 to the subject of the intercourse between our wives, when Harper said that his wife viewed my drawing the codicil differently from what he did and was offended, but that he hoped it would wear away in time and all would go right. I ought to mention that on my return from Natchez, the executors of Mr. Carroll had sent me a retaining fee of $\$ 100$ in the suit then pending between them and the legatees of Mr. Carroll, Harper among the rest. I declined receiving it, returned it, and 
excused myself from interfering in a cause where my friends were to be my opponents. This was a loss to me of about $\$ 1,500$ or $\$ 2,000$. I will also mention that I had met Mrs. Harper but once, and then she was freezing cold to me. The suit commenced soon after Mr. Carroll's death has just been terminated by compromise. The sanity and competency of Mr. Carroll have just been admitted. The will and the codicils have been proved; and at all events the instruments that I have prepared were executed by one of sound and disposing mind in the view of the world. So far I am satisfied. But this is nothing to me. The friendship of early life is broken up. Ever since the return of Mrs. Harper from Carolina the manner of her husband towards me has been changing, and we are now wholly estranged. I told him to tell her, in the hope of propitiating her, that I was sorry I had prepared the codicil- not that I thought it right for me to do so but because I was sorry that any instrument prepared by me should be a subject of anxiety or discontent to my friends, and I told him further to say all that a gentleman might say to a lady, without lowering himself, to make her satisfied. But in vain. Ever since her return, as I have said, the breach has been widening, and the bosom friends of years are now separated, perhaps forever. I attribute it to Mrs. H. I cannot think it is H's fault. He has sacrificed his friend to his wife; and if his wife demanded the sacrifice he could not do otherwise. I feel most deeply the loss of his friendship. I cannot supply his place. Never did I intentionally violate one tie of friendship, never forget an obligation. His conduct showed he did not think that I had done so, until other influences than his own good feelings worked upon him, and he became to me an altered man. I cannot bear him malice, though I think he has wronged me. I can but wish him well. I hardly think his heart acquits him." 
This friendship was the cordial "drop that made the nauseous draught of life go down." The fact is, this was one of the cases of a woman's jealousy of the friendship of her husband before their marriage. Mrs Harper took advantage of the fact that Mr. Latrobe had written the codicil to Mr. Carroll's will to break off the friendship between her husband and him, which was unquestionably of the closest character. Their letters to each other show how intimate they were, and how devoted to each other; but Harper's marriage resulted in a breach. In this connection, I find among the correspondence some letters from Mrs. Chiffelle, the mother of Mrs. Harper, in which she demands a picture of Charles Harper, claiming it as her property. Mr. Latrobe replies that the picture is his-that it had been hanging on his walls since 1828. Charles Harper apparently died in 1836-37, and it would seem reasonable that if this property belonged to Mrs. Chiffelle, she would have demanded it during his life, as they were estranged in 1833-34. Mrs. Chiffelle claimed that the picture had been left with Mr. Latrobe in order to enable him to make a copy of it. The result of this controversy was that Mr. Latrobe gave the picture to Mrs. Harper, the mother of Charles Harper.

After Mr. Carroll's death the parties interested in. his estate settled their differences by entering into the agreement set forth below. The clause suggesting the possibility of Legislative action to enable Mrs. McTavish to exercise the right of Executrix was due to the fact that her husband was a citizen of Great Britain, a Scotchman, and had never been naturalized. As after marriage the wife became a citizen of the country of her husband, it became necessary that Mr. McTavish should become a citizen of the United States. On February 24, 1834, he accompanied Mr. Latrobe to the City Court and there declared his intention to become a citizen. 
"The following are the terms on which the differences now existing in reference to the probate of the last codicil to the will of Charles Carroll of Carrollton have been adjusted by the counsel for the respective parties who have been fully authorized for that purpose:

"First. The caveat is to be withdrawn and the will and codicils immediately probated.

"Second. Mrs. Emily McTavish is to be appointed sole executrix and should it be found necessary to enable her to act as such, an application with the assent of all the parties is to be made to the Legislature for a law to authorize and empower her to act, she not to charge any commission, but not to be subjected to any expense.

"Third. Mr. McTavish and Doctor Stewart to renounce the trusts under the will and codicil except as to the Caton branch of the Carroll family.

"Fourth. The deeds from Charles Carroll of C. to Mrs. Emily McTavish and to Charles Carroll of Homewood for parts of Doughoragan Manor to be confirmed either now or hereafter, if required, by the several parties to this agreement, or their representatives.

"Fifth. The claims of Mr. Charles C. Harper, Mr. Charles Carroll of Homewood, and Mrs. Emily McTavish, and their respective branches of the family for negroes, \&c. received from the testator since the last codicil aforesaid made in 1831, as also the claims of Mr. and Mrs. McTavish for the notes of Charles Carroll of C. for $\$ 14,000$ and the contracts in reference to the building on the Folly Farm, the materials, hauling and so forth not yet paid or settled for by the estate of Charles Carroll of C., to be referred to Judges Stevenson Archer and Richard B. Magruder to be decided by them, and should they differ, they are to choose a third person, and then the award of the majority of the three to be final between the parties. 
"Sixth. The award of Richard Caton to be opened and the subject matter of it to be referred to referees to be chosen in the manner hereinafter specified. The referees to act under the same instructions and authority as the former referees who made said award were instructed and authorized to do, and as if Mr. Carroll's letters to the former referees had been directed to them. A case to be docketed against the executrix and this reference to be under a rule of Court, to which the terms in this stipulation are to apply. The award as it now stands shall not be impugned or impared by this assent to open it, should this reference by any means be frustrated, but it is to remain in full force and operation as it now does or ever did. The referees are to make their award during the present year; should they not, then this reference to be void. The referees are to be paid equally by the parties for their services. The counsel on each side are to name two persons, from whom each is to select one, the two thus selected to be the referees, and if they differ, then they to choose a third person and the award of the majority to be final.

"Mrs. Mc'Tavish is not to pay Mr. Caton's award, nor do anything to give validity to said award until a new award is made or Mr. Caton recovers his claim by a suit at law in the event of no award taking place.

"Seventh. In the litigation or examination before the arbitrators of the matter referred, the questions involved in the several issues are not to be agitated. In other words it will not be contended in opposition to the claims of Richard Caton and Mr. and Mrs. McTavish or any of them or those of any members of their families against $\mathrm{Mr}$. Carroll's estate that Charles Carroll of C. was incompetent, or that he was subject to the undue dominion or under the undue influences of any one, or that he was urged by any importunities which he was too weak to resist. 
"Eighth. It is expressly agreed and understood that no attempt shall be made by any of the parties to this agreement to enforce the forfeiture under the said last codicil for litigating before said referees any of the matters referred to them by and under this agreement, or for anything that has occured up to this time.

"Ninth. Should any further points of difference arise, which the counsel on either side signing this agreement should deem to have been omitted in the aforegoing stipulations, the same are to be decided either by the arbitrators now agreed on in this agreement, or by a common friend or friends as provided for in the will of Charles Carroll of Carrollton.

Baltimore,

12 Feby. 1834.

Reverdy Johnson,

John V. L. McMahon,

Charles Carroll.

"Charles C. Harper for himself and for Emily L. Harper and Robert G. Harper.

Richard H. Bayard,

J. Lee,

Fred'k. A. Schley,

Jno. Nelson,

W. S. Heath,

John Glenn,

Rich'd. Caton, for himself and

Louisa Caton, Marchioness of Carmarthen, Mary Caton

John McTavish for himself and as

Attorney for Mary Ann, Marchioness of

Wellesley, and Elizabeth Caton,

Emily MacTavish.

True Copy, Test,

Thos. Kell, Clerk." 


\section{CHAPTER XII}

Trip to New OrLeans by Sea and Return by Land, 1834Ratders and Natchez TrIP-NeW OrLeans and the QUADROON BALL-TRIP IN 1835 TO NEW ORLEANS AND Return With Wife to White Sulphur Sfrings.

"The health of Mrs. Latrobe after the birth of Ferdinand, our first born, became precarious and comparatively feeble, and Dr. Chatard; our family physician, advised a sea voyage and a winter in the South. We embarked at New York in the good ship 'Arkansas' in December 1834, and after a pleasant voyage, for the season, and a stay for a short time in New Orleans, reached 'Soldier's Retreat,' my brother-in-law's plantation. On her arrival here my wife had a severe attack of Cholera. As soon as she was out of danger, I returned to Baltimore via New Orleans, from which city I traveled by land, after crossing Lake Pontchartrain, to Weldon in a stage coach, and from Weldon to Baltimore by stage. I was twelve days on the road from New Orleans. In a volume of manuscript which I have labelled "Odds and Ends," I have collected letters and journals giving a detailed account of my visits to Virginia Springs and to Mississippi."

In these "Odds and Ends" I find the following description of his departure from Natchez, the journey down the Mississippi in a steamboat, the story of the destruction of the Natchez tribe of Indians, and a description of the City of New Orleans.

"November 1834, Natchez. The leaves are falling from the trees in thousands, in consequence of a frost, and make 
CINCINNATI (LOOKING UP THE OHIO), 1832

Painted by John H. B. Latrobe 
SE81,(01HO AHT QU DИTXOO.I) ITAVVIJKI')

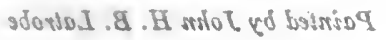




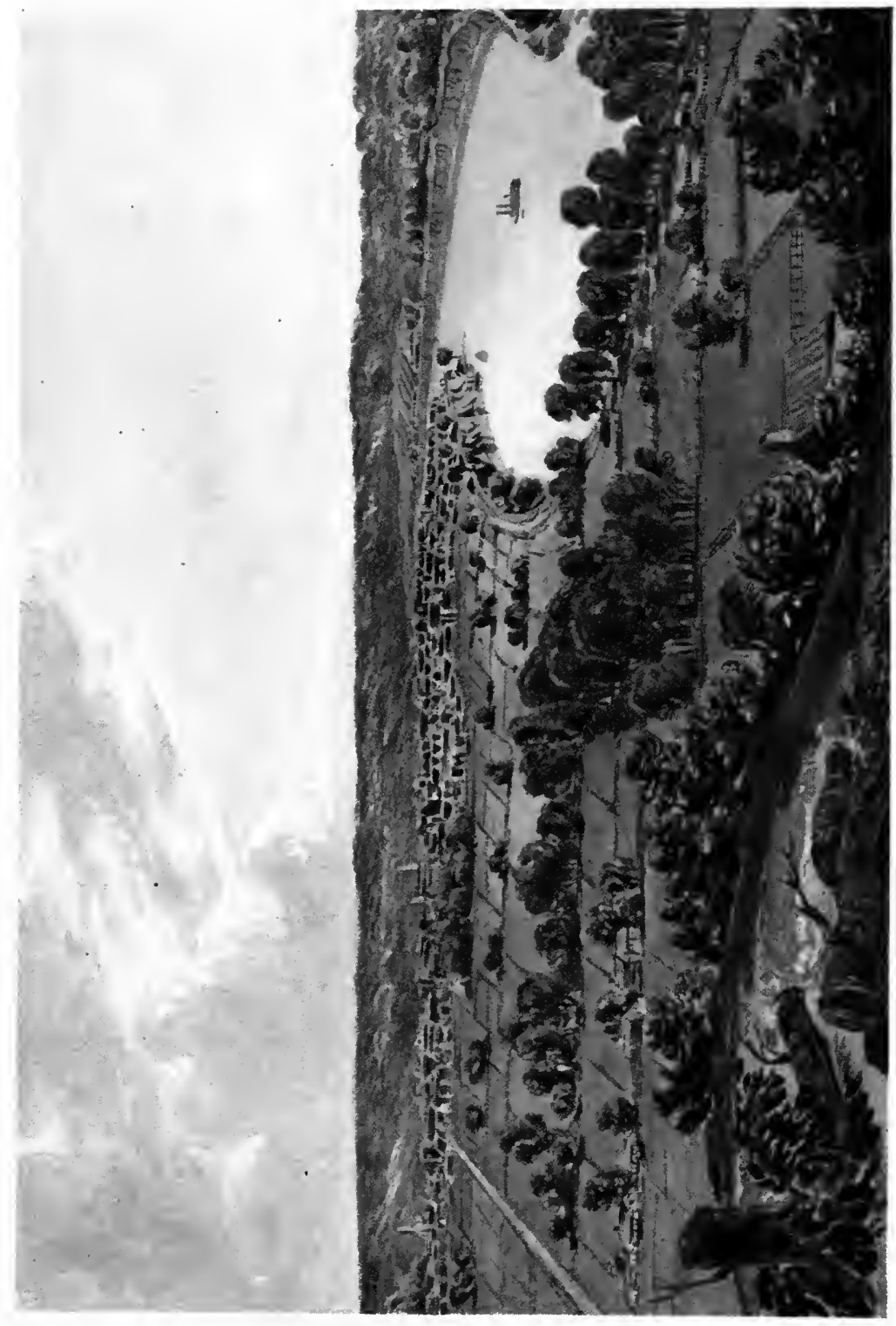



a melancholy rustle as they fall. There is not a breath of wind stirring. The sun shines brightly on the variegated foliage of these huge forest trees, and the air has a crisp and invigorating tone. It is such a time as this, that makes one acknowledge the truth of the beautiful and poetical name which we give to this season, when we entitle it the "Fall of the Year."

"Eighteen miles below Natchez we stopped at Mr. Hutchins, my wife's maternal uncle, to take in a quantity of cotton, which was piled on the banks waiting for a conveyance to New Orleans. I availed myself of the opportunity to call on Mr. Hutchins, and, while the boat laid along shore, had a most interesting conversation with him. He is an amiable and intelligent man, of upwards of fifty years of age, and was the first white man who was born within the limits of the state. He has been successively under the French, Spanish, English and American rule, and has experienced all the perilous experiences of a new settler in a new country. His father emigrated from Carolina to the banks of the Mississippi, and located himself near the village of "White Apple," one of the principal chiefs of the Natchez tribes of Indians. For several years the number of white people in the neighborhood did not exceed thirteen, and there were around them one thousand Indians to every white man. After the birth of Mr. Hutchins in 1774, the country. still remained very thinly settled, and it was interesting to hear him speak of the time during the last revolution.

"New Orleans was then a paltry village, and Natchez had no existence; and the upper Mississippi was considered a wilderness peopled by savages, who would not permit any intercourse with the Atlantic seaboard, or the country about the Alleghanies in that direction. The only flour which could be procured came from France, neatly put up 
in water tight casks lined with paper, and was sold readily at $\$ 25$ per barrel or cask. Tea was $\$ 10$ a pound, coffee and sugar $75 \phi$ per pound; salt $\$ 8$ per barrel, and other things in proportion. Freight to New Orleans was in those days at the rate of $\$ 5$. per barrel, and the length of the voyage was from 30 to 40 days. Everything was scarce, excepting venison and wild turkey-to say nothing of bear meat. There was food for everybody, if they were content with these. Beyond this nothing could be obtained, except at seasons, and at exorbitant prices. But little land was cleared, and Indian corn was not yet planted to any extent. Even this common grain was a rarity and a luxury. The fields had to be watched day and night as the ears approached perfection, to preserve them from the devastation of the Indians, who took with no affectation of secrecy whatever they could lay their hands on of the new product. Even when the settler succeeded in gathering some ears and boiling them for his table, if an Indian was seen approaching during a meal, the dish was hastily hidden, for the savage knew no ceremony and practiced no politeness. He helped himself, unbidden at the board, the weak hands around which not daring to provoke his anger by refusal.

"The war which raged from 1776 to 1783 gave rise to no hostilities on the banks of the lower Mississippi, and, excepting a single incident, peace, the most profound, prevailed during the entire period in this remote region.

"One bright spring morning, while my informant, Mr. Hutchins, was still an infant, the unaccustomed sound of a horse's hoofs was heard in the recesses of the forest, near White Apple Valley, and soon after a troop of white men, mounted on sorry horses and clothed in various guises, but well armed with sword and rifle, were seen urging their way along the narrow path until they emerged 
in the little clearing around the dwelling. The father of the family was away, his wife and her children, with a number of negroes, which last constituted his wealth and made him here a rich man, were left without their usual protector. Mrs. Hutchins, more astonished than alarmed at first by the coming of the strangers, spoke to their leader in terms of kindness and courtesy, and tendered him food for himself and his companions. She was answered by loud denunciations, in which her husband was charged with being a British subject, and liable in person and property to the Americans. The rude and ruffian troop yelled their approbation, and in the name of Congress proceeded to make themselves master of all the valuables they could find, and particularly the slaves, who were at once placed in strict confinement. Nothing was spared that could be carried off, much was destroyed, whose bulk prevented it from being turned to account. After some hours of stay, the troops rode off, having reduced Mr. Hutchins to poverty, and, passing through all the settlement in the same way, vanished as suddenly as they had appeared.

"This, it is true, is but the old story of a border foray, committed by land pirates, who at this period plundered indiscriminately on either side, under the flag that suited them best at the moment, and which it cost them no scruples of conscience and subjected them to no punishment to assume. Nor should I have told the tale here but for the sequel which followed. Ten years after the robbery just described, Mrs. Hutchins was accosted on a street of New Orleans by a man dressed in rags and bearing many marks of wretchedness, sickness and poverty. He held out his hat for alms like a beggar and told some incoherent story of distress. His strongly marked features caused her at once to recognize him as "Willing," the border plunderer, and 
she accosted him by name. She would have given him alms in silence, but she could not, and, as she dropped the money into his hat, she told him it came from the same hand, from which he had forced the silver spoons that she had prayed him to leave as a relic of the family, ten years before, near the White Apple Village. She repeated her words, when she saw the shame and confusion of the humbled outlaw, who then received good for evil when he probably least expected it. Before she returned home, she learned that he had perished in the street. The family is still in existence, and hold a most respectable rank in one of the Northern States.

"From Mr. Hutchins I heard the story of the destruction of the Natchez tribe of Indians. I had heard it before related, but forgot the details, and I now give Mr. Hutchins' narrative. He had it from his father, in whose lifetime it took place, and who got the particulars from the Indians themselves.

"When the French were in possession of the highland now named Ellis Cliffs, the bluffs at the present site of Natchez, they made the acquaintance of the chief of the White Apple Village which is situated about six miles from the former place and some distance from the banks of the River. He was a kind old man, and well disposed to the Whites; and he had great influence in the Natchez tribe of Indians, to which he belonged. He had a daughter, a warm hearted and beautiful girl, who became attached to a French officer who was stationed at the Cliffs, and, as the story goes, he returned her affection. For some time the French and Indians lived in great harmony; but the French at last became desirous of acquiring the cleared land of the Indians. The chief agreed to surrender the land, after they had harvested their crop. Not content with this concession, the French drove the Indians away and took possession 
of their land and crops. A great council was held by the Natchez, Choctaws and Chickasaws, at which it was agreed to attack the French. The time was fixed; and to each tribe was given a bundle of rods. One of these was to be drawn each day, and when the last was drawn, the tribe was to set forth to attack the French. The daughter of White Apple had assigned to her the duty of drawing the rods. She warned the French through her lover, but they paid no attention to her warning. She saw that they made no preparation to meet the threatened attack. She determined to draw two rods instead of one, to hasten the moment for the movement of her tribe, hoping that the French would be able to resist the assault of a single tribe, and thus escape destruction. When the bundle of rods was exhausted, the Natchez tribe began its march. Finding no one at the rendezvous they fell upon the French and massacred them. The other tribes arrived the next day, and seeing the Natchez had not kept faith with them and were inclined to boast of their action in destroying the French without their help, they fell upon them and annihilated the entire tribe of the Natchez, who from that day have been extinguished.

"I have seen many Choctaws on this journey, prowling about New Orleans and Natchez. Two years since I saw the tribe on its way to the Mississippi, the other side. The individuals I now meet are those who have been to their new home and returned. They are generally displeased with it, and are wandering off in various directions. Many persons think that in a few years the tribe will be extinct, and its members dispersed among other tribes or living about the settlements of the whites, finding an early death, the result of intemperance and improvidence. 
NEW ORLEANS AS MR. LATROBE SAW IT IN 1834.

Upon gaining the land once more, I found myself opposite the lower end of the vegetable market, a long and imposing building, supported on columns rough cast, and forming the shape of a "V" between two streets which have intersected each other very obliquely. Immediately in front of the levee, or raised mound interposed between the river at high water and the City, a crowd of men and boys were engaged in a game of ball, which gave rise to every species of vociferation. Among others were the Indians, their legs bare and a coarse sheet on their shoulders which did not cover the seat of honor. A cloth apron about eight inches deep scarcely answered to make them absolutely decent. Numbers of people were around, and the whole scene was unique for Sunday afternoon. Further on I came to the meat market, a building of excellent proportions formed by colonnades of square piers and arches. They were busily engaged in sweeping both markets, as I passed along, preparatory for business tomorrow morning. After pursuing La Rue De Levée until I came to the public square, I crossed and had before me the Cathedral, the Calaboose and the buildings in which the Courts are held. The Cathedral is a venerable looking building, for time and the climate have discolored the plaster with which its bricks are covered. It has a steeple and two towers, and its general effect, although it will not bear architectural criticism, is good. The Calaboose and Court House are on the other side of it, match each other and, with the Cathedral, exhibit to the coup d'oeil quite an imposing aggregation of Law, Religion and Punishment. Immediatcly in front of the Cathedral on the levee, vendors of various sorts of goods are holding open market, shouting forth in French and English and the negro patois the merits of their goods to passersby, while 
NEAR THE WHITE SULYHUR SPRINGS Painted by John H. B. Latrohe

Worsld you know where healls moy be wer found Till Time in his course Engulph her

$T$ is in that bright spot that the hills surround The found of the fomed White Sulphur.

(Jokn H. B. Latrobe) 
यूरा

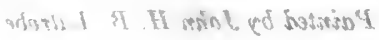

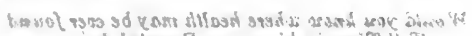

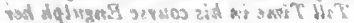

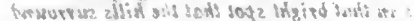

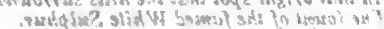
3

yderios. Al. 11 and. 


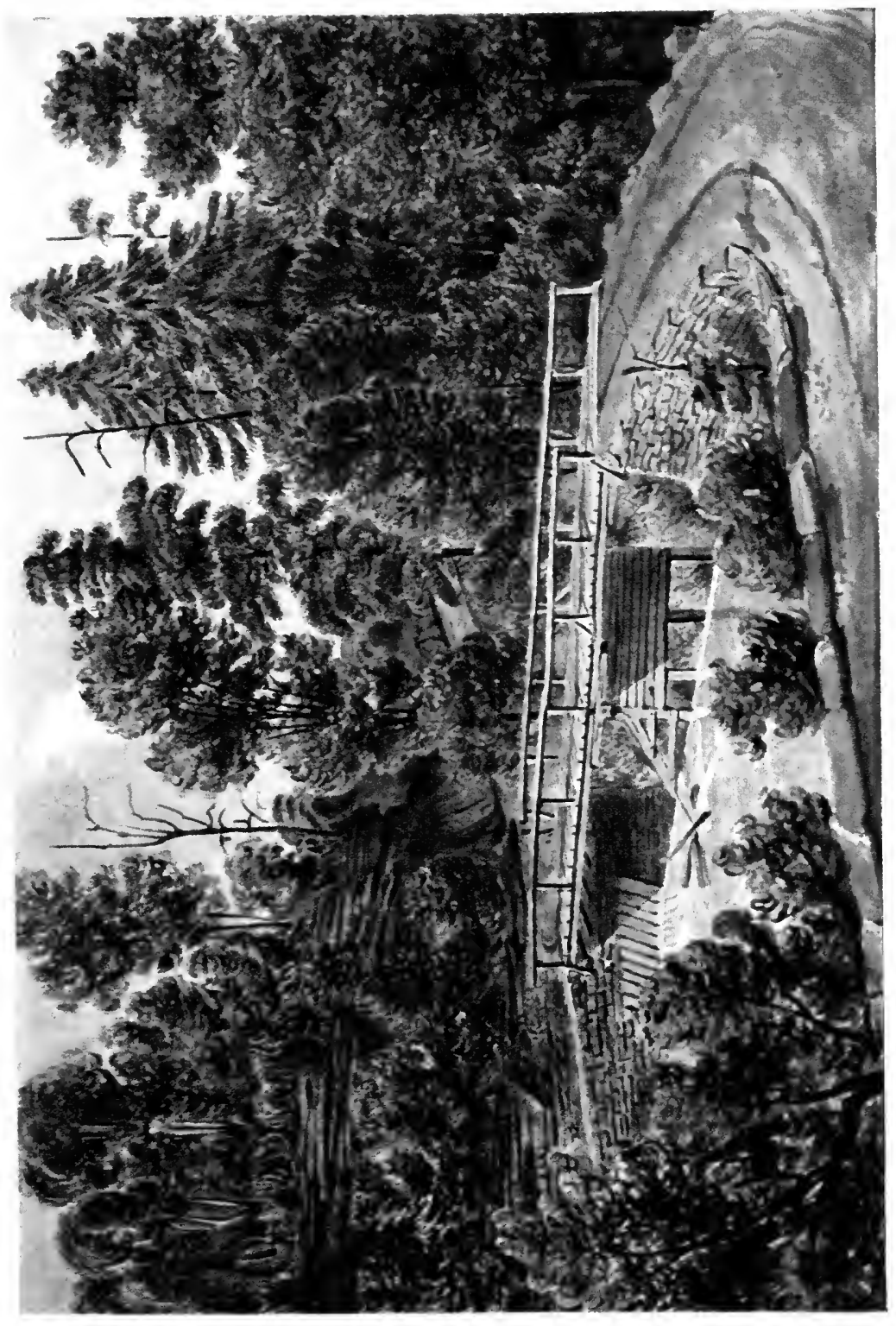



the seven bells of the metropolitan edifice were summoning the faithful to their prayers. In all the streets abound caf's; and barrooms, it would be unjust to call them grogshops, were open and in the receipt of a full and noisy custom. Rum and gin, Monongahela, and Tom and Jerry here live in palaces; and the genius of Intemperance driven from many of her dirty altars in the streets, alleys and cul de sacs of the Northern Cities may well console herself with the taste, elegance and refinement of her shrines in New Orleans. The drinking room is large, the ceiling high, a handsome lamp or chandelier hangs from the midst, a whole army of bottles with contents of all colors line the shelves in close array all around, and the counter with its marble slab or mahogany board decked off with shining brass work and full decanters, completes an arrangement for beastly gratification, such as is reserved for New Orleans, to an unequalled extent. But what is this in the public square? Soldiers in a gay and tasteful uniform are passing to and fro, and sundry thumps upon a bass drum speak martially to the ear. "Oh, nothing at all, Sir." "The weather is fine, and a volunteer company is going to church, I suppose." "Nothing less true, they are going to have a parade, which will end in taking refreshments at the Café Des Citoyens there at the corner." "Ah, well, that is all, is it? A pleasant time I wish them." "Allons! what next, you need not look with such astonishment." Nothing is more common than the billard tables which are in constant use today, and that shoemaker there whom you see in his shop stretching his arms so vigorously over his last is doing what all around him are doing-working on the Sabbath. Even will not the shoemakers be idle, an industrious people like this. St. Crispin's servants ought to keep quiet for one day in the seven at all events. Faith, these performances, though 
brandy may be drunk, and bons bons sold or bargains made, or soldiers drilled, make something of the picturesque. $\mathrm{Ha}$, what's that fine figure, a beautiful foot, an ankle like an angel, an air quite distingué, and all so strange and characteristic, so Spanish, with a long black veil over her head. "Allons! we will pass her, she is a mulatto." "Not at all, don't let her hear you, that is a quadroon." "A quadroon! Well, I'll know better next time. And are those quadroons on high there on the balcony that projects from that Spanish looking house with ornamental cornice and window frames and flat roof? One of them has a veil, and all that I see are darker than her we have just passed." "Heavens, no! They are creoles, native white, Spanish and French mixed, born in the country, very good society. No, indeed, they are not quadroon, you must make the distinction." "Faith, so I see, and here are more balconies, and more females, and there sits a solitary cigar smoker on a balcony by himself, and in another, look up at it, two old ladies. Quadroons?" "No, they are mulattoes." Well, be it so, the two old mulattoes are smoking cigars, under that pent house that projects from the edge of the tiles.

". . . . The City of New Orleans to the north of Canal Street. In the City there are whole squares filled with houses built during the time of the French and Spaniardslow browed dwellings, looking as if partly intended for defense, with entrances through courts. You want no guide to tell you that they are not American or English. They give a character to the quarter in which they are that cannot be mistaken. They abound in the picturesque, and were I to remain a long time here, nothing would give me more pleasure than to take views down many of the streets that I passed through today. The doors that I passed by were generally occupied by the female part of the inmates, and 
they were, in most cases, quadroons, or French of the inferior class, for the fashion of this quarter of New Orleans by no means corresponded with its picturesque appearance. We went to the Catholic burying ground. The tombs here are peculiar to the place. No grave could be dug of the usual depth without coming to water, and to obviate this difficulty in the sepulchre of the dead, the coffin is laid upon the surface of the ground, and a strong structure of brick built around it. This is then plastered and whitewashed. In some there are several bodies, and in others only one. On one side of the yard there is a range of catacombs, like the cells of a honey comb, in which the coffin is placed, and the mouth closed with a stone containing an inscription. I was informed that these cells were purchased for various lengths of time varying from 1 to 10 years, and some were owned in perpetuity. When the lease expired, the tenant, or what remained of him was removed, when the feelings of the relatives could not be shocked by the idea of his being burned instead of buried. The bones or remains are then piled together and burned. As Col. Hamilton says, all the people here are burned, and then the premises are ready for a new tenant. One of the cells was opened this evening.

"We passed the French theatre, a large and extensive range of buildings, containing also the City Assembly Room. At the further extremity is the home in which the quadroon balls are held, and the tickets to both being the same price, the holder of a ticket to the white ball, when tired, goes out, and exchanges with someone who has been among the ladies of the mixed blood and who gives his ticket to get into the crowd where the taint is moral, not physical.

"From the theatre we went to the French coffee house, 
or, as the sign over the door proclaims it to be, the "New Exchange." It is a very large room, with two columns in the centre which support the cciling. From the last are suspended four splendid chandeliers that make a blaze of light around the appartment. Around the walls are the usual notices of an exchange, sales arrivals, departures, \&c. A large portrait of Napoleon of full size in oil is on one side of the apartment, with General Washington for his vis-à-vis on the other. Here as elsewhere is a bar or counter where the usual refreshments are to be obtained. The coffee house has always a crowd of frequenters who lounge and get and retail the news-people from every quarter of the globe who are here gathered together in the commercial bustle of a great mart.

"From the coffee house I went to a gaming house. It was early in the evening, and the play had not yet commenced with any spirit. Some keen fellows, however, had set to quite early, and I saw the roulette wheel in its rapid motion and the faro table with its patent fraud-preventing box. In one house alone I counted six billiard tables, all occupied, and mostly with young men, evidently not natives, who were just acquiring a knowledge, never contemplated by the quiet dominie of the New England free school, where they received their education which they were supposed to avail themselves of in the acquisition of wealth, when they were sent to the unhealthy regions of the South. The number of gambling houses in New Orleans is very great. They are countenanced by law; as if half ashamed of the patronage that is afforded them, the ordinance of the corporation provides that they shall not have a door opening from the street into the gaming room, and there could not have been furnished a better sign to the property than this condition, intended to save appearances. As you pass 
along the Rue de Chartres, you see houses with wide and open doors, within which there is a board partition forming a vestibule of perhaps six or seven feet wide. In the partition is a door, proper to the gaming house. The clink of money is another sign here of the proximity of one of these halls, and is a sound which, on the night when gaming most flourishes, you hear at every few steps along the principal streets of the City. The keepers are generally Frenchmen, who sit at the tables with a silence that is never broken, and a gravity that would become the monks of La Trappe. During carnival the gamblers are most numerous and then is the harvest of the gaming houses. New Orleans is certainly a place after its own fashion.

"November 30, 1834-Meeting my friend, J. B. Harrison* as soon as I arrived, I agreed to dine with him and some of his friends. We remained at the table until it was time to go to the American Theatre, where I saw Mrs. Drake tear a tragedy into tatters, to the infinite delight of a house crowded with canaille. The interior of the theatre is only tolerable, the scenery better than we are accustomed to in the North, the French being the painters generally. The stage of the City is patronized to a considerable extent by the corporate authorities, for they have passed ordinances relating to the etiquette to be preserved, prohibiting any one sitting during the performance with his hat on, speaking loudly, thumping violently, or in any other manner disturbing or interfering with his neighbor. A copy of the Ordinance was printed on the play bill, so no one can have the excuse of ignorance. After the tragedy Harrison and I started off to a Bal Pièce et Masqué in the Salle Washington,

*Mr. J. B. Harrison was interested with Mr. J. H. B. Latrobe in Colonization, in the effort to solve the negro question. The present Governor (1916) of the Philippines is his grandson. 
Rue St. Phillippe-in other words a Quadroon Ball. On entering the room, which the payment of $\$ 1.00$ apiece authorized us to do, I was struck with the beauty and brilliancy. It was a very large room of an oblique shape. The sides are filled with alcoves, alternating with mirrors and nicely painted and gilded. The outlines $I$ have attempted on the margin. The ornaments are blue and gold, and from the ceiling which is well decorated there hang five enormous chandeliers blazing cut glass and gas light, making a brilliancy of the noon day in the ball room. An orchestra of excellent music occupied an elevated platform in the middle of one of the sides. An antechamber contained bars, and at a further extremity of the ball room was a large apartment opening into it, under the arches, corresponding to the alcoves, and similar to the opposite arches leading into the antechamber. Windows down to the floor led out upon an iron balcony and looked out over the southern parts of the City. Here many a tête-à-tête and doubtless many an intrigue is carried on. The beauty of the ball room far exceeds anything I have seen in the North of similar character. It was erected for the Quadroons, the light mulatto of this country who, prohibited by custom and law from many of the enjoyments of the whites, pass their life in prostitution, which is only the more odious because of the decencies with which it is surrounded and which by long usage render it less repugnant to the moral sense and feeling than the wretched and miserable practices of the Northern cities.

"There were about forty women present of all shades, from the dark mulatto to the light quadroon, whose person bore no mark of her descent, and whose degradation was a matter of position only. Nearly all had masks, white masks. Those who had not were young girls, as yet desti- 
tute of a keeper, and who, it seemed to me, show their faces as a merchant shows samples of his wares to entice purchasers. Some of the women, but not many, had fine forms, and a few were graceful and elegant dames.

"I was informed that the ball by no means exhibited the handsomest and gentlest of the quadroons. In the first place, it was the opening ball, to which it was not fashionable for them to come, and again it was more promiscuous than those balls which they have, and where a ticket is not a matter of purchase, but a favor. These last are called society balls, and the best quadroon society is to be found at them. There are no white women present, and none of the quadroons wear a costume, no other disguise to the person than a domino, and on the face a mask. The men were generally of very reputable appearance, all white, for quadroon men are negro, and must be negroes in all respects. Their sisters are the favored of the family. Some of the men who took an active part in the proceedings of the evening, dancing in every cotillon and talking with the girls in the intervals of the music, were past the prime of life and looked like father and grandfathers, but the most part were young men, the majority of whom seemed to be French and Spanish. Of course there were men who were only lookers on, but enough took part to keep the space appropriated to dancing fully occupied. There was a waltz between every two sets, and it was really a pretty sight to see some twenty or thirty couples wheeling one after another around the room. The waltz is different here from ours, the females turn around but slowly, and dance but little at each step, so that the quadroon is four times as long getting around the room as a Northern belle would be. The dance to me is a detestable one. I cannot bear it, and, were it not for the charge of want of civilization, should declare that nothing would ever 
induce me to let a wife or daughter of mine join in its mazes. It is pretty in the same way that an indecent picture may be a pretty one in every sense but the moral one. Many men were masked and in costume. Among the most conspicuous was a fellow in flesh colored clothes, fitting tight to the skin, and with the ornaments of a Peruvian Indian, as we sometimes see them in pictures. There were some Turks, many old men, and a capital countryman. The Peruvian got into a fight in the antechamber with a man who attempted to look under his mask, and, when he took it off to repair damages, exhibited a bull-necked savage looking person, who was recognized as the keeper and bully of the tavern on the levee. But the fellow was alone; the others in the room dressed and behaved like gentleman. The handsomest person at the ball, male or female, was a Spanish gentleman, who was dressed as a woman and was not discovered, although he wore no mask, until many of his sex had been introduced to him, some of acquaintances among the number, and proceeded to make love to him as a female. I had observed that this lady was in the habit of spitting and putting her foot on the result, and remarked it to a friend, but it was some time before the impostor was discovered. Curiosity kept me looking on for some time, and about midnight $I$ had the chance of seeing two excellent quarrels. There was a fight between two Frenchmen in one instance, which ended in one being knocked down, and a demand and promise of satisfaction; and the other quarres, between a Spaniard and a Frenchman, ended in arrangements for a duel. The Spaniard was so violent that he got into a half a dozen quarrels, and knocked down several who attempted to interfere and who got up only to demand and to be promised the reparation of their honor in mortal combat. It was curious to hear the Spaniard who cursed, 
swore and exclaimed in three different languages-English, Spanish and French-and spoke all equally well. The women ran into the alcoves when the quarrel began. The music ceased, and the gentlemen crowded around, jumping upon the chairs and benches, and then after some five minutes of excitement the fiddlers struck up, the women came back to their places in the cotillon, and everything went on as before, the quarrelers having by this time been pushed and elbowed either into the apartment at the extremity of the ballroom or into the antechamber. Below the ballroom was the supper room, where every delicacy could be procured at ten francs for the ladies and gentlemen who were inclined to get indigestion and headaches.

"Towards the close of the ball the room became very warm, and the smell of the heated quadroons and mulattoes was disagreeable to me who was not accustomed to it. I could not stand it and I went away.

"New Orleans would have far less of the picturesque, if it had more morals to recommend it. This much, however, I can safely say of it, that I never was in a more quiet or better ordered City at those periods when riot is rife ordinarily and when the night is made the periods of noise and disturbance. I would quite as soon trust myself in any part of New Orleans at that time as I would in any Northern city. So far as my personal comfort is concerned, I have been most kindly treated, and shall not soon forget the attentions that $I$ have received.

TRIP TO NATCHEZ BY MISSISSIPPI, AND RETURN WITH MRS. LATROBE TO WHITE SULPHUR SPRINGS, 1835.

"I had not been long enough from my office to affect my business, which I continued to work at steadily until June 1835, when, in company with Mrs. Latrobe's relative, Mr. 
C. L. Claiborne, a midshipman in the United States Navy, who had just passed his examination, I left Baltimore for Natchez, to bring back my wife and children, for Osmun had been born there after I left "Soldier's Retreat." We went to Frederick by rail, from there by stage coach across the mountains to Pittsburgh, descending the Ohio and Mississippi to Natchez. Returning with Charlotte and the children, we landed at "Guyandotte," and crossed the mountains to the White Sulphur. The boat in which we set out on our return was a Tennessee River one, which landed us at Smithland, where we had to remain until another boat came along on which we could embark. At Smithland we nearly lost Osmun with an attack of croup, which I mention only to give a recipe for making a child vomit. When everything else had failed, a Dr. Brown, who had been called in, took an unlighted pipe and placed the stem in a tea cup of water, and the bowl in his mouth, blew until the water was imbued with the narcotic. Giving this to the infant in teaspoonfuls, vomiting was produced, and the child's life was saved.

"We travelled by stage from Guyandotte to the White Sulphur, and passed the falls of the Kenawha. Here we found a very comfortable hotel. While dinner was preparing, I went to look at the falls, which gave their name to the village. I could not learn the perpendicular height, but should not suppose it to exceed twenty feet. The water was low, and large surfaces of flat sandstone were left bare along which I walked to the main channel, where the stream tumbled into a deep bowl in the shape of a horse shoe. The sketch I have made is a general one from the window of the Tavern. The spot is wild and very picturesque.

"Claiborne had left us at Smithland and went up the 
FALLS OF THE KENAWHA Painied by John H. B. Latrobe 


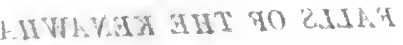

sdevol. . . H artol vo botrisat 


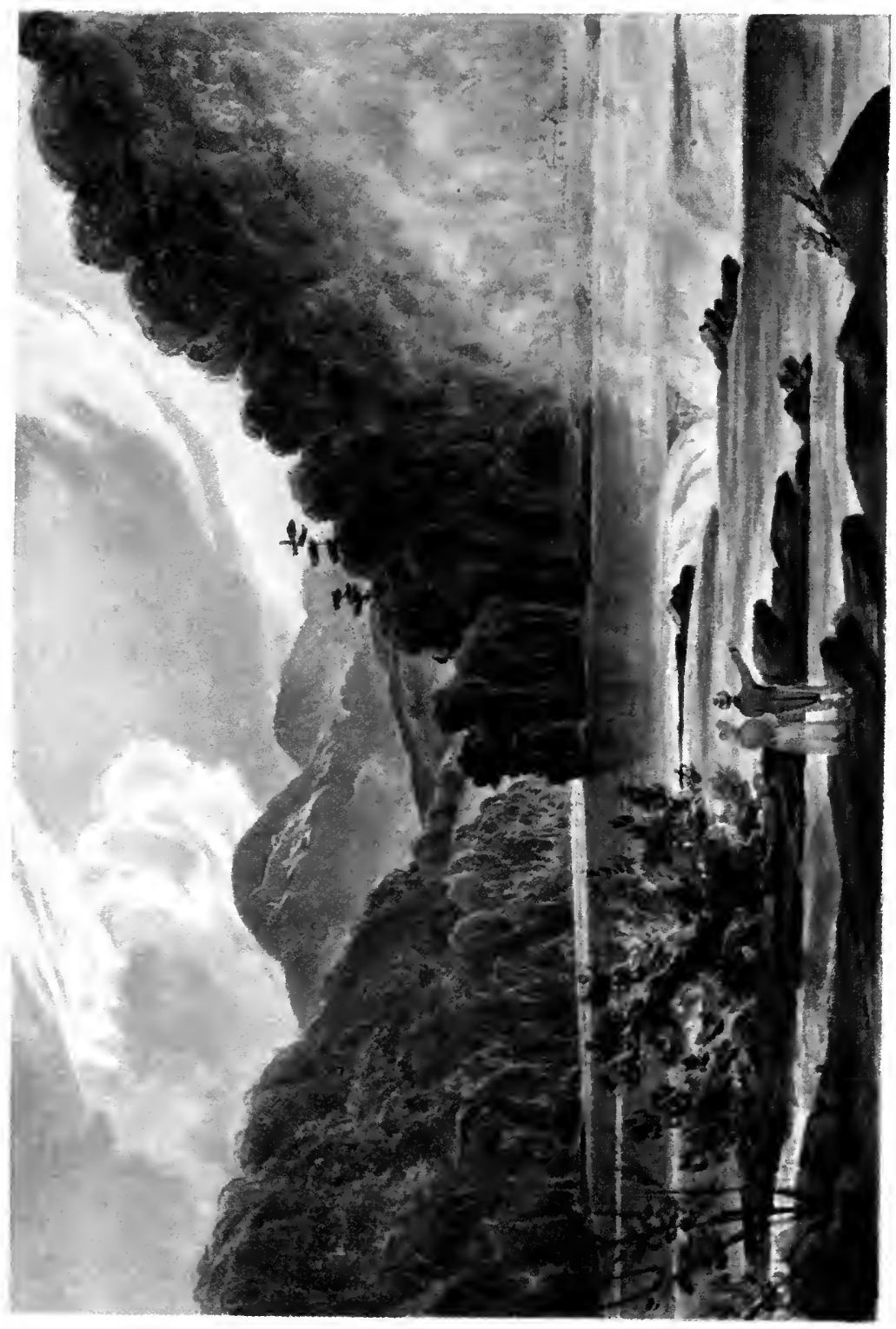



Cumberland, or Tennessee, I forget which, to visit his relatives at Nashville. Arrived at White Sulphur we remained there until the end of August 1835. On reaching Washington on our way back from the White Sulphur, we found the railroad in operation, and passed over it drawn by the grasshopper engine, a now long abandoned form of the locomotive, but a great affair in its day, notwithstanding.

"I have had rare travelling for a drudging lawyer. From Quebec, round the Capes of Florida, up and down the Ohio and the Mississippi, through the wilderness, North, South, East and West have my wanderings been. If not wiser I am healthier; and at all events if I have found my country with all the inconveniences occasionally of almost a savage State, I have seen her in her vastness, and now know and feel the certainty of her future and inevitable grandeur and glory among the nations of the earth." 


\section{CHAPTER XIII}

History of Mr. Latrobe's Great Client, the BaltiMORE \& OHIO RAILROAD AND ITS ConfLICT WITH THE Chesapeake \& Ohio Canal Company for the Valley of THE Potomac.

The civilization of the nineteenth century and its remarkable progress, as already stated, was due to the development of steam in rapid transportation, and to electricity in rapid communication; for until then little or no improvement over ancient methods had been made. Steam was recognized as foreshadowing great possibilities. Erasmus Darwin, a grandfather of the famous scientist, filled with the spirit of prophecy, wrote in 1786:

"Soon shall thy arm, unconquered steam, afar Drag the slow barge, or draw the rapid car;

Or on wide waving wings expanded bear The flying chariot thro' the fields of air."

Darwin died in 1802. Steamboats, steam railroads, and flying machines only existed in the mind of the poet.

Mr. Latrobe was born at the beginning of this development. He became intimately connected with matters relating to the development of transportation by steam, and was also the counsel of the first company in which electricity was used for any commercial purpose. He was one of the counsel of the Baltimore \& Ohio Railroad when it was incorporated in 1827 , and he was its counsel when he died in 1891. No other man has ever been counsel for a railroad for this length of time. 
When Morse was endeavoring to obtain recognition of his method of transmitting messages by electricity, he consulted Mr. Latrobe, who sent him to Mr. Louis McLane, then President of the Baltimore \& Ohio. I recollect Mr. Latrobe telling me that Mr. McLane stopped to see him at his office and told him of a visit he had had from Morse, whom he described as a crazy man who believed that he could send messages from Baltimore to Washington, and that he had replied, "The day when you and I are dead and forgotten, this man will be remembered."

Mr. Latrobe's life was so intimately associated and connected with the Baltimore \& Ohio railroad, that its history forms a part of Mr. Latrobe's biography. He was connected with the railroad, as already stated, through a period of sixty-three years, during which time the railroad struggled from very small beginnings to be an immense power. From a pamphlet entitled "Personal Recollections of the Baltimore \& Ohio," written by Mr. Latrobe, I shall quote fully.

In a lecture delivered by Mr. Latrobe before the Maryland Institute in March 1868 entitled "Personal Recollections," speaking of the enterprise of Baltimore and its desire to connect itself with the Great West in the early days, he says: "Railroads were then not thought of. Canals were the means relied upon."

The most practical route for a canal was discussed in public meetings in Baltimore. This was in 1824 and 1825, but the cost was so great that our people, like the Israelites of old, sat down by the Waters of Babylon, and wept.

At a dinner given by Colonel John Eager Howard, ${ }^{*}$ at his residence, "Belvedere," in 1825, Mr. Evan Thomas, just returned from England, described what he had seen of loads of coal drawn by engines from the mines on the Stock-

*Hero of Cowpens, Governor of Maryland and United States Senator. 
ton and Darlington railroads. (Co onel Howard died the year the Railroad was incorporated in 1827. Some of his sons were active in promoting the road started at their father's dinner table.)

Philip E. Thomas, a brother of Evan Thomas and President of the Mechanics Bank, a man of means and of great influence among his associates, was placed at the head of the scheme of a railroad from Baltimore to the Ohio. With the knowledge that we now have, the early efforts to accomplish this great purpose seem almost childish and futile, and the enterprise might be classed as a sort of "Jack the Giant Killer."

A charter, modelled upon the old Turnpike Charters, was prepared, and in March 1827 the first railroad company in the United States for general purposes of transportation was launched into existence, with a capital of $\$ 1,500,000$, with liberty to increase it. The City of Baltimore and the State were authorized to subscribe to the stock. There was great enthusiasm and a wild rush to subscribe to stock. A railroad mania took possession of the land.

Mr. Jonathan Knight was Chief Engineer, but with all the skill available ideas were most crude. One of these ideas was the method to be used in crossing the Allegheny Mountains. This was to be done by means of a double track with straight lines built straight up and over the mountains, after the system now used in coal mines, where a number of cars descend on one side loaded and a large number of empties are pulled up on the other side by means of a steel cable passing over a wheel.

The City Council, in its wisdom, required the railroad, in order to secure the City's contribution of $\$ 500,000$, to enter the City at sixty-six feet above grade and, instead of locating the road where it was located forty years afterwards, 
it reached the corner of Pratt and Amity Streets at this grade. Here the cornerstone was laid on the 4th day of July, 1828, and Mr. Charles Carroll of Carrollton that day struck the gavel and applied the square. With such a sponsor the Baltimore and Ohio Railroad might claim to be the most aristocratic Railroad in the country.

The last gush of enthusiasm came to an end with the laying of the cornerstone. Subscriptions were called, and people commenced to grumble. Many foolish things were done. Deep cuts were proposed to be made by the engineers without any method of drainage. Mr. Alexander Brown, one of the directors, stopped the making of one of these large cuts, and called attention to the fact that if it was dug as proposed, there was no method of getting rid of the water, and his common sense came to the rescue of the engineer.

A great excitement in the city was caused by the question as to how the railroad was to reach Light Street Wharf at a six foot grade, as it entered the City at a sixty-six foot grade. It was contended that it would be impossible, on account of the railroad having to cross streets where the drainage of the gutters ran at right angles, or north and south. The papers were full of this contention, and a war of words and discussions was entered into. At last some one suggested that if the railroad found the gutters of Baltimore impossible to cross, what hope could there be for the railroad crossing the Allegheny Mountains? This seemed to bring the people to their senses, and it was concluded that the difficulties could, and must, be overcome.

The first rail laid was an iron strap. The car wheels had flanges on the outside. The cars were like a country market wagon. In the beginning no one dreamed of steam upon the road. Horses were the power. The Relay House 
got its name from the fact that here it was that a relay of horses was stationed.

To reduce the friction on the axle was one of the great desiderata. Dr. William Howard, son of John Eager Howard, patented an ingenious and beautiful contrivance to accomplish this. Mr. Ross Winans introduced the "Winans Friction Wheel," an invention of great value.

The iron strap laid on longitudinal stone sleepers produced a noise which was deafening. Between the iron wheels and the stone, the straps were soon hammered out of existence. A wise suggestion was made to lay a thin strip of lead between the iron strap and the stone sleeper. It was found that the cost of this was something magnificent.

Stumbling along with many falls, the railroad was learning by sad experience how to be built.

We, in our wisdom, smile at the follies of our ancestors. A famous German engineer, Chevalier Von Gerstner, came to this country for information. When asked why he did not go to England, where the railroads had made considerable way, he said he wanted to escape from the English system, in which George Stephenson's thumb was impressed on every plan. "In America each one is trying to surpass his neighbor. There is a rivalry here out of which grows improvement. In England it is imitation; in America it is invention."

Steam had now made its appearance upon the Liverpool and Manchester Railroad (1825), but English roads were practically straight roads. American roads, for reasons of cost, had many curves in order to avoid obstructions-some of them with a very small radius. Mr. Latrobe goes on to speak of some of these curves.

How one of these curves between Baltimore and Wash. 
ington was finally gotten rid of is quite modern history. Mr. John W. Garrett was President of the railroad at the time. He was a very positive and determined character. $\mathrm{He}$ desired to have the trains run from Baltimore to Washington at a high rate of speed. The curve I speak of was a sharp reverse curve shaped like the letter $\mathrm{S}$ located between Baltimore and the Relay House. It was practically impossible to keep a long train on an even keel after it entered the curve. If a train was going at a high rate of speed the reverse part of the curve produced a sudden jerk. The engineers notified Mr. Garrett that it would be necessary to get rid of this curve if the trains were to be run at a high speed. Mr. Garrett stated that he did not see why this expense would have to be incurred, and refused to give his consent. Some time afterwards Mr. Garrett was in his private car going from Baltimore to Washington. The train was run at full speed over this section of the road, and Mr. Garrett, who was quite stout, was thrown against the arm of the seat. When he returned to Baltimore he consented to have the road bed changed at this point.

It was contended that the engines which would operate successfully upon an English road could not be used on a road with short curves.

To meet the difficulty growing out of the construction of the railroads in America, Mr. Peter Cooper of New York came forward and built an engine to demonstrate his contention that steam could be used upon American railroads around curves. His engine was not a very magnificent affair. The boiler was as large as the ordinary boiler in our kitchen, and the entire weight was a ton. After experimenting with the engine, his success was such that Mr. Cooper proposed a trial trip from Baltimore to Ellicott Mills, and 
so in the summer of 1830 the first trial trip in the United States was made by a steam engine pulling a passenger car. The speed at times was as high as eighteen miles an hour. Memorandum books were pulled out when at this highest speed. The occupants of the car wrote their names to prove that at this great velocity it was possible to do so. There was, however, a fly in the ointment. The triumph of the engine was not without a drawback. There were parallel tracks laid from Baltimore to Ellicott Mills, and at the Relay House, upon the return trip, Peter Cooper's Tom Thumb Engine was challenged to a race. On the track alongside a gallant gray had been hitched to a wicker car, and the race between horse and steam was on. The horse's steam developed more rapidly than the engine's, and he started ahead. The horse was a quarter of a mile ahead when the safety valve on the engine lifted, and the vapor issuing from it showed an excess of steam. The pace increased, the passengers shouted. The engine gained upon the horse, soon it lapped him, the whip was applied. The race was neck and neck, nose and nose. The engine passed the horse and a great "hurrah" heralded the victory. Just then, when the gray's master was about to give up, the band which drove the pulley, which drove the blower, slipped from the drum, the safety valve ceased to scream, and the engine for want of breath began to wheeze and pant. In vain Mr. Cooper, who was his own engineer and fireman, lacerated his hands in attempting to replace the band on the wheel. The horse gained on the machine and passed it, and, although the band was presently replaced, the horse was too far ahead to be overtaken and came in the winner of the race.

It was not until the year 1836 that horse power was abandoned on the railroad. 
To Mir. Ross Winans is to be credited the first eightv. Lcel rosscuser car.

It may re interesting to set forth a copy of the letter of Mr. Peter Croper of New York, who had accumulated a fortune, and in whose licnor the Cooper Institute is named.

"Mr. J. H. Latrobe, "New York, June 9, 1855.

"Dear Sir:-I received your favor requesting me to communicate such facts as I can recollect connected with an experiment made by me with a small locomotive engine on the Baltimore \& Ohio Railroad. The experimental engine was commenced, I believe, in the winter of 1829 and tried on the road during the summer of 1830 .

"For an account of the engine I will refer you to a communication made in August of 1830 by Mr. Ross Winans to the B. \& O. R. R. Co., in which you will find a more reliable description of the engine and its performance than I would be able to give after the lapse of so long a time, and having no record of it except in memory. The great advantages that were expected to result to all the great interests of Baltimore from the prosecution and completion of the road, led me with others to become largely interested in real estate in that city, which was mainly dependent for an increase of value on the rapid prosecution and completion of that work. Soon after the road had been commenced many unexpected difficulties were encountered, causing the stock to fall as the difficulties increased in number and magnitude, until, to cap the climax of discouragement, it was believed to have been demonstrated by an English work, that arpeared at that time, that a road with curves as short as those, which had been adopted and found unavoidable on that road, had ruined it for locomotive purposes. The provalcnce of this opinion caused the stock to decline to a 
mere nominal value. Under that state of discouragement many of the stockholders with whom I was acquainted were seriously considering the propriety of forfeiting their stock, in the belief that the short curves in the road caused it to become an entire failure. At this critical period in the affairs of the road I became satisfied that a locomotive could be made to work successfully around the many short curves of 400 feet radius, that were then common in the road. Believing this, I determined to build a small locomotive, and pursuaded my friends not to forfeit their stock until I could have an opportunity to show them that the road could yet be used successfully with locomotives. The engine, being the first one that I had attempted, was, after encountering many difficulties, completed and placed on the road, and succeeded in making its first trip on an ascending grade drawing one car with 30 passengers 13 miles in one hour and twelve minutes, making the return trip of 13 miles in 57 minutes. This result $I$ have the satisfaction of believing had the effect of turning the tide of public confidence in favor of the road-a road, if I am not mistaken, that will scarcely be exceeded in importance by any road in this or any other country. You will please excuse this imperfect sketch which would have been sent sooner but for the variety of things that constantly claimed my attention.

Very respectfully yours,

(Signed) Peter Cooper."

The trial trip over a railroad in the United States having been given, it is not uninteresting to compare this with an account of one of the first trips made over a railroad in England, which is found among the Creevy papers.

Speaking of the railroad, as he was one of the Committee to consider the matter in the House of Commons, he says 
on page 429 , March 16,1825 , referring to an advocate of the railroad:

"He quite foamed at the mouth with rage in our Railway Committee in support of this infernal nuisance, the locomonster, carrying eighty tons of goods and navigated by a tail of smoke and sulphur, coming thro' every man's grounds between Manchester and Liverpool."

On the 31st day of May he reports the result of the meeting of the Committee.

"This railroad is the devil's own, we very near did the business, we were 36 to 37 on the bill itself. . . . . Well, the devil of a railroad is strangled at last."

But the devil seems to have come to life again, for we find on page 545 a letter dated November 19, 1829, written to his step-daughter, Miss Ord.

"Today we have had a lark of a very high order. Lady Wilton sent over yesterday from Knowsley to say that the Loco-motor machine was to be upon the railway at such a place at 12 o'clock for the Knowsley party to ride in, if they liked, and inviting this House to be of the party, so, of course, we were at our post in three carriages and some horsemen, at the hour appointed. I had the satisfaction, I cannot call it pleasure, of taking a trip of five miles in it, which we did in just a quarter of an hour; that is, twenty miles an hour. As accuracy upon this subject is my great object, I held my watch in my hand at starting and all the time, and as it has a second hand I knew I could not be deceived, and it so turned out there was not the difference of a second between the coachman, or conductor, and myself.

I think we went at the rate of twenty-three miles an hour, just at the same ease as to the motion or absence of friction as at the other reduced pace, but the quickest motion is to me frightful; it is really flying, and it is impossible to divest 
yourself of the thought of instant death to all upon the least accident happening. It gave me a headache which has not left me yet. Sefton is convinced that some damnable thing must come of it, but he and I seem more struck with such apprehension than the others. The smoke is very inconsiderable indeed, but sparks of these are abroad in some quantity; one burnt Miss de Rois' cheek; another a hole in Lady Marian's silk pelice, and a third in someone else's gown. Altogether I am extremely glad indeed to have seen the miracle, and to have travelled in it. Had I thought worse of it than I do, I should have had the curiosity to try it, but having done so, I am quite satisfied with my first achievement being my last."

Sefton's conviction that something damnable would come of it seems to have had some justification, for in the opening of the Liverpool Railroad, the same engine ( $I$ think it was "The Rocket"'), ran over and killed Harkesson, the then Prime Minister of England.

The full effect of the introduction of this method of transportation was not realized at the beginning. It has revolutionized the world, and today the railroad, with its steel rails, holds together a country, which without this binding force would fall to pieces for want of cohesion in its huge bulk; for while we see and condemn many methods of the railroads, we should, in all fairness, recognize their necessity to our existence as a great nation. Distance is destroyed, and we are by this means, through intercourse, more centralized than a country of one-tenth our size before they came.

In this connection, it is interesting to note that in the discussions which took place in Congress in 1815 as to the advisability of establishing a post at the mouth of the Oregon or Columbia River and taking possession of the country, Senator Dickerson of New Jersey, speaking in opposition, 
stated that it would take not less than three fundred and fifty days to reach Washington from the post, and that each representative would be entitled to $\$ 3,720$ from the Government to pay the costs of his trip. As a consequence of this and other unfavorable criticism the bill was defeated, the Congress deciding that the distance between was so great as to render it most unlikely that the acquisition of the territory would ever benefit the nation. In the light of the history of the last hundred years, this incident contributes, in a remarkable way, to a realization of what the railroads mean to the very existence of this country.

The tremendous strides in progress made since the day when the United States rejected the North-west Territory on account of its remoteness and the cost of transportation are well illustrated by the latest marvel of wireless telephony described by Dr. Graham Bell in the National Geographic Magazine. By this achievement a conversation was carried on between Arlington in Virginia and the Eiffel Tower in Paris, which was overheard at Honolulu.

Mr. Latrobe has given the dramatis personae of those who were on the stage at this early period.

$\mathrm{He}$ describes them as meeting to inspect the gorge of the Patapsco, where the Relay House was afterwards established; Mr. Charles Carroll of Carrollton does not appear among those assembled who met on horseback. It is probable that his great age and infirmities kept him from being present, but he is described by Mr. Latrobe in the laying of the Cornerstone, as the last surviving signer of the "Declaration of Independence," a spare attenuated old man, verging on his four score years and ten, small in size, but active in his movement, with eyes still bright and sparkling, with a voice thin now and feeble, but clear and distinct, as, in emphatic utterances, the venerable and venerated man pro- 
phesied the success of the great work on whose cornerstone he that day struck the gavel and applied the square. The company consisted of the Directors of the Company and their counsel. Among the latter were Roger B. Taney, Messers. Wirt and Daniel Webster, William Gwynn, and young Reverdy Johnson. One of the directors, John B. Morris, was living at the time of the delivery of the address by Mr. Latrobe, who speaks of him as in a green old age, the honored representative of the road.

Mr. Robert Oliver, the leader of the hunt, was a grand looking man, far advanced in years, his few remaining locks snow white, but with all the vitality and vigor of youth. Straight as an arrow, broad chested and with the seat of a soldier in the saddle.

Next came Alexander Brown, with the grand frame of Mr. Oliver, but without that abandon which on such an occasion was the latter's peculiar characteristic. To Mr. Brown everything was a matter of business. He crossed the gap, and the two Irishmen stood together, watching their companions.

Mr. William Lorman followed, with his florid complexion, business aspect, keen bright eye and quiet self-possession. No stranger he to horsemanship.

Then came Mr. John McKim, Jr., a large square built man, with strongly marked Roman features, the character of whose expression was acute intelligence, but who rode with caution, as if the occasion was unfamiliar.

Then came Mr. Alexander Fridge, whose careful, hesitating guidance of his horse showed that an inexpert rider feared an accident; a pure man.

Then came Mr. William Patterson, a small spare man, of dark complexion, with great determination in his quiet look. 
Isaac McKim, spare and thin-visaged, acute and cautious, the only merchant of them all who sought political life, who built a ship and sent her, bearing his wife's name, around the world, whose beauty, the ship's not more than the lady's, was the pride of Baltimore.

Talbot Jones, a representative man, prudent on horseback as on "Change"-a merchant, liberal and enlightened in all his views, and whose whole heart was in the railroad.

George Hoffman, refined and eminently courteous in his bearing, prominent as a merchant, and the head of a family which was in those days a power in Baltimore.

John B. Morris, a gallant horseman, the handsomest of the group, as he was the youngest of the directors.

William Stewart, afterwards Mayor of Baltimore, came next, and last Mr. Philip E. Thomas, the president, on his ambling nag, with a kind word for all, and by all looked up to as the leader of the enterprise.

There has been more or less question as to which was the first railroad in the United States. There were one or two roads commenced at the same time, and it is possible that one of these, a coal road, may have existed before the Baltimore and Ohio's tracks were laid, but according to Mr. Latrobe's statement, the first actual railway for passengers and general traffic was the Baltimore and Ohio, and the first trip which might be called a "trial trip" was made over the Baltimore and Ohio in 1830. I recognize the fact that it is very difficult to make any statement on any public question existing so many years before, without stirring up a controversy. I once read that no one could strike a spade into Parnassus, without stirring up the bones of some old poet, and so it is about everything.

Mr. Latrobe was employed in acquiring rights of way in 1828. He says: 
"The route preferred was up the valley of the Potomac, and as it was known that this would be contested by the Chesapeake \& Ohio Canal Company, it was determined to obtain at once the right of way. I was employed for this between the Point of Rocks and Williamsport, and Jno. V. L. McMahon between Williamsport and Cumberland.

"The duties of this employment consisted in part of explanation, in part of argumentation, and in part of persuasion. I was furnished with a horse and honored with the company of Colonel Stephen H. Long of the U. S. Engineer Corps, an officer then in the service of the Railroad Company, and left Baltimore for the Point of Rocks.

"I owed my appointment to my good friend, William Gwynn, who was the personal friend of Philip E. Thomas and his counsel, and the counsel also of the Company. I had the engineering knowledge, acquired at West Point, that was necessary, or which it was expected might be useful, and an aptitude for just such a work as I would be required to do. It was in the month of May 1828, I think, that I commenced my travels. Colonel Long had become noted for his expedition to the Rocky Mountains, was an excellent engineer and a very pleasant companion. Dressed in civil garb, he had about as little of the look of a soldier about him as might be, and with his round shoulders and gold spectacles, was far less military in his appearance than his companion, who but a few years from West Point still prided himself upon the set-up of the institution. But the Colonel regarded me as 'an army man,' and we were good comrades for many a weary mile, slept in the same room at the farm houses, and had generally a jolly time. I remember his teaching me the way to let down bars as we plodded through the fields on the river bottoms by beginning at the bottom rail. When we had viewed the Point of Rocks 
and Cliffs at Harper's Ferry, where we crossed the Potomac by a rope ferry, and worked some distance up the steep cliffs approaching Williamsport, procuring releases as we went along from the proprietors who knew no more of a railroad than of Chinese, and to whom I could teach precious little, we were summoned back to Baltimore and informed that the mere releases with which we had been furnished would not do, but that we must procure regular deeds of the land to be occupied. In consequence I set out again, this time with a surveyor, a rodman, and a sort of messenger. The present General Isaac Trimble was the engineer.* Trimble laid down the lines of the tract wanted, I inserted them in the deed and Crawford, an employe of the company, rode off to get two Magistrates to go with me to the owner's house and take the acknowledgment of the instrument. This time Colonel Long remained at Baltimore and I became Captain of the host. It would be pleasant to recall the odd adventures of this expedition, but I have no time or place. I did the work sufficiently well to lay the foundation for the great case of the canal and railroad reported in 4th Gill and Johnson, page 1. I returned to Baltimore some time in June and in time to write the address delivered by Mr. Thomas at the laying of the corner stone of the road on July 4, 1828. By this time Mr. Thomas and I had become quite intimate, an intimacy that continued till his death. He made me executor of his will, and so I remained until his removal to New York made other dispositions expedient.

"I mention all this because it was my connection with the road at its commencement that gave me a strong push

* Both Colonels Long and Trimble were West Point men in the service of the United States in the early works of public improvement, when the services of Government Engineers were availed of. 
ahead in my profession. Its litigations gave me opportunity, and opportunity was what I wanted, just as all young men want it. My income with the fee from the railroad in 1828 was $\$ 2,000$, a sum on which in those days a man might marry, nor was I without my aspirations in this direction.

"From that time to the present I have been the counsel of the Company, engaged in all its litigation, and as thoroughly identified with its business as any other person in the community for the same period. Of all my professional engagements this was the one in which, at the time of which I am now writing, I took the most interest. It fell in with my mechanical tastes and my early education. For many years I have held my place as its counsel at what is almost a nominal salary of $\$ 1,000.00$ a year, when, out of its service and at liberty to take part in litigation against it, I could at season make ten times as much. I have held myself, I say, more out of pride and affection, than from any other motive, to the wonder of many of my friends. I am a sort of chronicle of the company's affairs. I dare say if I had asked for an increase of salary I might have obtained it, but I hated to do this, and so I suppose will jog on to the end."

The chief competitor of railroads in those days was water transportation, and the Baltimore and Ohio came into conflict with the Chesapeake and Ohio Canal. In the case of the Chesapeake and Ohio Canal vs. Western Maryland Railroad Company, reported in $99 \mathrm{Md}$. page 572, Judge Schmucker, speaking for the Court of Appeals, says: "It is unnecessary for the determination of its present status to review the history of that somewhat famous water-way or the litigation of which its career has been so fruitful." As a part of the history of the Baltimore and Ohio it is inter- 
esting to consider this fight between the Canal and the Railroad. The work of connecting the waters of the Ohio with the Chesapeake Bay was one of the grand ideas which were entertained in the latter part of the 18th Century, and it is said to have been one of the pet schemes of President Washington. The Potomac Company was created by concurrent legislation of the States of Virginia and Maryland in 1784 .

The title of the law is "An Act for opening and extending the navigation of the Potomac River." Under the fourth section of this Act, the Company was authorized to cut canals wherever necessary in its opinion. There are a number of clauses relating to powers which are claimed in the litigation, by the one side to restrict the Company to the use of canals in particular localities, and by the other that the right to cut canals was unlimited, and could be exercised at almost any time and anywhere in the Valley of the Potomac.

The reason that this matter is now considered is that it is apparent in the case of the Canal Company v. the Railroad 4 Gill \& Johnson, page one, that the Chief Justice, who delivered the opinion, based his opinion largely upon the theory that the Chesapeake \& Ohio Canal Company had acquired the right of the Potomac River Company, and, as he puts it, on page 62 :

"The question then presented for the consideration of this Court is whether the Chesapeake \& Ohio Canal Company has a priority of right in the choice or selection of ground for the route and site of the canal in the Valley of the Potomac."

The Chesapeake \& Ohio Canal Company was according to one claim incorporated prior to the incorporation of the Railroad. but while it is true the Act of 1825 provided for 
the existence of the canal, it also provided that before it would be entitled to accept the charter, certain conditions had to be performed-among others, the subscription to a certain amount of the stock. This stock was not subscribed to until the 24th day of May 1828. In the meanwhile the Baltimore \& Ohio Railroad Company had been incorporated by an Act passed on the 28th of February 1827, and was organized and had its stock subscribed by the 23rd day of April 1827; so that it is plain that unless the Canal Company could claim priority by reason of the fact that it had acquired the interests of the Potomac Company, the Baltimore \& Ohio Railroad Company was, so far as incorporation and completion of its corporal entity were concerned, established prior to the Chesapeake \& Ohio Canal Company.

It would take too much time and cover too much space to go into the reasons and the long arguments which appear in this case. The case covers one hundred and ninety-one pages of 4 th Gill and Johnson. There were at that time six Judges on the Bench of the Court of Appeals. They were John Buchanan, Chief Judge, Richard. Tillman Earle, William Bond Martin, John Stephen, Stevenson Archer and Thomas Beale Dorsey.

After the incorporation of the Railroad and its acceptance of the charter, it moved promptly. It located the route from Point of Rocks to Cumberland, along what is known as the left or Maryland side of the Potomac River, and proceeded to acquire rights of way. Even if the Canal Company had had a prior right to select a route, it was contended -and later court decisions say rightly contended-that this right could not be held in abeyance, but should have been exercised within a reasonable time, and rights of way acquired. To hold, as the Court did in this case, that the Canal Company had the right of priority by its charter to 
select any route in the Valley of the Potomac at any time would not be the view entertained by any Court of this country in later times.

The Canal Company filed a bill for an injunction restraining the Railroad and its agents from locating the road on the left side of the Potomac, claiming that it had a priority of right of selection in what was known as the "Valley of the Potomac."

The Railroad Company did not answer this Bill, but filed a Bill before Chancellor Bland for an injunction restraining the Chesapeake \& Ohio Canal Company from interfering with its work. The two cases were consolidated.

The Canal Company claimed that by certain surveys made long prior thereto by the Potomac Company, whose rights it acquired, the left-hand or Maryland side of the Potomac had been considered the better side upon which to construct a canal, and that the Canal Company had the right to select whatever place it desired in the Valley of the Potomac, between the Point of Rocks and Cumberland, and that the building of the Railroad would seriously increase its cost.

That the law was forced to grant the contention of the Canal Company must strike anyone who reads the opinion of Chief Justice Buchanan. He decides that the Chesapeake \& Ohio Canal Company had acquired the rights of the Potomac Company incorporated in 1784, and he gathers from the entire charter that the right to make the Potomac navigable would give the right to that Company to build a continuous canal from Washington to Cumberland.

He refers to the Fourth Section of the Act, and says that the Potomac Company unquestionably had a right to make canals, and if it had a right to make canals at different points, there was no reason why it could not extend such 
canals by other small canals, and thus having the right to make canals, Presto! we have a continuous canal.

$\mathrm{He}$ gets rid of the question of the Act being for the purpose of making the Potomac River navigable, by using the following language:

"Taking the charter then altogether, and construing one part by another, if there had been a canal or canals made along the shore of the Potomac, fed by the waters of the river, and capable of being navigated in dry seasons by vessels drawing one foot of water, the river would have been made navigable for vessels of that description in the obvious sense in which the language adopted by the respective Legislatures was used; although not a drop of water was left to flow in the natural channel, not being required to be kept there."

Thus the learned Judge decides that although there is not a drop of water in the river which is to be made navigable, if there is a canal made alongside of the river, the latter thereby becomes navigable; which, with all due consideration, seems to the ordinary mind a rather forced construction of the language of an act which provided for making a river navigable.

In this connection it is interesting to read the journal of Uria Brown, made in 1816, in which he tells of visiting Cumberland and makes the following statement:

"The beautifulest stone coal I ever saw is here from 8 to 12 cents per bushel. They ship in time of high water this coal and other products of this country to Georgetown and that neighboring country, and bring back in their boats in return one Ton to a man of Plaster, Herring, Shad and other Goods Materials as they want." (Md. His. Mag. Vol. X. No. 3 f 276.)

This is evidence that the Potomac River had at that time 
JOHN H. B. LATROBE at the age of 76 


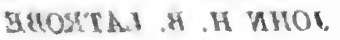
or fo zgn sat to 


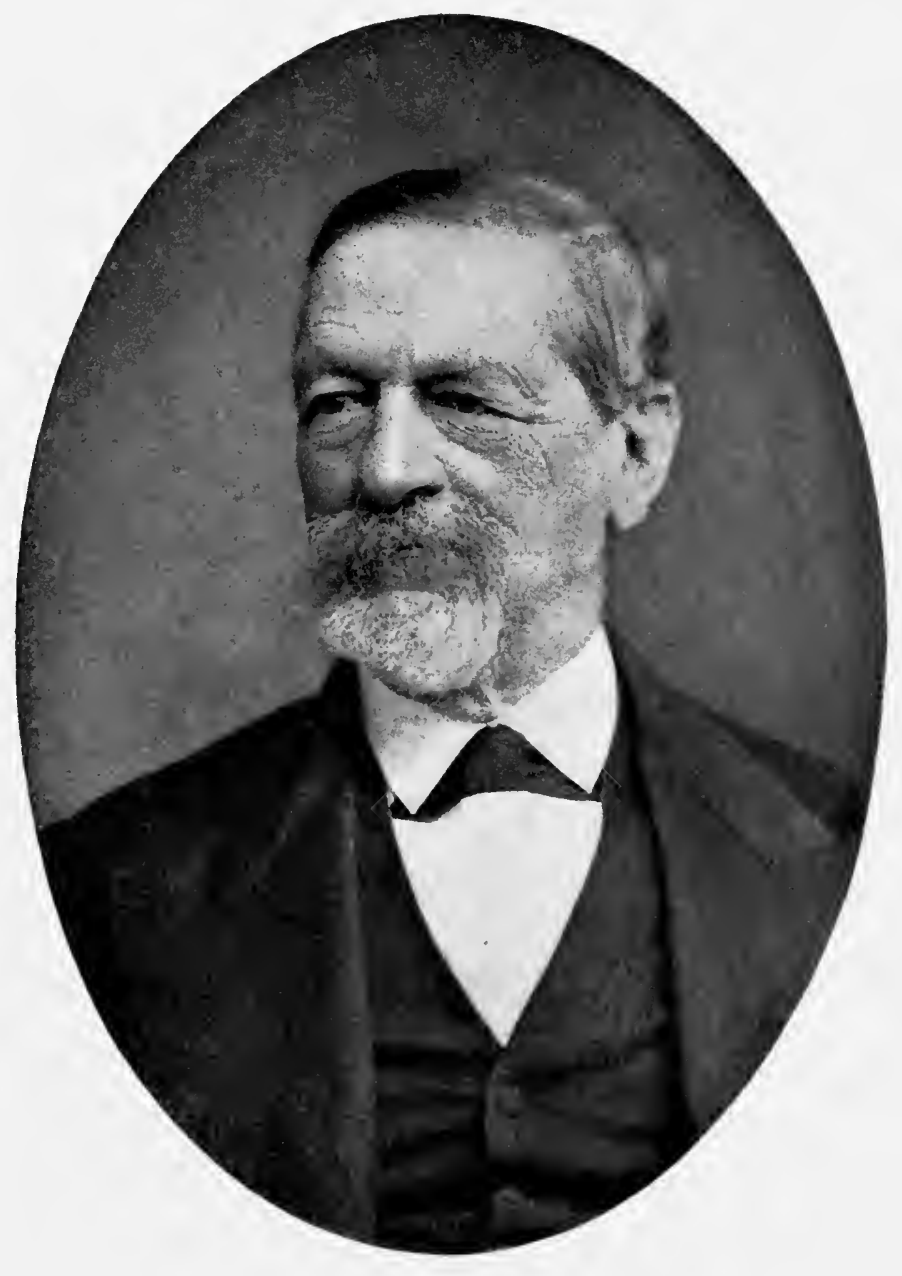



been made navigable to a certain extent. One of the arguments of the railroad was that the Potomac Company, by the preamble of the Act of Assembly of 1802 Chapter 84, was estopped from claiming the right to make a continuous canal. The recital declared "That the object contemplated by the Act of Assembly for establishing a company for opening and extending the navigation of the River Potomac has been accomplished." Subsequently, in order to furnish water to the canal at different points, its navigability was utterly destroyed, so that the building of the continuous canal, instead of making the river navigable, destroyed it. The case was tried out of place-advanced upon the theory that it was a great public question-and the decision rendered by Judges Buchanan, Earle and Stephen, Judges Archer and Dorsey dissenting, and one Judge, Martin, being absent sick.

In the language of Judge Dorsey, who delivered a dissenting opinion, "it is perfectly apparent that the case was urged by the Chesapeake \& Ohio Canal Company as being a matter of great public concern," while the railroad was described as an odious and enormous monopoly; that therefore the law should be interpreted most liberally and favorably to the Canal Company and most strenuously against this monopoly. Judge Dorsey said in his opinion:

"I shall endeavor to divest my mind of every impression which may have been made by the eloquent and forcible appeal, preferred to the patriotism and sympathies of this Court, by the appellant, to induce them to urge on the argument of this case against the consent of the appellees out of the regular order . . . that the appeal made to stimulate the patriotic energies of the Court to an unwonted expedition for the avowed purpose of removing the alleged 'only obstacle' to the speedy completion of the greatest of 
national objects - the consolidation and perpetuation of the vital principles of the Union and the establishment of a connected navigation between the eastern and western waters-cannot be followed by the contemplated result . . . So that this magnificent and stupendous enterprise is disrobed of its national character, and consequently high prerogatives, and sinks into a mere 'local' canal, whose extension is limited by the confines of Maryland."

This dissenting Judge was correct. The event proved it was not then or at any time a great national work, but a local canal, a mere political ditch.

Judge Buchanan said: "This grand object was a connection between the Atlantic States and the country West of the Alleghany Mountains to be effected in part by the extensions of the navigation of the Potomac River, a work not merely of local, but of great national importance."

At the time of the incorporation of the Potomac Company in 1774, railroads were not thought of. Spain held the mouths of the Mississippi, and was disposed to bar access to the Gulf of Mexico by this highway. The only method of developing the West and furnishing means for the transport of heavy freight was by connecting the waters of the Chesapeake Bay with the waters of the western rivers. Transportation by horse power such a distance was out of the question.

Washington was a strong advocate of this enterprise; and, in considering the Court's decree, extenuation and excuse can be found in the influence exerted upon men's minds at that period by the magic name "Chesapeake and Ohio."

The Court was carried away by the character ascribed to the canal by its promoters, and its great potential national importance as a waterway. But in spite of the name it bears, it has never brought one drop of water from the 
western rivers to the Chesapeake. It is called "The Chesapeake and Ohio Canal;" it has never struck the Ohio River, and meets the waters of the Chesapeake no nearer than its feeder - the Potomac River-at Georgetown. Instead of being a national enterprise, it is a Maryland enterprise which has cost the State of Maryland about thirty million dollars including interest, for which the State has never received one dollar in return.

The protest of the railroad against the case being advanced out of its place on the docket of the court was based, first, upon the fact that one of the Judges, Martin, was sick, and second, that if it was tried at the time fixed, other engagements would prevent the counsel for the railroad from being present. These counsel were William Wirt and Roger B. Taney, who were associated with Daniel Webster and Reverdy Johnson. Wirt was ill, Taney could not be present, and the case was tried by Webster and Reverdy Johnson for the railroad. Judge Martin was supposed to be favorable to the contention of the railroad. If this was true, the railroad would have won its case, because Chancellor Bland had decided in favor of the railroad, and the Court would have been equally divided, so that his decision would have controlled.

The railroad had no right of appeal, although the canal company had such right. Justice Buchanan says on page 116, when deciding against the railroad:

"These observations are elicited by our having been reminded in the course of the argument that in the event of a decision against the claim of the railroad, there could be no appeal, which we regret, but cannot honestly avoid the consequences."

The claim that the Court of Appeals "jockeyed" this case into position and placed the railroad at a great disad- 
vantage may or may not be true, for it is usual for lawyers, even now, when they lose cases, to complain that the Court of Appeals, or the Court that decides against them, has not given them a fair show. This habit of lawyers seems to have existed back in 1832 when this case was decided.

In this connection, it is interesting to refer to the letters of Mr. Roger B. Taney to Jno. H. B. Latrobe.

"Washington, Jan 6, 1832.

"My dear Sir:-

"The news of our defeat reached here on Wednesday night by express, and it is difficult to write to you on the subject without saying what I think about the conduct of the three judges who, it now appears, were determined to decide the case against us and resolved that they should do it, while, owing to the absence of one of the Judges, the power remained in their hands."

Again in his letter dated February 7, 1832, Mr. Taney says:-

"You will have seen by the letters to yourself and Mr. Gwynn that I entirely concur in the resolutions as first proposed. I would have preferred them to the resolutions which we published. It is useless and mischievous to indulge hopes ourselves, or to hold them out to others, without reasonable grounds for supposing that they may be realized. And what reasonable ground is there to expect anything from judges who have, by the act of mere despotic power and in such circumstances, ordered on a case of this description, and have decided without taking time to think of it and without having made up their minds what reasons are to be given for it? The argument was a solemn farce, and the determination to use the power in their hands too manifest to be mistaken; and it is useless to think 
of any further litigation with the canal company about going to Harper's Ferry, or on the left bank of the Potomac. . . . But a great community like Baltimore need not be afraid to expose injustice, even if it comes from the Bench. It has power to make itself heard, and need not be afraid of the consequences. You will, however, find that the same feeling which has produced this unprecedented conduct in the Court will influence the Legislature, and that a rehearing will be refused. The present Legislature, if I judge them rightly, are adverse to Baltimore . . . . make up your mind to cross by a viaduct to the Virginia side, and go up by that route."

So it was that the great case of the Canal Company and the Baltimore and Ohio was decided against the railroad, which was forced to cross the river, and run along the Virginia side. This apparent injustive proved beneficial to the railroad, as is shown by the subsequent history of the canal, which is herein set forth.

The Virginia side of the Potomac is mountainous and the tracks were laid a considerable distance above the river bed. While it is true that the bridge at Harpers Ferry has been washed away on one occasion, the location of the railroad has saved it from being destroyed by great freshets, as has been the fate of the canal on several occasions, the waters of the Potomac covering the low ground on the Maryland side.

The correspondence about this time is very interesting, but it is too voluminous to insert here. We find General Samuel Smith a strong advocate of the Railroad Company, as were many others, including Benjamin C. Howard, then a member of Congress, a man of high character. Mr. Howard, in a letter of January 15, 1832, speaking, among other things, of the railroad situation, says: 
"That said Potomac interest that I have been incessantly combatting ever since, and even before my entrance into political life, has upon the final struggle proved too strong even in the Temple of Justice, into which prejudice has crept, hiding itself beneath the sacred ermine . . . you must be strangled, or to use a modern term 'burked,' that your body may be sold after life is extinct."

Mr. Howard uses an unusual, but very appropriate word in this letter. The word "burke" must have just been coined, for it grew out of the crimes of one William Burke who was hanged in 1829 . Burke had been accustomed to sell bodies to a college for dissection. Not satisfied with disposing of the bodies of those who died from natural causes, he obtained subjects by murder, adopting a method of killing that would show no outward sign of the cause of death.

I am indebted to Mr. William Rawls, the well-known lawyer, for bringing to my notice the first recorded use of the word. Sir Walter Scott had advocated the passage of a reform bill, which, however, met with the violent opposition of the workmen of Jedburgh in 1841. They surrounded his house during a demonstration and uttered cries of "Burke Sir Walter Scott."

Following up the history of the Chesapeake \& Ohio Canal Company, we find that by a message of the President of December 3, 1823, a corps of engineers were appointed, and $\$ 30,000$. appropriated to make an immediate reconnaissance of the tide waters of the Potomac River, from the head of the steamboat navigation to the Ohio River. This reconnaissance was made, and it was suggested that the Maryland side of the Potomac River was the best adapted for the canal. Ultimately, the report of these engineers put the cost of the eastern section of the canal, that is, from Georgetown to Cumberland, at something over eight 
million of dollars, and they reported that the entire cost of the canal would be something over twenty-two millions. This report was made and published on the 7th of December, 1826. The Canal Company objected to this report as being entirely contrary to their own views, and two other engineers, James Geddes and Nathan S. Roberts, were appointed in May, 1827. They made a report on the 10th of March, 1828, that the cost of the eastern section of the canal would be about four and one-half million dollars. Engineers, therefore, differed somewhat in their estimates, as they did in the question of locality and the effect of building the canal, for it was forcibly contended that the placing of the railroad alongside of or near the canal would not in fact increase their expense very greatly, but that operating together it could be constructed at a much lower rate. However, the Court disregarded this, and took the opinion of one engineer, namely, that it would make the expense of the canal infinitely greater, or a "canal impracticability;" the Court of Appeals having made up its mind to disregard all views which would entertain the existence of the railroad. In the meanwhile the stock of the Canal Company, which was to be subscribed for before its charter could exist, was not subscribed for until sometime in May, 1828. Of this stock (about nine million dollars) seven and onehalf millions were subscribed by the State of Maryland, one million being subscribed by Congress and the rest by Georgetown and Alexandria. With this money the great canal was constructed as far as Dam No. 6 on the Potomac River, many miles short of Cumberland, which was the terminus of the eastern section which, according to Geddes and Roberts, was to cost $4 \frac{1}{2}$ millions. By 1844 the canal company had become hopelessly insolvent, having used up the money subscribed for stock and loans made by the 
State, and yet not completed the canal, even the eastern section being unfinished. By a new act passed in that year the canal company was authorized to borrow the money necessary to complete the canal as far as Cumberland, the State subordinating its liens under various mortgages which it held, in order to give priority to this loan upon the tolls and profits of the canal.

In these circumstances the company was able to borrow something under two millions, which completed the canal to Cumberland. The canal was operated by the State up to the year 1890. During the whole of this period, with the exception of a year or two between 1869 and, I think, 1872, when the President of the Canal Company was Mr. James Clark, it never paid one cent of interest either to the bondholders of 1844 or to any other parties, but it was a most valuable political asset. Senator Gorman at one time was President of this waterway and, it is believed, owed his political greatness to the control of the canal. It was commonly said that many of the supervisors and superintendents of the canal had never seen it. No stronger case against State or City ownership can be shown than this. As long as politicians consider their own and party aggrandisement rather than the interest of the City or State, no greater mistake can be made than to place in their hands the control of public utilities.

I recollect that some time in the latter part of the sixties or the early seventies, I found in a wash-stand drawer certain papers or bonds of the Chesapeake \& Ohio Canal Company, issued under the Act of 1844, and I asked my mother what they were. She said it was an investment of my father's which had never paid anything for many, many years, and was worthless. I took these down to Wilson \& Colston, Brokers, and I was surprised to find that they 
took an interest in them, and said that it might be possible to secure par for them, or $\$ 5,000.00$ for the lot. I took them then to Messrs. Nicholson \& Son, I think it was, and sold them for 105 per bond, and went home in great glee with a check for $\$ 5,500$. received from an investment which seemed to be practically worthless."

It was at this period that Clark was in charge, and had paid some of the coupons on the bonds of 1848, issued under the act of 1844. There was an effort being made at that time by a syndicate headed by Mr. Stewart, of Richmond, to acquire these bonds. Proceedings had been instituted in different courts-in Washington County and the Supreme Court of the District of Columbia. These suits were consolidated, and the result was a decree passed by Judge Alvey, dated the 2nd of October 1890, which placed the bondholders under the Act of 1844 in possession of the canal.

At this time it was declared that the canal was utterly insolvent. A freshet had destroyed a great part of the canal. In $1878 \$ 500,000$. had been borrowed to repair damages, but a second freshet had taken place since that time, and at the time of the filing of the bill in 1889 by George S. Brown and others, trustees of preferred construction bonds under the Act of 1844, Chapter 81, the canal had been wrecked by reason of a storm in May 1889 and was hopelessly insolvent.

This bill prayed that the Trustees under the mortgage should be allowed to take possession of the canal, put it in order and, if possible, obtain some revenue therefrom. It was resisted by the State, the latter claiming that while it is true it had released its liens for the purpose of placing this mortgage ahead of it, the mortgage of 1848 was not a mortgage on the corpus of the canal, but merely on the 
tolls and profits, and that it, the State, was desirous of having this canal sold. The Court held, and it seems to have been an equitable decision, that the State, having resigned its rights in favor of these bondholders and having managed the property without producing any revenue, ought not to be permitted to sell the canal and shut off the bondholders of 1844 from any claim whatever to profits and tolls - an act which would be highly inequitable; that the money advanced by these very bondholders completed the canal, and they were entitled to see whether any profits could or could not be made out of it and, until such time as it was shown that there could be no profits, they were to be entitled to keep possession. A period was fixed within which to demonstrate this, and these bondholders were allowed to purchase the claim of 1878 , which was to be subrogated to their rights. This was the loan of $\$ 500,000$. and was secured by a mortage not only on the tolls, but on the corpus of the canal. These trustees, being thus in control of the canal, proceeded to expend money to put it in repair, but the tolls and profits were not sufficient to pay back this expenditure as shown in the case of State of $\mathrm{Md}$. v. Trustees of Mortgage of 1848, $83 \mathrm{Md}$. 549. The State, being anxious to get back its valuable political asset, although it was of no value financially, filed a bill to enforce the sale of the property. It was again met by an opinion of the Court that it would be inequitable to oust these trustees. Judge McSherry filed an additional opinion. He agreed with the majority, but he took issue with them upon their opinion that the mortgage of 1844 merely pledged the tolls and profits, and claimed that in equity, in view of the circumstances (and he recites the history of the canal at great length), the State should not be permitted at any time to take possession of this canal until the mortgage of 1844 was 
paid off, and it would seem that this is the only logical position to take and should be the decision.

The State, still anxious to get possession, filed another bill, the proceedings of which appear in 94 Maryland, but again the time was extended, and today the Trustees of the mortgage of 1848 or the mortgage made under the Act of 1844 , are in possession of the canal.

In looking over the opinion of Judge Robinson, we find he uses the following language:-

"A good deal has been said about the veil which conceals the real motives, \&c. . . . . But we must deal with the case as we find it." The fact is that it was strongly suspected, and was probably true, that the Baltimore \& Ohio Railroad joined with Mr. Bryan, who was a son-in-law of Mr. Stewart, in the acquisition of the bonds issued under the Act of 1844, and that, as a matter of fact, the Baltimore \& Ohio Railroad is today in possession and control of the Chesapeake \& Ohio Canal.

While no one who knows the morals of railroads is apt to think or believe that it has been actuated by high or lofty motives, there seems to be some sort of poetic justice in the fact that, after the wrong sustained by the railroad by the decision of 1832 in favor of the Canal Company, this great national enterprise, which ended at Cumberland, and which has been used since its creation merely as a political instrument, should finally drop into the lap of its competitor, the Baltimore \& Ohio Railroad, which is described as being an odious and enormous monopoly, while its competitor is described as a great national enterprise! In Mr. Latrobe's diary we find entries which show that he not only acted as counsel, but in other capacities on behalf of the road. As stated, he prepared the speech delivered at the time the cornerstone was laid. 
"September 5, 1833. Gave directions for making new model of cars.

"September 6, 1833. At Reeder's Engine Shop, to give directions about locomotive engine, Davis' Building.

"September 7, 1833. At work on the 7th Annual Report of B. \& O.

"My relations with the railroad were at this time, as they have since continued, close. I was not only counsel, but my engineering knowledge made me useful otherwise, and I was not averse to the occasional mingling of the two professions. In a lecture delivered before the Maryland Institute in 1868, I have sketched the presidents and direcors of that day, and, if you have any curiosity on the subject, I refer you to that production which the railroad company treats as a part of its history.

"Looking back to these days, I find with no pretentions to modesty that I wonder at the confidence I must have inspired before I was thirty years of age. Among my correspondence will be found a letter to Mr. Philip E. Thomas, then the President of the B. \& O.R. R. Company, declining the Vice-Presidency which had been offered me, an office which, had I accepted it, would have cast the life of the young lawyer to whom the salary was a temptation into a different groove- with what an ending I cannot venture to guess at-from that which he has since been travelling in."

This letter, declining to consider the position of assistant to the President, seems of sufficient interest to reproduce. A production of such a character will give a more thorough knowledge of the man who is the subject of this sketch than anything I might write. When this letter was written he was thirty years of age: 
"Dear Sir:-

"Upon a recent occasion, you informed me that there existed some idea, in the Board of Directors of the Baltimore and Ohio Railroad Company, to appoint, at the suggestion of the President, an assistant to that office, and you desired to know whether, if such appointment were decided upon, I would accept it.

"I need hardly assure you how flattering I consider the intimation which you gave that I might aid you in the high and responsible station that you hold; and I almost regret the circumstances that would compel me to decline the office, were the offer of it made to me. But the profession that I have chosen limits in a great measure my employments to those connected with its pursuits; and so long as it continues to support me as it has done, I would not be justified to myself or others in neglecting or abandoning it. Although, however, I cannot be your assistant as an executive officer of the Company, yet if I can in any degree lighten your labors, I beg you to call upon me, not merely as one of the counsel of the Company, but as one who is deeply indebted to you for repeated acts of kindness. Early education and habits, whose influences even now affect me, make me feel a more than ordinary interest in the success of the road, and if, by any exertions of mine, I can, in the smallest or most remote degree, promote it, I shall be no less gratified than proud.

"Since our conversation before alluded to, I have thought much upon the nature of the new office that it is proposed to create, and presuming still further upon your kindness, I will take the liberty of suggesting what occurred to me when I considered myself personally interested in the subject. 
"The appointment of an assistant President would amount to dividing between two persons the duties which are performed in other companies by one. Now in order to decide upon the necessity for this division in the Balto. \& Ohio R. R. Co., we must ascertain what are the duties of the President of that body. They consist in acting as the presiding officer and official organ of the Board of Directors and the Company; in conducting the correspondence; and in exercising a controlling superintendence over all inferior officers. In the first of these duties, the President could neither require nor receive assistance, and with regard to the second, the experience of the last three years has shown how absolutely essential it is that the correspondence of the company should evince throughout the undeviating thought and purpose of a single mind. To divide it between two persons would be to run the risk in ninety-nine cases out of a hundred of manifold and, perhaps, injurious inconsistencies.

"The duty of the President to exercise a superintendence over all the officers of the Company is that, in reference to which the idea of an assistant most probably originated. I think, however, that even here it will be found upon consideration that a proper organization of the Company, such as is now rapidly progressing, will render the appointment of an assistant President, for this purpose, unnecessary; and unless such an appointment is a matter of absolute necessity, there are evils that might arise out of it that should prevent its being made.

"It appears to me that the business of the Company, other than that which, as above shown, belongs exclusively to the President, may be divided into three departments. 1. The fiscal concerns of the Company; 2 . The location and construction of the road, the laying of rails, preparation of 
machinery, building of depots, and the collection and preservation of materials, and 3. Transportation.

"1. At the head of the first Department is the Treasurer of the Company, and connected with him are the Auditor, the Transfer officer, clerks, book keepers, \&c.

"2. At the head of the second department is the Chief Engineer with various branches, each governed by a proper officer to be responsible for its condition.

"The Chief Engineer is, himself, the head of the first branch of his department, having control of the location of the Road and the principles upon which it is constructed.

"The superintendent of Graduation and Masonry is the second officer of this Department, with his duties clearly defined by his title. On this officer might be devolved the business of obtaining titles to land required for the road, having recourse, when necessary, to the counsel for the Company.

"The superintendent of Construction. This officer has the management of laying the rails and all matters connected therewith; the construction and arrangement of depots and the collection and preservation of all necessary materials. He might also be required to procure title by condemnation, with the assistance of the counsel for the Company, for stone, timber and sites for depots, \&c., when necessary.

"The superintendent of Machinery. This officer has the control of the construction of all vehicles to be used on the road; the preparation and preservation of material for them, and the repair of them, when required. The two officers last named, are more particularly under the immediate direction of the Chief Engineer.

" 3 . The superintendent of Transportation is at the head of the third department and should have the control of the 
entire Transportation upon the road; the procuring and providing of the care of horses; the purchase of fuel for engines; the government of depots, depot keepers, hands employed at depots, and drivers and conductors of trains; the receipt, weighing, storage and delivery of goods; and the preservation of the cars and carriages of all kinds on the road, both while in actual use and while unemployed. This Department will probably require subdivision into various branches, as the road extends and transportation increases.

"In the arrangement here detailed, and which is now rapidly going into efficient operation, there is no part of the business of the Company, which is not provided for; and if the officers of the several Departments and branches do their duty, as there is every reason to believe that they will do, no labor will fall upon the President that he will be unable to sustain, and when they neglect their duty, whether there is an assistant President or not, the President is the only proper person to act.

"Each of the superintendents should be held responsible for the correct execution of his respective work; and the heads of the three Departments that I have named should be considered, each for his own Department, as the assistant of the President, aiding him in the discharge of those duties which it might create, with an efficiency that would be the natural consequence of his own practical skill, science or experience. The Treasurer, the Chief Engineer, and the Superintendent of Transportation should, in fine, perform the duty that would be required of the Assistant President, and should be chosen, as they now are, for such qualifications as would entitle them to the same confidence that. the assistant President, were he appointed, would receive.

"In all companies and societies experience has shown the 
policy of having but one executive head. If, in the proposed arrangement, it is intended that the President shall still be consulted, and agree upon all matters as they arise, affecting the interests of the work, his labors will be in no wise diminished by it. If, with a view to diminishing them, however, they are divided into distinct parts with the Assistant President, the probability is that the same work may be carried on under different systems of policy, the consequence of the different modes of thinking of the two officers. Directors, superintendents, contractors and stockholders will all find themselves, perhaps, involuntarily taking sides and giving their preference to one or other of the divided executive, until a scene of confusion ensues, similar to that which you no doubt recollect to have occurred in the proceedings of a Board lately subordinate to your authority. There is no more reason why there should be two Presidents-which would be in fact the case, if the duties of the President were divided in order to diminish their labor-than that there should be three Chief Engineers, instead of one; and upon the policy of this the Board of Directors have already had considerable experience, and have pronounced their opinion.

"Require, Sir, that the officers already mentioned shall themselves relieve you of the burden of the labors that their respective departments give rise to. If they want more assistance, give it to them; if you want more superintendents for other branches, appoint them; if any department or branch is too large, divide it, but adhere to and insist upon the principle of holding the head of each branch responsible; and you will have gained the object proposed, without incurring the risk of the appointment of an officer who might, perhaps, afford you some assistance, but who might, quite as probably, only serve as a clog to that activity, which 
you have hitherto so efficiently exerted on behalf of the interests of the Company.

"There can be no doubt of the labor you have undergone; but you have now successfully passed the most arduous period of the Company's existence. Like a well regulated machine, the increased complication of the work it is engaged in does not derange its motion. The task of putting it together and adjusting each part to its proper place was one of difficulty and doubt; but that is now all happily accomplished; and in the future aspirations of the Company I feel satisfied that you will experience none, or but very little, of that perplexity and those harassing circumstances that have hitherto affected you and probably given rise to the plan that I have thus taken the liberty to comment upon. If the occasion for the proposed appointment ever really existed, I am satisfied that it is now past.

"In extending a note, that might have been very brief, to this unreasonable length, I must find my apology in your kindness, and in my own interest in whatever concerns the Company. And I beg you to believe me sincere, when I again express my hope that if any labor on my part can do you service you will call upon me to render it, not merely as counsel, but as a friend and well wisher.

Very truly and respectfully, Yours

John H. B. Latrobe."

"Philip E. Thomas, Esq.,

President, B. \& O. R. R. Company."

"Somewhere, I think in 1835-6, people in Baltimore had become satisfied that it was a.more difficult matter to build a railroad to the Ohio than was anticipated when the charter of the Baltimore \& Ohio Railroad was obtained in 1827 . 
And Mr. Thomas, who was doing as much as any man could do in the office of President, began to lose the popularity that eight or nine years before had placed him far above all others of his fellow citizens. No allowances were made for circumstances which it was impossible to control. Things deemed wise at the time of adoption were found by experience to be unwise; and ignorance which was common to all the engineers in the country in 1828 and for years afterwards was attributed to Mr. Thomas. A disappointed public, a dissatisfied body of stockholders, needed a scapegoat, and Mr. Thomas was made one, most unjustly, for perhaps no other person in the community could have done what he did more honestly, more prudently, or in any respect better, during the period of his presidency. But it was clear that he would have to resign, and resign he did in 1836, I think, and Joseph W. Patterson was his temporary successor, a wealthy gentleman, clear headed and cautious, but unwilling to hold the place permanently."

The following is an entry in Mr. Latrobe's diary:

"November 7, 1835-Mr. Thomas called and handed me a letter showing that he intended to resign the Presidency of the Baltimore \& Ohio, and stated that his reason for this was that he was tired, and that he had done so much for the Railroad, which was unpopular, that he felt discouraged. I told him that it would be a great pity for a man who had really been more instrumental in starting this enterprise than anyone else to give it up, and that if a higher dividend would be paid, he would find that the public would change their views.

"Casting about now for a President, Mr. Louis W. McLane* was thought of. He had been Secretary of the

*Mrs. M. B. Smith, in "The first forty years of Washington Society," speaks of Louis McLane of Delaware. This was the Mr. Louis McLane who accepted the 
Treasury in 1831, Secretary of State in 1833 and Minister to England, and was at the time President of the Delaware and Hudson Canal and Banking Company, residing in New Ÿork. Mr. Fallison, Mr. James Swann and myself were delegated a committee to visit him and offer to him the place, and accordingly in the winter of 1836-7 we went in stage coaches to New York, saw Mr. McLane, dined with him, offered him the presidency which he accepted, and came back, still in stages, to Baltimore.* On our way back, there were two vehicles in company. The front one upsetting, I went with other occupants of the second to the assistance of the wrecked passengers. The upturned stage lay upon its side, and out of the window of the door they were drawn one by one, some trouble which I have forgotten preventing our opening the door itself. When my hand was inserted into the opening, it was grasped by a lady, the distinguished actress Madame Celeste. No one was hurt, however, and the accident is mentioned here as a memorandum of the way of getting to New York thirty-five years ago.

An entry in Mr. Latrobe's diary, October 28, 1835:

"Celeste 'the Wept.' Of all the splendid pictures that I ever saw, the performances of this eminent actress are the most perfect. Every attitude is grace, every expression of her countenance is eloquence, and though no word falls

Presidency of the B. \& O. He was in the Senate from Delaware, and Mrs. Smith speaks of a visit from his wife, January 1829 , in which she says:-

"Mrs. McLane of Delaware has come. 'How many children have you brought with you?' I said. 'Let me see, three and a half. Am I not venturesome to come with half finished work?' Her husband has staked everything upon his political measures."

*The salary of four thousand dollars a year was sufficiently tempting to induce Mr. McLane to give up his position in New York. There has been a change since those days. Not long since Mr. Lorie, it is understood, received $\$ 500,000$ from the Chicago and Rock Island. He occupied the position of President for a year. 
from her lips, yet thought and feeling are as visible and intelligible as though poetry flowed from her tongue, instead of being expressed only in the magic movement of her form." Others appreciated her besides Mr. Latrobe, for she made a very successful stay in the United States, her receipts being placed at some $\$ 200,000$, a large sum in those days.

"Mr. McLane continued to be President of the B. \& O. R. R. Company for ten years, and during his administration the work was completed to Cumberland (1846). I never was quite sure that he took much interest in his office. $\mathrm{He}$ had an able, practical board of directors-H. W. Evans, Columbus O'Donnell, Joseph Wilkins, George Brown, of Brown Brothers, Johns Hopkins, who subsequently left his fortune to found Johns Hopkins Hospital and the University, Fielding Lucas, and others-and there was little to be done that required much more than business talents. The great trouble was the right of way beyond Cumberland. The route to Parkersburg was open to the Company and should have been adopted, and so most men thought. Mr. McLane thought otherwise, and was able to carry a majority with him and the right of way, which it required afterwards so much trouble to regain, was lost-for the time, at all events.

"The road to Cumberland from Harper's Ferry was built with the stock holdings of the Company, based upon the City of Baltimore subscription of three millions to the capital stock. My impression is that this was a suggestion of, Mr. H. W. Evans. I know that upon Mr. Evans, Mr. F. Lucas and myself devolved the work of carrying out the plan.

"Among many able men with whom I have been brought in contact, I never met one, I do not except Mr. Webster even, who possessed in the same degree the faculty of stat- 
ing a case clearly; and along with his statement he made' an argument in support of it, without doing more than to present his facts. I did not regard Mr. McLane as having the soundest judgment. I have had professionally to differ from him in opinion, but to form my own judgment I required time after hearing him, as I have told him again and again. His powers of statement were indeed most remarkable. Mr. McLane was not a lawyer. Although so much in public life, he was not a politician. I place him in the category of statesmen and high up on the list. Of course I saw a great deal of him during his presidency. He was not a pleasant person to get along with. He was peremptory and at times uncertain, and would not abide opposition or differences of opinion; and there were seasons in which it was doubtful whether I would remain his counsel. There were occasions, too, when I was satisfied he would have removed me from the position I held in the Company, had he felt sure it would have been approved by his board. I was no doubt positive and unyielding too, and looking back I am inclined to confess that, if we did not at times, and at times only, agree, I may have been in fault too. Generally, we were on cordial terms, and now that I survive him, I take great pleasure in recording my estimate of his great and statesmanlike qualities.

"That we parted good friends is proved by my being his counsellor in all matters connected with his leaving the company, at the expiration of ten years of service. I was the only person in whose judgment in this connection he seemed to have confidence. The public and the stockholders had become dissatisfied, the road stopped at Cumberland, and the same circumstances that operated to remove Mr. Thomas and make Mr McLane President, now bore upon Mr. McLane. He would have retained his place, if he 
could have done so, but there was a violent opposition, and the result of the election was doubtful. I thought he might succeed, and left him with the belief the day before the election that he was going to stand a poll, when.I received a note saying he had changed his mind and would decline being a candidate. This left the field open for Mr. Swann, who was then unanimously elected.

"After the election Mr. McLane, who had not yet then written his annual report, asked me to prepare one for him, and the last report of his happens to be verbatim, without alteration, my work. I mention this now to my own disadvantage, perhaps, should a comparison be made by you between my work and his. I mention it, however, as a proof that I had to the last the confidence of one of the ablest men it has been my fortune to come in contact with,

"Of all the Presidents of the Company since I have been its counsel, the ablest, most energetic and of the widest scope, was the late John W. Garrett who died in office a victim to his absolute and untiring devotion to the interests of the road. It was my fortune to be in his confidence, and he was my personal friend.

"I might fill a volume with details of my experiences as counsel of the Company. But I have said enough." 


\section{CHAPTER XIV}

Acquatntances Formed by Mr. Latrobe After 1830 and Students Who Studied in His Office-Directors of the Union Bank and Council-Bank Riots, 1835

Mr. Latrobe gives a number of pen portraits of men with whom he came in contact. Among others, he describes David Crockett, whom he met in Washington. Crockett's fame rests chiefly on his ability as a rifle shot. Everybody is familiar with the story which portrays the hopeless situation of a coon discovered up a tree by Crockett. "Don't shoot, Mr. Crockett, I'll come down," said the coon; and this saying serves even today to express the attitude of a person who is willing to surrender when defense is desperate.

David Crockett was unquestionably a rough character, lacking education. He was the typical pioneer of the early days, when it required pluck and courage to push forward in a new country. He was every inch a man. In 1836, probably realizing that he was out of place in Washington as a member of the law-making body, he joined the Texans in their fight with Mexico. He was one of the hundred and forty men who defended the Alamo, and was one of the six survivors who surrendered and were shot by order of Santa Anna, in direct violation of the terms of surrender.

I find the following entries in Mr. Latrobe's diary:

"Friday, December 20th, 1833. Yesterday at McHeath's I met Colonel David Crockett, a man whom the ignorance of the people in his district in Tennessee has sent to Con- 
gress to represent it; and whom the bad taste of the present day has brought into notoriety on account of those very characteristics which, in a better state of society, would sink into utter contempt and insignificance. Colonel Crockett is a tall muscular man of a good face rather, and one whom, dressed in a ploughman's frock with a flail over his shoulder, we would esteem a good representative of that class; or who, to meet him in the woods with a rifle on his shoulder and clad in deer skin, we would say was a proper hunter. Dressed in the clothing of a gentleman and occupying a seat in the National Legislature, he is as much out of his element as he well can be. Colonel Crockett is a man who boasts. For why he should tell it except to boast of it, I know not-that, when appointed a Justice of the Peace, he did not know how to write his name, but having a pretty smart constable, he managed to get along well enough. Furthermore, he says that happening to meet Mr. Polk of Tennessee, ${ }^{*}$ when the latter was a member of the Legislature of that State, Mr. Polk said to him that there would be probably a reform in the Judiciary, the meaning of which the Colonel not understanding, he "forthwith made tracks" - that is walked off to hide his ignorance. And yet this is a man who exercises an influence over the destinies of the American people, engaged as they are in the perfecting of the best system of government which the world has yet seen. They say the Colonel is shrewd and sensible. Maybe so, but he is ignorant and vulgar.

"December 30th. Enclosed to Robert Gilmor a cover of a letter with David Crockett's frank upon it, that Mr. Gilmor who is a collector of autographs might have a specimen of the sign manual of the wild beast who has got into Congress."

*(Afterwards President.) 
Among the men who worked with Mr. Latrobe in Colonization matters were Gerritt Smith, Leonard Bacon and Seth Terry. In his diary he writes:

"Elliott Emerson called upon me and took me to see Gerritt Smith, Leonard Bacon, Seth Terry, and a Mr. White on the way to Washington to a Colonization meeting.

"Gerritt Smith is a tall, strongly made man, with marked features, dark eyes and hair, and of a benevolent and sensible expression of countenance. His air and manner are dignified and imposing, and he well looks his character of a man of great wealth, devoted to the concurring in and execution of plans of benevolence.*

"Leonard Bacon-distinguished as a colonizationist, rather under the common size, with light hair, eyes and eyebrows, and his hair being close cut, he has a parsonlike appearance, but without much humility of expression of countenance, for his eye is quick, his mouth determined, and his utterance rapid. He is certainly a man of talent.

"Seth Terry, the Treasurer of the State of Connecticut, is a tall, thin man with gray hair, bold forehead, and altogether marked face; his complexion is dark, his manner gallant, and there is some humor in his countenance."

Mr. Latrobe was a strong Jackson man, but in a number of places he states his admiration for the qualities of Henry Clay, who was at one time President of the Colonization Society. On the visit to Washington, he met Mr. Clay at the Society's office. He relates:

"I found Mr. Clay with Dr. Alexander. The Committee having been introduced and seated, Mr. Clay continued a conversation in which he had been engaged with the Doctor, inveighed strongly against the corruption which pervaded

*He gave money to John Brown, but was not implicated in the latter's attack on Harper's Ferry. 
the administration of the government of the United States, particularly the Department of Indian affairs and Public Lands. He gave an instance of the corruption in the last. He said, however, the republic was never to be despaired of. He described General Jackson as adhering to his friends, through good and evil report, deeming the most venal virtuous, not having judgment or discernment to distinguish between them. Dr. Alexander was polite enough to say that the Jackson party, of which I happened to be one, was a set of banditti, in reply to an observation of Mr. Clay's that the General's attachment to his friends was to his credit. Mr. Clay is a polite, eloquent gentleman, but a politician. Dr. Alexander is but a farthing candle alongside of the sun when compared with him. Mr. Clay and $I$ are not on the same side, though I admit no less his splendid talent.

"Had a short conversation with Van Buren, in which, when I mentioned my anxiety lest Mr. Taney's appointment should not be confirmed, he told me he thought that there was nothing to apprehend on that score. I said to him sotto voce, the tone for his class of politician, 'If he should be rejected, Sir, I trust the people will support him as they did you,' alluding to his nomination and election as Vice President, after the Senate had refused to confirm him as Minister to England. He bowed, smiled, and I changed the conversation.

"Had a conversation with Judge Wayne who, if the present Speaker of the House should leave the seat, will no doubt be chosen Speaker. I asked him if it would not be well if the President in his message had recommended the repeal of the 'Force Bill,' so called. The occasion for it I thought had passed, and to repeal it would be a concession which the majority might make without a sacrifice of 
dignity. The Judge thought differently, and I understood from him that the repeal of the "Force Bill'* will be resisted by the Administration."

Colonization had among its advocates in those days some of the most prominent men of the day; and Mr. Latrobe, as an active worker in the cause, met many of them.

His connection with the Baltimore and Ohio Railroad extended this list of acquaintances. We find in his diary a reference to some of them. He seems to have adopted Pope's theory of life, that the proper study of mankind is man, for in his notes we constantly find a summing up or description of the men he meets. He writes:

"The litigation and contests of the Railroad Company have brought me in contact with prominent persons that $\mathbf{I}$ might not otherwise have known, or known so well. One of them was Charles Fenton Mercer, the President of the Chesapeake \& Ohio Canal Company, a highly educated and polished gentleman, the great objects of whose public life were, like those of my old master in the law, Colonization and Internal Improvement. Had Mr. Mercer been endowed with-what shall I say-well, with more Americanism of character, so far as manner went, he would have taken a much higher stand as a statesman than he did. In the

*The Force Bill mentioned by Mr. Latrobe was an Act of Congress, so-called, passed to enforce the collection of direct taxes levied on imports. This legislation created a considerable opposition on the part of a number of States. These States claimed the right to pass nullification acts, or in other words, that each State had a right to consider whether a law passed by Congress should be accepted, if, in the opinion of the State, it exceeded the power directly surrendered to the United States. This was a form of State's Rights or the Right of Secession.

Hayne and Webster had their great contest over this question of nullification, Hayne supporting it and Webster supporting the right of the Government to pass certain legislation. South Carolina had proposed to resist what was known as the Force Bill, but a compromise was effected through Henry Clay and the issue was postponed. This claim of right was kept alive and insisted upon at different times by different States, until ultimately the question resulted in the War of 1861 . 
strife of politics, in the 'shoulderings' of life, a certain rude energy goes a great way. I do not mean anything savouring of vulgarity, I rather mean the exhibition of a strong will, in contests for preeminence. Mr. Mercer wanted this. He was too refined and elegant a gentleman for the rough and tumble of the House of Representatives, of which he was for years a member. He was too courtly; and, although looked up to for information, indefatigable in the performance of public duties, rougher and more emphatic men passed him in the race. In person, Mr. Mercer was of the middle size, his features were plain, his voice high pitched, he was a graceful speaker, rather than a powerful one, never identified himself with other than leading questions, and upon all matters of internal improvement, was a recognized authority in Congress. As a Colonizationist, he was one of the earliest and most influential friends of the movement, and one of the most persistent advocates. We were thrown much together at Annapolis, nor was antagonism, as we advocated the conflicting claims of the Railroad and Canal, always as pleasant as it might have been.

"It ended, however, with our visit to Annapolis, and did not disturb the kindly relations which our sympathies on two great subjects made natural.

"Of Mr. Wirt I have already spoken; so I have of Mr. Taney, both of whom, though on opposite sides, were engaged in the railroad and canal controversy from its commencement. The most active of the counsel on the canal side, however, was Mr. Walter Jones, one of the cleverest lawyers in the United States, a small spare man of insignificant appearance, with plain features, except his eyes, which for piercing intelligence and shrewdness of expression I have never seen surpassed. His mental activity spoke in them, his voice was a thin, high pitched one, and he was without 
any pretension to grace of manner. Few men who occupied prominent places in the profession were ever listened to with more interest that Mr. Jones. His fluency was only equalled by the choiceness of his language. He was so deliberate, so quiet, that perhaps 'fluency' does not accurately describe his oratory. He was one of the closest reasoners. He never spoke at random. His style was simplicity itself. He was rarely at a loss for the best word in the proper place. Men talk nowadays of the great lawyers of a past generation, and refer to Webster, Choate, Pinkney, and others, without including in the category one who was inferior to few of them, Walter Jones. He had been a friend of my father, and I learned to know him well, when the great case threw us together at Annapolis.

"But the greatest of all the great men, with whom it has been my fortune to be associated or be acquainted with, was certainly Daniel Webster, who came into the railroad and canal case when it was before the Court of Appeals of Maryland, on an appeal from Chancellor Bland, and I may tell here, as well as anywhere else, what I know of him."

Mr. Latrobe's opinion of Daniel Webster is endorsed by the position Webster holds in the Hall of Fame: 1 George Washington, 2 Abraham Lincoln, 3 'Thomas Jefferson, 4 Daniel Webster.

"When the case here referred to was ready to be heard before the Court of Appeals, Mr. Taney was Attorney General of the United States, and unable to follow the case into the Appellate Tribunal. It was necessary to supply his place. When it was before the Chancellor I had taken part in the argument with Mr. Taney and Mr. Reverdy Johnson. The argument before the Court of Appeals, however, required heavier metal than I could furnish in those days; and, but two counsel being permitted to speak on the 
same side, I was necessarily excluded after the employment of Mr. Webster in Mr. Taney's place as senior counsel. Mr. Webster was staying in Baltimore at Mr. Hugh Birckhead's when it was determined to retain him, and I was sent to him for that purpose. He had just returned from dinner when I was introduced to him by our mutual friend, the master of the house. He had evidently dined well and was in rare good humor, when I took my seat on the sofa alongside of him and heard for the first time that deep, impressive and measured voice.

"Neither the time nor the place permitted me to do more than to explain my errand. He suggested that the time for adequate preparation was short, and made some difficulty about going into so heavy a case on such short notice, for I proposed he should set out with me for Annapolis the next day or the day after. When he found, however, that several days must elapse before the case would be reached, he agreed to take part in the argument, and accordingly on the following morning, we set out in company with Mr. William Gwynn, one of the company's counsel, for the capital of the State. The journey was performed in a hack and pair through the melancholy country lying between Baltimore and Annapolis, and occupied the greater part of the day. I had taken it for granted that the case would form the staple of the conversation, but it was scarcely mentioned. Mr. Webster soon found that Mr. Gwynn was a humorist, besides being a lawyer, and knew almost all the persons that he did, and they fell into a talk that was kept up from the commencement of the journey to the end. This I think was in the winter of 1831-2 and during my widower life. Gwynn was a theatre-goer, and intimate with all the celebrities of the stage. He was an editor, too, and knew all about the politicians. He knew the words of 
more songs than any man I ever met, and could or thought he could sing them to all the tunes that could be made up to fit them. One of the best tempered men in the world, aptest at all drollery, epigrammatist of the first water, and the kindliest of human beings, there was still a personal dignity, that prevented any of the liberties that such a character otherwise might seem to invite. Shrewdness was one of his traits, and acuteness as a lawyer was another. Mr. Webster took a fancy to him on the instant and amused himself in drawing Gwynn out. In this he had little diffculty, and the hours were winged to the listener, as the two men kept up one unbroken stream of talk during the journey. The only intermission was the wretched excuse for a meal at the Halfway House on the Annapolis Road, after which the stream flowed on until the carriage stopped at the Old City Hotel in Annapolis. Mr. Gwynn was in those days very fat, Mr. Webster was a stout man, and I was as thin as a lath; so Mr. Gwynn and I, as hosts, after a fashion, occupied one seat and gave the other to Mr. Webster as the visitor for the occasion. I have often wished that I had taken a note of all the good things said on this journey through the piney woods of Anne Arundel County.

"Nowadays steamboats or railroads take us to Annapolis in two hours.* My first visit there was with General Harper, and we slept at the Halfway House on the road, and a melancholy place it was, too. It had not improved when our trio passed over it.

"When we reached Annapolis there was some difficulty in obtaining quarters at the hotel. The Legislature was in session and every hole and corner of the little City seemed filled with visitors; so Mr. Webster and I were obliged to occupy the same room, a very large one on the first floor of

*In 1916 in one-half hour. 
an old mansion across the tavern yard, in one corner of which Mr. Webster had a bed, while I was in the bed diagonally opposite. There was a mighty fireplace with a high mantle, and huge logs, kept constantly ablaze, counteracted in some degree the draft of air that came into the apartment through the ill-fitting door and the shaking windows. There was no carpet, and a large table, a few chairs, and a washstand completed the furniture. After two or three days had passed we were accommodated with adjoining rooms on the second floor, a building like a barrack, and called, if I remember right, 'The Colony.'

"One would have thought that, as my mission was to cram Mr. Webster and his duty was to be crammed, the case to be argued would be our sole subject of conversation. On the contrary we but rarely spoke of it, after I had stated in a general way what had taken place before the Chancellor, and rehearsed as well as I could, from my notes, the argument of Messrs. Wirt and Jones. Sometimes I would begin on the case as we sat before our big fire, and Mr. Webster would apparently be listening, so far at least as to keep his great dark eyes fixed on mine; when instead of replying to me he would start some topic that had filled his thoughts while I was speaking, and go off in an entirely different direction from the controversy that had brought him to Annapolis.

"Twilight seemed to be a favorite time with Mr. Webster. After dining in the mess room of the Bench and Bar, we would go to our quarters to find the two tall candles lighted in the short winter days and the fire burning merrily to greet us. Mr. Webster would now take off his boots and, placing his chair on one side of the fireplace, tilt it back. With his feet in their stout yarn stockings against the mantle, as high as his head, he looked like anything but the great 
statesman and lawyer, whose eloquence and knowledge senators and courts alike acknowledged and deferred to.

"I wish I could recall all he uttered on those occasions. The three days in the oldtime room would fill a reasonable sized volume. Mr. Webster assumed and bore 'les frais de la conversation.' The two topics that I recall with most distinctness were Shakespeare and the old dramatists and anecdotes of his early life. Shakespeare was a theme of which he never wearied. I had some tastes in this direction, and was more or less familiar with the leading plays, and so we talked Shakespeare by the hour, and sometimes past the midnight hour. Even when we had separate quarters, Mr. Webster would sit by my fire and go over the same topics. I may say in passing that on his return to Washington and my return to Baltimore he sent me the folio edition of 1623 (Roxburgh Reprint) of the great dramatist as a token to recall the hours we had discussed him.

"No more delightful companion was to be found anywhere than Mr. Webster, when he chose to be agreeable. But this was not always, and, well as I learned to know him, I was never quite certain of his mood. In its worst shape, so far as my experience went, it was monosyllabic and curt, a curtness that prohibited familiarity of speech, and suggested the earliest possible termination of the interview. At Annapolis I saw none of this. Afterwards, at Washington, I saw it once or twice-perhaps but once, when Mr. Webster's name was before the public as a probable candidate for the Presidency.

"Anecdotes of his early life he told with great zest, and with a New England nasal twang, when necessary to give effect to a story.

"' 'Those were days,' he once said, 'when we lawyers went about from court to court in winter times in small one-horse 
sleighs. I had one, and was hurrying to my lodging place one night, when I found the way blocked by a lumber sled that filled the only track that had been worn deep into the snow.

"I knew the place well. It was at the foot of a steep hill, and the wagoner leaving his team had gone forward to a tavern at the top of the hill for an extra. None was to be had there for such occasion. It was a bright moonlight, and I could see the wagoner rising the summit. I never was averse to a joke, so I got my horse and sleigh into the wood and then unhitching the horse, put him in front of the lumberman's team, and soon had the load up the hill. Here I took off my horse and, leading him into the woods out of sight, watched to see the surprise of the wagoner when found his team had done this work without assistance. Soon enough he came back to where he found it, leading an extra horse. He stood silent for a moment, and then got angry and began to beat his team, exclaiming, 'You everlasting critters,' this in a strong nasal tone, 'so you pulled up the hill when my back was turned, and I paid 50 for nothing, you everlasting critters, you; I'll larrup you to teach you better, $\mathrm{d}-\mathrm{n}$ you, the next time;' when I came from my hiding place to save the larrupping by explaining the miracle.

"It was the inner frolic of the man illustrated by this story, rather than the facts, that made it interesting. His manner of telling it was inimitable.

"Another of his circuit rides was on a stage coach whose horses ran away, when Mr. Webster got out of the back window and, standing on the rack, watched the team over the top of the vehicle. Coming to a turnpike gate the mad beasts broke through it. This checked them, when the driver who had kept his place got down and, seeing $\mathrm{Mr}$. Webster, exclaimed, 'Waal, who'd a'thought Dan Webster, the lawyer, riding footman to Tim Strong, the driver, waal!' 
"On one occasion he gave me the particulars of an offer that had been made to him of a country clerkship, dramatizing the narrative as he went along. Speaking of age one day, he said: 'The worst standard by which to measure a man's years is the Parish Church's register. Some men, Sir, are born old, others are young all their lives, and I am sure that I belong to that class.'"

(Oliver Wendell Holmes gave voice to the same idea when he said he was eighty years young.)

"Again, speaking of an acquaintance one day, he said, 'Sir, he is one of the ablest lawyers I know, one of the most painstaking and laborious of men, a true friend, and unsurpassed in all the relations of husband, son, father and brother, but $\mathrm{d}-\mathrm{n}$, Sir, he never produced results.'

"Crossing the tavern yard to the mess room one evening, he stopped, turned so as to face me, when the full moon shone on his face, casting his eyes into the deep shadow of his massive brow, and placing his hands on my shoulders, said, 'My young friend, be in no haste to embark in politics, the time will come when all good men and true must rally around the constitution, and when we raise its banner it shall glitter like the "oriflamme." Removing his hands he resumed his walk, saying not one word more. These were then the nullification days of 1831-2. I had noticed that this evening he had been more than usually silent, as we sat on each side of the fire after dinner. His pent-up thought found expression in what he said to me. This story appears in his life by Curtis-a most excellent work, not on that account, of course, but as a succinct history of a most interesting time."

In Mr. Latrobe's diary is this reference to the meeting at Washington:

"Friday, December 20, 1833. I met Mr. Webster who 
seemed really pleased to see me, on the score of pleasant acquaintance at Annapolis. I asked him when he was going to raise the banner of the Constitution that was to glitter like the oriflamme of France, alluding to what he had said to me in Annapolis two years since. 'All in good time, my friend,' was the answer.

"On one of my visits to Washington, after we had met at Annapolis, I called on him, and, among other questions, he asked me what I was doing particularly. Replying that I had been busy preparing a speech that I had been appointed to deliver on the occasion of the celebration by the City authorities of Baltimore of the centenary of Washington's birth, he said that there had been some talk about getting up a dinner in Washington on the occasion, at which it was not unlikely he would be called upon to address the party of guests, 'So,' he said, 'that I might not be wholly unprepared, I have made a few 'scratches here, that might perhaps come into play, but the dinner has fallen through, and if they can be of any use to you, you are welcome to them; and he handed me a half sheet of blue letter paper, with some some six or eight short sentences upon it. I told him that my speech was already memorized, but that the paper would be a valuable autograph, and I would prize it accordingly.

"Now it so happened when I came to read the 'scratches' carefully, that there was a sentence among them, which would fit admirably into my oration. It was this: 'Washington stood not only at the commencement of a new era, but at the head of a new world.'

"Determined to do justice to this choice bit of epigrammatic eloquence in the delivery, I called on a very clever actor, the manager of the Front Street theater, which was to be the scene of my oratory, and whom I accidentally met there, when I went to look at the preparations, and 
repeating the sentence, took his judgment as to the most effective way of pronouncing it, and when the time came followed his instructions, and brought down the house.

"There were neither railroads nor telegraph in those days between Washington and Baltimore, and the public relied on stage coaches and the turnpike for the transmission of intelligence.

"The first stage that reached Baltimore after the 22nd of February brought me a letter from Mr. Webster while I was at breakfast, with a request on the back that it should be delivered promptly. It contained these words, and no more:

"My dear Sir: The dinner did come off after all, so look out.

Affectionately,

D. Webster."

"It was not long before I was at the Patriot newspaper office, where my speech was being set up for the afternoon paper, and struck out the interlarded sentence. It was well I did so, for when I read the report of Mr. Webster's after dinner speech, the sentence above mentioned was the only one of the 'scratches' that it contained. It is not everyone that is as considerate as Mr. Webster was on this occasion.*

"On one occasion I was in his office at his dwelling at Washington, writing at his dictation, in connection with a case in which we were interested, and raising my eyes when there was an unusual pause in the flow of words, I saw that he was sound asleep. I suppose he must have slept at least ten minutes, and then, awakening at the noise I made in moving my chair, to my astonishment he went on where he

\footnotetext{
*It seems to the writer that it would have been more considerate of Mr. Webster, after he had given" these "scratches" to Mr. Latrobe, not to have used them himself.
} 
left off in his dictation, and completed the paragraph as cleverly as though he had not slept as I have described.

"Mr. Webster was one of Mr. James G. Wilson's counsel, in the case of Woodworth and Rosseau-the great planing machine case. His colleagues were Reverdy Johnson, Wm. H. Seward, Henderson of Iowa, Phelps of Vermont, Hall of Washington and myself. It was necessary there should be a consultation before the argument in the Supreme Court, but the difficulty was to get counsel together to divide the points between them, if to do no more. At last Wilson in despair invited us all to supper at 9 o'clock at the National Hotel with the understanding we were to meet at eight to talk over the case. At about half-past eight we assembled, and sometime was lost in mutual greeting. Then Mr. Webster who was the senior called upon Governor Seward, and, pointing to a great volume of mss. upon the table, said in a solemn, sonorous voice, 'Brother Seward, suppose you commence the proceedings of this meeting by reading the record.' Now the reading of the record would have occupied hours, and we all laughed at the idea of beginning it except Mr. Webster and Governor Seward, the latter gravely taking up the mss. and reading, 'At a Circuit Court of the United States begun \&c., \&c.' This was more than enough to make our mirth obstreperous, when Mr. Webster said, 'It is moved that the reading of the record be dispensed with, and that Mr. Wilson inform his counsel when supper will be ready.' It was ready, for the folding doors were thrown open and the feast began.

"My seat was next to Mr. Webster, who on this occasion was in excellent spirits and until after midnight entertained us with an almost uninterrupted flow of narrative and anecdotes, now jocose, now pathetic, always apropos and entertaining. As may be readily imagined, nothing was 
said of Wilson v. Rosseau. But our Amphytrion, the plaintiff in error, was as well satisfied, he assured us, as if we had discussed nothing but the merits of the Woodworth planing machine during the evening; and as we won the case for him, he had, in addition to the victory, the recollection of an evening, such as, I warrant, neither his past nor his subsequent experience gave him any conception of.

"Observing that Mr. Webster drank no champagne, and that his only beverage was from the tumbler of water that he from time to time moistened his lips with, I remarked upon his abstemiousness. 'Taste it, Sir, taste it, Sir,' this in a whisper. Raising it to my lips, I found it was gin, and, as I thought, unadulterated. It is proper to say that more than a wine glass of it did not pass his lips. The attention paid him, the constant applause that he received, the roars of laughter he provoked, supplied on that evening all the excitement that was necessary. I have been to many consultations since with clever men, and in important cases, but the consultation in Wilson v. Rosseau stands alone.

"Though not in its place chronologically, I may as well mention here as later, in connection with Mr. Webster, what I have always regarded as one of the greatest compliments paid me as a professional man. It was in this same planing machine case.

"My first appearance was in the Supreme Court of New York and my associates were Daniel Webster, Reverdy Johnson, Judge Phelps of Vermont, Henderson of Iowa Wm. H. Seward, and Mr. Hall.

"I was to reply to Mr. Stevens of Albany when my turn came to speak, and Mr. Webster was to follow me upon the same side, and the same points were allotted to Mr. Webster and myself. Satisfied that I would occupy the remainder of the day to the adjournment, Mr. Webster, who had 
complained of not feeling well, had told me that so soon as I was under way, he would leave the Court Room; and accordingly I saw him in the seat just in front of me quietly inclose himself in his great coat which was on the back of the chair, and closing his portfolio, place his hat upon it, ready for a start. Something I said, however, seemed to attract his attention, and he turned to look at me. After some time he put his hat aside, and opened his portfolio and made a note, and turned to listen, and so he continued to listen and make notes until his great coat became uncomfortable; he then took this off, replaced it on the back of the chair, and only rose when I completed my spech and the Court adjourned." 'Why, Colonel,' he said, using a familiar nickname he had given me at Annapolis, 'You have called yourself the carpenter of the case, but you have done better as a lawyer, and I must stir myself between this and tomorrow.' Shaking me with unwonted cordiality by the hand, he said some other kind things which it is unnecessary to repeat."

The following are the "scratches" written by Daniel Webster and given to Mr. Latrobe:

"A century from the birth of Washington has changed the world and Washington is fit to be regarded as the first and greatest of the human agents that have wrought that change."

"The country of Washington has been the theatre on which a great part of the change has been wrought; and Washington himself is fit to be regarded among the first and greatest of the human agents who have accomplished it."

"Washington stands at the commencement of a new era, as well as at the head of a new world. His age and his country are equally full of wonders, and of both he is himself one of the chief wonders." 
"The age of Washington, what does it not comprise, in the progress of science, the development of new principles, and the progress of human improvement?"

"The country of Washington, what does it not exhibit, to attract the admirers of new enterprise, of new views of character, new and happy forms of civil policy, and of the universal spread of free institutions."

"America; Washington; what ideas will these names excite, a thousand years hence, among all the races and nations of men, that shall then inhabit our globe."

In closing the subject of Mr. Latrobe's association with Mr. Webster, I find the following notes and correspondence

"In my personal recollections of Daniel Webster, published in Harper's Monthly Magazine, I stated the circumstances under which Mr. Webster once said to me, "My young friend, be in no haste to embark in politics. The time will come, when all good men and true must rally round the Constitution; and when we raise its banner, it must glitter like an oriflamme."

"Nearly twenty years afterwards, Mr. Webster delivered the oration at the laying of the corner stone of the Capitol extension in Washington. In reply to a letter that I wrote to him on the occasion recalling the above piece of advice, I received the following:

"My dear Sir:

"Washington, July 10, 1851.

"I am exceedingly obliged to you for your friendly letter of the 7th inst. Our sojourn together at Annapolis, twenty years ago, is always recollected by me with pleasure. We attended to our professional duties, I hope, with diligence; but I remember that we had a good deal of general conversation, which was quite agreeable to me. We talked of Shakespeare and the player's edition of his plays; and, if 
I mistake not, settled the question whether shoes were made right and left in Shakespeare's time, by referring to the passage in King John in which the tailor tells his news.

Standing on slipper (which his nimble haste Had falsely thrust upon contrary feet.)

and I think we found other passages to the like effect. I remember also, that you kindly arranged to send me some Scotch Broom, then growing near Annapolis, and which is now flourishing at Marshfield. As to the particular occurrence which you mention, I recollect this, that sometime afterward, when we happed to meet, you recalled it to my attention.

My dear Sir, I am not worthy to be trusted with bearing up our great constitutional ORIFLAMmE; but I will do my best to keep it aloft, if you, and other men like you, will stand thick around.

I am, my dear Sir, with unabated friendship and regard Yours truly,

(signed) Daniel Webster.

John H. B. Latrobe."

"After the death of Mr. Webster, I sent to his executors, at their request, such memoranda as I happened to have in connection with him, and some time afterward received the following letter from Mr. Curtis, his biographer.

"My dear Sir:

“New York, January 31, 1870.

I take it for granted you will desire to repossess this valuable autograph. The anecdote to which it refers is told on your authority, in my second volume, and the letter quoted. The second volume will be out in a few days.

If you chance to meet Mr. Reverdy Johnson, please say 
to him that I hear he finds fault with the portrait in vol. 1st. So do a good many other people. The truth is that the picture from which the engraving was made was the best and most pleasing one extant of that time of life; and as it was a sort of historical picture, painted in reference to the Treaty (duplicate of that sent to Lord Ashburton) I ordered it to be done. But for the second volume I have obtained what I think the grandest head of Webster ever produced by the art of engraving. It is a very difficult thing to satisfy the recollections of those who knew him, or the conceptions of those who did not. But as far as the engraver's art can go, I think this last effort a success.

I would not send you this autograph, where I not afraid that you would assert your title by an action. It is worth its weight in gold, fifty times over. Pray give me a solemn acquittance.

Yours very truly,

George T. Curtis.

Jno. H. B. Latrobe, Esq."

"Among personal and professional associates, perhaps none have been more closely connected with me than the Winans family; and this is as proper a place as any other to introduce them.

"Ross Winans, the father, came to Baltimore, attracted by the fame of the Baltimore and Ohio Railroad Company's then great undertaking, in order to introduce upon its cars his invention of a 'friction wheel,' which at once excited, in an eminent degree, public curiosity. I have referred to it in my lecture of 'Personal Reminiscences' of this work. I became acquainted with him, of course, and saw a great deal of him. I became his counsel and attended to his law business, as well as his several inventions, for the 'Friction Wheel' was in the end the least of them, and was lost in 
the celebrity attaching to the eight-wheel car, of which he was unquestionably the author. This I argued for him in the Courts of Baltimore, in Cooperstown and the Courts of New York. I had so much to do with him and his inventions, was so well understood to be his intimate friend in business matters, that our names were associated in the public mind, and whenever his name was mentioned, it was a matter of course that I should be thought of. So much was this the case that when he was arrested in the commencement of the rebellion, it was proposed to arrest me too, it being taken for granted that if he was guilty of treason, I was equally so, and this, though I was in fact, a Union Man. I have this from Reverdy Johnson, who told me he dissuaded Mr. Seward from ordering my arrest when he ordered Winans'. The secret of our association, for it was association after all, rather than intimacy, was in my fondness for everything relating to mechanics, and the fertility of his mechanical knowledge. Besides this, it is proper to say that Mr. Winans was a man of more than ordinary mind, a bold and original thinker, with a good deal of the imaginative faculty. When he moved his family to Baltimore, it consisted of his father, wife, and several children, of whom Thomas and William were the eldest, both of whom have since become distinguished in connection with a great Russian contract, producing great wealth, and as inventors of what is known as the 'cigar' or 'spindle' steamer."

Mr. Latrobe has given above a short recital of his connection with Ross Winans. Mr. Ross Winans was a man whose career in Baltimore is closely connected with its progress; and his family, consisting of his sons and grandsons, have always been represented by Mr. Latrobe, or some member of his family, in this country. In another chapter, Mr. Latrobe's connection with the Winans in St. Petersburg is 
given in some detail. No account of the times of Mr. Latrobe will be complete without giving a short history of the Winans and their enterprises.

Mr. Ross Winans was born in New Jersey in October 1796, at Mt. Vernon Township, Sussex County. He came to Baltimore about 1826 or 1827 . As stated by Mr. Latrobe, he was brought here by his interest in the railroad, which was then being constructed. He was an inventive genius. The first invention mentioned was a plough. He was interested in steamboats, and advocated and patented "spindle shaped steamers," known as the cigar steamer. He invented the "friction wheel," also the outside bearing now universally used by railroads. This was unquestionably his suggestion. He invented the eight wheel coach. He invented a steam gun and many other devices.

According to a letter of Mr. Peter Cooper, which is embodied in this biography, he built the first steam engine used upon the Baltimore and Ohio in 1830. In 1834 we find that the firm of Gillingham \& Winans was building steam engines at their works, which were afterwards known as the "Mt. Clare Works," for the Railroad. These works were at the time among the largest machine shops in this country.

In looking over Mr. Latrobe's diary, I find the following entries:

"January 22, 1834. Winans came to see me.

"January 25, 1834. Saw Ross Winans who gave me a proposition of compromise with B. \& O. R. R.

"January 29, 1834. Considering claims of Ross Winans for compensation for use of outside bearing of the railroad carriage of which he is the patentee.

"January 31, 1834. At the railroad office. Gave Mr. Thomas, the President, my report upon the Winans case. 
"February 11, 1834. Saw Ross Winans and prepared assignment of the patent to B. \& O. R. R. Co.

"March 17, 1834. Went with Ross Winans to his house in the evening. He is experimenting on a form of the shape of steamboats.

"November 1, 1835. Drank tea and sat an hour with Winans. Afterwards talked about his patent right. Elgar sailed for Europe."

In his letter book, I find a letter of March 25, 1835.

"Wrote to Ross Winans that I wanted to see him in relation to Sullivan letter to the B. \& O. R. R.

"March 13, 1837. Saw Ross Winans about the suits in Boston.

"May 3, 1838. Had a meeting with McLane, Gillingham $\&$ Winans. They agree that the engine built for the B. \& O. should not be paid for until approved by the President and Board."

In a pamphlet written by Mr. Latrobe in 1868, he says, speaking of the ground through which the Baltimore and Ohio runs towards the Relay House:

"Now bounded by the rich meadows and thriving orchards into which Mr. Ross Winans' wealth and enterprise has converted the barren old fields that once belonged, \&c."

In the construction of engines and cars for the railroad, one great consideration was to reduce the friction of the axles in the boxes. About this time Mr. Ross Winans made his appearance in Baltimore, and instantly became a celebrity with his friction wheel, unquestionably an ingenious and beautiful contrivance. Mr. Winans suspended his wheel by a projecting flange on the interior periphery, on which the main axle revolved, dispensing thus with lateral guards, and meeting in many other ways the exigencies of the occasion, so long as slow speed alone was required: The 
town went wild with "Winans' Friction Wheel." Charles Carroll of Carrollton, who was then the great man on all great occasions in Baltimore, seated on a little car in one of the upper rooms of the Exchange, was drawn by a ridiculously small weight attached to a string passing over a pulley and dropping into the hall below. Around him were all the prominent men of Baltimore, and all were as much pleased as children with a new toy. In fact, there was an impression about railroad things in those days that was wonderful to recollect. Mr. Winans went to Europe with his invention, and was there plundered of the most valuable portion of it, the "outside bearing," through the bad faith of those whom he permitted to try it in public as an experiment. The outside bearing, of which he is unquestionably the inventor in its application to railroad carriages, is now the only bearing used throughout the world.

Mr. Winans planned the first eight wheel car ever built for passenger purposes, and called it by the appropriate name of "Columbus." To him is due the first organization of the sort made in the world. People pretended, when the railroad organization became too powerful to be resistedso powerful as to manufacture, through the vastness of the interests to be affected, the very credulity they wantedthat he had been anticipated, from the fact that long timbers like platforms had been carried on two cars temporarily united by their load; as though two men carrying a pole extending from the shoulder of one to the shoulder of the other could be called a "quadruped."

But due to the power of the railroad, as referred to by Mr. Latrobe, the inventor of railroad devices has a hard time, and it is very seldom that the original patentee of appliances used upon railroads ever receives compensation for his invention. The only way he ever realizes any benefit is to organize a combination strong enough to fight the railroad. 
Mr. Ross Winans was interested, as already stated, in the Mt. Clare Works, where a great number of what is known as "Camelback Engines" were built and used by the Baltimore and Ohio and other railroads. Ultimately these works were taken over by the Baltimore and Ohio.

Mr. Winans also invented a steam gun about the time of the breaking out of the war. An account of this appeared in the Baltimore News on April 12, 1911, and April 18, 1911. As shown by Mr. Latrobe's diary, the question of the shape of steamboats interested Mr. Ross Winans as far back as 1834. He advocated what is known as the "cigar steamer," a long and narrow steamer, the hull of which is a good deal more submerged than those in use at present; the shape, however, of the steamer suggested by him is now the one in common use. When a plan of one of these steamers is furnished from which to select a state room, one immediately perceives that the shape of the hull is exactly like that of a cigar. The Winans family worked over this shape of steamboat and spent an immense sum of money in so doing. They acquired large tracts of land on Whetstone Point, in Baltimore City, with a view to establishing machine shops for building ships. For many years the hull of one of these steamboats which had made a trip down the bay in 1850 or '51, was to be seen near the Light Street Bridge, but it was ultimately broken up.

In Chapter XVIII, a description is given of Mr. Latrobe's experiences in Russia, acting for the Messrs. Winans in what was known as the contract for the remount of the St. Petersburg and Moscow Railroad. In this matter, William Louis Winans, who was a son of Ross Winans, took the most active part, as is shown by Mr. Latrobe's account of his experiences there.

William Louis Winans, during his stay in Russia, built two vessels of the cigar boat character (which were in fact, 
submarines) for the Russian Government, for use in the Crimean war. Mr. Winans also built several monitors for the Russian Government-boats that were sunk very low in the water with turtle armored backs, so that the round shot used in those days would bound off the deck of the boat. He also armed them with guns on disappearing carriages. They were built prior to Ericson's monitors.

He received from the Emperor the Saint Anne Cross, the Stanislaus Cross, I think the Vladimir Cross, and, after he left Russia, the Emperor Alexander II gave him the star of the Stanislaus Order, which confers nobility in Russia.

Mr. Latrobe speaks in Chapter XVIII, page 7, of his being presented to the Grand Duke Constantine. Mr. William L. Winans was befriended by the Grand Duke Constantine in matters pertaining to the railroad, and the Grand Duke presented him with an oil painting of himself.

Mr. William L. Winans, who then resided in London, entered into a contract with his brothers, under the terms of which he was to perfect the steamboat, and was to be entitled in case of success to recoup his expenditures. The profits were then to be divided between William L. Winans, Thomas D. Winans, Walter Scott Winans and DeWitt Clinton Winans, in the proportion of four tenths to William, four tenths to Thomas and one tenth to each of the others. Mr. Ross Winans, the father, was dead at the time this agreement was entered into.

In the settlement of the estate of DeWitt Clinton Winans, who held a one-tenth interest as above specified, subject to this agreement, it became necessary to ascertain what amount of money had been expended by Mr. William L. Winans in the effort to perfect this patent. Detailed statements show that something over four millions of dollars had been expended in the effort to perfect this improvement, and for 
many years two large steamers lay in the river Thames, in London, belonging to Mr. Winans, upon which these sums had been spent. After the death of Mr. William L. Winans these vessels were broken up.

Mr. Ross Winans invested a considerable sum of money in building houses on Parkin Street, in the City of Baltimore, between McHenry and Ramsay Streets. His idea was to build houses which could be rented in floors to people of very moderate means. He expended something over $\$ 400,000$. in building these houses. They were a failure. Small houses could be rented at very low rates and people preferred to have their own roof tree rather than to live in buildings occupied by a number of families. Ultimately the property became in such condition that it was necessary to tear these houses down, as it was found that the revenue was not sufficient to justify their remaining. A large portion of this property is now held under lease by the Bartlett Hayward Company.

In $1861 \mathrm{Mr}$. Ross Winans was elected a member of the Legislature. At this time there was a strong feeling of sympathy for the South in Baltimore. Stanton gave orders for the arrest of Mr. Winans, Mr. Wallis, and a great number of the leading citizens of Baltimore; and they were confined in Fort Carroll. Here Mr. Winans used to deliver a sermon on each Sunday. Perhaps he was not very orthodox. He had written a book known as "One Religion and Many Creeds"-quite a remarkable work.

Mr. Ross Winans died in 1877 in Baltimore. He had been interested, together with his sons, in the building of the railroad in Russia. The Winans connection with this enterprise was brought about through George W. Whistler, an engineer.

Mr. Whistler was the son of Major John Whistler, who 
was wounded in a campaign against the Indians under Major St. Clair in 1791. He settled in Hagerstown, Maryland. Subsequently he moved to Jefferson Barracks, a short distance below St. Louis. Among a large number of children was George Washington Whistler, who was born at Fort Wayne, Ind. on the 19th day of May, 1800. He was a cadet at West Point on July 31, 1814. He was remarkable for his skill with his pencil, and this skill descended to one of his children, James McNeill Whistler, the great artist. Mr. Whistler graduated at West Point in 1819. It has been the custom for the Government to assist in works of public improvement by permitting the services of its officers and engineers to be engaged. Dr. Howard, Lieut. Colonel Long, Captain William Gibbs McNeill, Fassenden, Gwynne and Trimble were employed by the Baltimore and Ohio in this capacity. A special request was made by the directors of the Baltimore and Ohio in October 1828 for the services of Lieut. Whistler; and it was determined to send a deputation to England, composed of Jonathan Knight, William Gibbs McNeill, George W. Whistler and Ross Winans. The party left in November and returned in the following May. McNeill and Whistler were transferred in June 1829 to the Baltimore \& Susquehanna R. R. and made surveys of that road. Mr. Whistler resigned from the Army on December 3,1833 . He took control of the locomotive and machine works in 1834-37, and he constructed the railroad from Worcester and Springfield to Albany. While Whistler, McNeill and Swift were engineers building the railroad connecting Boston with the Great West, the Czar sent Chevalier von Gerstner in 1839 to the United States to obtain information concerning railroads in this country; as he contemplated building a line, at national expense, from St. Petersburg to Moscow. Von Gerstner was followed by a Committee 
of Engineers, Mentkoff and Kraft, who, like him, reported strongly in favor of the American system in preference to the English. They were so impressed by the ability of Whistler that he was invited by the Emperor to go to Russia to act as consulting engineer. He sailed for St. Petersburg in 1842. What is known as the battle of gauges occurred, resulting in the adoption of the gauge of five feet, advocated by Whistler. Rolling stock and fixed machinery were furnished by Winans, Harrison and Eastwick. The Winans contract was about five millions of dollars. Rolling stock construction was commenced in 1844. Works were established, Alexandroffsky became the name of the shops which were located near St. Petersburg. The Emperor visited these shops in 1847 . Whistler was decorated with the order of St. Anne. He had an attack of Asiatic Cholera in November, 1848 and died from its effects the 9th of April 1849. The road was opened on November 1, 1851.

The Government was so well satisfied with the work that it entered into a contract with Joseph Harrison, Thomas D. Winans and William L. Winans, to supply the road with rolling stock and keep it in condition. This new contract bears date August 25, 1850, and was to run until July 1856. The term used in describing the work to be done is the "remount of the St. Petersburg and Moscow Railroad." Mr. Ross Winans was not a party to this contract, but his sons were. The eldest son of George Whistler, George W. Whistler, also an engineer, continued in the Russian service. He had married Julia, the only daughter of Ross Winans. The contract was extended and in $1857 \mathrm{Mr}$. Latrobe visited Russia, as detailed in a subsequent chapter, in the interests of the Winans and others in reference to the performance of the contract.

Of the two sons who were parties to this contract, Thomas 
D. Winans is spoken of as an engineer in the Americana. He was born on December 6, 1820, in New Jersey, and died in Rhode Island in June 1878. We find him in 1861 establishing soup houses for the poor in the City of Baltimore. He had a country place near Baltimore, and he had a large dwelling house on Fremont Avenue and Baltimore Street, which was surrounded by a high brick wall. There seem to be two reasons for this high wall. The first is that Mr. Winans, who had great artistic taste, ornamented the ground with handsome statuary. The nude figures offended the residents to such an extent that, in order to do away with the objection, Mr. Winans built this wall. Another reason given for the erection of the wall was that there were two lions which ornamented the entrance to $\mathrm{Mr}$. Winans' residence, and that the patriotic citizens of Baltimore were so irritated by these emblems of Britain, that it was necessary, in order to protect them, to build the wall. In view of the fact that not many years ago the tails of the lions at the Calvert Street Bridge were broken off by some citizen who resented such an exhibition, there would appear to be some foundation for this second cause. These lions were re-tailed, and on examination will be found to be stone lions with metal tails.

Mr. William L. Winans, the other son who was interested in the Russian contract, never returned to this country. He died in England, possessed of a large fortune-some twenty odd millions of dollars. A suit was instituted which ultimately went to the House of Lords, Mr. Winans' estate claiming he had never given up his citizenship in this country. The decision of the House of Lords was in favor of the Crown.

William Louis Winans also designed and built the Nicholefsky stone bridge across the River Neva at St. Peters- 
burg, the first permanent bridge erected there. All former bridges had to be pontoon bridges and removed when the ice came down in the winter. This bridge was built with what was called the cigar shaped buttresses, pointed up stream, so that the ice would break against them and thus save the bridge from being carried away. There are two other stone bridges over the Neva, but this bridge is by far the most artistic, as well as beautifully proportioned. It is spoken of as a monument to William $\mathrm{L}$. Winans.

Mr. Walter Winans, one of the sons of William L. Winans, is the well known sportsman and sculptor, and recognized as the best pistol shot in the world. He recently executed a beautiful statue of Joan of Arc, copies of which are being sold for the benefit of the French Red Cross Fund.

The following is a list of the men who studied law in Mr. Latrobe's office, as described by him:-

"T. Yates Walsh, who afterwards became a prominent member of the Baltimore Bar, was a man of very decided talents, and a perfect walking dictionary of political events He finished his course of studies with me, after General Harper's death, and was so, accidentally, made my first student. He was a constant reader, but read miscellaneously; and when urged to adopt a plan of professional study, would laugh and say that in the Courts where he was a constant attendant, he could "pick up" what he wanted, and, strange to say, he picked up enough to make himself a far better lawyer than many a hard worker among his colleagues. There were few in the profession who were readier or better informed than he was. The only wonder was where he contrived to pick up what he knew.

"The second was Benjamin C. Presstman, afterwards a Judge, an intelligent man of sterling principles, highly re- 
spected, still living, but not very active in the profession. I recollect on one occasion, when he was in the Court, opposed to $\mathrm{Mr}$. Wallis, he appeared with a beautiful rosebud on the lapel of his coat. He used tobacco and was very careless, and his coat was covered with tobacco stains. He said to Mr. Wallis, pointing to the rosebud, 'Wallis, you cannot guess where that came from.' Mr. Wallis said, 'No, not unless it grew there.'

"Third, Charles Howard, a remarkable man, a cigar maker, of great ambition, studied the classics while he rolled cigars, moved to the West, but made no mark there-long since dead. Radcliffe, still alive, went to Washington, came back to Baltimore, but has made no figure.

"Henry Webster, a business man, but cut out for the law, an honest upright gentleman-dead.

"Philip Keyser, full of energy and enterprise, a gallant gentleman, went to California, where he is now a Judge, and has named a town after me.

"W. D. Fenton had the making of a sound counsellor, but, weak in health, went to Parkersburg and died there. Charles J. M. Gwynn, full of talent, laborious and energetic, is now Attorney General of the State.

"R. Van Winkle, clever, active, above mediocrity, I have lost sight of him.

"Wm. Urquhart, a young gentleman who read law, pour passer le temps.

"Archibald Sterling, altogether the most satisfactory of my students, taking him all in all, now United States Attorney for Maryland.

"John H. Ting, employed as my clerk, was admitted to practice from my office, bright and intelligent, and should have succeeded, but something was wanting.

"Llewellyn C. Barry, clever, gentlemanly, intelligent, married a rich wife, a refined man, but not a strong one. 
"Henry Latrobe, Ferdinand Latrobe, Osmun Latrobe, R. Stuart Latrobe, John Latrobe, my sons, all alive now except Henry, the son of my first wife. None took kindly to the law. Henry went into business, Ferdinand did the same, and so did Osmun. Both had the makings of lawyers. Ferdinand is Mayor of Baltimore, now in his 4th year of service. Osmun went into the Southern Army, left it as Chief of Staff to Longstreet, is now in Europe. Stuart and John are still at the Bar, but neither loves the law. My nephew, B. H. Latrobe, studied law with me, went to ministry, and is now rector of a church in Philadelphia. Joshua $\mathrm{J}$. Wilkinson, intelligent, but not cut out for the profession, has means, and still belongs to it. Jack Lucas, the son of my old and best friend, F. Lucas, was another student with plenty of ability. He died early. Thomas Whelan, still alive and busy in the profession in a quiet way. Charles W. Crocker was yet another student, whom I lost sight of after leaving the office. Marion, another lost sight of. Twentyfour in all.

Of Osmun Latrobe who died in 1915 we have the following record:-

"Colonel:-

"Headquarters First Army Corps, April 11, 1865.

"The deplorable events of yesterday will cause, for a time at least, our speedy separation. I seize a moment of leisure to express my profound regret at leaving you, as well as for the distinguished services you have done for the cause of the Confederate States.

"Commencing the war as A. D. C. to Brig. General D. R. Jones, your fidelity to duty and gallantry on the field won for you the promotion of Major in the Asst. Adjt. Genl.'s Department and assignment to me. 
"When Col. Sorrel was promoted to Brig. General, I felt that your intelligence, courage and devotion to principle, entitled you to your present rank, to which, in accordance with my recommendation, you were assigned. The ability with which you performed its responsible and arduous duties, always commanded my profound respect.

"With the most fervent hope for your future happiness and success, I am, Colonel,

Your sincere friend,

J. Longstreet,

Lieut. Gen'l.

To Lieut. Colonel Osmun Latrobe."

"Headquarters, Armies of the Confederacy.

11 April, 1865.

"The conduct of Lieut.Colonel Osmun Latrobe on the field and in camp frequently coming within my knowledge, I had good opportunity to judge of his merit and worth. Concurring in the commendation of Lieut.Gen'l. Longstreet, I take pleasure in bearing testimony to his high qualities as a soldier and a gentleman.

R. E. Lee, General."

"I forgot, when going over the names of the students of my law office, Moale, a very reliable young man, long since dead. The reference to my students reminds me of a coincidence occurring in the present year 1883, when Lord Coleridge visited the U.S. The Bar Association of Baltimore invited him to a dinner and I was appointed on the Committee that was to receive him on his arrival. When the Committee met at the R. R. Station, I found that of the four lawyers of whom it consisted, two had been my students, 
and these two the most distinguished of them, Mr. Gwynn, the Attorney General of Maryland, and Archibald Stirling, the U. S. Attorney, both now grayheaded men, who with their old instructor and Mr. Nevitt Steele received the Chief Justice of England. Since my enumeration of my students on the preceding page, Mr. Presstman, who has been a Judge of a Court in Baltimore, has died, respected by all who knew him, a high toned gentleman, honest as the sun. Radcliffe is dead, too, not long since. He had returned from Washington, to which place he had gone to practice law, and after a few years of professional life in his old hunting grounds he has passed away."

Mr. Latrobe was a director of and counsel for the Union Bank from 1832 to 1837. He thus describes his connection with the Bank:

"I forget when I was chosen a director of the Union Bank of Maryland, but think it must have been about the year 1832-perhaps a year or so before that date. I had fallen in with the President, Mr. Thomas Ellicott, and some fancy that he had for me was shown in putting me into the Board. I was a regular attendant and the appointment did me no disservice.

"Of those who sat at the Board of the Union Bank I am the only surviving director; the cashier, my friend, Robert Mickle, is still alive, an older man than I am and still in his office, as active and intelligent as ever.

"But by far the most remarkable person here was the late Thomas Ellicott, a man of rare qualities, of extraordinary intelligence, and as fit to command an Army as to determine questions of bank policy. His physique was remarkable. He must have been six feet four inches, a great, thin, broad-shouldered person, with a massive square brow shadowing deep sunk eyes that lit up a face, whose com- 
plexion was a pale, unhealthy one, with a stern determination. A heavy jaw and tightly compressed lips made firmness and iron will the characteristics of his countenance. Mr. Ellicott was a Quaker and, save that he dressed in black, wore the garb and hat of the sect. His stride was corresponding to his height and, although later in life he stooped, his carriage was eminently imposing, and strangers turned as he passed to look at the commanding person of Thomas Ellicott, Eleven men were on the Board, but it was Mr. Ellicott's will that swayed their actions. Thomas Ellicott was born 1777 and died in 1859.

"There were few men that the late Roger B. Taney had more regard for than Mr. Ellicott, and I am satisfied that the removal of the deposits and the pet bank system were promoted by him, even if not originated. Long before either measure was adopted, Mr. Ellicott and Mr. Taney were close friends, as it seemed to me. He was a visitor at Mr. Taney's house, and I saw him more than once, and on these occasions I know the financed affairs were the subject of conversation. Were I examined on this point, which is an interesting one, I might probably be driven to say that after all my opinion rested on my knowledge of Mr. Ellicott's views as expressed again and again before the deposits were removed. Their correspondence with those of Mr. Taney he developed by his action in this connection, and by the fact that among the first of the pet banks selected by Mr. Taney was the Union Bank, of which Mr. Ellicott was President.

"Mr. Ellicott was not without ambition. He wanted to go to Europe as the agent of the Bank to dispose of certain securities held by it; and circumstances at last made him unpopular. A combination was formed against him, and he and his Board, myself inter alios, were turned out of office 
-after 1837, I know, but when exactly I do not remember. I was a member in 1835 , for in the panic times of that year Mr. Mayhew and myself were authorized to exercise the powers of the Board which did not meet for several weeks, during which Mr. Mayhew granted or withheld discounts at his pleasure. He had the knowledge of parties applying for them that I wanted, and I had sense enough not to interfere with anything he did. When the Board resumed its sessions, it was to ratify all that the Committee had done during its recess. So much for my Bank directorship.

"The story of Mr. Ellicott's unpopularity is told in the history of Ellicott, Poultney \& Company. Mr. Evan Poultney was the President of the Maryland Bank; a combination was formed to control the Bank, through the ownership of the stock. In 1834, the Bank failed and made a Deed of Trust to Thomas Ellicott, at the suggestion of the creditors. J. B. Morris and R. W. Gill were made Trustees to act with Ellicott. John Glenn and Reverdy Johnson acted as counsel for the Trustees. There was much said as to the cause of failure. Fraud was charged, and an active paper war was waged. A delay of seventeen months was too much for the temper of the people, and on August 7, 8 and 9,1835 , a mob took possession of the town. They looted Reverdy Johnson's house on the corner of Fayette and Calvert Streets. They did the same to John Glenn's house on Charles Street. John B. Morris fared no better. Mr. Jesse Hunt was Mayor. I think he had been a director of the Maryland Bank. They looted his house and burned his furniture. They burned Johnson's house and Glenn's and Morris's. Jesse Hunt resigned his position of Mayor on the 11th day of August, 1835. The veteran warrior (eighty-three years old), General Samuel Smith, took command of the City, and on the 10th what is known as the 
Bank Riot was over. The State paid over $\$ 100,000$ to the people whose property was injured. Mr. Latrobe was absent from the City on a visit to Virginia Springs. He writes in his diary:

"Back to Baltimore on the 23rd August, 1835. The riots had occurred in the meantime, and I felt ashamed of the City of my selection when I saw the ravages of the insane mob."

Among the letters in the custody of the Maryland Historical Society is a quaint and interesting account of the riot known as the "Bank Riots of 1835."

"Edward Stabler,

Postmaster,

Sandy Spring,

Montgomery Co., Maryland.

Balto. 8 Mo. 12th, 1835. No. 76 So. Calvert Street. "Dear Edward:-

"Thine of 7th inst. is before me.

"We have seen things awfully strange in this City within a week, I tell thee. On fifth day night a considerable number of folk, good, bad and indifferent assembled in Monument Square, before the door of Reverdy Johnson (of Bank of Maryland memory). Without much ado they dispersed, because, as they said, that was not the time they intended to operate, that time being fixed for 7 th day night. On sixth day evening the crowd again met, in numbers greater than before. Some unruly spirits now threw a few stones and broke a few glass in R. Johnson's windows. They were again advised to desist, which they did and retired by 10 or eleven o'clock, giving clear indications that they would be punctual to their engagements by the next evening. Arrangements were now made, and a few armed men surrounded the property of Johnson on 7 th day evening for 
the purpose of protecting it. The Mob appeared, was beaten off and some three or five killed, and ten or twenty wounded. Finding themselves repulsed at Johnson's a detachment rushed round to Glenn's (of like memory) in Charles Street. Here they made an effectual and unresisted attack, and very soon had his furniture all in the street, where it was entirely destroyed by breaking and tearing it to pieces. The Mob now found themselves Masters, and went on unmolested in this part of the town. In the morning I went there, and saw that the House was too greatly injured.

"I do not know what Glenn's loss amounts to, but when I tell thee his wines alone are said to have cost over four thousand Dollars, I am very sure thee would not pay all his losses for a sum under Twenty Thousand Dollars. The rioters remained, I mean some twenty of them, picking at Glenn's house till 6 P.M. when they knocked off. Now, what think thee? These twenty persons carried on their un-lawful game in the presence of from 2000 to Five Thousand persons, who witnessed it and not one word of objection was raised!

"All first day it was well understood that destruction was to be the order of the night, yet not one step taken to prevent it by those who should have done so!

"But to my narrative. I say the mob boldly declared who might expect them, and accordingly before 9 o'clock in the evening a fire was built before the door of Johnson's house and his furniture was all thrown thereon and destroyed. His house very soon presented a fearful wreck. His loss must be over that of Glenn's-unless indeed P. E. Thomas should happen to find a part thereof to fall on him, as the owner in part of the House. This burning was an improvement on the Glenn plan. By eleven o'clock part of 
these Beauties passed down Calvert street to Hugh McEldrey's new House. They were about giving it a brush when the carpenter, who was building, appeared and told them if the House was destroyed the loss would fall on him, as he had not delivered the key. They then went to the house he occupied, which by the by he had left during first day, having taken a hint that his presence might be more agreeable to the mob, than theirs would be to him. So the owners of the house telling them the loss would not fall on McEldrey if they destroyed anything there, they went off, and found the House of Jesse Hunt (our poor frightened Mayor). His furniture was soon consigned to the flames, as had been that of Johnson.

"They now went after Dr. (Frederick E. B.) Hintze. The Dr. lives in Gay Street. He had killed one of the Mob on seventh day night as he said, and the great man had done more than that in his own conceit. He had really rode over many more. This boasting had inflamed them, so to him they went. His wife appeared before them. She declared the property was not the Doctor's, but all belonged to her, having been inherited from her father. They now went to Cpt. Benzinger, he was a Captain whom they didn't fancy, to him they gave sorrowful demonstrations of ill-will, as also to Willie, in Franklin Street, for no higher offence than doing his duty as a soldier. But now thee shall hear what was much worse as to destruction of property, than what relates to a dozen Captains or Soldiers. To my friend Jno. B. Morris in South Street they now pushed. His furniture was all destroyed by fire and House greatly injured; I should be within bounds were I to say his loss is greatest of any.

"From John's they went-I mean a party under the command of their leader called "Black Hawk" - to Light 
street wharf in search of McEldrey's Lumber yard. At the gate they were overheard by Cpt. Carver, who is my author, that they stated on examining the premises that it would not do to set it on fire as they had intended, owing to the destruction that must ensue to the owner of the adjoining yard. Black Hawk ordered them away, but one third still remained, intending, as is concluded, notwithstanding his orders, to fire the yard. Their leaders returned and commanded them to desist, but to go up Pratt Street and finish the work of the night on Evan T. Ellicott; so up they went. Saw Evan Poultney who confessed his sins, to which they replied, "for the present" they were satisfied and then went to work at Evan T. Ellicott's. I now say what I saw.

"Did thee ever see corn husked by about 50 spirited negroes? Just as the corn flies from their hands, so did Evan's furniture go on a burning fire that ascended half to the top of the House. An engine kept it from going to the top of the House. At about 4 they blew their horn and quickly retired, after spending with the latter director but about an hour and a half, at most not two hours. Thy friend Wm. E. Bartlett."

"My first sheet brings us down to a little past 4 o'clock on second day morning when I saw this outrageous proceeding terminate at Evan's-from thence I went to the other places of distinction. At Johnson's I saw about twenty operators as much interested in the work of destruction, as ever they were taken up in the salvation of their souls. Not a hand was raised-as at Glenn's, so here-5000 Persons stood looking on, men and boys, some of them, I am sure not over ten years of age, hauling and pulling at all parts of the house; it reminded me of a set of wood peckers on an old dry tree, so slow did they advance their work. In sickening disgust I crept down to my store, not knowing 
what to expect. The City was then in and under the control of a Mob; not a step being taken to arrest their course. But deliverance was at hand! Our Brave and worthy Citizen Genl. Smith was here. He rallied some of the Blood royals. These carrying the star spangled banner waving over their heads marched through the streets and thus collected a pretty considerable band. They adopted a course which being executed by sundown of second day, we had an assurance that the Laws of good order were again in force. We are now, thanks to Genl. Smith and his worthies, thanks to the good people of this insulted City, again safe. The City is alive all night - at every corner you may see large companies of worthies marching to and fro, and a mob man, as such, cannot be seen.

I am not sure that the mob is done, because they had work laid out, which has not been accomplished.

When thee learns the true cause of all this disturbance, thee will, I dare say, have a different view thereof than at first sight taken.

The Bank of Maryland injured thousands. All that were connected with that institution at the time it failed, have been considered by the people at large as being enriched at their expense. The sufferers bore their loss with commendable fortitude until they supposed no lawful remedy would avail them. They then followed the example of the Vicksburg people in attempting to inflict the Lynch Law; and I suppose had they been able to catch the Obnoctious Directors of said institution, they would have been altogether satisfied to have given each of them a dress of Tar and feathers. Not finding them, they fell-as I have shownon their property, and have doubtless distroyed one Hundred Thousand dollars worth thereof.

By the time this reaches thee I suppose myself, wife and little ones will be on our way to the Land of my nativity. 
I do not feel altogether easy to leave home during these times of Commotion and would not, were it not that our friends there will be put to some trouble if we do not go as promised them.

Jno. Livingston has told the Monthly Meeting that he intends to Marry Ann Scott.

\section{I am thy friend, Wm. E. Bartlett."}

In an interesting Life of Reverdy Johnson, by Bernard C. Steiner, will be found the details of this outbreak and its cause. A suit was brought against Reverdy Johnson, which was tried in 1836, and the jury acquitted him of all blame in connection with the failure of the Bank of Maryland. He filed a memorial in 1836 in the Legislature in the same year, claiming that he was entitled to be reimbursed for the destruction of his property; as did Jno. B. Morris. The report of the committee was favorable and damages were paid.

A bill alleging fraud was filed against Ellicott, Poultney \& Company, in 1836, to prevent the voting of certain stock of the Union Bank, which would enable the members of that firm to control the Bank. An injunction was granted, and Mr. Hugh W. Evans became President of the Union Bank, in place of Thomas Ellicott. In this connection the following poetic effusion represents the feelings of the times:-

\section{THE FOLLOWING HEROIC POEM}

Is Dedicated With Great Diffidence and Much Deference TO THE

ST OCKHOLDERS OF THE UNION BANK OF MARYLAND.

The devil was making a thunder-storm

At his lightning forge below,

When he heard the voice of "Bank Reform"

Across his kingdom go. 
He had been a reformer himself of old, And he knew the business well;

So he thought it would better, a hundred fold, The census-books of hell.

He called for a grey and grim, old sprite Who had lorded it in his day;

And gave him in hell a "Trustee's" might, While he himself was away.

He donned a hat, with a two foot brim, And turned his collar down;

His coat was a blue, of as solemn a trim As ever deceived the town.

A kerchief white, like a maiden's staid, Was tied around his fire-proof throat; His vest of broken-bank-notes was made, Here and there a protested note.

He started off at a whirlwind pace On his way to the seat of war;

But 'twas long and long ere he ran his race, The journey was so far.

The Devil got tired, and well he might, For he is no chicken now;

And the frosts of age are sparkling bright Upon his horny brow.

When he reached the earth, what should he see But an engine smoking near;

And as few like smoke as well as he, $\mathrm{He}$ mounted in the rear.

When the Devil had started at Ellicott's Mills And stopped at Ellicott's store, He thought he was doomed to ride and run Betwixt Ellicott's-evermore. 
He left the car, and up Market Street

In silence did he go,

When what should first his eye-sight greet

But Ellicott, Poultney \& Co.

He ran 'till he turned the corner 'round,

And he thought him then secure;

But not the Devil himself e'er found

One thing he could call sure.

For a huge brick house was before him then,

And a Bank he took it to be;

So he entered in with a crowd of men

The "Bank Reform" to see.

But when he was in, what should he hear

But the self-same sound as before;

And Ellicott-Ellicott-struck his ear,

Tom Ellicott-was the roar.

'Ha! ha! ha! ha! and I've got it at last'

Screamed out the father of evil;

'I've found whom I've sought for a century past,

I've found Old Tom the Devil.'

That moment he saw a man come forth

With a roll of notes in his hand;

And $\$ 25,000$ was on a box

Close by, where he saw him stand.

Now the Devil who knew a thing or two

Without need of being told,

When he saw the widow's pittance there,

Could not more his patience hold.

He gave brother Tom so loud a curse

That the specie jingled round;

And the quill-arm'd clerks jumped up and ran

At the fierce and dreadful sound. 
'Now pray, and who in the Devil art thou?' Friend Tom quite bravely cried.

'I'm your master, Sir, and the Devil too,'

The true old imp replied.

'Be thou what thou mayest,' cried Tom in turn,

'Avaunt, I know no fear,

I've got the proxies all settled for me, And I'm head-Devil here.'

Old Nick gave forth one loud, laughing yell, And seized him by the hair;

Before one minute was Tom in hell, Keeping "silent meeting" there.

And ever since then the Union's sky

Has met with cloudy weather;

So that you and all must up and try,

Or you'll go to the Devil together.

Old Nick went on to the Capitol

To get rid of the Ellicott name;

And were you half as wise as the Devil,

You'd endeavor to do the same.

Those who are familiar with Southey, think that the above should be headed "with apologies to the 'Devil's Walk." "The first verses show the origin of the writer's inspiration.

\section{THE DEVIL'S WALK.}

From his brimstone bed at break of day

A-walking the Devil has gone,

To look at his snug farm of the world,

And see how his stock went on.

Over the hill and over the dale,

And he went over the plain,

And backward and forward he swished his tail,

As a gentleman swishes his cane. 
How then was the Devil dressed?

Oh! he was in his Sunday best,

His coat was red and his breeches were blue, And there was a hole where his tail came through! 


\section{CHAPTER XV}

The Maryland Institute-The Maryland Historical Society-Latrobe Justice's Practice-Masonry-J. P. KenNEDy-Painter-GreENMOUNT-Mr. Latrobe's Poetic Talent

"It was soon after my admission to the bar, 1824-25, as nearly as I can recollect, that the plan of Mechanic's Institute originated with Dr. Birkbeck in London, and was followed by the establishment of the Franklin Institute in Philadelphia. This idea took my fancy greatly, and I thought that it might be carried out, perhaps, in Baltimore. I consulted with my good friend, Fielding Lucas, and Col. $\mathrm{Wm}$. Stewart, and perhaps one or two others, who agreed to sustain any effort I might make. So, providing a chairman and secretary, the latter being Mr. Smith, a teacher of drawing and an eager advocate, though a very modest, amiable man, I published a notice in the papers and, I think, an article or two, descriptive of what was intended, calling a meeting at a large room called 'Concert Hall,' in South Charles Street, then often used for such purposes, and in fact the only public room in Baltimore in those days suitable for the purpose. When the meeting assembled, I made a speech after the organization had been effected, and I remember was followed by Col. U. S. Heath, a prominent lawyer, afterwards a Judge, who was prompted by the spirit of the moment and proposed offhand measures that did not exactly correspond with the program I had prepared. Things for a moment threatened to go wrong, until Col. Heath, ascertaining that I had prepared what was to be 
done, came to me, scolded me for not having let him know what I was after, in a good humored way-and I soon had the satisfaction of seeing everything go off with a rush. In a little while the Institute was organized in a practical way. I prepared its charter, and it is still in existence, prospering and to prosper. We commenced with a feeble exhibition of manufactured articles, in the room where our public meeting was held-my main recollection of the display being immense specimens of cabinet wear, and an extraordinary smell of new leather. I have more than once since been recognized in public addresses as the founder of the Institute, and I am certainly proud of the part I took in the matter.

"Among the Laws of 1825, Chapter 4 is the law incorporating the Maryland Institute for the promotion of the Mechanic's Art.

"The officers named were William Stewart, President, George Warner, Fielding Lucas, Jr., Vice-Presidents, John Mouton, Recording Secretary, Dr. William Howard, Corresponding Secretary, Samuel Harden, Treasurer.

"Managers: James H. Clark, John D. Craig, D. G. McCoy, Jacob Deems, Solomon Etting, William H. Freeman, Benjamin C. Howard, Moses Hand, William Hubbard, William Krebs, Thomas Kelso, Robert Carey Long, John H. B. Latrobe, Peter Leary, William Meeter, James Mosher, Hezekiah Niles, Henry Parson, William Roney, Joseph K. Stapleton, William F. Small, James Sykes, James R. Sullivan, Samuel D. Walker." These were the men to whom Mr. Latrobe in another part of his note says Baltimore owes much.

"We wanted to get up a course of lectures, but it was heavy work. I contributed two on the law of apprentices which put, I think, a large part of my audience to sleep. I 
was more successful afterward, when, year after year, I delivered the opening address of each winter's course of instruction. I find among the papers a copy of a resolution on the subject, 1829.

Dear Sir:-

"Baltimore, 29th October, 1829.

I beg leave to hand you a copy of a resolution passed at a regular meeting of the Managers of the Maryland Institute held the 27th inst.

'Resolved unanimously, that the Chairman of the Board be requested to return the thanks of the Managers to J. H. B. Latrobe, Esq., for the very able and appropriate public address delivered by him, introductory to the commencement of the Lectures; and to request that he would be pleased to furnish a copy for publication.'

In compliance with this resolution of the Managers, and in their names, I have the pleasure to thank you for the very interesting and popular discourse delivered in the Institute (preparatory to the opening of the present course of Lectures) before a large assemblage of Beauty and Science, by whom the Hall was filled, and who appeared to listen with delight to every portion of your discourse, and to request, that you may be pleased to comply with the wishes of the managers and furnish them with a copy for publication, thereby gratifying a large portion of our fellow citizens (who could not be accommodated in the hall) with the views and object of the Maryland Institute; which, the Board of Managers feel assured, will, with suitable patronage, become one of the most useful and distinguished schools for extending the knowledge of the mechanic arts, and enlarging the bounds of Science in this or any other country.

I am with the greatest respect,

Dear Sir, your most obedient servant, Joseph K. Stapleton, Chairman Board Managers, Maryland Institute.

John H. B. Latrobe, Esq."

"As the thing became popular, and the membership was numerous, we obtained from Pixie in Paris an admirable 
selection of apparatus in the departments of chemistry and natural philosophy, in their application to the mechanic's arts. Mr. Smith gave lessons in drawing, and Dr. Wm. Howard on natural philosophy, and other gentlemen, whose names I have forgotten, lent their assistance as lecturers. We moved, too, from Charles Street to the Athenaeum Building, and the Institute prospered more and more every year, until the building was destroyed by fire, and all our records and collections were burnt up. This was in February 1835. Then it slept for years, until it was revived mainly by the efforts of Mr. B. F. Benson, and has since worked its way successfully in the building over the market house in Marsh Market Space. As a sample of its growth, it may be stated that Mr. Smith's twenty or thirty pupils in the drawing school have grown to be five hundred and upward in the school of design under the care of Professor Woodward. How often since, as I have spoken to thousands in the present spacious and brilliantly lighted hall, have I not recollected the modest days of the earlier existence of the Maryland Institute. Since then, through the generosity of Mr. Michael Jenkins and Mr. Carnegie, the Maryland Institute has a handsome home on Mt. Royal Avenue, in the City of Baltimore."

The Committee of the Maryland Historical Society appointed at the meeting held to commemorate Mr. Latrobe's death uses the following language:

"An institution or enterprise designed to promote that end (the welfare of the City and State), the Maryland Institute, of which he was one of the early Presidents, had his warm sympathies and constant support.

In a letter from Charles Harper to Latrobe, dated January 2, 1826, occurs the following:

"The creation of the Maryland Institute is your work." 
Mr. S. Teackle Wallis, one of the leaders of the bar, in delivering a lecture on the subject of art at the Maryland Institute, June 4, 1881, said:

"Of the conspicuous and valuable citizens who were the early friends and promoters of the institute, and who manifested their interest in it by their presence on the occasion, there are but few now left (referring to his address in 1851).

"My friend and professional brother, John H. B. Latrobe, whose varied and remarkable accomplishments and gifts seem to grow brighter from their constant and earnest application to all purposes of practical utility, is still as active and assiduous in the unpaid service of our people, as when he delivered the address before the Institute in 1848, at the opening of its first annual exhibition at Washington Hall."

In a book entitled "Baltimore, the Monumental City," is the following:

"The Maryland Institute was organized by Mr. Latrobe. Its first meeting was held at Concert Hall, South Charles Street. Removed to the Athenaeum Building and remained there until the building was destroyed by fire in 1835 . Reorganized in 1847, Mr. Latrobe delivering the opening address."

In a newspaper published in Baltimore, 1826:

"Resolved, unanimously, that, as a small mark of their esteem, the thanks of the readers of the Apprentices Library be presented to J. H. B. Latrobe, Esq., for his excellent course of lectures gratuitously delivered to them during the past winter.

"Resolved, that the proceedings of this meeting be signed by the Chairman and Secretary and the several editors requested to publish them in the papers.

George W. Sanders,

Charles F. Cloud, Chairman. Secretary." 
While these lectures were not an actual portion of the work of the Maryland Institute, they were in line with its course of instruction.

\section{MARYLAND HISTORICAL SOCIETY}

In the proceedings in commemoration of Mr. Latrobe, held September 11 and October 12, 1891, it was stated that "he was one of its original organizers and incorporators." The fact that he was on the nominating Committee to name the Board of Officers, explains his absence from that board. He was liberal whenever it needed financial aid and almost lavish in his gifts of his valuable time to promote its interests. From 1866 to 1871 he was one of the First VicePresidents of the Society, and for the succeeding twenty years, by annual re-election, he was its President. It was in 1844 that steps were taken to organize the Society. It was called together in the rooms of the Maryland Colonization Society, of which Mr. Latrobe was President. . . . Himself an artist of no small merit, he was active in establishing the Society Gallery of Paintings.

$\mathrm{He}$ valued most his distinction as President of the Maryland Historical Society and President of the American Colonization Society. "No other historical society in the country embraces in its membership such a remarkable and picturesque figure." Albert Ritchie.

In his diary, ten years before the Historical Society was incorporated, is the following entry:

"Friday-October 23, 1835. Yesterday Johnson, Donaldson and I proposed to get up a Historical Society in Maryland." (This is the beginning of the Maryland Historical Society.)

In response to an invitation George Bancroft writes: 
"Younger Brother:

"January 31, 1881.

"You draw me with a threefold spell; the opportunity to meet our Maryland Historical Society; to see Baltimore which I have loved from my youth; and to be your guest. Yet this year I cannot come. I am hard at work printing a book and dare not step from my post. Else I should obey your beckoning. With affectionate remembrance to your house.

"Ever yours,

(signed) George Bancroft,

Jno. H. B. Latrobe." Octogenarian.

\section{JUSTICE PRACTICE}

"I have forgotten an important undertaking in which I was engaged while yet a student of law-"Latrobe's Justice Practice." This was suggested to me by my good friend, Wm. Gwynn, and I began the work in almost utter ignorance of the subject matter. I taught myself, however, as I went along, and produced a guide for the "Dogberrys"-poor enough in its first edition, but so much better than the editions that had preceded it from other hands, that it met with a rapid sale, and in a few years I was called upon for a second, which has been followed by a third, fourth, fifth and sixth-and indeed a seventh is now wanted. All previous work had been arranged alphabetically, and a certain knowledge of the laws governing magistrates was required before they could be traced to advantage. The plan I adopted was to presume the reader to be totally ignorant of the whole matter and to teach him from the beginning, enabling him to perform his duties by turning over and reading from the pages of the volume laid open before him in any particular case. The success of the work, which 
has continued to be the standard, is the best proof that my innovation in respect to the arrangement is not without merit."

The only book published by Mr. Latrobe, besides that relating to his six months in Europe, is "Latrobe's Justice Practice." He makes but a very short reference to it in his autobiography, which is as follows:-

March 23, 1835-Office corner Lexington \& Courtland. "Thursday, April 24, 1835-Mr. Lucas stated when my "Justice Practice" was finished, he would give me his note at twelve months, for $\$ 375.00$, being fifty cents per copy on an edition of seven hundred and fifty copies. (The second edition I will now set to in good earnest)."

There are many other references to his working upon this book from time to time. It was in fact a most valuable practical book and is spoken of at different times by members of the Court of Appeals in very high terms. In writing to the present Clerk, C. C. Magruder, of the Court of Appeals, as to Mr. Latrobe's record, I have from him October 28, 1915:

"The data you have should make a very valuable and interesting sketch of Mr. Latrobe. His 'Justice Practice' would seem to be glory enough for one man, and generations have profited by it."

In the case of Hyde vs. Greuch, in 62nd Md., page 582, Judge Miller, delivering the opinion of the Court of Appeals, uses the following language, referring to peace warrants:

"The mode of obtaining the warrant, and all the proceedings thereon, are clearly stated in that excellent book, Latrobe's Justices' Practice, ch. 16. Simple and plain forms for the oath, the warrant, the commitment, the recognizance, and the release, are there given, and these are ac- 
companied with specific directions as to the general mode of procedure, so that the forms can be easily adapted to the circumstances of each case as it arises. These are so well known to the magistracy of the State, and have been so long in use, that we are unwilling to sanction any modification of them, or to introduce in their stead the more minute and elaborate forms set out in 1 Chitty's Genl. Pr. 679, which have been adopted in England from the common law, and the construction given by the English courts to the Statute, $34 \mathrm{Edw}$. III, ch. 1. It is proper to observe, however, that the forms found in Latrobe's Justice must be followed in every substantial particular. Any material omission or substantial departure therefrom, especially in regard to the oath and the warrant, will vitiate the whole proceeding."

Again in his journal on May 6, 1830:

"Sent by Robert Purviance, a copy of Justice of Peace and Practical Reading Lessons. Justice of the Peace for Peter Latrobe, Practical Reading Lessons for Charles Latrobe."

In a letter from Peter Latrobe, March 6, 1832, in acknowledging receipt of the copy he says:

"I must not forget to return my thanks for the copy of Latrobe's Justice Practice. A friend of ours, the private Secretary of the late Chancellor Eldon, looked at it with some discrimination and seemed to approve it much-and has already recommended two clients who had business in the United States by all means to report to your office."

In the memorial meeting which took place in 1891, a report made by the Committee appointed, Henry Stockbridge, Bradley $\mathrm{T}$. Johnson and Clayton C. Hall, is as follows:

"He held the office of Justice of the Peace and gave to 
the world the book which has been for more than half a century the sole guide to the practice of the law within the jurisdiction of the State of Maryland, the demand for which has required him to prepare edition after edition. In 1889, at the age of eighty-six, he revised the Eighth Edition."

I think the statement that he held the office of Justice of the Peace, is a mistake.

\section{MASONRY}

"I resume my memoranda after long intervals, and look carefully over the index I have made as I go along, lest I should repeat (not unlikely at my time of life) what I have already said. I do not find anything about my connection with masonry in my index. I was induced to join the order by the example of my then intimate friend, and afterwards brother-in-law, Dr. Rich. S. Stuart, who was at the time Master of Winder Lodge, No. 77, a new lodge, composed of the cleverest, they thought themselves, of the craft. At all events, they were associates, and were called by members of other lodges a "silk stocking set." The lodge has long since gone out of existence. I became master of it, and was reputed "bright." Certainly, it interested me much, and as I was interested at the same time in Colonization, I attempted to make masonry aid in the matter of funds for the Colonization Society. I prepared a circular, got the lodge to adopt it and vote $\$ 20,000$ to the Colonization cause, and, sending the circulars around, other lodges followed the example of Winder Lodge, and several hundred dollars were collected, I believe. But the idea would not take root well. The thing had its day, a very short one, and died out. I have no list of the members of our lodge, but recall some of the names, Dr. Stuart, Frank Davidge, a clever gentleman, a man of literary taste, and 
who would but for his preferences for literature, have made a clever lawyer. Jesse Willis, one of the handsomest men in Maryland, a merchant. Wm. Adus and his brother Thomas, Fred Dugan, James Rayborn, Charles Howard of Samuel and others, whose names I have forgotten, made a clever association. I remember that when the cornerstone of the B. \& O. R. R. was to be laid by the Masons, and a procession was to accompany them, we, of Winder Lodge, fancied it would be infra dig to trudge through the dust to the fields beyond Gwynns Run, which was selected as the place where the stone was to be deposited. But a knot of us, finding ourselves before the Masonic Hall, became imbued with the spirit of the occasion, and putting on our aprons we joined the others. As the youngest lodge we headed the procession, and as I was made the "Tiler" for the occasion, I led the march, with a drawn sword in my hand, little thinking of the active part I would take in subsequent years, in the affairs of the Company. I afterwards joined Phoenix Royal Arch Chapter, and in due course became its highest priest, and still have among my papers the eulogy I pronounced on one of my predecessors in the office.

"Not satisfied with being highest priest of a Chapter, I embarked in Scottish Masonry, and was advanced as far as the $32 \mathrm{~d}$ degree, adopting, as I have since been reminded, 'Perseverance' as my motto. I had written 'ambition' in the record after my name, but this was objected to, and I changed it for the other word. In those days I suppose I was ambitious. I cannot now recall the feelings which actuated me. I only remember that I worked the work of those days as they came around, anxious to succeed, but with no sentiment for strife, or desire to get above others, or gratification in doing so. It is said of some men that they mark 
out a plan of life and pursue it to the end. I have not been of this class. Circumstances as they arise control me, and have always done so. My father's death made me leave the army. Had he not died, I would probably have been an architect, if I had not, with my love for the profession and with an epaulet on my shoulder, preferred remaining in the army. I have often wondered why $I$ have so zealously and persistently adhered to African Colonization. I never expected to derive reputation from my advocacy. I took it up because General Harper led me into it-but I never planned for myself advancement to any position among its friends. I consulted my fancy quite as much as my judgment. When I had gotten up the Maryland State Society, I made prominent men its principal officers. I was but its Secretary. When years went by and I had only to say I would be the President, and as I did the work, the place was suggested to me, I made Colonel B. C. Howard the President, and when he resigned, I became the President without work or solitication of my own. I am now the President of the National Society. But I never intrigued for the place. When the purchase of Cape Palmas was made, my name was suggested as one proper to be perpetuated in Africa, but when I prepared the map I placed every other name upon it. Harper I called the principal town, out of love for my dead preceptor. Hoffman Town I so called, because George Hoffman was the first President of the State Society. Stuppand Lake was called by me after a friend; so my name is not on the map, though I do believe some of the Colonists gave it to a straggling village. I do not say this now in any arrogance of modesty, or to show that I was disinterested. I am as selfish, I suppose, as the run of men, but I say it because really I do not know what has been my leading motive now that I am from the grand 
climacteric looking back on seventy years of life. It seems to me as I have always said, that I have been doing from day to day the day's work, and drifting through life as circumstances controlled my course. But this is rare egotism, and so I'll go to something else."

In regard to Mr. Latrobe's connection with the Masons, while he gives a very short account of his association with this important body, in looking over a number of his addresses, we find that he delivered the address at the laying of the corner stone for the new Temple, November 20, 1866. $\mathrm{He}$ also delivered an address at the opening of the Grand Lodge of the Masons of Maryland, May 8, 1871. He was eight times elected as Chairman of the Board of Managers of the Masonic Temple.

The value of Mr. Latrobe's services to the order was recognized by the Masons as shown by the following resolution adopted at the time of his resignation as Chairman of the Board of Managers of the Masonic Temple:

"Report and Resolution adopted by the Board of Managers of the Masonic Temple at their regular meeting held January 14, 1879:

"The Committee appointed to draft resolutions expressive of the appreciation of the 'Board of Managers of the Masonic Temple' for the valuable services rendered by their late Chairman, the Hon. John H. B. Latrobe, Past Grand Master of Masons of Maryland, respectfully report the following:

Whereas, the Hon. John H. B. Latrobe, for eight successive terms the Chairman of the "Board of Managers of the Masonic Temple," Baltimore City, having by the zealous course he has pursued in the performance of his official duties as the executive head of the Board over which he presided with honor, dignity and superior ability, secured the respect and esteem of its members, and merited the gratitude of every Mason in our jurisdiction, therefore:- 
Resolved, That this Board be recreant in its duty if it did not in this manner recognize the results which our late Chairman's official devotion to Masonry has produced throughout our entire jurisdiction, not only for the present, but for the future; as displayed by the energy his influence has inspired, by the respect for the institution which his intelligence has aroused, and the active agencies he has awakened for the good of Masonry in Maryland and its reputation abroad.

Resolved, that the Secretary of this Board be directed to incorporate this report in his Minutes, and also to send a copy of the same to Past Grand Master Latrobe.

Respectfully and fraternally submitted, $\left.\begin{array}{l}\text { F. J. S. Gorgas, } \\ \text { Wm. M. Isaac, } \\ \text { Jacob E. Krebs, }\end{array}\right\}$ Committee.

J. H. Medairy, Grand Secretary."

Mr. Thomas J. Shryock, the present Grand Master of the Masons in Maryland, has called my attention to Mr. Latrobe's record as a Mason, as contained in the history of Freemasonry in Maryland by Schultz, Fol.4,Page 717, which gives in substance the following additional facts in reference to Mr. Latrobe's connection with the Order.

Mr. Latrobe was initiated in the Winder Lodge, No. 77, of Baltimore, on January 26, 1825, of which he was later elected Master. He acted as Tiler of his Lodge, in the laying of the corner stone of the Baltimore and Ohio Railroad in 1828. About this time he was exalted in Phoenix Koyal Arch Chapter No. 7, serving as High Priest in 1829 and 1830. He received the high degrees to that of the Royal Secret in Triple Unity Rose Croix Chapter and the Council Princes of the Royal Secret, that existed in Baltimore from 1820 to 1826 under the jurisdiction of the Grand Consistory of New York. The degree of Honorary Inspector General $33^{\circ}$ was conferred upon him in 1872 by the Supreme Council of the Southern jurisdiction. For a number of years, 
owing to the requirements of his professional engagements, he had retired from active participation in Masonic matters, but in 1870, at the unanimous wish of the brethren, he assumed the duties of Grand Master and was continuously and unanimously reëlected until 1878, when he declined further service.

There is a further statement that he delivered numerous public addresses-among which may be mentioned those delivered at the laying of the corner stones of the new Masonic Temple in 1866, the new City Hall in 1867, and the new Baltimore Post Office on November 21, 1882.

\section{AS A PAINTER}

In Mr. Latrobe's Russian experience he speaks of Madame Bartholomaie's beautiful hand, of which he had a model made. His admiration of hands seems to have existed very early in his life. Among his papers, his first effort in drawing, which still exists, is a drawing of a woman's hand, here reproduced-the date February 18, 1818. He was not yet fifteen years of age at that time. The only other specimen of his work of this early date is a water color representing the Light House at the entrance of New Haven Bay-"Latrobe, Cadet, August, 1821." Mr. Latrobe used whatever talent he had for his own amusement; and in a number of sketch books I find a record of his travels in this country and abroad. Most of these are pencil. Many of them are water colors. Some of his water colors are said by those, who are capable of judging, to be very fair productions, showing talent. At least, he was enabled by his pencil and brush to depict places, so as to have a pleasing record of his travels. One of these pictures, a water color here reproduced, represents the landing place at Three Rivers, Canada, in 1830, showing the character of the place 
DRAWN BY JOEN H. B. LATROBE In his 15th year 
AgOxThI A .H WHOL IR VWASG wose माटा 2 मी जI 


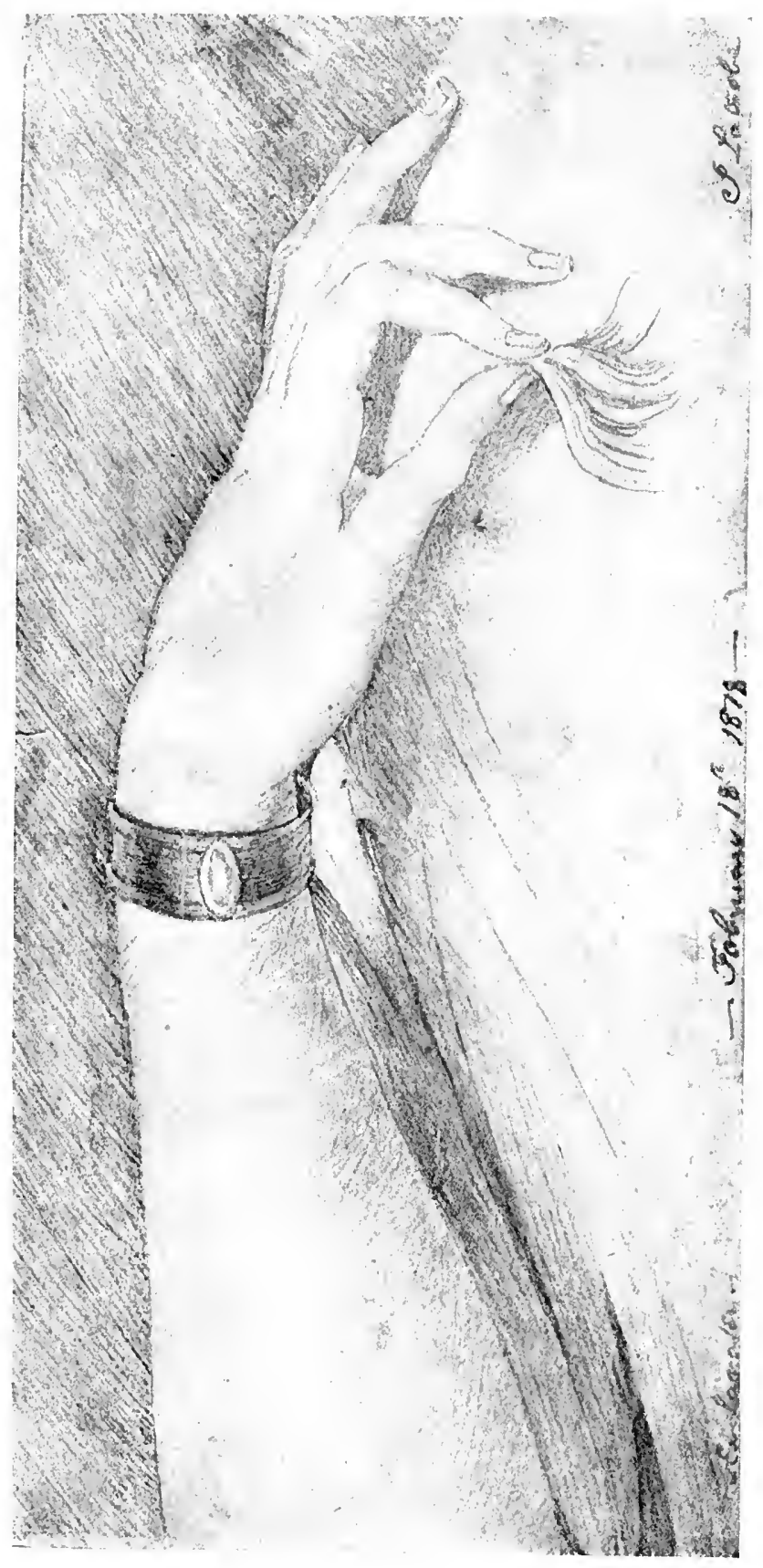



at that time. It has a certain historical value. The water colors of Louisville, Cincinnati and other places in 1835 have this additional value. He does not seem to have made water colors of any places in Europe, but is content with pencil sketches. One of the best of these is the Walhalla on the Danube. Walhalla, the temple to the Great men of Bavaria, looks down upon the Danube - it is a reproduction of the Parthenon. We have copied it in the Temple of Fame, in New York. He speaks of a number of designs in marble made by him, among others, the "Kosciuszko" monument.

He painted in water colors, and had a studio in his house at "Fairy Knowe," where he worked in the early or immaculate hours. He also painted in oils. He made some copies of paintings which are fairly good.

He painted a number of portraits, among others his father, B. H. Latrobe, and a portrait of Mrs. Latrobe for each of his children. He also painted a portrait of himself for each of his children. While at work at these, he asked me my opinion of the likeness. I told him that I thought he had made himself look much younger than he did look at the time the painting was supposed to represent him. He retorted: "Do you think if I had the power to obliterate the lines that now scar my face, I would not do so? I am treating the picture as I would my own face, if I had that power." He was not like Cromwell, who had warts on his face, and when asked how he would have his picture painted, answered, "Warts and all."

The following correspondence gives evidence of the interest Mr. Latrobe had in painting and painters. 
"Philadelphia, May 21, 1847.

"J. H. B. Latrobe, Esq.

"Dear Sir:-

"I have postponed writing in answer to yours of the 11th until I could examine a copy of the de Solis promised me. I have seen it and have considered the subject you mention as affording an excellent general design. The subject admits a great variety of individual expression-Cortez and Lopex you mention-and its various effects upon the principal actors to the scene-the quiet satisfaction of Sandoval, the more impetuous expression of the same feeling in Alvarado. One might imagine Bernal Diaz swelling with the thought of vengeance and conquest of the heathen; the commoners of the camp, a portion full of the wild Hurrah, the religious chorus or te deum of others; and the still deeper devotional exultation of others. The Indians wonder and the women make all that is needed for expression. Then the material for the general construction of the picture is fine, I think as far as picturesque, \&c., is concerned. The salute from the vessel on the lake is excellent, and the distant City and the mountains. In my copy of de Solis is a view of the city and lake that will be of much service, and also the Brigantines and the best pictures of Cortez after Titus engraved by Virtue I have ever seen. If you have decided upon it, when I hear from you I will begin the drawings. It has grown upon me very much since you first suggested it. What time in June do you expect to sail for Europe? "Very truly your

Obedient Servant,

P. F. Rothermel.

I will still continue my researches."

Peter Ford Rothermel, American painter -was born in Pennsylvania in 1817. In the Americana he is spoken of 
as being a painter of historical subjects. His pictures reveal a fine sense of color and a power of dramatic composition, which are not common."

A letter from Robert C. Winthrop.

"Washington, May 17, 1847.

"My dear Mr. Latrobe:-

"Your note came duly and I have been more successful than I could have hoped. I enclose a note from Prescott, with a sketch of the Brigantines. You may have the note, too, if you like, as an autograph, the signature and postscript are the veritable fist of the almost blind, but farsighted historian.

"In haste,

Very truly,

Robert C. Winthrop."

The enclosure reads as follows:

"Boston, May 18, 1848.

"My dear Mr. Winthrop:-

"I received from Mr. Davis the note of Mr. Latrobe, respecting the ancient Spanish vessels, and I am happy in being able to furnish the information he wants.

"One of the Spanish translations of my 'Conquest of Mexico' contains a number of prints purporting to have been made from paintings contemporary with the Conquest, or nearly so. One of these, representing the landing of Narvaez, has two vessels in it. I have had a drawing made of them, by my nephew, Edward Dexter, which I herewith enclose, and I will trouble you to send it to Mr. Latrobe. $\mathrm{He}$ will see that the artist will have to make but little alteration in the ships he has now painted, and this chiefly in the rigging. 
"I have seen several of Rothermel's pictures, and I consider myself very fortunate to have my work illustrated by so excellent an artist. The composition is very effective and his brilliant coloring is admirably suited to the rich and picturesque costume of the Aztecs and the Spaniards of the sixteenth century.

"Mr. Davis gives a warm report of his doings with you, which is confirmed by Judge Warren, who passed last evening with us. I should have liked very much to share your hospitality with them. But I must wait till a more auspicious dynasty is seated on the throne, when I trust to see you still occupying the high place which all agree you fill with so much dignity.

"Pray commend me to our friends, Holmes and Hilliard, and believe me,

"Ever faithfully yours, Wm. H. Prescott.

"Do you know that Circourt is on a mission for the Provincial Government in Berlin?"

JOHN P. KENNEDY-S. T. WALLIS-POEM DEDICATED TO GREENMOUNT

"Close to my office in the old Athenaeum Building was the office of John P. Kennedy, with whom I was on terms of intimacy. The room I occupied opened upon a yard in which was a spiral stairway that formed a communication with the floor on which Kennedy's door opened, and the visits we paid to each other were frequent, until the burning of the building drove us to seek other quarters. Kennedy was at this time engaged in writing 'Swallow Barn,' and chapter after chapter he read to me as the work progressed. It had been his intention to adopt for its name 'Hands Habines Sketches,' and it was not until the book was finished 
that the name was changed. Those who have read the volume will notice that it ends with a life of Captain John Smith. This was owing to Kennedy having exhausted his material for anecdotes of Indian life before the bulk was obtained that was necessary to give the respectability of size to the production. Captain Smith was a makeshift. So, too, 'Horseshoe Robinson' was read to me chapter by chapter. Here the names of many of the personages were changed. Both works were labored. Portions of them were often rewritten. It was not so with 'Rob of the Bowl,' which I have always thought had more genius in it than either of the others. It was struck off at the heat. Kennedy was too much addicted to politics and literature to make a distinguished lawyer. He spoke well and fluently, but he disliked the labors of the profession. Whatever he did, he did well, but it was pride, not fondness for the work, that urged him to effort. Full of general information of the most genial temperament, abounding in humor, and most apt in conversation, no man was better calculated to make friends, and few men had more. He was more of a statesman than a lawyer, fonder of the floor of Congress than of the courtroom, and when in the House of Representatives did himself great credit.

"As a political writer he was unsurpassed. His style, however, was graceful, rather than powerful. In all his writings there is not an ill-timed phrase. But there are few which leave a memory of them on the brain. Still his way of putting things was strong, and his style was especially attractive, whether in 'Rob of the Bowl,' his best novel, or the 'Annals of Quodlibet,' one of the very best of the political satires of the day. My last literary effort for pay, which by the way I never got, for I never asked for it, was a review of his novels published in the 'North American.' 
It was a labor of love on my part, and reflects $I$ think his own opinions of his work."

As early as $1827 \mathrm{Mr}$. Latrobe was on most intimate terms with Kennedy, who writes him of his troubles. Mr. Latrobe makes an entry in his diary saying- "Had a long explanatory talk with Miss G., endeavoring to get Kennedy out of a scrape caused by talking when he should have held his tongue." He writes Nov. 20, 1833-"Saw Kennedy who let me have a peep at the manuscript of his new novel 'Horseshoe Robinson.' I promised to write for him a drinking song to go into it, to be sung by one of his Tory characters."

The song is the one that is found on page 208, the first verse of which is:

You may talk as you please of your candle and book, And prate about virtue and sanctified look,

Neither priest, book nor candle can help you so well, To make friends with the world as the "Jolly Bottle."

Several years before Mr. Latrobe's death, I was paying him my usual morning visit when I stated that in reading the "Virginians" by Thackeray, I was surprised to find that he knew something about the local scenery about Cumberland, Maryland, my native town; that I was not aware of any book from which he could have obtained the local names, and I was sure he had never visited Cumberland. Mr. Latrobe said- "You have found the chapter that was written by John P. Kennedy." He then gave me the story. I had him write it out, and I have it pasted in my edition of Thackeray. I told the story to one of the editors of Scribner's I think it was. Mrs. Ritchie, Thackeray's daughter, took offense, and seemed to think it reflected upon her father's memory. 
I tried to find out what I could about the matter, and I here insert the story and the entries in Kennedy's Journal, which refer to it. He does not say that he wrote the chapter, but that a suggestion was made that he should do so.

That Mr. Latrobe years after should say that Kennedy told him he wrote a chapter in the "Virginians" would seem to be as near demonstration as one could get some twentyfive or thirty years after the event.

"January 31, 1884.

"I met the late John P. Kennedy after the publication of Thackeray's novel, the 'Virginians,' and while we were discussing it, he said that he had written one of the chapters. He was in Paris with the author, who was complaining to Kennedy that he had, much against his inclination, to supply his publisher in London with copy for the next chapter of the book, this coming out in numbers. 'I wish you would write it for me,' he said, half jesting. 'Well', was Kennedy's answer, 'So I will if you give me the run of the story.' More was said, the result of which was that Kennedy wrote Chapter 4 of the second volume, which explains the local accuracy of description of scenery, with which Kennedy was most familiar, and which Thackeray had never seen.

Jno. H. B. Latrobe."

Extract from Kennedy's published diary:

"Paris, Sept. 28, 1858.

"Thackeray calls to see me, and sits an hour or two. He is not looking well. He tells me he has need of my assistance, and says Heaven has sent me to be his aid. He wants to get his hero from Fort Duquesne where he is confined a prisoner after Braddock's defeat, and to bring him to the coast to embark for England. 
" 'Now you know all that ground,' he said to me, 'I want you to write a chapter for me to describe how he got off, and what trail he made.'

"He insists that I shall do it. I give him a doubtful promise to do it, if I can find time, in the thousand engagements that now press upon me, on the eve of my leaving Paris. I would be glad to do it, if circumstances will allow."

Mr. Latrobe was interested in what is known as Greenmount Cemetery, formerly the country seat of his friend and patron Robert Oliver, but long since included in the limits of the growing city. He took charge of the' dedication ceremony. The following is a letter from Kennedy at the time in Washington, a member of the House:

"My dear Latrobe:-

"How can you ask me to contract such engagements at such a time? Write for the Cemetery quotha! Dost want to put me in it. I' faith not a line does man, woman or child get from me, at nearest, before October. Here is a fellow boring me to get an autograph, devil take him. I shall write to him declining.

"House of Rep.

June 12, 1838.

"Yours in the midst of Clerk Franklin reading a long bill, J. P. K."

He took part in the dedication.

Two other letters among his correspondence with Kennedy relating to a picture painted by Latrobe.

"John P. Kennedy, Esq.

"Dear Kennedy:-

"Baltimore, February 18, 1844.

"So long ago, that, if a lady were not mentioned, I might almost name it as a matter which happened in the 'olden 
time,' I made a promise to Mrs. Kennedy that I would, in return for a present which you made me of a dozen of some prime 'old rye,' try to put on canvas some thing to remind you both that a brother of the craft of the lawyers occasionally put a palette on his thumb, and used a paint brush, where a pen was the more appropriate implement of his calling. This promise has at length been performed; and I beg your acceptance of the illustration from 'Swallow Barn' which accompanies this note. If I have succeeded, with the aid of bristles and pigments, in conveying even a faint idea of one of the most spirited sketches to be found in the writings of modern authors, the merit is yours not mine; for I have been but the copyist from your conception; and any similitude between the painting and the legend is a compliment to myself, inasmuch as it may show, that I have been able to make my imagination run parallel with yours.

$$
\begin{aligned}
& \text { "I am, dear Kennedy, } \\
& \text { "Most truly yours, } \\
& \text { John H. B. LATROBe." }
\end{aligned}
$$

"My dear Mr. Latrobe:-

"I take the first moment at my command, although a week behind my time, to thank you, both for Mrs. K. and myself, for your spirited sketch of Abe in his winter cruise to the wolf trap. It is a most acceptable memorial from an artist friend, who, in either character, brings so many pleasant inducements to be remembered. Such a distinguished debater at law, such a dab at the brush, will be regarded hereafter, as something of a prodigy in our City, where Fame is so scarce, even in one path. I shall appenid to this picture a certificate that the wight who had such a wolfish accomplishment as the masterpiece betrays, was, 
in fact, a thorough going, hard pounding juris-consult, of no little repute, and did actually put old Burns-not the poet, though, by the bye, he would tackle to him right manfully-old Burns in the shade, with a still more erudite Justice than that which was so long the Glory of England, 'Latrobe's Justice' being, as the proof shall show, the veritable prose of the artist."

"In earnest, I think the painting first rate-not dilettanti wise (are those two 'T's in the right place) but cognoscenti wise, and would do an infinite credit to a man who had never written a line to guide any 'Dogberry' upon earth, but had lived wholly on those green seas and feathery sprays and glancing lights, that furnish the toy ship of artist life-worth more, to my liking, than the compounders of a thousand statues in the Lycurgus school.

"The best wish I can return you for the token of friendship is that the day may come when you may revel over a fresh canvas with a conscience entirely at ease on the score of neglecting no duty to man or to Heaven.

"Yours truly,

"House of Rep. March 8, 1844.

J. P. Kennedy.

"John H. B. Latrobe."

Another of Mr. Latrobe's friends, a lawyer and poet, Mr. S. Teackle Wallis, gave his services in the dedication of Greenmount and wrote and read very touching verses:

\section{THE FIRST GRAVE.}

The city of the dead hath thrown wide its gates at last, And through the cold gray portal a funeral train has passed, One grave - the first-is open, and on its lonely bed, Some heir of sin and sorrow hath come to lay his head. 
PAINTED BY JOHN H. B. LATROBE

to illustrate the Novel

HORSE SHOE ROBINSON

By John P. Kennedy 


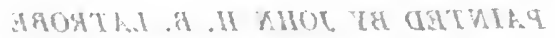

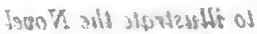

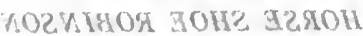
phatma 


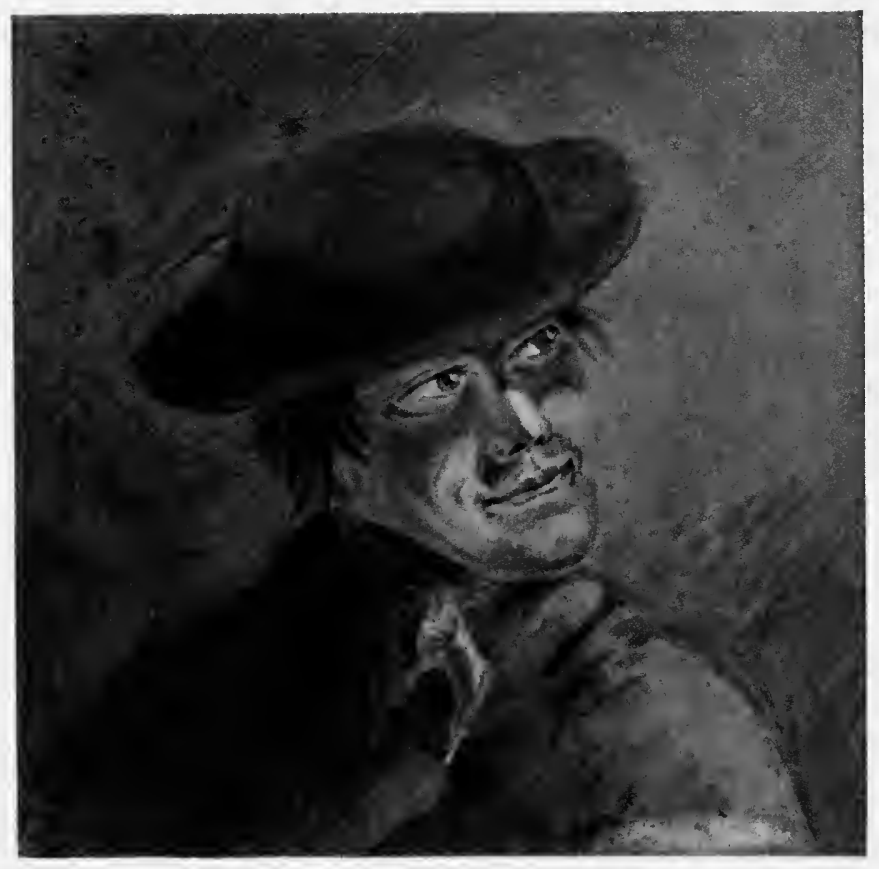



Perchance a hero cometh, whose chaplet, in its bloom, Hath fallen from his helmet, to wither on his tomb; It may be that hot youth comes-it may be, we behold Here, broken at the cistern, pale beauty's bowl of gold.

Mayhap that manhood's struggle, deplete of price and power, Hath ended in the darkness and sadness of this hour;

Perchance some white haired pilgrim, with travel sore oppressed Hath let his broken staff fall, and bent him down to rest.

But stay behold the sepulchre-nor age nor strength is there; Nor fame, nor price, nor manhood, those lagging mourners bear; A little child is with them, as pale and pure as snow, Her mother's tears not dried yet upon her gentle brow.

The step that tottered, trembling, the head that faltered too, At the faintest sound of terror the infant spirit knew, The eyes that glistened tearful when shadowy eve came on, Now show no dread of sleeping in darkness and alone.

And why, though all be lonely, should that young spirit fear, Through midnight and through tempest no shielding bosom near? Ere the clod was on the coffin, ere spade had cleft the sod, Bright angels clad an angel in the raiment of their God.

Green home of future thousands; how blest in sight of Heaven Are these tender firstlings, that death thee has given; Though prayer and solemn anthem have echoed from thy hill, This first fresh grave of childhood hath made it holier still.

The morning flowers that deck thee shall sweeter, lovelier bloom Along the spot where beauty like this hath found a tomb; And when the evening cometh, the very stars shall keep A vigil, as of seraphy, where innocence doth sleep.

Sweet Hope! that when the slumber of thy pilgrims shall be o'er And the valley of death's shadow hath mystery no more, To them the trumpet's clangor may whisper accents mild, And bid them wear the garlands that crown this little child. 
MR. LATROBE AS A POET

It was much in vogue in the early days of Mr. Latrobe's life to write verses. It was considered a part of one's education. "To drop into poetry," as Silas Wegg puts it, was much more common than it is today. Silas, in response to Mr. Boffin's inquiry when starting out upon his educational pilgrimage with Wegg as a leader, is informed "it will come dearer," for when a person comes to grind off poetry night after night, it is but right he should expect to be paid for its weakening effect on his mind.

Mr. Latrobe quite frequently wrote verses with more or less merit. He made a habit of writing a verse to his wife in commemoration of each birthday. Sometimes, of course, this was omitted. The verses to her on her seventy-first birthday have been reproduced in chapter X. Some of his productions of this character he published for private circulation, and a small book containing a number of his verses was entitled "Odds and Ends." The volume contained comparatively few of his productions. His papers and books contain a large number of them, which do not appear in this volume. He wrote an ode to be read at the Sesqui-centennial of Baltimore, and a number of other poems read upon different occasions.

He had, as Mr. Cowen puts it, the faculty of expressing himself in graceful lines. He writes at forty-one, speaking of the days gone by:

The world was sunshine then; it was the day

To scrape acquaintances; and on my way

To pass the winter with my old grandsire,

I formed a dozen friendships; now, alas,

The journey hath no charm, save in its end.

A letter from Mr. Joseph Barry, Harper's Ferry, Virginia, January 20, 1881, shows that in him he found a genuine 
admirer of the words written in the Sesqui-centennial Ode. He writes:

"I thank God, however, that my dreams are as vivid as in the Spring of life, when I had higher aspirations and higher hopes than I have now, and that I can at any time mount my Pegasus, and say of myself, in your own fine words:
All changed is here my sordid garb, $M y$ labor-hardened hand,
In purple robed, with gems bediked, The changeling of a summer night, I am lord of Fairyland,
With many a memory of the past
Recalled at $m y$ command.

"May God bless you for the words. I have muttered them a hundred times since I received the ode, greatly to the consternation of parties who happened to overhear me, and who, no doubt, thought the fairies had taken me in charge."

And so it is, if we wish to console ourselves for disappointments in real life. Imagination can people a world for us, and the landscape is our own. Why should any of us be held down to a sordid life? Those who, as Oliver Wendell Holmes says, carry about them on leash facts like bulldogs, ready to let them loose to tear to pieces our fabric, so lightly and beautifully constructed, let us not heed them.

Yet dreams to us are a storehouse of pleasures,

Where fancy throws light on the shadows of life, Fills one's long empty purse with ne'er failing treasures, And gives us an angel on earth for a wife.

Pleasures of the imagination, the happiness of life, are but a dream at sixty-five.

There were a number of letters received by Mr. Latrobe, acknowledging the "Odds and Ends." 
One from Mrs. L. H. Sigourney, dated June 5, 1865, reads ; "My dear Mr. Latrobe:

"Thanks for your beautiful book of poetry, which I have perused with much pleasure, and somewhat to the annoyance of those around, who fancied they had claims upon my attention, not being able to lay it down, until it was finished. Moreover, I said to myself, if such are the 'Odds and Ends,' what must be the exuberance of the loom from which the tapestry emanates."

Mrs Sidney Brooks wrote April 9, 1865:

"In hot haste I wish to acknowledge the pretty volume of 'Odds and Ends,' which announce you to me as a poet at the same time. Opening it casually, I found a song which has adorned my scrapbook for at least thirty years, the authorship of which I had been disposed to attribute to one of my own admirers."

From Mrs. Botta (formerly Miss Anna C. Lynch):

"Accept my best thanks for your pleasant little volume, which in my opinion, has but one defect; and that is its brevity. You leave us in the position of Oliver, asking for more; and $I$ have not the least doubt that if your portfolios and desks were carefully rummaged, more would be forthcoming. It cannot be that one who possesses so much of true poetic fire, and whose versification is so faultless and flowing, has written so little, and therefore I would urge Miss Virginia and Lilly to institute a careful search for hidden treasures which I have no doubt they will find."

Among others is a letter from Henry W. Longfellow, who writes, January 10, 1865.

"My dear Sir:

"I am much obliged to you for sending me a copy of your poems which I have read with great pleasure. It was a happy inspiration of your daughter to think of me as one 
who would sympathize with you; and I beg you to thank her for it. It is delightful to see that amid the cares and vexations of what Claudian calls 'the hoarse clamoring bar' you still find time to cultivate such flowers; so that you can always appear when you will with a rose in your button hole. Perhaps that is better than to become a regular market gardener, like some one.

"Very pleasant it is to get this glimpse of your inner self, which no casual meeting or chance conversation would have given me, and I beg you to accept my best thanks for the revelation.

"I wonder if you still remember, as I do, that agreeable dinner at Newport, where somebody asserted something about somebody else, and another somebody denied it, when you, out of a drawer and out of a pocketbook, drew simultaneously two printed proofs of the assertion.

"With great regard and kind remembrances to your daughter,

Yours very truly,

HeNRY W. LONGFELLOW." 


\section{CHAPTER XVI}

The Fireplace Heater-Experiences in PoliticsARCHITECTURAL EFforts-"FaIry KNOWE"-Rev. Peter Latrobe-Cost of Living in 1830-Narrow ESCAPE From Ruin by RobBery-State of Maryland DebT-Trip to EURope, 1847

In 1846 there was granted to John H. B. Latrobe a patent for improvement in stoves. This was the celebrated fireplace heater. Mr. Latrobe rather refrained from taking to himself any credit for this very useful invention, as not being in accord with his professional life. As he states in his memoranda, the case of Wilson v. Rosseau, already referred to, gave him a reputation in what was known as patent law, and he was engaged in many cases involving the validity of patents. He remarks that he is afraid that this has injured the reputation which he had at one time of being a sound lawyer. Still he says, "I have no reason to resent this for the returns in this description of practice are good, and I have had my share of it, and have now too short a time to practice anything new, or attempt to change, even if I desired it."

Feeling as he did about patent law, and that its practice was, to a certain extent, injurious to his reputation as a sound lawyer, he shrank from being known as the inventor of a stove, believing that his professional reputation would no doubt cease, and that he would be known only as a maker of stoves. We all have our weaknesses and this was one of Mr. Latrobe's. 
HEATER INVENTED BY JOHN H. B. LATROBE Known as the Latrobe Stove 


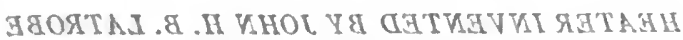

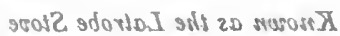




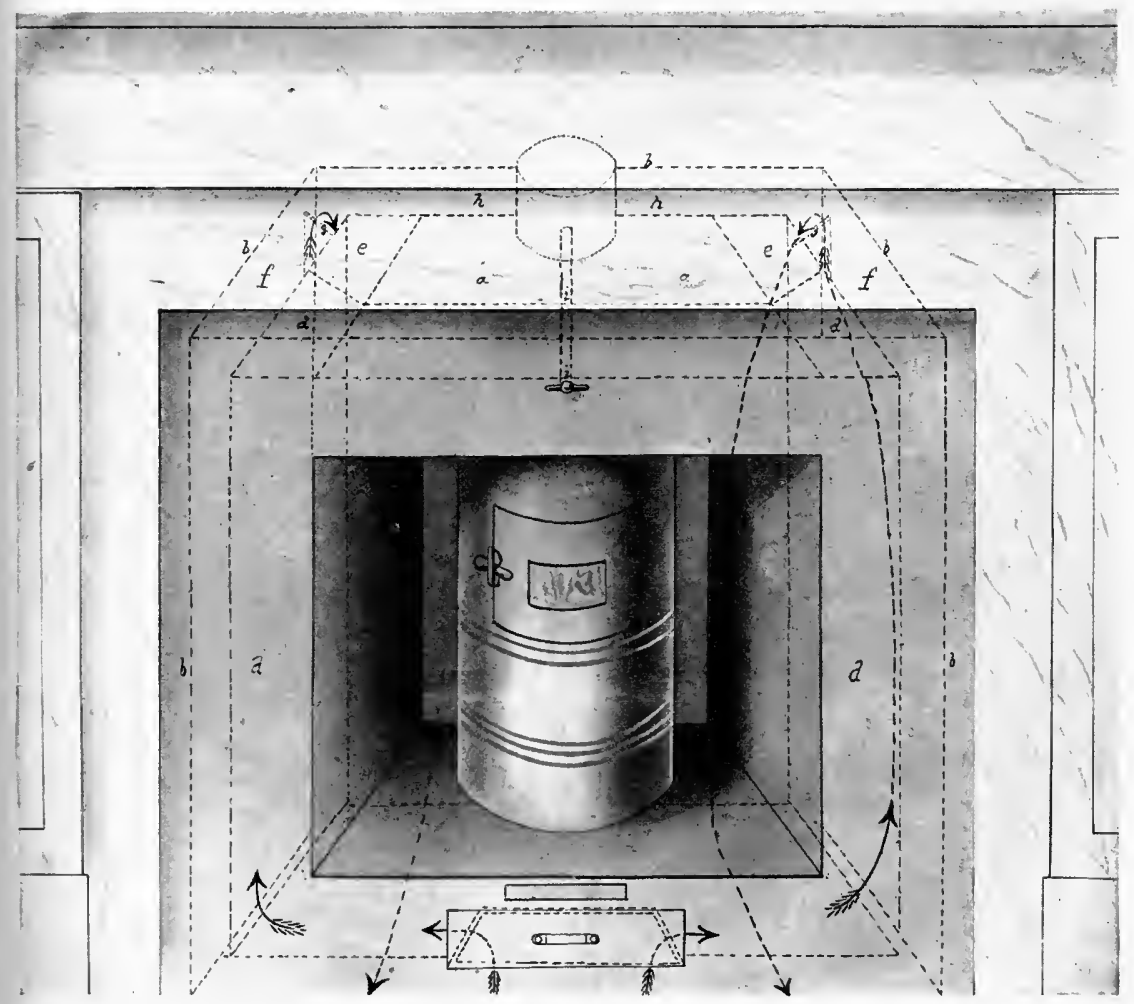



He told me once that the way he came to be interested in the question was through a complaint made by his wife, that the stoves then used (the "Franklin" and others) occupied so much space. He said he could remedy this, and would make a stove to be placed in the fireplace. This was the beginning of the fireplace heater, a copy of the design of which is here shown. The stove serves both as a stove and a furnace; the hot air above the stove being collected and carried by flues to the rooms above.

Franklin (Benjamin) was the inventor of the stove known as the "Franklin," so that, as an inventor of stoves, Mr. Latrobe was in good company. The fireplace heater became very popular in Baltimore. At one time there were in use about 300,000. Mr. Latrobe once said to me, if his pride had permitted him to do so, he could have realized more money from this invention than he did from the practice of law.

Mr. Latrobe never held a political office. He writes:

"I omitted to mention in the proper place my nomination for the legislature, along with Jesse Hunt, a prominent sadler and good man, * at a time when Baltimore had but two delegates. This was not long after my first marriage. It was a great temptation, but I had the sense to decline it, and stick to the law. I had been a stump speaker and harangued multitudes-a hot Jacksonian. A nomination was equivalent to an election; I had influence enough to have Spear Nicholas nominated in my place. The next year I exiled myself to have my friend C. C. Harper chosen. I never made a wiser determination in my life. This was in $1830, I$ think.

* Jesse Hunt was Mayor of Baltimore at the time of the Bank Riots of 1835 . His furniture was burned by the mob. 
"On more than one occasion I tried my hand at politics, but I had no natural turn that way and my efforts never amounted to anything. The trade was, so far as I was concerned, a profitless one. Some Governor, I have forgotten his name, made me a director in the Penitentiary, where I remained for a year, when I was turned out on a change of the State Executive. With this exception I have not been an office holder ever.

"I can recollect the sequence of events in my life up to my thirtieth year, much more distinctly than the order of their happening in the next thirty years. As I became more and more immersed in business, they crowded each other so fast that it is, I now find, difficult to separate them. I shall make no attempt at accuracy, therefore, in this respect hereafter."

Of architecture he says:

"From time to time I have dabbled somewhat in architecture; and here, as well as anywhere else, it may amuse my children to learn that, in addition to the Kosciuszko monument, I designed General Harper's monument, John Berryman's and Mr. Hall's, all in Greenmount. Also the southern porticos of the Belvedere, the Baltimore Cottages at the White Sulphur, the gateway at Druid Hill Park, the office near the gateway, the Rotunda, and the addition to the Old Mansion. The details of these structures in Druid Hill were the work of Mr. Frederick, except the gateway of which he has the drawing in its details as I made it. Painting and drawing has at all times afforded me great pleasure, but I need say nothing of this to my children, for they know all about it. The frontispiece of my house in Mulberry Street is of my design.

"In these years, the trustees of the Baltimore Cathedral, my vis-a-vis in Mulberry Street, determined to build the 
platform of the west portico and the southern tower, and as I was in possession of my father's plan, I undertook to superintend the work which I did, making all the working drawings. That I wanted practical knowledge became evident when the steps were laid. I had divided the height by the number of steps to get the depth of the rises, without allowing for the space to be filled by the mortar, nor did I find this out, until all the steps save two were laid. Hence it is that the risers of the two uppermost steps are less than those of the others.

"My ignorance displayed itself in another way. When I designed the yoke of the great bell, I forgot the fact that to make it ring the journals must be on the same line with the tongue of the clapper, against which last the side of the bell was to be brought when the rope was pulled. Of course, when they attempted to ring the bell no sound came from it. In vain the Irishman pulled at it, turning it over almost; it would not ring. At last one of the ringers proposed to 'exorcise' it, saying 'Shure, the divil was in it.' It was not until the next day I discovered the defect, and I believe the bell has now the right additions, that give the yoke the proper shape.

"I took, at this time, some pains to make a finished drawing of the portico as it was finished many years after, and a clever drawing in perspective of the building as it would be when completed. This I had framed, and presented it to the Cathedral.

"In 18- I accompanied Mr. Thomas Swann, then president of the B. \& O. Railroad Company to Richmond, Virginia, when I by mere accident had something to do with the choice of the model for the monument to Washington now erected there, which I have thought well worth recording.

"Among other gentlemen who were polite to me was Mr. 
Ritchie, the son of the well known editor of the Richmond Inquirer. And among others of the sights which I saw under his auspices was the Capitol. In one of the rooms that we visited was a collection of models, offered in competition for a monument to the memory of Washington, which the Legislature had determined to erect if it could agree upon a design. There were any number of obelisks, pyramids, broken columns, and the like, not one of which seemed to be suitable, nor did I wonder at the difficulty of choosing between them. Nothing was easier than to pronounce the whole lot unworthy of the occasion, and we were about leaving the room, when I saw on a window seat something in plaster which attracted my attention, and I called $\mathrm{Mr}$. Ritchie to look at it. It was very small, not more than a foot in height, but it represented accurately the idea that had been fully developed in the existing monument-Washington on horseback, surrounded by pedestrian figures representing the great Virginians who were his contemporaries. It struck me at once that it was the thing wanted, and I expatiated at length upon what seemed to me to be its incontestable merits. I remember we became quite vehement and that I succeeded in getting Mr. Ritchie to call Mr. Munford, connected with the Legislature in some way, if I recollect, to hear what I was saying. This set me off again, and in the end I made converts of both gentlemen, and Mr. Ritchie asked me to put my speech, for it became a speech in the end, on paper. This I at first declined to do. I was engaged in arguing a case before a Committee of the Legislature in regard to the route of the B. \& O. Railroad in Virginia, about which the members of the house and senate were as much divided as they were about the Washington monument, and I told Mr. Ritchie that if I took part in the discussion I might prejudice the matter 
which I had come to Richmond to advocate. He declared most solemnly that he was indifferent to my name-all he wanted was my argument. Relying on him, I addressed him a letter, explaining my views at length, and arguing the adoption of the little plaster model by the legislature signing my name as I would do to an ordinary letter. What was my mortification the next day to see my letter, signature and all, in the Richmond Inquirer, and to hear before night that I was thoroughly abused for interfering in a matter which I had nothing to do with. Whether the loss of my case, which followed, had anything to do with my aesthetic effort on this occasion, I do not know.

"Now it so happened that there was on the legislature, from Botecourt County I think, a cousin to my wife, Mr. Nathaniel Claiborne, a young man of handsome presence and remarkable eloquence, who at once called to see me, and got 'crammed' by me with the material for a speech, or indeed many speeches. He was just one of those men who carry things by the impetus of their manner and their personal magnetism, nor did he stop in season or out of season until the law was passed which adopted the design. The friend of Mr. Crawford, the sculptor in Richmond, was Mr. Conway Robinson, at whose house I dined a few days afterwards with the artist himself. Subsequently I sent to Mr. Crawford tracings of my father's study from the life of Patrick Henry, taken from one of his sketch books in 1796. Whether but for my agency in the business, Virginia would have erected an obelisk or a column, I, of course, cannot say. Crawford's model may have found its way from the corridor seat into the brains of the members. Still the facts were as I have here stated them, and I have always in a great way taken to myself some credit for directing public taste on this occasion into a proper channel." 
Mr. Latrobe met his English cousins while on a visit abroad. Charles J. Latrobe had visited him in Baltimore.

"While in London I made the acquaintance of my first cousin, the Rev. Peter Latrobe, who had succeeded his father as senior Bishop of the Moravian Church, an admirable gentleman, a Christian, and a man of learning and accomplishment. He introduced me to Lord Bexley, who had known my father and was now a very aged man. His daughters, the two Misses Vansettent, were present, fine looking women, but the most imposing person of the establishment, by far, was the porter at the front door who admitted us - one of the handsomest men I ever saw, who looked as if he ought to have been a Duke at least, must have weighed 250 or 300 pounds, was dressed in purple velvet and satin bow and wore small clothes, and had calves, ye Gods! what calves.

"My maternal grandfather has been mentioned by me in the commencement of this letter, but I have said nothing of my grandfather on my father's side, whose authenticated claim to a descent from the historical family of the Bonevals of France was a preliminary to the marriage of my Uncle Frederick with the Baroness Stackelberg, of Dorpat, Livonia. The ancestor who left France was a Huguenot, who is said to have left his native land for a God that he never knew-in other words, though a Huguenot he was not a religious man, in the sense of many others. He went to Holland, became attached to the Prince of Orange and accompanied him to England, where he was wounded at the Battle of the Boyne. I am not an accurate genealogist, as perhaps I ought to be, and it may have been the father of the wounded officer, who emigrated to Holland. My grandfather was a friend of Count Tingendorff, and became attached to the Moravian Church, in which he rose 


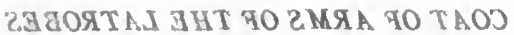




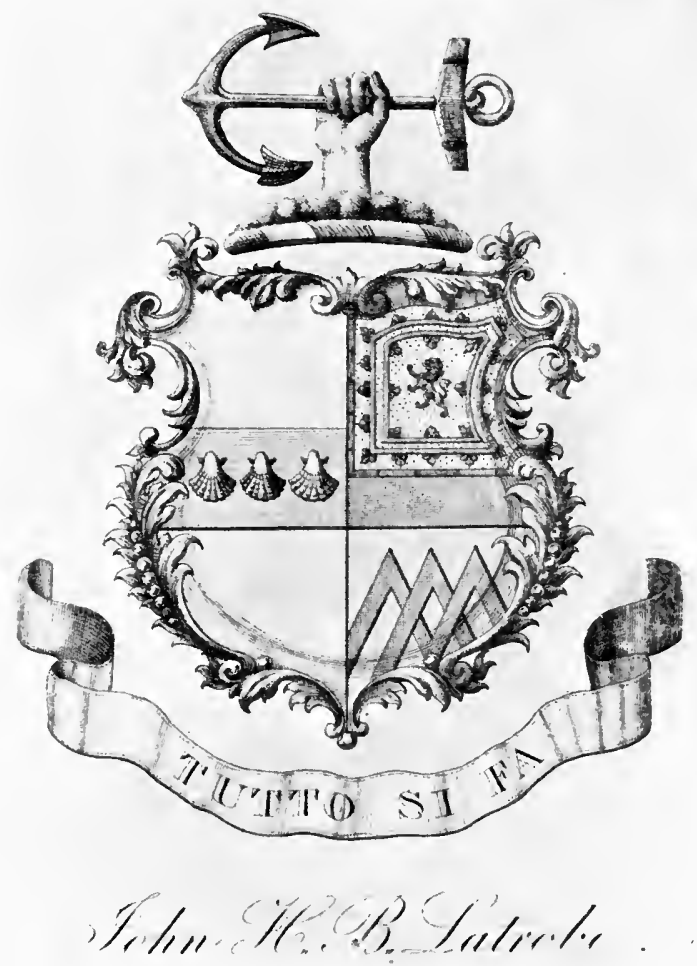


to distinction, and his name is held in great esteem by all the members of that congregation. I wish I could be more accurate here. While I am on the subject, I may as well state the tradition as regards my coat of arms. Three escallop shells on a blue bar across a white shield. The crest a hand holding an anchor. The hand and forearm issuing from clouds, motto, tutto si fa. The origin of this coat is said to have been as follows: A remote ancestor, going as a man at arms to the Crusade indicated by the shells, bore himself bravely, was knighted, and on his return to Italy had his arms blazened by the heralds there. A simple shield, three escallop shells, and the Italian motto, "Nothing is impossible." Religion ran in the family, it would seem. The hand and arm issuing from clouds and the emblem of hope are very religious in their meaning.

"No one knows better than myself that if I am unworthy of my ancestry, it is not because they have not set me a good example. On my father's side, they were brave, honest, true men, and if three of my children won credit for bravery in the late war, they did not do any more than illustrate their origin behind their father at any rate. 'Courage is justly held to be entitled to first place among the virtues, for without it no other virtue is safe.' How I could have turned out, had I pursued my early career of soldier, none can tell. I think I should have hated the necessity of going into battle, but I do not think I should have hesitated physically. I rather think I could have gotten fairly through, and been very glad when it was all over. On one or two occasions I have, during my life, been where I had to expose myself, once in boarding a vessel, supposed to have a mutinous crew, a duty that devolved upon me as Captain of a military company at that time, and when I hailed the ship under the expectation of being 
shot at, I was extremely uncomfortable, but managed to keep cool, and do what was necessary. Luckily, no one was on board the ship. The mutinous sailors had taken the boats and deserted. I make this digression because I have often thought about what constitutes bravery, and have come to the conclusion that there are so few cowards, because there are so few who are brave enough to run away, or otherwise exhibit their actual feeling at the moment."

This account of Mr. Latrobe's, crediting himself with an act of bravery, when in fact there was no danger, can, I think, be duplicated in almost every man's life.

I recollect distinctly, when trying to determine whether or not I would be brave under certain conditions, that I always harked back to an experience that I had in the country, with a degree of satisfaction to myself.

My wife would frequently wake up during the night and hear a noise, or violent barkings of the dog, and would insist upon my getting up to see whether there was anybody about, and as soon as I left the room, in which she and the children were, I would hear the bolt sprung and the door locked. She said it was her duty to protect the children and herself, so that I always felt that there would be no aid from this source. I would then wander about, looking for the supposed trouble.

One night, the dog was barking fiercely, so rapidly in fact that he had no time between his barks. He seemed to be pushed up against the kitchen door. I went to the library window, clad in a very light costume, having drawn on my pantaloons and put on my slippers, and called to the dog. He started off towards the stable, still barking, and came back barking. I then went downstairs, and went out and followed him to the stable, which was some distance from the house. He then seemed to lose all interest in the cause 
of the trouble. As I started to return to the house, I saw, not very far from the path down which I had come, the figure of a man, as I supposed. It was a dim moonlight night, and I did not have on my glasses, but I was sure that a man was standing there. I had no weapon, except a pruning knife, and I debated whether I should go after the man, or whether I should go to the next door neighbor for help. I concluded, fortunately for myself, that it was better to get after the man, because I felt pretty sure that if he saw me coming he would run away, so I started after him, having opened my knife with great difficulty. Much to my surprise and disappointment, he did not run, but I went on until I came within five or six feet of this object, when I saw that it was my bathing suit hung by the neck near a tree, and that the wind had inflated it, and it had the appearance of a man's figure. My heart was beating with great rapidity, because I expected the next moment to be in a death grapple. It was unquestionably this figure that alarmed the dog. When he passed it he saw his mistake and took no further notice of it, not wanting to admit that he had been making the noise for nothing. But I congratulated myself that I had not gone to my friend, Rutherford, for help, for I never would have gotten over the story, that I had called for help against my own bathing suit, and I credited myself with courage, inasmuch as I should have acted in that way if it had been a real danger; just as Mr. Latrobe credits himself with his bravery in going upon a ship in which there was nobody to resist him.

I merely write this to show how prone we all are to pat ourselves on the back for virtues which we may, or may not possess, but which we are all ready to attribute to ourselves on very slight foundations. 
DESCRIPTION OF MR. LATROBE'S COUNTRY HOME

"I have already more than once skipped from place to place in my life in these memoranda, which unquestionably have nothing of the Lucidus ordo; and their want of consecutiveness is owing no doubt in some degree to my memory in resuming my pen from time to time during the last three years. Just now I am writing on the third of July at 'Fairy Knowe,' my country residence, and a word or two as to this one of my possessions may not be uninteresting to those that will, I hope, continue as my descendants to possess the very lovely spot which has grown to its present beauty from the end of the spur of a Chestnut ridge overlooking the Patapsco, where this stream breaks through the primitive rock to wend its way to the Chesapeake through alluvial lands.

"My wife was an invalid after a year or so of married life, and I took her every summer to the White Sulphur Springs, where I immediately became the owner of a cottage, which after a plan of my own had many innovations, and the row used to be known, and perhaps still is known, as Baltimore Row. One year, 1840 or 1841, she was not strong enough to take the journey to Virginia, and we obtained quarters at the Relay House, on the B. \& O. R. R. Here she improved in health so much, that I determined to have a cottage built on the present site, which burnt down in 1850 and was replaced by the present mansion, and hence my ownership of as pretty a place as there is in Maryland. It is indebted for its name to my wife. A dozen were proposed and she fixed on its present title. 'Fairy Knowe' is the place where the catastrophe of Old Mortality is made to take place. The predecessor of the present dwelling burnt down in the last week in May, 1850, I think, in the middle of the day. Nothing was left standing but the 
stack of chimneys to greet me, when I rode on horseback from Baltimore on hearing of the fire, a sorely tired and bemired equestrian. There was a crowd on the land whom I set to work at once to clean up the ground; the chimney stack was toppled over, and things made presentable by sundown. I sent to town for an architect, and he came the following day, Sunday. We had a consultation in the summerhouse, and determined upon a plan. On Monday I had a superintending carpenter, and the cellar was begun, and without going into details the present dwelling was erected in fifty-four working days, papered, supplied with water, gas, speaking tubes, and all the modern arrangements for comfort. When it is remembered that the home is in the general shape of an L, 63 feet front, 33 feet on one side, and 54 on the other, with two stories of twelve feet, and one of nine, this was something of a feat, at least so considered at the time. The material is of wood, inch weatherboarding, brick nogged, and at the end of 25 years without a crack. For seven years we lived at Fairy Knowe all the year around, from 1857 to 1863 .

" 'Fairy Knowe' cannot be spoken of with fairness, without reference to Ben the gardener. Ben Barclay, or Barckedge, was employed as an assistant to a gardener that I had and who was a sorry fellow that I had to part with. When he left $I$ was at a loss for his successor, and as a pis aller took Ben on trial, and he has been with me ever since. He came- a tall boy who had been at the counter of a country grocery. He married in my service, and is now the father of eight children, and an honester, truer, worthier man does not live. He deals with the place as his own, keeps it in prime order, and is the very right hand of Mrs. Latrobe and myself.

"I had not sufficiently investigated the water supply 
when I made my original puchase of five acres, afterwards enlarging to eighteen, and the well that I had dug giving out I was in a dilemma. At this time I saw in an English paper the advertisement of a water ram, with a puff, and ordering one I put it up, and after some discouragement got it to work. This was in '43 or ' 44 I think. Since then it has been my faithful, untiring servant, without repair, or trouble to me. It was the first put up in America. I published a detailed account of it, and the next year a dozen patents for improvement were obtained. Among others who heard of it was a friend, the late Judge Glenn, who having seen that the idea originated in France with Montgolpher, sent for his gardener, whom we will call Mr. Bujac, to be advised of the value of the new machine. Now the Judge knew more of law than he did of French, so he said to his man who knew no English, 'Monsieur Bujac, connaissez vous le-le-confound the name-Oh, I have it-'Monsieur Bujac, connaissez vous le mouton masculin de Montgolpher.' 'Vraiment,' replied the Frenchman, whose cue it was to know everything, 'je le connais bien, et c'est très bon mouton aussi.' The Judge told me the story, and when I told him that 'belier' was ram in French, and the name of the machine 'le -belier hydraulique,' he laughed as heartily as I did as his paraphrases.

\section{COST OF LIVING}

"By this time, 1831-32, I was doing well in my profession. Had long since paid off old debts, and might have begun to lay by money, had I been so disposed, but I was not disposed to the extent I should have been. I purchased a home on Mulberry Street, opposite the Cathedral then under way, agreeing to give for it in fee when completed $\$ 8,500$. I managed to pay $\$ 3,500$ by the time it was ready for occu- 
pation, and the balance I borrowed on mortgage at six per cent, a mortgage which I ought to have paid off by a sinking fund out of my profession, but which I let remain on the property for years, paying the interest, and spending all I made. The year I became a widower, my receipts were $\$ 3500$, I remember, a handsome income in those days, when oak wood, I see by a memorandum I have, was $\$ 2.62 \frac{1}{2}$ a cord, and a pair of fowls cost $31 \frac{1}{2} \mathrm{c}, 50 \mathrm{c}$ being a very high price. Everything else was in proportion."

In his diary I find the following protest against the exorbitant charge of $\$ 3$ for consultation, and $\$ 2$ per visit made:

"July 7, 1830. R. H. Hall, M.D.-As executor I have to decline to pay the bill of $\$ 57.00$ for medical services, as the ordinary fee for consultation is $\$ 2.00$ and $\$ 1.00$ per visit. You have charged $\$ 3.00$ for consultation and $\$ 2.00$ a visit. I would not be justified as executor in paying such a bill. This I know from my own experience and from my investigation of the matter to be the proper charge.

"It just occurs to me here to mention a narrow escape I had from ruin, so narrow that I sometimes almost shudder to think of it. The iron safe in my office was locked with a small key piece that fitted into a handle, which without the piece was useless. This piece I carried in my pocketbook, and on one occasion lost it, and had another made like it from a duplicate belonging to my son, and then forgot my loss. I had living with me then an Irishwoman whom we afterwards discovered to be a thief, and who, I had never doubted, found the lost piece, and having seen me use it, or learned its use, gave it to a confidant who, making into my office, unlocked the safe, and took from it a large pocketbook in which I had been in the habit of keeping the securities of estates of which I was trustee. A short time before 
the robbery there was in this pocketbook coupon bonds of a greater amount than all my property, and for which I was personally responsible. It so happened, however, that only a short time before $I$ had placed all the securities in the Safe Deposit Company of which I had just become a stockholder, leaving the pocketbook, however, in its usual place, filled with deeds, policies of insurance, and other papers of value indeed, but all of which could be replaced, so that the robber had his trouble for his pains. The publication of the account of the robbery was not a bad advertisement for the Safe Deposit Company which was then just established.

"I ought to mention now that the only coupon bond in the safe was one for $\$ 100$ belonging to my son Stuart, the price in part of his Confederate horse, and which had been put into the safe after I had removed the valuables from the pocketbook. This disappeared with the book. He regarded it, he said, as a punishment for having put the representative of a good Confederate horse in the custody of the United States 5.20 bond."

The danger and narrow escape from ruin by the robbing of his safe, which Mr. Latrobe speaks of, reminds me of an incident that occurred in his office while I was there. Few valuables were kept in the safe at that time. There was an inner drawer which was locked, and the key placed in Mr. Latrobe's desk. A Mr. Cumberland (I think that was his name-he was a mind reader, or something of the sort) was giving entertainments in Baltimore at the time. He had some difficulty with the theatre people and employed Mr. Latrobe to solve the difficulty. The matter had been adjusted, and Cumberland came to the office. Mr. Latrobe asked him whether there was really anything in his mind reading. Cumberland said 'Yes.' Mr. Latrobe said- 
'Can you demonstrate it?' Cumberland said 'If you will give me your hand, and permit me to place the fingers of my other hand on your forehead, and you will concentrate your mind on one subject, I can tell you what it is.' I was the audience. Mr. Latrobe closed his eyes as directed, and sat perfectly still. After a short interval Cumberland said, 'You were thinking of a key, the key to the inner door of your safe in the corner.' And so it was. Cumberland said he could not explain how he did it, but he had the power.

I could multiply anecdotes, but they say it is the evidence of senility. I look back on my intercourse with Mr. Latrobe and our talks while walking from his office to his home, but their description would take up too much space.

STATE OF MARYLAND DEBT AND MR. LATROBE'S EMPLOYMENT BY ITS CREDITORS, THE BARING BROTHERS-TRIP TO EUROPE IN 1847

"The troubles of 1837, the suspension of specie payments and the failure of the State of Maryland to pay the interest on the public debt, were the means of bringing me into contact with Mr. Thomas W. Ward of Boston, an agent for the Barings, who came to Baltimore on a railroad inspection tour, and I went up the B. \& O. Railroad with him. We became warm friends on the instant I should say, and through him I became counsel for the creditors of the State, and worked year after year in their behalf, until at length the credit of Maryland was restored. Those were busy times. It was after all this trouble was over that in 1847 I paid my first visit to Europe."

The following is a letter from the Barings to Mr. Latrobe, as the result of his meeting with Ward: 
"J. H. B. Latrobe, Esq.,

"London, September 3, 1842.

Baltimore.

"Sir:

"The financial affairs of the State of Maryland being a subject of great interest, both to ourselves and many of our friends, Mr. Ward has forwarded to us for perusal the detailed statement he lately received from you, showing the present and prospective revenue which is deriveable from the various sources you point out, and we cannot deny ourselves the pleasure of writing to express to you how much satisfaction it has afforded us, to have had a opportunity of perusing a document drawn up with so much ability and clearness. We fear much of your time must have been taken up in collecting the valuable information it contains and we cannot but appreciate the great sacrifice you have made in order to satisfy the enquiries of our agent. The reasoning with which your statement concludes is not of less value than the other parts, more of detail, embraced in it, and the impression it leaves upon our mind is that good management and economy on the part of the State and a continuance of patience for a little time, longer on the part of its creditors, are all that is required to enable Mayland to resume the high ground she formerly occupied as a wealthy and enlightened part of the Union.

"We trust you will make allowance for our being desirous to obtain the most correct information as to any improvement or change which may take place in the financial position of your State, which induces us to express a hope that you will communicate to Mr. Ward any circumstances which may come to your knowledge, likely to have any influence on the decrease or development of her resources, and with warmest acknowledgments, we remain, Sir,

"Your Obedient Servants, "Baring Brothers Company." 
THE WALHALLA ON THE DANUBE 


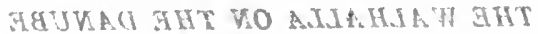




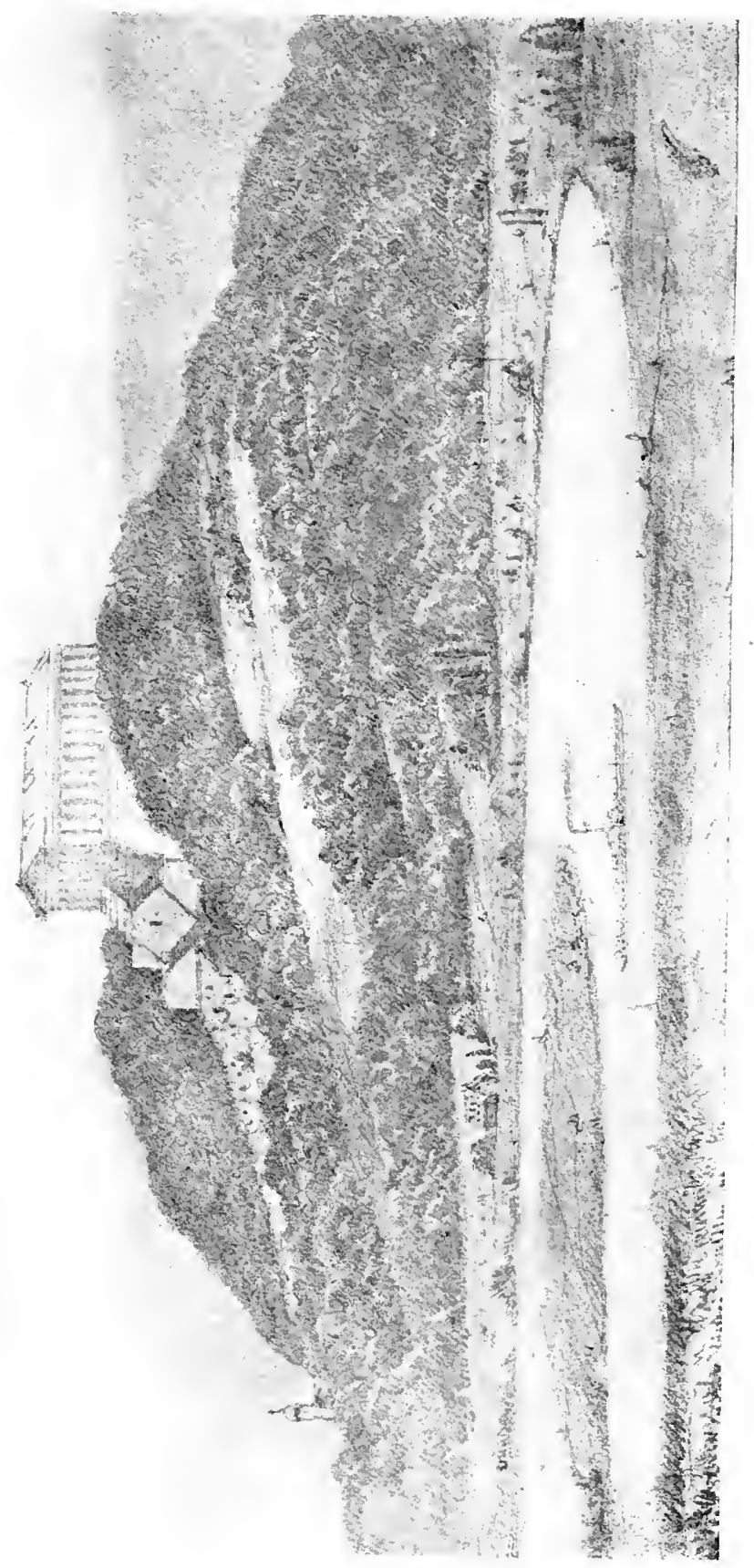



"I was in but tolerable health when I went to Europe, and was only too glad to have a traveling companion, Mr. James Swann, an acquaintance of many years standing, whose counsel I had been on more than one occasion. The only trouble was that our tastes were not at all the same. $\mathrm{He}$ was indifferent to art, took no interest in pictures, and did not sympathize with my enthusiasm. But a more hightoned honorable gentleman lived not, and, while we differed often, we got along on the whole admirably. We were fourteen days on the voyage out, in the Cunard steamer 'Brittanica,' Captain Harrison, landing at Liverpool towards the end of June. We went to London, crossed over after a short stay there to Ostend, made our way to Paris, thence to Geneva, visited Milan and Venice, crossed the Brenner, got upon the Rhine, went to Amsterdam, thence to Rotterdam, and thence by steamer to London. I reached home in September much improved in health, and quite ready to make another trip acoss the Atlantic. Before I left America, I had been paid my fee for professional services on behalf of the foreign creditors. I remember charging $\$ 1,000.00$. While in Paris, a letter from the Messrs. Baring was forwarded to me by my wife. It informed me that I had underrated my services, and that I had a credit with them for $£ 500$. The note was a very elegant one, and, even had its style been rugged, the contents would have smoothed it. My correspondence with Mrs. Latrobe, which she has, I know, carefully preserved, contains a minute account of my European wanderings.

"I have already mentioned my introduction to Thomas W. Ward and my employment, in consequence, as attorney in Maryland for the foreign creditors of the State. A word or two more on the same subject. Mr. Ward became as I have said, my intimate friend, and I cannot let the occa- 
sion pass without a fuller notice to one of the honestest men it has been my good fortune to call a friend. I was warmly attached to him. He was a true man. He said, 'It is the time for me to go off the stage, the world is moving too fast for me. The telegraph confuses me. This having to act on the instant is not what I have been accustomed to. I used to think I could anticipate months ahead commercial probabilities. Now I have to make up my mind at a moment's notice. What is to be the end of it, who can tell? Can you?' And yet there probably never was a man who was more accurate in his judgment than Mr. Ward. He may be said to have been never wrong. Cool and determined action with him was intuition, and while he really believed all that he said of himself, he never fell short of the occasion. It was only necessary to look into his twinkling hazel eye to see determination. He was not misled by false and glittering statements. He never lost sight of the true point. That much for one of whom history will make no mention-who did his duty only, and who has passed away.

"And yet another word about Thomas W. Ward. During the period when Maryland was behindhand in the payment of the interest on her debt, an opportunity presented itself by which the agents of the State, the Barings, for whom Mr. Ward acted, could have made large profits by purchasing the State's securities at the market rate. Whether Maryland would ever pay them was doubtful. The ablest men in the commercial world doubted it. But they did not know as much as others, among whom were the Barings. An agent that I had employed in Maryland pressed the opportunity strongly upon Mr. Ward, dwelling upon the advantages of the speculation. 'Sir,' said Mr. Ward, 'the question is not what profit they may make, but what it becomes the House of Baring to do.' 
"My agency for the foreign creditors brought me in contact with Mr. Thomas Baring when he came over to America, a tall, rather stout, florid complexioned, genial Englishman, and straightforward. I learned to know him well, and we got on excellent terms. One day in my office he saw hanging up Dr. Johnson's prayer in commencing the study of the law. He pretended to be amused at seeing it where it was. 'But,' said he, 'that, Mr. Latrobe, is, I take it, for the students.'

As Mr. Baring says, the prayer was intended for students and is headed 'Prayer before the study of law.' Whether we are better than we used to be and need not pray, I do not know, but I know of no lawyer's office that has it on its walls. I recollect it as it occupied a conspicuous place in Mr. Latrobe's office. It was a good prayer; perhaps we lawyers have it so deeply engraved in our anatomy, that we need not have it made visible. It reads:

Sept. 26, 1765.

Almighty God, the giver of wisdom, without whose help resolutions are vain, without whose blessing study is ineffectual; enable me, if it be thy will, to attain such knowledge as may qualify me to direct the doubtful and instruct the ignorant; to prevent wrongs and terminate contentions; and grant that I may use the knowledge which I shall attain to thy glory and my own salvation, for Jesus Christ's sake, Amen.

"Another person with whom I became acquainted in this connection was Nathan Hale of Boston, Editor of the 'Daily Advertiser,' a tall, square-shouldered New England looking man, but the very impersonation of common sense, and one of the cleverest writers I ever met with on practical subjects. We wrote Maryland right; and Mr. Hale's articles were among the best that passed through my hands. He often 
came on to Baltimore to consult with me, and always to my advantage.

"Looking back now, it seems strange how much trouble it took to bring about the payment of interest on the public debt. Year after year went by. The State was in sad credit. At Annapolis one winter, Otto Scott, then in the Senate, told me that the State had already paid one half her debt, and he bet me a case of champagne that in another year she would pay the whole of it, her stock being then 50c on the dollar and he being sure that in winter months it would be utterly worthless.

"At last, when all things seemed ripe, a conclave was held, and it was agreed that such and such men should be brought forward for the Legislature. Mr. John P. Kennedy was one of these, and he was made speaker of the House of Delegates, with the understanding he was to appoint Mr. Thomas Donaldson Chairman of the Committee of Ways and Means.

One night Mr. Donaldson came up from Annapolis for consultation, the question being whether the law insuring the payment should be pressed, and a vote taken. Coupons had been received in payment of taxes, and there was a large party who desired that this system should continue. It was doubtful, Mr. Donaldson said, whether if the Bill for immediate resumption should be pressed, it would pass, and it had been determined that I should, as the recognized agent of the foreign creditors, decide the question. I remember well the sense of responsibility that oppressed me. It was evident that the friends of resumption were uncertain. Luckily, I had the pluck to say much or nothing, and the vote was taken, and the bill was passed and the moment it was passed, the wonder was that there could ever have been a doubt on the subject. The State drew a long breath, and has breathed freely ever since. Mr. Don- 
aldson behaved like a man, so did Mr. Kennedy, and many, many others, and above all, Governor Pratt was most influential. It was not the agreement to pay that perplexed people who were politicians, but the necessity for direct stamp and tax duties which were then for the first time in the history of the State imposed. The delegates and senators had angry constituencies to meet, and they met them and were sent back to increase the taxation, which they did; and Maryland redeemed herself, despite Sidney Smith's twaddle.

"I find that I have said nothing about the incidents of my first visit to Europe, and yet a word or two in regard to those I met there may as well form a part of these memoranda.

"Mr. Louis McLane gave Mr. Swann and myself letters which were valuable introductions to distinguished people. Among others was a letter to Samuel Rogers, the poet, then an old, very old man. He invited Mr. Swann and myself to breakfast, where we met a company whose names I do not recall, if I ever knew them at all. Some ten of us sat down to the meal. To me the great object of interest was Mr. Rogers himself. He talked a good deal, and his conversation was, out of politeness to his guests, mainly upon American subjects. I well remember him saying that he recalled the breaking out of the American Revolution. 'Sir', said he, 'my father, who took a great interest in the affair of your country, deeply deplored the war. He was on your side, Sir, and when the news of the battle of Bunker Hill reached England, he sent for his haberdasher and ordered a suit of mourning, and did not cease to wear the habiliments of woe until the close of that most unnatural contest.' It was something to have seen one who could narrate such an anecdote. Mr. Rogers had 
known Mr. Webster when the latter had visited England, and spoke a good deal about him, and drew a parallel between him and Mr. Clay, describing Mr. Clay as an orator and Mr. Webster as a statesman. 'Sir,' said he, 'when Mr. Clay's speeches will cumber unheeded the shelves of ancient libraries, the works of Mr. Webster will be worn books of the politicians and statesmen of your country.' Mr. Rogers had the appearance of an octogenarian. His mouth was sunken, and his head and neck sunken between his shoulders. His speech was mumbling and somewhat indistinct, but there was an animation in his eye that indicated an intelligence as bright as ever.

"Among other letters which we had was one to Sir Robert Inglis, with whom we breakfasted. He had a hearty English look and was very kind. Having been told that I was interested in Colonization and the African Race in consequence, he placed me at the table so that I sat opposite a portrait of Wilberforce which, if I am not mistaken in my recollection, was finished only so far as the head, the drapery and background being only sketched on the canvas. Sir Robert interested himself in our journey on the continent and made out an itinerary with the aid of Lady Inglis, writing it with a pencil in the intervals of the breakfast. I remember he had a large loaf by him which he cut in pieces, and asked me whether I would have a slice or 'a chunk,' explaining to me the meaning of the term, which was a novel one.

"A letter to the Honorable Mr. Harris, Under-Secretary of State for the Colonies, was followed by an invitation to dinner where we met many clever persons, among others the Surveyor-General of India and the Dean of Westminster. I recall the pleasure I derived from the conversation of my righthand neighbor, a very brilliant woman, whose 
features even at this late day I can recall distinctly. Free trade was one of the topics introduced and our American tariff was criticised, when, as an illustration of English free trade, I told of my having had to pay on half a dozen cigars, which the Custom House Officers happened to see in my waistcoat pocket when I landed. Of course this was told in a joke. The dinner was one of the most agreeable description.

"Lord Bexley had known my father when they were both boys, and my cousin, Mr. P. Latrobe, took me to pay. my respects to him. He seemed to me to be as old as Mr. Rogers, but a wholly different looking man-very thin, very gray, with a feeble piping voice, but an interesting. conversationalist. He warmed up more than I expected him to do when it was to be recollected that it was in the last century that he knew my father.

"We had letters to the Earl of Leicester and Lord Monteagle, but were prevented by circumstances from availing of them.

"Parliament was in session when we were in London, and. Mr. Swann and myself, through the kindness of Mr. William. Brown, were admitted to the floor of the House of Lords, outside the bar, where we were introduced to a very handsome Sir Somebody, Augustus I think, Clifford, who was. polite. He was Usher or I forget what, and carried a long thin rod.

"When in the House of Lords I heard the Marquis of Lansdowne speak, Brougham, I am not sure he was Lord Brougham, though of course he must have been, and an old gentleman with an enormous hook nose. 'Pray, who is that' I asked of my next neighbor, a person who seemed on familiar terms with the Lords as they passed in or out and stopped and shook hands with them. 'Why, that is 
the Duke,' was his reply. 'What Duke?'I said. The gentleman turned to look at me. 'Why, the Duke of Wellington,' he answered, with some surprise in his tone. 'Ah', I rejoined. 'Well, he speaks indistinctly, but it is something at all events to have heard the sound even of the voice that commanded at Waterloo.' This led into a further conversation, and ended by my friend giving me his card, 'The Very Reverend Principal Lee,' I think it was of the University of Edinborough, and he pressed me warmly to call on him if I passed through the capital of Scotland. I might have done so, but I did not, to my regret ever since.

"Landing at Liverpool Mr. Swann and I went to York and afterwards to London, then from Dover to Ostend, then to Paris, to Geneva, across the Simplon to Milan, to Venice, to Innspruck, to Basle, down the Rhine to Baden, Wiesbaden, Arnheim, Amsterdam, to Rotterdam, to London, to Edinborough, back to London, to Southampton and home.

"In my notice of my first visit to Europe in 1847, I say nothing of an event which certainly made a great impression at the time, and threatened to put a stop to all autobiographical writing on my part. The Brittanica was approaching the American coast in very heavy weather, and through a dense fog, and for three days the Captain had not had an observation. One day the sea went down suddenly, though there seemed to be no abatement of the wind, and it came to my mind that the abatement of the sea was due to our being under the lee of Cape Race, which, as the wind was, would account for the condition of the sea; and leaving the dinner table and joining Captain Harrison on the bridge, I told him of my apprehension. He said he knew where we were, and that in a little while we would run out of the fog, and find ourselves running our course with the 
land about Cape Race on our starboard beam. There were no soundings taken, no abatement of the speed and I returned to the dining room to find that my apprehensions were participated in by other passengers. Still we drove on, and after a while the passengers went on the upper deck, and I was left alone in the cabin. In my turn I too went out and had just reached the gangway when I heard the cry 'half beat - back her, back her', and a great stamping of feet forward, and looking over the rail I saw looming out of the fog a promontory of rocks, and almost at the same moment felt and heard the keel grate upon the rocks three times, when the ship stopped, her bow high up above the proper level of the deck. Of course, there was confusion for a moment or so, when all the passengers who had assembled on the upper deck became silent and, as may be supposed, anxious enough. The Captain was directing all the forward weight, \&c., to be moved aft, and there was a steady batting of the wheel. I stood near two sailors who were sounding astern. Looking seaward I saw what might have been taken for a wall of water moving towards the vessel. It reached her, passed under her, and broke in thunder upon the shore. But it raised the vessel to an even keel as it passed, and dropped her with a thud, that threw everyone off his feet. 'Look here, Tom,' said one of the sailors, 'another such shock, and the mast will go through the bottom.' Another shock did come, but the wheel had forced the vessel backward, and the shock was less, then there came another, and the shock was slight, and then the rocks were lost sight of, and we were running, stern foremost, out to sea, and pieces of the false keel floating on the surface were rapidly left behind, and we were safe. A few yards to the right or left and we would have been lost. As it was we providentially ran into a small cove between two projecting headlands. 
So much for the boasted care of the Cunarders. Of course, we held a meeting the next day, and whitewashed the captain who should have been lowered. But we were too grateful to be just. On board with me was Mr. Robert C. Winthrop, still alive, and Colonel Airey with whom I became intimate, and who subsequently became distinguished in the Crimean War. My second visit to Europe was in an American steamer the Asago, and my last in a French one, going and returning.

"Our resolutions saved Captain Harrison, and for several years afterwards I used to meet him at Newport, which he occasionally visited in the intervals of his summer voyages. He was promoted to the command of the Great Eastern, but made no voyage in her, having been drowned by the upsetting of a skiff in Southampton Water." 
OUTLINE OF THE HORIZON AT ROME

At Sunsel-from the Pincian Hill, June 26, 1857, drawn by John H. B. Latrobe 
AMOA TA VOSIMOH GHT 90 GVIJUO

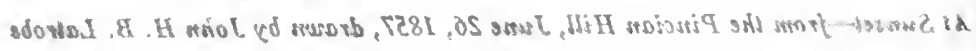




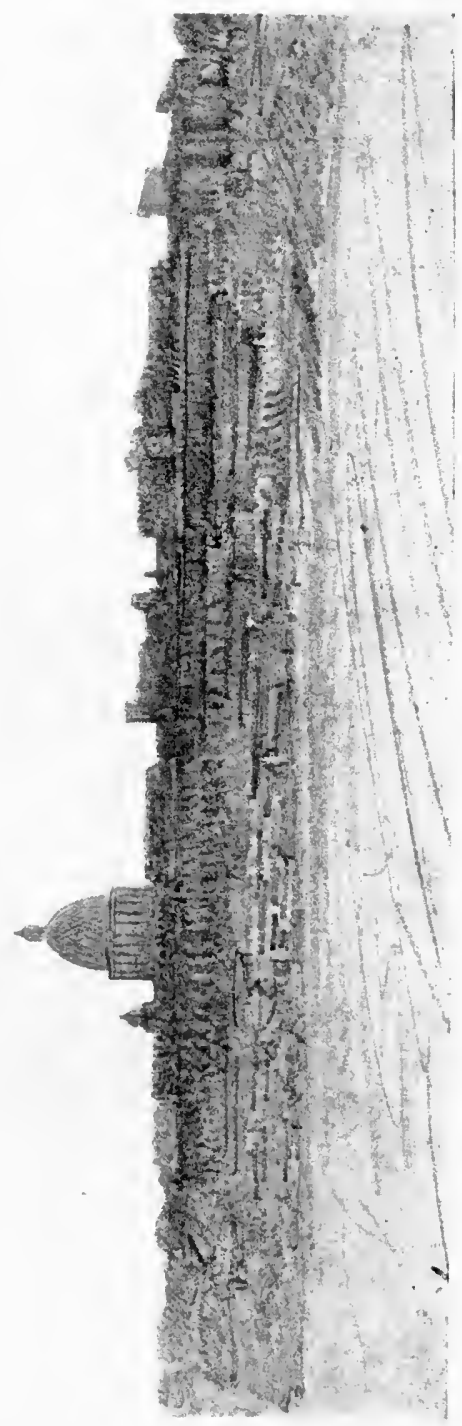





\section{CHAPTER XVII}

TrIP to EUROPE IN 1857-CounSEL FOR the WINANS RAILROAD INTERESTS IN RUSSIA

During the year 1857, Mr. Latrobe was in ill health due to impure water, which he drank at the National Hotel in Washington, and, in order to recuperate, he determined upon a trip to Europe. He left Baltimore on the 28th of May, 1857, and sailed for Havre from New York on the "Arago" on the 30th. Turning to his passport, dated the 14th day of May 1857, we find the following description: "Fifty-three years old, six feet high; eyes, hazel; nose, common; hair, brown; mouth, small; chin, broad; complexion, light; face, oval."

A photograph of Mr. Latrobe taken while in Russia is here reproduced.

He took quite an extensive trip through Europe, stopping at different places of interest. As was his custom, he drew pictures - pencil sketches - of places which he visited. One of them, which has considerable merit, is the outline of the horizon at Rome, at sunset, from the Pincian Hill, June 28, 1857. Another is a sketch, unfinished as to color, of St. Peters, June 29, 1857, showing one of the devotees of the church kissing the Pope's toe.

Mr. Latrobe upon this trip visited England and there met Mr. Winans. The Winans people were having trouble in St. Petersburg with the railroad. The Government did not agree with them, and on September 19, while in Paris, Mr. Latrobe received a telegram from Mr. William L. Winans asking him if he would go to St. Petersburg to repre- 
sent Winans, Harrison \& Winans. The result was his employment. He writes:

"I might as well here, as elsewhere, recite an episode in my professional life, which has probably few parallels. When I attended the meeting of the American Colonization Society as its President, in the month of January, 1857, I took a parlor and chamber at the National Hotel which had been occupied at one time by President Buchanan and was known as the 'President's room.' Here I received the mem. bers of the Society, who called to pay their respects. In the centre of the parlor was a round table, I recollect, on which was a pitcher of ice water, of which I drank frequently and freely, and to this temperate indulgence I have always been satisfied that I owed the sickness with which I was affected on my return to Baltimore. So many of the guests at the house at this time were affected in the same way that the name of "The National Hotel disease" was given to the derangement of the bowels which they suffered from. One of the symptoms, according to my experience, was a terrible depression of spirits which seized me daily and always at the same hour. I expected to have fallen away in flesh, but it was not so. On the contrary my face became fuller, if anything, but my complexion was of a tallowy hue; medicine could do nothing for me and month after month passed without any change for the better. At length, in a sort of despair, I resolved to try what effect a sea voyage would have, and taking with me my son Ferdinand, I left Baltimore on my second visit to Europe, sailing from New York in the Steamer 'Arago' in May, 1857. We landed at Havre, and went at once to Paris. My voyage had not benefited me much, and I was still suffering from periodical depression of spirits, when one afternoon, as I was seated in misery in the Garden of the Tuileries, Ferdinand proposed, 
in the hope of rousing me, that we should go to the Theatre. We went there accordingly, and procured seats in the stalls, in front of the boxes and in a most conspicuous position. While here, Mr. William L. Winans recognized me, and coming to where I sat, between the acts, introduced himself, for I had not seen him for years, and invited me to dine with him the next day. We had a capital dinner and parted with a promise on my part that I would let him know at Brighton, where his family then were, when I reached London.

"Ferdinand and I then made the tour of Europe, going to Marseilles, Naples, Rome, Florence, Venice, Bologna, 'doing' Switzerland and Holland and bringing up at London, where I kept my promise to Mr. Winans. He came up to London and took us down to Brighton. The firm of Winans, Harrison and Winans had just secured the contract with the Russian Government for the remount of the Nicolai Railway between St. Petersburg and Moscow, and Mr. Winans showed me the ninety-odd articles of it, and we passed a morning going over it, his object being to have my opinion upon certain questions that might possibly arise under it. He noted my answers to inquiries that he made, and, laying business aside, treated me en prince, dined me, drew me out, and did everything in his power to make my visit a pleasant one. The next day Ferd and I returned to London and set to work sight seeing. The day after I received a note from Mr. Winans with his check on Baring Brothers for $£ 200$ - a most unexpected fee for my morning's chat, for it was little more, over the Russian contract.

“After 'doing' England and Holland, we went again to Paris to wait there for the sailing of the 'Arago,' in which we were to return to America. There we met Judge Dobbin and his son George, and took up our quarters in the Hotel du Louvre. 
"I had paid my passage, and had packed my trunk, and was altogether anxious for home, when the day before we were to leave France I received a telegram from Mr. Winans, to whom I had given my address in Paris, in these words'What sum will induce you to pass the winter with me i St. Petersburg?' Now I had no desire to go to Russia. $I$ had been absent from my office in Baltimore some four or five months. I was in good practice. I did not want to interfere with it, and naturally I wanted to see my family. So I held grave counsel with Ferdinand as to the reply that I should make to this most unexpected proposal. When I gave him my reasons for returning to America, he suggested that I should make my answer declining the Northern visit a very courteous one, seeing how liberally I had been paid for my Brighton trip. Suddenly it occurred to me that I would fix a price for my services that would be too great for Mr. Winans to give, though not too large for me to ask, looking to the possible consequences of so long an absence from my practice. We had talked of $\$ 50,000$, a sum that would be very reasonable under the circumstances, but with little expectation that it would be paid, and when I said I would name $\$ 60,000$, I was very sure that this amount would be regarded as more than the occasion warranted, while it was not more than was proper to compensate for all the services I might render and the risk to health and life that I might run. And so I telegraphed back to London the words 'For $\$ 60,000$, and my expenses from now until my return to Baltimore I will pass five months with you in St. Petersburg.' I had no expectation, or at all events but little, of my proposition being accepted; although Judge Dobbin, then Mr. Dobbin, thought it would be. He thought that my long experience in all railroad matters would make my services in Russia to Mr. Winans 
regarding the contract for the remount peculiarly valuable, and that Mr. Winans would so consider it. Then, I confess, I awaited the reply with considerable anxiety, for by this time I had become desirous of going to St. Petersburg. The next day brought it, in these words-'Your proposition accepted, meet me tomorrow at Calais en route for Russia.' This settled the business. I wrote at once to Mrs. Latrobe, referring her to Ferdinand for particulars, executed a full power of attorney to my son Osmun, who was then in my office, and, shaking hands with Dobbin and Ferd, saw them, the same afternoon, off for Havre, and the next morning took the railroad for Calais, where I stood on the pierhead and was hailed by Mr. Winans, as the boat from Dover steamed round it. The next day I left for Russia, via Berlin where Col. Klockoff, advised of my coming by Mr. Winans, was awaiting me, and by him I was escorted, via Stettin and the Gulf of Finland, to St. Petersburg. The voyage was a pleasant one. The steamer was crowded with persons returning home after a summer's trip to the watering places. I made agreeable acquaintances, and, forgetting my Baltimore office and clientele, prepared for the new experience of my Russian winter. I landed at the English quay, got into a Drosky, and, rattling over the roughest pavements in the most miserable of vehicles, was soon installed in the Gastanuza (Hotel) Kle, the principal hotel in St. Petersburg, as my headquarters for the next five months.

"My accommodations in the Hotel Kle were indifferent, until Mr. Winans arrived, when he at once changed them. I was then installed in an apartment, consisting of an ante room, a large and lofty parlor, and a bed room almost as large beyond it; looking out, on the one side upon a wide and handsome street and on the other upon a public square. 
Nothing could have been more agreeable to my taste, barring furniture, which was scant enough; indeed, I recall a lounge, a table, a looking glass and an escritoire. One angle of the parlor was cut off by a large stove plated with glazed white tiles. The floor was waxed once a week and kept polished as smooth as ice. There were, I think, three or four chairs, only scattered here and there. The furniture of the bed-room was not more ample, and my bed was, I am sure, not more than three feet wide, if as much. After a while I procured a double bed, and was then much more comfortable. The furniture of the ante room was limited to the stand on which visitors hung their cloaks. When I got a servant, a cot was placed there for his accommodation, and high up in one angle of the room he hung the picture of a saint, before which a taper was kept at all times burning. This suite was vacated by Prince Galitzin. On the margin the plan of the apartment is given.

"After Mr. Winans had seen me fairly installed in these rooms, I gradually acquired a sort of home feeling in connection with them. The Landlord and oberkellner were most obliging. I dined in the coffee room and began to study the language; and by the end of the first week had settled down for the winter. Colonel Klockoff procured me seats for the season at the Grand Opera, and saw that I was supplied with a coupé and pair and a suitably dressed coachman. Afterwards I provided myself with a valet. One day as Mr. Winans and myself were passing through the hall, we met a distinguished looking lady whom he had known in Paris at the Hotel du Louvre, and introduced me to her. This was the Madam Helène de Bartholomaie, with whom and whose family I afterwards became so intimate. Above the common height of woman, and of a good figure and animated countenance, she was one of the most graceful 
and at the same time dignified women I have ever seen. Full, too, of high spirits, she had all the attractions which make the sex attractive to men. She was always striving to be of service to somebody, and seemed never happier than when doing a good turn. Her husband, General D. Bartholomaie, was a distinguished officer, and in command, at this time, of the Fortress of Brest on the frontiers of Poland. She had lost two lovely daughters just as they were emerging into womanhood, and, although this was years before, I know the recollections of them were still vivid enough to cloud her natural gaiety when circumstances recalled her loss. Her son, Alex., was a captain in the Grand Duke Constantine's Hussars, and I became much attracted to him. He was passing the winter in St. Petersburg with his mother. Another, Michael, was in the Diplomatic Service. He is now Chancellor of the Russian Legation at Sidonio, in 1877, and would have come to the United States as Ambassador, had the new minister who succeeded Baron Burow at the Court of St. James been able to dispense with his services there. Madame Bartholomaie was one of the few Russian women I have ever seen who had splendid teeth. The marble copy of her hand is on the centre table in Baltimore. ( $\mathrm{I}$ write this at Fairy Knowe.) It was celebrated for its beauty, and her foot corresponded with it. At this time Madame was 45, admitted, and her hair, when she was not in full dress, showed it; but, en grande tenue, she was certainly one of the most striking women I have ever seen, and looked much younger. So much for a lady to whom I was indebted for much pleasure, and whose standing was of the highest, and whose introduction of me to the Bulongyansky family, her sisters, five of them, was of much service to me socially while I remained in Russia. What has become of her now I do not know. We corresponded 
for many years, and I met her with her son at Berne in Switzerland, when I took my wife and daughter to Europe in 1868. Soon after I was introduced to her, she left the Hotel Kle, and made her home for the winter at the Hotel de Mouth.

"As soon as I had settled down, I called on the American Minister, Mr. Thos. A. Seymour, who became my intimate friend while I was in Russia, and whose death not long after his return to America I sincerely regretted. We were constantly together, dined together, drove together, went into society together, and, as Mr. Seymour spoke no language but his own, I was not only his companion, but his interpreter too. It was through him I was presented to the Emperor, which led to my presentation to each member of the Imperial family in succession.

"In a paper that I prepared to be read at the Town \& Country Club at Newport in the summer of 1876, I have given an account of my different presentations, as well as of other matters during my winter at the Russian Capital. This is among my papers and I shall refer to it rather than repeat what $I$ have there written very much in detail. Some matters, however, I omitted that I may as well record now.

"The next presentation in order, after the Emperor had received me, was to the Grand Duke Constantine, and when I saw that it had taken place without my being invited, I was afraid that perhaps there had been some mistake made by me at the Winter ${ }^{\mathrm{r}}$ Palace. This was not so, however, and a note through Mr. Seymour invited me to the Marble Palace, the residence of the Grand Duke, where I was to be received in his private cabinet. This was far more satisfactory, and I accordingly was punctual in my attendance at the appointed hour. I was shown at first 
into a handsome apartment, where there were many models of ships and other nautical matters, and where I remained until the Grand Duke had dismissed a prior visitor. The usher then showed me into a large room filled with booksevidently a library - the private cabinet of his Highness. He rose as I entered and advanced towards me holding out both hands, and saying, as he mentioned my name, 'Out and out an American.' 'Yes, Your Highness, out and out an American.' He then seated himself at a sort of secretary and motioned me to a chair which placed me vis-à-vis to him with the angle of the writing table of the secretary between us.

"At first our conversation was purely conventional. When had I arrived in Russia? how the climate suited me; how I was lodged, \&c., \&c., when he said suddenly, 'Why is it that Americans and Russians like each other so much?' He spoke English fluently, and with a very slight accent indeed. 'We are both of us new people in one sense-we have each of us a future. If the old countries can maintain their present power and wealth, it is as much as they can do, but Russia and America are in their youth, and a great development is to be anticipated for both.' 'Any other reason?' he then asked. 'We are both large countries, your Highness, and, as among boys, the big sympathize and associate with the big.' He smiled and said, 'Well, what other reason?' 'We neither of us are satisfied with the extent of our territorial possessions.' 'Ah! what do you mean by that?' 'We are charged by the world with wanting Mexico and Canada, and scandal, your Highness, whispers, perhaps you would not be unwilling to add Constantinople.' Here the Grand Duke laughed as he said, 'But don't you think, Mr. Latrobe, that we have territory enough each of us already?' 'Certainly, your Highness, according to the 
American definition of "enough.", "Yes? And pray what is the American definition of "enough" '? "Enough" in America, your Highness, means a little more.' Here the Grand Duke laughed very heartily, and repeated my words, which seemed to amuse him greatly. Presently he said 'But you have not mentioned the most powerful reason of all.' 'And, if I may venture to ask,' I inquired, 'what may that be, your Highness'? 'We have a common enemy, cotton is all that makes England the friend of America.' I forget what I said in reply, but I remember that I did not discuss the subject, and the conversation turned in another direction. He talked of sending a fleet to visit the United States, when I promised it a welcome. The extension of the railroad system over Russia was spoken of. The expense of transportation to Sevastopol during the Crimean War was mentioned. I spoke of the value of the system, as a military aid to attack and defense. I told him about Liberia, and promised to write him a letter on the subject, for he knew very little about it. And anticipating the nod which terminated such interviews ordinarily, by rising after such a long conversation, I terminated the longest conversationand a most agreeable one, too-that I ever had with Royalty.

"When I got back to the Hotel after this interview with the Grand Duke, I prepared carefully a monograph about Liberia, which the Grand Duke had translated into Russian and published in the official Journal of the Marine I think.

"In the library at 'Fairy Knowe' there is a letter from the Grand Duke, thanking me for an autograph of General Washington. One day when visiting the Imperial Library, I found that in a collection of autographs of distinguished men, Washington was wanting, much to the regret of the Baron, the librarian. I at once wrote to America to several friends, and, among others, to my brother-in-law, Dr. 
Stuart, who procured a receipt given by General Washington to General Mercer for some corn. I think that it was to be credited on account of a debt. I at once sent it to the Grand Duke to be presented to the Emperor, and the letter in the library is the reply to my communication.

"The Grand Duke Constantine Nicolaivitch, when I knew him, was a man below the common height, but without being a small man. He had a soldierly carriage, and a most pleasant and agreeable manner, offhand and genial. I met him after our interview at the Marble Palace and was always cordially greeted by him.

"Sometime afterwards he sent a fleet to America, and I was one of a Committee of citizens of Baltimore at large to visit New York and invite the Admiral to bring his ships to Baltimore. I was certainly the only one of the Committee that could boast of the acquaintance of the High Admiral.

"I have mentioned and described Madame de Bartholomaei. I ought to speak kindly of her, for on one occasion she was, under Providence, the means of saving my life. The 'Hotel disease' still afflicted me after my arrival in St. Petersburg, and I regarded a more than usual irregularity in my bowels as but another manifestation of it that would soon pass away. As it turned out, however, this was but a premonitory symptom of Asiatic Cholera. I had been one day at Levitzsky's, the photographer, with Madame de Bartholomaei, and found myself in a good deal of pain, so much so that I was about sending an apology to Madame Kaphen, Madame de Bartholomaei's sister, where I had agreed to pass the evening, taking Madame de Bartholomaei in my carriage. Feeling better, however, when we left Levitzsky's, I told my companion I would call for her which I did, and between seven and eight o'clock we were set 
down at Madame de Kaphen's door. It was a family party, mostly children collected to see the sleight of hand tricks of a lad, Prince B., who instead of attending to his books in the Corps des Pages, had made himself a very tolerable juggler. Here I suffered great pain until midnight, when my carriage was announced, and I handed Madame $B$. into it with intense relief at the prospect of getting to my hotel. I had to set my companion down on the way and, before I reached the Hotel de Mouth, was seized with agonizing spasms which it was impossible for me to conceal. She saw my condition-that I was not able even to see her to her apartment, and as my servant closed the carriage door, I heard her say to the coachman in Russ, 'Scarey, scarey, ('Hurry, hurry').

"When I got to the Hotel Kle it was after midnight, and the Swiss helped me from the carriage and to my room. I should have kept my servant, but as soon as I was in the hands of the Swiss, Mr. Frederick washed his hands of me and went home. Then the Swiss disappeared and the hotel was closed for the night. I now rang the bell which was answered by a man, a sort of watchman, whom I got to understand with the few Russian words at my command that I wanted water-hot water-very hot water. This was brought to me quickly, but it did me not the slightest good, and $I$ undressed and went to bed in the hope that a recumbent position might benefit me. But I was mistaken; cramps came on, cold sweat was on my forehead, and, deserted by the servants and unable to help myself, I was just as miserable as I could be. I was lying on my back with my knees drawn up, when a knock on the outer door was followed by the entrance of Madame de Bartholomaei's servant, a German who spoke no language but his own and Russ. He brought me a note which said 'Let me know how you are; 
you were in pain.' I was just able to scrawl a word or two, which Korf scarcely waited for before he was off to report my condition to his mistress. It seemed but a few minutes before I heard a sleigh stop at the door of the hotel and immediately afterwards there was a knock at the ante-room door, accompanied by the words 'Puis j' entrer?' and without waiting for an answer Madame de B. stood at the foot of my bed, a mass of furs and many wrappings. Her first words were to ask the name of my physician, if I had one. I answered, Dr. Rogers, living on the Galerie. She disappeared, the sleigh bells rattled again, and when she came back, it was to regulate the room, rouse the oberkellner, send for my servant, and generally assume control while I lay speechless with misery and pain.

"It seems that, after I left Madame de B. at her hotel, her son came from a party and hearing him in conversation with Korf, it occurred to her to send the latter to see how I was; telling him to look up at my windows from the street, and not to go to my room unless he saw a light there. In that event, he was to deliver her note. Korf's report had alarmed her, made her fear that I had the cholera and brought her to my relief. Had she not come I might have been a dead man before morning.

"It was not long before Dr. Rogers was with me, and, without going into detail, he brought me through with God's assistance. He remained with me an hour and Madame de B. not leaving me at the same time, I said something about her staying with me at the Hotel, now that the physician had taken his leave. She laughed and then remarked-'N'ai je pas le rang, et n'ai je pas l'age pour faire sans reproche les devoirs d'une femme russe?' By this time I was out of pain, and at the end of a week was quite well of Asiatic cholera, and along with it disappeared 
what remained of the 'Hotel Disease.' So much for Madame de B. In 1868, when Mrs. Latrobe and Virginia and Lillie met her at Berne, she was quite gray, and my wife was charmed with her. She was then sixty, she said, and still had the bearing that distinguished her in 1857 .

"My duty at St. Petersburg was to answer questions submitted to me by Mr. Winans, growing out of his contract with the Government. My office was at Alexandroffsky. It comprised a suite of rooms, an ante-room, in which was a billiard table, a large room adjoining in which I worked, and beyond that a room for a clerk when I required one. My hours were from 10 a.m. until 3 p.m., barring Sundays and Holy days, when I remained in St. Petersburg. When the roads were free from snow I drove to Alexandroffsky in my coupe; when there was snow on the ground I went to and fro in my sanyat or sley. And this routine was uninterrupted except when I was kept in St. Petersburg by my cholera trouble.

"One day I was at the English Magazine with Governor Seymour, and had just passed through the anteroom of a long range of apartments, when I noticed that the doors in front of us were thrown rapidly open by the liveried attendants, and low obeisances were made to a very handsome woman, fashionably dressed, as she passed through them on her way out of the building. She was under the middle size of her sex, but of a very queenly carriage, and I noticed that she did what always attracts my attention-walked well. Mr. Seymour and I stood aside, and as she went by, she nodded-no, she did not nod, a graceful motion of the head was anything but a nod, accompanied as it was by a pleasant smile of recognition. 'Confounded pretty woman that, Governor,' I said in a whisper, louder than I intended and which I am sure she heard. 'Hush, my good Sir,' was the 
PASS OF JAMES RIVER, 2 MILES BELOW BALCONY FALLS Painted by John $B$. B. Latrobe 


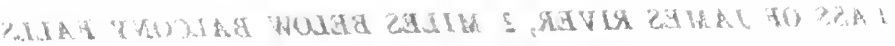

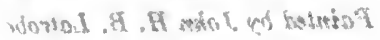




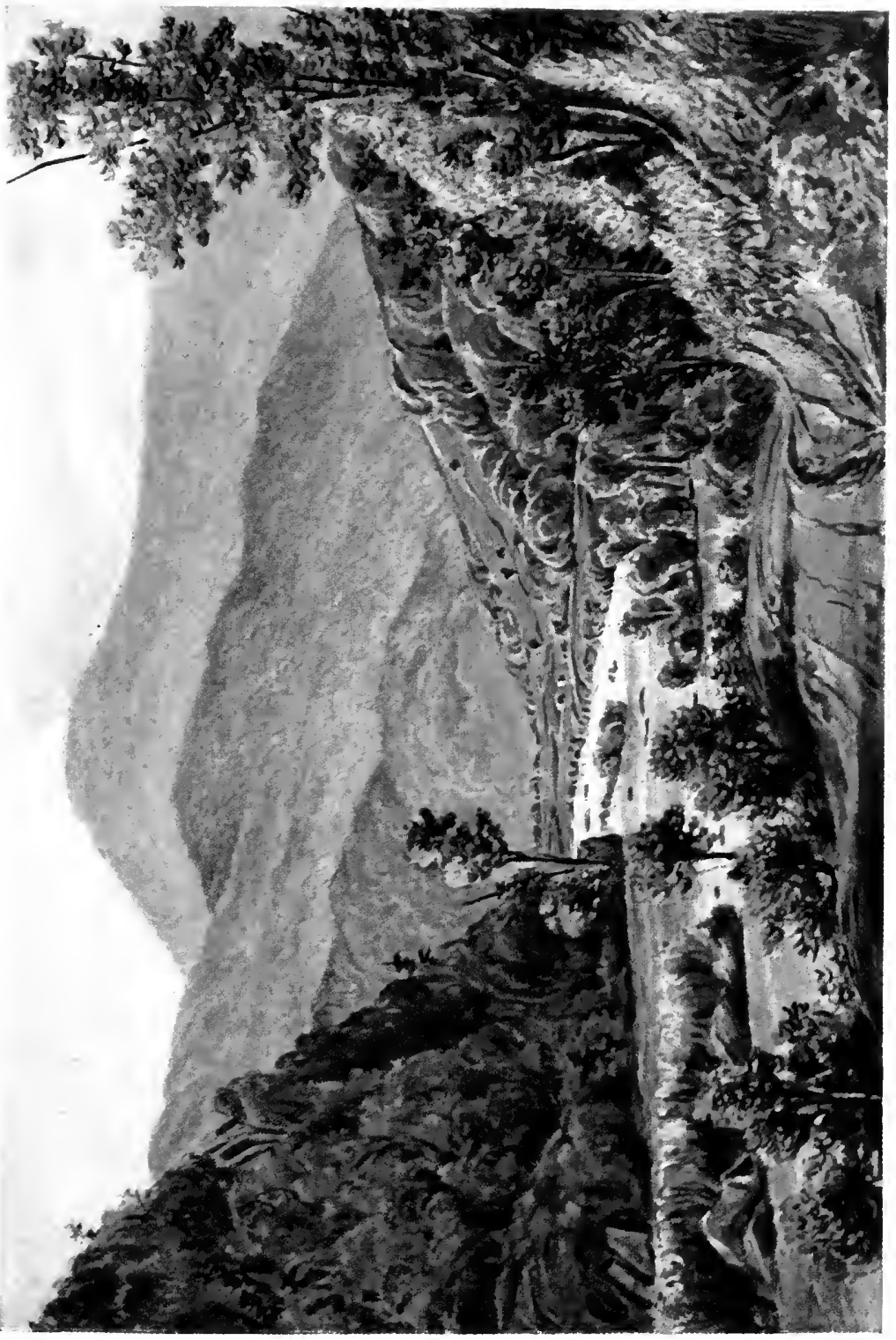



reply, 'why, that's the Grand Duchess Marie'-nor am I sure that my rudeness was not overlooked in the compliment paid by one who evidently did not know that she belonged to royalty. I saw her frequently afterwards, in the array of the ballroom, and could not make up my mind which became her most-diamonds and pearls, or the pink morning walking dress that she wore on the occasion referred to. My seat at the opera was next to her husband, Count Strogonoff, one of the handsomest men I saw in Russia. He was a great lover of music apparently, while I visited the opera as a means of passing an otherwise stupid evening. I not infrequently went sound asleep, and, when aroused by the applause of the audience, woke up to join in it. This amused my neighbor, who once asked me what brought me to the opera when I was so indifferent to the performance. 'To have the pleasure of being seated next to Count Strogonoff.' He bowed and laughed and said something about the readiness of the American.

"One evening Mr. Seymour called on me with one of the best conversationalists I have ever met, Mr. Henry Wykoff, better known as the Chevalier Wykoff. We sat together until long after midnight; and, while he remained in St. Petersburg I saw a great deal of him. He knew a great many persons whose names had been in people's mouths with terms of greater or less praise. Louis Napoleon he had visited in Havre. He had known him at Lady Blessington's. Louis Napoleon, he told me, remarked one day that 'the regiments which guarded the castle were frequently changed; they feared to let one remain longer than a few months, for fear I should corrupt it. At the rate they are going on,' he said laughingly, 'they are giving me an opportunity to corrupt the entire army!' Wykoff was an intimate of Count D'Orsay, and his account of the circumstances of 
Lady Blessington's death was very interesting. He had been invited to dine at her house, and was told as he was ascending the stairs that she was dead-had just died. As told by Wykoff, the account was truly affecting. The Guicciola was another of his acquaintances. I cannot pretend, however, to recollect all he told me of the world of a certain class in London, but it was excessively amusing.

In a letter of October 17, 1857, Mr. Latrobe repeats some stories and, quoting the language used by Wykoff, says:

"Ah! by the way, there's something just comes to my mind. Poor Lady Blessington! Poor D'Orsay! You know, perhaps you don't know, that I had the entrée at Gore House. Every one went there-all the men, at least. You met Brougham and Louis Napoleon, and LaBlack, and all the clever people about London. None went but persons who had something to say. Well, I saw the last days of Gore House; and the next I saw of Lady Blessington was in Paris. Her coming there rather annoyed Louis Napoleon. He was President then and aimed at the strictest respectability; and poor Lady Blessington living with D'Orsay terribly outraged the proprieties. But still, he had been a habitué at Gore House, and she was to be attended to; so he gave her a breakfast at the Elysee. I was there and the company was the old London set as far as was practicable; and it all went off well. Then, there was another person in Paris, who had the same feeling about Lady Blessington; and that was the Marchioness de Boissy, la Guicciola, Byron's friend, you know, and all that, but who now moved among the Montmorencies, and so on. She, too, had been intimate at Gore House; and so she gave Lady Blessington a dinner, and intended quietly to let things drop. I had been invited; indeed, I had known the Countess well and had helped to make up the list. Lady 
Blessington was there; she was fifty-two or fifty-three, looked lovely. She was dressed in white satin with turquoise ornaments, and her figure, still the perfection of elegance, was admirable. We talked of Brougham, and the Dukes and the Marquises that she had fêted in England, and it was pleasant indeed. Never was she more brilliant. She said I must dine with her. She had moved from her Hotel to a bel apartement in the Champs Elysées, and I must dine with her on Monday (this was on Friday) to inaugurate her new apartement. Of course, I was only too happy; and I was to meet O'Meara, connected with the London Times, who wanted to know her. You may suppose we were punctual. As I passed the Concierge, I said, 'I recollect Lady Blessington's suite of rooms and will ascend to them.' 'Stay,' the man replied, 'do you know what has happened?' 'No' I replied. 'Don't you know,' went on the man, 'Lady Blessington is dead.' 'Dead!' 'Yes, indeed, she died this morning at ten o'clock.' 'Well, you may suppose,' continued Wykoff,' what a shock that was, but I sent up my card to D'Orsay and he received me. The gay, gallant, handsome man of the world, always in fine spirits, always in society, was weeping like a little child, so utterly prostrated. $\mathrm{He}$ gave me an account of her death. She had been well the night before, had risen in the morning, complained of oppression, and breathed her last before the physician arrived. And she made no will, and D'Orsay's wife, Lady Blessington's daughter, who was then Spencer Cooper's mistress, came into her fortune, and when D'Orsay died, which he did in 1851, Spencer Cooper married her, and she is now Lady Cooper, having had many a lover on her way from her husband's arms to Spencer Cooper's. And by the way, went on Wykoff, did you ever hear about Mrs. B-t's mistake at Broadlands, Lord Palmerston's seat? You know 
Lady Palmerston was Lady Cooper, and you know the extraordinary likeness between Spencer Cooper and my Lord. Well! the world gave reasons for it, which everybody believed; and one day, at a State dinner, poor Mrs. B-t, looking across the table at Spencer, said, loud enough for all around to hear, 'Surely, my Lord, I cannot be mistaken, that gentleman is undoubtedly your son.' Everyone believed so at the board, but as everyone knew that Spencer was born during the life of Lord Cooper no one had ventured before so publicly to declare it, and Spencer Cooper married the Countess D'Orsay, and poor D'Orsay was penniless. His sister, the Duchess de Grammont, gave him something, but not much, poor woman, she had little enough for herself. You know that anecdote about her, \&c., \&c., \&c."

"Another American flashed upon my Russian winterJohn M. Botts of Virginia-a prominent and well known politician. He had been employed to visit St. Petersburg in the interest of a company who had a patented dry dock, if I recollect aright, to dispose of, and had in vain sought access to the Grand Admiral; not that this high official was inaccessible, but Mr. Botts took his own way of securing an interview. At last he went to the Admiralty Building, an immensely long building, and beginning at one end of the main corridor, he opened door after door on either side, asking in each, as he entered, if there was anyone of its occupants who spoke English, and receiving the answer, 'Niest penny nie,' or something sounding so and meaning, 'I do not understand.' At last he found a person who spoke English and to him he gave his packet of papers, and solicited an interview that he might explain personally the merits of his plan. Having done this much, and understanding that delay was a characteristic of Russian negotiations, he 
determined to avail himself thereof by going to Moscowand to Moscow he went accordingly. When he returned, after an absence of three or four days, what was his horror to find that the Grand Admiral had sent for him during his absence! He wrote a letter at once, explaining the cause of his absence and, with many apologies, begging the appointment of another day. To this an answer was given at once, regretting that the engagements of the Grand Admiral prevented his seeing Mr. Botts, and suggesting correspondence as all-sufficient. I am not sure that my recollection is accurate here. I am inclined, as I write, to think that the Grand Admiral stated that he had examined Mr. Botts' plans and that, at present in any case, there did not seem any occasion for availing of them. At all events, Mr. Botts had his journey due North for nothing. I found him a frank, genial gentleman, a thorough-going Virginian, and somewhat given to political disquisition. Whatever pleasure his visit to Moscow may have given him at the time, I doubt whether the recollection of its consequences was particularly agreeable.

"Returning one evening after dark from Alexandroffsky, my coupé struck some object with great violence and I was roused from the doze into which I had fallen. I noticed that Wassily put his horses to a gallop and soon afterwards left the high road, turning suddenly to the left. He had not proceeded far in the new direction when he stopped, got down and blew out the carriage lamp. It was some time before I reached the Hotel. The next day I obtained an explanation. He had run over a man, and was afraid of being accused, if he paused to see what hurt had been done. In Russia, in such a case, the driver is sent to Siberia; the horses and carriage are confiscated for the benefit of the fire department; and the owner of the vehicle is made to 
support the family of the injured party, if he dies leaving one. Whether this was likely to have happened here, I never knew.

"I resumed my memoranda after a year's interval, during which news came to me of the death of Madame de Bartholomaie. A little while before her death, she told her eldest son, Michael, who is Chancellor of the Russian Legation in London, to write to me to let me know that she was no more. In this way the information reached me, and it touched me much that my good friend should have remembered me in her last moments. We had corresponded from time to time after I left Russia, and there was a letter half written to her on my desk, when I received the intelligence that she was no more. She was a very gracious lady.

"At the close of my Russian visit I went to Moscow with Mr. Winans, making the journey in four days, so as to inspect the road thoroughly. After a short stay at Moscow I returned to St. Petersburg, and in a week was in the Malle port on my way over land to Paris. Until I reached the railroad at Rompling, the journey was an abomination. Sometimes in the coach on wheels, sometimes in the coach on runners, sometimes in a sled, travelling day and night, I was thoroughly disgusted with the experience I had.

"At Dorpat in Livonia, I was surprised when greeted by name by the hotelkeeper, with the unction of old acquaintanceship. As he spoke Russ I could not make out what he said, to account for his satisfaction at our meeting, and I appealed to a fellow traveller who spoke French, as an interpreter. It turned out that I had been taken for a cousin, a son of my Uncle Frederick who had married a Baroness Stackelberg, of Dorpat, where he was a Professor in the wellknown University. The family likeness must have been very striking. One of three cousins came to see me in St. 
Petersburg, a most gentlemanly person in appearance, whose photograph is at Fairy Knowe. His mother was still alive and had written to me on seeing my presentation to the Emperor reported in the Court Journal.

"On my way back to America I visited London; and returned to Paris and sunshine out of fog and smoke, sailing from Havre in the 'Argo.' Altogether my visit to Russia was a rare episode in a lawyer's life, and its memories often recur to me."

We have Mr. Latrobe's account of his trip and his stay at St. Petersburg, at which place he arrived on the 29th of September. While in Russia he was received in a most unusual way. It is very difficult for strangers to get into society. But he was introduced to the very best society. His record of this is found in letters to the members of his family, in which he described how he was received at court and his interviews with the highest in the land-the Czar, his brothers the Grand Dukes Nicholas and Constantine, Prince Gortschakoff, and many others. He says that the display of jewels and costumes was beyond anything that he could have anticipated; but afterwards we find him stating that, at one of the magnificent banquets, the people used their knives as forks in many instances. In fact, the condition of the social life was rather barbaric. There was a lack of refinement. At one place he speaks of seeing at a ball one of Catherine the Great's Maids of Honor, over ninety years of age.

I recollect that he told me that he was very fortunate, in that the Czar approved of a very diplomatic speech which he made on one occasion. He was asked about his travels in Russia, and upon stating that he wished to see Moscow, the Czar said, "Are not the attractions of our principal City, St. Petersburg, sufficient to satisfy you; why do you wish 
to go to Moscow?" He then reollected that he was talking to the nephew of Alexander 1, who destroyed Moscow at the time of Napoleon's invasion. He turned to him and said, "Having seen the City that Peter the Great built to adorn his country, I desire to see the City that Alexander destroyed to save it."

Mr. Latrobe was quick to think, and had the happy faculty of saying the right thing at the right time.

We were trying a case of a patent, in which a certain line in the model reduced the chances of a time lock passing, without opening, the point at which it should open, and it was claimed that this curve or line in the model protected the patent against an infringement. It was a difference of a fraction of an inch and the counsel on the other side insisted that the difference was so small that one could not see it. Mr. Latrobe picked up a law book which was lying upon the table, held it up and asked the counsel if he could see it. The latter said "Yes." "How thick is this book," asked Mr. Latrobe. "About two inches," opposing counsel replied. "Well," said Mr. Latrobe, "there are five hundred pages in this book, and I now hold up one page. Can you see it? It is one two-hundred and fiftieth part of an inch."

Many of us have what a witty Frenchman described as "stairway wit." We think, as we shut the door and pass down the steps, of the number of things that we might have said.

Mr. Latrobe speaks of the strong resemblance between Russia and the United States, in that they are both new countries and have a great future before them. He says that the Russian people themselves remind him of the citizens of the United States in many things.

He gives a description of the celebration of New Year, when everyody kisses everybody else; and when he parts 
JOHN H. B. LATROBE at the age of 54 


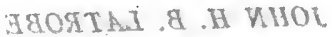

pe to sge and is 


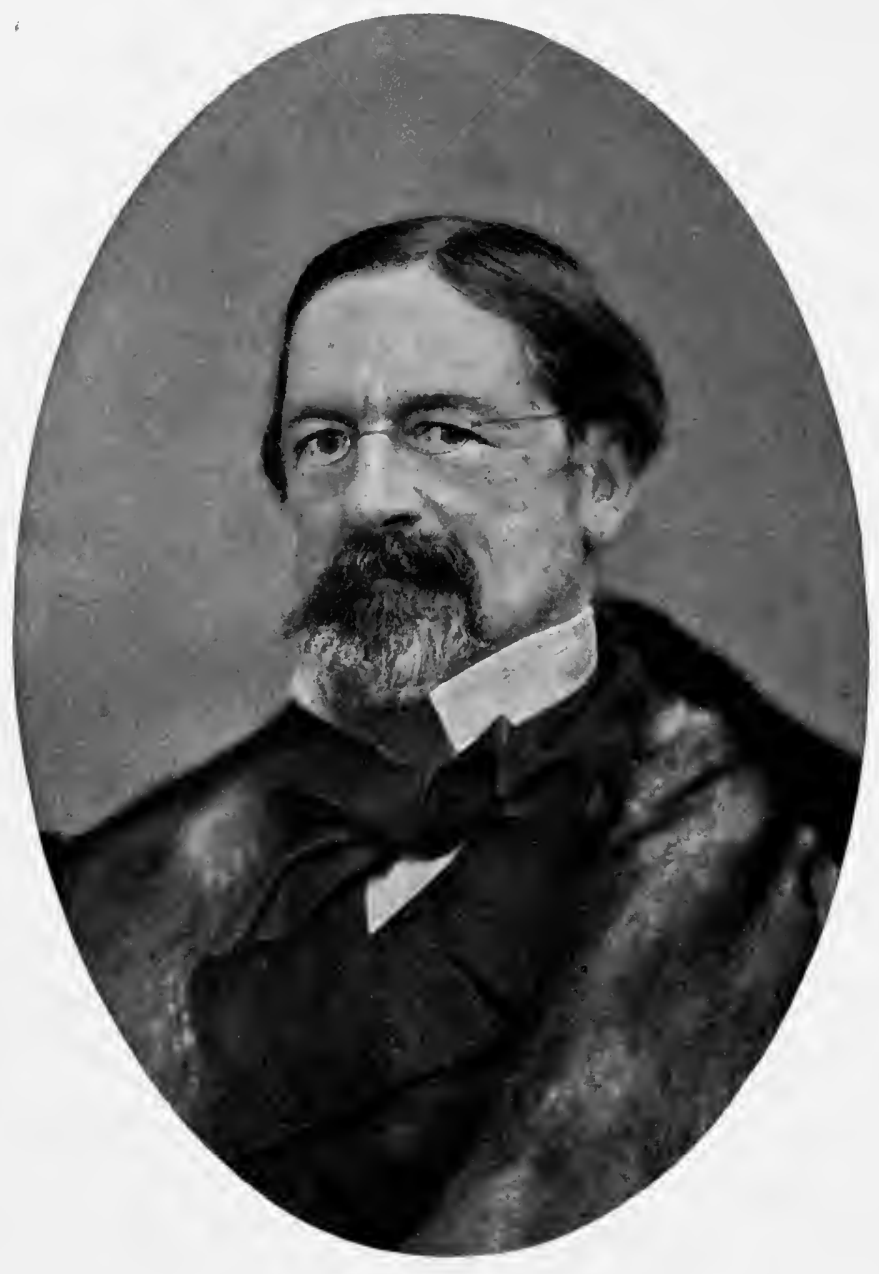



from his valet and his driver, he kisses them on each cheek, adopting the customs of the country, which, I must admit, are not very attractive, in this particular, to me, for I recollect on one occasion being very much overcome by this custom in St. Petersburg. At a dinner one of our fellow countrymen unfortunately poured out some vinegar into a tumbler and offered it to a Russian officer who made a face, but thinking it was an attempt at a practical joke, drank it. The interpreter explained the matter, and, in a moment of bravado, I said, in order to restore good fellowship, that I would drink the same amount. The vinegar was bad enough, but the kissing that I was subjected to was even worse.

It will be observed that, in 1857 , he calls attention to the use of a piece of lemon in tea in place of cream. We have, since that time, adopted the Russian custom; but we have not the Russian tea, which is infinitely superior to anything that we drink here.

Militarism was greatly in evidence in Russia in 1857. Things that were not military were not worth while. Their hatred of the English was great. The Crimean War was just over, a war in which England and France had gone to the assistance of the Turks to prevent Russia from reaching Constantinople, her objective for the last two hundred years. Russia attributed her failure and her defeat to England.

In Russia much consideration is paid to appearances, and Mr. Latrobe says that a man's position in life is graded by the furs he wears. In order to measure up to a high standard, it became Mr. Latrobe's duty to provide himself with an outfit which would obtain for him that consideration which such things do in Russia, and it may be seen by his letters that fur coats cost something like three or four 
thousand dollars; although he contented himself with having his fur coat lined with cheaper material, with a collar at $\$ 200.00$.

I have supplemented Mr. Latrobe's account of his sojourn in St. Petersburg, with extracts from some of his letters to members of his family.

"October 11, 1857.

"I am to have a handsome coupé with a pair of fast horses, with an Isrotshick or driver. Mr. Winans, who does everything 'right off,' sent at once for the man who was to furnish this part of my outfit, and gave his orders in Russ to the poor fellow, who stood hat in hand trembling in the majestic presence of two Americans. How all this strikes me, this excessive humility in inferiors. There is a Russian with a red calico shirt over his pantaloons, which are tucked into his boots, his waistoat over his shirt, and his hair cut by a bowl, who brushes my clothes and attends to the stove. He never sits for a moment in the passage when I appear. Indeed for that matter, it is only necessary for me to leave my room to make half a dozen jump to their feet and bow. . . . Here the fur which a man wears is an index of his eminence. I bought a paletôt or rather the furs for one, with a real beaver collar, the most beautiful fur that is worn for the purpose, and the tailor came to measure me this morning, and such bowing . . . . We saw fur paletôts costing $\$ 3,000$. Mr. Winans bought sable for the lining of his coat. I contented myself with martin. When it came to the collar, fur after fur was shown. At last Mr. Winans selected one of a pair. They always come in pairs of the same quality. He seemed to want me to turn out 'just right', so I said, 'Well, William, for old acquaintance sake, we will walk down Nevsky with the same fur outside at least. I will take the fellow collar to yours.' The paletôt, 
however, is but a part of the furs for the street, opera, \&c. There is another, and a more important called the 'Shubi,' an enormous fur robe that you envelope yourself in, coming down to your heels. My cap is yet to be procured.' Mr. Latrobe here gives directions for double windows to be placed in his house at Fairy Knowe. He says-'But before the double windows are put in, set between them half a gill of salt in a little cup, or if there is not room for a cup, put salt in a paper. This prevents moisture from accumulating between the glasses.' One is struck with Mr. Latrobe's faculty of observing and his close attention to detail.

There is no more valuable characteristic than the habit of observation. In children we find at an early age, the want to know why? Their life is an interrogation point and it is a great mistake to discourage this attitude of mind.

The custom of placing salt between double windows is referred to in Tolstoi's "Childhood-Youth." He writes "When I returned to the room the little bricks and salt pyramids were already lying on the sill and Nikolai, with a wing duster, was sweeping the sand and driving flies through the open window."

A friend of mine, Judge Henry D. Harlan, told me that he was struck with this characteristic of Mr. Latrobe's, of absorbing minute details. That it was his custom to call upon Mr. Latrobe to procure his signature to the diplomas issued by the law school to graduates. Mr. Latrobe stated that parchment contained oil, and that before you signed your name you should rub the place where you proposed to write your name with a piece of India rubber to remove the oil.

Continuing, Mr. Latrobe writes:

"I dine between five and six, and take tea again in a tumbler, the true way, at nine o'clock. The Nevsky, this 
most wonderful street, is crowded. The military predominates everywhere. As to the women, one meets out of doors very few good looking among the natives. Nobody is anybody here, who is not a General.

"I am becoming accustomed to my daily drive to Alexandroffsky, and go it in thirty minutes at a spanking gait. First, I turn out of the beautiful street that I live in, the Michelsky, into the Nevsky, the great artery of St. Petersburg, and mix in the throng of vehicles of all sorts that are dashing as fast as horses can be driven along it, in opposite directions, upon its opposite sides. Rattle, rattle, away I go over the horrid pavements, and pass the Post Aritchkoff with its fine statuary; then the Bladimirsky, and after a long stretch see the railroad station away on my right; then I turn to the left a little, and passing between long ranges of Government store houses find myself in front of a great church on the outskirts of the City. This I have to pass around, when I reach the banks of the Neva, where the hay boats land their cargoes, and have, for the first time since leaving the hotel, to check my speed among the hay wagons. Then I come to the Russian Guard House on my left, and see the sentinel in his gray great coat and fancy the fellows at Sebastopol looked just like him. I now, generally, overtake three lancers on horseback going to relieve guard somewhere-saucy looking chaps, who peep into the carriage as it passes them. Then I find myself among some villas and $\log$ houses-villa fashion, and see away ahead the tall chimney of a cotton factory at Alexandroffsky.* All this time every description of vehicle is passing me and the highway is crowded with foot passengers, among whom soldiers largely predominate-looking unromantic enough in

* The first Cotton Factory in Russia was erected in 1840, using cotton raised in Turkestan. 
their caps and gray great coats. On the right there are bare fields, where there are no houses, and on the left is the Neva, a dark and rapid stream. At the cotton factory there is always a crowd in the road, getting through which at unchecked speed the carriage rattles over a bridge and on the right is the immense establishment of Winans, Harrison and Winans, extending a long distance along the road, at the far end of which are two gates, into the second of which I turn, full tilt, stopping with a jerk at the door of the dwelling in which my rooms are. I descend, say to Wassily, my coachman, who is on his box, 'Niert schnapps, daite mnr, careta tre chsof,' 'don't drink, bring the carrage at three o'clock.' He bows, shakes his head, takes the horses to the stable, and I, saying 'Eiastiche' to the servant who opens the door, am soon busy at my work, when I have anything to do."

"October 27, 1857.

"You should see me in my 'pelesee,' coming down into the hall after breakfast. There is first the blue coated Swiss with his gold lace, who springs to the door, and shouts 'Wassily,' the name of my coachman. Then there is John the Commissionaire, who jumps up and takes off his hat, and three other servants who all spring to their feet, and make low bows. Then there is the German maitre d'hotel, who, in French, trusts that I have rested well and continue satisfied, and after these is the wellbred landlord, who desires to know if there is anything to be done for me. The 'Shubi' I have not yet had occasion to wear. It is a load for a horse. It is something strange to walk through a suite of half a dozen rooms. You reach the last, in which are seated the lady and gentlemen you go to see, and what is odd in these Russian rooms is the number of exotic plants everywhere. All up the stairs are boxes of earth, and at 
General Dainzer's, yesterday, there were really almost flower beds, with wire trellises, in the main or central apartment of the suite. As I have already stated, appearances are very important in Russia. The cut of the coat, the arrangement of a dress, or the character of the fur, settles a great many people's destiny in the fashionable world. Tell Lilly that she would laugh to see how the people use their heads for the carriage of loads; I saw five men yesterday, under a grand piano, keeping step with their hands swinging at their sides. They walk in the middle of the street. The tea here is drunk from tumblers, and with a slice of lemon in it. (The lemon we have adopted). Their order in eating is odd, according to our custom. First soup, along with what is a little pie, with force-meat in it, about as large as one's middle finger, which you eat in the place of bread. Then there is beef à.la mode, or au naturel, or cutlets. Then comes fish, then cauliflower, asparagras or peas, then chicken, or turkey with salad, then pastry or jellies, and then coffee, but the great thing for me is chi, or tea, which is capital here, everywhere. I have it at night at ten o'clock, and relish it more than I can tell. I am known among the servants as Ivan Denianvivovitch, which they have settled down to as my real name. My good fortune socially has been to get among Russians, and see their domestic life, when I am the only person who is not a Russ. Last night I went to the Baroness Medem. You do not know how popular I seem to be with my bad French; how they get around me to hear me talk, tell stories and sketch. The women are of an intelligence that is rare in my experience. They listen to and talk about the gravest subjects-affairs of government, systems, and all seemingly interest them. A Countess, I cannot recall the name, spoke of Russian serfdom, a feature of Russia, in a way that would have become a statesman, not 
in a fussy way, but in a quiet, colloquial tone, and with interest. The others listen and join in, and give me a better idea of the relation between owners and serfs than I have yet had. Young women do not count. The married women are the ones that reign. Intelligence and information are what gives influence. I like the true Russ in his domesticity, and tomorrow go to a family of distinction, on the occasion of their daughter's fete. It just occurs to me to add that this is written by candle light, at half past two o'clock P.M. The sun was setting yesterday when I drove into town at three o'clock, and just rising when I reached Alexandroffsky, at nine. There is one thing that strikes me about the Russians, it takes so little to make them pleased. On Thursday I went to the opera, and saw the Ballet of Armide, unquestionably the most wonderful thing I ever saw or dreamed of. The Stabat Mater of Latrobe, my Uncle, is the favorite music of the Churches here, so De Bock tells me. It seems strange that I should come so far and find relations and name known.

December 10, 1857.

"Gortschakoff is the real Emperor, the great man of Europe. I was rather more anxious about my interview with him than I had been in the case of M. de Noroff."

Prince Gortschakoff is thus described in "Memories" by Lord Redesdale, Vol. 1, folio 228:

"The first time that I saw Prince Gortschakoff come into a drawing room, I looked around for Mr. Winkle, Mr. Tracy Tapman and the poet Snodgrass, for there was Mr. Pickwick in person.

"Barring the white kerseymere and the black gaiters, the likeness was complete. The round, good humored face, very pink and white, the grey hair, eyes beaming rays of 
human kindness out of a pair of gold rimmed spectacles, a most genial smile, the perfection of good manners, pleasant to everybody-altogether a most engaging personality."

A photograph given by Prince Gortschakoff to Mr. Latrobe enables one to determine how far his appearance corresponds with Lord Redesdale's ideal of the great Pickwick.

"In our conversation, Prince Gortschakoff discussed with me the relation between our country and his, and the reasons that the countries felt so drawn to each other. $\mathrm{He}$ spoke of the size of the two countries.

Prince Gortschakoff: "Yes, there is a resemblance in the great distance in miles, but there are many things which draw the two countries, Russia and America, together. Feelings and interests can be recognized."

Mr. Latrobe: "They are also the only great undeveloped countries in the world, all the other nations are conservative. They have no development before them."

Prince Gortschakoff: "True, Russia needs development, the world does not know her capabilities, they are ignorant of her productions. In her development she will do much that the world is not prepared for. The Russians themselves scarcely know the capacities of their own country, but her development is slow."*

Mr. Latrobe: "Both countries are retarded by slavery."

Prince Gortschakoff: "Yes, it is so. Slavery, I do not like the word, still it expresses an idea. I do not know whether I should say so; yes, certainly, I am opposed to it. It is to be abated here in Russia. There are great difficulties in the way, it must be a thing of time. There are so many interests to deal with. We must proceed very cau-

* In 1912 her crops were 727 million bushels of wheat, 1 billion bushels of oats, 1 billion bushels of rye, 464 million bushels of barley, $1 \frac{1}{4}$ billion bushels of potatoes, 2 million tons of sugar. 
$-$ 


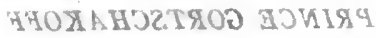




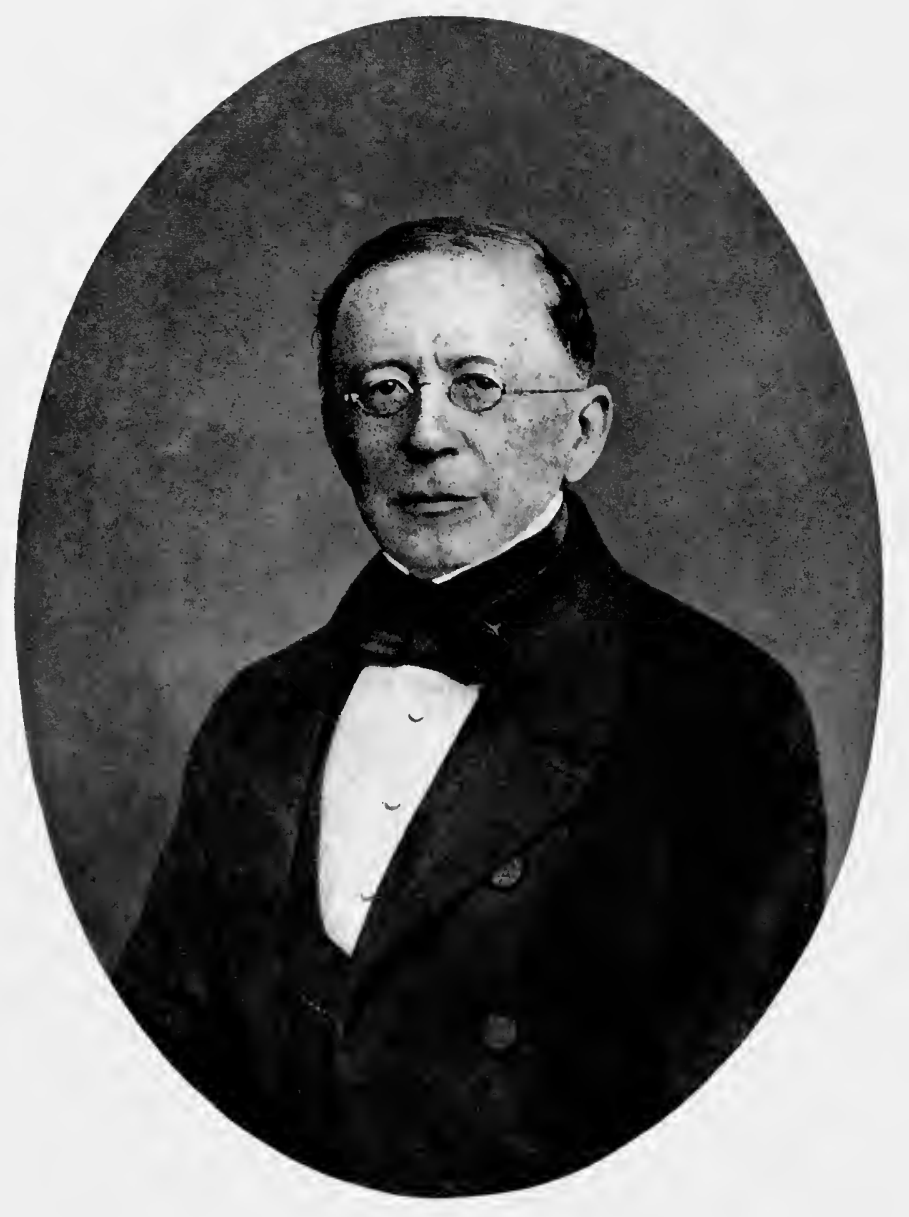



tiously; yes, I think it will be brought about. I will tell you, as to its being slavery, it is a name only. You have seen the silverware on the Nevsky. Mr. Seymour, my good friend Mr. Seymour, has no doubt shown them to you. These wares are valuable and are all made by serfs. The stores are all owned by serfs, more than that, many of them have four or six thousand rubles a year and who pay five francs a year to Prince Tchernitieff, that is all. He is of immense wealth. They have again and again tried to buy themselves. They have offered one thousand, three thousand, but no, he will not raise the tax on them, but he will not sell them. It is a matter of feeling, one thing his father told him. Well, you cannot call this slavery-a man who gains thousands of rubles a year and pays ten to a nominal master is not a slave. Then, too, the serfs have their privileges. I take a piece of paper not larger than this, I write my name, I give it to my serf. He is a laborer on his account, but I am his endorser. I must support him with my life's blood. There is no absolute law, but the law is one of duty, feeling, price. There is no resisting it, you must understand."

Mr. Latrobe: "We understand it well, M. le Prince, in the United States."

Prince Gortschakoff: "So then this is not slavery. But even this must not exist. Time will do away with it. We are engaged with it at present. Still there are many difficulties. Thus, for instance, the serf wants to be free, because freedom has been talked about; but then again, if he is free, his bit of land becomes the property of his master. Freed from his right, the serf's right to it, he says, 'I want my land; true if I have a master, I have also land. I want to be free, but then there is the land." "

The Prince said: "I am opposed to slavery under whatever name. The difficulty is to deal with it." 
He then said later in the conversation: "I do not expect emancipation will take place without disturbance. Of course, it is to be expected that we should have trouble, but no matter, in the end it will be alright."

"Tomorrow I am to be presented to the Emperor. You would be amused to see how formally my presentation had to be accomplished. I send you a copy of Count Tolstoy's note. I open my letter to say I have just come home. I dined with the Minister of the Low Countries, the Swedish Minister, the Bavarian, the Secretaries of Legation, and a great Russian Admiral.

"St. Petersburg, December 14.

"Mr. Seymour did what he never did before, went with me to the Palace, which, of course, gave my worship a more worshipful character, and set the Court world to wondering who it could be, that was so distinguished. Mr. Seymour has been prodigal of his kindness to me. The Emperor is the image of his portraits. His step not slow or dignified, but quick and natural. He seemed to walk on his toes. A jaunty movement, and at once spoke. The Emperor is taller than I am, and with a fine, soldierly figure. He had two stars, and several orders upon his breast. He wore a straight sword and spurs. His hands rested one over the other on the hilt of his sword. When he spoke to me, as his hair was cut close like a soldier, I observed the shape of his ear, which was peculiar, being without a lobe. His face is not remarkable for force. His eyes have a stare in them, which deprives them of effect or force, and they seem to me to be of a light color. His face was roundish and full. I should set him down as a clever man, a good fellow, of not very great ability, given more to amusement than hard work. I think but for his height, he would not be noticed 
in a crowd, but say what you will, there is something in Alexander II's presence that speaks the word "Emperor" pretty plainly. I afterwards met the Empress. When she came opposite to me, I made a profound bow, and I heard my name announced. I was in hopes the Empress would have spoken in English, but she spoke in French. We had quite a conversation. I felt more the presence of power in the Empress than in her husband, though she looked so good and gentle, and seemed to regard the whole ceremony timidly:

"St. Petersburg, December 21, 1857.

"A few days ago, I received an invitation to a ball given by the nobility to the Imperial Family. The ball was the most brilliant thing I ever saw or expect to see. A magnificent room, lighted by eight chandeliers, each having at least three hundred wax candles. The chandeliers were masses of chains of cut glass, giving to each chandelier the appearance of a bright diamond. The attendants glitter in gold and scarlet. The floor was crowded with dancers, the display was dazzling. Crimson, white, blue, green, brown and scarlet appeared in the uniforms of the soldiers of this vast Empire. The women en grande toilette blazed with diamonds and precious stones. I met Prince Orloff who was in scarlet, with a number of orders in diamonds on his breast. A noble looking old man, erect as an Indian. I had a good look at the Emperor, dressed in the scarlet uniform of a Guard. He was a striking figure. I liked his looks better than I did on the former occasion. Mary Worthington was much handsomer than the Russian women, who are not beauties, wanting with few exceptions air, as much as they want beauty. Princess Davidoff introduced me to her mother, a queenly looking lady, every inch a Princess. As a distinguished stranger, I was ushered into the diplomatic supper-room. 
St. Petersburg, date uncertain.

"Yesterday I was presented to the Grand Duke Constantine . . . . I advanced to meet a youngish looking, bright-faced man of middle stature, who came towards me; taking a cigar from his mouth he spoke to me. He was dressed in a half military frock coat, shook my hand and cordially said he was glad to meet me, and pointed to a chair. His first remark was in English, "So you are an American-out and out, an American."

(The details are given in Mr. Latrobe's notes.)

"By the way, I have now a valet, Piotter. After my sickness I determined I would have a servant to be all the time in my room and with the carriage, except when I went to Alexandroffsky, and I am suited very well with a Russian. It is true he cannot speak a word of English, French or German. But I know enough Russ to get along with him, having managed yesterday to tell him to go to the tailor's and have my pantaloons and dress coat repairedand this I did without signs, by word of mouth alone. You would be amused to see him with his great fur collar alongside of Wassily on the box, and then to see him when the carriage stops. How he springs down, rings the bell of the house I am visiting, gives my name 'Lampode Gospodin Americanskoi,' then jumps to the carriage door, opens it with an air, offers his arm as I step out, follows me to the anteroom, takes off my paletôt, which he throws over one arm, with my scarf on the other, my hat in one hand, my galoshes in the other, waiting until I finish my visit; while poor 'Wassily' waits on the outside uncomplainingly and not thinking of complaint, hour after hour; though with our feeling I always say to him, 'Stoupai Kanusne damoi a padoi palasmoi vossem chsofe,' which sends him to the stables to return at half-past seven o'clock, or at such other hour as 
I require. If I go into a store, my servant follows me in, and holds my fur if I desire to take it off, opens and shuts the store door for me, and if I walk in the street follows me at three or four paces off. 'Piotter' sleeps in the room alongside of the ante chamber, and day and night is within call, knowing where my friends and the doctor live. I am only afraid he will brush my coats to pieces, so clean does he keep them. In fact, if I am not eight feet high when I return to America, it won't be for want of change in my habits of life. Let me tell you, by the way, that I have gotten entirely rid of the pain and soreness in my left knee which has troubled me for some years, and am really excellently well.

"On. Monday night, I was in my usual place at the opera and had the whole of royalty within twenty feet of me-Emperor, Empress, Grand Duke Constantine, his wife, and the Grand Duchess Marie, whose husband, Count Strogonoff, is my left hand neighbor in the parterre. The Empress out of her imperial robes was not unlike any other woman. The Grand Duchess Marie is very handsome, and so is the Grand Duke Constantine's wife. The toilette of the ladies was very simple indeed. The Emperor sat back in the box, which is the lowest on the left as you face the stage. This is not the Imperial box proper, which is in the center of the row above, but the box in which I always saw some member of the Imperial family, notably the Grand Duchess Marie. The opera was the Barber of Seville, and it was admirably performed--Bosio playing the principal part, with Tamberlik.

"On Wednesday, I went to the reception of M. de Noroff in his grand suite of rooms in the Palace of Public Instruction, and saw crowds of starred and decorated personscrowds-crowds. Some of them I knew, and I was intro- 
duced to others. I had been presented, and the St. Petersburg world knew all about the black crow that stalked the halls. The pleasantest part of the evening I passed chatting merrily with the Princess Davidoff, who, when she found I was willing to.be agreeable, made herself eminently so, and took care to let me know she was single when I addressed her as Madame la Princesse, by saying soon after that married women always wore lace at the back of their heads, turning her's at the same time to let me see that there was none there. The toilettes here were admirable, but severe in taste-rich rather than striking in color or ornament. 'The Princess' lace I saw was rare, and all she wore was costly, but on the whole she was simply dressed. She amused me much with an account of Russian superstitions. If you pass a priest, it is bad luck unless you turn around and throw a pin after him with the point towards him.

"I went the other day with Madame Bartholomaei to the Maison des Vieilles Filles and the Maison des Veuves (old maids and widows), noble and imperial establishments, both of them. What Madame Bartholomaei said about me in Russ I do not know; but it would have made you smile to see the way in which I was treated by the gray-headed MajorGeneral and his staff in uniform that escorted me everywhere, cap in hand and bows abundant. Madame B. said she only told them that $I$ was an American of distinction who had been presented to His Imperial Majesty. But I am satisfied she must have said that I was the grandfather of the President, or the King of the Pottowattamies. I was fortunate in getting in here. The arrangement had been made by Madame $\mathrm{B}$. beforehand. The visit was a most interesting one. Among the persons that I saw was a nun who had been with the army in the Crimea and wore the decoration. I had been told there was such a person and 
asked to see her. She was sent for immediately-a nice looking little woman, the widow of an officer-officers' widows being the only ones admitted here, where they are made public nurses. She stood demurely before me with her hands crossed on her breast, while I thought of what she must have seen in the casemates of the Malakoff. Presently I said I wanted to shake hands with her. This is a great honor in Russia between parties so different in rank. But my request was translated and as the little dumpy hand was held out I stopped and kissed it, as that belonging to a ministering angel. The little owner of the hand seemed quite surprised, but she smacked me heartily on my right cheek and curtsied to me. 'Americanskoi' was repeated several times by the attendant staff officers and $\dot{m} y$ act was regarded as abzzanirie. But it seemed to win all hearts, and my old Major-General made me a low reverence in consequence. We know nothing in America about the privileges of rank; and, as I happen just now to be associated with the highest and it has become known, I have the benefit, such as it is, of distinction and deference, which, satisfactory as my association is at home, have never been experienced by me. Honestly and truly it is annoying rather than grateful to me. I enclose the Major-General's card, for the good old man called on me the next day; also the card of Baron Medem of Kass, the eldest son of my good friend the Baroness. He distinguished himself at the siege and capture and was in charge of General Williams when the latter was made prisoner. The day after tomorrow is the first ball of the Noblesse, where I am to go with a senator of the Empire in scarlet and gold and orders, while I shall be in black like my friend the crow, who is now hopping about the street before my window.

"Yesterday Mr. Seymour received a notice that I would 
be presented to the Grand Duke Nicholas Nicholaevitch and the Grand Duchess Alexandrovna Petrovna in the evening at seven o'clock; and at the appointed hour I went to the Winter Palace, and found myself with the same set that had been presented with me to the Empress, with some members of the Spanish Embassy added. The presentation to the Grand Duke took place first in a handsome room in the Palace. He is a fine looking young man, with an agreeable, kind expression, and wore a handsome dark uniform and sword. He walked easily round the circle, and asked me whether I was English or American, and whether I liked the Country and proposed going into the interior. He spoke French to me. I made satisfactory replies, made my bow and closed the ceremony, for without diplomatic rank I am the last in the ring always - the foot of the class, in my black clothes. We then returned to the Salle d'Audience, and while waiting with the glittering crowd, who should come in but Mary Worthington, admirably dressed and looking really handsome-very handsome. She passed through, making quite a sensation, to be presented in an inner room to the Grand Duchess, Mr. Seymour accompanying her as far as the door. In about ten minutes she returned and was at once surrounded by gentlemen. The Turkish Minister, a little man all jewels and gold, was very emphatic in his admiration. Every one seemed to know her. She shook hands with me very cordially and at once began to scold me for something I had said, telling me I was to make all these men go to Tamberlik's benefit at the opera, and making herself quite at home with me; giving me a prominence that $I$ had no especial desire for. As she turned to join Mr. Seymour, who had been absent when she entered the Salle d'Audience, after her presentation to the Grand Duchess, she held out her hand, and when I took it I said, 
'Well, I hope you will forgive me.' 'Yes, yes, but kiss my hand, there, kiss my hand.' I did so, and offered my right cheek for a salute in return; but she laughed and said she would tell Mrs. Latrobe. How strange all this is. This Baltimore County girl-certainly one of the most admired women of St. Petersburg-and I, meeting in one of the noblest palaces in the world and enacting such a scene, while the men around-every one of them-envied me. So much for beauty; its power is everywhere. Mary's fastness is originality here, and is infinitely preferred to the stately poses of the Princess Dolgorouki.

"January 3rd, 1858.

These good Russians are a great people for observing the New Year. I was invited by the Baroness Medem to the family party-all were in fancy dress, and they danced the minuet masked. It was most graceful. Just as it was over, the bell struck the hours of midnight. The Company stood as if petrified until the last stroke sounded. The band struck up a lively air, the masks were discarded and everybody kissed everybody. When members of the family kissed each other, they asked pardon for offenses committed during the past year. I had liked the Russians much, but had never seen this character so amiably exhibited before.

"Wassily, my coachman, and Piotter, my valet, wish to go with me to America.

"I cannot make better use of the paper, which, as you see, has been in imperial custody, than by appropriating it to a description of what took place when I had the honor conferred on me which it refers to. I went in my usual suit of black to the place prescribed, and found that I had been assigned to the magnificent entrance of the Ambassadors, and was accordingly marched up the most royal flight of 
stairs, perhaps, in the world, by a plumed gentleman, who turned round from time to time to see if $\mathrm{I}$ was following him, when he always took occasion to bow to me, into a Hall that opened into another Hall, that in its turn opened into another Hall, each more magnificent, if anything, than the last, until I found myself in the Hall of Peter the Great, where I found myself in charge of my good friend Kondrazoff, the Master of Ceremonies, and in company with the Diplomatic Corps. But this time I strode along through crowds and crowds of officers, in brilliant uniforms, all turning to look at me, made conspicuous by my black dress, the only one to be seen. By this time, however, I had become accustomed to be stared at, and I satisfied my curiosity as I walked along after my guide. Such splendor I certainly never dreamed of. The whole Russian army appeared to have its representatives in the Halls I passed through. There was no one, comparatively, at my presentation to the Emperor, so great were the uniformed number now. A palace without such crowds as these wants its greatest charm. Nor, willing as I am to attempt it, could I describe to you the magnificence of the Halls I passed through, even without their accompanying crowds-where even a company of the cuirassiers of the guard seemed lost as it stood on parade in one corner of one of the halls, as it might be, arraying themselves in the recess of the drawing room at Fairy Knowe to make a tumble from the sublime to the ridiculous. I tried to recollect some of the uniforms, but can only recall one, that of the Cossacks from the Black Sea. As to stars and ribands and orders, they were innumerable. In the Hall of Peter the Great, my friend and connection, Captain de Bock, came up to me, and under his guidance I went into other halls, the Hall of St. George among them, but hastened back when I saw the crowd moving towards the avenue 
along which the Emperor was to pass on his way from Mass. There seemed to be from two to three thousand persons in uniform in the Palace, and the space around the building was black with the carriages that deposited them at its several entrances. The Persians and I got together again, and the Spaniards and Dutch and Swedes and others renewed our acquaintance. At last things in the Hall of Peter the Great seemed to be getting into some order, as the Grand Master of Ceremonies, list in hand, began to marshal the various diplomats. I had met Mr. Seymour and Mr. Pearce on entering the Hall, and was told that I would have to take care of myself, as they would have to take their places in the circle arranged by the grand master in the order of diplomatic rank. As name after name was called; the persons referred to took their places fronting the windows, two large ones with deep embrasures. Those not named were in this way crowded back against the wall opposite, and here I found myself at the canopied dais, of one or two steps high, which seemed to have been placed there as a sort of throne on a small scale. Alongside of me was a very tall grenadier, standing at "order arms," grim and statuesque. As I had become very tired of standing, I took my seat on a step of the dais, and had given up all expectation of seeing the procession, which was to pass between the diplomatic circle and the windows, when I heard the grand master of ceremonies, who had been going regularly through his list, cry out, 'Etrangers distingués, M. le Prince de Hohenlohe, M. le Duc d'Ossunce, M. Latrobe.' Passing through the crowd in front of me and through the circle of Diplomats, and crossing the open space between it and the windows, I was told by the Grand Master to take my place at one of the windows where I had as good a place as I could desire to see the procession, for 
the light was behind me and shone full in the faces of the Empress, Emperor and the rest. At last the head of a column of gentlemen, all gold embroidery, appeared and moved forward in the direction of the arrows and disappeared, leaving the Emperor and Empress at the head of the circle where I have marked two crosses where they paused before the oldest ambassador. Gradually they came down the ring. The Emperor was dressed in a General's uniform, and wore two stars and four orders, and looked a great deal better than when I was presented to him. The dress of the Empress was indeed imperial, I cannot well describe it. It was low in the neck, but the neck was covered partially with laces, and I think there was some white fur. The skirt of the dress was white satin, down which in front were stripes of pale blue embroidered with gold, and either upon the satin or over it, on some gauze material, were little gold spots smaller than spangles. I did not see the body of the dress, for the Empress crossed her arms in front when she addressed me, but the most striking portion of her array was the train which was trimmed with sables, and was kept spread upon the parquet floor by two young men in the uniform of the Corps des Pages, as in the margin. Baron Gevers told me that the sables alone were worth 20,000 roubles. The effect was very beautiful, and I saw an Empress who looked an Empress. The line of Ambassadors had by this time fallen back into the arc of a circle, and this brought me without moving near the end of it. There were then but three distinguished strangers-the Prince Hohenlohe, an erect, soldierly looking man, whiteheaded and moustached, in uniform, with collars, stars and ribands countless; the Duke d'Ossunce, a fat, gentlemanly person with the Order of the Golden Fleece about his neck, and a star on his breast; and myself, in plain clothes. At 
first, the Prince and Duke were on my right, but, insensibly, as the Emperor approached, they got upon my left, and so preceded me when addressed by him. As we stood, Count W- (name indistinct), who was behind me, asked in English some question in connection with Finance, to my annoyance, though he seemed taken by my replies, especially when I said to him, speaking of the condition of the United States generally. 'Drunken men, M. le Comte, buy more than sober ones, and we in America have been drunk with prosperity, but we are getting sober, only to get drunk again. These crises will always be periodical.' Presently Prince Gortschakoff came up and shook hands with me. Then Prince Adlerburg with his dyed whiskers joined the group; then more of the High Nobles, till our end of the circle was a jam almost as the Emperor approached, I being always left in front sufficiently to speak to him, occasionally looking back through the doorway upon a sea of heads and faces. When the Emperor got to Prince Hohenlohe, he gave a rapid glance at the end of the circle, where I was, and I caught his eye. So, when he reached me, he was considerate enough to speak English, which he did with an accent. He said 'Why are there so many banks in Rhode Island?' When I told him they were the aggregation of small amounts placed to be loaned by men in whom the owners had confidence, the Presidents, \&c., he continued to talk with a pleasant air and agreeable good humored gentlemanly smile. I was much more gratified than I was when presented to him, when his manner was more quick and soldierly. Then came the Empress, and she too, spoke English, and smiled so sweetly and gently and looked so good and true a woman, and was really so handsome with the costume I have tried to describe, that I could not avoid feeling as I would have done to any other gentle being of her sex. She 
was far more attractive than on the night of my presentation. When they had thus gone through the circle, the Emperor standing quietly by the Empress, while she addressed anyone, we all made our reverence, and they resumed their progress followed by all the Imperial family. I did not observe particularly this part of the procession, for I was attending to Prince Gortschakoff, who was commenting to me upon the dress of the Empress, the fur of which he said came from near my country, the banks of the Amur, and which he admired excessively; and, when I turned from him, a train of light blue velvet, trimmed with ermine, was sweeping by. Following the Imperial family came the ladies of the Court in the national costume, and a collection of plainer looking persons, with reverence be it spoken, I rarely if ever saw collected together. There was not one handsome looking woman in the whole hundred. By the way, the Empress wore the national headdress. When the Imperial cortège passed, the ceremony was over, and the company broke into groups. My friend, General Stolssakoff, one of Russia's real soldiers, now came up to me, in his grand-occasion-dress with his red riband over his shoulder, and his diamond hilted sabre of honor for service in the field at his side; then my dashing young friend, Alexander Bartholomaei, in his handsome Hussar dress of light blue and silver, with his Hussar jacket lined with yellow satin, quite a picture for a picture-book, shook hands with me, and laid his cheek on mine; then my connection, de Bock, in his uniform of Captain of a Frigate; then Baron Gevers in his striking dress as Chamberlain of the King of Holland and Ambassador; then Baron Adelward of Sweden; then my handsome acquaintance of the Spanish Legation, who is in love with Mary Worthington, in his crimson and gold array; then du Messan, Kondrazoff and others; all were chatted with, and then 
we all disappeared, and the grand ceremony of the day was over. I descended the great staircase of the Ambassadors, and met the porteurs coming up to remove the traces of the Imperial Circle from the floors. In the Hall I waited until Gospodin Amerikanskoi was cried out by the porter at the entrance, when I got into my carriage and drove off to leave cards on Prince Gortschakoff, Narishkin, Count Borche, M. Ravaillon, Mr. Winans, Madam Bodisco, Baron Gevers (where I was to dine en petite comité) and others according to the Russian fashion. At half past five, after writing the first half of this letter, I went to dine en famille with Baron $\mathrm{G}$. and his wife, and have a standing invitation to dine there daily.

"This evening I go to the reception at Prince Gortschakoff's, which he told Mr. Seymour, as the latter informed me, to remind me of. Tomarrow night I go to Narishkin's, on Saturday night I go to the Medem's, and the next week looks threatening of more places to go; but it is all terribly empty, and far less grateful to me than my New Year's Eve with my Russian friends in their domestic circle.

"No one, save an Emperor, or an Emperor's brother, seemed to have a house to himself.

\section{MY VISIT TO THE GRAND DUCHESS MARIE}

"I was admitted by a seven foot porter, in red, into a splendid hall, where I left Piotter and my furs, and was shown up a flight of stairs, narrower than I had yet observed, without servants or soldiers on it, but richly carpeted and brilliantly lighted, to a noble room some five and twenty feet in height, with statuary in it, and the frieze of which had designs taken from the Flaxman, among which I noticed the fight for the body of Patroclus, and the parting of Nestor and Andromache. Here I remained alone for a 
short time, admiring the beauty of everything and warming myself by two cheerful open wood fires of capacious dimensions, in which the wood was placed on end. The Spaniards came in first, and we had a pleasant chat. Then came the Turks, then the English, some of whom thawed out far enough to speak to me, then came the Persians, and I had a pleasant talk with Moiza Petros. As they came, so they disappeared, with the Masters of Ceremony who were flitting about the while in their rich dresses. Finally, I was left alone for some ten minutes, when M. Latrobe, American, was called at the door, and out I went through many halls, until I reached the anteroom of the Grand Duchess. Here I found the lady of honor, in waiting, and as she spoke English well, I had just got into pleasant conversation when a door opened, and I was called by name, and a richly apparelled gentleman looked profoundly at me. I looked through the open door and, in the centre of a richly furnished apartment, saw a lady standing, dressed I think in gold colored silk and black lace-a Spanish looking costume. She was of a truly imperial presence, and bore herself every inch a queen, very handsome in the face, with regular features, a little passée, perhaps, and inclined to embonpoint, full decidedly, yet not fat. It was the Duchess of Lichtenberg, widow of the Duke of that name and wife by a morganatic marriage of Count Strogonoff, my neighbor on my left at the opera. This lady realized all my notions of a queen, perhaps a queen of love (but then her reputation suggests ideas). I walked up to within three paces of her, and made a low bow (one keeps one's heels together, and bows the body from the hips, the head looking down, the hat in hand always; and you need a new one, with an unstained white lining. So much for details).

"The Grand Duchess advanced a step and the following dialogue took place in French: 


\section{PALLS OF THE OHIO}

Painted by John H. B. Latrobe 


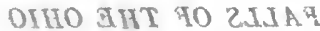

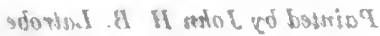




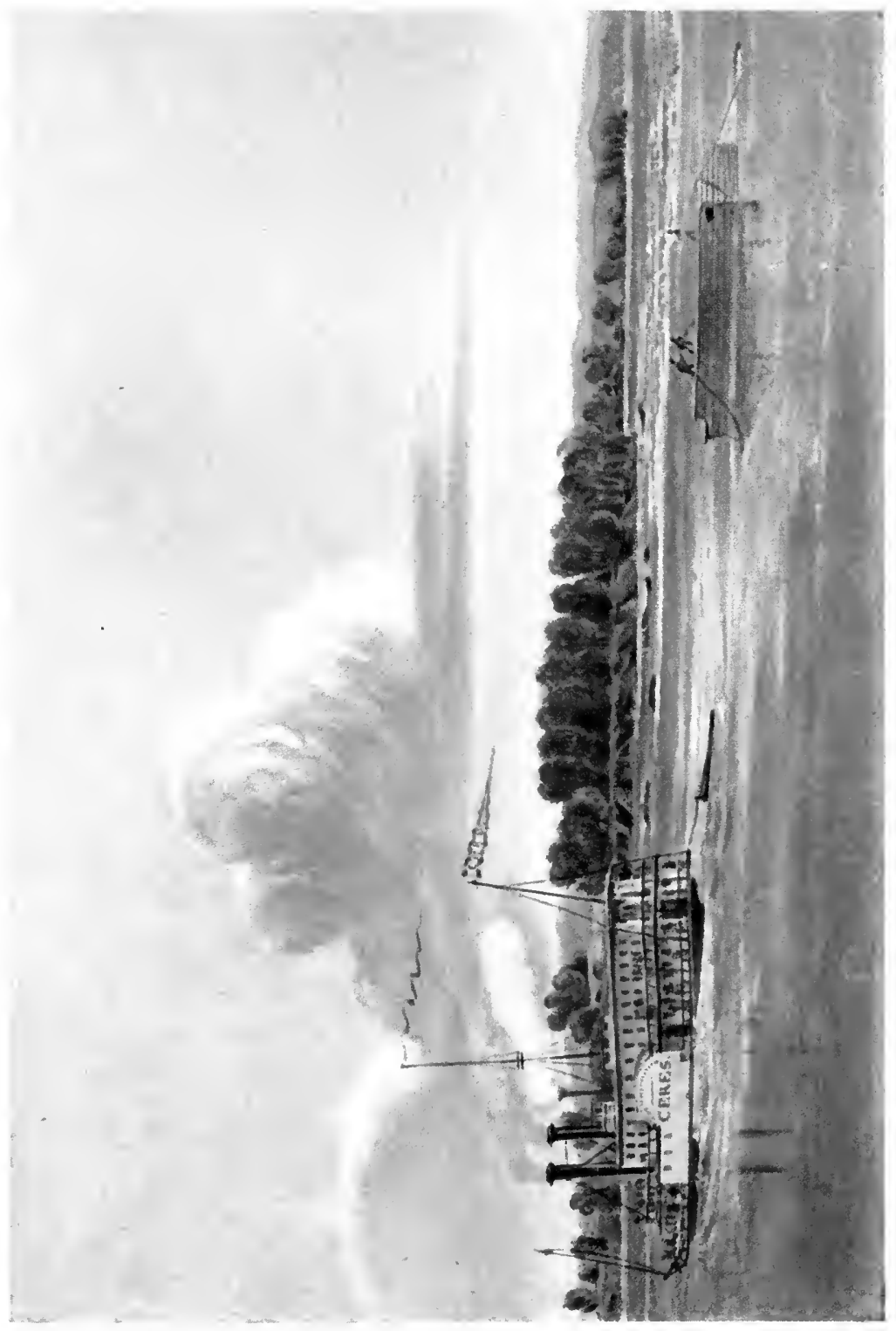



Grand Duchess: "You have traveled much in Europe and elsewhere?"

Mr. L.: "Much, Your Highness, now and on a former visit to the old world."

Grand Duchess: "You have traveled much, too, in America?"

Mr. L.: "Yes, your Highness, one ought not to travel in strange lands until one has become acquainted with one's own."

Grand Duchess: "Very true, very true, one should see one's own land first. Have you traveled much in Russia?"

Mr. Latrobe: "Very little, your Highness."

Grand Duchess: "You do not find traveling agreeable in Russia?"

Mr. Latrobe: "You have your railroad, your Highness."

Grand Duchess: (A little impatiently) "Yes, a railroad."

Mr. Latrobe: "And I found my journey from Stettin here very agreeable."

Grand Duchess: "Ah, you came that route, did you? Have you many acquaintances in St. Petersburg?"

Mr. Latrobe: "Not many. I am intimate with the American Minister, and all the Americans that are here I believe I know."

Grand Duchess: "Do you know Madame de Bodisco?" Mr. Latrobe: "Very well indeed, Your Highness."

Grand Duchess: "And the young lady that is with her. She is very pretty."

Mr. Latrobe: "Quite well, your Highness-Mary Worthington is my compatriot. We come from the same place in America."

Grand Duchess: "Ah, where is that?"

Mr. Latrobe: "Baltimore, in Maryland, one of the United States." 
Grand Duchess: "Maryland, ah yes, Maryland, there is where we obtain" - and here with the right hand she made the motion of putting a cigar into her mouth and withdrawing it and puffing away the smoke with her pretty lips.

Mr. Latrobe: "But, if your Highness will permit me, we do not smoke our own tobacco in Maryland. We smoke Havannah tobacco."

Grand Duchess: "Havannah? Yes, I know about Havannah and their cigars. You do not smoke your Maryland tobacco?"

Mr. Latrobe: "No, your Highness, no one is a prophet in his own country."

Grand Duchess: "Very true indeed," said with a little half laugh; and bowing her head in a way that was imperial, an end was put to my interview with a very clever woman.

"Odd that with every other person I was presented to from the Emperor down, I observed the smallest particular of dress and furniture, but here the Grand Duchess absorbed me altogether. I saw her and nothing else.

"I have been presented to every member of the royal family, beginning with the Emperor and ending last Saturday with the Grand Duchess Marie. I was not prepared for the splendor exhibited at the reception at the Winter Palace, and the peculiar crowd. A Tartar Chieftain, a Circassian Prince, a Cossack General, and officers bejeweled and bediamonded and decorated with orders, all unite to make a most dazzling result.

"Most of the Russ women that I have met with preserve a taste for society during their lives, and at the late ball I actually saw a lady ninety years of age with the costume of the day, without crinoline or being cut low in the neck, however, who had been a maid of honor in the reign of Catherine II; Matilieff, I think her name was. We have no 
such female society in America as I meet with here. Single women are nobodies; the married women are those who receive attention, and are the rulers in the ballroom and in the Court.

"The more I see of Russians, the more I am struck with their resemblance as a people to the Americans-the same shrewdness and the same intelligence, the same look as a general thing, the same manner. There are many points of difference, but there are many points of great similitude.

"Moscow, Hotel de Dresden, February 28, 1858.

"Here I am in the heart of Russia. I was four days in getting here. The usual time is 24 hours, but Mr. Winans' visit was one of inspection, and we traveled but 150 versts* a day. His whole arrangement for his management is very admirable, and does him great credit; it could not well be better. I could see he was desirous of making a thorough inspection, and I may say I have done so without a doubt, for I have gone through every engine house on the line. We staid the first night at Martainsky, the second at Balagoy, the third at Tver and the fourth at Mossow. A good breakfast that was a dinner, then a dinner, then a supper that was a dinner, and then Chi before going to bed. Whistler and I slept always in the same room, in their abominable narrow Russian beds. The journey was tedious, of course, but not without its interest. At one of our dinner places for instance, I walked to a couple of Russian villages and saw the whole domestic system of the peasantry and went into one of their baths - to see, if not to take it. Was invited by the people to take Chi, and they all seemed disappointed when I declined. I had, of course, a person with me, for though I can

* A verst is $66 / 100$ of a mile. 
get along in a hotel with Russ, yet beyond that I am dumb. At Klin we had a Troika ride, and such a ride! Three horses going as fast as legs could be laid to the ground in a racing gallop. The driver standing up and racing like mad, and the sled in which we were, the rudest of the rude, but strong as could be. We went ten versts - four Troikas, like the wind. As to a horse falling, why he was dragged until he got up, and then got beaten for his pains."

This reckless method of driving seems still to be the fashion in Russia. In a recent work published in 1916-"Through Russian Central Asia," by Stephen Graham, he thus describes a drive:

"The horses bounding along, neck by neck; over hump, over crevice, over chasm, up hill, down dale, never slacking (there is no brake to the wooden arba), coming with a great splash on to a stream, the arba just floated on it, as the horses plunged through it, up the bank. What matter stones-even milestones."

The arba is a wheel vehicle. Mr. Latrobe's drive he described as a "troika ride." This refers to the peculiar Russian method of driving three horses abreast. It may be in a wheel vehicle, a sled or sleigh. In this case the vehicle was a sled.

"At Moscow we found a Russ dinner prepared for us at the Novi Troieka, the great Russ eating house. It was a Russ dinner with all its peculiarity, and I found it pretty good, except the fish soup, which is absolutely detestable. We had nameless things and were served by waiters dressed in spotless white from head to foot, looking like so many ghosts. After dinner, we went about the town and in the light moonlight had pleasant sleigh riding. The next morning Mr. Winans and Whistler returned to St. Petersburg with the men, and I leave for the same place tomorrow at 
$12 \mathrm{M}$. After they left, I got a guide, one of their clerks, and $I$ went to the Kremlin and into the churches there, where I saw almost idolatry and religion in the oddest possible shapes. The churches are a mixture of Tartar, Byzantine, and more modern forms, but quaint, grotesque and bizarre. But the bells, you never heard bells before. The astounding ring and yell and whirl of sound shake the heavens. Poe ought to have been here to have completed his poem on "The Bells"-the Moscow bells.

"The Kremlin is a walled fortress in the heart of the City, and you look from its terraces over the City stretched over a rolling, hilly ground on every side, and literally pierced through with spires. There are four hundred churches in Moscow, and all steepled ones at that. The great new church. and the Hopital des Enfants Trouvés are the most prominent objects from the Kremlin. I went to the Kremlin twice, the last time at four p.m., and it was delicious, after the jangling of the Kremlin bells had ceased, to listen to the roll and swell and exquisite harmony of the bells of the four hundred churches as they made Moscow one great bell, of heavenly sounding tone. One of the gates into the Kremlin is the Holy Gate, and I had, along with the rest of the crowd that passed through, to doff my hat and walk under the long archway with it in my hand. There is a soldier who stands there to see the duty performed. Though the Kremlin is surrounded with walls people and vehicles pass through it as through any other part of the City. It contains the Palace, which I am to visit today, and the Treasury. Then I am to see the 'Enfants Trouvés,' and some of the Churches, and Moscow is 'done.'

"Last night I went to a concert and tableaux at the Theatre which is probably the finest in the world. That of St. Petersburg is small in comparison. But I had pre- 
viously gone to the Riding School, a hall that is six hundred and thirty feet long by eighty-one wide, under a single roof. I saw the Big Bell and the Big Cannon, and the Long Cannon and the Little Cannon, for Russia has captured cannons, as well as others, and is equally proud of displaying them. Then I called on Mr. Claxton, our Consul, and General de Bartholomaei, the husband of Madame de Bartholomaei, who I knew was here, and found an admirable specimen of a Russian officer of the highest grade-I mean soldier officer-well educated, polite, elegant in manner, and although older by some years than I am, with the vivacity and animation of a younger man. I was much pleased with him, and will see him in St. Petersburg.

"I drove along the bed of the Moskva, now covered with ice, to look at the construction of a stone bridge which they are now taking down, and then through various parts of the City, stopping every now and then to clear the ice from my moustache and beard when it became too heavy for comfort.

"I forgot to say that the whole country between St. Petersburg and Moscow is the flattest and most uninteresting in the world, considering all things, no hills, no towns, nothing prominent save here and there the dome and campanile of the Russian Church which may be thirty miles off, so flat is the country and remote the horizon."

"I had just finished the last page of my letter when Mr. Claxton arrived to breakfast with me in company with Prince Bourussoff, who, hearing that I was in Moscow, was kind enough to express a wish to assist in doing me the honors. I found him a most intelligent, well educated and agreeable gentleman, whose first act was to invite me to dine with them at a Russian traiteur, $\grave{a}$ la Russe, the only way, in which, on so sudden a notice, he could pay me attention, 
and so costly is such a dinner that it amounts to no small attention. After breakfast, that is to say about 11 o'clock, we commenced our rounds with the Enfants trouves, a much larger establishment than that at St. Petersburg, commenced by Catherine II, and continued by her successors until it has attained its present enormous dimensions. Here, in addition to what I have already described in regard to the regiments of babies and nurses, I saw the governess's institution, whose six hundred young women are educated for the duties of governesses in families; and I never saw education in all branches, even the highest accomplishments, pushed to the same extreme of perfection. We walked six miles through the vast halls, before we were finally dismissed, everybody vying in doing me politeness. The visit was a most interesting one. From thence we went to the Kremlin, where I saw the Treasury to begin with, in which are arranged all the ornaments and services of gold and silver belonging to the deceased Emperors, their state carriages, the sleds in which they used to make their journeys from St. Petersburg to Moscow, the chair in which Charles XII was carried wounded from the battle of Pultowa, and the like. Crowns, sceptres and the paraphernalia of imperial greatness are here as common as children's playthings. From the Treasury we went to the Palace, where we saw what exceeded in splendor, even though less in extent, the Winter Palace - the Hall of St. George in white, the Hall of St. Alexander Nevsky in purple and gold, the Hall of St. Andrew surpassing all the rest. We then went into the private apartments of the Emperor when he is here, and then to the old Kremlin, of the days of Boris Gadoneff. Everything quaint, bizarre, but supremely interesting. The old armor of Russian infantry, when Poland was greater than Russia, was passed in review before 
"From all this I was taken to the Treasury of the Synod, and saw the jewels of the Greek Church in quantities that surprised me, accustomed even as my eyes had become to jewels, diamonds, pearls, and so on and so on. The square capped Greek priest who showed the jewels had got to speak in a sort of chanting way and was as polite to the Americanskoi as possible. From the Synod, having done 'the Kremlin,' we returned to the Hotel de Dresden, where we had a long and pleasant talk and then a drive through the town, and then to the traiteurs-'Trakter' in Russ-to dinner. The dinner was an admirable one, and I ate enough roast pig to serve me for the balance of my life. The Prince was the most elegant of hosts, and when we parted kissed me three times à la Russe.

"Nothing could have been more delightfully hospitable than his manners. The Kremlin was before us, and the loveliest of Russia's winter scenes shone on its battlements as we sat down to dinner; and I gazed on the buildings with an interest entranced by the fact that I was so soon to leave them forever.

Mr. Latrobe's next letter was written after his return to St. Petersburg: "I was introduced to Lady Woodhouse by the Baroness. She made me the usual curtsey, and then forgot I was in existence. She is a very little woman who has been a beauty. She dresses in a most immodest way, and was clothed in a "figment of the imagination." "She is the talk of St. Petersburg,' said a gentleman the other day. 'If you find a ring it is mine, if you find a dress it is Lady Woodhouse's.' The emperor spoke to me and talked of my visiting Moscow.

"This court life is a peculiar one-highly artificial-but with a good deal of sense about its details looking to the system of which it forms a part. The Russians around, 
noticing the Emperor's manner to me, commented, I was told afterwards, upon his kindness to the Gospodin Amerikanskoi!! However, the Americans were in high feather to night, for Mary Worthington and Madame Bodisco were unquestionably the handsomest and most attended to women in the room, Mary making a sensation and being followed by Princes in wondering admiration apparently. Her manner was more subdued than usual, and really she was a most agreeable and effective personage. I was envied, I doubt not, by dozens, as we shook hands together upon her meeting me."

She married Count Cypriani afterwards and died, leaving a son.

"I gave a dinner to my friends, the sisters Bulongyansky, at my apartments at the Hotel Kle. The last course was a surprise. There are no bells hung in St. Petersburg.* The servants are called by ringing a hand bell on the table, or elsewhere of convenient access, and I had made six silver hand bells, on which I had engraved 'from the American.' These were placed on their plates and under each was a copy of verses in English printed on satin, all covered with a napkin. When the napkins were removed, I stood up and read the verses in English and Michel Daragan read a French translation. Madame Daragan then rose and came around to where I sat and kissed me, and the other sisters followed her example.

"The last verse reads:

Thus spoke the stranger, and to each of those he loved so well He gave, to call his memory back, a little silver bell.

How oft' they'll ring it, years to come, those years alone can tell; But till he dies, he'll listen in spirit for its spell."

* Tolstoy's Childhood-Youth, f. 323. "Upon my ringing the bell, at the time a great rarity in Moscow, the door was opened by a tiny neatly dressed boy." Tolstoy was born in 1828; he wrote of the period 1847-1860. 
"I miss a letter, in which I gave an account of a visit that I paid to the Hôpital des Enfants Trouvés in St. Petersburg, which I recollect amused me at the time. After a journey through the immense establishment, I found myself, with the friend that accompanied me, in the Chapel, I think; at any rate, a spacious, lofty apartment in the centre of which was what looked like a large silver vase. It so happened that the tenth or twelfth infant that had been left on that day was ready for baptism, and, to do me honor, it was to be baptised with full ceremonial of the Russian church. The director of the establishment, a priest, and some twenty neatly dressed girls, who formed choir, Madame Bartholomaei, and myself were the company, from which should not be omitted the Finland woman with her red cap, with the baby in her arms, upon which the blessing of the church was to be bestowed. At the proper time, the priest took the child, who was stark naked, in his arms, and I noticed that there was some conversation between the priest, the director and my companion, the end of which was that the baby was to be named after the Gospodin Amerikanskoi. This honor was duly conferred on the child, who was a boy, as he was dipped into the silver vase, and who screamed as loudly as his little lungs would permit, until he was wrapped again in his blanket, and his nurse carried him away. As a matter of course, when I was told what was done, I handed the nurse five roubles, apparently to her astonishment. I had no sooner done so, than the choir struck up, as I was informed, a song in honor of the generous American, who, the priest, nurse and baby having disappeared, was left standing alone by the silver vase to receive the compliment. Five more roubles to be spent in bonbons for the choir completed the ceremony. I have often thought $\mathrm{I}$ would like to know what became of Ivan Ivanovitch Latrobvitchif - that was the shape the name assumed. 
I remember that on this occasion the Director called my attention to the priest, who was a remarkably handsome young man, and who, the Director said, was much to be pitied, for he was a widower, doomed to celibacy for the rest of his life, the Russian church not permitting second marriages among the priesthood; construing literally the injunction of St. Paul, that a Bishop must be the husband of one wife, and rejecting the more liberal interpretation which declares that he shall have but one wife at a time.

"Here are two persons on whom I was greatly dependent -my coachman, Wassily, and my valet, Piotter, both of them accomplished in their respective callings. They are in the dress in which they appeared when I used the carriage, Piotter seating himself on the box with Wassily. Poor Wassily was a serf when I was in St. Petersburg, and, in addition to what I paid at the livery stable for the carriage, I paid wages to Wassily to enable him to pay his 'obiok - 'the sum paid by him to his owner for the privilege of acting as a free man. I used at first to give him a rouble from time to time as a pour-boire or trink-gelt. One day, however, I got out of the carriage near the statue of Peter the Great and saying 'storepai kanusne,' which they understood, whether good or bad Russ, as a direction to go to the stable, was surprised to see Wassily descend from his box and join Piotter at the door of the vehicle which he had just closed, and begin to talk to me in Russ with ample gesticulation. Presently Piotter joined in, and there I was, not understanding then more than half a dozen Russian words. It was snowing slightly at the time, and in the immense square there did not seem to be a soul except ourselves. I was going to Mr. Seymour's at the time, and thought of reëntering the carriage and driving there, when Ivan, his chauffeur, who spoke English, would interpret between the master 
and his men. But no; both coachman and valet held their places and continued their conversations and gesticulations, in which I recognized but two words 'obiok' and 'vodka,' whisky. However, by means of the most expressive pantomine, I made out the following purpose, as clearly as if it had been expressed in these words, 'Gospodin, you are very good to me; you give me roubles when you are pleased with me. Sometimes every day, sometimes not for many days, then with money in my pocket I get drunk and am in trouble. So give me the same amount, but at stated times as wages; then I don't drink whiskey, but go, as soon as I get the money, to my owner and pay my 'Obiok.' So I paid Wassily wages afterwards and I never saw him drunk.

"Piotter was an unequalled valet; he grieved much when, the first morning after his employment, I refused to let him put my shirt over my head. Otherwise he aided me to dress daily, and took care, when I went out, to see that I was in trim array. He was very proud of my furs and boastful in regard to them.

"My friends came to bid me farewell. It was quite a painful affair; old Mr. Winans, Whistler and Ross came in from the country, General Bartholomaei and his wife, Alexander, the Captain, Michael Daragan, Senator Kaphen and his wife, Mr. and Mrs. Ravaillon, Mr. Henry Harrison, Mr. Poulter, Gov. Seymour and many others. I kissed all the Russians, and shook hands with the Americans. I kissed my coachman Wassily on both cheeks, his great red beard and my black one coming in contact; then I kissed Piotter, my valet; such was the custom of the country. And so I left St. Petersburg. 
WASSILY AND PIOTTER

Coackmen and Valet to John H.B. Lalrobe during his Residence in St. Pelersburg 
RaTTOI9 GИA YJIZ2A

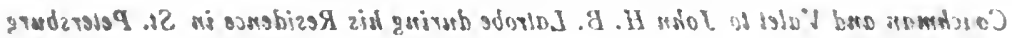




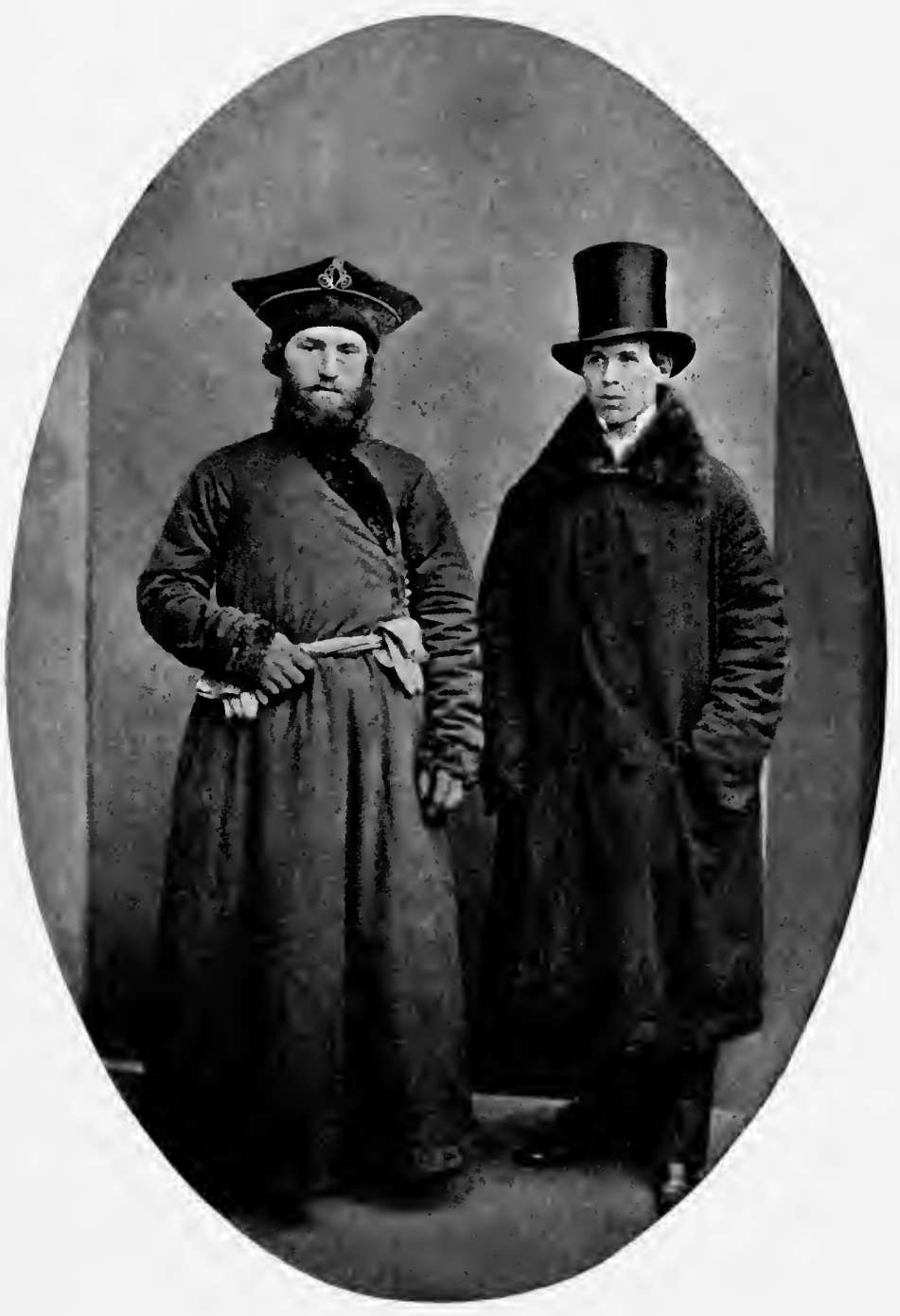





\section{TRAVELING IN RUSSIA}

"It was a dark night with spitting snow when the diligence on runners commenced its journey. I had taken two seats and had the coupé to myself, and on we went in the dark and cold in the monotony of stage riding. I had plenty of wrappings. A pillow had been made for me by Madame Bartholomaei, and my big bottle, filled with claret, was a present from another friend, and I worried through the night. The morning found me in a flat country, but the sun was shining. We dined poorly, oh! so poorly, at Naeva, and kept on through another night passing through Livonia now, and reached Dorpat on Sunday to dine there. While in the Hotel, an old gentleman asked a fellow passenger my name, my face and carriage being so familiar. He was sure he had seen me before. He was an acquaintance, or had been, of my Uncle Frederick and was struck with the family likeness. How odd, I heard of the Latrobes here from various persons, and the highest characters of all of them-the very highest.

"On we went and now got into Courland; and the next day at three o'clock the snow became so thin that we left our big diligence on runners, and got into a light open sled, where I became soaking wet with snow and rain, and reached Riga miserably uncomfortable. Now we were put on wheels, passed the Dvina, I think, on the ice, and kept on through the night and until the next day at twelve o'clock, when snow again put our whole party on runners. At this time we had ten horses to the diligence. This change was terrible - the sleds were open, and such snowing I never saw. We were in the forests of Lithuania. Every 20 versts there was a posthouse, where we changed sleds and horses both, and were repacked with our baggage upon other sleds. All that I could have imagined of the dreariness of Russian 
travel in dead winter was here more than realized. The snow, the gloom, the cold, the horses' hoofs scarce heard, the single bell borne by one of them, ten poor travelers crouching together to keep warm and to shelter themselves from the snow-all this I experienced for hours and hours and until we reached the Russian frontier at Taurogen, where I was found overcome with drowsiness, asleep in the sled with more than an inch of snow over me, which the driver shook off as he roused me. It was truly a terrible journey. At Taurogen we got some poor tea and were put at daylight into a worse sled which took us across the river and into Prussia. Here we had comfortable sleds and were carried decently into Tilsit, where we had the first thing that could be called good food, beyond tea and bread, since leaving St. Petersburg. At Tilsit we got again upon runners for two posts, then upon wheels for one; then upon runners for two, and then on wheels again for one into Königsberg, making so far a most annoying and fatiguing journey.

"At Königsberg we remained until after dinner, some seven or eight hours, during which I saw the old town and got a good dinner after the German fashion of cooking, which is bad enough. But here I got upon railroads, and the next morning, after sleeping in the cars, reached Berlin by daylight. 


\section{CHAPTER XVIII}

First MeEting With Indians, 1832-Contract with Choctaws and Chickasaws, 1868

In Mr. Latrobe's trip from Baltimore to Natchez in November 1832, he came into contact at Columbus, Mississippi, with the Indians, who were then moving and being moved West of the Mississippi. He says:

"The recent treaty with the Choctaw Indians, by which they agreed to relinquish their territory in Mississippi for another on the other side of the great river of the West had opened a section, hitherto unknown and closed, to the speculations of the adventurous; and I found at Columbus, Mississippi, which is on the border of the Indian nation, a great number of people going to or returning from 'the Nation.' Some were surveyors with compass, some were land jobbers, men as distinguishable by their appearance as negro traders, others were bona fide purchasers, whose desire was to settle where they bought at once. In the three entire days that I remained at Columbus, one of my amusements was to sit in the bar room and hear what these men had to say about 'pararas,' as they called the prairies, cane brakes, reed brakes, bars, as they term bears, 'coons,' Injuns, and the like. I picked up a good collection of slang, and saw as strange a collection of beings as one desires to meet with in a summer day, as the saying goes.

"While waiting for a conveyance Southward, I had nothing to do but walk about the town, and my path most frequently led me to the ferry, where I crossed the river* and went for

* The Tom-Bigbee. 
a mile or two into the Indian nation of which the river is the boundary. I saw but little to interest me there-some wretched cabins of the same class and order as are to be, found in the negro quarters on a Prince George's County farm. The ferry was more interesting to watch, as it conveyed wagons and horsemen, and whole regiments of negroes on their way to people the new territory obtained from the Indians, while droves of horses were being driven across the stream to escape the ferry charge. And when I went back to the tavern I would stand at the door and watch the men in their blanket great-coats of white, with the broad black stripes appearing in odd places; for the material had been cut with no regard to symmetry in any respect. Some wore gray, some green, and some great coats of bright scarlet, all made of Mackinaw blankets with the long wool side turned out. On the second day of our arrival we decided to go on, and set about making preparations for departure. This was easier said than done, and numerous difficulties appeared on every side. We had engaged places in a stage which was to leave that evening, and while waiting at the door of the Tavern for the ladies, a rickety vehicle, which had once been a proper stage, rattled up to the door and, in response to our inquiring where it could be intended to send such a thing, we were told that we were to be sent off in it through the Indian Nation that evening. To trust the ladies in this stage we at once determined was out of the question. The next stage that came along was from the North and we pinned our faith to this, but when it drove up to the inn we were again doomed to disappointment, as there was not a vacant place to be had for any sum. But relief was at hand. The driver of the Mail Coach, who had taken a fancy, so he said, to our party, offered to take us on for the sum of three hundred and fifty dollars. This was 
of course most infamous robbery, but as it looked like our only alternative to passing the winter in our miserable halting place, we decided to go on, and on Sunday morning we packed ourselves into a very small stage and started off.

"All that day we drove through stretch after stretch of prairie, the utter loneliness of which struck forcibly myself and my companions. Occasionally could be seen what looked like ants in the distance, but on a close approach they would turn out to be a group of horesmen, clad in their various colored great-coats. As they galloped by, there rose from the grass a noiseless and soaring flight of prairie hawks, which after several turns in the air resumed the rest, from which the riders had disturbed them. Sometimes we would pass the whitened skeleton of a horse by the roadside; remnants of oyster shells that sent the mind wandering back to find out what the prairie had once been; and in every quarter of the horizon columns of smoke were rising from the clearings that the white man was making in the home of the Indian. We now passed Fulsoms, a name well known in this part of the world as one of the most influential among the Indians, the Choctaw tribe being his adopted countrymen. He is a white man who married an Indian woman, by whom he had several children. His house is after the usual fashion hereabout. Two log houses under the same roof with a space between them and a long low broad porch or piazza in front. An Indian home, or one built by the Indians, may be immediately recognized by the great projection of the roof, not only at the eaves, but over the gable ends, that are like pictures of Swiss cottages that I have seen. The door is very low, and there are no windows, and greater pains are taken by mud daubing and other means to exclude the external air than you see used in the cabins built by the white settlers. The out-buildings, 
which are generally numerous, are clustered around the principal dwelling, without regard to order, but with a decidedly picturesque effect; and there is, over the whole, an air or character which is different from anything that one is accustomed to see.

"Fulsom, Greenwood La Tour, a half breed, but a man of force and energy, and a few others, were the means of bringing about the recent treaty in regard to the Choctaw lands. Twenty thousand of the nation have already crossed the river. From all I could learn the Indians are completely under the influence of the half breeds who have received education and possess ambition enough to make themselves leaders. If you can see a nice farm in the Nation you are told that it is the property of a half breed; fine cattle, they are the same. If you hear any name more often than others in the mouths of the people, it is that of a half breed. The Indians of the full blood care for nothing but their personal ease; and are satisfied, so long as they have game in plenty, and can procure those articles with facility, which their intercourse with the whites has made necessary to them. They care not, except for the trouble of the journey, on which side of the Mississippi they may rest in their graves. The noise we hear about Indians' wrongs proceeds not from the Indian of the full blood, I am satisfied now, though I once thought otherwise. They would say 'Chickamoo,' it is good, to any proposition which secured to them this comfort and saved their habits and customs from interruption. It is the half breeds who have good farms and well cultivated fields, and enjoy and wield an influence among the Indians, which they cannot preserve if they remain on their plantations which they want to keep. There is little of that attachment to the 'Natale solin,' which is dwelt upon with so much emphasis by the enthusiasts who 
have been ringing the changes of the Indians' wrongs among the Indians themselves. Remove every half breed from among the Cherokees, and offer them such a treaty as has been given to the Choctaws, and my life for it, not one in ten, aye, not ane in one hundred, would hesitate to remove. The lex taliones is in full force among the Choctaws; an eye for an eye and a tooth for a tooth is still Choctaw law. There are still eight or ten thousand Indians in the 'Nation,' who are to remove in the spring, and I constantly meet with individuals and families on the road journeying or camping on the way to the Mississippi to the other side.

"We reached Holderness, where we stopped for the night -a miserable place. We got a tolerable supper, however, and managed to get thro' the night. We had an unfinished $\log$ cabin still open to the air for our sleeping accommodations.

"The mail came up at daylight and was packed upon our already overladened stage, and our old friend, Major Dooley, arriving on horseback at the same time, we agreed to take him on with us, and started as day began to dawn, in the hopes of completing our journey thro' the Nation in the next twenty-four hours."

The number of Choctaws alive in 1832 is stated by Mr. Latrobe to be 28,000 . The census of 1910 gives the number of the tribe as 15,917-about one-half of Mr. Latrobe's estimate. Of these about 1200 are still in Mississippi.

Mr. Latrobe renewed his acquaintance with the Indians a long time afterwards. He was working hard to preserve the Union between the States. He wrote to friends North, South, East and West, urging them to attempt to settle the difficulty and bring about a reconciliation.

His stirring call to "The States of the Border," written on the assembling of the Peace Convention early in 1861, is inserted here to show the spirit that inspired him. 


\section{THE STATES OF THE BORDER}

Haste, haste! Men of the Union all,

Willing to save us from wrath and disorder;

Haste, haste! Fail not to meet the call

Made on the true by the States of the Border.

Broadly, still overhead,

Star-spangled Banners spread,

Dimmed in their radiance, but not in their story;

Hasten, oh! hasten then,

Called by the Border men,

Sons of the free, to restore them their glory.

Come from the hills of the swift Susquehannah,

Come from the cities that stand by the sea;

Come from each mountain and glen and savannah

Hallowed of old by the flag of the free,

Turmoil is round us,

Evils confound us,

True men alone can restore us to order.

Come then, Oh! come then,

Fearless and gallant men,

Come when convened by the States of the Border.

Come, Indiana, Missouri, Rhode Island,

Come, Tennessee, Arkansas, Illinois, Come, Jersey, Ohio, come, lowland and highland,

New York and Kentucky, let none remain coy,

Leave party behind us,

Its instincts but blind us,

Platforms must yield, if it's needed to save us.

Are we not brothers?

Then, by our mothers,

Swear to preserve what our forefathers gave us.

Come with no purpose of force or coercion,

Come but as freemen should come to the free;

Come with affection and not with aversion,

Come not for contest, but come to agree. 
Then, as the sunbeams

Chase from the summer streams

Fogs of the morning with sickness their story,

So shall be lightened,

Made broader and brightened,

The Star-Spangled Banner, in all its old glory.

Haste then, $\mathrm{Oh}$ ! haste then, men of the Union all;

Palm-tree or pine-tree, what matters the sign;

Thousands on thousands will tearfully greet you all,

Praying for each inspiration divine.

But for agreeing,

Anarchy fleeing,

End shall be put unto wrath and disorder;

And, to the latest days,

Loudly shall millions praise

Those who convened at the call of the Border.

Among other efforts, Mr. Latrobe urged upon the Nations that they maintain a neutral position. It was rumored that the Choctaws and Chicasaws intended to join forces with the Southern States. He invited the leaders to his house, as shown by the following letter:

"Dear Sir:

"Kirkwood House, Washington, 28th February 1861.

"The House today voted down the Senate's amendment to the Indian appropriation bill in favor of the Choctaws by a large majority, the Republicans voting almost in a body against it. One of them told an old friend and college mate of mine (Geo. W. Stevenson, of Kentucky, who is a member of the house), that the reason was that they understood the Choctaws were about to attach themselves to the Southern Confederacy.

"The matter goes back to the Senate for a Committee of 
conference. Everything will depend on the report of that Committee. Now a word from influential Republican quarters would settle the whole favorably. The slightest interest taken for the Choctaws by such men as Governor Seward or Thurlow Weed would settle it.

"Mr. Sampson Fulsom, who was present at the Choctaw council, says I was right in my surmise in regard to the outside pressure upon the Choctaw council. That it was deemed necessary to assure the border people of Arkansas and Texas of the friendly feelings of the Choctaws. The Choctaws dreaded lest some pretext would be made to pour in upon their country white men, whom they might afterwards find it hard to get rid of. I felt sure there must have been some strong motive to have caused the Council to disregard the advice given them, viz., to remain silent and to preserve strict neutrality.

"Now if the Republicans refuse to do justice to the Choctaws because they are Southern Indians, it will alienate their affections from the United States Government. If, when they are almost in a state of starvation, money justly due them is withheld, because they are suspected of disloyalty, they will become disloyal.

"As conclusive evidence that they contemplated no withdrawal from the protection of the United States, the same council passed the resolutions referred to, and instructed their delegates here 'to see the President of the United States and confer personally with him as to the interests of the Choctaw people.' The session is drawing rapidly to a close and the committee of conference will probably report tomorrow or next day, when the matter will again come up. If you can do anything for the Choctaws, it will be necessary to write immediately to your friends. I hope you will excuse the trouble I have given you. . My 
only excuse is the anxiety I feel that justice should be done the Indians. They ask nothing more.

"Respectfully and truly,

"Jno. H. B. Latrobe.

"D. H. Cooper."

"Kirkwood House, Washington, 9th March 1868.

"Dear Sir:

"The Choctaw and Chickasaw Delegations have accepted the invitation to 'Fairy Knowe' on the Monday next. We will come out on the train, which leaves here about 3 o'clock p.m. The Choctaw delegation consists of these personsCol. P. P. Pitch, Rev. Israel Fulsom, and Rev. Peter Fulsom; the Chickasaw delegation of old Col. Edmund Pickens (for many years Chief of his tribe), Sampson Fulsom and James Gamble, who is also U. S. Interpreter of the Chickasaw tribe.

"Peace counsel seems to be on the ascendency here. I begin to believe the administration really means peace. But, as old Father Richie was wont to say, Nous Verrons.

Yours truly,

D. H. Cooper."

"Jno. H. B. Latrobe.

Under the treaties by which the Indians surrendered their lands and moved to other reservations, the Government agreed to pay a certain sum annually, as well as other amounts for the expense of moving, \&c. In view of the negotiations of the Nations with the Southern States, the Government withheld these payments which it said would simply furnish aid to those who would be its enemies. The Indians were in the midst of the Southern States; their sympathies were with the people-their neighbors. Besides, their fear, as shown by the above correspondence, 
was that if they did not join the South they would be swamped. The efforts to hold them neutral were ineffectual. They cast their lot with the South, and the Government repudiated its obligation to pay what it owed them.

After the war was over the Commissioners of the United States took the position that the Choctaw and Chickasaw Nations had forfeited their claims against the United States; and it was proposed that, in order to preserve their right to the remainder of the land, they should cede one-third of their present holdings to the United States, to enable the latter to distribute them among those Indians who had remained friendly to the United States in the war. A treaty to this effect was presented to the Nations.

The argument of the Government that the Choctaws and Chickasaws, by reason of the fact that they had fought for the cause of the Southern States, had forfeited their right to the annuities and the balance due them for land taken under the treaty, by which they had agreed to give up the land occupied east of the Mississippi for a territory on the west side of the Mississippi, is without merit. The Indians were not citizens of the United States. They were an independent people. Fortunately, the Government did not add this blot to its record.

The attitude assumed by the Commissioners so alarmed the delegates that, while refusing to sign the treaty surrendering any part of their territory, they announced that they, would suffer the loss of all their rights to annuities and moneys, rather than yield any territory. A Mr. John T. Cockrane and General D. H. Cooper represented the Nations, and employed Mr. John H. B. Latrobe to represent them. Mr. Latrobe succeeded in procuring the treaty of 1866. Following here I have set forth the questions and amounts involved, and the results obtained by the terms 
of the treaty, which in fact preserved and restored all the rights previously enjoyed by the Indians-including back annuities, School Fund, General Fund, and payment for land surrendered in Mississippi.

The permanent annuities of the Choctaws, enumerated in the Act of Congress making appropriations for the Indian service for the fiscal year ending June 30th, 1861, amounted to $\$ 35,520$. Unpaid for five and one-half years, they aggregated in 1866:

The Choctaw General Fund was. ...........\$453,734.71

The Choctaw School Fund was............ 98,391.79

$\$ 195,360.00$

$552,126.50$

Interest on these sums for five and one-half years, at six per cent which was the rate they bore, was...............

The capital sum on which annual appropriations had been made for "Permanent annuities" and "Permanent provision and education," under the Treaty of 1855 , was............

Total.

$182,201.74 \frac{1}{2}$

$675,333.33 \frac{1}{3}$

$\$ 1,605,021.57 \frac{5}{6}$

Add to this the $\$ 250,000$ of Bonds ordered to be issued by the Act of 1861 , and confiscated by the Act of 1862 ; but restored by the 10 th Article of the Treaty of $1866 . . . \ldots \ldots \ldots \ldots . . . . .$.

$250,000.00$

And we have, without interest on the last item, a total of

$\$ 1,855,021.57 \frac{5}{6}$

The Choctaw delegates were authorized to yield the whole of this large amount, if they could only save "the territory that was so dear to them" from encroachment or diminution.

In addition to these admitted amounts the 10th article of the treaty of 1866 reinstated the claim of the Choctaws to the net proceeds of their lands east of the Mississippi, which an award of the Senate had fixed at $\$ 2,332,560.85$, on which there had been a payment on account of $\$ 250,000$. in 1861.

So much for the Choctaws. Joint owners of the territory, though in different proportions, the Chickasaws were equally interested with the Choctaws in the preservation of it, re- 
garded it with the same affection, and were moved by the same considerations in making the agreement which they did respecting it. They, too, had large pecuniary interests at stake.

The United States held their national fund of. . . . . $\$ 1,382,947.97 \frac{2}{3}$

${ }^{*}$ On which interest was due for five and one-half years. .

$445,867.78$

Total.

$\$ 1,828,815.75$

add to this the Choctaw claims of . . . . . . . $\ldots \ldots \ldots, 855,021.57$

making the total preserved by the treaty of 1866 to the two nations...................... $\$ 3,683,837.32$

* $\$ 1,175,281.31$ bore 6 per cent interest, $\$ 141,0005$ per cent, and $\$ 66,666.66 \frac{2}{3}$, $5 \frac{1}{4}$ per cent, averaging $\$ 81,066.87$ per annum for $5 \frac{1}{2}$ years from January 1,1861 , to July 1,1866 , or $\$ 445,867.78$ as above.

Add to this the loss to the two nations, had the United States taken from them, at its own valuation, one-third of their eleven million acres of land, and it is certainly within bounds to say that their pecuniary interests, affected by their course during the rebellion, and admitted by their delegates to be so, in the preliminary treaty of Fort Smith did not fall far short of $\$ 5,000,000$; all of which, with the exception only. of the land, the delegates were instructed to yield rather than that the land should be affected, and all of which was saved by the treaty.

Advantages secured by treaty of 1866 , in addition to preservation of pecuniary interests.

From another point of view these pecuniary interests were not the most important of those secured by the Treaty of 1866. It provided for the growth and improvement, socially and politically, of the two nations, and the adaptation to their condition of all that had made other people prosperous and great. It applied to their territory, in minute detail, the system of surveys of the public lands of the United States, and for holdings in severalty in place of 
in common, with a provision to protect the ownership of the thriftless and improvident. It provided for the organization, in all its departments, of a general council, embracing the five civilized tribes; for the extension of railroads, in which the Indians, in exchange for the property taken for right of way, and to the extent of alternate sections of land for six miles on each side thereof, might become stockholders; for the capitalization and payment per capita, after the survey and allotment of the lands to each individual entitled thereto, of the permanent annuities; for a school system to be sustained by grants of sections of land; for the purchase for $\$ 300,000$ by the United States, upon certain conditions, of the land west of $98^{\circ}$ West Longitude; for missionary establishments; for post-offices; for putting the oaths of Indians and whites upon the same footing; for the introduction of Northern Indians as Choctaw and Chickasaw citizens; for the disposition of the freemen who might desire to emigrate; and, in fine, for all that it was thought would promote their prosperity and happiness. It was the first Indian treaty that had dealt with these subjects in this manner.

. The contract which was made with Mr. Latrobe by the agents, Cockrane and Cooper, was that he should be entitled to receive fifty per cent of the back annuities if they were recovered. His proportion of this was $\frac{1}{3}$. In other words, the compensation was to be divided between himself and these agents.

In 1872 the matter came up for the annual appropriations and was referred to the Committee on Indian affairs. This year an act was passed making it penal to contract with Indians for professional services without the consent of the Secretary of the Interior. This law could not affect Mr. Latrobe's contract completed in 1866, the payment of which 
had been made in part; the balance being paid as the annual appropriations were made and paid by the Government.

The Chairman of the Committee, after the adjournment of Congress, submitted a report made in the most vindictive language. It charged in effect that Mr. Latrobe had received millions from the Indians, that the contract was a fraudulent one, because the Delegates were to receive a part of the compensation, that the services of Mr. Latrobe were of trivial character, and the fee exorbitant. The newspapers took this up, and, while the ultimate result was a complete vindication of $\mathrm{Mr}$. Latrobe and his contract was sustained, it created a great deal of annoyancé. He regretted always that the contract should have been made in his name, when, as a matter of fact, he received only a small part of the compensation. The general law being that an agent has no right to participate in a contract made for his principal, it gave a color or right to the attack. However, the fact was that the settled policy of both the Chocktaw and Chickasaw Nations was for years to require the delegates to pay their own expenses in visiting Washington for the prosecution of claims, and look to the fees or profits in said business for their compensation. Not only was this the policy, but in prior cases it had been done and this action and the contract had been ratified by the Nations with knowledge.

In $1873 \mathrm{Mr}$. Latrobe published an address to the Choctaw and Chickasaw Nations placing the whole matter before them in answer to the charge that the fee was exorbitant, and the services small. He said:

"The late Chairman evidently regards this as a case of professional extortion; but I have no hesitation in asserting that, had the entire sum, of which I received but one-sixth, been my own particular fee, there is not a member of my profession of any standing, who would be willing to say 
that, contingent as it was, and measuring it by the interests at stake and the results accomplished, it would have been more than I was entitled to.

"It has been said there was no merit in its negotiation, and that another could have done all that I did and for much less compensation. To pretend that I was the only person who could have prepared and negotiated it, would be as absurd as it would be idle to assert. Another could have prepared the 10th Article, which reaffirmed all obligations of the United States arising 'from treaty stipulations or acts of legislation,' and which preserved to the two nations all that the Choctaw delegates had been instructed to yield for the preservation of their land; or the 45th Article which reinstated them in all their rights, privileges and immunities; and others, doubtless, could have devised all that has above been enumerated. Still, it fell to my lot to do this; and, whether ill done or well done, the work was mine. To say that the treaty, or anything like it, was prepared at the Department is to misrepresent the fact. Competent as was the Secretary of the Interior or the Commissioner of Indian Affairs to suggest and prepare just such a treaty as was made, it so happened that on this occasion their part of the work was to discuss what was offered to them. The treaty itself was prepared by me in consultations with your delegates, held day after day, during the winter of 1865-6; altered, amended, changed and improved until the nine articles of the project of Fort Smith, which were all that the Indian Bureau proposed in the first instance as a basis, were expanded into fifty-one articles of the treaty that was finally ratified by the Senate."

Turning now to what Mr. Latrobe is pleased to call the "Memoranda of life" he writes:

"The remainder of these memoranda will aim at no con- 
nections, and is written after my seventy-fifth year which I reached on the 4th of May, 1878.

"In $1865 \mathrm{I}^{\circ}$ was employed by the Choctaw and Chickasaw Nations. They were on their way to Washington under the impression that the consequence of the part they took in the Civil War was that their treaties with the United States had become nullities, and they were at the mercy of the Government. After a brief interview in Baltimore, they proceeded to the Capital and left me to examine the law bearing on their relations. I found that they were mistaken in regard to the abrogation of the treaties. Congress had authorized the President of the United States to abrogate them if he thought it could be done consistently with national honor. The war had ended and there had been no proclamaion to their prejudice, and now it was too late. This was a great comfort to the delegates, and I was at once authorized to negotiate a new treaty. This I did, passing a great part of the winter of 1865-66 in Washington. The Treaty of 1866 is my work and will speak for itself. It makes provision for subjects looking to the civilization and improvement of the new nations, all of which I suggested and persuaded the delegates to consent to." When the treaty was before the Senate it was spoken of in terms of praise, and I regard it as one of the creditable efforts of my professional life. It has involved me in much trouble and subjected me to much mortification. I had nothing to do with the compensation part of it. That was settled by General D. H. Cooper, who had introduced the Indians to me. With General Cooper was joined Mr. John D. Cockrane, of Washington, and the two transacted what business there was that partook of the nature of lobbying. By them I was informed the compensation for services, present and prospective, was $\$ 100,000$ from each of the nations, which 
was to be divided between Cooper, Cockrane and myself as to $\$ 50,000$, and $\$ 50,000$ was to be distributed among the delegates for services that were to be rendered by them in connection with claims that were still to be prosecuted. I received my share, $\$ 16,000$ from $\mathrm{Mr}$. Cockrane, who made the settlement on the part of the Choctaws, and some $\$ 10,000$ or thereabouts from the Chickasaws, the settlement then becoming complicated in some way that I never clearly understood. I was in Europe at the time and my son Ferdinand acted for me. Cooper had been a General under the Southern Confederacy, and Cockrane was a Secessionist, while I was a Union man. Hence the contract was made by Cooper and Cockrane in my name, and without any formal execution of it by me became binding upon me, and when the money was paid under the contract I signed the receipt. The Chickasaws, by an Act of their Legislature passed the year after it was made and the money paid, ratified and confirmed it, and the Choctaws understood it - the Choctaw people-I was fully assured. But as time rolled on, political parties in the two nations becoming embittered, the Latrobe contract, as it was called, was brought before Congress and was referred to a Committee at the head of which was a member who, without malice.I may say, was desirous to become the agent for the Indians in the prosecution of their claims in the United States; and obtaining leave of his Committee to write the report after the adjournment of Congress, remained in Washington and published a mass of vituperation that has probably rarely been equalled. To this I wrote a reply, which I published; copies of it are to be found among my papers. I do not go over the grounds of it now. It states what I did and contends that had the whole amount charged gone into my pocket, the compensation would have been not more than was my due. Among 
my papers, too, will, I think, be found newspaper articles that I have had occasion to write from time to time in this connection. We are all wise after the event, and were the matter to be gone over again, I would not have allowed my name to be used or have receipted for the compensation. My error was in allowing others to act for me and in taking for granted all they represented, satisfied in doing my part of the work, and I might say all of it, regarding the payment of my portion of the fee the end of it. Years rolled on and the matter died out, the world got interested in other matters, and I was forgotten in this connection, remembering the subject, however, always with pain and mortification.

"In this connection I ought to say that, when I read my address to the Indians to my friends, Reverdy Johnson and S. Teackle Wallis, they both regarded it as conclusive, Mr. Wallis making some suggestions that I adopted. Mr. Johnson went further. He addressed letters, wholly unbeknown to me, to the Chancellor of New York, to David Dudley Field and Mr. Stoughton, enclosing copies of the address, and sent me their replies expressing their satisfaction with my statement, and regarding it as altogether sufficient for my vindication. Mr. Johnson wrote me a note enclosing them in which he said that if litigation was ever connected with the matter, I was to regard him as my counsel without remuneration. Of Johnson's kindness I cannot say too much. If there is one who reverences his memory, I am the man.

"I made a mistake in the business, however. My wife was bitterly adverse to any notoriety. I ought to have sued the author of the report for libel, for the report was his individual act and not protected under the circumstances by his position in Congress, but my wife so bitterly opposed my doing anything to give occasion for newspaper comment, 
that I let the matter die. The story is a long one, but my address to the Indians contains my vindication, and to this my children must refer when I am gone."

It is a remarkable coincidence that in his journey to the Mississippi, Mr. Latrobe went through the reservations of the Indian nations east of the Mississippi, and described them very fully in his letters; little anticipating that thirtythree years afterwards, he would represent them in their struggle to retain their lands declared forfeited to the United States for their hostility during the Civil War. 


\section{CHAPTER XIX}

Mr. Latrobe's Connection with the First Telegraph Company-Druid Hill Park-Edgar Alian PoeLast Case in the Court of Appeals of MarrlandLAST YeARS 1881-1891

John H. B. Latrobe bears the remarkable and unique distinction of having been intimately associated with the two great inventions of the nineteenth century, from their first commercial exploitation in this country-the steam railroad and the electric telegraph.

I have already referred to his meeting with Morse. This resulted in the incorporation, under the Acts of Assembly of 1846, Ch. 36, passed Feb. 4, 1847, of the Magnetic Telegraph Company and the Western Telegraph Company. It seems that both of these companies were incorporated under one Act, the Magnetic Telegraph Company to conduct and carry the electro-magnetic telegraph, invented by Morse, from the City of Washington to the City of New York; the other, under the 13th Section, to build the Morse electromagnetic telegraph on the road from Baltimore to the western limits of the State. There was an appropriation by Congress about this time, which enabled a line to be built along the Baltimore and Ohio Railroad from Baltimore to Washingon; and over this line the first message, ever sent by electricity, traveled. The message, sent by Miss Ellsworth, was "What hath God wrought." From this beginning has been developed the immense electrical business for transmission of news, which places at the breakfast table the particulars of the transactions and occurrences over the whole world. 
RECEIPT GIVEN TO JOHN H. B. LATROBE

As one of the Subscribers to the first Telegraph Company ever Organized 


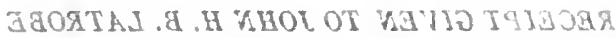

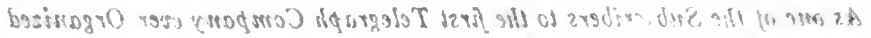




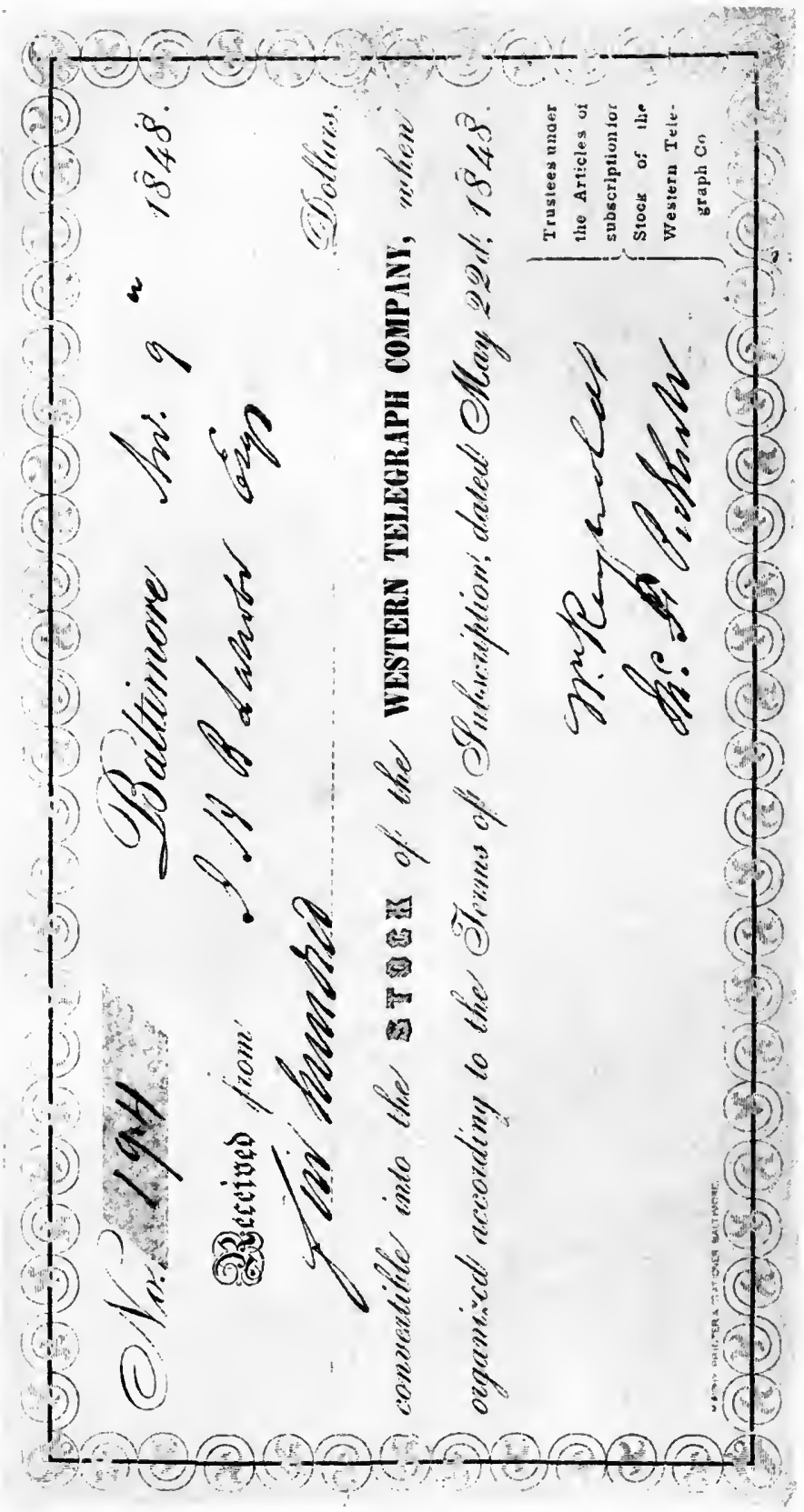



I have before me the following paper:

"No. 194:

"Baltimore, November 9, 1848.

"Received of John H. B. Latrobe, Esq., five hundred dollars $(\$ 500.00)$, convertible into the stock of the Western Telegraph Company, when organized, according to the terms of subscription, dated May 22, 1848.

"(Signed) Wm. Reynolds,

M. C. F. Pickett,

Trustees under the Articles of

Subscription for the stock of the

Western Telegraph Company."

This receipt was printed by Murphy and Co., printers and stationers, Baltimore. These receipts were never converted into the stock, but were held by the persons who received them as the stockholders of the Western Telegraph Company. This constitutes, therefore, the first subscription made by individuals for the purpose of building a telegraph line. One hundred and forty thousand dollars were subscribed to this Company. The subsequent history and the fate of the investment of a large number of those who had placed their money in this enterprise are found in three decisions, which appear in the Court of Appeals for the State of Maryland, namely: Sprigg v. Western Telegraph Company, 46 Md. 67, Western Telegraph Company v. B. \& O., 69 Md. 211, and Latrobe v. Western Union and Western Telegraph Company, $74 \mathrm{Md}$. 232.

The Western Telegraph Company made a contract in 1853 with the Baltimore and Ohio Railroad, under the terms of which it obtained the right to construct its telegraph lines along the railroad and to maintain them there as long as it existed as a telegraph company. It had been incorporated in 1847 for thirty years, the Legislature reserving 
the right to alter and amend the charter. The Western Telegraph Company subsequently leased its lines for something over $\$ 10,000$ a year to the American Telegraph Company, its only property being the right under this agreement of 1853. The American Telegraph Company was absorbed by the Western Union Telegraph Company. The Baltimore and Ohio Railroad and the Western Union having had some disagreement, the former was anxious to get rid of the Western Union and to turn the telegraph lines along the railroad over to the Atlantic and Pacific Telegraph Company. Mr. Charles J. M. Gwynn was then the counsel of the Western Union Telegraph Company. As the railroad was entitled to take possession of this property, if the Western Telegraph Company ceased to exist, Mr. Gwynn proceeded to extend, as he thought, the life of the Western Telegraph Company by availing himself of the General Incorporation Law of 1868, Ch. 471, which provided that any existing corporation could take advantage of this Act and reincorporate itself under the terms of the General Act. The Baltimore and Ohio, probably being of the opinion that the effect of this Act would be to extend the life of the Western Telegraph Company, determined to prevent this, if possible. It therefore purchased from Mr. William O. Sprigg two shares of Western Telegraph stock and filed a bill, in his name, to prevent it from incorporating under the Act of 1868. When this case reached the Court of Appeals, Judge Robinson stated that Sprigg had omitted to state the existence of the contract of 1853, and had failed to make an honest and fair disclosure of the facts, which failure would of itself deprive him of the right of equity interference. The bill recited that, by taking advantage of this Act, a new corporation was about to be created, to which it was intended to transfer all the property rights of the Western Telegraph 
Company; by which action the plaintiff would be compelled to become a member of the new corporation. The case appears in $46 \mathrm{Md}$., page 67: "The court says that Sprigg does not state that the old Company was chartered in 1847 , for a term of thirty years, and that the period thus fixed was about to expire, and that the Legislature had expressly reserved thc right to alter or amend its charter at pleasure. $\mathrm{He}$ does not state the fact of the agreement between the Company and the Baltimore and Ohio Railroad, under which the telegraph company acquired the license to construct its lines within the limits of said railroad, and that it is stipulated among other things that in the event of dissolution of the telegraph company, the railroad company was authorized to take charge of the telegraph line until the company should resume active operations; that the telegraph company had in 1859 leased all of its lines to the American Telegraph Company for a period of thirty years, and that this was its sole income." The court then goes on to say on page 77: "The organization under the Act of 1868 was absolutely necessary to protect the property of the company from passing into the possession and control of the railroad company and also necessary to enable the telegraph company to perform its covenants under the lease from which its entire income was derived." This was decided March 1, 1877. The Baltimore and Ohio, determined not to be thwarted in its efforts to get this property, seized it on March 10, 1877 and dispossessed the Western Union Telegraph Company, the lessees; and from that time the Western Union ceased to pay rent and the stockholders of the Western Telegraph Company ceased to receive dividends.

In the meanwhile the Western Union Telegraph Company had become the holder of the majority of the stock by pur- 
chase of the stock of the Western Telegraph Company. There was considerable litigation between the Baltimore \& Ohio and the Western Union Telegraph Company. The latter subsequently bought out the Atlantic and Pacific and the Baltimore and Ohio Telegraph Company, and resumed friendly relations with the railroad company.

A suit was instituted by Mr. Latrobe against the Western Union Telegraph Company and the Western Telegraph Company for the purpose of requiring the Western Telegraph Company, which was represented by the Western Union, to account for the property of the Western Telegraph and the right or license, or whatever it might be, which the Western Telegraph Company claimed to have in the lines along the $\mathrm{B} . \& \mathrm{O}$. This case appears in $74 \mathrm{Md}$. 232. A change seems to have to come over the Court of Appeals, for the opinion is delivered by Judge Bryan in which he decides that the incorporation of the Western Telegraph Company under the Act of 1868 created a new corporation, and that by this action the Western Telegraph Company had cut its own throat; that, as it was a new corporation, it had no rights under the contract with the Railroad Company, and that all this property became vested in the latter.

This may seem to the ordinary mind to be a little inconsistent with the decision rendered by Judge Robinson, in 46 Md., in which he says "that the organization under the Act of 1868 was absolutely necessary to protect the property of the Company from passing into the possession and control of the Baltimore and Ohio Railroad Company," but it is a hopeless task to reconcile some of the decisions of our Court of Appeals. There is no question that the Western Telegraph Company's minority stockholders, by reason of Judge Bryan's decision, were absolutely deprived of any property which they may have had, and these stockholders, 
like most pioneers in great enterprises, had their investment swept away.

This closed Mr. Latrobe's connection with the telegraph company, and his estate has, as the result of his investment, a certificate for $\$ 500$ as already stated, its only value being the fact that it represents an investment in the first telegraph line in the world.

In Mr. Latrobe's memoranda of this period we find the following interesting description of his association with Morse:

"I should have said something about the Electric Telegraph earlier in these memoranda. One day Mr. McLane said to me while I was with him in the R. R. Company's office: 'There is a Mr. Morse who has been talking to me about a telegraph to be worked by electricity, and which he has obtained an appropriation of $\$ 30,000$ from Congress to experiment upon. He wants to put or construct his first ine between this and Washington. You know more of these things than I do. I wish you would have a talk with him, and let me know what you think of his scheme. Come at such an hour and I will introduce you to him, and you can tell me afterward if the company is authorized under its charter to allow him to put his line upon the road.' Later in the day Mr. Morse was introduced, and I invited him to take tea with me. I knew him well already, by his profession as a painter, and had especially admired a noble, full length portrait which $I$ had seen in an exhibition of pictures in New York, and was greatly pleased to know him personally, irrespective of the telegraph.

"After tea-I remember it as though it were but yesterday-Mr. Morse and I sat down at my desk on a table in the recess next the fire place, and taking a half sheet of letter paper, he made his diagram of his plan, and pro- 
ceeded to explain to me his system. I very soon understood it, and became offhand enthusiastic. Indeed, it was impossible to resist the eager eloquence of the speaker. Presently, he wrote down his alphabet for me, and proceeded to prophesy a future which scarcely fell short of what the world witnessed. It was late, very late, when we separated.

"The next morning I called on Mr. McLane. 'Well,' said he, 'what do you make of Mr. Morse and his plans?' 'Why, Mr. McLane,' I replied, 'you have been Secretary of State, Secretary of the Treasury, Minister to England, and have a place in history, but you will never reach the pinnacle that Morse will occupy. I am not sure that your best claim to immortality will not rest on the fact that you will have promoted Morse's first construction of a telegraph for practical purposes.' I would not swear now to the exact words which $I$ have repeated again and again since, but I know they were to this effect. Mr. McLane, to whom I then proceeded to explain what Morse had taught me, took in the whole subject on the instant, and, when I told him there was no legal difficulty, granted to Mr. Morse at once the privilege he desired.

"In those days, incredulity as to Morse's success was very general, and the majority hooted at the idea of an electric telegraph.

"It is my impression that Mr. Morse's description to me contemplated a double wire, one for each direction. I have no recollection of his referring to the earth as completing his circuit. I know, however, that the idea of the present poles was not what he began with. His wires were crossed with threadlike women's bonnet wires, and were enclosed in a three inch lead pipe, which was coiled on a spool in the rear of a plow and laid in the furrow which it made, 
being carried up by a couple of rollers that pressed the earth, removed by the share, upon the tube. This plan was pursued as far as the Relay House, seven miles from Baltimore. There was a double difficulty met with here. The furrow could not be made across the bridge (Thomas viaduct), and the water condensed in the tube and destroyed the insulation. This led to the adoption of the poles, which I have every reason to believe that Mr. Morse regarded at first as but a temporary contrivance.

"My country residence being hard by the Relay House, I saw the work going on from day to day, and speak of what I know.

"The person in charge was Mr. Vail, with whom I became quite well acquainted; with Mr. Morse, too, I was thrown in frequent contact. He was a charming companion, full of enthusiasm, free in conversation, and, although he devoted himself to his telegraph, still loved his art as a painter, and was glad on occasion to talk about it. It was impossible to know Mr. Morse without becoming attached to him. I would I could recall all that he told me about the difficulties he met with in the prosecution of his great design. I have survived him to honor his memory, and to feel proud of the scant association with him, here detailed, into which accident threw me."

It was over this line constructed between Baltimore and Washington that the message sent by Miss Ellsworth flashed-"What hath God wrought."

"In a previous part of these memoranda, there is an account of my connection with the early history of the telegraph, and in $1877 \mathrm{I}$ was employed in the great suit in New York between the Atlantic and Pacific Telegraph Company on the one part and the Western Union on the other. Here 
the question was as to the right to use the Quadruplex system, by which two messages were sent in the same direction over one wire, while at the same time two messages were sent in the opposite direction over the same wire; and since then we have the telephone, and what will we not have next?"

So something over thirty years after he first met Mr. Morse, he was employed in a case between the two rival electric telegraph companies, the winning or losing of which would have cost the defeated company its life, so important was this question of the Quadruplex system. I was in $\mathrm{Mr}$. Latrobe's office at the time this suit was in progress. I remember General Benjamin Butler was one of the associates. According to my recollection, testimony was taken, volumes of it. Money was spent, several hundred thousand dollars. The result was a compromise of some kind, and ultimately the Atlantic and Pacific Telegraph Company was absorbed or swallowed by the Western Union, a performance in which that Company was an adept.

This was the last great patent case Mr. Latrobe took part in. He was some seventy-four or seventy-five years of age when he was retained in this case.

As early as 1851, Mr. Latrobe advocated the idea of Public Parks in Baltimore. It was suggested that a boulevard be constructed around the city. In June of that year, John H. B. Latrobe, James Carroll, Fielding Lucas, Jr., and John H. B. Jerome were appointed as a Committee by the Mayor and City Council to inquire into and report upon the subject.

Public opposition was so determined that the matter was dropped. In 1856-1860 Thomas Swann was Mayor. Applications for franchises were made by the Street Railway; 
and these franchises were granted on condition that a certain percentage of the earnings of the Company should be paid to the city- to be applied either to the creation of a boulevard or else to the purchase and maintenance of public parks.

By a resolution approved June 4,1860, a commission was appointed, to serve without compensation, to purchase a site or sites for a public park. The commissioners were Thomas Swann, John H. B. Latrobe, Columbus O'Donnell, William E. Hooper, and Robert Leslie. Druid Hill was selected. It was purchased at the rate of a thousand dollars an acre for five hundred and twenty acres (the area has since been increased to about twelve hundred acres). Mr. Lloyd N. Rogers, who was ithe owner of about four hundred and seventy-five acres of the land, objected to receiving city stock in payment. Mr. Achibald Sterling, a friend of Mr. Rogers, induced him to make the sale, provided onefourth of the amount was paid in cash. The following named gentlemen came to the rescue of the city's credit, each agreeing to purchase city stock to the amount of ten thousand dollars cash apiece: Thomas Swann, John H. B. Latrobe, Columbus O'Donnel, John F. Orem, John F. Gittings, George S. Brown, William E. Hooper, Thomas Winans, and Chauncey Brooks. So Druid Hill was purchased and is, in the opinion of many, the most beautiful natural park in the country. The dedication ode was written by Mr. Latrobe and sung by the school children.

Mr. Latrobe was President of the Park Board from 1860 to 1891 . The gateway at Madison Avenue was of his design. He always looked upon the park as his particular property. Few things were done without his approval. $\mathrm{He}$ was one of the commissioners of the Centennial in 1876, and the Maryland House at the Centennial was taken down 
and placed upon one of the hills near the Mansion House, and is now used as a museum. A flock of Southdown sheep was one of the matters of interest. Mr. Latrobe wished the shepherd to wear a costume, which would be more in keeping with the landscape. The shepherd did not like the idea. He had an old blue army coat, which he would don every time Mr. Latrobe turned his back.

\section{MR. LATROBE AND EDGAR ALLAN POE}

In "Kennedy Square," one of the novels of the late Hopkinson Smith, we find the following references to Mr. Latrobe's association with Edgar Allan Poe:

Page 198: "Mr. John P. Kennedy, the widely known author and statesman, and Mr. John H. B. Latrobe, equally noteworthy as counsellor, mathematician, and patron of the fine arts, both of whom had been Poe's friends for years, and who had first recognized his genius."

Page 227: "Hospitality of that kind was understandable in men like Kennedy and Latrobe, the first one of the leading literary lights in his State, whose civic duties brought him in contact with all classes; the other a distinguished man of letters as well as being a poet, artist, and engineer, who naturally touched the sides of many personalities."

Page 201: " . . . . While Latrobe, both in his dress and dignified bearing, easily held first place as the most distinguished looking man in the room."

Mr. Latrobe never saw Edgar Allan Poe but once. I found in his journal the following entry:

"Monday-October 7, 1833. After dinner Kennedy and Dr. Miller met at my house to decide the merits of certain compositions offered for premiums for the 'Saturday Visitor,' and made our selection of prose and poetry, and had altogether quite a pleasant afternoon and evening." 
It was at this meeting, held at Mr. Latrobe's house, that the prize was awarded to the author (unknown) of "A MS. found in a Bottle."

Mr. Latrobe in an address delivered by him on the occasion of the unveiling of the monument to Edgar Allan Poe, in December, 1875 , says:

"About the year 1832, there was a newspaper in Baltimore, called 'the Saturday Visitor,' an ephemeral publication, that aimed at amusing its readers with light literary productions, rather than the news of the day. One of its efforts was to procure original tales, and, to this end, it offered, on this occasion, two prizes, one for the best story and the other for the best short Poem-one hundred dollars for the first, and fifty dollars for the last. The judges appointed by the Editor of the Visitor were the late John P. Kennedy, Dr. James H. Miller, now deceased, and myself; and, accordingly, we met one pleasant afternoon in October, 1833, in the back parlor of my house, in Mulberry street; and, seated around a table garnished with some old wine and some good cigars, commenced our critical labors. As I happened then to be the youngest of the three, I was required to open the packages of Prose and Poetry, respectively, and read the contents. Alongside of me was a basket, to hold what we might reject. Some were condemned after a few sentences had been read. Some were laid aside for reconsideration-not many. These last failed to pass muster afterwards; and the Committee had about made up their minds that there was nothing before them to which they could award a prize, when I noticed a small quarto bound book that had, until then, accidentally escaped attention, possibly because so unlike, externally, the bundles of manuscript that it was to compete with. Opening it, an envelope with a motto, corresponding with one in the 
book appeared, and we found that our Prose examination was still incomplete. Instead of the common cursive manuscript, the writing was in Roman characters - an imitation of printing. I remember that, while reading the first page to myself, Mr. Kennedy and the Doctor had filled their glasses and lit their cigars, and when I said that we seemed at last to have a prospect of awarding the prize, they laughed as though they doubted it, and settled themselves in their comfortable chairs as I began to read. I had not proceeded far before my colleagues became as much interested as myself. The first tale finished, I went to the second, then to the next, and did not stop until I had gone through the volume, interrupted only by such exclamations as 'capital,' 'excellent,' 'how odd,' and the like, from my companions. There was genius in everything they listened to. There was no uncertain grammar, no feeble phraseology, no illplaced punctuation, no worn-out truism, no strong thought elaborated into weakness. Logic and imagination were combined in rare consistency. Sometimes the writer created in his mind a world of his own, and then described ita world so weird, so strange-

Far down by the dim lake of Auber,

In the misty mid region of Weir;

Far down by the dank tarn of Auber,

In the ghoul-haunted woodland of Weir.

and withal so fascinating, so wonderfully graphic, that it seemed for the moment to have all the truth of a reality. There was an analysis of complicated facts, an unravelling of circumstantial evidence, that won the lawyer judges; an amount of accurate scientific knowledge that charmed their accomplished colleague; a pure and classic diction that delighted all three. 
MEMPHIS, MISSISSIPPI, 1832.

Painted by John H. B. Lalrobe 
SE81, 14प122122IM ,2TH NaM

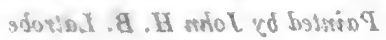




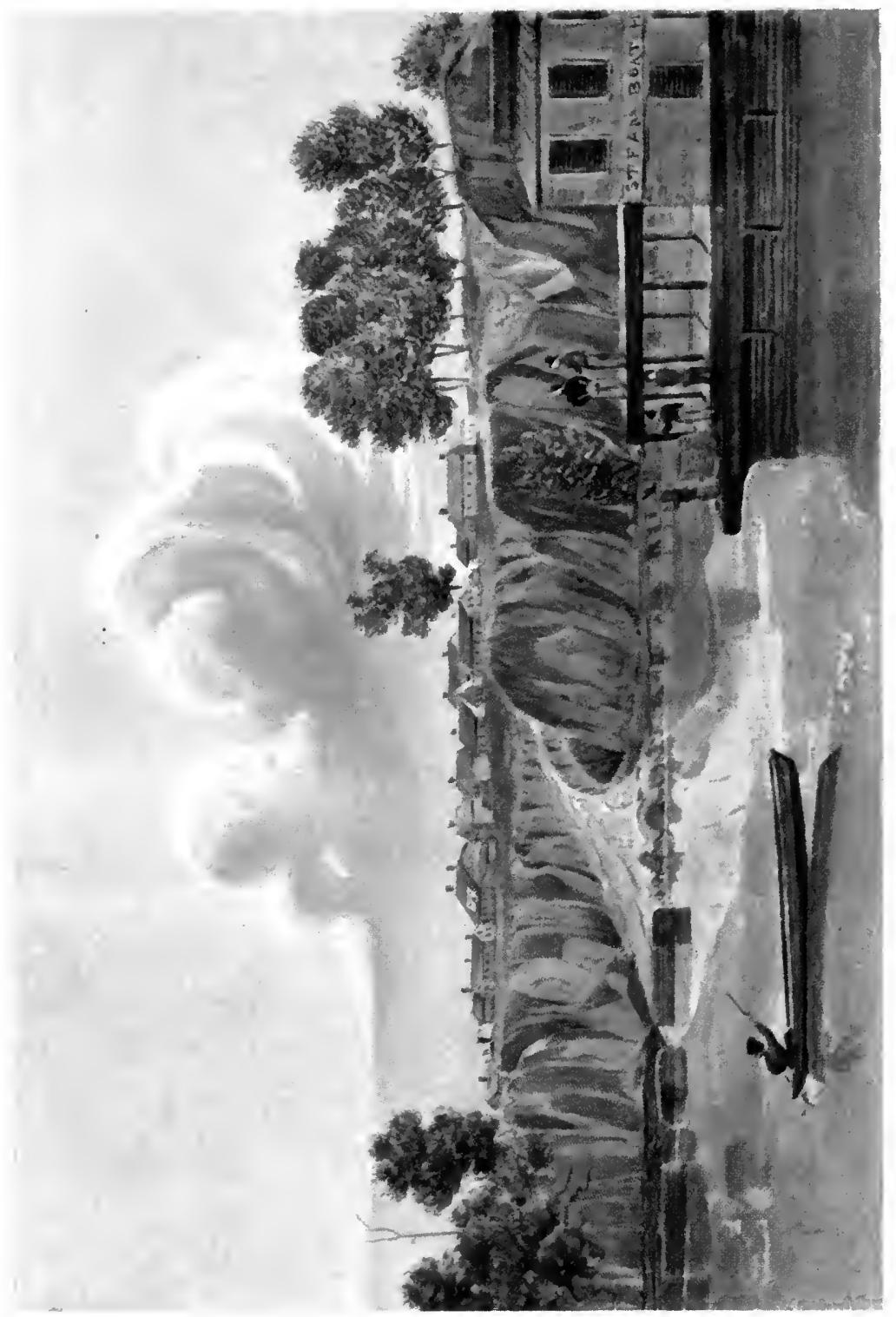



"When the reading was completed, there was a difficulty of choice. Portions of the tales were read again; and finally the Committee selected 'A MS found in a Bottle.' One of the series was called 'A Descent into the Maelstrom;' and this was at one time preferred. I cannot now recall the names of all the tales. There must have been six or eight. But all the circumstances of the selection ultimately made have been so often since referred to in conversation, that my memory has been kept fresh, and I see my fellowjudges over their wine and cigars in their easy chairs-both genial, hearty men, in pleasant mood-as distinctly now as though I were describing an event of yesterday.

"I believe that up to this time not one of the committee had ever seen Mr. Poe, and it is my impression that I was the only one that had ever heard of him. When his name was read, I remembered that on one occasion, Mr. William Gwynn, a prominent member of the bar of Baltimore, had shown me the very neat manuscript of a poem called 'Al Aaraaf' which he spoke of as indicative of a tendency to anything but the business of matter of fact life. Those of my hearers who are familiar with the poet's work will recollect it as one of his earlier productions. Although Mr. Gwynn, besides being an admirable lawyer, was noted as the author of wise and witty epigrams, 'Al Aaraaf' was not in his vein, and what he said of the writer had not prepared me for the production before the Committee. His name I am sure was not at that time a familiar one. The next number of the 'Saturday Visitor' contained the 'MS found in a Bottle,' and announced the author. My office in those days was in a building now occupied by the Mechanics' Bank, and I was seated at my desk on the Monday following the publication of the tale, when a gentleman entered and introduced himself as the writer, saying that he came 
to thank me, as one of the committee, for awarding in his favor. Of this interview, the only one had with Mr. Poe, my recollection is very distinct indeed, and it requires but a small effort of imagination to place him before me now, as plainly almost as I see my audience. He was, if anything, below the middle size, and yet cannot be described as a small man. His figure was remarkably good, and he carried himself erect and well, as one who had been trained well. He was dressed in black, and his frock coat was buttoned to the throat, where it met the black stock, then in universal use. Not a particle of white was visible. Coat, hat, boots, and gloves had evidently seen their best days; but so far as mending and brushing could go, everything had been done, apparently, to make them presentable. On most men his clothes would have looked shabby and seedy; but there was something about this man that prevented me from criticising his garments, and the details I have mentioned were only recalled afterwards. The impression made, however, was that the award in Mr. Poe's favor was not inopportune. Gentleman was written all over him. His manner was easy and quiet, and although he came to return thanks for what he regarded as deserving them, there was nothing obsequious in what he said or did. His features I am unable to describe in detail. His forehead was high, and remarkable for the great development at the temples. This was the characteristic of his head, which you noticed at once, and which I have never forgotten. The expression of his face was grave, almost sad, except when he was engaged in conversation, when it became animated and changeable. His voice, I remember, was very pleasing in its tone, and well modulated, almost rhythmical, and his words were well chosen and unhesitating. Taking a seat, we conversed awhile upon ordinary topics, and he informed me 
that Mr. Kennedy, my colleague on the committee, on whom he had already called, had either given, or had promised to give him a letter to the Southern Literary Messenger, which he hoped would procure him employment. I asked whether he was then occupied with any literary labor. He replied that he was engaged in a voyage to the moon, and at once went into a somewhat learned disquisition upon the laws of gravity, the height of the earth's atmosphere, and the capacities of balloons, warming in his speech as he proceeded. Presently, speaking in the first person, he began the voyage, after describing the preliminary arrangements, as you will find them set forth in one of his tales, called the 'Adventure of Hans Pfaal,' and, leaving the earth and becoming more and more animated, he described his sensations as he ascended higher and higher, until at last he reached the point in space where the moon's attraction overcame that of the earth, when there was a sudden bouleversement of the car and a great confusion among its contents. By this time the speaker had become so excited, spoke so rapidly, gesticulating much, that, when the turn upside-down took place, and he clapped his hands and stamped his foot by way of emphasis, I was carried along with him, and, for aught to the contrary that I now remember, may have fancied myself the companion of his aerial journey. The climax of the tale was the reversal I have mentioned. When he had finished his description he apologized for his excitability, which he himself laughed at. The conversation then turned upon other subjects, and soon afterward he took his leave. I never saw him again. Dr. Griswold's statement 'that Mr. Kennedy accompanied him (Poe) to a clothing store and purchased for him a respectable suit with a change of linen and sent him to a bath' is a sheer fabrication.

"That I heard of him again and again, year after year, in 
common with all English speaking people, more and more, it is unnecessary to say. I heard of him in terms of praise sometimes, sometimes in terms of censure, as we all have done; until now that he has passed away, leaving his fame behind him, to last while our language lasts, I have grown to think of him only as the author who gave to the world 'The Raven' and 'The Bells,' and many a gem beside of noble verse; who illustrated the power of the English tongue in prose composition not less logical than imaginative; and I forget the abuse, whether with or without foundation, that ignorance, prejudice or envy has heaped upon his memory. Unfortunate in his first biographer following his death, where the author, with a temper difficult to understand, actually seemed to enjoy his depreciation of the Poet's life, Edgar Allan Poe was seen by a malignant eye, and his story was told by an unkindly tongue, and the efforts since made by friends to do him justice are slowly succeeding in demonstrating that there was in him an amount of good which, in all fairness, should be set off against that weakness which we must regret while we attempt to palliate it."

To Poe, then, may well be applied the verse of one of the most gifted of our Poetesses, addressed to a great name in a different sphere.

The moss upon thy memory? No!

Not while one note is rung

Of those divine immortal lays

Milton and Shakespeare sung,

Not till the gloom of night enshrouds

The Anglo-Saxon tongue.

Emerson characterizes Poe as the Jingle Man, presumably referring to the 'tintinnabulation of the bells.' It may not be uninteresting to know that it was through Mr. Latrobe that the monument, which now marks the grave 
of Poe, was paid for by George W. Childs, of Philadelphia. Mr. Childs became interested through his friendship for Mr. Latrobe, who called his attention to the fact that no tablet marked Poe's grave. Among Mr. Latrobe's papers is this letter; the result of which was that Mr. Childs had the monument erected.

"George W. Childs, Esq.,

"Baltimore, May 23, 1874.

Philadelphia,

$\mathrm{Pa}$.

"Dear Sir:

"You must excuse me for not answering your favor of the 18th sooner, but I had understood that something was being done in regard to placing a monument over the grave of Mr. Poe. I called on Mr. Danskin, who is a spiritualist, and has written me something that I consider means nothing, as it refers to what he wanted to do some ten or fifteen years ago. In his note he speaks to me of a bust of Pallas, surmounted by a raven, and of having the remains removed to Greenmount Cemetery, but I presume it will amount to nothing. If you will do me the favor to say about the cost of a tomb you would prefer, I will take pleasure in sending you some sketches to select from, in case I cannot go to Philadelphia. There might be some trouble in having the remains removed to another cemetery, but I can see no trouble in placing a tomb over his grave, and I would suggest something plain and neat. Anything I can do to assist you in your worthy enterprise will be done cheerfully. Awaiting your reply,

I am,

Yours truly,

Hugh Sisson. 
An effort had been made in 1865 by the Public School Teachers' Association to secure funds to erect a suitable monument. Literary entertainments were given by the young ladies of the Western High School. The sum realized was $\$ 627.50$. On September 2, 1874, the amount in hand had grown to $\$ 887.50$. The Committee took the matter up with George A. Frederick who submitted a design which would have cost more than the amount at their disposal. Mr. Childs was a very intimate friend of Mr. Latrobe, and he agreed, as evidenced by the above letter of Mr. Sisson, to be responsible for the amount. The memorial meeting was held November 17th, 1875.

I became associated with Mr. Latrobe in 1876, under an agreement made for three years. I had practiced a year in Cumberland. My arrangement with him was to attend to office work for him, for which he paid me a certain sum. I was to have an office of my own with the right to practice on my own account. Ferdinand was absorbed in politics; John was in Samoa; Steuart had an office in the Marshall Building, but would not attend to the details of the office; Osmun was in Europe. I took the position made vacant by the departure of Carroll Sprigg who accepted an offer from New York.

When I first met Mr. Latrobe in his office, he stated that he found that his temper had not improved with age, that he at times was irritated and irritable. If matters did not go just right, he might say unjust and unpleasant things to me; that he wished now to make an apology for anything he might say. I was to remember that he was seventy. three years old, and would, after he had said anything harsh, regret having said it more than I could to have heard it said. 
When I left his office, John having returned from Samoa, I reminded him of the standing apology he had made, and that, during my stay with him, I had never had to draw upon it. I became very intimate with John, and I know his father was most grateful to me for the interest I took in him. John was most attractive personally, and a gentleman always. He was drowned in 1882, poor fellow. His father used to speak of me as his adopted son, and to his interest and affection I owe most of the opportunities given me in my professional career.

My first case in the Court of Appeals was the case of Silljacks v. Presstman. Mr. Latrobe associated me with him. Against us was Benjamin Presstman, a former student of Mr. Latrobe's, and Orville Horwitz. I studied the case, and I knew every authority on the subject; though feeling somewhat oppressed by the idea of speaking before such august persons as the members of the Court of Appeals. Mr. Latrobe encouraged me by saying, "You know twice as much of the law on the subject as any member of the bench who, if they ever knew, or were familiar with the law, have forgotten it, and you are just fresh from the authorities. Go ahead and tell them about it." One of the questions in the case was the right of a tenant to deny the landlord's title without vacating the property. In the case at bar the landlord had himself a leasehold which, during the occupancy of his tenant, he had allowed to expire; so that we were not in fact denying that he had a title at the time that our client took possession as his tenant, but claiming the right to show that he, the landlord, had lost his title by his failure to renew it at its expiration. Lord Ellenborough, in one of his opinions, had decided that even in such a case the tenant would be obliged to relinquish possession and could not, without such action, show that 
the landlord's title had expired. About ten years after this decision, his Lordship in another case reviewed this opinion, and repudiated it, stating frankly that he was in error.

Mr. Horwitz, a first-rate lawyer, commenced his speech with a statement that it was Horn-Book law that a tenant could not, in such a case as the one at bar, question his landlord's title, and quoted the first case decided by Lord Ellenborough. I turned to Mr. Latrobe and told him of the subsequent case. He said, "Don't interrupt him, but let him consume as much of his time as he will in reading that authority. Send for the other book, and give it to me." I did so and when Mr. Horwitz sat down, Mr. Latrobe asked permission of the Court, in order to save them from needless consideration of Mr. Horwitz's position, to read one line from the authority that Mr. Horwitz had quoted, namely, Lord Ellenborough; and having obtained permission, he read "I have, after due consideration, come to the conclusion that I was in error, in deciding as I did, in . . ." (the case quoted by Mr. Horwitz). We were successful. This was the last case in which Mr. Latrobe appeared as counsel in the Court of Appeals.

In $1880 \mathrm{Mr}$. Latrobe had attained the age of seventyseven.

Yet in looking over a list of addresses, etc., delivered by him after 1880, of which a record was kept in the Maryland Historical Society, I find the following:

Liberia, its origin, rights, progress and results, Address, 1880.

McDonough Institution, Address, 1880.

Baltimore Sesqui-Centennial, Ode, 1880.

Capitol at Washington, Beginning of the 19th Century, 1881.

Laying the Cornerstone of the new Post Office, Address, 1882. 
Reminiscences of West Point from 1818 to $1882,1882$.

Centenary Commemoration of the Diocese of Maryland, 1783 to 1883.

Maryland in Liberia, 1885.

Revised edition of Latrobe's Justice, 1886.

All this work was outside of the duties devolving upon him in the discharge of his obligations as counsel for the different corporations represented by him, and his daily active life in his studio and elsewhere, attending to the duties of President of the Colonization Society, President of the Historical Society, and Chairman of the Park Board.

He became the counsel of the Annapolis and Baltimore Short Line, a railroad built from Baltimore to Annapolis, which was constructed in 1880 , one of the shortest in this country, and he used to say that as counsel of the Baltimore and Ohio and the Annapolis and Baltimore, he was counsel for one of the greatest railroads in the country and one of the smallest, but both of them had the same width of gauge. In 1886 he bought a typewriting machine and learned how to use it. He was then eighty-three.

Even when he reached an age beyond that usually allotted to men, he never belonged to those who look upon the world "mounted upon the chariot of time with their backs to the horses and their faces to the past."

"Forward" was the motto he painted on the flag of his Chasseurs, and it was his motto during life.

To grow old gracefully is an art. Many grow old clinging to the banisters, and will not recognize that age prevents them from being able to discharge active duties.

No such struggle was made by Mr. Latrobe. Old age came upon him gracefully and kindly.

He suffered one great sorrow-the loss of his youngest 
son, John, who, as I have already said, was drowned in 1882. He kept up and performed such duties as were his. When he felt no longer able to walk home from his office, he used a small one horse carriage. I remember with what regret I accepted his decision that he was no longer able to take the walk, which deprived me of the opportunity of hearing him tell of the past, and acquiring what he always considered the most valuable information, namely, that which we pick up as "we drift along shore." No young man can overvalue the advantage of his opportunity to hear from the lips of his seniors the result of their experience. Such was the ancient custom, when schools were founded by wise men who were attended by young disciples drawing inspiration from their words of wisdom.

At his death I felt I had lost my best and most valued friend; and in compiling this biography I have undertaken to mark in some degree this friendship, by describing some of the work that he did for the benefit of the people.

At a banquet held at Staten Island December 16, 1885, to celebrate the success of the Baltimore \& Ohio Railroad in reaching New York, one of the speakers was John $\mathrm{K}$. Cowen, one of the brightest and most capable lawyers we have ever had in Maryland; who subsequently as Receiver managed the affairs of the railroad so successfully that it did not remain long under a receivership. He had been associated for a number of years with Mr. Latrobe who had always occupied the position of general counsel of the Baltimore \& Ohio Railroad. Mr. Cowen spoke of Mr. Latrobe as follows:

"I very much regret that Mr. Latrobe is not here with us tonight to speak for himself. A severe cold which he contracted some days since is the cause of his absence. At his request I propose reading to you what he had intended 
to say. But before I do so, I ask you to bear with me a moment while I speak of my friend, Latrobe, himself. I regard him as one of the most interesting figures in the history of the railroads of this country. He wrote the address delivered at the laying of the cornerstone of the Baltimore \& Ohio Railroad, on the 4th day of July, 1828. He was one of the counsel who prepared its charter, which was passed by the Legislature of Maryland in February, 1827. From that day to this he has been its advocate and its legal adviser. But, aside from the interest that attaches to him because of this early connection with the first railroad of the country, he is an interesting man in himself, and I exceedingly regret that he is not here tonight, that you might make his acquaintance and might hear his voice. He is, if you will permit me to say it to you busy men, and to you gentlemen who delight to call yourselves men of business, a bright example of what a man can do, who, while devoting more hours than most of us have the physical strength to devote to the arduous labors of a profession, has still been able to cultivate that which is graceful in life; or, to use the expressive language of him who spoke with such hearty welcome and in such felicitous phrase, 'the amenities, the graces, the finer forces of life.' Within ten years past I have known Mr. Latrobe to be, at the early hour of six in the morning, at his canvas with the brush which he handles with such skill and cleverness; and I know the fact that many an hour which otherwise might have been an idle one has been filled by him with graceful lines. Indeed, he is one of those men who are so fortunately constituted, if you will permit me to use the language of another, that 'they can find leisure in the midst of the most absorbing employment, and expansion in the very pressure of contracting influence; to whom literature blossoms as the spon- 
taneous wayside flower along their path, and art and fancy, and taste and graceful and refining thought and occupation come smiling and ministering like the reaper's joyous children who troop around him even in the harvest field.' Such is Mr. Latrobe, who was expected to respond to this toast tonight. He was present at the commencement of the Baltimore \& Ohio Railroad, nearly sixty years ago. As a young lawyer, and its counsel, his face was then radiant with the sunrise he was intently watching. He had hoped to be here tonight, although there is now upon his face the glow of the sunset."

\section{FINIS}

It was Mr. Latrobe's custom while away from home, to write daily letters to his wife. He used to spend several months at Saratoga every year, and it was in the late summer of 1891 that one of the letters which he wrote to his wife was not signed-and was not ended. Upon its receipt, Mrs. Latrobe immediately asked her son Osmun to go to Saratoga to ascertain what was the matter with his father. When Osmun reached there, he found his father somewhat dazed. He suggested that he wanted to go to West Point, but Osmun brought him home. He would clear up every now and then. I called upon him, I think it was the day before he died, and he said that "the machine was worn out." He died at his home on the corner of Charles and Read Streets.

In an old prayer book I found a prayer written in $\mathrm{Mr}$. Latrobe's handwriting. The date reads "Fairy Knowe, June 24. 1846:"

Oh! Almighty and ever living God, through the influence of Whose Holy Spirit, the hearts of Thy creatures are brought to the truthful knowledge of Thy Word, I humbly thank 
Thee that in the study of the scriptures up to this time, the same convictions have been produced thereby upon the minds and hearts of my dear wife and myself. Grant, I beseech Thee, that these convictions may grow in strength, that our love of Thee may be increased, that our faith in our Saviour, Thy Blessed Son, may be made more lively. That we may feel more and more that, except through His merits, we can have no hope for the happiness which is promised to those who put their trust in Him, and that at last, and not remotely, we may have courage humbly to present ourselves to Him, to receive in commemoration of His great sacrifice the emblems of that Body and Blood which were freely offered upon the Cross, that we might be saved. Hear then my imperfect prayer, Oh! Heavenly Father, for Christ Jesus' sake. Amen.

He was a member of the Episcopal Church, and attended Emanuel Church, where he had a pew; but he was very liberal in his ideas about religion. He once said to me that he looked upon all the different divisions of the Christian Church or sects with considerable doubt, that it struck him that these people had built up a wall between man and their God, and that they had cut doors in this wall. At each door was a door-keeper, who demanded certain requirements before anyone would be permitted to approach his Maker.

The sentiment expressed by Mr. Latrobe, namely, that religious sects build up a wall between man and his God is expressed in a letter of Jefferson to Mrs. S. H. Smith, dated August 1816. Speaking of priests, he says:

"The artificial structure they have built on the purest of all moral systems for the purpose of deriving from it pence and power, revolts those who think for themselves, and who read in that custom only what is really there." 
Towards the end, I used to hear him repeating Bryant's Thanatopsis:

So live, that when thy summons comes to join The innumerable caravan which moves

To that mysterious realm where each shall take

His chamber in the silent hall of death, Thou go, not like the quarry slave at night

Scourged to his dungeon, but sustained and soothed By an unfaltering trust. Approach thy grave

Like one that wraps the drapery of his couch About him, and lies down to pleasant dreams.

and so it was with John H. B. Latrobe, on September 11, 1891. 


\section{LATROBE GENEALOGY}

The Latrobe family descended from Count Henri Boneval, who fled from France to Holland after the revocation of the Edict of Nantes and entered the service of the Prince of Orange in 1685. He accompanied the Prince to Ireland, was wounded in the Battle of the Boyne, and settled in Dublin. His descendants migrated to Yorkshire, England, and from this branch are descended the American Latrobes.

A. Henri Boneval de la Trobe married Adelaide de Montmorenci. They had the following children: 1, César; 2, another son; 3, Jean Henri Boneval de la Trobe; 4, James Boneval de la Trobe.

3. Jean Henri Boneval de la Trobe had two children, Thomas and Henri, This branch need not be followed, as it is a collateral.

4. James Boneval de lá Trobe was born in 1702 and died in 1752. His first wife was a Miss Thornton. They were married in 1724 and had seventeen children of whom thirteen survived. His second wife was Miss Rebecca Adams, by whom he had four children.

B. Reverend Benjamin Latrobe, son of James Boneval, was born in 1726 and died in 1786. He married Anna Margaret Antes in 1756. She was the daughter of Henry Antes, who settled in Philadelphia in what is known as Germantown and was a prominent man of the times. Benjamin Latrobe was Bishop of the Moravian. Church and lived in England. He had six children: 1, Christian Ignatius; 2, Anna Eleanora, who married William Foster; 3, Benjamin Henry; 4, Justina who died in infancy; 5, Mary 
Agnes who married John Frederick Bateman; 6, John Frederick.

1. Christian Ignatius was born in $\mathbf{1 7 5 8}$ and died in $\mathbf{1 8 3 6 .}$ $\mathrm{He}$ became the Bishop of the Moravian Church in succession to his father. He wrote several books and was a musical authority. His wife died in 1824 . There are records of six of his children. The eldest was Charlotte, who died unmarried. The second was Peter, who succeeded his father as Bishop of the Moravian Church. He married his cousin, the daughter of the Fosters, and left two children, Benjamin and Louisa. He also was a noted musician. Agnes, the third child of Christian Ignatius, died unmarried. The fourth child was Charles Joseph, who was born in 1801. He became Governor of Australia and wrote several books: Alpenstock Sketches; The Pedestrian; The Rambler in North America; The Rambler in Mexico; etc. The fifth child was John Frederick, a physician. He married a Miss Scott and in 1836 was living at Armly, near Leeds. A sixth child was John, of whom we have no record.

2. Anna Eleanora married William Foster. She died in 1824. One of her children was John Frederick Foster, Barrister, Manchester, England, as shown by a letter which he wrote to John H. B. Latrobe in Novermber 1857.

3. Mary Agnes married John Frederick Bateman.

4. John Frederick married the Baroness von Stackelberg at Dorpat in Livonia. They had six children, but there are records only of four who were living in 1857. These were Edward; Sophia; Alvina; and John Henry. Sophia married Waldemar von Bock. Alvina married Leo Manteuffel. John Henry, in 1857, was living in Poll, Weissenberg.

This completes the records at hand of the collateral branches. 
5. Benjamin Henry Latrobe. His first wife was Lydia Sellen who died in 1793. His second wife was Mary Elizabeth Hazlehurst, of Philadelphia. They were married on May 2, 1800. She died October 16, 1841. The children of the first marriage were Henry S. Latrobe, who died in 1817, unmarried; and Lydia Latrobe, who married Nicholas J. Roosevelt in 1809. There were seven children of this marriage. This collateral branch is scattered throughout the United States. Of the second marriage of Benjamin Henry Latrobe there were five children, two of whom died in infancy; John H. B. Latrobe, born May 4, 1803, died September 11, 1891; Julia, born July 17, 1804, died unmarried March 3, 1890; Benjamin H., Jr., born December 19, 1806, died October 19, 1878.

A. John H. B. Latrobe. Twice married. His first wife was Margaret Stuart, daughter of Dr. Stuart. She died in 1830, leaving one son, Henry.

1. Henry Latrobe died in $\mathbf{1 8 7 5}$ or 1876 without leaving issue, his only child dying in infancy.

The second wife was Charlotte Virginia Claiborne, who bore him seven children: 2, Ferdinand C.; 3, Osmun; 4, Virginia, died in infancy; 5, R. Steuart; 6, Virginia; 7, John H. B.; 8, Lydia.

2. Ferdinand C. Latrobe was born in 1833 and died in 1911. He was twice married. His first wife was Miss Swann, who had one son, T. Swann Latrobe, who died unmarried. The second wife had been a Miss Penrose, who at the time of the marriage was the widow of Thomas Swann. She bore three children: (1) Charlotte; (2) Ellen Virginia; and (3) Ferdinand C., 'Jr.

(1) Charlotte Latrobe was twice married; first to $O$. Howard Harvey; second to David Stevenson. There are no children. 
(2) Ellen Virginia Latrobe is unmarried.

(3) Ferdinand C. Latrobe, Jr., married Miss Aileen Ford. There are two children of this marriage.

3. Osmun Latrobe, the second son, died in 1915 without leaving issue.

5. R. Steuart Latrobe married Mary MacTier. They had four children: (1) Mary MacTier, born in 1873, married Colonel Arthur P. D. Harris of the English Army and lives in England; (2) Osmun Latrobe, born in 1874, married Maria Laguna in 1900. They have three children: Mary Steuart; William Claiborne; and Osmun. (3) Emily Latrobe, born in 1876, married Sidney Browne, in 1899. They have one child, Sidney H. Browne, born in 1901. (4) Edna Claiborne Latrobe, the youngest child of $R$. Steuart Latrobe, is unmarried.

6. Virginia Latrobe was born in 1845. She married Judge Cogswell, and has one son, Latrobe Cogswell.

7. John H. B. Latrobe, the youngest son, was born in 1847 and died unmarried in 1882.

8. Lydia Latrobe married Dr. Loring of Washington, and has one daughter living-Lydia Loring.

B. Benjamin H. Latrobe, Jr., was born on December 19, 1806, and died October 19, 1878. He married Maria Eleanor Hazlehurst on March 12, 1833. She died in 1872. They had five children: 1, Charles H. Latrobe; 2, Mary Elizabeth Latrobe; 3, Agnes C. Latrobe; 4, Benjamin H. Latrobe; and 5, Maria Eleanor Latrobe; besides a sixth, Edward, who died in infancy.

1. Charles H. Latrobe, in 1861, married a Mrs. Holliday, who was a Miss Letitia Breckenridge Gamble. She died in 1867, leaving the following children: (1) Elise Gamble Latrobe, born on May 6, 1863; (2) Eleanor B. Latrobe, born October 6, 1864; and (3) Gamble Latrobe, born January 21, 1866. 
(1) Elise Gamble Latrobe was twice married: first to Alexander McKim, who died in January 1884, leaving one child, Letitia Latrobe McKim, who was born in the same year; second to Dr. William Barton Hopkins by whom she had four children: Eleanor Barton Hopkins; Elise L. Hopkins; and Marian B. Hopkins and William B. Hopkins, Jr., who died in infancy.

(2) Eleanor B. Latrobe died unmarried in 1890.

(3) Gamble Latrobe married Emma Crozer, of Uplands, $\mathrm{Pa}$. They have two children; Charles $\mathrm{H}$. Latrobe, born on February 25, 1895; and Gamble Latrobe, Jr., born on May 26, 1896. Following in his grandfather's footsteps, Gamble Latrobe holds an important position as an engineer in the service of the Pennsylvania Railroad.

Charles H. Latrobe was married three times. In 1869 he married Rosa Wirt Robinson, who died in 1870 without issue; and in 1881 he married Louise, the widow of Isaac McKim. He died on September 19, 1902.

2. Mary Elizabeth Latrobe was born in August 1836. She married Henry Onderdonk. They had two children, Latrobe and Adrian Holmes. She died in 1916.

Latrobe Onderdonk was born on May 12, 1872, and died November 9, 1883. Adrian Onderdonk was born in 1877. He married Evelynne Richardson; and they have one son; Adrian H. Onderdonk, Jr., who was born in August, 1913.

3. Agnes C. Latrobe was born December 25, 1838. She married Cornelius Weston; and died April 26, 1915. They had three children: Benjamin Latrobe Weston; Henry B. Weston; and Arthur Hazlehurst Weston.

B. Latrobe Weston was born on December 8, 1868. He married Virginia Rich in 1913. Henry B. Weston was born on January 2, 1871, and married Ethel L. Reid, of Norfolk, in 1916. Arthur Hazlehurst Weston was born 
August 18, 1872. He married Parthenia Passano in 1899. They have three children: Arthur H., Jr., born January 19, 1904; Leonard P. Weston, born May 24, 1906; and William, born December 4, 1908.

4. Benjamin H. Latrobe was born December 4, 1840, and died July 5, 1901. He married Jane Yates, and had one son, Lawrason Riggs Latrobe, born in 1875, who married, in 1903, Mrs. Morris (born Maria Douglas Allen.)

5. Maria Eleanor Latrobe married Hammond Vinton, and died in 1911, leaving three children: Eleanor L. Vinton, born November 7, 1879; Lillian Hazlehurst Vinton, born June 5, 1881; and Pamela B. Vinton, born on January 28, 1883, and married to Hans Strunz in 1906, and now living in Germany.

The early records of the Latrobe family as shown in the foregoing can be substantiated by a reference to an application made by John Frederick Bateman to the British authorities for permission to change his name by the addition of the name of Latrobe. He is now known by the full name of John Frederick Latrobe Bateman. 


\section{INDEX}

A

Adair, Thomas, 222, 226

Adair, William R., 226

Adams, John, 240

Adams, John Quincy, 119, 240

Addison, Rev. Thomas G., 169

Adelaide, Queen, 219

Adelward, Baron, 512

Adlerburg, Prince, 511

Adus, Thomas, 422

Adus, William, 422

Airey, Colonel, 468

Albright, 187

Alexander I, Emperor, 490

Alexander II, Emperor, 390, 393, 476, $489,490,500,501,503,504,508,509$,

$510,511,512,516,522,523$

Alexander, Dr., 366, 367

Alexander, Sir William, 283

Alexandrovna Petrovna, Grand Duchess, 506

Allen, Solomon, 185

Alvey, Judge, 349

Anderson, Dr., 149

Anderson, James M., 124

Andrei, 45

Antes, John Frederick, 97

Antes, Margaret (wife of Rev. B. H.

Latrobe), 97

Archer, Judge Stevenson, 299, 338, 341

Armistead, Colonel George, 72

Ashburton, Lord, 384

Ayres, Dr. Eli, 141, 142, 145 .

\section{B}

Bache, R., 16, 18

Bacon, Leonard, 366

Bagot, Sir Charles, 217
Baker, (Secretary to British Minister), 19

Bakewell, 51

Baltimore, Lord, 280

Baltzell, Philip, 172

Bancroft, George, 150, 151, 283, 417, 418

Barbour, Governor, 253

Barbour, Miss, 253

Barclay, Ben (Barckedge), 453

Barclay, Dr., 248

Baring Brothers Co., 457, 458, 459, 460, 471

Baring, Thomas, 461

Barlow, Mr. and Mrs. Joel, 35, 240

Barlow, Mrs. Joel, 54, 57, 63

Barnes, Mr. and Mrs., 188

Barney, Lieutenant Joshua, 222, 223, 224

Barnum, P. T., 189

Barrett, 35, 36

Barrett (shipping master), 288

Barrett, Lieutenant Thomas, 124

Barry, Joseph, 438

Barry, Llewellyn C., 396

Bartholomaie, Alexander de, 475, 476, $481,512,528$

Bartholomaie, de, General, 475, 520, 528

Bartholomaie, Helene de, Madame, $426,474,475,476,479,480,481$, $482,488,504,520,524,526,528$

Bartholomaie, Michael de, 475, 488

Bartholomew, Dr., 183

Barlett, William E., 405, 407

Bartol, Judge, 179

Barton, 253

Bateman, John Frederick Latrobe, 5, 98

Bayard, 18 
Bayard, Richard H., 301

Bell, Alexander Graham, 331

Belles, John, 281

Belton, Colonel, 224

Benson, B. F., 415

Benzinger, Captain, 404

Bernard, General, 139

Berryman, John, 444

Bexley, Lord, 448, 465

Bigelow, Chief Justice, 131

Birckhead, Hugh, 371

Birkbeck, Dr., 412

Black, Colonel, 136

Black Hawk, 404, 405

Bland, Chancellor, 339, 370

Blessington, Lady, 483, 484, 485

Blodgett, Charles, 289

Blyden, Dr. E. W., 163, 167

Bock, de, Captain, 497, 508, 512

Bodisco, Madame de, 513, 515, 523

Boissy, Marchioness de. (See Guicciola)

Bollman, George, 51

Bomford, Colonel, 62, 68

Bonaparte, Jerome, 40, 42, 43

Bonaparte, Jerome (son of above) $43,44,45,128$

Bonaparte, Madame (Elizabeth Patterson), 16, 22, 34, 40, 41, 42, 43, 44, 45,219

Bonaparte, Napoleon, 42, 43, 240, 490

Boneval, the, family, 448

Booth, the elder, 188

Borch, Count, 513

Bordeaux, Miss, 10

Bosio, 503

Bosley, Nicholas M., 200

Botta, Mrs. (Anna C. Lynch), 440

Botts, John M., of Virginia, 486, 487

Bouis, John, 287

Bourussoff, Prince, 520, 522

Boynton, Ed. C., 126

Brichard, 49

Breck, Mrs., 19

Breckinridge, 185

Brice, Judge, 143, 197, 200
Brissot, 167

Brooks, Chauncey, 557

Brooks, Governor, 38

Brooks, Lieutenant, 38

Brooks, Mrs. Sidney, 440

Brougham, Lord, 465, 484, 485

Brown, 243

Brown, Alexander, 183, 323, 332

Brown, Dr., 318

Brown, General, 81

Brown, George, 183, 361

Brown, George S., 349, 557

Brown, Uria, 340

Brown, William, 465

Brune, 183

Bryan, 351

Bryan, Judge, 552

Bryan, William J., 135

Buchanan, 183

Buchanan, James (President), 470

Buchanan, John (Chief Justice), 213, $338,339,341,342,343$

Bujac, 454

Bulongyansky, the, family, 475, 523

Burke, William, 346

Burns, Miss Marcia, 40

Burow, Baron, 475

Burr, Aaron, 205

Butler, Benjamin (General), 556

Byron, Lord, 236, 484

C

Cadwallader, General, 124

Caldwell, 18, 252

Calhoun, John C., 63

Calvert, the, family, 283

Campbell, 253, 254

Capellano, 46

Carey, Matthew, 103

Carlton, 253, 257

Carlton, Miss, 253

Carmarthen, Marquis of (Duke of

Leeds), 220

Carnahan, 57

Carnegie, Andrew, 415

Carroll, Barrister, 182 
Carroll, Charles, of Carrollton, 42, 70, $104,106,150,181,182,214,215,216$, $217,218,219,220,284,290,291,292$, 294, 295, 296, 297, 298, 299, 300, 301, $323,331,388$

Carroll, Charles, of Homewood, 70, 71, 182, 214, 217, 295, 299

Carroll, Charles, of the Manor, 108, 118, 217, 292, 296, 301

Carroll, Charles, the elder, 214

Carroll, David, 214

Carroll, James, 556

Carroll, John," Bishop (later Archbishop), 42, 183

Carroll, John, of the Manor, 218

Carter, 13

Carter, Mrs., of Virginia, 12

Carver, Captain, 405

Catherine the 2nd, the Great, 489, 521

Caton, the elder, 218

Caton, Elizabeth (Lady Stafford), 219, 220, 301

Caton, Louisa Catherine, (See Lady Harvey)

Caton, Richard, 106, 192, 214, 215, 216, $217,219,220,291,294,300,301$

Caton, Mrs. Richard (Mary Carroll), $214,216,219,301$

Celeste, Madame, 360, 361

Charles I, 280

Charles XII, 521

Charley, the butcher, 257, 258

Chase, Judge, 204, 205

Chase, Mrs. B., 112, 113

Chase, Samuel, 244

Chatard, Dr., 302

Chevelier, Michael, 156

Chew, Miss (married Charles Carroll, of Homewood), 182

Chiffelle, Miss, (See Mrs. Charles Carroll Harper)

Chiffelle, Mrs., 298

Childs, George W., 565, 566

Choate, 370

Circourt, 430

Claiborne, the, family, 262, 264, 265
Claiborne, C. L., 318

Claiborne, Miss Charlotte Virginia, (See Mrs. John H. B. Latrobe)

Claiborne, Ferdinand Leigh, General, 260,283

Claiborne, James H., 268, 269, 302

Claiborne, Mrs. James H., (Miss

Kershaw of Carolina), 262, 268, 269

Claiborne, Nathaniel, 447

Claiborne, William, 280, 282, 283

Claiborne, William C., 17, 18

Clapham, Samuel, 64

Clapperton, 243

Clark, James, 348, 349

Clark, James H., 413

Claxton, 520

Clay, Henry, 45, 142, 150, 153, 161, $162,240,253,254,366,367,368,464$

Clay, Mrs. Henry, 45, 253

Clifford, Judge, 177

Clifford, Sir Augustus (?), 465

Clinton, Vice-President, 14

Cloud, Charles F., 416

Coale, Edward L., 105

Cochrane, Lord, 288

Cockrane, John T., 538, 541, 544, 545

Coke, of Holkham, 6

Coke, Mrs., of Holkham, 6

Coke, Thomas William (Earl of Leicester), 192, 193

Cole, Lady F., 218

Cole, John, 186, 188

Coleridge, Lord, 398

Colt, R. L., 183

Compher, 198, 199, 200

Constantine, Grand Duke, 390, 475, $476,477,478,479,489,502,503$

Conway, Moncure D., 9

Conwell, H. C., 155

Cooke, Captain, 142

Cooper, D. H., General, 537, 539, 541, 544,545

Cooper, Lord, 486

Cooper, Peter, 325, 326, 327, 328, 386

Cooper, Spencer, 485,486

Cornwallis, Lord, 280 
Gittings, John F., 557

Glenn, Judge, 454

Glenn, Elias, 198, 199

Glenn, John, 206, 207, 301, 401, 403, 405

Golden, 31

Goldsborough, Charles, 19

Gorgas, F. J. S., 425

Gorman, Senator, 348

Gortschakoff, Prince, 489, 497, 498, 499, $500,511,512,513$

Gow, John L., 127

Grady, of Georgia, 158, 162

Graham, Alfred, 76

Graham, Campbell, 75

Graham, Stephen, 518

Graham, William, 63

Grammont, Duchesse de, 486

Grassi (President of Georgetown), 54

Greenhow, Dr., 254

Greville, Lady C., 218

Griffith, Thomas, 102, 103

Griswold, Dr., 563

Grundy, George, 182

Guicciola, la., 484

Gwynn, Charles, J. M., 396, 399, 550

Gwynn, William, 102, 103, 108, 181, $184,185,186,187,207,208,289,290$, $332,334,344,371,372,418,561$

Gwynne, 392

\section{$\mathrm{H}$}

Hale, Nathan, of Boston, 461

Halfehide, John, 281

Hall, 444

Hall, of Washington, 379, 380

Hall, Clayton C., 180, 420

Hall, Dr. James, 144, 145, 148, 149, 167

Hall, Dr. R. H., 455

Halleck, General, 131

Hamilton, the, family, of Philadelphia, 16,17

Hamilton, Archibald, 21

Hamilton, Mrs. Archibald, 21

Hamilton, Colonel J. P., 186, 187, 188, 311
Hamilton, Miss Mollie, of Philadelphia, 24

Hamilton, Paul (Secretary of the Navy) $20,34,40$

Hamilton, Susan, 40

Hamilton, Thomas, 156

Hand, Moses, 413

Hanson, the, family, 16

Harden, Samuel, 413

Harkesson, 330

Harlan, Henry D., Judge, 493

Harper, Charles Carroll, 61, 108, 118, $142,143,145,168,174,217,222,223$, $224,234,238,239,244,262,263,284$, 292, 293, 294, 295, 296, 297, 298, 299, $301,415,443$,

Harper, Mrs. Charles Carroll, 222, 292, 293, 294, 296, 297, 298

Harper, Emily L., 244, 292, 294, 301

Harper, Robert G., 301

Harper, Robert Goodloe, General, 16, $18,33,61,69,83,92,96,100,101$, $102,104,106,108,109,110,111,116$, $117,118,119,121,122,139,140,141$, $142,174,183,190,196,200,214,218$, $224,244,293,294,372,395,423,444$

Harper, Mrs. Robert Goodloe, 214, 234, 292, 294, 298

Harris, 90

Harris, Hon. Mr., 464

Harrison, Captain, 459, 466, 467, 468

Harrison, Hall, 224

Harrison, Henry, 528

Harrison, J. B., 313

Harrison, Joseph, 393

Harrison, W. G., 224

Hartnet, 65

Harvey, Lady (Duchess of Leeds), 217, $218,219,220,301$

Harvey, Sir Bathurst, 220

Hascall, 129, 130

Hayne, 368

Hayward, The Bartlett, Co., 391

Hazlehurst, Isaac, 4, 47, 67, 70, 72, 85.99 
Hazlehurst, Mary Elizabeth. (See Mrs. Benjamin H. Latrobe)

Hazlehurst, Samuel, 284

Heath, Colonel U. S., 107, 108, 412

Heath, W. S., 301

Henderson, 287, 379, 380

Henry, 55

Henry, Patrick, 244, 447

Hewley, Lady, 176

Hilliard, 430

Hintze, Dr. Frederick E. B., 404

Hobert, Sam, 93

Hoffman, the, family, 183

Hoffman, George, 147, 333, 423

Hoffman, S. Owings, 118

Hohenlohe, Prince, 509, 510, 511

Holdship, 48

Holland, John C., 82, 83

Hollins, 183

Holmes, 430

Holmes, Dr., 149

Holmes, Oliver Wendell, 376, 439

Hooper, William E., 557

Hopkins, Johns, 361

Horwitz, Orville, 567, 568

Howard, B. C., 210, 345, 346, 413, 423

Howard, Ben, 226

Howard, Charles, 143, 145, 226, 396

Howard, Charles, of Samuel, 288, 422

Howard, Mrs. Charles (daughter of Francis Scott Key), 226

Howard, George (Governor of Maryland), 111, 222, 226

Howard, John, 226

Howard, John Eager, Colonel, 124, 134, 183, 191, 321, 322

Howard, Sophia (Mrs. William George

Read), 226

Howard, William, 226

Howard, Dr. William, 191, 323, 392, 413,415

Howell, Senator, 20

Hubbard, William, 413

Hughes, Christopher, 138

Hull, Commodore, 21

Hunt, Jesse, 401, 404, 443
Hunter, of Rhode Island, 22

Hunter, Rev. Dr., 37

Hunter, David, 38

Hunter, Moses, 38

Hurd, Abe, 140, 141

Hurley, 48, 51

Hutchins, the, family, 305

Hutchins, 303, 304, 306

Hutchins, Mrs., 305, 306

I

Inglis, Sir Robert, 464

Inglis, Lady Robert, 464

Innes, James, 7, 8, 9

Irving, 18

Irving, Washington, 98, 138

Isaac, William M., 423

\section{$\mathrm{J}$}

Jackson, Andrew, 111, 366, 367

Jay, John, 244

Jay, Mrs. John, 14

Jefferson, the elder, 35, 188

Jefferson, Thomas, 4, 10, 11, 13, 34, $157,164,167,238,240,245,246,247$,

$248,249,250,251,370,573$

Jenkins, Michael, 415

Jennings, Thomas, 200

Jerome; John H. B., 556

Johnson, 243, 263

Johnson, Bradley T., 169, 283, 420

Johnson, Reverdy, 202, 203, 208, 253, $254,301,332,343,370,379,380,383$, $385,401,402,403,404,405,407,417$, 546

Johnson, Mrs. Reverdy, 253, 254

Jones, D. R., Brigadier General, C. S.A. 397

Jones, John Paul, 240, 244

Jones, Talbot, 333

Jones, Walter, 19, 202, 369, 370, 373,

Josephine, Empress, 42

$\mathbf{K}$

Kaphen, de, Senator, 528

Kaphen, Madame de, 479, 480, 528 
Kell, Thomas, 301

Kelly, 54

Kelso, Thomas, 413

Kemble, 135

Kemp, Bishop, 109

Kennedy, Mrs., 57

Kennedy, John P., 182, 191, 222, 224, $225,234,244,282,289,412,430$, $431,432,433,434,435,436,462,463$, $558,559,560,563$,

Kennedy, Mrs. John P., 435

Keppel, Lady (wife of Coke of Norfolk), 193

Key, Francis Scott, 45, 48, 61, 62

Keyser, Philip, 396

King, Bennett, 127

Kirkland (President of Harvard), 78

Kitty, Mammy, 36, 37, 56, 58

Klockoff, Colonel, 473, 474

Knight, Jonathan, 322, 392

Knowles, Sheridan, 187

Knox, Rev. Samuel, 246

Kondrazoff, 508, 512

Korf, 481

Kosciuszko, Colonel, 126

Kraft, 393

Krebs, Jacob E., 423

Krebs, William, 413

L

La Black, 484

Lafayette, Marquis de, 118, 119, 120 121, 122, 196

Lafayette, George Washington, 121

Landers, John, 140, 243

Landers, Richard, 140, 243

Lane, Colonel, 59

Lansdowne, Marquis of, 465

La Tour, Greenwood, 532

Latrobe, Agnes, 98

Latrobe, Benjamin H., Jr., 18, 23, 32, $53,56,72,73,83,90,91,99,106$, $113,114,173,220,223,284,285$

Latrobe, Benjamin H., 1, 3, 4, 5, 6, 7, 8, $9,10,11,14,17,19,23,24,25,27,30$,
$31,32,33,34,35,36,40,41,46$, $48,49,50,51,52,53,56,57,58,59$, $60,62,63,64,65,66,67,68,69,71$, $72,83,85,86,88,89,90,91,92,97$, $98,99,106,107,172,218,245,250$, $251,423,427,445,447$

Latrobe Mrs. B. H. (Lydia Sellen), 1 Latrobe, Mrs. Benjamin H. (Mary E. Hazlehurst), 4, 12, 13, 14, 15, 16, 17, $18,19,20,21,22,23,24,25,34,39$, $40,41,45,52,53,56,57,58,61,72$, $73,83,84,85,90,92,99,106,107$, $112,127,172,239,270,348$

Latrobe, Rev. B. H., Jr., 397

Latrobe, Rev. Benjamin Henry (afterwards Bishop), 97

Latrobe, Charles, 99

Latrobe, Charles Joseph, 29, 98, 99, 420,448

Latrobe, Charlotte, 98

Latrobe, Christian Ignatius, Bishop, 97, 98, 99

Latrobe, Edward de, 97

Latrobe, Ferdinand C., 99, 302, 397, $470,471,472,473,545,566$

Latrobe, Frederick, 98, 99

Latrobe, Gamble, 99

Latrobe, Henry S., 1, 17, 18, 33, 60, 88, 397

Latrobe, John, 98, 99

Latrobe, John Frederick, 97, 98, 448, 497, 524

Latrobe, Mrs. John H. B., 41, 135, 136, $137,147,169,237,260,261,262$, $264,267,268,269,270,284,296,302$, $303,317,318,427,438,452,453,459$, $473,476,482,507,572,573$

Latrobe, John H. B., Jr., 99, 137, 397, $566,567,570$

Latrobe, Julia, 23, 40, 57, 72, 83, 86, 87, $88,90,98,99,112,220,221,222,223$

Latrobe, Lillie (Lydia), 440, 482, 496

Latrobe, Lydia، (See Mrs. Nicholas J. Roosevelt) 
Latrobe, Mary Agnes (Mrs. Bateman), 97,98

Latrobe, Osmun, 33, 99, 318, 397, 398, $473,566,572$

Latrobe, Peter, 98, 99, 420, 442, 448, 465

Latrobe, R. Stewart, 99, 397, 456, 566

Latrobe, Virginia, 440, 441, 476, 482

Laurenson, Philip, 172, 187

Law, 14

Lawrence, Sir Thomas, 194

Leary, Peter, 413

Lee, J., 301

Lee, Robert E., 398

Lee, Very Reverend Principal, 466

Legox, Peter, 13

Leicester, Earl of, 465

L'Enfant, Major, 75

Leslie, Robert, 557

Levering, Thomas, 226

Levitzsky, 479

Lewis, Captain (Secretary to Thomas Jefferson), 12

Lincoln, Abraham, 156, 161, 164, 165, 370

Lincoln (Attorney-General under Jefferson), 12

Livingston, 254

Livingston, Cora, 253

Livingston, John, 407

Livingston, Mr. \& Mrs., 253

Livingstone, Chancellor, 27, 30, 31, 33

Lloyd, John I., 143

Lloyd, Mrs., 19

Long, Robert Carey, 181, 186, 413

Long, Stephen H., Colonel, U. S. A., $334,335,392$

Longfellow, Henry W., 440, 441

Longstreet, J., General, 397, 398

Louis XVIII, 240

Lucas, Fielding, 102, 103, 104, 105, 184, $185,361,397,412,419$

Lucas, Fielding, Jr., 413, 556

Lucas, John, 397

Lurman, William, 181, 332
M

Macaulay, Commodore Charles, 37

McClellan, General, 131

McClure, James, 178

McCoy, D. G., 413

McCullough, 116, 198, 199, 200

McCullough, Dr., 185

McCullough, Colonel James H., 182

McDonald, General, 122

McDonough, John, 286

McDowell, 243

McEldrey, Hugh, 404, 405

McElroy, Father, 55

McHeath, 364

McKim, Anne, 181, 333

McKim, Isaac, 181, 333

McKim, John, 183

McKim, John, Jr., 332

McKim, William, 183

McLane, Louis, 189, 321, 359, 360, 361, $362,363,387,463,553,554$

McLaughlin, Brigadier General, 122

McMahon, 207

McMahon, John V. L., 301, 334

McMechen, Judge, 197, 200

McNeill, Captain William Gibbs, 392

McSherry, Judge, 350

MacTavish, the, family, 220

MacTavish, Charles Carroll, 220

MacTavish, Charles Carroll, the younger, 220

Mac'Tavish, Emily, 220

MacTavish, John Lovet, 214, 220, 298, 299, 300, 301

MacTavish, Mrs. John Lovet (Emily Caton), 214, 219, 220, 292, 294, 298, 299, 300, 301

MacTavish, Maris Mayo, 220

MacTavish, Miss Virginia, 220

Madison, James, 12, 14, 20, 24, 34, 45, $60,65,150,238,239,240,241,242$, 243, 244, 245, 246

Madison, Mrs. James, 13, 14, 19, 20, $22,45,46,53,239,240,241,242$ 
Magruder, C. C., 419

Magruder, Richard B., Judge, 222, 224, 299

Mahan, Professor, 130, 133, 134

Mann, Horace, 127, 128

Mansfield, Colonel, 84

Marie, Grand Duchess (Duchess of Lichtenberg), 482, 483, 503, 513, 514, 515,516

Marion, 397

Marshall, John, Chief Justice, 7, 24

Martin, Luther, 204, 205

Martin, William Bond, Judge, 338, 341, 343

Maser, Miss, 253

Mason, General, 14

Mason, Jonathan, 78

Massasoit, 154

Mathews, Charles, Sr., 107

Matilieff, 516

May, Miss Anna, 253

May, Dr. Frederick, 18

May, Sophia, 16, 18

Mayer, Charles F., 213, 284

Mayer, the, family, 183

Mayhew, 401

Mead, General, 129, 130

Medairy, J. H., 425

Medem, Baroness, 496, 505, 507, 513

Medem, Baron, of Kass, 505

Meeter, William, 184, 413

Melvin, 59

Mentkoff, 393

Mercer, Charles Fenton, 368, 369

Mercer, General, 479

Mercer, John, 253

Mercy, General, 129

Meredith, Jonathan, 206, 208, 209, 213

Meredith, Thomas, 222, 226

Merry (British Minister), 16

Messan, du, 512

Messen, King Freemans, 149

Mickle, Robert, 399

Middleton, Arthur, 40, 253

Miller, Dr. James H., 558, 559, 560

Miller, Judge, 419
Miller, Juliana, 15, 18, 25

Mitchell, Charles, 207

Mitchell, Dr., 24

Mitchell, James D., 108, 109

Moale, 398

Monroe, James, 60, 61, 66, 243

Monroe, Mrs. James, 61

Monteagle, Lord, 465

Montmorencies, the, 484

Mordecai, Alfred, 78

Morier, 18

Morris, Captain, U. S. N., 21

Morris, John B., 179, 332, 333, 401, 404, 407

Morris, Robert, 4, 23

Morse, S. B., 321, 548, 553, 554, 555, 556

Morton, 107

Mosher, James, 181, 413

Moss, 262

Mouton, John, 413

Munford, 446

Murphy, John, \& Co., 549

$\mathbf{N}$

Nagle, 187

Napoleon, Louis (Emperor), 483, 484

Narishkin, 513

Neal, John, 185

Nelson, John, 207, 301

Nevins, Rev. Dr., 144

Nicholas, John Spear, 122, 123, 253, 254,443

Nicholas Nicholaevitch, Grand Duke, 489, 506

Nicholson and Son, 349

Niles, Hezekiah, 184, 413

Noroff, de, 497, 503

$\mathrm{O}$

O'Connor, Miss, 94, 95

O'Donnel, General, 125

O'Donnell, 183

O'Donnell, Columbus, 361, 557

Oliver, Robert, 107, 182, 183; 191, 192, $224,225,332,434$ 
Oliver, Thomas, 222, 224

Oliver, Mrs. Thomas, 222

O'Meara, 485

Orange, Prince of, 448

Ord, Miss, 329

Orem, John F., 557

Orloff, Prince, 501

Ossunce, Duke of, 509, 510, 511

Otis, Mrs., of Boston, 16

Otis, Harrison Gray, 78

Otis, William, 94

Owens, Robert Dale; 11

\section{$\mathbf{P}$}

Paine, Anne, 242

Palmerston, Lady (Lady Cooper), 486

Palmerston, Lord, 485, 486

Parson, Henry, 413

Pascault, Louis, 182, 183

Patterson, 26

Patterson, Joseph W., 359

Patterson, Robert, 44, 192, 217

Patterson, Mrs. Robert (Mary Caton) subsequently Marchioness of Wellesley, 43, 44, 192, 194, 216, 217, 218, 219, 220

Patterson, William, 41, 42, 44, 182, 183, 332

Patton, James, 54

Peale, Charles Wilson, 189

Peale, Rembrandt, 181, 189

Pearce, 509

Pennington, Josiah, 289

Pepin, 49

Peter the Great, 490, 527

Petroa, Moiza, 514

Phelps, Charles E., Judge, 151, 152

Phelps, Judge, of Vermont, 379, 380

Phelps, Miss (Mrs. John Carroll, of the Manor), 218

Philip, King, 154

Pickens, Colonel Edmund, 537

Pickett, M. C. F., 549

Pierrepoint, 185

Pinkney, 110, 203, 204, 205, 207, 244, 370
Pinkney, Colonel William, 125

Piotter, 502, 503, 507, 513, 527, 528

Pitch, Colonel P. P., 537

Pixie, 414

Poe, Edgar Allan, 519, 548, 558, 559, $560,561,562,563,564,565$

Politica, 18

Polk, James, 365

Porter, David, Commodore, 38

Potter, General, 136

Poulter, 528

Poultney, Evan, 401, 405

Poussin, 59

Prescott, Jonathan, 78

Prescott, William H., 429, 430

Presstman, Benjamin C., 395, 396, 399, 567

Priestly, Dr., 13

Purviance, 14

Purviance, John, 206

Purviance, Robert, Judge, 105, 183, 420

$\mathbf{R}$

Rachel, 35

Radcliffe, 396, 399

Randolph, Miss, 253

Randolph, Mrs., 13

Randolph, Edmund, 7, 8, 9

Randolph, John, 243, 290

Ravaillon, 513, 528

Ravaillon, Mrs., 528

Ravenswood, Fitzhugh, 143

Rawls, William, 346

Rayborn, James, 422

Read, William George, 108, 109, 226

Readel, Dr. John, 185, 186

Redesdale, Lord, 497, 498

Reynolds, William, 549

Richardson, George, 195, 207

Ridgeley, Colonel, 120

Ridgeley, John, of Hampton, 183

Ringgold, Samuel, 20

Ritchie, 446

Ritchie, Mrs. (daughter of Thackeray), 432

Ritchie, Albert, 179, 417 
Rives (Minister to France), 224, 294

Roberts, 195

Roberts, Nathan S., 347

Robinson, Conway, 447

Robinson, Judge, 351, 550, 552

Rodney (Attorney-General), 14

Rogers, Dr., 481

Rogers, Lloyd N., 557

Rogers, Samuel, 463, 464, 465

Roney, William, 413

Roosevelt, Nicholas J., 25, 26, 27, 29, 30, 31, 33, 48, 52

Roosevelt, Mrs. Nicholas J., 1, 24, 28, $29,38,70$

Roosevelt, Theodore, President, 26

Rosalie, Mademoiselle, 223

Rothermel, Peter Ford, 129, 428, 430

Royall, Madam Ann, 65, 216

Rush, Mrs., 17

Russwurm, John B., 149, 150, 167

Rutherford, 451

S

St. Clair, Arthur, General, 47, 392

Sanders, George W., 416

Schley, Frederick A., 301

Schley, William, 207

Schmucker, Judge, 336

Schoolfield, 136

Scott, Marcella (Mrs. Charles Carroll Mac'Tavish), 220

Scott, Mary Ann (Mrs. John Livingston), 407

Scott, Otto, 462

Scott, Sir Walter, 346

Scott, Winfield, General, 128, 220

Sefton, 330

Semmes, John E., 11, 26, 210, 211, 212, $213,246,432,450,451,456,457$, $566,567,570$

Semmes, Mrs. John E., 450

Serrurier (French Minister), 15, 16, 19, 24

Seward, William H., 379, 380, 385, 536
Seymour, Thomas A., 476, 482, 483, $499,500,505,506,509,513,527,528$

Sheppard, Moses, 145, 285, 286, 287

Sheridan, General, 128

Shipley, Richard, 287

Shryock, Thomas J., 425

Shufelt, Commodore, 165

Sigourney, Mrs. L. H., 440

Sinnott, 71

Sisson, Hugh, 565, 566

Skinner, John S., 220, 226

Skinner, Mrs. John S., 220, 226

Small, Jacob, 102

Small, William F., 413

Smith, 14, 183, 412, 415

Smith, Brigadier General, 122

Smith, Dr., 148

Smith, F. Hopkinson, 558

Smith, Gerritt, 336

Smith, Captain John, 431

Smith, Matthew, 288

Smith, Samuel, General, 345, 401, 406

Smith, Sidney, 463

Smith, Mrs. S. H., 573

Smith, S. Stanhope, 76

Smith, Thomas, 281

Snyder, 118

Sorrel, Colonel, 398

Sparks, 243

Spear, Miss, 16

Sprigg, Mrs. Benjamin, 17

Sprigg, Carroll, 566

Sprigg, William O., 550, 551

Stabler, Edward, 402

Stabler, Edward, Jr., 105

Stackelberg, Baroness (wife of John Frederick Latrobe), 97, 98, 488, 489

Stafford, Baron, 219

Standard, of Richmond, 253, 254

Stanley, Henry M., 166

Stanton, Edwin (Secretary of War), 131, 391

Stapleton, Joseph K., 413, 414

Starr, Frederick, 166, 167

Steele, 195 
Steele, Nevitt, 399

Steiner, Dr. Bernard C., 246, 407

Stephen, John, Judge, 338, 341

Stephenson, George, 31, 324

Sterling, Archibald, 396, 399, 557

Stevens, 30

Stevens, Governor, 117, 119

Stevens, Mrs., 39

Stevens, M. C., 380

Stevenson, George W., 535

Stewart, of Richmond, 349, 351

Stewart, Captain, U. S. N., 21

Stewart, Dr., 299

Stewart, David, 105, 195

Stewart, Jack, 7

Stewart, James E., 124

Stewart, Colonel William, 184, 333, 412, 413

Stockbridge, Henry, Judge, 179, 420

Stockton, Captain, 141

Stockton, Rev., 48, 49, 51

Stolssakoff, General, 512

Stone, Governor, 280

Story, Judge, 177

Stoughton, 546

Strogonoff, Count, 483, 503, 514

Strong, Tim, 375

Stuart, Bessie, 236, 237

Stuart, Gilbert, 24, 45, 240

Stuart, Dr. James, 182, 234, 235, 237, 478, 479

Stuart, Miss Margaret (first wife of John H. B. Latrobe), 227, 228, 230, $231,232,233,234,235,236,237$, 286

Stuart, Dr. Richard S., 421

Stuppand, 423

Sullivan, James R., 413

Sully, 187

Surly, William, 172

Svenin, 24

Swann, James, 360, 363, 459, 463, 465, 466

Swann, Thomas, 445, 556, 557

Swift, 392
Swift, General, 62

Sykes, James, 413

Tamberlik, 503, 506

Taney, Roger B., later Chief Justice, U. S. Supreme Court, 26, 200, 201, 202, 203, 207 208, 209, 244, 283, 291, $294,332,343,344,367,369,370,371$, 400

Taylor, Zachary, General and President, 125, 127, 129

Tchernitieff, Prince, 499

Tennant, Thomas, 182, 183

Terry, Seth, 366

Tevis, 195

Thackeray, William Makepeace, 432, 433

Thaesses, Major, 77

Thayer, 188

Thayer, Sylvanus, Major, afterwards General, 62, 74, 75, 76, 77, 84, 92, 116, $130,131,132,133,134,392$

Thomas, Evan, 321, 322

Thomas, Phillip E., 322, 333, 334, 335 $352,358,359,362,386,403$

Thompson, A. W. 124

Thompson, Henry, 234

Thompson, Mrs. Henry, 234

Thompson, the Misses, 85, 128

Thornton, Dr. William, 9, 10, 12, 167

Ticknor, George, 130, 131

Ting, John H., 396

Tingendorff, 448

Tingey, Commodore, 22, 36

Todd, Paine, 240, 242

Tolstoy, Count, 500, 523

Trimble, Isaac, General, 76, 335

Trumbull, 240

Turnbull, Alexander, 289

Turnbull, Miss Alison (afterwards Mrs.

Samuel Lawrence), 222, 223, 224

Turner, B. H. M., Bishop, 157, 164

Tyler, 127

Tyson, Mrs. Rebecca (widow of William Howard), 226 
U

Urquhart, William, 396

\section{V}

Vail, 555

Vallenilla, Madame, 222, 223, 225

Van Buren, Martin, 367

Van Dyke, Henry,' 11

Van Ness, Ann, 40

Van Ness, John Peter, M. C., 40

Vansettent, the Misses, 448

Van Winkle, R., 396

Vestris, the, 223

Von Blume, Baron, 97

Von Blume, Baroness, 97

Von Gerstner, Chevalier, 324, 392

Von Kapf, the, family, 183

\section{W}

Walker, Samuel D., 413

Wallack, Mrs. Francis, 188

Wallis, 391, 396

Wallis, Severn Teackle, 416, 430, 436, 546

Walsh, Charles, 289

Walsh, T. Yates, 108, 395

Ward, Thomas W., 457, 458, 459, 460

Warden, 18

Waren, 280, 281

Waring, Mrs., 187

Warner, 20

Warner, George, 413

Warren, 35, 187

Warren, Judge, 430

Washington, Bushrod, 9, 14, 150

Washington, Mrs. Bushrod, 14

Washington, George, 3, 4, 9, 10, 193, $240,244,342,370,377,381,382$, 478

Wassily, 479, 487, 495, 502, 505, 507, 527,528

Watkins, 243

Watkins, Thomas N., General, 125

Wayne, Judge, 367, 368
Webster, Daniel, 332, 343, 361, 368, $370,371,372,373,374,375,376$, $377,378,379,380,381,382,383$, 384,464

Webster, Henry, 396

Weed, Thurlow, 536

Welch, B. T., 141

Wellesley, Marquis of, 44, 219

Wellesley, Marchioness of (see Mrs. Robert Patterson.)

Wellington, Arthur, Duke of, 43, 44, $117,220,466$

Wellington, Duchess of, 220

West, William, 185

Wharton, Colonel, 36

Whelan, Thomas, 397

Whistler, George Washington, 391, 392, 393

Whistler, George W., Jr., 393, 517, 518, 528

Whistler, James McNeill, 392

Whistler, Major John, 391, 392

White, 366

White Apple, Chief, 306, 307

White, Edward D. (Chief Justice), 90

Wilberforce, 170, 464

Wilde, Oscar, 16

Wilkins, 188

Wilkins, Joseph, 361

Wilkins, Ross, 48,49

Wilkinson, Joshua J., 397

William 4th, 219

Williams, General, 505

Williams, Miss, 44

Williams, Nathaniel, 145

Willing, the Border Ruffian, 305, 306

Willis, Jesse, 422

Wilson, the, family, 183

Wilson, Senator, 131

Wilson and Colston, 348

Wilson, James, 264

Wilson, James G., 379, 380

Wilton, Lady, 329

Winans, the, firm, 389, 469

Winans, Harrison \& Eastwick, 393 
Winans, Harrison \& Winans, 470, 471, 495

Winans, De Witt Clinton, 390

Winans, Julia (Mrs George W. Whistler, Jr.), 393

Winans, Ross, 182, 324, 327, 384, 385, $386,387,388,389,390,391,392$, 393, 528

Winans, Ross, Jr., 528

Winans, Thomas D., 182, 385, 390, 393, 394, 557

Winans, Walter, 395

Winans, Walter Scott, 390

Winans, William Louis, 385, 389, 390, $391,393,394,395,469,471,472$,

$473,474,482,488,492,513,517$, Wynd, 196 518
Winchester, George, 185, 205, 206, 207

Winthrop, Robert C., 181, 429, 468

Wirt, William, 26, 201, 202, 207, 332, $343,369,373$

Wise, 178

Wood, 187

Woodhouse, Lady, 522

Woodward, Professor, 415

Worth, Major, 77, 78, 79, 91

Worthington, Judge, 197, 200

Worthington, Mary, 501, 506, 507, 512, 514. 523

Wykoff, Henry, Chevalier, 483, 484, 485 



\section{TOPICAL INDEX}

A

Addresses delivered after 1880, 568569

African colonization, 61-62, 139-171, $285,366,368-369,421,423,464$, 470

Exploring the Niger, 140-141

Making Map of Liberia, 141

Naming Liberia, 142

Emigration to Liberia from Baltimore, 144, 147-148.

Writing a constitution, 146-147

Elected President of American Colonization Society, 150

Letters from George Bancroft, 150151

Public appreciation of work, 151$153,168-171$

Slavery, 153-156, 162-167

Lincoln on slavery, 156-157, 161, 164-165

Grady's speech in Boston, 158-159

Maryland the leader in colonization, 167-169

Elected head of State Society, 167 "Alliance" frigate which made first voyage from America to India, 23 Ancestry, 97, 448-449

Appearance of B. H. Latrobe, 23

Appearance of Mrs. B. H. Latrobe, 23 Appearance of John H. B. Latrobe, 97 Appearance, regard for, in Russia, 491, 496

Cost of fur coats, 491-492

Architectural efforts, 444-447

Architectural work of elder Latrobe, 33, $40,46,69$

Architecture, American, 11

Associates in law office, student, 108109
B

Ball, subscription, for Greek struggle for Independence, 111-112

Baltimore and Ohio Railroad, 189, $320-363,368,387,392$

Louis McLane invited to presidency, 189

Latrobe as counsel for Railroad, 320, $336,352$.

First railroad company in U. S. organized, 322

Methods of building proposed, 322326

Race between first engine and car and horse, 326

Letter from Peter Cooper, 327-328

Description of early railway ride in England, 328-330

Personages present at laying of $\mathbf{B}$. \& O. corner stone, 331-333

Acquiring rights of way, 333-335

Letter declining high office in Company, 352-358

Description of presidents of Company, 358-363

Ross Winans' railroad inventions, 384-389

Winans friction wheel, 384-385, 387388

Baltimore in 1824, 180-184

Benefit of clergy, 281-282

Bonaparte, Madame, 40-41

Her marriage, 42

Its annulment, 43

Character, 44

Death, 45

Botetourt Springs, description of, 263264

Bowie (Bouy) knife, 275 
Bravery, discussion on, 449-451

Brother changes his profession, 284285

\section{C}

Canal routes, 139

Capitol, design of, 10-11, 33

"Corn-cob" capitals designed by B. H. Latrobe, 11

Sculptors imported to work on, 46 Elder Latrobe's work praised by Madame Royall, 65

Carroll family, 214-220

Appearance of Charles Carroll of Carrollton, 215

Appearance of Mrs. Robert Patterson, 216-218

Chesapeake and Delaware Canal, 4

Chesapeake and Ohio Canal, 336-351, 368

Litigation with B. \& O. Railroad, 337-345

History of, 344-351

Claiborne family, 280

"Claiborne Rebellion," 280-281, 282283

Clients, early, 287-288

Coat of arms of Latrobe family, 449

Conversation with James Madison, 242-245

Cost of living in Baltimore in 1830, 455

Cost of living in the Mississippi region during the Revolution, 303-304

Cottages in Baltimore Row at White Sulphur designed by Latrobe, 452

Country home, 452-454

$\mathrm{D}$

Dancing teacher of Marie Antoinette, $39-40$

Death of Latrobe, 572

Debt of Maryland, 457-463

Appointed counsel for creditors, 457

Letter from Baring Brothers, the .creditors, 458
Generous compensation by the Barings, 459

Honorable methods of the Barings, 460

Delphian Club, 184-187

Dinners at White House, 12-14

Drama in Baltimore, 187-188

Drawing, cleverness in, 58-60

E

Earthquake shock in Washington, 17

Eulogy, in speech of John $\mathrm{K}$. Cowen, 570-572

\section{F}

Family nurse, devotion of, 36-37

Death by burning, 56-57

Fancy ball in Baltimore in 1829, 220-223, 226, 287

Fireplace heater, 442-443

Flute, learning to play, 114

\section{G}

Georgetown College, life at, 53-57, 63

H

Hairdressing, two centuries ago, 6

I

Inauguration of Monroe, 60

Indian nations, 529

Journey through territory, 529-533

Effort at keeping them neutral, 535-537

Discussion of their claims, 537-540

Treaty made in 1866, 540-541

Contract as counsel, 541-547

Vindictive attack by congressman, 542-543, 545-546

\section{J}

Journey down Mississippi described by sister, $86-88$

Journey to and from Natchez, 264-270, 302-303, 317-319 
Accident to carriage, 268-269

Return after marriage to Baltimore, 270-280

Voyage down Mississippi, 302-303

$\mathrm{K}$

King Ball, a, in St. Louis, 272-273

L

Lady Blessington, reminiscences of, 483-485

Latin verse, facility in, 57-71

Lawyer, life as, 172-226 "

Starting in straitened circumstances, 172-173

Admission to Bar, 107-108, 196

Admission to Courts, 174

Advice to young lawyers, 175-178

Eulogy pronounced by Historical Society, 179-180

Remarkable case of identification, 197-198

McCullough, the counterfeiter, 198200

Famous legal associates, 200-210, 369-384

Students in his law office, 395-399

Letter from Christopher Hughes, 137138

Literary efforts, 102-105, 288, 290, 432-433

Justice Practice, 418-419

Eulogies of the Practice, 419-420

Poetical writings, 438-439

Letters from Mrs. Sigourney, 440

Letter from Longfellow, 440-441

Louis Napoleon, reminiscences of, 484-485

Louisville, in 1833, 278

\section{M}

Manners in America a century ago, 276-277

Marriage, first, 227

Description of Margaret Stuart, 235237
Marriage, second, 260

Devotion to wife, 260-262

Description of Charlotte Claiborne, 270

Maryland Historical Society, 415, 417418

Maryland Institute, 184, 412-417

Eulogies on his work for, 415-416

Masonry, connection with, 421-422, 424-425

Elected Grand Master, 426

Military career, 116

Sword presented by Duke of Wellington to General Harper, 117

Review of militia, 117

Captain of military company, 117118

Reception to Lafayette, 118-121

Baltimore Light Infantry visits Philadelphia, 122-124

Offered command of volunteer regiment, 124

Review of battles of Mexican War, 125, 127-128

Kosciuszko Monument, 125-127

President of Board of Visitors to West Point, 127-129

Efforts at obtaining promotion for Colonel Thayer, 130-134

Letter from John Eager Howard,134

Letter from General John Gibbon, 135-137

Mind reading seance, 456-457

Minute details, attention to, a characteristic, 492

Miserliness, as a means to charity, 285-286

Monticello, description of, 248-251

Montpelier, description of, 239-240

Mud-daubers, habits of, 4-5

$\mathrm{N}$

Natchez Indians, destruction of, 306307

New Orleans, in 1834, 308-317

Quadroon Ball, 313-317 
New Orleans Water Works, 32-33, 60

Novels and writings of John P. Kennedy, $430-434$

\section{O}

Oregon country, rejection of, advocated in 1815 because of difficulties of travel, 330-331

Osmun Latrobe's military services, 397-398

\section{$\mathbf{P}$}

Painter, ability as a, 426-427

Letter from Rothermel, 428

Letter from Prescott, the historian, 429-430

Illustration made for Swallow Barn, 435

Parks, public, in Baltimore, 556-558

Druid Hill Park acquired for city, 557

President of Park Board, 557-558

Personal associations with Latrobe, $566-567,570$

Associated in suit with Latrobe, 567-568

Cleverness shown by Latrobe in this case, 568

Philokrisean Society, 102, 107, 195, 290

Pittsburgh,

Journey of family to, $46-48$

Life of family in, 48-53

Return of family from, 53

Poe, Edgar Allan, 558-566

First discovery of Poe's genius, 559-561

Meeting with Poe, 561-563

Monument erected by Childs, 564566

Poem, called "States of the Border," written as an appeal in 1861, 534-535

Poem written by $\mathrm{S}$. Teackle Wallis for dedication of Greenmount Cemetery, 436-437
Political activities, 443-444

Nomination for legislature declined, 443

Appointed director of Penitentiary, 444

Prayer for law students by Dr. Johnson, 461

Prayer written in $1846,572-573$

\section{$\mathrm{R}$}

Raid by border ruffians, 304-306

Relatives, 97-99

Ruin, narrow escape from, by theft, 455-456

Russian experiences, 474-528

Meeting with Madame de Bartholomaie, 474-475

Presented to Emperor, 476, 500, 507-513

Presented to Empress, 505, 507513

Presented to Grand Duke Constantine, 476-478

Presented to Grand Duke Nicholas, 506

Presented to Grand Duchess Marie, 513-516

Letter from Grand Duke Constantine acknowledging gift of Washington autograph, 478 ,

Seized with Asiatic cholera, 479482

Meeting with Russian relative in St. Petersburg, 488-489

Daily drive, 494

Interview with Prince Gortschakoff, 498-500

Ball given to Imperial family, 501

Valet, 502-503, 507, 527-528

Opera, 503

Visits to institutions for noble women, 504-505

Journey to Moscow, $\mathbf{5 1 7}$

Troika ride, description of, 518

Visit to the Kremlin, 519, 521-522

Moscow theatre, 519 
Visit to Moscow Foundling Asylum, $521,525-526$

Farewell dinner to friends, 523

Travelling in Russia, 524-525

Coachman, 527-528

Russian women intelligent, 496-497

$S$

Scale of living in Baltimore in 1824, 189-190

Society in Washington a century ago, 15-16

Steamboats

First one on western waters built by Nicholas J. Roosevelt, 25-29 Fulton's claims, 29-31

Built by father in Pittsburgh, 32-33 Shipbuilding works in Pittsburgh, 48 Launchings of first steamboats, 5153

Suspected of treason in 1861, 385

\section{$\mathrm{T}$}

Telegraph, electric, first, company, 548556

Meeting with Morse, 553-554

First line between Baltimore and Washington, 555

Transportation methods, comparison of, 1-2, 320, 330-331

Treaty with Great Britain, 14-15

U

Union Bank of Maryland, 399-410

Elected director, 399

Description of bank riots, 401-407

University of Virginia, description of, 246-248

\section{$\mathbf{V}$}

Versatility, 174

Voyage, first, to Europe, 459, 463-468

Meets Samuel Rogers, 463

Visits the House of Lords, 465

Ship goes on rocks on return trip, 466-468
Voyage, second, to Europe in 1857, 469

Meets W. L. Winans in London, 469

Tour of Europe with son, Ferdinand, 471

Return to London, 471

Consulted by Winans about Russian railroad contract, 471

Liberal compensation, 472

Offered big fee by Winans to go to Russia, 472

Leaves for St. Petersburg, 473

Departure from St. Petersburg, 488489,528

W

War with Great Britain, 19, 46

Captured British colors, 21-22

Capitol burned by British, 32

Vessel containing father's machinery captured by British, 32

Battle of Lake Champlain, 49

Peace concluded, 52

Washington monument, 194

Watch House, 195

West Point

Entrance first suggested, 62

Ordered to, for examination, 63

Journey to, 73

Life at, $74-85$

March of Cadets to Boston, 77-81

Narrow escape from death at salute firing, 81-82

Honor man of Senior class, 84

Resignation from, 91-92

Verses written when leaving, 95

White Sulphur Springs, description of, 251-259

Will of Charles Carroll of Carrollton, 291

Cause of estrangement of Charles Harper, 292-298

Agreement of relatives on, 298-301

Winans railroad in Russia, 389-391, 393-395 


THIS BOOK IS DUE ON THE LAST DATE STAMPED BELOW

RENEWED BOOKS ARE SUBJECT TO IMMEDIATE RECALL

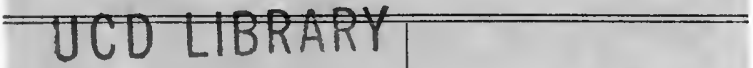

DUE SEP $\approx 51972$

JUN 4 REC'D

LIBRARY, UNIVERSITY OF CALIFORNIA, DAVIS

Book Slip-35m-7,'62 (D296s4)458 


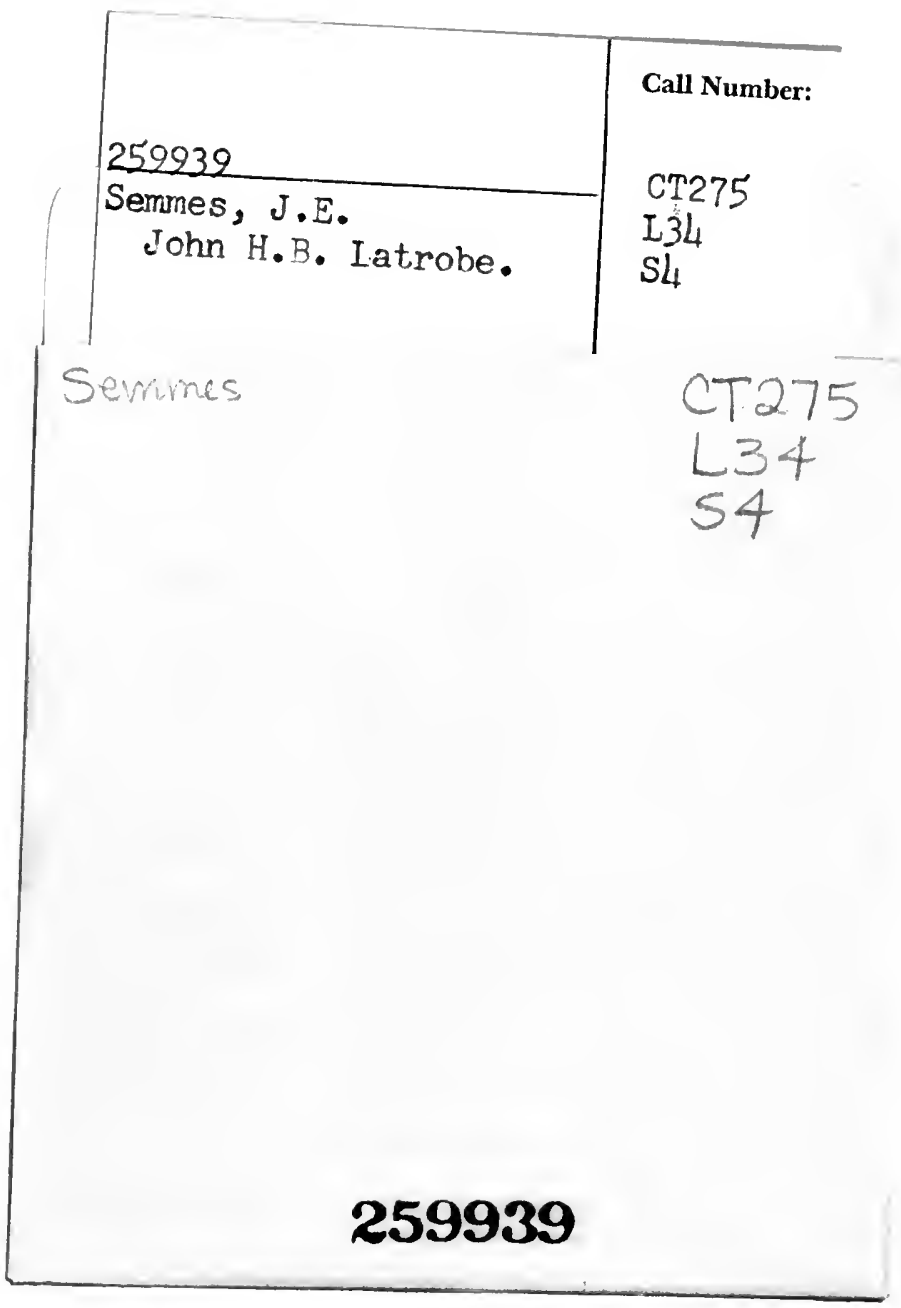


. 